\title{
Publications of the U.S. Army Engineer Research and Development Center: October 1999-December 2015
}

Compiled by James A. Dolan 
The U.S. Army Engineer Research and Development Center (ERDC) solves the nation's toughest engineering and environmental challenges. ERDC develops innovative solutions in civil and military engineering, geospatial sciences, water resources, and environmental sciences for the Army, the Department of Defense, civilian agencies, and our nation's public good. Find out more at www.erdc.usace.army.mil.

To search for other technical reports published by ERDC, visit the ERDC online library at https://erdc-library.erdc.dren.mil/. 


\section{Publications of the U.S. Army Engineer Research and Development Center: October 1999-December 2015}

Compiled by James A. Dolan

Information Technology Laboratory

U.S. Army Engineer Research and Development Center

3909 Halls Ferry Road

Vicksburg, MS 39180-6199

Final report

Approved for public release; distribution is unlimited.
Prepared for U.S. Army Corps Engineer Research and Development Center 3909 Halls Ferry Road
Vicksburg, MS 39180-6199




\section{Abstract}

Publications issued October 1999 through December 2015 by the U.S. Army Engineer Research and Development Center (ERDC) are listed. The publications are grouped according to the technical laboratories or technical program for which they were prepared. Procedures for obtaining ERDC reports are included in the Preface.

DISCLAIMER: The contents of this report are not to be used for advertising, publication, or promotional purposes. Citation of trade names does not constitute an official endorsement or approval of the use of such commercial products. All product names and trademarks cited are the property of their respective owners. The findings of this report are not to be construed as an official Department of the Army position unless so designated by other authorized documents. 


\section{Contents}

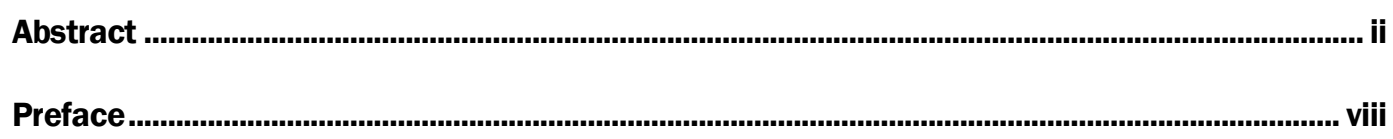

1 Engineer Research and Development Center (ERDC)...................................................... 1

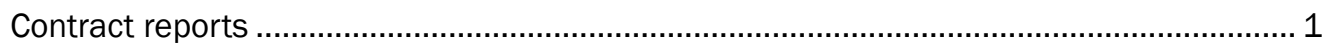

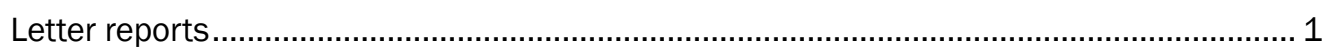

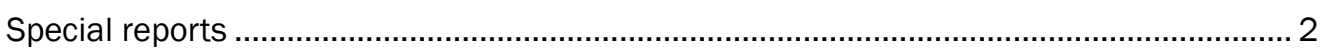

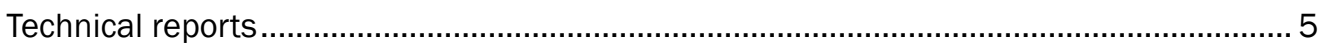

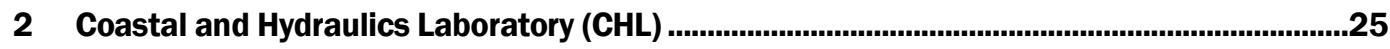

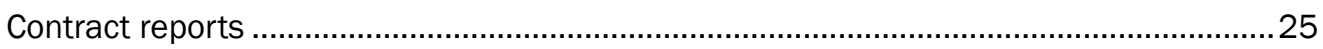

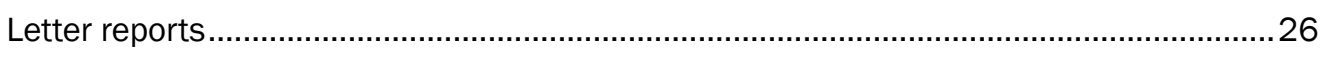

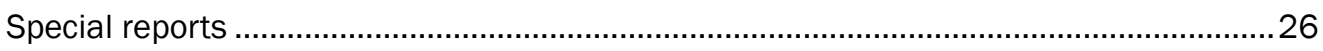

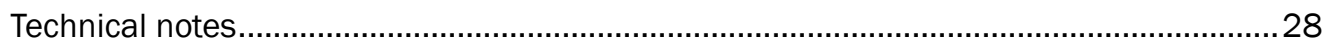

Section I - Waves and coastal flooding........................................................................... 28

Section II - Beach behavior and restoration ..................................................................... 29

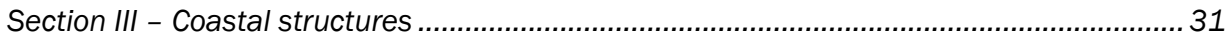

Section IV - Inlets and estuary channels ...................................................................... 32

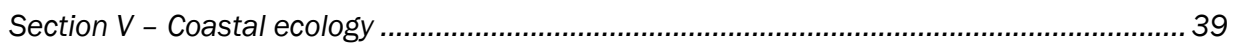

Section VI - Miscellaneous coastal subjects........................................................................ 39

Section VII - River engineering and sedimentation .............................................................. 40

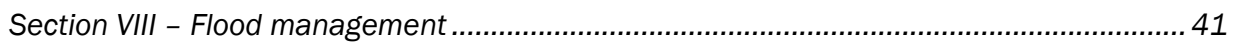

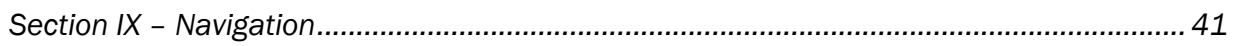

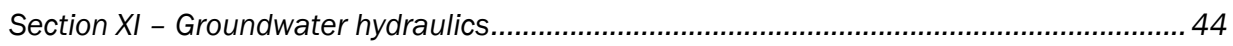

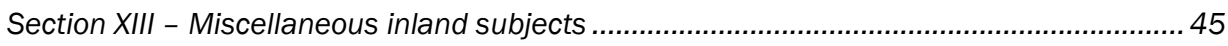

Section XIV - Regional sediment management ............................................................. 45

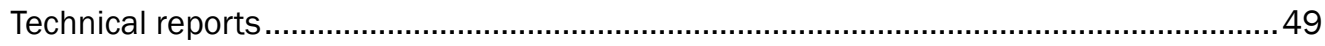

3 Cold Regions Research Engineering Laboratory (CRREL) ...................................................76

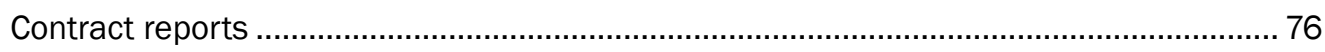

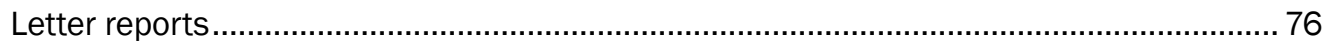

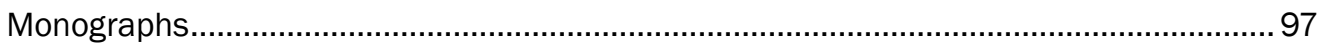

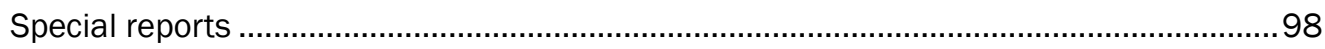

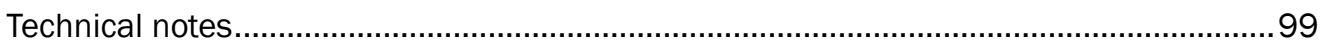

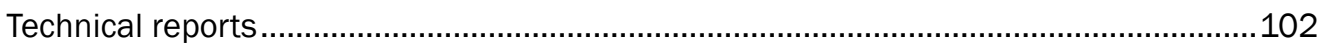

4 Construction Engineering Research Laboratory (CERL) ...............................................127

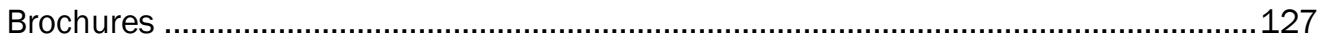

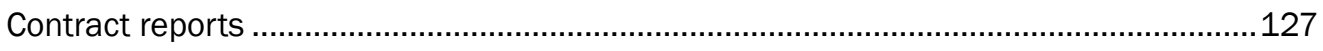

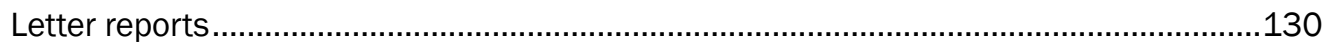

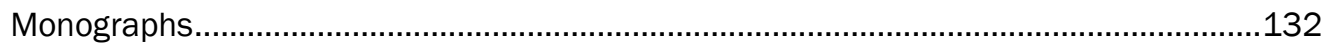

Miscellaneous papers ..............................................................................................132

Repair, Evaluation, Maintenance, and Rehabilitation Research program .......................134 


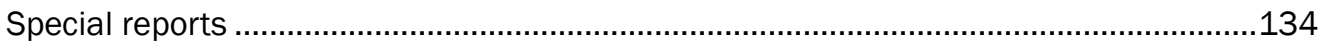

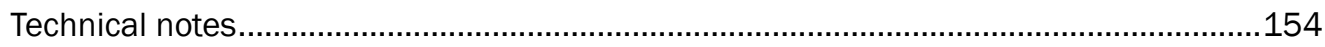

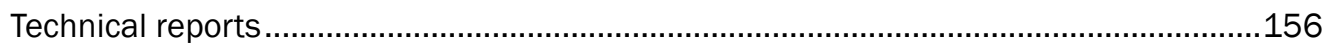

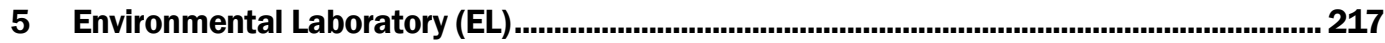

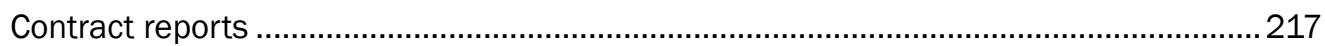

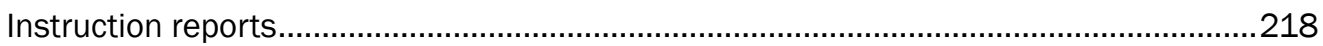

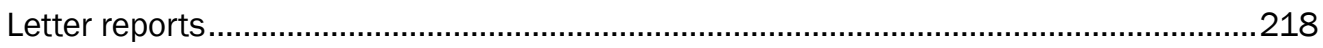

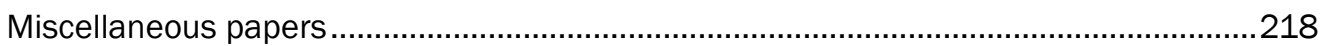

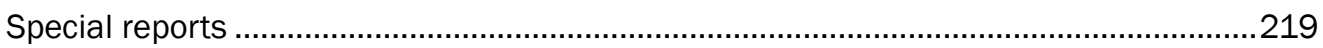

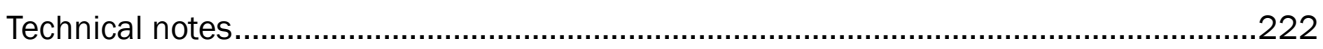

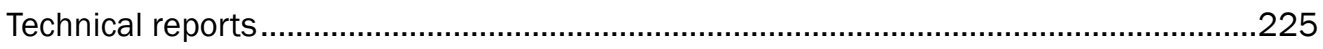

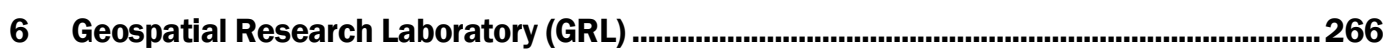

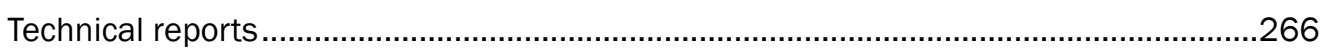

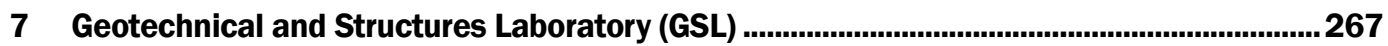

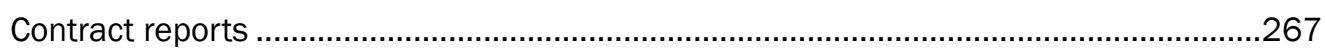

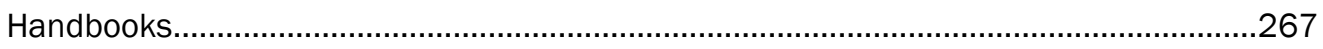

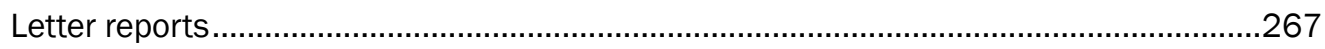

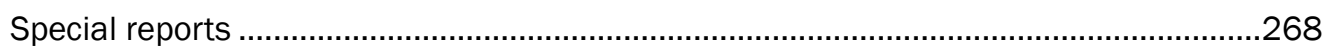

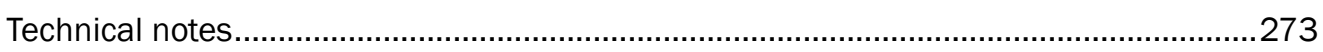

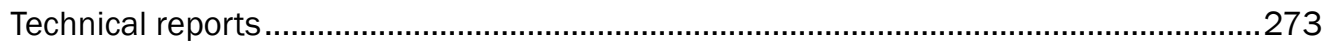

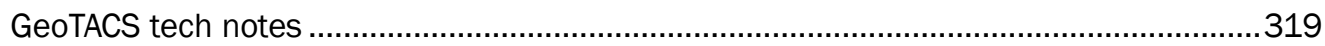

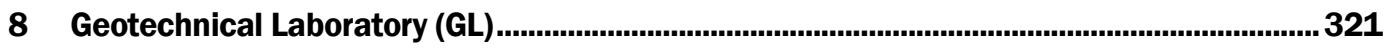

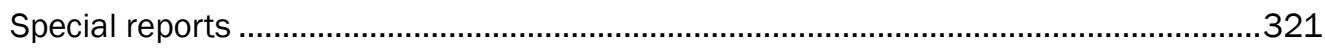

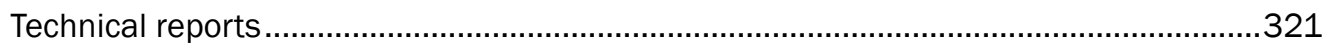

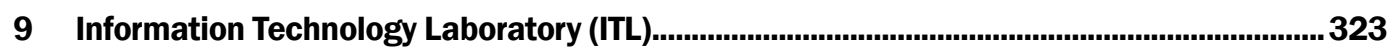

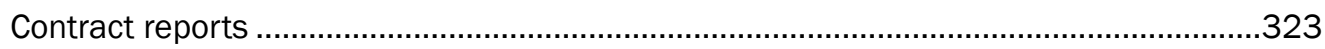

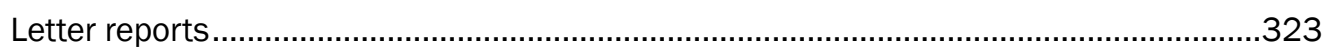

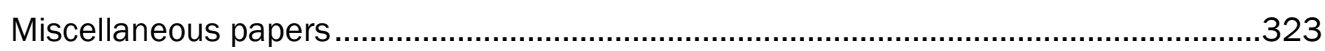

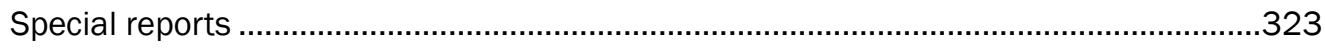

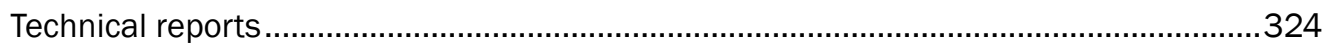

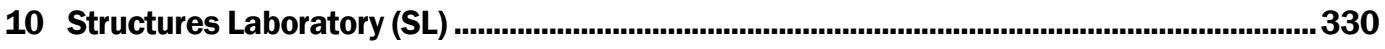

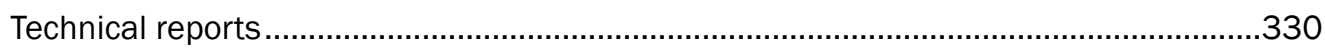

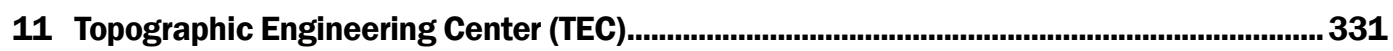

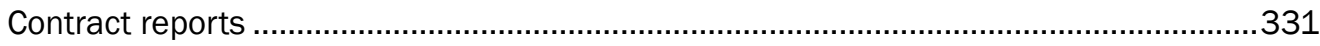

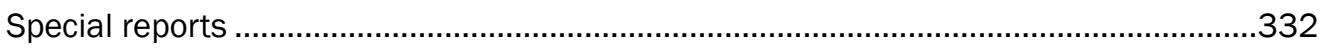

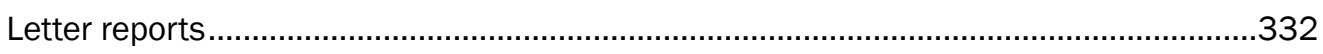

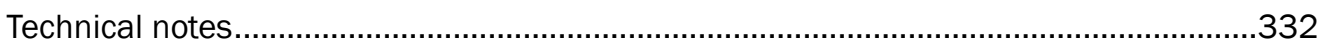

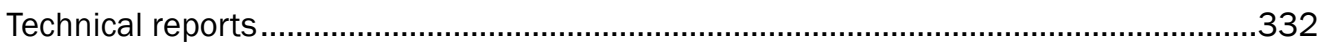

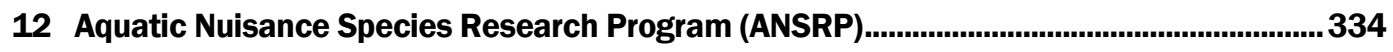


Bulletins

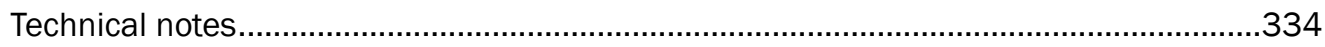

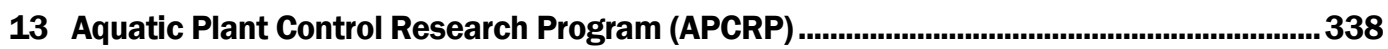

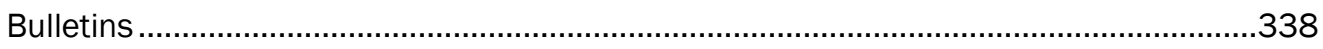

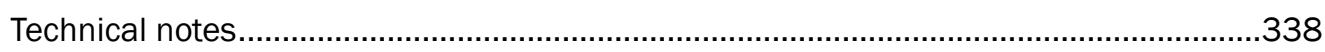

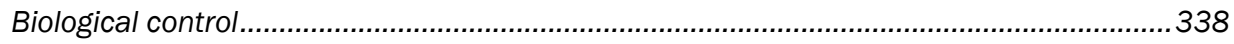

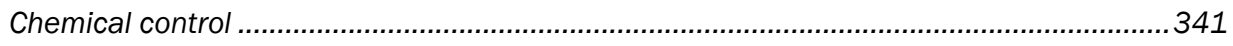

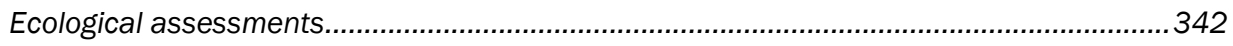

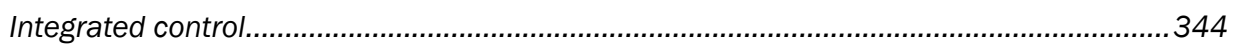

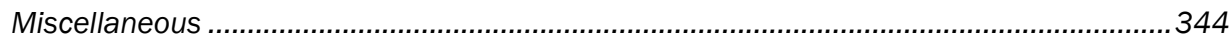

14 Dredging Operations and Environmental Research Program (DOER) ................................345

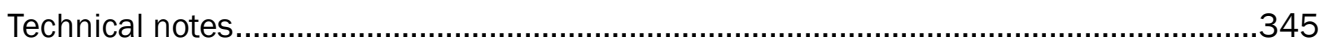

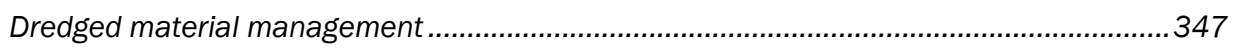

Environmental resource protection..............................................................................348

Innovative operations technologies ............................................................................. 351

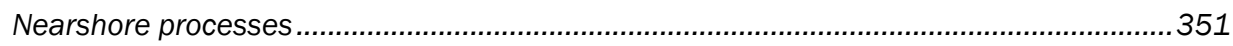

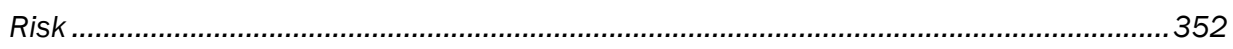

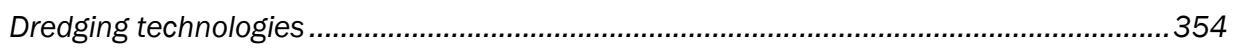

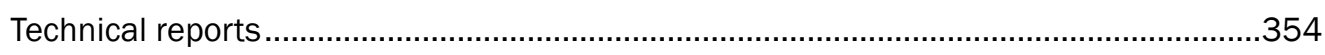

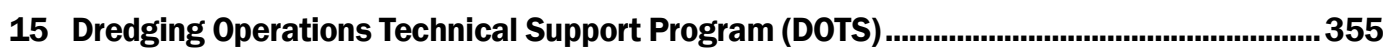

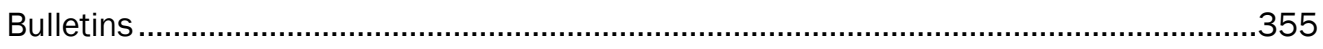

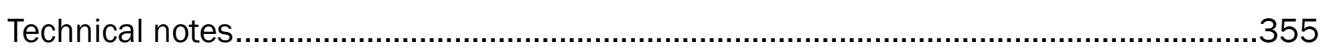

16 Ecosystem Characterization and Monitoring Initiative Program (ECMI) ............................356

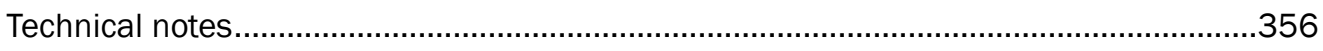

17 Ecosystem Management and Restoration Research Program (EMRRP) .......................... 357

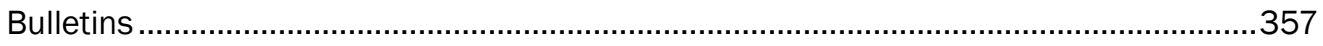

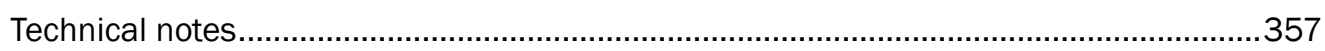

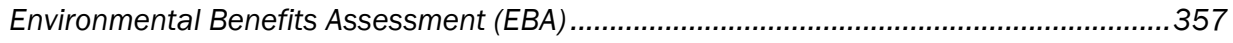

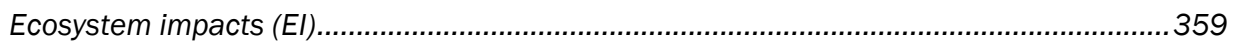

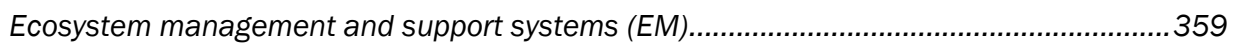

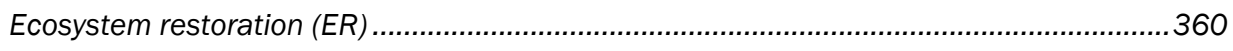

Rapid quantification and assessment methods $(R Q)$.......................................................361

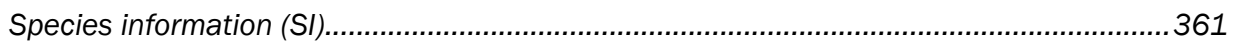

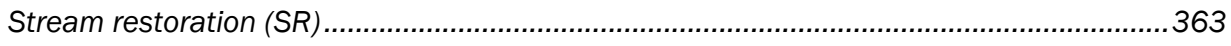

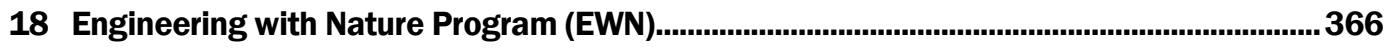

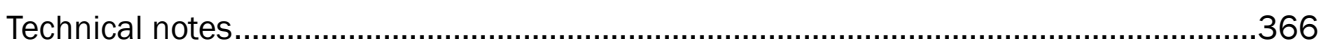

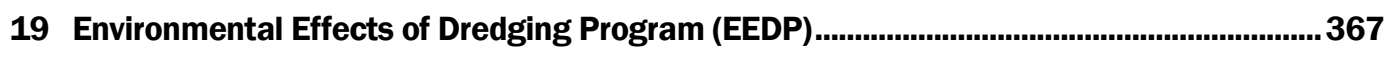

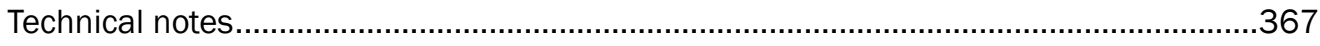

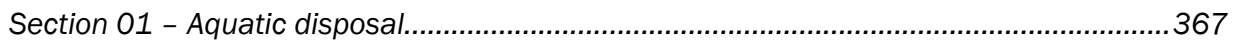

Section 02 - Upland disposal ................................................................................. 


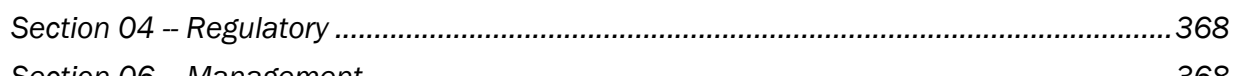

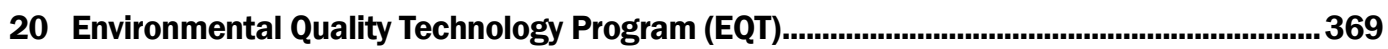

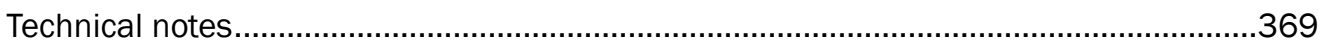

21 Innovations for Navigation Projects Research Program (INP)............................................. 370

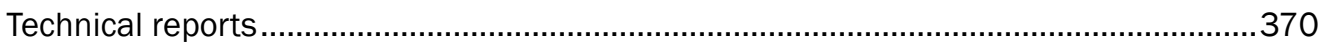

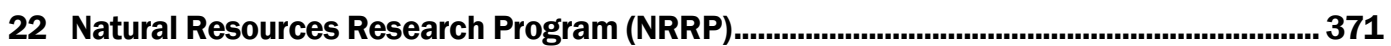

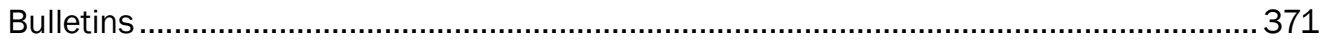

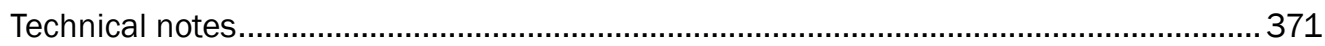

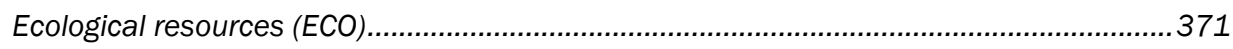

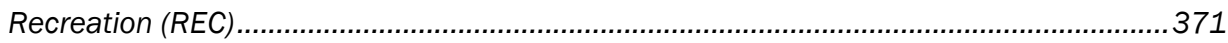

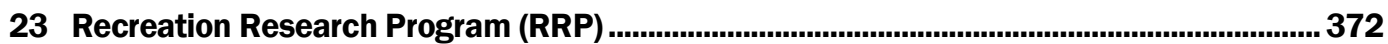

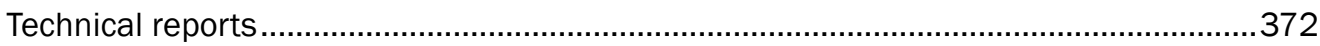

24 Regional Sediment Management Demonstration Program (RSM)......................................

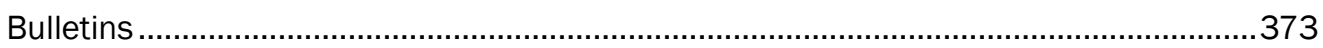

Technical notes (also published as ERDC CHETNs and one CRREL tech note).................373

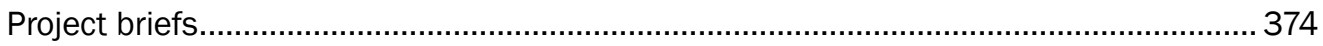

25 Strategic Environmental Research and Development Program (SERDP)............................375

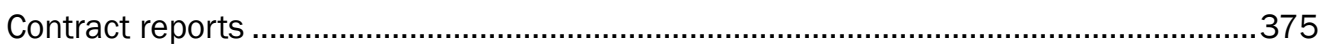

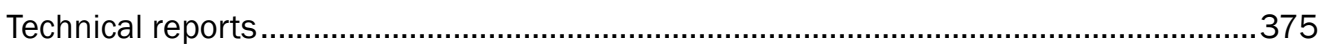

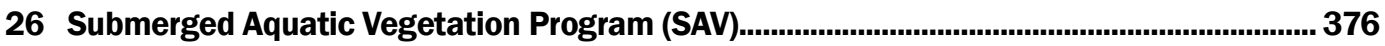

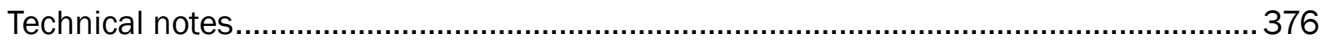

27 System-wide Modeling, Assessment, and Restoration Techniques Program

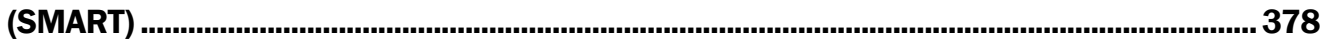

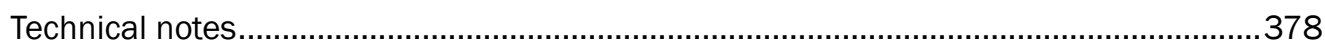

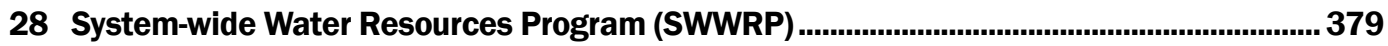

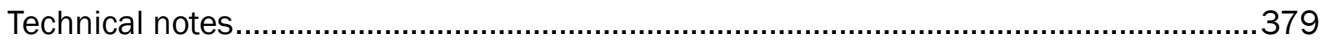

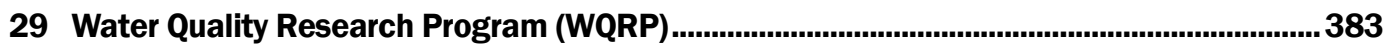

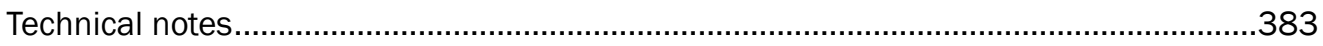

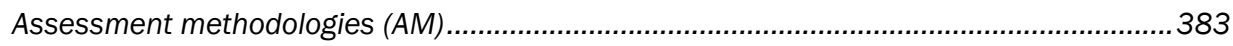

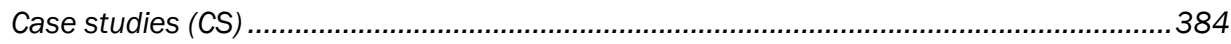

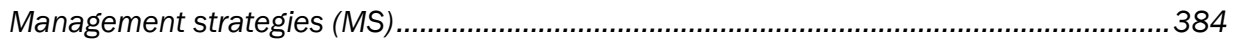

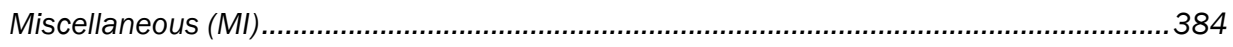

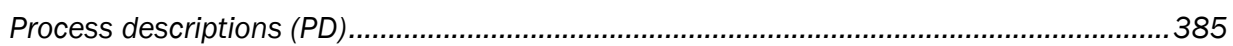

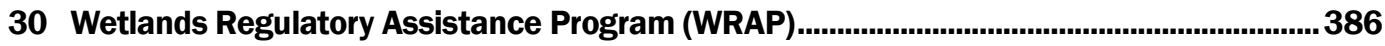

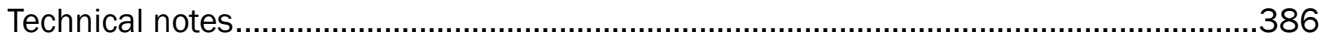

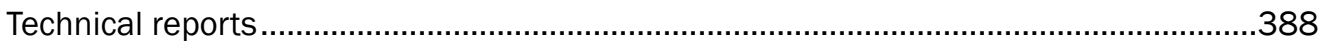


31 Wetlands Research Program (WRP) ............................................................................. 389

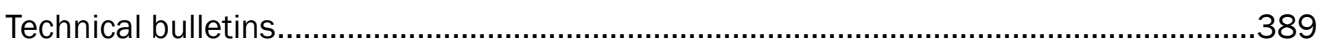

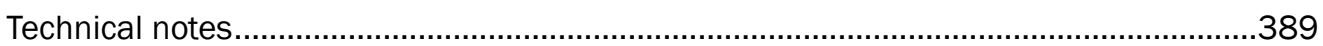

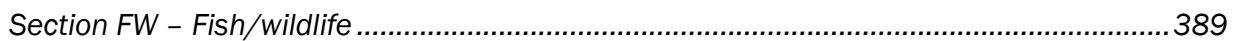

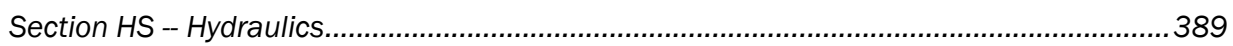

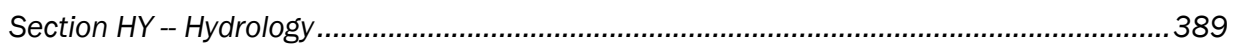

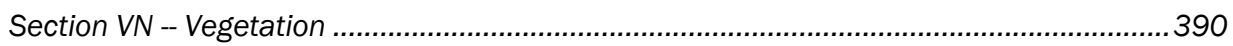

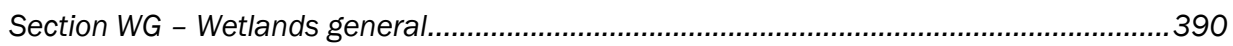

32 Zebra Mussel Research Program (ZMR)......................................................................... 391

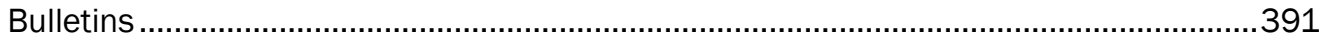

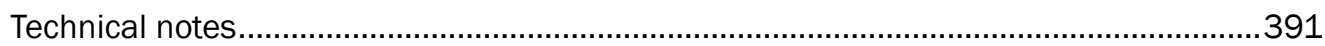

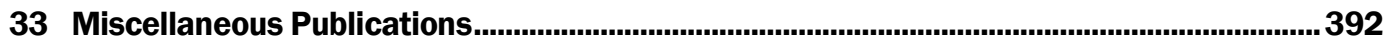

Report Documentation Page 


\section{Preface}

Publications issued October 1999 through December 2015 by the U.S. Army Engineer Research and Development Center (ERDC) are listed herein. The publications are grouped according to the technical laboratories and/or technical programs for which they were prepared. The purpose of this report is to provide a comprehensive list of existing literature produced by the ERDC.

ERDC publications containing the statement "Approved for Public Release; Distribution is Unlimited" are available electronically from the ERDC Library's digital repository at https://erdc-library.erdc.dren.mil/. A footnote by the report number denotes a limited distribution report. Limited distribution reports are available to qualified agencies from the Defense Technical Information Center (DTIC) at www.dtic.mil. For ordering purposes and when available, $\mathrm{AD}$ numbers have been supplied.

When electronic access is not an option, library-to-library loaning is available through Online Computer Library Center (OCLC). The ERDC Library's OCLC symbol is AERDC. Requestors should contact their local library for interlibrary loans. The ERDC Library does not loan directly to individuals. The loaning of limited distribution reports is at the discretion of the ERDC Library and only if the requestor meets the qualifications of the report's limited distribution statement.

This report was compiled by the U.S. Army Engineer Research and Development Center, Information Technology Laboratory (ERDC-ITL), under the general supervision of Susan D. Kitchens, Chief, Information Science and Knowledge Management Branch, ITL; Ken Pathak, Chief, Software Engineering and Informatics Division, ITL; Patti S. Duett, Deputy Director, ITL; and Dr. Reed L. Mosher, Director, ITL.

At the time of publication, COL Bryan S. Green was the Commander of ERDC. Dr. Jeffery P. Holland was the Director. 


\section{Engineer Research and Development Center (ERDC)}

\section{Contract reports}

$\begin{array}{lll}\underline{\text { Report Number }} & \underline{\text { Date }} & \text { Title } \\ \text { 1ERDC CR-00-1 } & \text { Aug 2000 } & \begin{array}{l}\text { EDYS Applications: Two-Year Validation Results for } \\ \text { Grassland Communities at Fort Bliss, Texas, and } \\ \text { Fort Hood, Texas, by T. McLendon, W.M. Childress, } \\ \text { and C. Coldren }\end{array}\end{array}$

AD Number

ADB258381

\section{Letter reports}

$\begin{array}{lll}\text { Report Number } & \text { Date } & \text { Title } \\ \text { ERDC LR-00-1 } & \text { Sep 2000 } & \begin{array}{l}\text { Directory of Wetland Sites Being Used for Long-term } \\ \text { Shallow Groundwater Monitoring, by C.B. Whitten } \\ \text { and J.S. Wakeley }\end{array} \\ \text { ERDC LR-02-1 } & \text { Feb 2002 } & \begin{array}{l}\text { Seismic Stability of St. Stephen Hydropower Plant, } \\ \text { South Carolina, by R.M. Ebeling, R.L. Hall, R.W. } \\ \text { Strom, D.E. Yule, and M. Chowdhury }\end{array} \\ \text { ERDC LR-02-1 } & \text { Nov 2006 } & \begin{array}{l}\text { Seismic Stability of St. Stephen Hydropower Plant, } \\ \text { South Carolina, by R.M. Ebeling, R.L. Hall, R.W. }\end{array} \\ \text { Rev. } & \text { Strom, D.E. Yule, and M. Chowdhury } \\ \text { 1ERDC LR-12-1 } & \text { May 2012 } & \begin{array}{l}\text { Using Ecological Modeling to Identify Species } \\ \text { Dispersal Corridors, by J.H. Sperry, C.M. Armstrong, } \\ \text { W.D. Meyer, J.D. Westervelt, R.F. Lance, and W.A. }\end{array} \\ \text { Boyd }\end{array}$

$\underline{\text { AD Number }}$

ADA399836

ADA457763
Rev.
S. Bourne, and T. Cary

\footnotetext{
1 Limited distribution; see Preface.
} 


\section{Special reports}

\begin{tabular}{|c|c|c|c|}
\hline$\underline{\text { Report Number }}$ & Date & $\underline{\text { Title }}$ & $\underline{\text { AD Number }}$ \\
\hline ERDC SR-01-1 & Feb 2001 & $\begin{array}{l}\text { Water Quality and Potential Sediment Erosion } \\
\text { Assessment for Proposed Construction at Fort } \\
\text { Knox, Kentucky, by S.L. Ashby, W.D. Martin, and } \\
\text { C.N. Gaines }\end{array}$ & ADA389236 \\
\hline ERDC SR-01-2 & Jul 2001 & $\begin{array}{l}\text { Design, Setup, and Operation of the Fixed-Site } \\
\text { TeleEngineering Communications System, by J.L. } \\
\text { Williamson, C.J. Smith, L.N. Lynch, and B.A. Register }\end{array}$ & ADA395366 \\
\hline ERDC SR-01-3 & Sep 2001 & $\begin{array}{l}\text { Strategic Environmental Research and } \\
\text { Development Program (SERDP) Ecosystem } \\
\text { Management Project (SEMP) FYOO Annual Report, } \\
\text { by H.E. Balbach, W.D. Goran, T. Aden, D.L. Price, } \\
\text { M.R. Kress, W.F. DeBusk, A.J. Krzysik, V.H. Dale, C. } \\
\text { Garten, and B. Collins }\end{array}$ & ADA399457 \\
\hline ERDC SR-02-1 & Mar 2002 & $\begin{array}{l}\text { The SEMP Approach: Plans and Progress of the } \\
\text { Strategic Environmental Research and Development } \\
\text { Program (SERDP) Ecosystem Management Project } \\
\text { (SEMP), by W.D. Goran, T.Aden, H.E. Balbach, B. } \\
\text { Collins, V. Dale, T. Davo, B.J. Guertin, J. Hall, R. } \\
\text { Kress, D. Price, and P. Swiderek }\end{array}$ & ADA402344 \\
\hline ERDC SR-02-2 & Mar 2002 & $\begin{array}{l}\text { Strategic Environmental Research and } \\
\text { Development Program (SERDP) Ecosystem } \\
\text { Management Project (SEMP) FYO1 Annual Report, } \\
\text { by H.E. Balbach, W.D. Goran, T. Aden, D.L. Price, } \\
\text { M.R. Kress, W.F. DeBusk, A.J. Krzysik, V.H. Dale, C. } \\
\text { Garten, and B. Collins }\end{array}$ & \\
\hline ERDC SR-02-3 & Aug 2002 & $\begin{array}{l}\text { Army training and Testing Area Carrying Capacity } \\
\text { (ATTACC) Vehicle Severity Factor (VSF) and Local } \\
\text { Condition Factor (LCF) Calculator User Manual, } \\
\text { Version 1.0, by A.B. Anderson and P. Sullivan }\end{array}$ & ADA406275 \\
\hline ERDC SR-02-4 & Sep 2002 & $\begin{array}{l}\text { Design, Setup, and Operation of the Third- } \\
\text { Generation TeleEngineering Communications } \\
\text { Equipment-Deployable (TCE-D) System, by J.L. } \\
\text { Williamson, L.N. Lynch, J. Powell, and B. Register }\end{array}$ & \\
\hline ERDC SR-02-13 & Sep 2002 & $\begin{array}{l}\text { Geophysical Archeological Survey at Poverty Point } \\
\text { State Historic Site (16WC5) West Carroll Parish, } \\
\text { Louisiana, by T. Britt, M. Hargrave, and J. Simms }\end{array}$ & ADA469531 \\
\hline ERDC SR-03-1 & Jun 2003 & $\begin{array}{l}\text { Product Life Cycle Planning, by J.L. Walaszek, W.D. } \\
\text { Goran, C.D. Butler, K.C. McGuire, T.L. Pickett, K.D. } \\
\text { White, and W.J. Wolfe }\end{array}$ & ADA419127 \\
\hline
\end{tabular}



ERDC SR-04-1 Aug 2004 Proceedings of the Symposium: The Pantanal: Scientific and Institutional Challenges in Management of a Large and Complex Wetland Ecosystem; 24th Annual Meeting of the Society of Wetlands Scientists, 8-13 June 2003, New Orleans, Louisiana, by D.J. Tazik, A.A.R. loris, and S.R. Collinsworth, editors

ERDC SR-04-2 Oct 2004 Proceedings of the International Workshop on Uncertainty, Sensitivity, and Parameter Estimation for Multimedia Environmental Modeling; August 1921, 2003

\begin{tabular}{|c|c|c|c|}
\hline & & $\begin{array}{l}\text { Uncertainty, Sensitivity, and Parameter Estimation } \\
\text { for Multimedia Environmental Modeling; August 19- } \\
21,2003\end{array}$ & \\
\hline ERDC SR-04-3 & Oct 2004 & $\begin{array}{l}\text { Setup and Operation of the Third-Generation } \\
\text { TeleEngineering Communications Equipment-Fixed } \\
\text { Site (TCE-F), Version II, by J.L. Williamson, L.N. } \\
\text { Lynch, J. Powell, and B. Register }\end{array}$ & ADA429405 \\
\hline ERDC SR-04-4 & Oct 2004 & $\begin{array}{l}\text { Setup and Operation of the Third-Generation } \\
\text { TeleEngineering Communications Equipment- } \\
\text { Deployable (TCE-D) System, Version II, by J.L. } \\
\text { Williamson, L.N. Lynch, J. Powell, and B. Register }\end{array}$ & ADA429284 \\
\hline 1ERDC SR-06-1 & Jun 2006 & $\begin{array}{l}\text { SERDP Ecosystem Management Project (SEMP): } \\
2004 \text { Administrative Report }\end{array}$ & \\
\hline ERDC SR-06-2 & Jun 2006 & $\begin{array}{l}\text { SERDP Ecosystem Management Project (SEMP): } \\
2004 \text { Technical Report }\end{array}$ & ADA451758 \\
\hline ERDC SR-06-3 & Jun 2006 & $\begin{array}{l}\text { SEMP Monitoring and Research Infusion } \\
\text { Technology Transition Plan, by J.S. Fehmi, H.E. } \\
\text { Balbach, and W.D. Goran }\end{array}$ & \\
\hline ERDC SR-07-1 & Jan 2007 & $\begin{array}{l}\text { eXtensible Model Data Format (XMDF), by C.D. } \\
\text { Butler, D.R. Richards, R.M. Wallace, N.L. Jones, and } \\
\text { R. Jones }\end{array}$ & ADA461368 \\
\hline ERDC SR-07-2 & Mar 2007 & $\begin{array}{l}\text { SERDP Ecosystem Management Project (SEMP): } \\
2005 \text { Annual Report, by H.E. Balbach and } \\
\text { E.L. Keane }\end{array}$ & ADA467767 \\
\hline ERDC SR-07-3 & Jul 2007 & $\begin{array}{l}\text { Acoustic Propagation Through a Forest Edge: Data } \\
\text { Report for Camp Ripley, Minnesota, by M.E. } \\
\text { Swearingen, M.J. White, P.J. Guertin, J.A. Mifflin, T.E. } \\
\text { Onder, D.G. Albert, S.N. Decato, and A. Tunick }\end{array}$ & ADA470913 \\
\hline ERDC SR-07-4 & Nov 2007 & $\begin{array}{l}\text { Setup and Operation of the TeleEngineering } \\
\text { Communications Equipment - Fixed Site (TCE-F), } \\
\text { Version III, by J.L. Williamson, L.N. Lynch, J. Powell, } \\
\text { B. Register, R. Burrow, J. Stringer, and W.C. Fryer }\end{array}$ & ADA473828 \\
\hline
\end{tabular}

ADA444623 
ERDC SR-09-1 Apr 2009 Installation and Operation of the Automated Route

Reconnaissance Kit (ARRK), by J.D. Jorgeson, J.M.

Jackson, S.K. Fairley, W.W. Berry, J.F. Powell, J.L.

Williamson, J.C. Ray, T.R. Stanton, and B.T. Webb

ERDC SR-09-2 Apr 2009 Ecosystem Management: Synthesis and Findings,

by D.W. Imm, H. Westbury, L. Mulkey, R.R. Sharitz,

ADA608300

H. Balbach, V. Dale, B. Collins, A. Kryszik, R. Reddy,

C. Garten, D. Price, G. Lockaby, J. DiLustro, and

W. Goran

ERDC SR-10-1 Jul 2010 Beyond the Factor of Safety: Developing Fragility

Curves to Characterize System Reliability, by M.T.

ADA525580

Schultz, B.P. Gouldby, J.D. Simm, and J.L. Wibowo

ERDC SR-10-2 Dec 2010 Literature Review - Vegetation on Levees, by M.K.

ADA547778

Corcoran, D.H. Gray, D.S. Biedenharn, C.D. Little,

J.R. Leech, F. Pinkard, P. Bailey, and L.T. Lee

ERDC SR-11-1 Oct 2011 Anticipating Climate Change Impacts on Army

ADA559185

Installations, by R.C. Lozar, M.D. Hiett, J.D.

Westervelt, and J.W. Weatherly

1ERDC SR-12-1 Aug 2012 Microwave Antenna Test Bed and Free Space Data

Collection System, by R.M. Castellane III, E.L. Miller, and C.B. Blount

ERDC SR-12-2 Nov 2012 The US Army Corps of Engineers Roadmap for LifeCycle Building Information Modeling (BIM), by US

Army Corps of Engineers, Directorate of Civil Works, Engineering and Construction Branch

ERDC SR-12-2 Nov 2012 The US Army Corps of Engineers Roadmap for Life-

Sup. 1

Cycle Building Information Modeling (BIM).

Supplement 1- BIM Implementation Guide for

Military Construction (MILCON) Projects Using the

Autodesk Platform, by Autodesk, Inc.

ERDC SR-12-2 Nov 2012 The US Army Corps of Engineers Roadmap for Life-

Sup. 2

Cycle Building Information Modeling (BIM).

Supplement 2 - BIM Implementation Guide for

Military Construction (MILCON) Projects Using the

Bentley Platform

ERDC SR-13-1 Feb 2013 Investigation of the Corrosion Mechanism and

ADA591856

Determination of the EMS Estimated Service Life at

Site 81, by V.F. Hock Jr., C.A. Weiss, Jr., R.D. Moser,

S.W. Morefield, and J.B. Bushman

ADB391753

ADA576135

ADA576142

ADA578649

AD




$\begin{array}{lll}\text { ERDC SR-15-1 Jan } 2015 \quad \begin{array}{l}\text { Use of Natural and Nature-Based Features (NNBF) } \\ \text { for Coastal Resilience, by T.S. Bridges, P.W. Wagner, } \\ \text { K.A. Burks-Copes, M.E. Bates, Z.A. Collier, C.J. } \\ \text { Fischenich, J.Z. Gailani, L.D. Leuck, C.D. Piercy, J.D. } \\ \text { Rosati, E.J. Russo, D.J. Shafer, B.C. Suedel, E.A. } \\ \text { Vuxton, and T.V. Wamsley }\end{array} \\ \text { ERDC SR-15-2 Jun 2015 } & \begin{array}{l}\text { Energy and Resource Recovery from Wastewater } \\ \text { Treatment: State of the Art and Potential } \\ \text { Application for the Army and the DoD, by V.F. } \\ \text { Medina, R.J. Scholze, S.A. Waisner, and C.S. Griggs }\end{array}\end{array}$

ADA613224

ADA619808

\section{Technical reports}

\begin{tabular}{|c|c|c|c|}
\hline Report Number & Date & $\underline{\text { Title }}$ & $\underline{\text { AD Number }}$ \\
\hline ERDC TR-00-1 & Apr 2000 & $\begin{array}{l}\text { Hydrodynamic and Water Quality Model Study of } \\
\text { San Juan Bay Estuary, by B.W. Bunch, C.F. Cerco, } \\
\text { M.S. Dortch, B.H. Johnson, and K.W. Kim }\end{array}$ & ADA378533 \\
\hline ERDC TR-00-2 & Jun 2000 & $\begin{array}{l}\text { A Methodology for Estimating Army Training and } \\
\text { Testing Area Carrying Capacity (ATTACC) Vehicle } \\
\text { Severity Factors and Local Condition Factors, by } \\
\text { P.M. Sullivan and A.B. Anderson }\end{array}$ & ADA379393 \\
\hline ERDC TR-00-3 & Jul 2000 & $\begin{array}{l}\text { Multiuser Disposal Sites (MUDS) for Contaminated } \\
\text { Sediments from Puget Sound-Subaqueous Capping } \\
\text { and Confined Disposal Alternatives, by M.R. } \\
\text { Palermo, J.E. Clausner, M.G. Channel, and D.E. } \\
\text { Averett }\end{array}$ & ADA380336 \\
\hline ERDC TR-00-4 & Jul 2000 & $\begin{array}{l}\text { Procedures for Determining Integrity of UXO and } \\
\text { Explosives Soil Contamination at Firing Ranges, by } \\
\text { J.M. Brannon, T.F. Jenkins, L.V. Parker, P. Deliman, } \\
\text { J.A. Gerald, C. Ruiz, B. Porter, and W.M. Davis }\end{array}$ & ADA383113 \\
\hline ERDC TR-00-5 & Aug 2000 & $\begin{array}{l}\text { Analysis of Explosives-Related Chemical Signatures } \\
\text { in Soil Samples Collected Near Buried Land Mines, } \\
\text { by T.F. Jenkins, M.E. Walsh, P.H. Miyares, J.A. } \\
\text { Kopczynski, T.A. Ranney, V. George, J.C. } \\
\text { Pennington, and T.E. Berry, Jr. }\end{array}$ & ADA381896 \\
\hline ERDC TR-00-6 & Sep 2000 & $\begin{array}{l}\text { Evaluation of Three-Component Magnetic Sensors } \\
\text { for Delineation and Identification of UXO, by J.E. } \\
\text { Simms, L.B. Smithhart, and D.K. Butler }\end{array}$ & ADA383795 \\
\hline ERDC TR-00-7 & Sep 2000 & $\begin{array}{l}\text { Olmsted Wicket Blank Experiment in 1:5-Scale } \\
\text { Hydraulic Flume Model, by M.R. Chowdhury and } \\
\text { W.G. Davis }\end{array}$ & ADA384493 \\
\hline ERDC TR-00-8 & Sep 2000 & $\begin{array}{l}\text { Guidelines for Mapping Vegetation on Army } \\
\text { Installations, by L.J. O'Neil, and A. Hill, editors }\end{array}$ & \\
\hline
\end{tabular}




\begin{tabular}{|c|c|c|}
\hline ERDC TR-00-9 & Nov 2000 & $\begin{array}{l}\text { U.S. Army Corps of Engineers Geospatial Data and } \\
\text { Systems Management, by N.H. Greeley, K.M. Dilks, } \\
\text { C.M. Adams, and G.C. Hoge }\end{array}$ \\
\hline ERDC TR-01-1 & Mar 2001 & $\begin{array}{l}\text { A Community-Based Regional Plan for Managing } \\
\text { Threatened and Endangered Species on Military } \\
\text { Installations in the Southeastern United States, by } \\
\text { C.O. Martin, M.G. Harper, A.T. Shapiro, and R.A. } \\
\text { Fischer }\end{array}$ \\
\hline ERDC TR-01-2 & Jan 2001 & $\begin{array}{l}\text { Decision Support Capabilities for Future } \\
\text { Technology Requirements, by M.P. Case, W.D. } \\
\text { Goran, T.A. Gunther, J.P. Holland, D.M. Johnston, G. } \\
\text { Lessard, and W.J. Schmidt }\end{array}$ \\
\hline ERDC TR-01-3 & Mar 2001 & $\begin{array}{l}\text { Planning, Engineering, and Design of Sustainable } \\
\text { Facilities and Infrastructure; An Assessment of the } \\
\text { State of Practice, by S.N. Flanders, R.L. Schneider, } \\
\text { D. Fournier, B. Neal, and A.L. Stumpf }\end{array}$ \\
\hline
\end{tabular}

ERDC TR-01-4 Apr 2001 Delineating Playas in the Arid Southwest; A

Literature Review, by W. Brostoff, R. Lichvar, and S. Sprecher

ERDC TR-01-5 Jul 2001 Characterization of Explosives Contamination at Military Firing Ranges, by T.F. Jenkins, J.C. Pennington, T.A. Ranney, T.E. Berry, Jr., P.H. Miyares, M.E. Walsh, A.D. Hewitt, N.M. Perron, L.V. Parker, C.A. Hayes, and E.G. Wahlgreen

ERDC TR-01-6 Aug 2001 Design, Setup, and Operation of the Deployable TeleEngineering Communications System, by J.L. Williamson, C.J. Smith, L.N. Lynch, and J. Powell

ADA386667

ADA385925

ADA391851

ADA388921

ADA389351

ADA392827

ADA395367

ERDC TR-01-7 Aug 2001 Groundwater Flow and Contaminant Transport Modeling Near the Peele Dixie Well Field; Including Florida Petroleum Reprocessors Superfund Site, Ft. Lauderdale and Davie, Broward County, Florida, by M.E. Glynn, S.E. Howington, W.L. Murphy, J.P. Hallberg, M. Zakikhani, R.S. Maier, and B.A. Abraham

ERDC TR-01-8 Aug 2001 Development of a Geomorphology-Based Framework for Cultural Resources Management, Dworshak Reservoir, Idaho, by M.K. Corcoran, L.M. Smith, L.D. Wakeley, and P.R. Nickens

ERDC TR-01-9 Aug 2001 Instrumentation at the National Center for Asphalt Technology Test Track, by R.B. Freeman, H.T. Carr, T. McEwen, and R.B. Powell

ADA395602

ADM001314

ADA395602

ADA395937

Base-Induced 2,4,6-Trinitrotoluene Transformation,

ADA394461 Titration Studies, by L.D. Hansen, D.D. Ringelberg, D.R. Felt, and J.D. Davis 


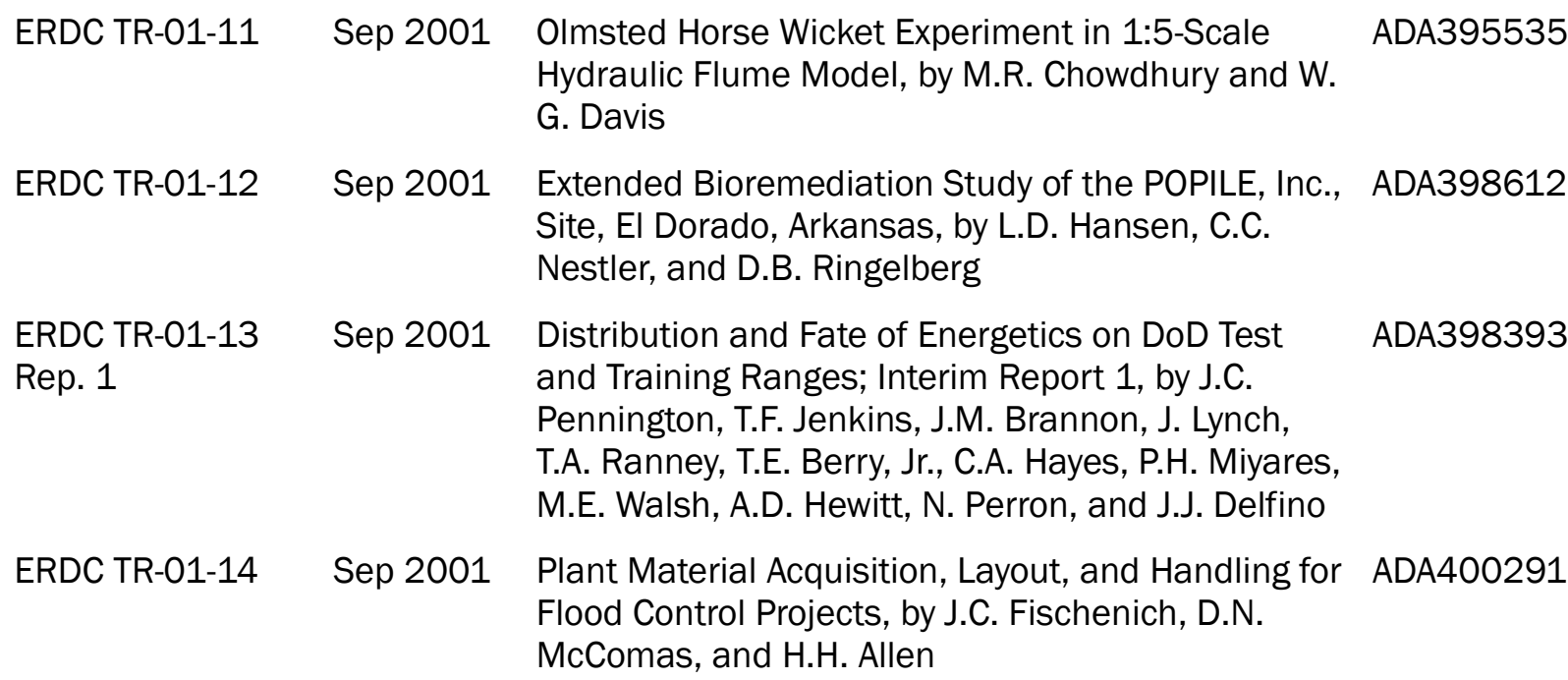

ERDC TR-01-15 Nov 2001 Monitoring of Marseilles Dam Submersible Gates, Illinois River, Illinois, by D.R. Cooper, T.L. Fagerburg, T.N. Waller, S.W. Guy, and A. Tuthill

ERDC TR-01-16

ERDC TR-01-17

ERDC TR-02-1 Jan 2002

ERDC TR-02-2 Mar 2002

ERDC TR-02-3 Apr 2002

ERDC TR-02-4

ERDC TR-02-5

ERDC TR-02-6

Dec 2001
Environmental Considerations for Vegetation in Flood Control Channels, by J.C. Fischenich and R.R. Copeland

Nov 2001 Seismic Testing of a 1/20 Scale Model of Koyna Dam, by J. Wilcoski, R.L. Hall, E.E. Matheu, J.B. Gambill, and M.R. Chowdhury

Freeze Concentration of Pinkwater, by C.J. Martel, S. Taylor, and S.W. Maloney

Assessment of Geology as it Pertains to Modeling Uplift in Jointed Rock: A Basis for Inclusion of Uncertainty in Flow Models, by W.L. Murphy, R.M. Ebeling, and J.M. Andersen

Automated Environmental Data Collection at Fort Benning, Georgia, from May 1999 to July 2001, by C.D. Hahn and D.L. Leese

Apr 2002 Tributary Refinements to the Chesapeake Bay Model, by C.F. Cerco, B.H. Johnson, and H.V. Wang

Sep 2002 Field Pilot Study of In Situ Capping of Palos Verdes Shelf Contaminated Sediments, by T.J. Fredette, J.E. Clausner, M.R. Palermo, S.M. Bratos, T.L. Pickett, B.H. Johnson, M.S. Brouwer, J.A. Ryan, L.J. Smith, E.E. Nevarez, F.K. Schauffler, and S. McDowell

Sep 2002 Assessment of DDT Bioavailability in the Little Sunflower River Sediment and Agricultural Soil, by R. Wade, G.R. Lotufo, J.A. Steevens, J.G. Houston, H.L. Fredrickson, E.J. Perkins, A.B. Morrow, C.A. Weiss, J.S. Furey, D. Felt, M. Duke, and J.W. Talley
ADA399683

ADA400227

ADA401013

ADA398637

ADA401845

ADA401416

ADM001411

ADA408898

ADA408220 
$\begin{array}{lll}\text { ERDC TR-02-7 Dec 2002 } & \text { Biaxial Loading and Failure Behavior of Brick } \\ & \text { Triplets With Fiber-Reinforced Polymer Composite } \\ & \text { Upgrades, by J.B. Berman, G.K. Al-Chaar, and P.K. } \\ & \text { Dutta }\end{array}$

ERDC TR-02-8 Oct 2002

Rep. 2

ERDC TR-03-1 Mar 2003

ERDC TR-O3-1

ERDC TR-03-2

Rep. 3

ERDC TR-03-3

1ERDC TR-03-4

Vol. 1
Distribution and Fate of Energetics on DoD Test and Training Ranges: Interim Report 2, by J.C. Pennington, T.F. Jenkins, G. Ampleman, S. Thiboutot, J.M. Brannon, J. Lynch, T.A. Ranney, J.A. Stark, M.E. Walsh, J. Lewis, C.A. Hayes, J.E. Mirecki, A.D. Hewitt, N. Perron, D. Lambert, J. Clausen, and J.J. Delfino

Application of LEEDTM and SPiRiT to a Proposed Building Design, by S. Nemeth, D. Fournier, R. Schneider, R. Ducey, F. Holcomb, E. Johnson, P. Loechl, P. Perregrin, A. Phelps, G. Phetteplace, R. Scholze, D. Schwenk, A. Stumpf, W. Taylor, M. Tooker, J. Vavrin, and J. Webster

Sep 2003 Distribution and Fate of Energetics on DoD Test and Training Ranges: Interim Report 3, by J.C. Pennington, T.F. Jenkins, G. Ampleman, S. Thiboutot, J.M. Brannon, J. Lewis, J.E. DeLaney, J. Clausen, A.D. Hewitt, M.A. Hollander, C.A. Hayes, J.A. Stark, A. Marois, S. Brochu, H.Q. Dinh, D. Lambert, A. Gagnon, M. Bouchard, R. Martel, P. Brousseau, N.M. Perron, R. Lefebvre, W. Davis, T.A. Ranney, C. Gauthier, S. Taylor, and J. Ballard

Sep 2003 Evaluation of Island and Nearshore Confined Disposal Facility Alternatives, Pascagoula River Harbor Dredged Material Management Plan, by B.W. Bunch, M. Channell, W.D. Corson, B.A. Ebersole, L. Lin, D.J. Mark, J.P. McKinney, S.A. Pranger, P.R. Schroeder, S.J. Smith, D.H. Tillman, B.A. Tracy, M.W. Tubman, and T.L. Welp

Oct 2003

Condition Assessment of U.S. International Boundary and Water Commission, Lower Rio Grande Valley Levees, South Texas. Volume I, Main Text and Appendices, by J.B. Dunbar, R.F. Ballard, W.L. Murphy, T.E. McGill, J.L. Llopis, L.D. PeymanDove, and M.J. Bishop
ADA410920

ADA432763

ADA417819

ADA417955

ADB294050

\footnotetext{
1 Limited distribution; see Preface.
} 


\begin{tabular}{|c|c|c|c|}
\hline $\begin{array}{l}\text { ERDC TR-03-4 } \\
\text { Rep. } 5\end{array}$ & Jan 2007 & $\begin{array}{l}\text { Condition Assessment of Levees, U.S. Section of } \\
\text { the International Boundary and Water Commission. } \\
\text { Report 5: Flood Simulation Study of Retamal } \\
\text { Levee, Lower Rio Grande Valley, Texas, Using } \\
\text { Seismic and Electrical Geophysical Models, by J.B. } \\
\text { Dunbar, J.L. Llopis, G.L. Sills, E.W. Smith, R.D. } \\
\text { Miller, J. Ivanov, and R.F. Corwin }\end{array}$ & ADA464953 \\
\hline ERDC TR-04-1 & Jan 2004 & $\begin{array}{l}\text { Review of Ordinary High Water Mark Indicators for } \\
\text { Delineating Arid Streams in the Southwestern } \\
\text { United States, by R.W. Lichvar and J.S. Wakeley, } \\
\text { editors }\end{array}$ & ADA424157 \\
\hline ERDC TR-04-2 & Mar 2004 & $\begin{array}{l}\text { Phenomenological Models for Landscape } \\
\text { Signatures: Review and Recommendations, by J.R. } \\
\text { Ballard, G.L. Mason, J.A. Smith, and L.K. Balick }\end{array}$ & ADA424543 \\
\hline ERDC TR-04-3 & Sep 2004 & $\begin{array}{l}\text { Investigation of Cyclodextrin-Enhanced } \\
\text { Electrokinetic Soil Remediation. Fate and Transport } \\
\text { of Nitroaromatic Contaminants and Cyclodextrin } \\
\text { Amendments in Expansive Clays, by D. Kessler, C.P. } \\
\text { Marsh, J.J. McCormick, D.M. Cropek, A.R. } \\
\text { Deguzman, R. Robles, and D. Gent }\end{array}$ & ADA440999 \\
\hline
\end{tabular}

ERDC TR-04-4 Nov 2004 Distribution and Fate of Energetics on DoD Test

Rep. 4

and Training Ranges; Interim Report 4, by J.C.

Pennington, T.F. Jenkins, G. Ampleman, S.

Thiboutot, J. Brannon, J. Clausen, A.D. Hewitt, S.

Brochu, P. Dube, J. Lewis, T. Ranney, D. Faucher, A. Gagnon, J.A. Stark, P. Brousseau, C.B. Price, D.

Lambert, A. Marois, M. Bouchard, M.E. Walsh, S.L. Yost, N.M. Perron, R. Martel, S. Jean, S. Taylor, C.A. Hayes, J. Ballard, M.R. Walsh, J.E. Mirecki, S.

Downe, N.H. Collins, B. Porter, and R. Karn
ERDC TR-04-5 Nov 2004 Constitutive Analyses of Nontraditional Stabilization Additives, by J.S. Tingle, S.L. Larson, C.A. Weiss, J.K. Newman, J.F. Peters, B. Tardy, and E.S. Berney IV

ADA429132

ADA429182

ERDC TR-04-6 Dec 2004 Characterization of Soils from the Night Vision and

ADA430311 Electronic Sensors Directorate Mine Lane Facility, Fort Belvoir, VA, by J.O. Curtis, D. Leavell, C. Weiss, R. North, E. Smith, J. Cortes, R. Castellane, and M. Fields

ERDC TR-05-1 Feb 2005 Using High Spatial Resolution Digital Imagery, by M.V. Campbell, R.L. Fischer, T. Pangburn, and M.J. Hardenberg 


\begin{tabular}{|c|c|c|c|}
\hline $\begin{array}{l}\text { ERDC TR-05-2 } \\
\text { Rep. } 5\end{array}$ & Apr 2005 & $\begin{array}{l}\text { Distribution and Fate of Energetics on DoD Test } \\
\text { and Training Ranges; Interim Report 5, by J.C. } \\
\text { Pennington, T.F. Jenkins, S. Thiboutot, G. } \\
\text { Ampleman, J. Clausen, A.D. Hewitt, J. Lewis, M.R. } \\
\text { Walsh, M.E. Walsh, T.A. Ranney, B. Silverblatt, A. } \\
\text { Marois, A. Gagnon, P. Brousseau, J.E. Zufelt, K. } \\
\text { Poe, M. Bouchard, R. Martel, D.D. Walker, C.A. } \\
\text { Ramsey, C.A. Hayes, S.L. Yost, K.L. Bjella, L. } \\
\text { Trepanier, T.E. Berry, D.J. Lambert, P. Dube, and } \\
\text { N.M. Perron }\end{array}$ & ADA433648 \\
\hline ERDC TR-05-3 & May 2005 & $\begin{array}{l}\text { Methodology for Risk Analysis of Dam Gates and } \\
\text { Associated Operating Equipment Using Fault Tree } \\
\text { Analysis, by R.C. Patev, C. Putcha, and S.D. Foltz }\end{array}$ & ADA441161 \\
\hline ERDC TR-05-4 & Apr 2005 & $\begin{array}{l}\text { Characterizing Land Use Change Trends Around the } \\
\text { Perimeter of Military Installations, by R.C. Lozar, } \\
\text { W.D. Meyer, J.D. Schlagel, R.H. Melton, B.A. } \\
\text { MacAllister, J.S. Rank, D.P. MacDonald, P.T. } \\
\text { Cedfeldt, P.M. Kirby, and W.D. Goran }\end{array}$ & ADA461426 \\
\hline 1ERDC TR-05-5 & Sep 2005 & $\begin{array}{l}\text { Geospatial Risk Assessment Modeling System } \\
\text { (GeoRAMS) }\end{array}$ & ADB313400 \\
\hline ERDC TR-05-6 & Sep 2005 & $\begin{array}{l}\text { Gopher Tortoise Nest Detection at Camp Shelby, } \\
\text { Mississippi, by H.H. Bennett, Jr., J.E. Simms, L.B. } \\
\text { Smithhart, M.L. Hargrave, T. Britt, H. Balbach, and } \\
\text { D. Pitts }\end{array}$ & ADA448909 \\
\hline ERDC TR-05-7 & Sep 2005 & $\begin{array}{l}\text { NAVPAT Application to Winfield Pool, Kanawha } \\
\text { River, and Evaluation of NAVPAT Habitat } \\
\text { Relationships, by S. Maynord, J. Killgore, B. Payne, } \\
\text { S. Bourne, and J. Cote }\end{array}$ & ADA438049 \\
\hline ERDC TR-05-8 & Sep 2005 & $\begin{array}{l}\text { New Lock for Soo Locks and Dam, Sault Ste. Marie, } \\
\text { Michigan, St. Mary's River; Hydraulic Model } \\
\text { Investigation, by J.E. Hite, Jr., and A.M. Tuthill }\end{array}$ & ADA438018 \\
\hline ERDC TR-05-9 & Sep 2005 & $\begin{array}{l}\text { Rainfall Lysimeter Evaluation of Leachability and } \\
\text { Surface Transport of Heavy Metals from Six Soils } \\
\text { With and Without Phosphate Amendment, by S. } \\
\text { Larsen, B. Tardy, K. Rainwater, and J.S. Tingle }\end{array}$ & ADA439193 \\
\hline ERDC TR-05-10 & Nov 2005 & $\begin{array}{l}\text { Identity and Distribution of Residues of Energetic } \\
\text { Compounds at Military Live-Fire Training Ranges, } \\
\text { by T.F. Jenkins, S. Thiboutot, G. Ampleman, A.D. } \\
\text { Hewitt, M.E. Walsh, T.A. Ranney, C.A. Ramsey, C.L. } \\
\text { Grant, C.M. Collins, S. Brochu, S.R. Bigl, and J.C. } \\
\text { Pennington }\end{array}$ & ADA441160 \\
\hline
\end{tabular}




\begin{tabular}{|c|c|c|c|}
\hline ERDC TR-05-11 & Dec 2005 & $\begin{array}{l}\text { Installation and Operation of the Automated Route } \\
\text { Reconnaissance Kit (ARRK), by L.N. Lynch, J.M. } \\
\text { Jackson, K. Fairley, J.L. Williamson, J.C. Ray, T.R. } \\
\text { Stanton, T.C. Falls, B.T. Webb, J.L. Crockett, and J.F. } \\
\text { Powell }\end{array}$ & ADA441367 \\
\hline ERDC TR-06-1 & Apr 2006 & $\begin{array}{l}\text { FASST Soil Moisture Prediction Error at Yuma, } \\
\text { Arizona, by B.E. Skahill and S. Frankenstein }\end{array}$ & ADA447546 \\
\hline ERDC TR-06-2 & Apr 2006 & $\begin{array}{l}\text { Effects of Pool Drawdown and Wing Dams (Pool 8), } \\
\text { and Closure Dams (Pool 13), on Navigation } \\
\text { Channel Sedimentation Processes, Upper } \\
\text { Mississippi River, by D.D. Abraham, M.A. Cowan, } \\
\text { J.S. Hendrickson, W.M. Katzenmeyer, K.J. } \\
\text { Landwehr, and T.C. Pratt }\end{array}$ & ADA447295 \\
\hline
\end{tabular}

ERDC TR-06-3 Jun 2006 Response Amplification of Idealized Powerhouse

ADA452386 Substructures to Earthquake Ground Motions, by R.M. Ebeling, E.J. Perez-Marcial, and D.E. Yule

\begin{tabular}{|c|c|c|c|}
\hline ERDC TR-06-4 & Jul 2006 & $\begin{array}{l}\text { Emerging Species of Concern Resulting from } \\
\text { Urbanization Encroachment Near Military } \\
\text { Installations, by D.P. MacDonald and R.C. Lozar }\end{array}$ & ADA452366 \\
\hline ERDC TR-06-5 & Aug 2006 & $\begin{array}{l}\text { Evaluation of Ground Vibrations Induced by Military } \\
\text { Noise Sources: Final Report for SERDP SEED } \\
\text { Project SI-1410, by D.G. Albert, P. Boulanger, K. } \\
\text { Attenborough, and M.J. White }\end{array}$ & ADA452588 \\
\hline ERDC TR-06-6 & Sep 2006 & $\begin{array}{l}\text { A GIS System for Inferring Subsurface Geology and } \\
\text { Material Properties: Proof of Concept, by L.W. } \\
\text { Gatto, M.V. Campbell, J. Ehlen, C.C. Ryerson, L.E. } \\
\text { Hunter, and B.T. Tracy }\end{array}$ & ADA455819 \\
\hline RDC TR-06-7 & Sep 2006 & $\begin{array}{l}\text { Erodibility Study of Passaic River Sediments Using } \\
\text { USACE Sedflume, by T.D. Borrowman, E.R. Smith, } \\
\text { J.Z. Gailani, and L. Caviness }\end{array}$ & ADA456816 \\
\hline 1ERDC TR-06-8 & Sep 2006 & $\begin{array}{l}\text { Technology Requirements Study for a New Central } \\
\text { Heating and Power Plant at Fort Wainwright, AK, by } \\
\text { J.L. Vavrin, M.R. Kemme, W.T. Brown, V. Boddu, G.E. } \\
\text { Phetteplace, D.L. Bonk, J. Westerman, R.T. Lorand, } \\
\text { V. Vaysman, D. Stauffer, K. Hudson, M. DeLallo, } \\
\text { and T. Buchanan }\end{array}$ & ADB325953 \\
\hline ERDC TR-06-9 & Oct 2006 & $\begin{array}{l}\text { Electro-Osmotic Pulse Technology for Control of } \\
\text { Water Seepage in Various Civil Works Structures, } \\
\text { by V.F. Hock, O.S. Marshall, M.K. Mclnerney, S. } \\
\text { Morefield, P. Malone, C. Weiss, J. Kleinschmidt, A. } \\
\text { Harrer, K. Holtz, D. Goran, K. Richardson, and R. } \\
\text { Condon }\end{array}$ & ADA459075 \\
\hline
\end{tabular}
Condon

\footnotetext{
1 Limited distribution; see Preface.
} 
$\begin{aligned} \text { ERDC TR-06-10 Oct } 2006 \quad & \text { Building Information Modeling (BIM): A Road Map } \\ & \text { for Implementation to Support MILCON } \\ & \text { Transformation and Civil Works Projects within the } \\ & \text { U.S. Army Corps of Engineers, by B.A. Brucker, M.P. } \\ & \text { Case, E.W. East, B.K. Huston, S.D. Nachtigall, J.C. } \\ & \text { Shockley, S.C. Spangler, and J.T. Wilson }\end{aligned}$

ERDC TR-06-10

Sup. 2

Jan 2011

Building Information Modeling (BIM) Roadmap:

Supplement 2 - BIM Implementation Plan for Military Construction Projects, Bentley Platform, by Bentley Systems, Inc.

ERDC TR-06-11 Oct 2006

Screening Level Ecological Risk Assessments of Some Military Munitions and Obscurant-related Compounds for Selected Threatened and Endangered Species, by K. Von Stackleberg, C. Amos, C. Butler, T. Smith, J. Famely, M. McArdle, B. Southworth, and J. Steevens

ERDC TR-06-12 Nov 2006

Distribution and Fate of Energetics on DoD Test and Training Ranges: Interim Report 6, by J.C. Pennington, T.F. Jenkins, G. Ampleman, S. Thiboutot, A.D. Hewitt, S. Brochu, J. Robb, E. Diaz, J. Lewis, H. Colby, R. Martel, K. Poe, K. Groff, K.L. Bjella, C.A. Ramsey, C.A. Hayes, S. Yost, A. Marois, A. Gagnon, B. Silverblatt, T. Crutcher, K. Harriz, K. Heisen, S.R. Bigl, T.E. Berry, Jr., J. Muzzin, D.J. Lambert, M.J. Bishop, B. Rice, M. Wojtas, M.E. Walsh, M.R. Walsh, and S. Taylor

ERDC TR-06-13 Nov 2006

Distribution and Fate of Energetics on DoD Test and Training Ranges: Final Report, by J.C. Pennington, T.F. Jenkins, G. Ampleman, S. Thiboutot, J.M. Brannon, A.D. Hewitt, J. Lewis, S. Brochu, E. Diaz, M.R. Walsh, M.E. Walsh, S. Taylor, J.C. Lynch, J. Clausen, T.A. Ranney, C.A. Ramsey, C.A. Hayes, C.L. Grant, C.M. Collins, S.R. Bigl, S. Yost, and K. Dontsova

ERDC TR-06-14

Nov 2006

Strategic Plan Outline for the Army Utilities Modernization Program: Fiscal Years 2008-2013, by W. Brown, J. Vavrin, N. Potts, C. Marsh, V. Hock, A. Zhivov, F. Holcomb, C. Sohn, R. Scholze, H. Gignilliat, C. Zeigler, P. Volkman, C. Jones, and G. Phetteplace

ERDC TR-06-15

Nov 2006

Waves in Seagrass Systems: Review and Technical Recommendations, by E.W. Koch, L.P. Sanford, S. Chen, D.J. Shafer, and J.M. Smith

ERDC TR-06-16 Dec 2006

\section{Guidance for Mitigating Environmental Concerns} During Range Siting, by R. Busby, M. Chawla, M. Denight, D. Gebhart, H. Howard, T. Palazzo, and N. Svendsen
ADA480246

ADA539810

ADA467991

ADA458384

ADA458391

ADA460736

ADA458760

ADA460059 


$\begin{array}{ll}\text { ERDC TR-07-1 Jan } 2007 & \text { Characterization and Fate of Gun and Rocket } \\ \text { Rep. 1 } & \text { Propellant Residues on Testing and Training } \\ & \text { Ranges: Interim Report 1, by T.F. Jenkins, J.C. } \\ & \text { Pennington, G. Ampleman, S. Thiboutot, M.R. } \\ & \text { Walsh, E. Diaz, K.M. Dontsova, A.D. Hewitt, M.E. } \\ & \text { Walsh, S.R. Bigl, S. Taylor, D.K. MacMillan, J.L. } \\ & \text { Clausen, D. Lambert, N.M. Perron, M.C. Lapointe, } \\ & \text { S. Brochu, M. Brassard, R. Stowe, R. Farinaccio, A. } \\ & \text { Gagnon, A. Marois, D. Gilbert, D. Faucher, S. Yost, } \\ \text { C. Hayes, C.A. Ramsey, R.J. Rachow, J.E. Zufelt, } & \text { C.M. Collins, A.B. Gelvin, and S.P. Saari }\end{array}$

ERDC TR-07-2 Jul 2007

Long-Term Monitoring of Natural Attenuation of Explosives at the Louisiana Army Ammunition Plant, Five-Year Data Report, by D.W. Harrelson, M. Zakikhani, M.K. Corcoran, J.U. Clarke, and W.A. Sniffen

ERDC TR-07-3 Jul 2007

Flood-Fighting Structures Demonstration and Evaluation Program: Laboratory and Field Testing in Vicksburg, Mississippi, by F. Pinkard, T. Pratt, D. Ward, T. Holmes, J. Kelley, L.T. Lee, G. Sills, E. Smith, P.A. Taylor, N. Torres, L. Wakeley, and J. Wibowo

\begin{tabular}{|c|c|c|}
\hline ERDC TR-07-4 & Jul 2007 & $\begin{array}{l}\text { Standards for the Mobility Common Operational } \\
\text { Picture (M-COP): Elements of Ground Vehicle } \\
\text { Maneuver, by P.W. Richmond, C.L. Blais, J.A. Nagle, } \\
\text { N.C. Goerger, B.Q. Gates, R.K. Burk, J. Willis, and R. } \\
\text { Keeter }\end{array}$ \\
\hline ERDC TR-07-5 & Aug 2007 & $\begin{array}{l}\text { Fate and Transport of Tungsten at Camp Edwards } \\
\text { Small Arms Ranges, by J.L. Clausen, S. Taylor, S.L. } \\
\text { Larson, A.J. Bednar, M. Ketterer, C.S. Griggs, D.J. } \\
\text { Lambert, A.D. Hewitt, C.A. Ramsey, S.R. Bigl, R.N. } \\
\text { Bailey, and N.M. Perron }\end{array}$ \\
\hline ERDC TR-07-6 & Sep 2007 & $\begin{array}{l}\text { Geologic Conceptual Model of Mosul Dam, by L.D. } \\
\text { Wakeley, J.R. Kelley, C.A. Talbot, M.L. Pearson, and } \\
\text { S.W. Broadfoot }\end{array}$ \\
\hline ERDC TR-07-7 & Aug 2007 & $\begin{array}{l}\text { The TeleEngineering Toolkit Software Reference } \\
\text { Manual, by J.D. Jorgeson, W.W. Berry, R.D. Taylor, } \\
\text { S.K. Fairley, J.M. Jackson, J.L. Williamson, and B.T. } \\
\text { Webb }\end{array}$ \\
\hline ERDC TR-07-8 & Sep 2007 & $\begin{array}{l}\text { Camp Humphreys, Korea, Groundwater } \\
\text { Assessment, by D.W. Harrelson, M. Zakikhani, and } \\
\text { M.J. Waterbury }\end{array}$ \\
\hline
\end{tabular}

ADA471046

ADA470948

ADA470946

ADA471941

ADA472031

ADA471784

ADA471650 


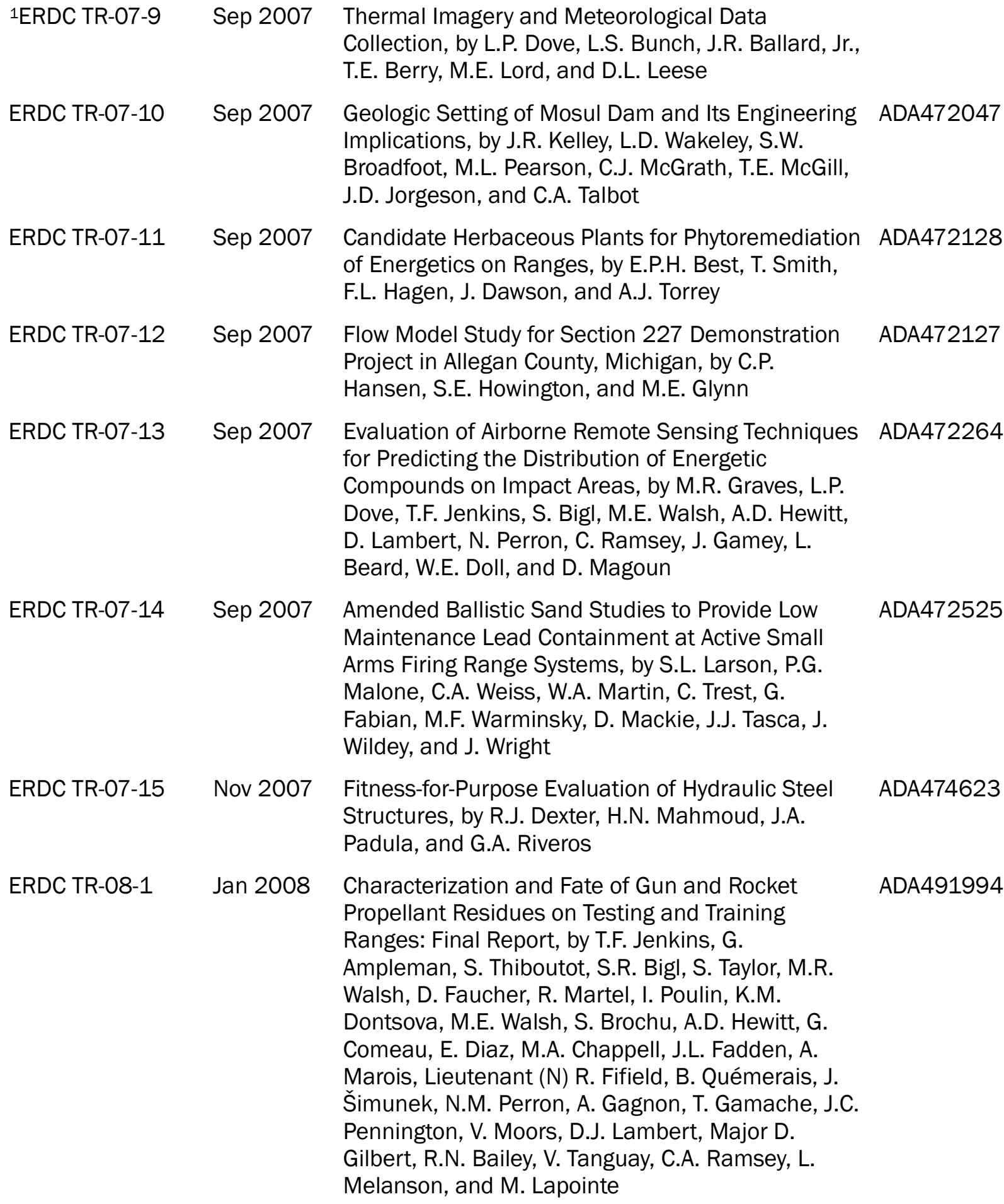

1ERDC TR-08-2 Feb 2008 Trafficability Cone Index Dataset, by D. Diemand, S.A. Shoop, G.L. Mason, P.M. Seman, and G.M. Brandon 
1ERDC TR-08-3 Feb 2008 Port of Los Angeles: Inner Cabrillo Beach, Water Quality Improvement Project, by S.K. Martin, D.H. Tillman, W.C. Seabergh, R. McAdory, B.W. Bunch, M.J. Briggs, H. Acuff, and F.C. Carson

ERDC TR-08-4 Mar 2008 Change Material Survey, by J.L. Alvarado, B.G. Jones, C.P. Marsh, D.A. Kessler, C.W. Sohn, C.A. Feickert, G.E. Phetteplace, J.J. Parilla, E.D. Crowley, R.J. Franks, and T.A. Carlson

ERDC TR-08-5 Mar 2008 Boat-Wave-Induced Bank Erosion on the Kenai River, Alaska, by S.T. Maynord, D.S. Biedenharn, C.J. Fischenich, and J.E. Zufelt

1ERDC TR-08-6 Apr 2008

Circulation and Water Quality Modeling in Support of Deepening the Port of Los Angeles: Alternative Disposal Sites, by D.H. Tillman, R. McAdory, B.W. Bunch, S.K. Martin, M.J. Biggs, F.C. Carson, G. Savant, and N.K. Raphelt

ERDC TR-08-7 Jun 2008 Assessment of the Effectiveness of Clay Soil Covers as Engineered Barriers in Waste Disposal Facilities with Emphasis on Modeling Cracking Behavior, by E.S. Berney IV, W.D. Hodo, J.F. Peters, T.E. Myers, R.S. Olsen, and M.K. Sharp

ERDC TR-08-8 Sep 2008 Capacities of Candidate Herbaceous Plants for Phytoremediation of Soil-based TNT and RDX on Ranges, by E.P.H. Best, T. Smith, F.L. Hagen, J.O. Dawson, and A.J. Torrey

ERDC TR-08-9 Sep 2008 Estimating Bottom Water Dissolved Oxygen in the Mississippi River Gulf Outlet and Gulf Intracoastal Waterway Resulting from Proposed Structures, by M.S. Dortch and S.K. Martin

ERDC TR-08-10 Nov 2008 Invasive Species Biology, Control, and Research. Part 1: Kudzu (Pueraria montana), by P.J. Guertin, M.L. Denight, D.L. Gebhart, and L. Nelson

ERDC TR-08-11 Nov 2008 Invasive Species Biology, Control, and Research. Part 2. Multiflora Rose (Rosa multiflora), by M.L. Denight, P.J. Guertin, D.L. Gebhart, and L. Nelson
ADA489006

ADA489595

ADA491410

ADA492988

ADB337015

ADA489460

ADA479220

ADB339195

ADA484170

ADA489595

ADA491410

ADA492988
1ERDC TR-08-12 Dec 2008
Expectation Filtering to Improve Automated Mine Detection Systems: Concept Description and Preliminary Evaluation, by B. Sabol, W. Johnson, J.R. Fairley, G.M. Brandon, and B.D. Durst

\footnotetext{
1Limited distribution; see Preface.
} 


\begin{tabular}{|c|c|c|c|}
\hline 1ERDC TR-09-1 & Feb 2009 & $\begin{array}{l}\text { Protocol for Field Sampling of Soils to Support Soil- } \\
\text { Sensor Technology and IED Blast-Phenomenology } \\
\text { Modeling, by L.D. Wakeley, J.R. McKenna, J.R. } \\
\text { Kelley, T.E. Berry, S.S. Jackson, S.G. Bourne, and E. } \\
\text { Villanueva }\end{array}$ & \\
\hline ERDC TR-09-2 & Feb 2009 & $\begin{array}{l}\text { Permanent Seismically Induced Displacement of } \\
\text { Rock-Founded Structures Computed by the } \\
\text { Newmark Program, by R.M. Ebeling, M.T. Fong, D.E. } \\
\text { Yule, A. Chase, Sr., and R.V. Kala }\end{array}$ & ADA494750 \\
\hline ERDC TR-09-3 & Jan 2009 & $\begin{array}{l}\text { Sensitivity Analysis of QSAR Models for Assessing } \\
\text { Novel Military Compounds, by J.L. Clausen, E. } \\
\text { Bennett, and I. Linkov }\end{array}$ & ADA494746 \\
\hline ERDC TR-09-4 & Feb 2009 & $\begin{array}{l}\text { Evaluation of DOD Priority Species at Risk (SAR) } \\
\text { and Applications for Remote Sensing, by M.V. } \\
\text { Campbell, S.D. Newman, and S.A. Tweddale }\end{array}$ & ADA494705 \\
\hline 1ERDC TR-09-5 & May 2009 & $\begin{array}{l}\text { Actionable Cultural Understanding for Support to } \\
\text { Tactical Operations (ACUSTO): Analysis of Text } \\
\text { Mining for Socio-Cultural Data Extraction, by L.A. } \\
\text { Whalley, W.D. Meyer, D.A. Krooks, T.K. Perkins, P.J. } \\
\text { Guertin, J.L. Jarrett, M.K. Chawla, K. McGuire, and } \\
\text { M.D. Ginsberg }\end{array}$ & \\
\hline ERDC TR-09-6 & May 2009 & $\begin{array}{l}\text { Mobility Performance Algorithms for Small } \\
\text { Unmanned Ground Vehicles, by P.W. Richmond, } \\
\text { G.L. Mason, B.A. Coutermarsh, J. Pusey, and V.D. } \\
\text { Moore }\end{array}$ & ADA500849 \\
\hline 1ERDC TR-09-7 & Aug 2009 & $\begin{array}{l}\text { Protocol for Field Sampling of Soils to Support } \\
\text { Three-Dimensional Modeling of Geo-environments } \\
\text { and Soil-Sensor Interaction, by L.D. Wakeley, J.R. } \\
\text { Kelley, T.E. Berry, S.S. Jackson, and S.G. Bourne }\end{array}$ & \\
\hline ERDC TR-09-8 & Sep 2009 & $\begin{array}{l}\text { High Strain-Rate Testing of Mechanical Couplers, } \\
\text { by S.P. Rowell, C.E. Grey, S.C. Woodson, and K.P. } \\
\text { Hager }\end{array}$ & ADA508609 \\
\hline ERDC TR-09-9 & Nov 2009 & $\begin{array}{l}\text { Attenuation of Electromagnetic Energy in Soil from } \\
\text { Yuma Proving Ground, by G. Koh and L.D. Wakeley }\end{array}$ & \\
\hline ERDC TR-09-10 & Dec 2009 & $\begin{array}{l}\text { Phytoremediation of Composition-B Derived TNT } \\
\text { and RDX in Herbaceous Plant-vegetated and Bare } \\
\text { Lysimeters, by E.P.H. Best, J.C. Smith, and D.B. } \\
\text { Ringelberg }\end{array}$ & ADA529164 \\
\hline 1ERDC TR-10-2 & Mar 2010 & $\begin{array}{l}\text { Database of Properties of Iraq Soils, by L.D. } \\
\text { Wakeley, S.S. Jackson, L. Walizer, and J.R. } \\
\text { McKenna }\end{array}$ & \\
\hline
\end{tabular}

1 Limited distribution; see Preface. 


\begin{tabular}{|c|c|c|c|}
\hline 1ERDC TR-10-3 & May 2010 & $\begin{array}{l}\text { Land Warrior Strike System: Results from Blast } \\
\text { Load Simulator Experiments, by C.F. Johnson, L.L. } \\
\text { Smith, D. Hollenbaugh, D. Copeland, and H. } \\
\text { Lilienfield }\end{array}$ & \\
\hline ERDC TR-10-4 & May 2010 & $\begin{array}{l}\text { Laboratory and Field Evaluation of Rapid Setting } \\
\text { Cementitious Materials for Large Crater Repair, by } \\
\text { L.A. Barna, J.S. Tingle, and P.S. McCaffrey }\end{array}$ & ADA554424 \\
\hline ERDC TR-10-5 & May 2010 & $\begin{array}{l}\text { A Generic Reaction-Based BioGeoChemical } \\
\text { Simulator (RBBGCS), Version 1.O, by H. Cheng, S.E. } \\
\text { Howington, M.W. Farthing, C.J. McGrath, and J.C. } \\
\text { Cheng }\end{array}$ & ADA529172 \\
\hline 1ERDC TR-10-6 & Jul 2010 & $\begin{array}{l}\text { Military Utility Assessment of the Computer Aided } \\
\text { Tele-Operation and Computer Aided Robotic } \\
\text { Manipulation Technologies with the TALON IIIB, by } \\
\text { C.T. Goodin, J.A. Nagle, S. Werkmeister, S.N. } \\
\text { Decato, and A. Bodenhamer }\end{array}$ & \\
\hline ERDC TR-10-7 & Aug 2010 & $\begin{array}{l}\text { Deformable Bullnose Energy Absorbing System } \\
\text { (BEAS). Report 1: Initial Development and Concept } \\
\text { Design, by R.M. Ebeling, J.E. Hite, Jr., R.W. Strom, } \\
\text { and B.C. White }\end{array}$ & \\
\hline ERDC TR-10-8 & Sep 2010 & $\begin{array}{l}\text { Multibeam Bathymetry, Terrestrial LiDAR } \\
\text { Topography, and Three-Dimensional Velocity } \\
\text { Structure Observations of the Ice Marginal Marine } \\
\text { Environment at Hubbard Glacier, AK, by D.C. } \\
\text { Finnegan, D.E. Lawson, W. Butler, T. Waller, and T. } \\
\text { Pratt }\end{array}$ & \\
\hline ERDC TR-10-9 & Sep 2010 & $\begin{array}{l}\text { Geophysics for Military Construction Projects, by } \\
\text { K.L. Bjella, B.N. Astley, and R.E. North }\end{array}$ & ADA531964 \\
\hline 1ERDC TR-10-10 & Sep 2010 & $\begin{array}{l}\text { Dominguez Channel: Hydrodynamic and TMDL } \\
\text { Tools, by G. Savant, D.H. Tillman, S.K. Martin, B.W. } \\
\text { Bunch, R.T. McAdory, and M.J. Briggs }\end{array}$ & \\
\hline 1ERDC TR-10-11 & Nov 2010 & $\begin{array}{l}\text { Development and Testing of Innovative Repair } \\
\text { Materials for Blast Mitigation Application on } \\
\text { Navigation Lock Walls, by C.A. Weiss, Jr., R.W. } \\
\text { Haskins, B.H. Green, B.H. Sherwin, J. Morson, and } \\
\text { A.M. Sutin }\end{array}$ & \\
\hline ERDC TR-10-12 & Nov 2010 & $\begin{array}{l}\text { Decision Making Under Uncertainty, by M.T. } \\
\text { Schultz, K.N. Mitchell, B.K. Harper and T.S. Bridges }\end{array}$ & ADA534878 \\
\hline ERDC TR-11-1 & Jan 2011 & $\begin{array}{l}\text { Tungsten Speciation in Firing Range Soils, by J.L. } \\
\text { Clausen, B.C. Bostick, A. Bednar, J. Sun and J.D. } \\
\text { Landis }\end{array}$ & ADA535133 \\
\hline
\end{tabular}

1 Limited distribution; see Preface. 


\begin{tabular}{|c|c|c|}
\hline ERDC TR-11-2 & Jan 2011 & $\begin{array}{l}\text { Application of Long Distance Conveyance (LDC) of } \\
\text { Dredged Sediments to Louisiana Coastal } \\
\text { Restoration, by T. Welp and G. Ray }\end{array}$ \\
\hline ERDC TR-11-4 & Jul 2011 & $\begin{array}{l}\text { Erie Harbor, Pennsylvania, Channel Shoaling } \\
\text { Analysis, by M. Zakikhani, D.W. Harrelson, M. Mohr, } \\
\text { and S. Chader }\end{array}$ \\
\hline ERDC TR-11-5 & Jul 2011 & $\begin{array}{l}\text { Deformable Bullnose Energy Absorbing System } \\
\text { (BEAS). Report 2: Head-On Impact with a } \\
\text { Deformable BEAS and Introducing a Collapsible } \\
\text { Arch, by R.M. Ebeling, B.C. White, R.W. Strom, J.E. } \\
\text { Hite, Jr., B.C. Barker, and R.W. Haskins }\end{array}$ \\
\hline 1ERDC TR-11-6 & Jul 2011 & $\begin{array}{l}\text { Military Utility Assessment of Standoff Explosive } \\
\text { Detection System, by P.J. Durst, C.T. Goodin, J.A. } \\
\text { Nagle, and S. Werkmeister }\end{array}$ \\
\hline 1ERDC TR-11-7 & Aug 2011 & $\begin{array}{l}\text { Active Seismic Imaging at San Luis, Arizona, in } \\
\text { Support of Tunnel Detection, by S.D. Sloan, J.R. } \\
\text { McKenna, S.W. Broadfoot, O.M. Metherny, R.D. } \\
\text { Miller, S.L. Peterie, J. Ivanov, and L.D. Wakeley }\end{array}$ \\
\hline ERDC TR-11-8 & Aug 2011 & $\begin{array}{l}\text { Risks to Navigation at the Matagorda Ship Channel } \\
\text { Entrance, Texas, Phase 2: Evaluation of Significant } \\
\text { Risk Factors, by S.T. Maynord, L. Lin, N.C. Kraus, } \\
\text { D.W. Webb, G. Lynch, R.E. Wahl, D.A. Leavell, D.E. } \\
\text { Yule, and J.B. Dunbar }\end{array}$ \\
\hline 1ERDC TR-11-9 & Sep 2011 & $\begin{array}{l}\text { Distributing and Modeling Soil Properties in a Near- } \\
\text { Surface Geologic Environment, by L.D. Wakeley, } \\
\text { S.W. Broadfoot, B.D. Haugen, S.G. Bourne, C.A. } \\
\text { Talbot, J.R. Kelley, S.S. Jackson, C. Roig-Silva, and } \\
\text { J.R. McKenna }\end{array}$ \\
\hline
\end{tabular}

ERDC TR-11-10 Sep $2011 \quad \begin{aligned} & \text { PT123: A Multi-Dimensional Particle Tracking } \\ & \text { Computer Program, Version 1.0, by H. Cheng, M.W. }\end{aligned}$

ADA552797 Farthing, K.D. Winters, S.E. Howington, J.C. Cheng, and $A$. Hines

ERDC TR-11-11 Sep 2011 Field-portable Gas Chromatograph Mass Spectrometer (GC-MS) Unit for Semi-volatile Compound Analysis in Groundwater, by A.J. Bednar, A.L. Russell, T. Georgian, D. Splichal, C.A. Hayes, P. Tackett, W.T. Jones, D. Justes, L. Parker, R.A. Kirgan, and M. Wells

ADA547402

ADA536630

ADA546701

ADA546504

Evaluation of Sampling and Sample Preparation

ADA556161 Modifications for Soil Containing Metallic Residues, by J.L. Clausen, T. Georgian, J. Richardson, A. Bednar, N. Perron, A. Bray, P. Tuminello, L. Penfold, D. Anderson, G. Gooch, T. Hall, W. Jones, S. Tazik, and E. Butterfield 

1ERDC TR-12-2 Feb 2012 Overhead Coverage System - Large Rocket
Protection: Full Scale Experiment, by C.D. Price, W.J. McCleave, R.N. Boone, T.R. Slawson, and C.E. Grey
1ERDC TR-12-3
Mar 2012
Military Utility Assessment of the Autonomous Robotic Countermine System 2 (ARCS2) with the Talon IIIB, by C. Goodin, J.A. Nagle, and S.
Werkmeister

ERDC TR-12-4 Jun 2012
Fragility Analysis of a Concrete Gravity Dam Embedded in Rock and Its System Response Curve Computed by the Analytical Program GDLAD_Foundation, by R.M. Ebeling, M.T. Fong, J.L. Wibowo, and A. Chase, Sr.

ERDC TR-12-5 Apr 2012
Environmental Assessment During Intelligence Preparation of the Battlefield (IPB) - Evaluation of the TIC-Master Computer Program, by V.F. Medina, D.L. Brandon, K.J. Hay, D.S. Khona, H.K. Smith, and A.B. Morrow

1ERDC TR-12-6

Apr 2012

Automated Detailed Equipment Decontamination Advanced Technology Demonstration Baseline Experiment, by C. Goodin, J.A. Nagle, P.J. Durst, and M.K. Klaus

ERDC TR-12-7 Aug 2012

The Quantification and Evolution of Resilience in Integrated Coastal Systems, by M.T. Schultz, S.K. McKay, and L.Z. Hales

ERDC TR-12-8 Aug 2012 Biopolymers as an Alternative to Petroleum-Based Polymers for Soil Modification; ESTCP ER-0920: Treatability Studies, by S.L. Larson, J.K. Newman, C.S. Griggs, M. Beverly, and C.C. Nestler

ERDC TR-12-9 Aug 2012 Towards Development of a Super Ceramic Composite - Initial Investigation into Improvement of Strength and Toughness of Polycrystalline Ceramics, by J.F. Peters, J.P. Allen, P.G. Allison, T.A. Carlson, M.Q. Chandler, C.F. Cornwell, B.D. Devine, F.C. Hill, N.J. Lee, C.P. Marsh, P.B. Stynoski, L. Walizer, and C.R. Welch

ERDC TR-12-10 Jun 2012 Index of Available Research on Military Impacts: Optimal Allocation of Land for Training and Nontraining Uses, by M.E. Ricci, A.P. Dain-Owens, A.B. Anderson, R.A. Jones, H.R. Howard, A.M. Effinger, and J.S. Fehmi
ADB397428

ADB395218

ADA582505

ADA559632

ADA570387

ADA565795

ADA570342

ADA566092

\footnotetext{
1 Limited distribution; see Preface.
} 
ERDC TR-12-11 Sep 2012 Lake Michigan Bluff Dewatering and Stabilization

ADA570013

Study - Allegan County, Michigan, by M.E. Glynn,

R.B. Chase, A.E. Kehew, J.P. Selegean, M.G. Ferrick, and C.M. Hansen

ERDC TR-12-12

Sep 2012 Data Preparation Procedures for the ERDC High-

Energy Large-Scale Blast Sound Propagation

Experiment, by D.P. Valente, L. Ronsse, R.D. Serwy,

J. Barr, K. Claffey, M.J. White, and M.E. Swearingen

ERDC TR-12-13 Dec 2012 GEOTACS: Countermine Computational Testbed

Results for an Undifferentiated Highlands Climatic

Zone, Part 1. A Comparison of Field-collected

Electro-optical/Infrared Imagery to Simulation

Results from the Countermine Computational

Testbed, Soil Model Only, by O.J. Eslinger, A.M.

Hines, C. Winton, S.E. Howington, R. Goodson, R.

Kala, J.R. Fairley, S. Price, and K. Elder

ERDC TR-12-14 Dec 2012 Demonstration of a Rapid Energy Audit Procedure

ADA582697 for use with an Army Sustainment Management System (SMS), by J.E. Karbarz and M.N. Grussing

ERDC TR-12-15

Dec 2012

ROOFER Inventory Procedures and Inspection

ADA582971 Manual for Metal Panel Roofing, by D.M. Bailey, J.E. Karbarz, and K.E. Sweeton

ERDC TR-12-16

May 2012

Molecular Modeling of Chem-Bio (CB) Contaminant

ADA614352 Sorption/Desorption and Reactions in Chlorinated Water Systems, by M.D. Ginsberg, V.F. Hock, M. Hurley, F. Hill, A. Aksimentiev, R.C. Carr, J.R. Comer, K.A. Guy, A. Beckman, M. Rivera-Sustache, A.

Nelson, M. Page, A. Ehmann, and V.L. Van Blaricum

ERDC TR-13-1 Jan 2013 Rapid Evaluation Of Water Phoenix Portable Wastewater Treatment System, by J.I. Oren, R.T. Affleck, S.D. Hart, S.W. Maloney, C.M. Reynolds, D.B. Ringelberg, M.A. Page, and R.J. Scholze

1ERDC TR-13-2 Feb 2013 Reststrahlen Studies at Yuma Proving Ground and China Lake, by S.E. Robert, G. Koh, and J.R. Fairley

ERDC TR-13-3 Jul 2013 Assessing Corrosion Damage and Corrosion Progression in Multistrand Anchor Systems in Use at Corps Projects, by R.M. Ebeling, R.W. Strom, J.E. Hite Jr., R.W. Haskins, and J.A. Evans

ERDC TR-13-4 Aug 2013 Small Wind Turbine Installation Compatibility Demonstration Methodology, by C. Ryerson, K.

ADB390384

ADA582963 MacDonald, S. Rowley, W. Stein, D. Albert, G. Koenig, G. Koh, A. Song, C. Schadock, and J. Wagner

1 Limited distribution; see Preface. 


\begin{tabular}{|c|c|c|}
\hline ERDC TR-13-5 & Aug 2013 & $\begin{array}{l}\text { Incremental Sampling Methodology (ISM) for } \\
\text { Metallic Residues. Project ER-0918, by J.L. } \\
\text { Clausen, T. Georgian, and A. Bednar }\end{array}$ \\
\hline ERDC TR-13-6 & Sep 2013 & $\begin{array}{l}\text { Investigation of the Use of Geobags to Immobilize } \\
\text { Submerged Munitions: A Report on the Concept, } \\
\text { Development, and Testing, by B.W. Bunch, C.E. } \\
\text { Ruiz, S.E. Bailey, W.A. Martin, R.S. Chapman, and P. } \\
\text { Sheehan }\end{array}$ \\
\hline ERDC TR-13-7 & Aug 2013 & $\begin{array}{l}\text { Analysis Techniques, Materials, and Methods for } \\
\text { Treatment of Thermal Bridges in Building } \\
\text { Envelopes, by B.P. Barnes, A. Pagán-Vázquez, A.P. } \\
\text { Heffron, B.B. Mehnert, M.P. Case, A. Kumar, J.L. } \\
\text { Lattimore, R.J. Liesen, L.D. Stephenson, J.C. } \\
\text { Trovillion, and J.B. Allen }\end{array}$ \\
\hline
\end{tabular}

ERDC TR-13-8 Sep 2013 Development of Parallel GSSHA, by P.R. Eller, J.C. Cheng, A.R. Byrd, C.W. Downer, and N. Pradhan ERDC TR-13-9 Sep $2013 \quad \begin{aligned} & \text { Demonstration of Incremental Sampling } \\ & \text { Methodology for Soil Containing Metallic Residues. } \\ & \text { Project ER-0918, by J.L. Clausen, T. Georgian, A. }\end{aligned}$

ADA601818 Bednar, N. Perron, A. Bray, P. Tuminello, G. Gooch, N. Mulherin, A. Gelvin, M. Beede, S. Saari, W. Jones, and S. Tazik

ERDC TR-13-10

Sep 2013 Cost and Performance Report of Incremental Sampling Methodology for Soil Containing Metallic

ADA585469

ADA586172 Residues. Project ER-0918, by J.L. Clausen, T. Georgian, and A. Bednar

ERDC TR-13-11 Sep 2013 Laboratory Studies of Wave Attenuation through Artificial and Real Vegetation, by M.E. Anderson, J.M. Smith, D.B. Bryant, and R.G.W. McComas

ERDC TR-13-12 Sep 2013 Mississippi Coastal Improvements Program; Evaluation of Barrier Island Restoration Efforts, by T.V. Wamsley, E.S. Godsey, B.W. Bunch, R.S. Chapman, M.B. Gravens, A.S. Grzegorzewski, B.D. Johnson, D.B. King, R.L. Permenter, D.H. Tillman, and M.W. Tubman

ERDC TR-13-13 Sep 2013 Indigenous Construction Materials for Theater Facilities, by G. Al-Chaar, L.A. Whalley, J.T.

ADA586271 ADA584926

ADA586365

ADA586333

ADA586360 Beckstrom, H.G. Anderson, R.T. Affleck, M. Carr, and J.S. Macpherson

ERDC TR-13-14 Oct 2013 Mobile Information Collection Application: Water Equipment Tracker (MICA:WET) Tool, by L.E. Curvey, R. Phillips, N.L. Potts, J. Stinson, and E. Roth

ADA589483 
ERDC TR-13-15 Nov $2013 \quad \begin{aligned} & \text { Development of a Coupled Framework for } \\ & \text { Simulating Interactive Effects of Frozen Soin }\end{aligned}$

ADA588992 Hydrological Dynamics in Permafrost Regions, by N.R. Pradhan, C.W. Downer, S. Marchenko, A. Liljedahl, T.A. Douglas, and A. Byrd

ERDC TR-13-16

1ERDC TR-13-17

ERDC TR-14-1

ERDC TR-14-2

ERDC TR-14-3

1ERDC TR-14-4

ERDC TR-14-5

ERDC TR-14-6

ERDC TR-14-7
Sep 2013

Asset Management and Facility Equipment Maintenance Nexus: Maintenance Effectiveness, by S.D. Foltz, C.B. Bislip-Morales, and E.A. Hammack

Dec 2013 Silicon Carbide Fiber-Reinforced Glass "Super Ceramic" Composite Preliminary Design and Predicted Properties, by C.R. Welch, J.B. Allen, C.F. Cornwell, T.A. Carlson, and C.P. Marsh

Feb 2014

Interaction between Brash Ice and Boat Propulsion Systems, by K.L. Haskins, Z.R. Courville, D.S. Sodhi, J.M. Stanley, L.J. Zabilansky, and J.M. Story

Apr 2014

Composting Assessment for Organic Solid Waste at Fort Polk, Louisiana, by V.F. Medina, M. Wynter, S. Cosper, G. Rodriguez, D. Gebhart, S. Hunter, and P. Kemme

May 2014

Anaerobic Digestion Assessment for Contingency Base Waste, by V.F. Medina, S. Waisner, S. Cosper, G. Rodriguez, D. Gilbert, R. Tucker, I. MacAllister, R. Scholze, J. Burken, and J. Wang

Jul 2014

ERDC Dismount Counter Improvised Explosive Device (CIED) Task Force Study, by J.R. Fairley, S.E. Robert, G.G. Koenig, Y.G. Koh, D.G. Albert, K.F. Jones, J.E. Fiori, N.J. Lamie, B.J. Jones, J.M.

Stanley, E.S. Berney, IV, S.J. Price, R.V. Kala, D.P. Mclnnis, C.A. Barela, and R.D. Ellison

Aug 2014

Storm-Water Sampling for Depleted Uranium at Makua Military Reservation, Oahu, Hawaii, by C.W. Downer, S.J. Trumbull, D.W. Harrelson, A.L. Bufkin, and N. Torres

Sep 2014

Comparison/Validation Study of Lattice Bo
and Navier Stokes for Various Benchmark Applications: Report 1 in "Discrete Nano-Scale Mechanics and Simulations" Series, by J.B. Allen, W.D. Hodo, L. Walizer, D.P. McInnis, A. Carrillo, B. Jelinek, D. Johnson, J. Peters, and S.D. Felicelli

Sep 2014 Three-Dimensional Shallow-Water Adaptive Hydraulics (ADH-SW3): Hydrodynamic Verification and Validation, by G. Savant, R.C. Berger, T.O. McAlpin, and C.J. Trahan

ADA596756

ADA601307

ADB401198

ADA610898

ADA610237

ADA599276

AD

ADA601295

ADA601307 
ERDC TR-14-8 Mar 2015 Modeling of Waves, Hydrodynamics and Sediment

ADA614136

Transport for Protection of Wetlands at Braddock

Bay, New York, by Z. Demirbilek, L. Lin, E. Hayter, C.

O'Connell, M. Mohr, S. Chader, and C. Forgette

ERDC TR-14-9 Sep 2014 Technical Guidelines on Performing a Sediment

ADA610123

Erosion and Deposition Assessment (SEDA) at

Superfund Sites, by E. Hayter, K. Gustavson, S. Ells,

J. Gailani, J. Wolfe, T. Dekker, and T. Redder

ERDC TR-14-10

Oct 2014 Laboratory Evaluation of Expedient Low-

ADA610768

Temperature Admixtures for Runway Craters in Cold Weather, by J.I. Oren, R.D. Moser, V. Boddu, C.A.

Weiss, Jr., and J. Clausen

ERDC TR-14-11

Nov 2014

Ecological Modeling System: Conceptual

Development and Design Specification, by T.

Swannack, J. Westervelt, J. Hensley, and R.

Kennedy

ERDC TR-14-12 Dec 2014 Experimental Evaluation of the Failure of a Seismic Design Category - B Precast Concrete Beam-

Column Connection System, by J.O. Torres-Alamo, V.P. Chiarito, and H.L. Blake

ERDC TR-15-1 Mar 2015 Field Biogeochemical Measurements in Support of

ADA614441

Remote Sensing Signatures and Characterization

of Permafrost Terrain: Integrated Technologies for

Delineating Permafrost and Ground-State

Conditions, by R.A. Barbato, J.E. Anderson, J.D.

Edwards, K.L. Foley, C.M. Reynolds, and T.A.

Douglas

ERDC TR-15-2 Jun 2015 High-Performance Plastic Sled Design for Polar

Traversing, by J.C. Weale, J.H. Lever, and J.

Trovillion

1ERDC TR-15-3 Aug 2015 DBA-105P Re-development, Sensitivity Studies on Oxidizer Chemistry and Slurry Mixing, by M.J. Roth, D.V. Senior, B.W. Bullock, D.C. Guynes, R.E. Magee, C.W. Ertle II, A.J. Bednar, and C.A. Hayes

ERDC TR-15-4 Aug 2015 Hydrologic Analysis of Fort Leonard Wood, Missouri, by M.L. Follum, D.C. McVan, E.M. Jenicek, and M.P. Case

ADA613557

ADA619010

Persistent Monitoring of Urban Infrasound

Phenomenology. Report 1: Modeling an Urban

Environment for Acoustical Analyses using the 3-D

Finite-Difference Time-Domain Program PSTOP3D,

by M.E. Pace, S.L. McComas, and M.H. McKenna

ADA620554

ADA621157

Rep. 1

Aug 2015

1 Limited distribution; see Preface. 
ERDC TR-15-6 Aug 2015 User's Manual for Armor Stone Evaluation Model

ADA620723 (ARMOR): Great Lakes Armor Stone Study, by M. Zakikhani, D.W. Harrelson, A.L. Tillotson, and J.D. Ables

ERDC TR-15-7 Aug 2015 Investigation of Soil and Vegetation Characteristics

ADA623196 in Discontinuous Permafrost Landscapes Near Fairbanks, Alaska, by J.F. Berkowitz, C.A. Hiemstra, and T.A. Douglas

ERDC TR-15-10 Nov 2015 Analysis of Operational Data: A Proof of Concept for ADA624478 Assessing Electrical Infrastructure Impact, by R.T. Affleck, J.M. Roningen, J.S. Macpherson, B. Tracy, and D.E. Voyadgis 


\section{Coastal and Hydraulics Laboratory (CHL)}

\section{Contract reports}

\begin{tabular}{|c|c|c|c|}
\hline Report Number & Date & $\underline{\text { Title }}$ & $\underline{\text { AD Number }}$ \\
\hline ERDC/CHL CR-01-1 & Sep 2001 & $\begin{array}{l}\text { Channel Restoration Design for Meandering } \\
\text { Rivers, by P.J. Soar and C.R. Thorne }\end{array}$ & ADA396990 \\
\hline $\begin{array}{l}\text { ERDC/CHL CR-02-1 } \\
\text { Rep. } 1\end{array}$ & Sep 2002 & $\begin{array}{l}\text { Humboldt Bay, California, Entrance } \\
\text { Channel. Report 1: Data Review, by S.L. } \\
\text { Costa and K.A. Glatzel }\end{array}$ & ADA409102 \\
\hline ERDC/CHL CR-05-1 & Aug 2005 & $\begin{array}{l}\text { Waves, Currents, and Sediment Transport in } \\
\text { the Surf Zone Along Long, Straight Beaches, } \\
\text { by Y. Tajima and O.S. Madsen }\end{array}$ & ADA438823 \\
\hline ERDC/CHL CR-06-1 & Jul 2006 & $\begin{array}{l}\text { Chesapeake Bay Breakwater Database } \\
\text { Project, Section } 227 \text { Demonstration Site: } \\
\text { Hurricane Isabel Impacts to Four } \\
\text { Breakwater Systems, by C.S. Hardaway, Jr., } \\
\text { D.A. Milligan, C.A. Wilcox, L.M. Meneghini, } \\
\text { G.R. Thomas, and T.R. Comer }\end{array}$ & ADA453291 \\
\hline ERDC/CHL CR-07-1 & Sep 2007 & $\begin{array}{l}\text { A Unified Sediment Transport Formulation } \\
\text { for Coastal Inlet Application, by B. Camenen } \\
\text { and M. Larson }\end{array}$ & ADA472064 \\
\hline ERDC/CHL CR-10-1 & Jul 2010 & $\begin{array}{l}\text { State of Flood Related Modeling Along } \\
\text { Middle Rio Grande: Report Documentary } \\
\text { 2007-2008 Work, by J. Coonrod }\end{array}$ & ADA530200 \\
\hline ERDC/CHL CR-10-2 & Aug 2010 & $\begin{array}{l}\text { Coupling of Hydrologic/Hydraulic Models } \\
\text { and Aerial Photographs Through Time, Rio } \\
\text { Grande Near Albuquerque, New Mexico: } \\
\text { Report Documentary } 2007 \text { Work, by B. } \\
\text { Swanson, G. Meyer, and J. Coonrod }\end{array}$ & ADA529438 \\
\hline ERDC/CHL CR-10-3 & Sep 2010 & $\begin{array}{l}\text { Rio Grande Lidar Bank Erosion Monitoring: } \\
\text { Preliminary 2007-2008 Results and Survey } \\
\text { Design Considerations, by T.F. Wawrzyniec, } \\
\text { J.D. Frechette, J. Coonrod, and J. Stormont }\end{array}$ & ADA527914 \\
\hline ERDC/CHL CR-10-4 & Sep 2010 & $\begin{array}{l}\text { Evapotranspiration, Water Table } \\
\text { Fluctuations, and Riparian Restoration: } \\
\text { Report Documentary 2007-2008 Work, by } \\
\text { J.R. Cleverly, K. Vanderbilt, C. Dahm, J.R. } \\
\text { Thibault, and M.C. Martinet }\end{array}$ & ADA528082 \\
\hline ERDC/CHL CR-11-1 & May 2011 & $\begin{array}{l}\text { Investigating Groundwater/Surface Water } \\
\text { Interaction at Diversion Dam Site: Report } \\
\text { Documentary 2007-2008, by J. Coonrod, C. } \\
\text { Crawford, J. Stormont, C. LeJeune, and I. } \\
\text { Pedro }\end{array}$ & \\
\hline
\end{tabular}


ERDC/CHL CR-15-1 Jun 2015 Three-Dimensional Shallow Water Adaptive

ADA620180 Hydraulics (ADH-SW3): Turbulence Closure, by G. Savant

\section{Letter reports}

\begin{tabular}{|c|c|c|}
\hline Report Number & Date & $\underline{\text { Title }}$ \\
\hline 1ERDC/CHL LR-15-1 & Mar 2015 & $\begin{array}{l}\text { Scour Model Study for Proposed Pier } \\
\text { Extensions, by J.A. Sharp, R.E. Heath, H.E. } \\
\text { Park and D.P. May }\end{array}$ \\
\hline 1ERDC/CHL LR-15-2 & Mar 2015 & $\begin{array}{l}\text { Two-Dimensional Model Study of Santa Ana } \\
\text { River Railroad Bridge Pier Extensions, by } \\
\text { J.A. Sharp and R.E. Heath }\end{array}$ \\
\hline 1ERDC/CHL LR-15-3 & Apr 2015 & $\begin{array}{l}\text { A Flood Analysis of the Niger River and } \\
\text { Major Tributaries in Africa, by W.C. LaHatte, } \\
\text { M.R. Jourdan, and J.D. Ellis }\end{array}$ \\
\hline${ }^{1}$ ERDC/CHL LR-15-4 & Apr 2015 & $\begin{array}{l}\text { Aswan High Dam - Dam Breach Study, by J. } \\
\text { Ellis and M.R. Jourdan }\end{array}$ \\
\hline ERDC/CHL LR-15-6 & Nov 2015 & $\begin{array}{l}\text { Tuttle Creek Dam Siphon Dredging } \\
\text { Investigation, by B.C. McFall and T.L. Welp }\end{array}$ \\
\hline ERDC/CHL LR-15-7 & Nov 2015 & $\begin{array}{l}\text { Evaluating Sediment Mobility for Milford, CT } \\
\text { Nearshore Placement, by B.E. McFall, C.E. } \\
\text { Pollock, and K.E. Brutsche }\end{array}$ \\
\hline${ }^{1}$ ERDC/CHL LR-15-8 & Dec 2015 & $\begin{array}{l}\text { Savannah Ocean Dredged Material Disposal } \\
\text { Site: Waves, Currents and Water Level Data } \\
\text { Summary, by E.R. Smith }\end{array}$ \\
\hline
\end{tabular}

\section{Special reports}

\begin{tabular}{|c|c|c|c|}
\hline Report Number & Date & $\underline{\text { Title }}$ & AD Number \\
\hline ERDC/CHL SR-00-1 & Mar 2000 & $\begin{array}{l}\text { Site Visit and Evaluation of New Cremona } \\
\text { Lock Filling and Emptying System }\end{array}$ & ADA375857 \\
\hline ERDC/CHL SR-00-2 & Jun 2000 & $\begin{array}{l}\text { Channel Stability Problems, lao Stream, } \\
\text { Maui, Hawaii: U.S. Army Engineer } \\
\text { Committee on Channel Stabilization Report } \\
\text { of the } 64 \text { th Meeting-September 1999, } \\
\text { Edited by R.R. Copeland and D.N. } \\
\text { McComas }\end{array}$ & ADA379413 \\
\hline
\end{tabular}

${ }^{1}$ Limited distribution; see Preface. 


\begin{tabular}{|c|c|c|}
\hline ERDC/CHL SR-00-3 & Aug 2000 & $\begin{array}{l}\text { Channel Stability Problems, Pajaro River, } \\
\text { Watsonville and Pajaro, California: U.S. } \\
\text { Army Engineer Committee on Channel } \\
\text { Stabilization Report of the 63rd Meeting, } \\
\text { Edited by R.R. Copeland and D.N. } \\
\text { McComas }\end{array}$ \\
\hline ERDC/CHL SR-01-1 & Feb 2001 & $\begin{array}{l}\text { STWAVE: Steady-State Spectral Wave Model } \\
\text { User's Manual for STWAVE, Version 3.0, by } \\
\text { J.M. Smith, A.R. Sherlock, and D.T. Resio }\end{array}$ \\
\hline ERDC/CHL SR-06-1 & Sep 2006 & $\begin{array}{l}\text { Gridded Surface Subsurface Hydrologic } \\
\text { Analysis (GSSHA) User's Manual: Version } \\
1.43 \text { for Watershed Modeling System } 6.1 \text {, } \\
\text { by C.W. Downer and F.L. Ogden }\end{array}$ \\
\hline ERDC/CHL SR-06-2 & Sep 2006 & $\begin{array}{l}\text { Navigation Lock and Dam Inspection and } \\
\text { Emergency Repairs Workshop Summary, by } \\
\text { J.E. Hite, Jr., J.E. Clausner, and D.N. } \\
\text { McComas, editors }\end{array}$ \\
\hline ERDC/CHL SR-07-1 & Sep 2007 & $\begin{array}{l}\text { Theoretical Underpinnings of the Other } \\
\text { Social Effects Account, by C.M. Dunning } \\
\text { and S. Durden }\end{array}$ \\
\hline ERDC/CHL SR-09-2 & Aug 2009 & $\begin{array}{l}\text { Hurricane Ivan Nearshore Wave Data, } \\
\text { Perdido Pass, Alabama, by M.A. Sabol, J.P. } \\
\text { McKinney, and L. Lillycrop }\end{array}$ \\
\hline ERDC/CHL SR-09-6 & Aug 2009 & $\begin{array}{l}\text { Beach-fx User's Manual: Version 1.0, by } \\
\text { C.M. Rogers, K.A. Jacobson, and M. } \\
\text { Gravens }\end{array}$ \\
\hline
\end{tabular}

ADA381913

Watsonville and Pajaro, California: U.S.

Stabilization Report of the 63rd Meeting, Edited by R.R. Copeland and D.N.

ADA388197 User's Manual for STWAVE, Version 3.0, by

Gridded Surface Subsurface Hydrologic

ADA455335 Analysis (GSSHA) User's Manual: Version 1.43 for Watershed Modeling System 6.1,

ERDC/CHL SR-11-1 Sep 2011

STWAVE: Steady-State Spectral Wave Model ADA550608 User's Manual for STWAVE, Version 6.0, by T.C. Massey, M.E. Anderson, J.M. Smith, J. Gomez, and R. Jones

ERDC/CHL SR-15-1 Mar 2015

GenCade Version 1 Quick-Start Guide: How

ADA614444 to Start a Successful GenCade Project, by S. Munger and A.E. Frey

ERDC/CHL SR-15-2 Mar 2015

Conceptual Regional Sediment Budget for USACE North Atlantic Division, by J.D. Rosati, A.E. Frey, A.S. Grzegorzewski, C.K. Maglio, A. Morang, and R.C. Thomas

ADA508612

ADA508629

ADA471773

Technical Basis for Flood Protection at Nuclear Power Plants, by J.R. Leech, L.L. Wehmeyer, D.A. Margo, L.T. Lee, A.R. Byrd, and D.L. Ward

ADA614647

ADA621451

ERDC/CHL SR-15-3 Jul 2015

\section{ADA621451}




\section{Technical notes}

\section{Section I - Waves and coastal flooding}

\begin{tabular}{|c|c|c|}
\hline Report Number & $\underline{\text { Date }}$ & $\underline{\text { Title }}$ \\
\hline ERDC/CHL CHETN-I-64 & Sep 2001 & $\begin{array}{l}\text { Modeling Nearshore Wave Transformation } \\
\text { with STWAVE, by J.M. Smith }\end{array}$ \\
\hline RDC/CHL CHETN-I-65 & Jun 2002 & $\begin{array}{l}\text { Comparisons of Physical and Numerical } \\
\text { Model Wave Predictions with Prototype Data } \\
\text { at Morro Bay Harbor Entrance, California, by } \\
\text { R.R. Bottin, Jr. and E.F. Thompson }\end{array}$ \\
\hline RDC/CHL CHETN-I-66 & Jun 2002 & $\begin{array}{l}\text { Grid Nesting with STWAVE, by J.K. Smith } \\
\text { and S.J. Smith }\end{array}$ \\
\hline RDC/CHL CHETN-I-67 & Jun 2003 & $\begin{array}{l}\text { Tedious Creek Small Craft Harbor: CGWAVE } \\
\text { Model Comparisons Between Existing and } \\
\text { Authorized Breakwater Configurations, by } \\
\text { M.J. Briggs, B.P. Donnell, Z. Demirbilek and } \\
\text { R.D. Carver }\end{array}$ \\
\hline ERDC/CHL CHETN-I-68 & Mar 2004 & $\begin{array}{l}\text { How to Use CGWAVE with SMS: An Example } \\
\text { for Tedious Creek Small Craft Harbor, by } \\
\text { M.J. Briggs, B.P. Donnell, and Z. Demirbilek }\end{array}$ \\
\hline ERDC/CHL CHETN-I-69 & Mar 2005 & $\begin{array}{l}\text { BOUSS-2D Wave Model in SMS: } 1 . \\
\text { Graphical Interface, by Z. Demirbilek, A. } \\
\text { Zundel, and O. Nwogu }\end{array}$ \\
\hline ERDC/CHL CHETN-I-70 & May 2005 & $\begin{array}{l}\text { BOUSS-2D Wave Model in SMS: } 2 \text {. Tutorial } \\
\text { with Examples, by Z. Demirbilek, A. Zundel, } \\
\text { and O. Nwogu }\end{array}$ \\
\hline ERDC/CHL CHETN-I-71 & Mar 2006 & $\begin{array}{l}\text { Full Plane STWAVE: SMS Graphical } \\
\text { Interface, by J.M. Smith and A. Zundel }\end{array}$ \\
\hline ERDC/CHL CHETN-I-72 & Aug 2006 & $\begin{array}{l}\text { Ship Squat Predictions for Ship/Tow } \\
\text { Simulator, by M.J. Briggs }\end{array}$ \\
\hline ERDC/CHL CHETN-I-73 & May 2007 & $\begin{array}{l}\text { Infra-Gravity Wave Input Toolbox (IGWT): } \\
\text { User's Guide, by Z. Demirbilek, O.G. Nwogu, } \\
\text { and A.K. Zundel }\end{array}$ \\
\hline ERDC/CHL CHETN-I-74 & May 2007 & $\begin{array}{l}\text { WABED Model in the SMS: Part 2, Graphical } \\
\text { Interface, by Z. Demirbilek, L. Lin and A. } \\
\text { Zundel }\end{array}$ \\
\hline ERDC/CHL CHETN-I-75 & Aug 2007 & $\begin{array}{l}\text { Full-Plane STWAVE with Bottom Friction: II, } \\
\text { Model Overview, by J.M. Smith }\end{array}$ \\
\hline RDC/CHL CHETN-I-76 & Aug 2007 & $\begin{array}{l}\text { Modeling Nearshore Waves for Hurricane } \\
\text { Katrina, by J.M. Smith }\end{array}$ \\
\hline
\end{tabular}




\begin{tabular}{|c|c|c|}
\hline ERDC/CHL CHETN-I-77 & Jul 2009 & $\begin{array}{l}\text { Influence of Marsh Restoration and } \\
\text { Degradation on Storm Surge and Waves, by } \\
\text { T.V. Wamsley, M.A. Cialone, J. Westerink, } \\
\text { and J.M. Smith }\end{array}$ \\
\hline ERDC/CHL CHETN-I-78 & Jul 2009 & $\begin{array}{l}\text { Idealized Marsh Simulations: Sensitivity of } \\
\text { Hurricane Surge Elevation and Wave Height } \\
\text { to Seabed Elevation, by N.M. Loder, M.A. } \\
\text { Cialone, J.L. Irish, and T.V. Wamsley }\end{array}$ \\
\hline ERDC/CHL CHETN-I-79 & Jul 2009 & $\begin{array}{l}\text { Idealized Marsh Simulations: Sensitivity of } \\
\text { Hurricane Surge Elevation and Wave Height } \\
\text { to Bottom Friction, by N.M. Loder, M.A. } \\
\text { Cialone, J.L. Irish, and T.V. Wamsley }\end{array}$ \\
\hline ERDC/CHL CHETN-I-80 & Jul 2009 & $\begin{array}{l}\text { Idealized Marsh Simulations: Sensitivity of } \\
\text { Hurricane Surge Elevation and Wave Height } \\
\text { to Marsh Continuity, by N.M. Loder, M.A. } \\
\text { Cialone, J.L. Irish, and T.V. Wamsley }\end{array}$ \\
\hline ERDC/CHL CHETN-I-81 & Jul 2010 & $\begin{array}{l}\text { TWAVE Users Guide with Example } \\
\text { Application to Oahu, Hawaii, by J. Goo, Z. } \\
\text { Demirbilek, and J. Smith, and A. Sanchez }\end{array}$ \\
\hline ERDC/CHL CHETN-I-82 & Sep 2011 & $\begin{array}{l}\text { Wave Dissipation by Vegetation, by M.E. } \\
\text { Anderson, J.M. Smith, and S.K. Mckay }\end{array}$ \\
\hline ERDC/CHL CHETN-I-84 & Feb 2012 & $\begin{array}{l}\text { HAKOU v3: SWIMS Hurricane Inundation } \\
\text { Fast Forecasting Tool for Hawaii, by J.M. } \\
\text { Smith, M.E. Anderson, A.A. Taflanidis, A.B. } \\
\text { Kennedy, J.J. Westerink, and K.F. Cheung }\end{array}$ \\
\hline ERDC/CHL CHETN-I-85 & Feb 2015 & $\begin{array}{l}\text { Implementation of Wave Dissipation by } \\
\text { Vegetation in STWAVE, by M.E. Anderson } \\
\text { and J.M. Smith }\end{array}$ \\
\hline ERDC/CHL CHETN-I-86 & Jul 2015 & $\begin{array}{l}\text { Computer-Based Model Calibration and } \\
\text { Uncertainty Analysis: Terms and Concepts, } \\
\text { by A. Sanchez, B. Skahill, W. Scharffenberg, } \\
\text { and C.H. Smith }\end{array}$ \\
\hline ERDC/CHL CHETN-I-87 & Jul 2015 & $\begin{array}{l}\text { Introduction to Phase-Resolving Wave } \\
\text { Modeling with FUNWAVE, by M. Malej, J.M. } \\
\text { Smith, and G. Salgado-Dominguez }\end{array}$ \\
\hline
\end{tabular}

\section{Section II - Beach behavior and restoration}

$\begin{array}{lll}\text { Report Number } & \text { Date } & \underline{\text { Title }} \\ \text { ERDC/CHL CETN-II-41 } & \text { Dec 1999 } & \begin{array}{l}\text { Sand Bypassing Cost and Performance } \\ \text { Database, by J.E. Clausner }\end{array} \\ \text { ERDC/CHL CETN-II-42 } & \text { Dec 1999 } & \begin{array}{l}\text { An Analytical Model to Predict the Response } \\ \text { of Mounds Placed in the Offshore, by M. } \\ \text { Larson and B.A. Ebersole }\end{array}\end{array}$




\begin{tabular}{|c|c|c|}
\hline ERDC/CHL CETN-II-43 & Jun 2000 & $\begin{array}{l}\text { Sediment transport Analysis from } \\
\text { OBS/EMCM during Storms, by J.Z. Gailani } \\
\text { and S.J. Smith }\end{array}$ \\
\hline ERDC/CHL CHETN-II-44 & Sep 2001 & $\begin{array}{l}\text { Beach Erosion Hot Spots: Types, Causes, } \\
\text { and Solutions, by N.C. Kraus and F.A. } \\
\text { Galgano }\end{array}$ \\
\hline ERDC/CHL CHETN-II-45 & Mar 2002 & $\begin{array}{l}\text { Wave Transmission at Detached } \\
\text { Breakwaters for Shoreline Response } \\
\text { Modeling, by T. Wamsley, H. Hanson, and } \\
\text { N.C. Kraus }\end{array}$ \\
\hline ERDC/CHL CHETN-II-46 & Mar 2002 & $\begin{array}{l}\text { Longshore Sand Transport - Initial Results } \\
\text { from Large-Scale Sediment Transport } \\
\text { Facility, by P. Wang, B.A. Ebersole, and E.R. } \\
\text { Smith }\end{array}$ \\
\hline ERDC/CHL CHETN-II-47 & Mar 2004 & $\begin{array}{l}\text { Identification of and Remedial Approaches } \\
\text { to Hot Spots, by D.K. Stauble and M.B. } \\
\text { Gravens }\end{array}$ \\
\hline ERDC/CHL CHETN-II-48 & Nov 2005 & $\begin{array}{l}\text { Influence of Grain Size on Sediment } \\
\text { Transport Rates with Emphasis on the Total } \\
\text { Longshore Rate, by D.B. King, Jr. }\end{array}$ \\
\hline ERDC/CHL CHETN-II-49 & Jan 2006 & $\begin{array}{l}\text { Sheldon Marsh - Section } 227 \\
\text { Demonstration Project - Physical Model } \\
\text { Study, by S.A. Chader, M.C. Mohr, A. } \\
\text { Morang, D. Ward, and W.R. Curtis }\end{array}$ \\
\hline ERDC/CHL CHETN-II-50 & Sep 2006 & $\begin{array}{l}\text { Geotextile Tube Structures Guidelines for } \\
\text { Contract Specifications, by D.L. Jones, J.E. } \\
\text { Davis, W.R. Curtis, and C.E. Pollock }\end{array}$ \\
\hline ERDC/CHL CHETN-II-51 & Jan 2008 & $\begin{array}{l}\text { Interaction of Shore-Parallel Geotextile } \\
\text { Tubes and Beaches along the Upper Texas } \\
\text { Coast, by D.J. Heilman, M.C. Perry, R.C. } \\
\text { Thomas, and N.C. Kraus }\end{array}$ \\
\hline ERDC/CHL CHETN-II-52 & Jul 2010 & $\begin{array}{l}\text { Emergency Beach-Fill Procedures: Lessons } \\
\text { Learned From } 2004 \text { Hurricane Season, by } \\
\text { D. Haubner, R. McMillen, M. Chasten, L. } \\
\text { Lillycrop, and G. Williams }\end{array}$ \\
\hline ERDC/CHL CHETN-II-53 & Jun 2011 & $\begin{array}{l}\text { Planning Regional Flood and Coastal } \\
\text { Erosion Foresight Studies, by M.T. Schultz, } \\
\text { S.E. Durden, P.B. Sayers, B.P. Gouldby, J.D. } \\
\text { Simm, W.R. Curtis, and J.E. Davis }\end{array}$ \\
\hline ERDC/CHL CHETN-II-54 & Jan 2012 & $\begin{array}{l}\text { First Year Morphological Evolution of an } \\
\text { Artificial Berm at Fort Myers Beach, Florida, } \\
\text { by K.E. Brutsche and P. Wang }\end{array}$ \\
\hline
\end{tabular}


ERDC/CHL CHETN-II-55 Dec 2013 Shoreline Change Modeling Using One- Line Models: General Model Comparison and Literature Review, by R.C. Thomas and A.E. Frey

\section{Section III - Coastal structures}

\begin{tabular}{|c|c|c|}
\hline Report Number & Date & $\underline{\text { Title }}$ \\
\hline ERDC/CHL CHETN-III-64 & $\begin{array}{l}\text { Dec } 2005 \\
\text { REV }\end{array}$ & $\begin{array}{l}\text { Damage Development on Stone-Armored } \\
\text { Breakwaters and Revetments, by J.A. Melby }\end{array}$ \\
\hline ERDC/CHL CHETN-III-65 & Mar 2003 & $\begin{array}{l}\text { Periodic Inspections of Coastal Structures } \\
\text { with Stone Armor, by R.R. Bottin, Jr. }\end{array}$ \\
\hline ERDC/CHL CHETN-III-66 & Jun 2003 & $\begin{array}{l}\text { Periodic Inspections of Concrete-Armored } \\
\text { Coastal Structures, by R.R. Bottin, Jr. }\end{array}$ \\
\hline ERDC/CHL CHETN-III-67 & Sep 2003 & $\begin{array}{l}\text { Wave Momentum Flux Parameter for } \\
\text { Coastal Structure Design, by S.A. Hughes }\end{array}$ \\
\hline ERDC/CHL CHETN-III-68 & Sep 2003 & $\begin{array}{l}\text { Estimating Irregular Wave Runup on } \\
\text { Smooth, Impermeable Slopes, by S.A. } \\
\text { Hughes }\end{array}$ \\
\hline ERDC/CHL CHETN-III-69 & Mar 2004 & $\begin{array}{l}\text { Effectiveness of Pocket-Wave Absorbers in } \\
\text { Vertical-Wall, Coastal Entrance Structures, } \\
\text { by E.F. Thompson, R.R. Bottin, Jr., and J.P. } \\
\text { Selegean }\end{array}$ \\
\hline ERDC/CHL CHETN-III-70 & Jul 2005 & $\begin{array}{l}\text { Estimating Irregular Wave Runup on Rough, } \\
\text { Impermeable Slopes, by S.A. Hughes }\end{array}$ \\
\hline ERDC/CHL CHETN-III-71 & Dec 2005 & $\begin{array}{l}\text { Breakwater and Revetment Armor Stability, } \\
\text { by J.A. Melby }\end{array}$ \\
\hline ERDC/CHL CHETN-III-72 & Feb 2006 & $\begin{array}{l}\text { Uses for Marine Mattresses in Coastal } \\
\text { Engineering, by S.A. Hughes }\end{array}$ \\
\hline ERDC/CHL CHETN-III-73 & Jul 2006 & $\begin{array}{l}\text { Wave-Action Balance Equation Diffraction } \\
\text { (WABED) Model: Tests of Wave Diffraction } \\
\text { and Reflection at Inlets, by L. Lin, H. Mase, } \\
\text { F. Yamada, and Z. Demirbilek }\end{array}$ \\
\hline ERDC/CHL CHETN-III-74 & Aug 2006 & $\begin{array}{l}\text { Effect of Armoring a Cohesive Nearshore } \\
\text { with a Thin Cobble Lag, Shoreham, } \\
\text { Michigan, by M. Dibajnia, J. Selgean, and A. } \\
\text { Morang }\end{array}$ \\
\hline ERDC/CHL CHETN-III-75 & Jan 2007 & $\begin{array}{l}\text { Irregular Wave Forces on Heavily } \\
\text { Overtopped Thin Vertical Walls, by S.A. } \\
\text { Hughes }\end{array}$ \\
\hline
\end{tabular}


ERDC/CHL CHETN-III-76 Jun 2007

ERDC/CHL CHETN-III-77 Jan 2008

ERDC/CHL CHETN-III-78 May 2008

ERDC/CHL CHETN-III-79 Jan 2009

ERDC/CHL CHETN-III-80 Aug 2010
A GSSHA Model of the Perris Basin of the San Jacinto River Watershed, Riverside County, California, by M.T. Fong, C.W. Downer, and A.R. Byrd

Estimation of Overtopping Flow Velocities on Earthen Levees Due to Irregular Waves, by S.A. Hughes

Estimation of Combined Wave and Storm Surge Overtopping at Earthen Levees, by S.A. Hughes

Shear Stress Estimates for Combined Wave and Surge Overtopping at Earthen Levees, by N.C. Nadal and S.A. Hughes

A Review of Coastal Navigation Asset Management Initiatives Within the Coastal Inlets Research Program (CIRP) Part 1: Coastal Structures, by K.N. Mitchell

\section{Section IV - Inlets and estuary channels}

\begin{tabular}{|c|c|c|}
\hline Report Number & Date & $\underline{\text { Title }}$ \\
\hline $\begin{array}{l}\text { ERDC/CHL CHETN-IV-12 } \\
\text { REV }\end{array}$ & Dec 2000 & $\begin{array}{l}\text { Where and Why Inlet Channels Shoal: A } \\
\text { Conceptual Geomorphic Framework, by J. } \\
\text { Pope }\end{array}$ \\
\hline ERDC/CHL CHETN-IV-21 & Dec 1999 & $\begin{array}{l}\text { Surface-Water Modeling System Tidal } \\
\text { Constituents Toolbox for ADCIRC, by A. } \\
\text { Militello and A.K. Zundel }\end{array}$ \\
\hline ERDC/CHL CHETN-IV-22 & Dec 1999 & $\begin{array}{l}\text { Shoal-Reduction Strategies for Entrance } \\
\text { Channels, by J.D. Rosati and N.C. Kraus }\end{array}$ \\
\hline ERDC/CHL CHETN-IV-23 & Mar 2000 & $\begin{array}{l}\text { Hydraulic Processes Analysis System } \\
\text { (HyPAS), by T.C. Pratt and D.S. Cook }\end{array}$ \\
\hline ERDC/CHL CHETN-IV-24 & Mar 2000 & $\begin{array}{l}\text { Field Data Collection at Coastal Inlets, by } \\
\text { T.C. Pratt, T.L. Fagerburg, and D.C. McVan }\end{array}$ \\
\hline ERDC/CHL CHETN-IV-25 & Jun 2000 & $\begin{array}{l}\text { Enhancements of the Numerical Model of } \\
\text { the Longshore Current NMLONG to Include } \\
\text { Interaction Between Currents and Waves } \\
\text { (NMLong-CW), by M. Larson and N.C. Kraus }\end{array}$ \\
\hline ERDC/CHL CHETN-IV-26 & Jun 2000 & $\begin{array}{l}\text { Simulation of Current-Induced Scour in } \\
\text { Movable-Bed Inlet Models, by S.A. Hughes }\end{array}$ \\
\hline ERDC/CHL CHETN-IV-27 & Sep 2000 & $\begin{array}{l}\text { Reresentation of Hydrodynamic Model } \\
\text { Results through Graphical Displays, by M.S. } \\
\text { Gosselin, R.B. Taylor, and K.R. Craig }\end{array}$ \\
\hline
\end{tabular}




$\begin{array}{llll}\text { ERDC/CHL CHETN-IV-28 Sep 2000 } & \begin{array}{l}\text { Introduction to the Diagnostic Modeling } \\ \text { System (DMS), by N.C. Kraus }\end{array} \\ \text { ERDC/CHL CHETN-IV-29 Sep 2000 } & \begin{array}{l}\text { Circulation Patterns at Tidal Inlets with } \\ \text { Jetties, by A. Militello and S.A. Hughes }\end{array} \\ \text { ERDC/CHL CHETN-IV-30 Dec 2000 } & \begin{array}{l}\text { Natural Mechanisms of Sediment } \\ \text { Bypassing at Tidal Inlets, by D.M. } \\ \text { FitzGerald, N.C. Kraus, and E.B. Hands }\end{array} \\ \text { ERDC/CHL CHETN-IV-32 Jun 2001 } & \text { Dec 2000 } & \begin{array}{l}\text { Database of Inlet Navigation Projects and } \\ \text { Structures, by S.A. Hughes } \\ \text { Leaky Internal-Barrier Normal-Flow } \\ \text { Boundaries in the ADCIRC Coastal } \\ \text { Hydrodynamics Code, by J.J. Westerink, R.A. } \\ \text { Luettich, and A. Militello }\end{array}\end{array}$

ERDC/CHL CHETN-IV-33 Jun 2001 Morphologic Asymmetries at Entrances to Tidal Inlets, by E.E. Carr and N.C. Kraus

ERDC/CHL CHETN-IV-34 Jun 2001

ERDC/CHL CHETN-IV-35 Jun 2001

ERDC/CHL CHETN-IV-36 Jun 2001

ERDC/CHL CHETN-IV-37 Sep 2001

ERDC/CHL CHETN-IV-38 Sep 2001

ERDC/CHL CHETN-IV-39 Mar 2002

ERDC/CHL CHETN-IV-40 Mar 2002

ERDC/CHL CHETN-IV-41 Jun 2002
Estimation of Suspended Sediment Trapping Ratio for Channel Infilling and Bypassing, by M. Larson and N.C. Kraus

Mathematical Model for Rapid Estimation of Infilling and Sand Bypassing at Inlet Entrance Channels, by N.C. Kraus and M. Larson

Chronic Beach Erosion Adjacent to Inlets and Remediation by Composite (T-Head) Groins, by H. Hanson and N.C. Kraus

A GIS Based Tool for Extracting Shoreline Positions from Aerial Imagery (BeachTools), by R.K. Hoeke, G.A. Zarillo, and M. Synder

Field Data Recovery in Tidal System Using Artificial Neural Networks (ANNs), by B.B. Hsieh and T.C. Pratt

Reservoir Model for Calculating Natural Sand Bypassing and Change in Volume of Ebb-Tidal Shoals, Part I: Description, by N.C. Kraus

Guidelines for Using Eastcoast 2001 Database of Tidal Constituents within Western North Atlantic Ocean, Gulf of Mexico and Caribbean Sea, by A.Y. Mukai, J.J. Westerink, and R.A. Luettich

SMS Steering Module for Coupling Waves and Currents, 1: ADCIRC and STWAVE, by A.K. Zundel, M.A. Cialone, and T.J. Moreland 
ERDC/CHL CHETN-IV-42 Jun 2002

ERDC/CHL CHETN-IV-43 Jun 2002

ERDC/CHL CHETN-IV-44 Jun 2002

ERDC/CHL CHETN-IV-45 Jun 2002

ERDC/CHL CHETN-IV-46 Jun 2002

ERDC/CHL CHETN-IV-47 Jun 2002

ERDC/CHL CHETN-IV-48 Sep 2002

ERDC/CHL CHETN-IV-49 Sep 2002

ERDC/CHL CHETN-IV-50 Sep 2002

ERDC/CHL CHETN-IV-51 Sep 2002

ERDC/CHL CHETN-IV-52 Sep 2002

ERDC/CHL CHETN-IV-53 Dec 2002

ERDC/CHL CHETN-IV-54 Dec 2002

ERDC/CHL CHETN-IV-55 Mar 2003
Coupling of Regional and Local Circulation Models ADCIRC and M2D, by A. Militello and A.K. Zundel

SHOALS Toolbox: Software to Support Visualization and Analysis of Large, HighDensity Data Sets, by J.M. Wozencraft, W.J. Lillycrop, and N.C. Kraus

Inlet Spits and Maintenance of Navigation Channels, by N.C. Kraus and W.C. Seabergh

Comparison of Predicted and Measured Shoaling at Morro Bay Harbor Entrance, California, by E.F. Thompson, I.P. DiRamos, and R.R. Bottin, Jr.

Deployment of Oceanographic Instruments in High-Energy Environments and Near Structures, by P.D. Osborne, D.B. Hericks, and N.C. Kraus

Tidal Velocity Asymmetry at Inlets, by $\mathrm{T}$. Walton

Estimating Along-Channel Flow and Sediment Transport at Tidal Entrances EbbJet Calculator, by M.S. Gosselin and K.R. Craig

Video-Based Wave Direction Measurements in a Scale Physical Model, by W.R. Curtis, K.K. Hathaway, K.T. Holland, and W.C. Seabergh

Quantifying Potential Measurement Errors and Uncertainties Associated with Bathymetric Change Analysis, by M.R. Byrnes, J.L. Baker, and F. Li

Inlets Online: A Tutorial for Evaluating Inlet/Beach Processes Using Aerial Photography, by M.R. Byrnes, F. Li, and J.D. Rosati

Inner-Bank Erosion Processes and Solutions at Coastal Inlets, by W.C. Seabergh

Weir Jetties at Coastal Inlets: Part 1, Functional Design Considerations, by W.C. Seabergh

Weir Jetties at Coastal Inlets: Part 2, Case Studies, by W.C. Seabergh and L.J. Thomas

CHL Precision Flow Table-Description and Applications, by S.A. Hughes 
ERDC/CHL CHETN-IV-56 Mar 2003

ERDC/CHL CHETN-IV-57 Mar 2003

ERDC/CHL CHETN-IV-58 Mar 2003

ERDC/CHL CHETN-IV-59 Mar 2003

ERDC/CHL CHETN-IV-60 Dec 2003

ERDC/CHL CHETN-IV-61 Dec 2003

ERDC/CHL CHETN-IV-62 Sep 2004

ERDC/CHL CHETN-IV-63 May 2005

ERDC/CHL CHETN-IV-64 Jun 2005

ERDC/CHL CHETN-IV-65 Aug 2005

ERDC/CHL CHETN-IV-66 Feb 2006

ERDC/CHL CHETN-IV-67 Feb 2006

ERDC/CHL CHETN-IV-68 Aug 2006
Coastal Barrier Breaching, Part 1: Overview of Breaching Processes, by N.C. Kraus and T.V. Wamsley

Human-Induced Changes in Back-Barrier Environments as Factors in Tidal Inlet Instability with Emphasis on Florida, by R.A. Davis, Jr. and G.A. Zarillo

Application of an Artificial Neural Network to Predict Tidal Currents in an Inlet, by W. Huang and C. Murray

Uncertainty in Bathymetric Surveys, by S. Johnston

SMS Steering Module for Coupling Waves and Currents, 2: M2D and STWAVE, by A. Militello and A.K. Zundel

Jetty Spurs at Coastal Inlets for Reduction of Navigation Channel Shoaling, by W.C. Seabergh and J. Krock

Dependence of Total Longshore Sediment Transport Rates on Incident Wave Parameters and Breaker Type, by E.R. Smith, B.A. Ebersole, and P. Wang

Representation of Nonerodible (Hard) Bottom in Two-Dimensional Morphology Change Models, by H. Hanson and A. Militello

Coastal Inlet Navigation Channel Shoaling with Deepening and Widening, by J.D. Rosati

Coastal Barrier Island Breaching, Part 2: Mechanical Breaching and Breach Closure, by T.V. Wamsley and N.C. Kraus

Jetty Spur Functional Design at Coastal Inlets: Effects on Nearshore Circulation and Potential Sediment Movement, by W.C. Seabergh

Frequently-Asked Questions (FAQs) About Coastal Inlets and U.S. Army Corps of Engineers' Coastal Inlets Research Program (CIRP), by S.A. Hughes and N.C. Kraus

Sand Waves That Impede Navigation of Coastal Inlet Navigation Channels, by S.J. Whitmeyer and D. FitzGerald 
ERDC/CHL CHETN-IV-69 Jul 2007

ERDC/CHL CHETN-IV-70 May 2008

ERDC/CHL CHETN-IV-71 Jul 2008

ERDC/CHL CHETN-IV-72 Aug 2008

ERDC/CHL CHETN-IV-73 Sep 2008

ERDC/CHL CHETN-IV-74 Sep 2009

ERDC/CHL CHETN-IV-75 May 2010

ERDC/CHL CHETN-IV-76 Jul 2010

ERDC/CHL CHETN-IV-77 Aug 2010

ERDC/CHL CHETN-IV-78 Jan 2011

ERDC/CHL CHETN-IV-79 Apr 2011

ERDC/CHL CHETN-IV-80 Jan 2012

ERDC/CHL CHETN-IV-81 Apr 2012

ERDC/CHL CHETN-IV-82 Apr 2012
Tips for Developing Bathymetry Grids for Coastal Modeling System Applications, by M.E. Brown and N.C. Kraus

Concept Design for Emergency Closure System for Inland Navigation Structures, by J.E. Hite Jr.

Particle Tracking Model (PTM) in the SMS10: IV, Link to Coastal Modeling System, by Z. Demirbilek, K.J. Connell, N.J. MacDonald, and A.K. Zundel

Interactions Between Wetlands and Tidal Inlets, by A. Sanchez

A GIS Based Tool for Extracting Shoreline Positions from Aerial Imagery (BeachTools) Revised, by G.A. Zarillo, J. Kelley, and V. Larson

Concepts for Functional Restoration of Barrier Islands, by J.D. Rosati

Proactive Strategy for "Dredge-Ready" Operation and Maintenance at Low-Use Navigation Projects, by H.T. Arden and N.C. Kraus

CMS-Wave Model: Part 3, Grid Nesting and Application Example for Rhode Island South Shore Regional Sediment Management Study, by L. Lin, I Watts, and Z. Demirbilek

Concepts and Applications of Water Transport Time Scales for Coastal Inlet Systems, by H. Li

Applying Particle Tracking Model in the Coastal Modeling System, by H. Li, L. Lin, and M.E. Brown

CMS-Wave Model: Part 4, An Automated Procedure for CMS-Wave in ResourceDemanding Applications, by M.E. Anderson, L. Lin, and Z. Demirbilek

Salinity Calculations in the Coastal Modeling System, by H. Li, C.W. Reed, and M.E. Brown

CMS-Wave Model: Part 5, Full-plane Wave Transformation and Grid Nesting, by L. Lin, J. Rosati, III, and Z. Demirbilek

Use of the PTM with CMS Quadtree Grids, by $\mathrm{H}$. Li and N. MacDonald 
ERDC/CHL CHETN-IV-83 Aug 2012

ERDC/CHL CHETN-IV-84 Aug 2012

ERDC/CHL CHETN-IV-85 Aug 2012

ERDC/CHL CHETN-IV-86 Sep 2012

ERDC/CHL CHETN-IV-87 Jan 2013

ERDC/CHL CHETN-IV-88 Mar 2013

ERDC/CHL CHETN-IV-89 Aug 2013

ERDC/CHL CHETN-IV-90 Aug 2013

ERDC/CHL CHETN-IV-91 Aug 2013

ERDC/CHL CHETN-IV-92 Aug 2013

ERDC/CHL CHETN-IV-93 Aug 2013

ERDC/CHL CHETN-IV-94 Aug 2013

ERDC/CHL CHETN-IV-95 Aug 2013
WaveNet: A Web-Based Metocean Data Access, Processing and Analysis Tool, by D. Wilson, J. Rosati, Z. Demirbilek, and L. Lin

Coupled BOUSS-2D and CMS-Wave Modeling Approach for Harbor Projects, by L. Lin and Z. Demirbilek

GenCade Application at Onslow Bay, North Carolina, by A.E. Frey, S. Munger, G.L. Williams, M.J. Wutkowski, and K.B. Conner

New Gridded Surface Subsurface Hydrologic Analysis Model Computer-based Calibration Capabilities, by B.E. Skahill and C.W. Downer

Practice Driven and State-of-the-art Methods to Quantify Hydrologic Model Uncertainty, by B.E. Skahill

AutoRoute Rapid Flood Inundation Model, by M.L. Follum

Initial Morphologic Evolution of Perdido Key Berm Nourishment, Florida, by P. Wang, K.E. Brutsche, T.M. Beck, J.D. Rosati, and L.S. Lillycrop

The Sediment Budget Calculator: A Webtool to Develop a Family of Viable Inlet and Adjacent Beach Sediment Budget Solutions, by J.D. Rosati, C.A. Sumner, and D.A. Wilson

TideNet: A Web-based Tidal Data Access, Processing and Analysis Tool, Part 1 - NWS Tidal Database, by Z. Demirbilek, L. Lin, D. Wilson, and J. Rosati

WaveNet: A Web-Based Metocean Data Access, Processing and Analysis Tool, Part 2 - WIS Database, by Z. Demirbilek, L. Lin, D. Wilson, and J. Rosati

Implementation of Structures in the CMS: Part I, Rubble Mound, by H. Li, A. Sanchez, W. Wu, and C. Reed

Implementation of Structures in the CMS: Part II, Weir, by H. Li, A. Sanchez, W. Wu, and C. Reed

Implementation of Structures in the CMS: Part III, Culvert, by H. Li, A. Sanchez, W. Wu, and C. Reed 
ERDC/CHL CHETN-IV-96 Aug 2013

ERDC/CHL CHETN-IV-97 Sep 2013

ERDC/CHL CHETN-IV-98 Sep 2013

ERDC/CHL CHETN-IV-99 Jun 2014

ERDC/CHL CHETN-IV-100 Jun 2014

ERDC/CHL CHETN-IV-101 Sep 2014

ERDC/CHL CHETN-IV-102 Sep 2014

ERDC/CHL CHETN-IV-103 Feb 2015

ERDC/CHL CHETN-IV-104 Aug 2015

ERDC/CHL CHETN-IV-105 Aug 2015

ERDC/CHL CHETN-IV-106 Oct 2015
Implementation of Structures in the CMS:

Part IV, Tide Gate, by H. Li, A. Sanchez, and W. Wu

Wave Data Processing and Analysis Tools for Developing Wave Boundary Forcing for CMS-Wave and GenCade Numerical Models: Part 1, by K.J. Connell and R. Permenter

Wave Data Processing and Analysis, Part 2: Codes for Coupling GenCade and CMSWave, by R. Permenter, K.J. Connell and R. Permenter

WaveNet: A Web-Based Metocean Data Access, Processing and Analysis Tool; Part 4 - GLOS/GLCFS Database, by Z. Demirbilek, L. Lin, and D. Wilson

WaveNet: A Web-Based Metocean Data Access, Processing, and Analysis Tool; Part 3 - CDIP Database, by Z. Demirbilek, L. Lin, and D. Wilson

Efficient Use of Prior Information to Calibrate the Gridded Surface Subsurface Hydrologic Analysis (GSSHA) Hydrology Model, by B.E. Skahill and C.W. Downer

Shoreline Change Modeling Using One-Line Models: Application and Comparison of GenCade, Unibest, and Litpack, by K.E. Townsend, R.C. Thomas, and A.E. Frey

WaveNet: A Web-Based Metocean Data Access, Processing and Analysis Tool; Part 5 - WW3 Database, by Z. Demirbilek, L. Lin, D. Wilson, and J. Rosati

Automated Method to Develop a Clark Synthetic Unit Hydrograph within ArcGIS, by M. Follum

Using GenCade to Create a Sediment Budget in SBAS, by A.E. Frey

Three Dimensional Shallow Water Adaptive Hydraulics (ADH-SW3): Waterborne Vessels, by G. Savant and C.J. Trahan 


\section{Section V - Coastal ecology}

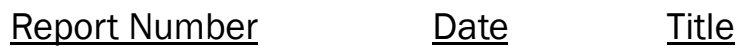

ERDC/CHL CHETN-V-23 Jun $2014 \quad$ Linking Critical Ecological Processes to Landscape Pattern: Implications for USACE Planning and Operations, by S. Altman, M. Reif, and T. Swannack

\section{Section VI - Miscellaneous coastal subjects}

\begin{tabular}{|c|c|c|}
\hline Report Number & Date & $\underline{\text { Title }}$ \\
\hline ERDC/CHL CHETN-VI-33 & Mar 2000 & $\begin{array}{l}\text { Monitoring Completed Navigation Projects, } \\
\text { Lessons Learned IV, by R.R. Bottin, Jr. }\end{array}$ \\
\hline RDC/CHL CHETN-VI-34 & Sep 2000 & $\begin{array}{l}\text { Deploying and Recovering Marine } \\
\text { Instruments With a Helicopter, by D.D. } \\
\text { McGehee and C.J. Mayers }\end{array}$ \\
\hline RDC/CHL CHETN-VI-35 & Mar 2001 & $\begin{array}{l}\text { Dredge Bucket Comparison Demonstration } \\
\text { at Boston Harbor, by T. Welp, D. Hayes, M. } \\
\text { Tubman, S. McDowell, T. Fredette, J. } \\
\text { Clausner, and C. Albro }\end{array}$ \\
\hline ERDC/CHL CHETN-VI-36 & Sep 2001 & $\begin{array}{l}\text { Boston Harbor Dredged Material Capping } \\
\text { Simulation, by L.T. Lee, Jr. }\end{array}$ \\
\hline ERDC/CHL CHETN-VI-37 & Sep 2002 & $\begin{array}{l}\text { Estimating Surface Currents Using Dyes } \\
\text { and Drogues, by S.A. Hughes }\end{array}$ \\
\hline ERDC/CHL CHETN-VI-38 & Jun 2003 & $\begin{array}{l}\text { Collecting Field Data in a Small Boat Harbor } \\
\text { for a Multiphase Numerical Study, by T.C. } \\
\text { Pratt }\end{array}$ \\
\hline ERDC/CHL CHETN-VI-39 & Dec 2003 & $\begin{array}{l}\text { Model for the Computation of Time-Steady } \\
\text { Nearshore Currents, by B. Johnson }\end{array}$ \\
\hline ERDC/CHL CHETN-VI-40 & Jun 2005 & $\begin{array}{l}\text { Use of Sediment Trend Analysis (STA®) for } \\
\text { Coastal Projects, by S.A. Hughes }\end{array}$ \\
\hline ERDC/CHL CHETN-VI-41 & Dec 2005 & $\begin{array}{l}\text { Determination of Standard Response } \\
\text { Spectra and Effective Peak Ground } \\
\text { Accelerations for Seismic Design and } \\
\text { Evaluation, by E.E. Matheu, D.E. Yule, and } \\
\text { R.V. Kala }\end{array}$ \\
\hline ERDC/CHL CHETN-VI-42 & Mar 2006 & $\begin{array}{l}\text { Branchbox Breakwater Design at } \\
\text { Pickleweed Trail, Martinez, CA, Section } 227 \\
\text { Demonstration Project, by S.T. Maynord, } \\
\text { M.F. Winkler, and D.E. Demko }\end{array}$ \\
\hline ERDC/CHL CHETN-VI-43 & Jul 2010 & $\begin{array}{l}\text { Hatteras Breach, North Carolina, by T.V. } \\
\text { Wamsley, K.K. Hathaway, and M. Wutkowski }\end{array}$ \\
\hline
\end{tabular}


ERDC/CHL CHETN-VI-44 Aug 2013 Land Building Models: Uncertainty in and

Sensitivity to Input Parameters, by T.V.

Wamsley

\section{Section VII - River engineering and sedimentation}

\begin{tabular}{|c|c|c|}
\hline$\underline{\text { Report Number }}$ & Date & $\underline{\text { Title }}$ \\
\hline ERDC/CHL CHETN-VII-1 & Sep 2001 & $\begin{array}{l}\text { Analysis of Near-Field Hydrodynamics of } \\
\text { Submerged Weirs, by S.H. Scott, Y. Jai, } \\
\text { S.S.Y. Wang, and Y. Xu }\end{array}$ \\
\hline ERDC/CHL CHETN-VII-2 & Sep 2001 & $\begin{array}{l}\text { Multidimensional Models Used in Rivers } \\
\text { and Streams, by N.K. Raphelt and M.P. } \\
\text { Alexander }\end{array}$ \\
\hline ERDC/CHL CHETN-VII-3 & Dec 2001 & $\begin{array}{l}\text { Design Considerations for Siting Grade } \\
\text { Control Structures, by D.S. Biedenharn and } \\
\text { L.C. Hubbard }\end{array}$ \\
\hline ERDC/CHL CHETN-VII-4 & Jun 2002 & $\begin{array}{l}\text { Quantification of Bed-Load Transport on the } \\
\text { Upper Mississippi River Using Multibeam } \\
\text { Survey Data and Traditional Methods, by } \\
\text { D.D. Abraham and T. Pratt }\end{array}$ \\
\hline ERDC/CHL CHETN-VII-5 & Dec 2003 & $\begin{array}{l}\text { Effects of Drawdown and Structures on } \\
\text { Bed-Load Transport in Pool } 8 \text { Navigation } \\
\text { Channel, by D. Abraham and J. Hendrickson }\end{array}$ \\
\hline ERDC/CHL CHETN-VII-6 & Sep 2006 & $\begin{array}{l}\text { Predicting Sediment Transport Dynamics in } \\
\text { Ephemeral Channels: A Review of } \\
\text { Literature, by S.H. Scott }\end{array}$ \\
\hline ERDC/CHL CHETN-VII-7 & Sep 2006 & $\begin{array}{l}\text { Application of the SAM Computer Program } \\
\text { for Truckee River Stable Channel Analysis, } \\
\text { by S.H. Scott }\end{array}$ \\
\hline ERDC/CHL CHETN-VII-8 & Sep 2006 & $\begin{array}{l}\text { Two-Dimensional Simulation of Truckee } \\
\text { River Hydrodynamics, by S.H. Scott }\end{array}$ \\
\hline ERDC/CHL CHETN-VII-9 & Nov 2008 & $\begin{array}{l}\text { River Diversions and Shoaling, by J.V. Letter, } \\
\text { Jr., C.F. Pinkard, Jr., and N.K. Raphelt }\end{array}$ \\
\hline ERDC/CHL CHETN-VII-10 & Aug 2010 & $\begin{array}{l}\text { Innovative Streambank Protection in an } \\
\text { Urban Setting, Accotink Creek, VA, by D.L. } \\
\text { Derrick and M.M. Jonas }\end{array}$ \\
\hline ERDC/CHL CHETN-VII-11 & Mar 2011 & $\begin{array}{l}\text { Robust Prediction of Hydraulic Roughness, } \\
\text { by S.K. McKay and J.C. Fischenich }\end{array}$ \\
\hline ERDC/CHL CHETN-VII-13 & Sep 2013 & $\begin{array}{l}\text { A Simplified Analytic Investigation of the } \\
\text { Riverside Effects of Sediment Diversions, by } \\
\text { G.L. Brown, J.V. Letter, Jr., R.E. Heath, R. } \\
\text { McAdory, L.L. Wehmeyer, and B.L. Gunkel }\end{array}$ \\
\hline
\end{tabular}


ERDC/CHL CHETN-VII-14 Aug 2015 Simulation of Ohio River Hydrodynamics to

Support Emergency Maintenance

Operations on Lock and Dam 52, by N.

Clifton, S. Scott, and D. Abraham

\section{Section VIII - Flood management}

\begin{tabular}{|c|c|c|}
\hline Report Number & Date & $\underline{\text { Title }}$ \\
\hline ERDC/CHL CHETN-VIII-1 & Apr 2000 & $\begin{array}{l}\text { Increasing Reservoir Storage or Spillway } \\
\text { Capacity using Fusegates, by J. Hite, Jr. and } \\
\text { C. Mifkovic }\end{array}$ \\
\hline ERDC/CHL CHETN-VIII-2 & Jul 2000 & $\begin{array}{l}\text { Hydraulic Modeling of Trapezoidal High- } \\
\text { Velocity Channels, by R.L. Stockstill }\end{array}$ \\
\hline ERDC/CHL CHETN-VIII-3 & Dec 2000 & $\begin{array}{l}\text { Determination of Flow Resistance } \\
\text { Coefficients Due to Shrubs and Woody } \\
\text { Vegetation, by R.R. Copeland }\end{array}$ \\
\hline ERDC/CHL CHETN-VIII-4 & Dec 2000 & $\begin{array}{l}\text { Effective Discharge Calculation, by D.S. } \\
\text { Biedenharn and R.R. Copeland }\end{array}$ \\
\hline ERDC/CHL CHETN-VIII-5 & Dec 2000 & $\begin{array}{l}\text { Channel-Forming Discharge, by R.R. } \\
\text { Copeland, D.S. Biedenharn, and J.C. } \\
\text { Fischenich }\end{array}$ \\
\hline ERDC/CHL CHETN-VIII-6 & Sep 2007 & $\begin{array}{l}\text { Lateral Inflow into High-Velocity Channels } \\
\text { by, R.L. Stockstill }\end{array}$ \\
\hline ERDC/CHL CHETN-VIII-7 & Sep 2013 & $\begin{array}{l}\text { Initial Development and Testing of a State- } \\
\text { of-the-Art Method to Quantify Hydrologic } \\
\text { Model Uncertainty, by B.E. Skahill }\end{array}$ \\
\hline
\end{tabular}

Section IX - Navigation

\begin{tabular}{|c|c|c|}
\hline Report Number & Date & $\underline{\text { Title }}$ \\
\hline ERDC/CHL CHETN-IX-2 & Apr 2000 & $\begin{array}{l}\text { Modeling Surges in Navigation Lock } \\
\text { Approaches, by R.L. Stockstill }\end{array}$ \\
\hline ERDC/CHL CHETN-IX-3 & Apr 2000 & $\begin{array}{l}\text { Performance of Precast Concrete Stay-in- } \\
\text { Place Forming System for Lock Walls } \\
\text { Rehabilitation, by J.E. McDonald and R.R. } \\
\text { Bottin, Jr. }\end{array}$ \\
\hline ERDC/CHL CHETN-IX-4 & Dec 2000 & $\begin{array}{l}\text { Simulation of Flow in Hydraulic Structures } \\
\text { using ADH, by R.L. Stockstill and R.C. Berger }\end{array}$ \\
\hline ERDC/CHL CHETN-IX-5 & Sep 2001 & $\begin{array}{l}\text { Monitoring Completed Navigation Projects } \\
\text { Program, by R.R. Bottin, Jr. }\end{array}$ \\
\hline ERDC/CHL CHETN-IX-6 & Dec 2001 & $\begin{array}{l}\text { Modeling Navigation Conditions at Lock } \\
\text { Approaches, by by R.L. Stockstill }\end{array}$ \\
\hline
\end{tabular}




$\begin{array}{lll}\text { ERDC/CHL CHETN-IX-7 } & \text { Dec 2001 } & \begin{array}{l}\text { Deep-Draft Entrance Channels: Preliminary } \\ \text { Comparisons Between Field and Laboratory } \\ \text { Measurements, by M.J. Briggs, I. Melito, Z. } \\ \text { Demirbilek, and F. Sargent }\end{array} \\ \text { ERDC/CHL CHETN-IX-8 } & \text { Jun 2002 } & \begin{array}{l}\text { General Guard Wall Design Considerations } \\ \text { for Tow Entry and Exit, by H. Park }\end{array} \\ \text { ERDC/CHL CHETN-IX-9 } & \text { Jun 2002 } & \begin{array}{l}\text { Mooring Model for Barge Tows in Lock } \\ \text { Chamber, by R.L. Stockstill }\end{array} \\ \text { ERDC/CHL CHETN-IX-10 Sep 2002 } & \begin{array}{l}\text { Monitoring Completed Navigation Projects, } \\ \text { Lessons Learned V, by R.R. Bottin, Jr. }\end{array} \\ \text { ERDC/CHL CHETN-IX-11 Dec 2002 } & \begin{array}{l}\text { Current Direction and Velocity } \\ \text { Measurements Using GPS Receivers } \\ \text { Mounted on Floats at Tom Bevill Lock and } \\ \text { Dam, by M.F. Winkler and R.T. Wooley }\end{array}\end{array}$

ERDC/CHL CHETN-IX-12 Dec 2003

ERDC/CHL CHETN-IX-13 Dec 2003

ERDC/CHL CHETN-IX-14 Mar 2004

ERDC/CHL CHETN-IX-15 Mar 2005

ERDC/CHL CHETN-IX-16 Sep 2006

ERDC/CHL CHETN-IX-17 Oct 2008

ERDC/CHL CHETN-IX-18 Jan 2009

ERDC/CHL CHETN-IX-19 Aug 2009

ERDC/CHL CHETN-IX-20 Aug 2009

ERDC/CHL CHETN-IX-21 Aug 2009
Defining Angle and Spacing of Bendway Weirs, by M.F. Winkler

Monitoring Navigation Using Time-Lapse Video Recorders, by M.F. Winkler, R.T. Wooley, and B.C. Barker

Charleston Harbor Ship Motion Data Collection and Squat Analysis, by M.J. Briggs, S.T. Maynord, C.R. Nickles, and T.N. Waller

Modeling of Vessel Effects: Selection of Adaption Parameters for Modeling Vessels in $\mathrm{ADH}$, by $\mathrm{C}$. Berger and L. Lee

Numerical Evaluation of Stress Intensity Factors $\left(\mathrm{K}_{\mathrm{i}}\right)$ J-Integral Approach, by G.A. Riveros

Considerations for Modeling VesselGenerated Currents and Bed Shear Stresses, by E.A. Hammack and J.N. Tate

Computational Model of a Lock Filling System, by R.L. Stockstill

Ankudinov Ship Squat Predictions - Part I: Theory, Parameters, and FORTRAN Programs, by M.J. Briggs

Ankudinov Ship Squat Predictions - Part II: Laboratory and Field Comparisons and Validations, by M.J. Briggs and L. Daggett

Calculating Forces on Components of Hydraulic Structures, by E.A. Hammack, M.T. Fong, and R.L. Stockstill 
ERDC/CHL CHETN-IX-22 Jun 2010

ERDC/CHL CHETN-IX-23 Aug 2010

ERDC/CHL CHETN-IX-24 Aug 2010

ERDC/CHL CHETN-IX-25 Aug 2010

ERDC/CHL CHETN-IX-26 Mar 2011

ERDC/CHL CHETN-IX-27 Oct 2011

ERDC/CHL CHETN-IX-28 Mar 2012

ERDC/CHL CHETN-IX-29 Apr 2012

ERDC/CHL CHETN-IX-30 Oct 2012

ERDC/CHL CHETN-IX-31 Jan 2013

ERDC/CHL CHETN-IX-32 Aug 2013

ERDC/CHL CHETN-IX-33 Dec 2013

ERDC/CHL CHETN-IX-34 Dec 2013
Mississippi River Sediment Availability Study: Summary of Available Data, by S. Filippo

Acoustical Imaging Cameras for the Inspection and Condition Assessment of Hydraulic Structures, by J.A. Evans

Predicting Deterioration of Navigation Steel Hydraulic Structures with Markov Chain and Latin Hypercube Simulation, by G.A. Riveros and E. Arredondo

Guide to the Development of a Deterioration Rate Curve Using Condition State Inspection Data, by G.A. Riveros and E. Arredondo

Design Concept and Analysis for a Navigation Dam Gate Guard, by E.A. Hammack, R.L. Stockstill, and J. Vaughan

Computational Flow Model of a Reverse Tainter Valve, by E.A. Hammack and R.L. Stockstill

Post-tensioned Multistrand Anchorage Capacity Deterioration Due To Corrosion: John Day Lock Project, by R. Ebeling, R. Haskins, D. Scofield, J. Hite, and R. Strom

A Review of Coastal Navigation Asset Management Efforts within the Coastal Inlets Research Program (CIRP) Part 2: The Channel Portfolio Tool, by K.N. Mitchell

Lock Manifold Port Coefficients, by R.L. Stockstill, E.A. Hammack, and J.M. Vaughan

Modeling Flow through a Lock Manifold Port, by R.L. Stockstill and E.A. Hammack

Trunnion Rod Microcrack Detection, by J.A. Evans, R.W. Haskins, J.A. Padula, and J.E. Hite

Hydrodynamic Forces on Reverse Tainter Valves; Hydraulic Model Investigation, by R.L. Stockstill, E.A. Hammack, D.S. Smith, J.M. Vaughan, and K. Green

Field Experience with Lock Culvert Valves, by R.L. Stockstill, E.A. Hammack, T.E. Hood, and J.M. Vaughan 
ERDC/CHL CHETN-IX-35 Apr 2014

ERDC/CHL CHETN-IX-36 Apr 2014

ERDC/CHL CHETN-IX-37 Sep 2014

ERDC/CHL CHETN-IX-38 Sep 2014

ERDC/CHL CHETN-IX-39 Sep 2014

ERDC/CHL CHETN-IX-40 Aug 2015

ERDC/CHL CHETN-IX-41 Oct 2015
Guided-Wave Testing of Trunnion Rods at Greenup Lock and Dam, Kentucky, by J.A. Evans and R. Haskins

Development of a Guided-Wave Technology Capable of the Detection of Open Cracks and Microcracks in Embedded Trunnion Anchor Rods, by J.A. Evans and R. Haskins

Acoustic Nondestructive Testing and Measurement of Tension for Steel Reinforcing Members: Part 1-Theory, by M.K. Mclnerney

Acoustic Nondestructive Testing And Measurement of Tension for Steel Reinforcing Members: Part 2 - Field Testing, by M.K. Mclnerney

A Survey of Corrosion and Conditions of Corrosion Protection Systems in Civil Works Structures of the U.S. Army Corps of Engineers, by M.K. Mclnerney, C.P. Marsh, V.F. Hock, and T.A. Carlson

Archival Automatic Identification System (AIS) Data for Navigation Project Performance Evaluation, by B. Scully and K.N. Mitchell

Shoaling Analysis at Brazos Island Harbor Inlet, Texas, by E.R. Smith, T.C. Lackey, D.B. King, and R. Styles

\section{Section XI - Groundwater hydraulics}

$\begin{array}{lll}\text { Report Number } & \text { Date } & \underline{\text { Title }} \\ \text { ERDC/CHL CHETN-XI-1 } & \text { Mar 2004 } & \begin{array}{l}\text { DDJC-Sharpe Defense Distribution Depot: } \\ \text { FEMWATER 3D Transport Model of TCE } \\ \text { Plume Migration with Natural Attenuation, } \\ \text { by B.P. Donnell and the ERDC-CHL } \\ \text { Groundwater Team }\end{array} \\ \text { ERDC/CHL CHETN-XI-2 } & \text { Aug 2014 } & \begin{array}{l}\text { Seepage-Based Factor of Safety Analysis } \\ \text { Using 3D Groundwater Simulation Results, } \\ \text { by H.P. Cheng, K.D. Winters, S.M. England, } \\ \text { and R.E. Pickett }\end{array} \\ & & \begin{array}{l}\text { A Geology-Based Estimate of Connate Water } \\ \text { Salinity Distribution, by H.P. Cheng, K.D. } \\ \text { Winters, S.M. England, R.E. Pickett, M.D. } \\ \text { Shafer, and T.M. North }\end{array}\end{array}$


ERDC/CHL CHETN-XI-4 Aug 2015 Computing Flow through Well Screens Using an Embedded Well Technique, by H.P.

Cheng

\section{Section XIII - Miscellaneous inland subjects}

$\begin{array}{lll}\text { Report Number } & \text { Date } & \text { Title } \\ \text { ERDC/CHL CHETN-XIII-1 } & \text { Aug 2006 } & \begin{array}{l}\text { Modeling Free-Surface Flow Over a Weir, by } \\ \text { R. Stockstill, C. Kees, and C. Berger }\end{array} \\ \text { ERDC/CHL CHETN-XIII-2 } & \text { Jan 2008 } & \begin{array}{l}\text { Implementation of Discontinuous Galerkin } \\ \text { Methods for the Level Set Equation on } \\ \text { Unstructured Meshes, by M.W. Farthing and } \\ \text { C.E. Kees }\end{array} \\ & & \begin{array}{l}\text { Basics of Physical Modeling in Coastal and } \\ \text { ERDC/CHL CHETN-XIII-3 Sep 2013 }\end{array} \\ & & \text { Hydraulic Engineering, by M.J. Briggs }\end{array}$

\section{Section XIV - Regional sediment management}

\begin{tabular}{|c|c|c|}
\hline Report Number & Date & $\underline{\text { Title }}$ \\
\hline ERDC/CHL CHETN-XIV-1 & $\begin{array}{l}\text { Jan } 2004 \\
\text { REV }\end{array}$ & $\begin{array}{l}\text { The Corps of Engineers National Regional } \\
\text { Sediment Management Demonstration } \\
\text { Program, by J.D. Rosati, B.D. Carlson, J.E. } \\
\text { Davis, and T.D. Smith }\end{array}$ \\
\hline ERDC/CHL CHETN-XIV-2 & $\begin{array}{l}\text { Jun } 2003 \\
\text { REV }\end{array}$ & $\begin{array}{l}\text { Tools for Regional Sediment Management, } \\
\text { by J.M. Wozencraft, L. Hardegree, L.M. } \\
\text { Bocamazo, J.D. Rosati, and J.E. Davis }\end{array}$ \\
\hline ERDC/CHL CHETN-XIV-3 & $\begin{array}{l}\text { Jun } 2003 \\
\text { REV }\end{array}$ & $\begin{array}{l}\text { Sediment Budget Analysis System (SBAS): } \\
\text { Upgrade for Regional Applications, by J.D. } \\
\text { Rosati and N.C. Kraus }\end{array}$ \\
\hline ERDC/CHL CHETN-XIV-4 & $\begin{array}{l}\text { Jun } 2003 \\
\text { REV }\end{array}$ & $\begin{array}{l}\text { Overview of Regional Coastal Sediment } \\
\text { Processes and Controls, by M. Larson, J.D. } \\
\text { Rosati, and N.C. Kraus }\end{array}$ \\
\hline ERDC/CHL CHETN-XIV-5 & $\begin{array}{l}\text { Jun } 2003 \\
\text { REV }\end{array}$ & $\begin{array}{l}\text { Lessons Learned from Existing Projects on } \\
\text { Shoaling in Harbors and Navigation } \\
\text { Channels, by T.M. Parchure and A.M. Teeter }\end{array}$ \\
\hline ERDC/CHL CHETN-XIV-6 & $\begin{array}{l}\text { Jun } 2003 \\
\text { REV }\end{array}$ & $\begin{array}{l}\text { Potential Methods for Reducing Shoaling in } \\
\text { Harbors and Navigation Channels, by T.M. } \\
\text { Parchure and A.M. Teeter }\end{array}$ \\
\hline ERDC/CHL CHETN-XIV-7 & $\begin{array}{l}\text { Jun } 2003 \\
\text { REV }\end{array}$ & $\begin{array}{l}\text { Sediment Budget Analysis System-A: SBAS- } \\
\text { A for ArcView@ Application, by R. Dopsovic, } \\
\text { L. Hardegree, and J. Rosati }\end{array}$ \\
\hline
\end{tabular}




\begin{tabular}{|c|c|c|}
\hline ERDC/CHL CHETN-XIV-8 & $\begin{array}{l}\text { Jun } 2003 \\
\text { REV }\end{array}$ & $\begin{array}{l}\text { Authorities and Policies Supporting } \\
\text { Implementation of Regional Sediment } \\
\text { Management, by L.R. Martin }\end{array}$ \\
\hline ERDC/CHL CHETN-XIV-9 & Jan 2004 & $\begin{array}{l}\text { Local-Scale Technologies for Measuring and } \\
\text { Monitoring Sediment Process, by D.Y. Eng }\end{array}$ \\
\hline ERDC/CHL CHETN-XIV-10 & Jan 2004 & $\begin{array}{l}\text { Design Approach for Regional Sediment } \\
\text { Management, by D.S. Biedenharn }\end{array}$ \\
\hline ERDC/CHL CHETN-XIV-11 & Feb 2004 & $\begin{array}{l}\text { Application of Regional Sediment Approach } \\
\text { to Hickahala Creek Watershed, Northern } \\
\text { Mississippi, by D.S. Biedenharn, C.C. } \\
\text { Watson, J.B. Smith, and L.C. Hubbard }\end{array}$ \\
\hline ERDC/CHL CHETN-XIV-12 & May 2004 & $\begin{array}{l}\text { Lessons Learned in Regional Sediment } \\
\text { Management: The Mobile District } \\
\text { Demonstration Program; Technical Program } \\
\text { Implementation, by L.S. Lillycrop, J.M. } \\
\text { Wozencraft, L.C. Hardegree, R. Dopsovic, } \\
\text { and W.J. Lillycrop }\end{array}$ \\
\hline ERDC/CHL CHETN-XIV-13 & Sep 2004 & $\begin{array}{l}\text { Coastal Overwash: Part 1, Overview of } \\
\text { Processes, by C. Donnelly, N.C. Kraus, and } \\
\text { M. Larson }\end{array}$ \\
\hline ERDC/CHL CHETN-XIV-14 & Sep 2004 & $\begin{array}{l}\text { Coastal Overwash: Part 2, Upgrade to } \\
\text { SBEACH, by M. Larson, R.A. Wise, and N.C. } \\
\text { Kraus }\end{array}$ \\
\hline ERDC/CHL CHETN-XIV-15 & Sep 2004 & $\begin{array}{l}\text { Regional Morphology Analysis Package } \\
\text { (RMAP): Part 1, Overview, by B.K. Batten } \\
\text { and N.C. Kraus }\end{array}$ \\
\hline ERDC/CHL CHETN-XIV-16 & Aug 2005 & $\begin{array}{l}\text { Regional Sediment Management } \\
\text { Opportunities within the Intracoastal } \\
\text { Waterway (IWW) Dredging Program in the } \\
\text { State of Florida, by D.A. Abecassis }\end{array}$ \\
\hline ERDC/CHL CHETN-XIV-17 & Sep 2005 & $\begin{array}{l}\text { Northern Gulf of Mexico (NGOM) Regional } \\
\text { Sediment Management Demonstration } \\
\text { Program Initiatives, by L.E. Parson and S.I. } \\
\text { Rees }\end{array}$ \\
\hline ERDC/CHL CHETN-XIV-18 & Sep 2009 & $\begin{array}{l}\text { Regional Morphology Analysis Package } \\
\text { (RMAP): Version 3, User's Guide and } \\
\text { Tutorial, by A. Morang, B.K. Batten, K.J. } \\
\text { Connell, W. Tanner, M. Larson, and N.C. } \\
\text { Kraus }\end{array}$ \\
\hline ERDC/CHL CHETN-XIV-19 & Jan 2012 & $\begin{array}{l}\text { An Update on Nearshore Berms in the } \\
\text { Corps of Engineers: Recent Projects and } \\
\text { Future Needs, by T.M. Beck, J.D. Rosati, and } \\
\text { J. Rosati }\end{array}$ \\
\hline
\end{tabular}




\begin{tabular}{|c|c|c|}
\hline ERDC/CHL CHETN-XIV-20 & Sep 2012 & $\begin{array}{l}\text { Implementation of Regional Sediment } \\
\text { Management through Dredged Material } \\
\text { Management Planning, by W. Aley }\end{array}$ \\
\hline ERDC/CHL CHETN-XIV-21 & Sep 2012 & $\begin{array}{l}\text { Barren Island Dredged Material Placement } \\
\text { for Regional Sediment Management, by } \\
\text { R.N. Blama }\end{array}$ \\
\hline ERDC/CHL CHETN-XIV-22 & Sep 2012 & $\begin{array}{l}\text { Regional Sediment Management at East } \\
\text { Rockaway Inlet, NY, Utilizing the USACE } \\
\text { Coastal Modeling System, by US Army } \\
\text { Engineer District, New York }\end{array}$ \\
\hline ERDC/CHL CHETN-XIV-23 & Sep 2012 & $\begin{array}{l}\text { Estuarine Sediment Budgets for } \\
\text { Chesapeake Bay Tributaries, by J.D. Herman }\end{array}$ \\
\hline ERDC/CHL CHETN-XIV-24 & Sep 2012 & $\begin{array}{l}\text { Practical Recommendations for Regional } \\
\text { Sediment Management: Lessons Learned } \\
\text { at St. Johns County Shore Protection } \\
\text { Project, by R.C. Thomas, M.H. Schrader, J.A. } \\
\text { Engle, and K.R. Legault }\end{array}$ \\
\hline
\end{tabular}

ERDC/CHL CHETN-XIV-25 Sep 2012

ERDC/CHL CHETN-XIV-26 Mar 2013

ERDC/CHL CHETN-XIV-27 Mar 2013

ERDC/CHL CHETN-XIV-28 Apr 2013

ERDC/CHL CHETN-XIV-29 Jun 2013

ERDC/CHL CHETN-XIV-30 Jun 2013

ERDC/CHL CHETN-XIV-31 Jun 2013
Practical Recommendations for Regional Sediment Management: Lessons Learned as part of the Niobrara River Basin Initiative, by P.M. Boyd

Evaluation of Regional Sediment Management Actions Using Government Shallow Draft Dredges, by R. Thorsen and M. Chasten

Identification of Regional Sediment Management (RSM) Opportunities Along the Upper Texas Coast Through Sediment Budget Analysis, by S. Willey, T. Campbell, S. Lambert, A. Morang, D. King, and R. Thomas

Review of Innovative Sediment Delivery Systems, by T.D. Smith

Regional Sediment Management (RSM) Principles in Flood Recovery: Incorporating RSM after the 2011 Missouri River Flood, by P.M. Boyd

Creation of Island Habitat in Jacksonville Harbor, FL, by S. Groleau

Hawaii Regional Sediment Management: Application of SBAS for ArcGIS(C) 10 to Develop Regional Sediment Budgets for the Island of Maui, HI, by J.H. Podoski 
ERDC/CHL CHETN-XIV-32 Jun 2013

ERDC/CHL CHETN-XIV-33 Jun 2013

ERDC/CHL CHETN-XIV-34 Sep 2013

ERDC/CHL CHETN-XIV-35 Sep 2013

ERDC/CHL CHETN-XIV-36 Jun 2014

ERDC/CHL CHETN-XIV-37 May 2014

ERDC/CHL CHETN-XIV-38 Jun 2014

ERDC/CHL CHETN-XIV-39 Jun 2014

ERDC/CHL CHETN-XIV-41 Apr 2015

ERDC/CHL CHETN-XIV-43 Mar 2015

ERDC/CHL CHETN-XIV-44 Dec 2015

ERDC/CHL CHETN-XIV-45 Dec 2015
Hawaii Regional Sediment Management: Regional Sediment Budget for the Kekaha Region of Kauai, HI, by J.H. Podoski

Hawaii Regional Sediment Management: Regional Sediment Budget for the Poipu Region of Kauai, HI, by J.H. Podoski

Sediment as a Regional Resource in the Low-Commercial-Use Navigation Program, Mathews County, VA, by D. Stamper, J. Swallow, D. Milligan, and S. Hardaway

Regional Sediment Management for Atlantic Coast of Maryland and Assateague Island Seashore (Assateague By-Pass Project), by T.D. Laczo, M.L. Gomez, and R.N. Blama

Regional Sediment Management (RSM) Modeling Tools: Integration of Advanced Sediment Transport Tools into HEC-RAS, by P.M. Boyd and S.A. Gibson

Potential Regional Sediment Management (RSM) Projects in the Haleiwa Region, Oahu, Hawaii, by T.D. Smith

Regional Sediment Budgets for the Haleiwa Region, Oahu, Hawaii, by J.H. Podoski

The Atlantic Coast of Maryland, Sediment Budget Update, by J.C. Reed

Regional Sediment Management (RSM) Strategy for Mobile Bay, Alabama, by L. Parson, N. Lovelace, E. Godsey, K. Reine, and J. Gailani

Reservoir Sediment Management Workshop for Tuttle Creek Lake and Perry Lake Reservoirs in the Kansas River Basin, by J. Shelley

Alternatives to Reduce Shoaling in the Gulf Intracoastal Waterway and Prevent Erosion of Bay Islands along the North Shoreline of West Galveston Bay, by K. Townsend, E.

Wood, D. Thornton, J. Miller, T. Campbell, S. Willey, L. Lin, C. Maglio, and R. Thomas

Identification of Alternatives to Reduce Shoaling in the Galveston Entrance Channels, Texas, by K. Townsend, R. Thomas, T. Campbell, S. Willey, A. Frey, A. Morang, and D. King 


\section{Technical reports}

\begin{tabular}{|c|c|c|c|}
\hline Report Number & $\underline{\text { Date }}$ & $\underline{\text { Title }}$ & $\underline{\text { AD Number }}$ \\
\hline $\begin{array}{l}\text { ERDC/CHL TR-99-19 } \\
\text { Rep. } 3\end{array}$ & Sep 2001 & $\begin{array}{l}\text { DMS: Diagnostic Modeling System. Report } \\
\text { 3, DMS Data Manager--A User's Guide, by } \\
\text { K.R.Craig, M.S. Gosselin, D.S. Cook, and } \\
\text { T.C. Pratt }\end{array}$ & ADA397613 \\
\hline $\begin{array}{l}\text { ERDC/CHL TR-99-19 } \\
\text { Rep. } 4\end{array}$ & Sep 2002 & $\begin{array}{l}\text { DMS: Diagnostic Modeling System. Report } \\
\text { 4, Shoaling Analysis of St. Marys Entrance, } \\
\text { Florida, by S. Johnston, N.C. Kraus, M.E. } \\
\text { Brown and W.G. Grosskopf }\end{array}$ & ADA408476 \\
\hline $\begin{array}{l}\text { ERDC/CHL TR-99-19 } \\
\text { Rep. } 7\end{array}$ & Aug 2001 & $\begin{array}{l}\text { DMS: Diagnostic Modeling System. Report } \\
\text { 7, The DMS Data Manager - Updated User's } \\
\text { Guide, by S. Johnston and K.R. Craig }\end{array}$ & ADA408477 \\
\hline TR CHL-99-20 & Oct 1999 & $\begin{array}{l}\text { Los Angeles and Long Beach Harbors Model } \\
\text { Enhancement Program: Long Waves and } \\
\text { Harbor Resonance Analysis, by W.C. } \\
\text { Seabergh and L.J. Thomas }\end{array}$ & ADA370942 \\
\hline TR CHL-99-21 & Dec 1999 & $\begin{array}{l}\text { Use and Application of the Empirical } \\
\text { Simulation Technique: User's Guide, by N.W. } \\
\text { Scheffner, J.E. Clausner, A. Militello, L.E. } \\
\text { Borgman, B.L. Edge, and P.J. Grace }\end{array}$ & ADA376132 \\
\hline ERDC/CHL TR-00-01 & Mar 2000 & $\begin{array}{l}\text { Demonstration Erosion Control Project } \\
\text { Monitoring Program: Fiscal Year } 1995 \\
\text { Report, by D.S. Biedenharn, N.K. Raphelt, } \\
\text { and C.C. Watson }\end{array}$ & ADA375784 \\
\hline ERDC/CHL TR-00-02 & Mar 2000 & $\begin{array}{l}\text { Barbers Point Harbor Physical Model } \\
\text { Navigation Study, by G.S. Harkins and C.C. } \\
\text { Dorrell }\end{array}$ & ADA377888 \\
\hline ERDC/CHL TR-00-03 & Apr 2000 & $\begin{array}{l}\text { First Powerhouse, Bonneville Dam, } \\
\text { Columbia River, Oregon: Report 1, Proposed } \\
\text { Trash Holding System, by R. Davidson }\end{array}$ & ADA376795 \\
\hline ERDC/CHL TR-00-03 & Apr 2000 & $\begin{array}{l}\text { First Powerhouse, Bonneville Dam, } \\
\text { Columbia River, Oregon: Report 2, Tracking } \\
\text { Velocities; Hydraulic Model Investigation, by } \\
\text { R. Davidson }\end{array}$ & ADA376794 \\
\hline ERDC/CHL TR-00-04 & Apr 2000 & $\begin{array}{l}\text { Salinity Intrusion in the Panama Canal, by } \\
\text { T.M. Parchure, S.C. Wilhelms, S. Sarruff, } \\
\text { and W.H. McAnally }\end{array}$ & ADA378475 \\
\hline ERDC/CHL TR-00-05 & Apr 2000 & $\begin{array}{l}\text { Sedimentation Study and Flume } \\
\text { Investigation, Mission Creek, Santa } \\
\text { Barbara, California, Corte Madera Creek, } \\
\text { Marin County, California: Numerical and } \\
\text { Hydraulic Model Investigation, by R.R. } \\
\text { Copeland, D.C. McVan, and S.E. Stonestreet }\end{array}$ & ADA378135 \\
\hline
\end{tabular}




\begin{tabular}{|c|c|c|c|}
\hline $\begin{array}{l}\text { ERDC/CHL TR-00-06 } \\
\text { Rep. } 1\end{array}$ & Apr 2000 & $\begin{array}{l}\text { Study of Navigation Channel Feasibility, } \\
\text { Willapa Bay, Washington, by N.C. Kraus, } \\
\text { Editor }\end{array}$ & ADA378474 \\
\hline $\begin{array}{l}\text { ERDC/CHL TR-00-06 } \\
\text { Rep. } 2\end{array}$ & Jul 2002 & $\begin{array}{l}\text { Study of Navigation Channel Feasibility, } \\
\text { Willapa Bay, Washington. Report 2, } \\
\text { Entrance Channel Monitoring and Study of } \\
\text { Bay Center Entrance Channel, by N.C. } \\
\text { Kraus, H.T. Arden, and D.P. Simpson, Editors }\end{array}$ & ADA406177 \\
\hline ERDC/CHL TR-00-07 & Apr 2000 & $\begin{array}{l}\text { Unrestrained Cylinders Rolling in Steady } \\
\text { Uniform Flows, by J.E. Davis }\end{array}$ & ADA377851 \\
\hline ERDC/CHL TR-00-08 & May 2000 & $\begin{array}{l}\text { Aggregation and Deposition of Estuarial } \\
\text { Fine Sediment, by W.H. McAnally }\end{array}$ & ADA379002 \\
\hline ERDC/CHL TR-00-09 & Jun 2000 & $\begin{array}{l}\text { Oakland Harbor Navigation Study, by G.C. } \\
\text { Lynch and P. Van Norman }\end{array}$ & ADA379099 \\
\hline ERDC/CHL TR-00-10 & Jun 2000 & $\begin{array}{l}\text { Lower St. Johns River and Estuary, Florida, } \\
\text { Numerical Model Study, by J.A. Sanchez and } \\
\text { R.A. Evans, Jr. }\end{array}$ & ADA379450 \\
\hline ERDC/CHL TR-00-11 & Jul 2000 & $\begin{array}{l}\text { Comite River Diversion Project--Diversion } \\
\text { Channel Stage Control Structure (Lilly Bayou } \\
\text { Structure) Comite River, Louisiana: } \\
\text { Numerical Model Investigation, by J.E. Hite, } \\
\text { Jr. and J.E. Myrick }\end{array}$ & ADA380037 \\
\hline ERDC/CHL TR-00-12 & Jul 2000 & $\begin{array}{l}\text { Periodic Inspection of Burns Harbor North } \\
\text { Breakwater, Indiana: Armor Unit Monitoring } \\
\text { for Period 1994-1999, by R.R. Bottin, Jr. } \\
\text { and M.K. Tibbetts }\end{array}$ & \\
\hline ERDC/CHL TR-00-13 & Aug 2000 & $\begin{array}{l}\text { Effects of Lock Sill and Chamber Depths on } \\
\text { Transit Time of Shallow Draft Navigation, by } \\
\text { S.T. Maynord }\end{array}$ & ADA381143 \\
\hline ERDC/CHL TR-00-14 & Aug 2000 & $\begin{array}{l}\text { Corte Madera Creek Marin County, } \\
\text { California, Modified Unit } 4 \text { Sedimentation } \\
\text { Study: Numerical Model Investigation, by } \\
\text { R.R. Copeland }\end{array}$ & ADA382213 \\
\hline ERDC/CHL TR-00-15 & Aug 2000 & $\begin{array}{l}\text { Effective Discharge Calculation: A Practical } \\
\text { Guide, by D.S. Biedenharn, R.R. Copeland, } \\
\text { C.R. Thorne, P.J. Soar, R.D. Hey, and C.C. } \\
\text { Watson }\end{array}$ & ADA383261 \\
\hline ERDC/CHL TR-00-16 & Aug 2000 & $\begin{array}{l}\text { Riverflow/River Stage Prediction for Military } \\
\text { Applications Using Artificial Neural Network } \\
\text { Modeling, by B.B. Hsieh and C.L. Bartos }\end{array}$ & ADA382991 \\
\hline ERDC/CHL TR-00-17 & Sep 2000 & $\begin{array}{l}\text { Model Study of Prado Spillway, California, by } \\
\text { R.R. Copeland and B.P. Fletcher }\end{array}$ & ADA382559 \\
\hline
\end{tabular}




\begin{tabular}{|c|c|c|c|}
\hline ERDC/CHL TR-00-18 & Aug 2000 & $\begin{array}{l}\text { Cape Fear-Northeast Cape Fear River, North } \\
\text { Carolina: Numerical Model Study, by R.T. } \\
\text { McAdory, Jr. }\end{array}$ & ADA384556 \\
\hline ERDC/CHL TR-00-20 & Sep 2000 & $\begin{array}{l}\text { Navigation Span Location Study for } \\
\text { Greenville Bridge Reach, Mississippi River, } \\
\text { by D.C. Wilson }\end{array}$ & ADA384705 \\
\hline ERDC/CHL TR-00-21 & Sep 2000 & $\begin{array}{l}\text { Wave Climate and Littoral Sediment } \\
\text { Transport Potential, Long Beach Island, New } \\
\text { Jersey, by M.A. Cialone and E.F. Thompson }\end{array}$ & ADA385444 \\
\hline ERDC/CHL TR-00-22 & Sep 2000 & $\begin{array}{l}\text { Sedimentation Response to Wharf } \\
\text { Expansion Plans for the Columbus Street } \\
\text { Terminal, Charleston, South Carolina, by } \\
\text { A.M. Teeter, G.L. Brown, C.J. Callegan, D.C. } \\
\text { McVan, and M.S. Sarruff }\end{array}$ & ADA385073 \\
\hline ERDC/CHL TR-00-23 & Sep 2000 & $\begin{array}{l}\text { Design of Sediment Trap at Rollover Pass, } \\
\text { Texas, by T.M. Parchure, B. Brown, and R.T. } \\
\text { McAdory }\end{array}$ & ADA384299 \\
\hline ERDC/CHL TR-00-24 & Sep 2000 & $\begin{array}{l}\text { New McAlpine Lock Filling and Emptying } \\
\text { System, Ohio River, Kentucky: Hydraulic } \\
\text { Model Investigation, by J.E. Hite, Jr. }\end{array}$ & ADA385017 \\
\hline ERDC/CHL TR-00-25 & Oct 2000 & $\begin{array}{l}\text { Determination of Resistance Due to Shrubs } \\
\text { and Woody Vegetation, by G.E. Freeman, } \\
\text { W.H. Rahmeyer, and R.R. Copeland }\end{array}$ & ADA383997 \\
\hline ERDC/CHL TR-00-26 & Nov 2000 & $\begin{array}{l}\text { Navigation Study, Colorado Locks, Colorado, } \\
\text { Matagorda, Texas, by R. McCollum }\end{array}$ & ADA386627 \\
\hline ERDC/CHL TR-01-01 & Jan 2001 & $\begin{array}{l}\text { HyPAS User's Manual: A Hydraulic } \\
\text { Processes Analysis System, an Extension for } \\
\text { ArcView GIS, Version 4.0.1, by T.C. Pratt and } \\
\text { D.S. Cook }\end{array}$ & ADA387601 \\
\hline
\end{tabular}

$\begin{array}{lll}\text { ERDC/CHL TR-01-02 Feb } 2001 & \begin{array}{l}\text { Periodic Inspection of St. Paul Harbor } \\ \text { Breakwater, Alaska, by R.R. Bottin, Jr. and }\end{array}\end{array}$

ADA387489 A.C. Jeffries

ERDC/CHL TR-01-03 Feb 2001 Kaumalapau Harbor, Lanai, Hawaii, TwoDimensional Breakwater Stability Study, by E.R. Smith

ERDC/CHL TR-01-04 Mar 2001 Outdraft at Lock Approach, Tom Bevill Lock and Dam, Alabama: Hydraulic Model Investigation, by G.C. Lynch

ERDC/CHL TR-01-05 May 2001 Navigation Study of Lower Lock Approach, John Day Lock and Dam, Columbia River, Oregon, by D.C. Wilson, D.M. Maggio, and P.S. Van Norman

ERDC/CHL TR-01-06 Apr 2001 Port of Baltimore Navigation Simulation Study, by G.C. Lynch

ADA389104

ADA389692

ADA391877

ADA391922 


\begin{tabular}{|c|c|c|c|}
\hline ERDC/CHL TR-01-07 & Apr 2001 & $\begin{array}{l}\text { Wave Breaking on a Current at an Idealized } \\
\text { Inlet with an Ebb Shoal, by J.M. Smith and } \\
\text { W.C. Seabergh }\end{array}$ & ADA393100 \\
\hline ERDC/CHL TR-01-08 & May 2001 & $\begin{array}{l}\text { Pool Lowering at Lock and Dam } 1 \text { Using the } \\
\text { Lock Filling and Emptying System, } \\
\text { Mississippi River, Minnesota, by R.L. } \\
\text { Stockstill, T.L. Fagerburg, and T.N. Waller }\end{array}$ & ADA392082 \\
\hline ERDC/CHL TR-01-09 & May 2001 & $\begin{array}{l}\text { Model Study of Kentucky Lock Addition, } \\
\text { Tennessee River, Kentucky: Hydraulic Model } \\
\text { Investigation, by J.E. Sanchez }\end{array}$ & ADA392021 \\
\hline ERDC/CHL TR-01-10 & May 2001 & $\begin{array}{l}\text { Design for Small-Boat Harbor Improvements } \\
\text { and Tidal Flushing, St. Paul Harbor, St. Paul } \\
\text { Island, Alaska: Coastal Model Investigation, } \\
\text { by R.R. Bottin, Jr. and H.E. Acuff }\end{array}$ & ADA392226 \\
\hline ERDC/CHL TR-01-11 & Jun 2001 & $\begin{array}{l}\text { Coast of South Carolina Storm Surge Study, } \\
\text { by N.W. Scheffner and F.C. Carson }\end{array}$ & ADA394525 \\
\hline
\end{tabular}

ERDC/CHL TR-01-12 Jun 2001

Beach Erosion and Sediment Processes

ADA394319

Study, North East Marina, Erie County,

Pennsylvania, by A. Morang and J. Melton

ERDC/CHL TR-01-13 Jul 2001 Performance Characteristics of a Rapidly

ADA395021 Installed Breakwater System, by M.J. Briggs

ERDC/CHL TR-01-14 Jul 2001

Salinity Changes in Pontchartrain Basin Estuary, Louisiana, Resulting from Mississippi River-Gulf Outlet Partial Closure Plans: Numerical Model Investigation, by A.R. Carrillo, R.C. Berger, M.S. Sarruff, and B.J. Thibodeaux

$\begin{array}{lll}\text { ERDC/CHL TR-01-15 } & \text { Aug 2001 } & \begin{array}{l}\text { Hydrodynamic and Sediment Transport } \\ \text { Study of Sudbury River, Massachussetts: } \\ \text { Numerical Model Investigation, by G.H. Nail } \\ \text { and D.D. Abraham }\end{array} \\ \text { ERDC/CHL TR-01-16 } & \text { Aug 2001 } & \begin{array}{l}\text { Impact of Relocation of the Gulf } \\ \text { Intracoastal Waterway on Circulation and } \\ \text { Salinity in Matagorda Bay System, Texas, by } \\ \text { S.R. Vemulakonda }\end{array} \\ \text { ERDC/CHL TR-01-17 } & \text { Aug 2001 } & \begin{array}{l}\text { First Powerhouse, Bonneville Dam, } \\ \text { Columbia River, Oregon, Fish Guidance } \\ \text { Efficiency System: Hydraulic Model } \\ \text { Investigation, by R. Davidson }\end{array} \\ & & \text { London Locks and Dam, Kanawha River, } \\ \text { ERDC/CHL TR-01-18 } & \text { Sep 2001 } & \text { West Virginia: Navigation Study, by R.A } \\ \text { McCollum, B.T. Crawford, and K. Anderson- } \\ \text { Smith }\end{array}$

ADA395560

ADA397428

ADM001347 
ERDC/CHL TR-01-19

ERDC/CHL TR-01-20

ERDC/CHL TR-01-21

ERDC/CHL TR-01-22

ERDC/CHL TR-01-23

ERDC/CHL TR-01-24

ERDC/CHL TR-01-25

Rep. 1

ERDC/CHL TR-01-26

ERDC/CHL TR-01-27

ERDC/CHL TR-01-28

ERDC/CHL TR-01-29

ERDC/CHL TR-01-30

Nov 2001

ERDC/CHL TR-01-31

Sep 2001

Sep 2001

Sep 2001

Sep 2001

Sep 2001

Sep 2001

Nov 2001
Analytical and Numerical Models of the RIBS XM99 Ocean-Scale Prototype, by M.J. Briggs

Sep 2001 Tidal Inlet Equilibrium Area Experiments, Inlet Laboratory Investigations, by W.C. Seabergh, D.B. King, Jr., and B.E. Stephens

Sep 2001 Morro Bay Harbor, California, Wave and Current Data Summary Report, by A.W. Garcia

Sep 2001

Development of a Large-Scale Laboratory Facility for Sediment Transport Research, by D.G. Hamilton, B.A. Ebersole, E.R. Smith, and P. Wang

Ship Navigation Simulation Study, Kalihi Channel Reopening, Honolulu Harbor, Oahu, Hawaii, by G.C. Lynch and J.A. Sanchez

Study of Complex Flows in the Lower San Bernard River, Texas, by J.A. Sanchez and T.M. Parchure

BOUSS-2D: A Boussinesq Wave Model for Coastal Regions and Harbors. Report 1, Theoretical Background and User's Manual, by O.G. Nwogu and Z. Demirbilek

Impacts of Navigation Channel Maintenance Dredging on the Coastal Processes of Chatham, Massachusetts, by D.K. Stauble

Monitoring of Boston Harbor Confined Aquatic Disposal Cells, by L.Z. Hales

Sep 2001 Hydraulic Design of Stream Restoration Projects, by R.R. Copeland, D.N. McComas, C.R. Thorne, P.J. Soar, M.M. Jonas, and J.B. Fripp

Design for Enhancement of Wave-Induced Circulation at Kaunakakai Harbor, Molokai, Hawaii: Coastal Model Investigation, by R.R. Bottin, Jr., and H.F. Acuff

Desktop Study for Shoaling Prediction in Corpus Christi Navigation Channel, Texas, by T.M. Parchure, S. Sarruff, and B. Brown

Dec 2001 Boat Waves on Johnson Lake and Kenai River, Alaska, by S.T. Maynord
ADA397637

ADA397931

ADA398613

ADA399451

ADA399666

ADA399389

ADA400294

ADA400385

ADA400341

ADA400662

ADA398409

ADA400290

ADA398623 


\begin{tabular}{|c|c|c|c|}
\hline ERDC/CHL TR-02-01 & Jan 2002 & $\begin{array}{l}\text { Typhoon-Induced Stage-Frequency and } \\
\text { Overtopping Relationships for the } \\
\text { Commercial Port Road, Territory of Guam, } \\
\text { by E.F. Thompson and N.W. Scheffner }\end{array}$ & ADA400206 \\
\hline ERDC/CHL TR-02-02 & Mar 2002 & $\begin{array}{l}\text { Bluestone Lake Dam, West Virginia, Rating } \\
\text { Curve and Overtopping Study, by B.D. Fuller }\end{array}$ & ADA40031 \\
\hline ERDC/CHL TR-02-03 & Apr 2002 & $\begin{array}{l}\text { Kentucky Lock and Dam, Tennessee River, } \\
\text { Kentucky: Navigation Study, by R.A. } \\
\text { McCollum and B.T. Crawford }\end{array}$ & ADA40152 \\
\hline ERDC/CHL TR-02-04 & May 2002 & $\begin{array}{l}\text { Guadalupe River, California, Sedimentation } \\
\text { Study: Numerical Model Investigation, by } \\
\text { R.R. Copeland and D.N. McComas }\end{array}$ & ADA40253 \\
\hline ERDC/CHL TR-02-05 & May 2002 & $\begin{array}{l}\text { Red River Below Denison Dam, Texas, } \\
\text { Oklahoma, Arkansas, and Louisiana: } \\
\text { Numerical Model Investigation, by R.R. } \\
\text { Copeland }\end{array}$ & ADA40317 \\
\hline ERDC/CHL TR-02-06 & May 2002 & $\begin{array}{l}\text { Red River Waterway, John Q. overton Lock } \\
\text { and Dam: Navigation Alignment Conditions, } \\
\text { Hyydraulic Model Investigation, by D. Wilson } \\
\text { and R. Wooley }\end{array}$ & ADA40247 \\
\hline ERDC/CHL TR-02-07 & Jun 2002 & $\begin{array}{l}\text { Periodic Inspection of Nawiliwili Harbor } \\
\text { Breakwater, Kauai, Hawaii: Armor Unit } \\
\text { Monitoring for Period 1995-2001, by R.R. } \\
\text { Bottin, Jr., and D.T. Meyers }\end{array}$ & ADA40316 \\
\hline $\begin{array}{l}\text { ERDC/CHL TR-02-08 } \\
\text { Vol. } 1\end{array}$ & Jul 2002 & $\begin{array}{l}\text { Biscayne Bay Field Data: Volume 1, Main } \\
\text { Text, by R. McAdory, T.C. Pratt, M.T. Hebler, } \\
\text { T.L. Fagerburg, and R. Curry }\end{array}$ & ADA4056 \\
\hline $\begin{array}{l}\text { ERDC/CHL TR-02-08 } \\
\text { Vol. } 2\end{array}$ & Jul 2002 & $\begin{array}{l}\text { Biscayne Bay Field Data: Volume 2, Plates } \\
\text { and Appendices, by R. McAdory, T.C. Pratt, } \\
\text { M.T. Hebler, T.L. Fagerburg, and R. Curry }\end{array}$ & ADA4056 \\
\hline ERDC/CHL TR-02-09 & Jul 2002 & $\begin{array}{l}\text { Investigations for Providing Wave Protection } \\
\text { in Concert with Preserving the Maalaea } \\
\text { Pipeline at Maalaea Harbor, Maui, Hawaii: } \\
\text { Coastal Model Investigation, by R.D. Carver, } \\
\text { H.F. Acuff, S. Boc, E.F. Thompson, and G.B. } \\
\text { Myrick }\end{array}$ & ADA4056 \\
\hline ERDC/CHL TR-02-10 & Aug 2002 & $\begin{array}{l}\text { Coastal Processes Study of San Bernard } \\
\text { River Mouth, Texas: Stability and } \\
\text { Maintenance of Mouth, by N.C. Kraus and } \\
\text { L. Lin }\end{array}$ & ADA40776 \\
\hline ERDC/CHL TR-02-11 & Aug 2002 & $\begin{array}{l}\text { Periodic Inspections of Kahului and } \\
\text { Laupahoehoe Breakwaters, Hawaii: Armor } \\
\text { Unit Monitoring for Period 1992/93-2001, } \\
\text { by R.R. Bottin, Jr., and D.T. Meyers }\end{array}$ & ADA412C \\
\hline
\end{tabular}




\begin{tabular}{|c|c|c|c|}
\hline ERDC/CHL TR-02-12 & Aug 2002 & $\begin{array}{l}\text { Salinity Changes in Pontchartrain Basin } \\
\text { Estuary Louisiana, Resulting from } \\
\text { Mississippi River-Gulf Outlet Partial Closure } \\
\text { Plans with Width Reduction, by J.N. Tate, } \\
\text { A.R. Carrillo, R.C. Berger, and B.J. } \\
\text { Thibodeaux }\end{array}$ & ADA408114 \\
\hline ERDC/CHL TR-02-13 & Aug 2002 & $\begin{array}{l}\text { Navigation Conditions in Lower Lock } \\
\text { Approach of Ice Harbor Lock and Dam, } \\
\text { Snake River, Washington, by H. Park and D. } \\
\text { Fuller }\end{array}$ & ADA412062 \\
\hline ERDC/CHL TR-02-14 & Aug 2002 & $\begin{array}{l}\text { Hydraulic Evaluation of Whitten Lock Filling } \\
\text { and Emptying System, Tennessee- } \\
\text { Tombigbee Waterway, Mississippi, by R.L. } \\
\text { Stockstill }\end{array}$ & ADA407990 \\
\hline ERDC/CHL TR-02-15 & Sep 2002 & $\begin{array}{l}\text { GREENUP Environmental Mitigation, R. C. } \\
\text { Byrd Locks and Dam, Ohio River: Navigation } \\
\text { Model Study, by R.A. McCollum }\end{array}$ & ADA410765 \\
\hline ERDC/CHL TR-02-16 & Sep 2002 & $\begin{array}{l}\text { Atlantic Coast of New York Monitoring } \\
\text { Program: Cross-Shore Profiles, Quality- } \\
\text { Control Procedures, Monumentation, and } \\
\text { Data Archiving, by A. Morang }\end{array}$ & ADA408791 \\
\hline ERDC/CHL TR-02-17 & Sep 2002 & $\begin{array}{l}\text { Circulation Modeling for Proposed Port } \\
\text { Facility at Ponce and Guayanilla, Puerto } \\
\text { Rico, by N.W. Scheffner, F.C. Carson, and } \\
\text { D.J. Mark }\end{array}$ & ADA407769 \\
\hline ERDC/CHL TR-02-18 & Sep 2002 & $\begin{array}{l}\text { Monitoring of Entrance Channel Navigation } \\
\text { Improvements at Morro Bay Harbor, Morro } \\
\text { Bay, California, by E.F. Thompson, R.R. } \\
\text { Bottin, Jr., and A.T. Shak }\end{array}$ & ADA407961 \\
\hline ERDC/CHL TR-02-19 & Sep 2002 & $\begin{array}{l}\text { Desktop Study for LaQuinta, Project: } \\
\text { Shoaling Prediction in La Quinta Navigation } \\
\text { Channel and Effect of a Barrier on Siltation } \\
\text { in Extended La Quinta Channel, by T.M. } \\
\text { Parchure, S. Sarruff, and B. Brown }\end{array}$ & ADA407991 \\
\hline ERDC/CHL TR-02-20 & Sep 2002 & $\begin{array}{l}\text { Wave Response, Pago Pago Harbor, Island } \\
\text { of Tutuila, Territory of American Samoa, by } \\
\text { E.F. Thompson and Z. Demirbilek }\end{array}$ & ADA407963 \\
\hline ERDC/CHL TR-02-21 & Sep 2002 & $\begin{array}{l}\text { Wave Climate and Wave Response, } 2025 \\
\text { Plan, Kahului Harbor, Maui, Hawaii, by E.F. } \\
\text { Thompson and Z. Demirbilek }\end{array}$ & ADA408026 \\
\hline $\begin{array}{l}\text { ERDC/CHL TR-02-22 } \\
\text { Rep. } 2\end{array}$ & Sep 2002 & $\begin{array}{l}\text { NMLONG: Numerical Model for Simulating } \\
\text { Longshore Current. Report 2, Wave-Current } \\
\text { Interaction, Roller Modeling and Validation } \\
\text { of Model Enhancements, by M. Larson and } \\
\text { N.C. Kraus }\end{array}$ & ADA408263 \\
\hline
\end{tabular}




\begin{tabular}{|c|c|c|c|}
\hline ERDC/CHL TR-02-23 & Sep 2002 & $\begin{array}{l}\text { Effects of Adding Barge Lanes Along } \\
\text { Houston Ship Channel Through Galveston } \\
\text { Bay, Texas, by A.R. Carrillo, M.S. Sarruff, and } \\
\text { R.C. Berger }\end{array}$ & ADA408790 \\
\hline ERDC/CHL TR-02-24 & Sep 2002 & $\begin{array}{l}\text { Eastcoast 2001, A Tidal Constituent } \\
\text { Database for Western North Atlantic, Gulf of } \\
\text { Mexico, and Caribbean Sea, by A.Y. Mukai, } \\
\text { J.J. Westerink, R.A. Luettich, Jr., and D. Mark }\end{array}$ & ADA408733 \\
\hline ERDC/CHL TR-02-25 & Sep 2002 & $\begin{array}{l}\text { Upper Mississippi River Lock Filling and } \\
\text { Emptying System: Hydraulic Model } \\
\text { Investigation, by J.E. Sanchez, M.J. Sanchez, } \\
\text { and J.E. Hite, Jr. }\end{array}$ & ADA408191 \\
\hline ERDC/CHL TR-02-26 & Sep 2002 & $\begin{array}{l}\text { Engineering Studies in Support of the } \\
\text { Delong Mountain Terminal Project, by R. } \\
\text { Jensen, N. Scheffner, S.J. Smith, D. Webb, } \\
\text { and B.A. Ebersole }\end{array}$ & \\
\hline ERDC/CHL TR-02-27 & Sep 2002 & $\begin{array}{l}\text { Physical Model Study of Wave Diffraction- } \\
\text { Refraction at an Idealized Inlet, by W.C. } \\
\text { Seabergh, W.R. Curtis, L.J. Thomas, and } \\
\text { K.K. Hathaway }\end{array}$ & ADA595763 \\
\hline ERDC/CHL TR-02-28 & Oct 2002 & $\begin{array}{l}\text { Physical Model Test for Bendway Weir } \\
\text { Design Criteria, by Waterway Simulation } \\
\text { Technology, Inc. }\end{array}$ & ADA408861 \\
\hline ERDC/CHL TR-03-01 & Jan 2003 & $\begin{array}{l}\text { Periodic Inspection of Ofu Harbor } \\
\text { Breakwater, American Samoa: Armor Unit } \\
\text { Monitoring for Period 1996-2002, by R.R. } \\
\text { Bottin, Jr., and D.T. Meyers }\end{array}$ & ADA411567 \\
\hline ERDC/CHL TR-03-02 & Jan 2003 & $\begin{array}{l}\text { Primer: Using Watershed Modeling System } \\
\text { (WMS) for Gridded Surface Subsurface } \\
\text { Hydrologic Analysis (GSSHA) Data } \\
\text { Develoment-WMS } 6.1 \text { and GSSHA 1.43C, by } \\
\text { C.W. Downer, E.J. Nelson, and A. Byrd }\end{array}$ & ADA412251 \\
\hline ERDC/CHL TR-03-03 & Mar 2003 & $\begin{array}{l}\text { Inner Harbor Navigation Canal Replacement } \\
\text { Lock Filling and Emptying System, Inner } \\
\text { Harbor Navigation Canal, New Orleans, } \\
\text { Louisiana: Hydraulic Model Investigation, by } \\
\text { J.E. Hite, Jr. }\end{array}$ & ADA413187 \\
\hline ERDC/CHL TR-03-04 & Apr 2003 & $\begin{array}{l}\text { South Jetty Sediment Processes Study, } \\
\text { Grays Harbor Washington: Evaluation of } \\
\text { Engineering Structures and Maintenance } \\
\text { Measures, by P.D. Osborne, T.V. Wamsley, } \\
\text { and H.T. Arden }\end{array}$ & ADA414192 \\
\hline
\end{tabular}




$\begin{array}{ll}\text { ERDC/CHL TR-03-05 Jul } 2003 \quad \text { Monitoring Dredged Material Disposal at } \\ & \text { Mouth of Columbia River, } \\ & \text { Washington/Oregon, USA, by J.Z. Gailani, } \\ & \text { J.W. Smith, N.C. Kraus, D.D. McGee, E.B. } \\ & \text { Hands, C.J. Mayers, H.R. Moritz, H.P. Moritz, } \\ & \text { M.D. Siipola, D.B. Slocum, M.R. Byrnes, F. } \\ \text { Li, T.L. Dibble, W.H. Hollings, C.R. Lund, C.K. } & \text { Sollitt, and D.R. Standley }\end{array}$

ERDC/CHL TR-03-06 Jul 2003 Flow Table Study of Cook Inlet, Alaska, by S.A. Hughes, and G.M. Pizzo

ERDC/CHL TR-03-07 Aug 2003

Model Study of Monongahela Dam \#4 Lock

Replacements, Monongahela River,

Pittsburgh, Pennsylvania: Hydraulic Model

Investigation, by J.E. Sanchez

ERDC/CHL TR-03-08 Aug 2003

In-Chamber Longitudinal Culvert Design for Lock Filling and Emptying System, by J.E.

Hite, Jr. $\begin{aligned} \text { ERDC/CHL TR-03-09 Aug 2003 } & \begin{array}{l}\text { Monitoring Barnegat Inlet, New Jersey, } \\ \text { South Jetty Realignment, by W.C. Seabergh, } \\ \text { M.A. Cialone, J.W. McCormick, K.D. Watson, }\end{array}\end{aligned}$ and M.A. Chasten

ERDC/CHL TR-03-10 Sep 2003

Development of Two-Dimensional Numerical ADA417838 Model of Hydrodynamics and Salinity for Biscayne Bay, Florida, by G.L. Brown, R. Mcadory, G.H. Nail, M.S. Sarruff, R.C. Berger, and M.A. Granat

ERDC/CHL TR-03-11 Sep 2003 Tom Bevill Upper Lock Approach, Tennessee-Tombigbee Waterway, Alabama: Hydraulic Navigation Investigation, by M.F. Winkler

ERDC/CHL TR-03-12 Sep 2003 Vol. 1

ERDC/CHL TR-03-12 Jun 2004 Vol. 2

ERDC/CHL TR-03-13 Sep 2003

ERDC/CHL TR-03-14
North Jetty Performance and Entrance Navigation Channel Maintenance, Grays Harbor, Washington. Volume I, Main Text, by N.C. Kraus, and H.T. Arden, editors

North Jetty Performance and Entrance Navigation Channel Maintenance, Grays Harbor, Washington. Volume II, Appendices, by N.C. Kraus, and H.T. Arden, editors

Lower Monumental Spillway Hydraulic Model Study, by S.C. Wilhelms, T.E. Murphy, Jr., and L.I. Yates

Sep 2003 Overtopping Studies of a Stepped Revetment for City of Chicago, Illinois, by D.L. Ward
ADA417099

ADA417600 ADA417681

ADA416481

ADA416791

ADA416898

ADA417838

ADA417681

ADA418043

ADA426228

ADA417964

ADA417848 


\begin{tabular}{|c|c|c|c|}
\hline ERDC/CHL TR-03-15 & Sep 2003 & $\begin{array}{l}\text { Ship Effects Before and After Deepening of } \\
\text { Sabine-Neches Waterway, Port Arthur, } \\
\text { Texas, by S.T. Maynord }\end{array}$ & ADA417939 \\
\hline ERDC/CHL TR-03-16 & Sep 2003 & $\begin{array}{l}\text { Assessment of Changes in Channel } \\
\text { Morphology and Bed Elevation in Mad River, } \\
\text { California, 1971-2000, by K. Knuuti and D. } \\
\text { McComas }\end{array}$ & ADA418489 \\
\hline ERDC/CHL TR-03-17 & Nov 2003 & $\begin{array}{l}\text { Upper Guadalupe River Flood Control Weir, } \\
\text { San Jose, California, by B.D. Fuller }\end{array}$ & ADA419476 \\
\hline ERDC/CHL TR-04-01 & Feb 2004 & $\begin{array}{l}\text { Typhoon-Induced Stage-Frequency } \\
\text { Relationships for the Island of Rota, } \\
\text { Commonwealth of the Northern Mariana } \\
\text { Islands, by E.F. Thompson and N.W. } \\
\text { Scheffner }\end{array}$ & ADA422625 \\
\hline ERDC/CHL TR-04-02 & May 2004 & $\begin{array}{l}\text { Two-Dimensional Depth-Averaged } \\
\text { Circulation Model M2D: Version 2.0, Report } \\
\text { 1, Technical Documentation and User's } \\
\text { Guide, by A. Militello, C.W. Reed, A.K. } \\
\text { Zundel, and N.C. Kraus }\end{array}$ & ADA425094 \\
\hline ERDC/CHL TR-04-03 & Jun 2004 & $\begin{array}{l}\text { Demonstration Project on Dredging and } \\
\text { Marsh Development Using a Flexible- } \\
\text { Discharge Dustpan Dredge at Head of } \\
\text { Passes/Southwest Pass Mississippi River, } \\
\text { by T.L. Welp, J.E. Clausner, D. Thompson, J. } \\
\text { Mujica, and G. Boddie }\end{array}$ & ADA426739 \\
\hline ERDC/CHL TR-04-04 & Jun 2004 & $\begin{array}{l}\text { Design Considerations for Upper } \\
\text { Approaches to Navigation Locks, by R.L. } \\
\text { Stockstill, H.E. Park, J.E. Hite, Jr., and T.W. } \\
\text { Shelton }\end{array}$ & ADA425880 \\
\hline ERDC/CHL TR-04-05 & Jul 2004 & $\begin{array}{l}\text { Navigation Study for Port Jersey } 50 \text {-ft } \\
\text { Channel Improvements, New York Harbor, } \\
\text { by D.W. Webb }\end{array}$ & ADA426314 \\
\hline ERDC/CHL TR-04-06 & Jul 2004 & $\begin{array}{l}\text { Navigation Study for Arthur Kill 50-ft } \\
\text { Channel Improvements, New York Harbor, } \\
\text { by D.W. Webb }\end{array}$ & ADA426317 \\
\hline ERDC/CHL TR-04-07 & Aug 2004 & $\begin{array}{l}\text { J. T. Myers Lock Filling and Emptying } \\
\text { System, Ohio River, by J.E.Hite, Jr. and J.P. } \\
\text { Crutchfield }\end{array}$ & ADA426933 \\
\hline ERDC/CHL TR-04-08 & Aug 2004 & $\begin{array}{l}\text { Toussaint River, Ohio, Ordnance Migration } \\
\text { Study, by T. Welp, M. Tubman, A. Hamm, } \\
\text { and K. Redman }\end{array}$ & ADA426932 \\
\hline ERDC/CHL TR-04-09 & Aug 2004 & $\begin{array}{l}\text { J. T. Myers Lock Outlet Study, Ohio River: } \\
\text { Hydraulic Model Investigation, by J.E. Hite, Jr. }\end{array}$ & ADA426934 \\
\hline
\end{tabular}




\begin{tabular}{|c|c|c|}
\hline ERDC/CHL TR-04-10 & Sep 2004 & $\begin{array}{l}\text { Multidimensional Numerical Modeling of } \\
\text { Surges Over Initially Dry Land, by R.C. } \\
\text { Berger and L.M. Lee }\end{array}$ \\
\hline ERDC/CHL TR-04-11 & Sep 2004 & $\begin{array}{l}\text { Inspections of Previously Monitored Rubble- } \\
\text { Mound Coastal Structures, by R.R.Bottin, Jr., } \\
\text { L.R. Tolliver, and G.B. Myrick }\end{array}$ \\
\hline ERDC/CHL TR-04-12 & Sep 2004 & $\begin{array}{l}\text { ENPAC 2003: A Tidal Constituent Database } \\
\text { for Eastern North Pacific Ocean, by E.A. } \\
\text { Spargo, J.J. Westerink, R.A. Luettich, Jr., and } \\
\text { D.J. Mark }\end{array}$ \\
\hline ERDC/CHL TR-04-13 & Sep 2004 & $\begin{array}{l}\text { Navigation Study for Savannah Harbor } \\
\text { Channel Improvements, by D. Webb }\end{array}$ \\
\hline ERDC/CHL TR-05-01 & Jun 2005 & $\begin{array}{l}\text { Monitoring Stone Degradation on Coastal } \\
\text { Structures in the Great Lakes : Summary } \\
\text { Report, by D.W. Marcus, J.A. Kissane, D.A. } \\
\text { Leinhart, K.E. Henn III, and S.M. Agar }\end{array}$ \\
\hline ERDC/CHL TR-05-02 & Jul 2005 & $\begin{array}{l}\text { Geomorphic Analysis of Mattituck Inlet and } \\
\text { Goldsmith Inlet, Long Island, New York, by } \\
\text { M.J. Morgan, N.C. Kraus, and J.M. } \\
\text { McDonald }\end{array}$ \\
\hline
\end{tabular}

ADA427993

ADA427989

ADA429079

ERDC/CHL TR-05-03 Jul 2005

Compilation Report on Effects of Distortion:

ADA437071

From the Writings of John J. Franco and James E. Glover, by T.J. Pokrefke, Jr.

ERDC/CHL TR-05-04 Jul 2005

Monitoring of Beachsaver Reef with Filter

Blanket and Double-T Sill at Cape May

ADA428028

ADA437139

Point, New Jersey, Section 227

Demonstration Site: First Year Monitoring -

2002-2003, by D.K. Stauble, R.A. Wise, and J.B. Smith

ERDC/CHL TR-05-05 Aug 2005

Computational Model of Ice Harbor Forebay,

ADA438852

Washington, by R.E. Stockstill, J.E. Hite, Jr., and J.M. Vaughan

ERDC/CHL TR-05-06 Aug 2005

Texas city Ship Channel Deepening Study, Hydrodynamic Model, by L.M. Lee, J.N. Tate, and R.C. Berger

ERDC/CHL TR-05-07 Sep 2005 Effect of Organic Materials on Bulk Density and Erodibility of Fine Sediment Beds, by

ADA437082

ADA439419 T.M. Parchure and J.E. Davis

ERDC/CHL TR-05-08 Sep 2005 Laboratory Study of Hydrodynamics Near Absorbing and Fully Reflecting Jetties, by W.C. Seabergh, L. Lin, and Z. Demirbilek

ADA439292

$\begin{array}{ccl}\text { ERDC/CHL TR-05-09 Sep 2005 } & \begin{array}{l}\text { Computational Model of Lower Monumental ADA439940 } \\ \text { Forebay, by R.E. Stockstill, J.E. Hite, Jr., and }\end{array}\end{array}$

$\begin{array}{rrr}\text { ERDC/CHL TR-05-09 Sep } 2005 & \begin{array}{l}\text { Computational Model of Lower Monumenta } \\ \text { Forebay, by R.E. Stockstill, J.E. Hite, Jr., and }\end{array}\end{array}$ J.M. Vaughan

ADA438016

ADA439869 ADA439940 


\begin{tabular}{|c|c|c|c|}
\hline ERDC/CHL TR-05-10 & Sep 2005 & $\begin{array}{l}\text { Monitoring of Dolos Armor Units at Crescent } \\
\text { City, California, by G.B. Myrick and J.A. } \\
\text { Melby }\end{array}$ & ADA438855 \\
\hline ERDC/CHL TR-05-11 & Sep 2005 & $\begin{array}{l}\text { Geology and Historical Evolution of Sheldon } \\
\text { Marsh Nature Preserve, Lake Erie, Ohio, by } \\
\text { A. Morang and S. Chader }\end{array}$ & ADA438950 \\
\hline ERDC/CHL TR-05-12 & Sep 2005 & $\begin{array}{l}\text { Life-Cycle Analysis of Mid Bay and Poplar } \\
\text { Island Projects, Chesapeake Bay, Maryland, } \\
\text { by J.A. Melby, E.F. Thompson, M.A Cialone, } \\
\text { J.M. Smith, L.E. Borgman, Z. Demirbilek, J.L. } \\
\text { Hanson, and L. Lin }\end{array}$ & ADA438863 \\
\hline ERDC/CHL TR-05-13 & Sep 2005 & $\begin{array}{l}\text { Structural Methods to Reduce Navigation } \\
\text { Channel Shoaling, by T.M. Parchure }\end{array}$ & ADA439868 \\
\hline ERDC/CHL TR-06-1 & Apr 2006 & $\begin{array}{l}\text { Evaluation of Downdrift Shore Erosion, } \\
\text { Mattituck Inlet, New York: Section } 111 \\
\text { Study, by B.K. Batten and N.C. Kraus }\end{array}$ & ADA446878 \\
\hline ERDC/CHL TR-06-2 & May 2006 & $\begin{array}{l}\text { Automated Design of a High-Velocity } \\
\text { Channel, by J.P. Hallberg }\end{array}$ & ADA449175 \\
\hline ERDC/CHL TR-06-3 & Jun 2006 & $\begin{array}{l}\text { Monitoring of Entrance Channel Navigation } \\
\text { Improvements at Pentwater, Michigan, and } \\
\text { Design Guidance for Pocket Wave } \\
\text { Absorbers, by E.F. Thompson, G.B. Myrick, } \\
\text { N.J. Zager, } \\
\text { R.R. Bottin, Jr., M.A. Sabol, J.P. Selegean, } \\
\text { J.P. McKinney, Z. Demirbilek, and H.F. Acuff, } \\
\text { Jr. }\end{array}$ & ADA451109 \\
\hline ERDC/CHL TR-06-4 & Aug 2006 & $\begin{array}{l}\text { Evaluation of Potential JHSV Port and } \\
\text { Alternative Offload Sites in Coastal North } \\
\text { Carolina, by A. Morang and D.T. Resio }\end{array}$ & ADA453994 \\
\hline ERDC/CHL TR-06-5 & Jul 2006 & $\begin{array}{l}\text { Hydraulic Design of Channels Conveying } \\
\text { Supercritical Flow, by R.L. Stockstill }\end{array}$ & ADA454871 \\
\hline ERDC/CHL TR-06-6 & Aug 2006 & $\begin{array}{l}\text { Wave Climate and Wave Response, } \\
\text { Kawaihae Deep Draft Harbor, Island of } \\
\text { Hawaii, Hawaii, by E.F. Thompson, Z. } \\
\text { Demirbilek, and M.J. Briggs }\end{array}$ & ADA454655 \\
\hline ERDC/CHL TR-06-7 & Aug 2006 & $\begin{array}{l}\text { Matagorda Ship Channel, Texas: Jetty } \\
\text { Stability Study, by N.C. Kraus, L. Lin, B.K. } \\
\text { Batten, and G.L. Brown }\end{array}$ & ADA452983 \\
\hline ERDC/CHL TR-06-8 & Aug 2006 & $\begin{array}{l}\text { Houston-Galveston Navigation Channels, } \\
\text { Texas Project: Navigation Channel } \\
\text { Sedimentation Study, Phase 1, by J.N. Tate } \\
\text { and R.C. Berger }\end{array}$ & ADA454124 \\
\hline
\end{tabular}




\begin{tabular}{|c|c|c|c|}
\hline ERDC/CHL TR-06-9 & Aug 2006 & $\begin{array}{l}\text { Two-Dimensional Depth-Averaged } \\
\text { Circulation Model CMS-M2D: Version 3.0, } \\
\text { Report 2, Sediment Transport and } \\
\text { Morphology Change, by A.M. Buttolph, C.W. } \\
\text { Reed, N.C. Kraus, N. Ono, M. Larson, B. } \\
\text { Camenen, H. Hanson, T. Wamsley, and A.K. } \\
\text { Zundel }\end{array}$ & ADA453954 \\
\hline ERDC/CHL TR-06-10 & Aug 2006 & $\begin{array}{l}\text { Mid-Bay Islands Hydrodynamics and } \\
\text { Sedimentation Modeling Study, } \\
\text { Chesapeake Bay, by W.J. Dinicola, E.T. } \\
\text { Fulford, M.R. Henderson, N.C. Kraus, L. Lin, } \\
\text { R.K. Mohan, M. Reemts, A.R. Sherlock, J.M. } \\
\text { Smith, and O. Yucel }\end{array}$ & ADA455640 \\
\hline ERDC/CHL TR-06-11 & Aug 2006 & $\begin{array}{l}\text { Boston Harbor, Massachusetts, Deep-Draft } \\
\text { Navigation Improvement Project Feasibility } \\
\text { Study: Channel Improvement Investigations, } \\
\text { by D.W. Webb and M.L. Habel }\end{array}$ & ADA454965 \\
\hline ERDC/CHL TR-06-12 & Aug 2006 & $\begin{array}{l}\text { Including Nearshore Processes in Phase- } \\
\text { Averaged Hydrodynamics Models, by B.D. } \\
\text { Johnson }\end{array}$ & ADA454396 \\
\hline ERDC/CHL TR-06-13 & Aug 2006 & $\begin{array}{l}\text { Potential Improvements for HEC-HMS } \\
\text { Automated Parameter Estimation, by B.E. } \\
\text { Skahill }\end{array}$ & ADA455236 \\
\hline ERDC/CHL TR-06-14 & Sep 2006 & $\begin{array}{l}\text { Greenville Bridge Reach, Bendway Weirs, by } \\
\text { M.F. Winkler }\end{array}$ & ADA455396 \\
\hline ERDC/CHL TR-06-15 & Sep 2006 & $\begin{array}{l}\text { Half Moon Bay, Grays Harbor, Washington: } \\
\text { Movable-Bed Physical Model Study, by S.A. } \\
\text { Hughes and J. Cohen }\end{array}$ & \\
\hline ERDC/CHL TR-06-16 & Sep 2006 & $\begin{array}{l}\text { Effects of Breakwater Construction of } \\
\text { Tedious Creek Small Craft Harbor and } \\
\text { Estuary, Maryland, by B.P. Donnell, M.J. } \\
\text { Briggs, Z. Demirbilek, T.C. Pratt, M.W. } \\
\text { Tubman, R.D. Carver, and K.M. Nook }\end{array}$ & ADA455336 \\
\hline ERDC/CHL TR-06-17 & Sep 2006 & $\begin{array}{l}\text { North Texas Sediment Budget: Sabine Pass } \\
\text { to San Luis Pass, by A. Morang }\end{array}$ & ADA456230 \\
\hline ERDC/CHL TR-06-18 & Sep 2006 & $\begin{array}{l}\text { Longshore Sediment Transport Rate } \\
\text { Calculated Incorporating Wave Orbital } \\
\text { Velocity Fluctuations, by E.R. Smith }\end{array}$ & ADA455449 \\
\hline ERDC/CHL TR-06-19 & Sep 2006 & $\begin{array}{l}\text { Atkinson Island Mooring Basin Alternatives, } \\
\text { Houston Ship Channel, by S.T. Maynord, J.E. } \\
\text { Hite, Jr., and M.J. Sanchez }\end{array}$ & ADA455331 \\
\hline
\end{tabular}




\begin{tabular}{|c|c|c|c|}
\hline ERDC/CHL TR-06-20 & Sep 2006 & $\begin{array}{l}\text { PTM: Particle Tracking Model: Report 1, } \\
\text { Model Theory, Implementation, and } \\
\text { Example Applications, by N.J. MacDonald, } \\
\text { M.H. Davies, A.K. Zundel, J.D. Howlett, Z. } \\
\text { Demirbilek, J.Z. Gailani, T.C. Lackey, and J. } \\
\text { Smith }\end{array}$ & ADA455437 \\
\hline ERDC/CHL TR-06-21 & Sep 2006 & $\begin{array}{l}\text { Beach Erosion Mitigation and Sediment } \\
\text { Management Alternatives at Wallops Island, } \\
\text { VA, by A. Morang, G.G. Williams, and J.W. } \\
\text { Swean }\end{array}$ & ADA457769 \\
\hline ERDC/CHL TR-06-22 & Sep 2006 & $\begin{array}{l}\text { Breach History and Susceptibility Study, } \\
\text { South Jetty and Navigation Project, Grays } \\
\text { Harbor, Washington, by T.V. Wamsley, M.A. } \\
\text { Cialone, K.J. Connell, and N.C. Kraus }\end{array}$ & ADA456060 \\
\hline ERDC/CHL TR-07-1 & May 2007 & $\begin{array}{l}\text { Barbers Point Harbor, Nighttime Simulation, } \\
\text { by G.C. Lynch }\end{array}$ & ADA468127 \\
\hline ERDC/CHL TR-07-2 & Jun 2007 & $\begin{array}{l}\text { Shoaling of Aguadilla Harbor, Puerto Rico, } \\
\text { by S.A. Hughes and L.Z. Hales }\end{array}$ & ADA469085 \\
\hline ERDC/CHL TR-07-03 & Jun 2007 & $\begin{array}{l}\text { Boston Harbor Navigation Channel } \\
\text { Improvement Project: Field Data Collection } \\
\text { Program Final Report, by M.W. Tubman }\end{array}$ & ADA469604 \\
\hline ERDC/CHL TR-07-4 & Jul 2007 & $\begin{array}{l}\text { Laboratory Study of Wind Effect on Runup } \\
\text { over Fringing Reefs. Report 1, Data Report, } \\
\text { by Z. Demirbilek, O.G. Nwogu, and D.L. } \\
\text { Ward }\end{array}$ & ADA471044 \\
\hline ERDC/CHL TR-07-5 & Jul 2007 & $\begin{array}{l}\text { Little Sand Island Turning Basin and } \\
\text { Channel Widening, Mobile Bay, AL, Deep } \\
\text { Draft Navigation Improvement Project, by } \\
\text { G.C. Lynch and D.W. Webb }\end{array}$ & \\
\hline ERDC/CHL TR-07-6 & Aug 2007 & $\begin{array}{l}\text { Wave and Beach Processes Modeling for } \\
\text { Sabine Pass to Galveston Bay, Texas, } \\
\text { Shoreline Erosion Feasibility Study, by D.B. } \\
\text { King, Jr. }\end{array}$ & ADA471889 \\
\hline ERDC/CHL TR-07-7 & Aug 2007 & $\begin{array}{l}\text { Ship Forces on the Shoreline of the } \\
\text { Savannah Harbor Project, by S.T. Maynord }\end{array}$ & ADA471737 \\
\hline ERDC/CHL TR-07-8 & Aug 2007 & $\begin{array}{l}\text { Data Report: Laboratory Testing of } \\
\text { Longshore Sand Transport by Waves and } \\
\text { Currents; Morphology Change Behind } \\
\text { Headland Structures, by M.B. Gravens and } \\
\text { P. Wang }\end{array}$ & ADA471785 \\
\hline ERDC/CHL TR-07-9 & Sep 2007 & $\begin{array}{l}\text { PAR3D: Numerical Model for } \\
\text { Incompressible Flow with Application to } \\
\text { Aerosol Dispersion in Complex Enclosures, } \\
\text { by R.S. Bernard, P.V. Luong, and M.J. } \\
\text { Sanchez }\end{array}$ & ADA471741 \\
\hline
\end{tabular}




\begin{tabular}{|c|c|c|c|}
\hline ERDC/CHL TR-07-10 & Sep 2007 & $\begin{array}{l}\text { Lateral Inflow in Supercritical Flow, by R.L. } \\
\text { Stockstill }\end{array}$ & \\
\hline ERDC/CHL TR-07-11 & Sep 2007 & $\begin{array}{l}\text { Hurricane Barriers in New England and New } \\
\text { Jersey - History and Status After Four } \\
\text { Decades, by A. Morang }\end{array}$ & ADA473784 \\
\hline ERDC/CHL TR-07-12 & Dec 2007 & $\begin{array}{l}\text { Boussinesq Modeling of Wave Propagation } \\
\text { and Runup over Fringing Coral Reefs, Model } \\
\text { Evaluation Report, by Z. Demirbilek and } \\
\text { O.G. Nwogu }\end{array}$ & ADA475264 \\
\hline ERDC/CHL TR-08-1 & Feb 2008 & $\begin{array}{l}\text { Stability and Overtopping Study of Montrose } \\
\text { to Irving Reach of Chicago, IL, Shoreline } \\
\text { Revetment, by E.C. Burg and J.A. Melby }\end{array}$ & ADA477634 \\
\hline ERDC/CHL TR-08-2 & Feb 2008 & $\begin{array}{l}\text { Physical Model Study of Wave Action in New } \\
\text { Thomsen Harbor, Sitka, Alaska, by S.A. } \\
\text { Hughes, J. Cohen, and H.F. Acuff }\end{array}$ & ADA477897 \\
\hline ERDC/CHL TR-08-3 & Mar 2008 & $\begin{array}{l}\text { Wave Modeling for Jetty Rehabilitation at } \\
\text { the Mouth of the Columbia River, } \\
\text { Washington/Oregon, USA, by Z. Demirbilek, } \\
\text { L. Lin, and O.G. Nwogu }\end{array}$ & ADA481734 \\
\hline ERDC/CHL TR-08-4 & Apr 2008 & $\begin{array}{l}\text { Long-Term Structural Solution for the Mouth } \\
\text { of Colorado River Navigation Channel, } \\
\text { Texas, by N.C. Kraus, L. Lin, E.R. Smith, D.J. } \\
\text { Heilman, and R.C. Thomas }\end{array}$ & ADA480608 \\
\hline ERDC/CHL TR-08-5 & Apr 2008 & $\begin{array}{l}\text { Impact of Savannah Harbor Deep Draft } \\
\text { Navigation Project on Tybee Island Shelf } \\
\text { and Shoreline, by J.M. Smith, D.K. Stauble, } \\
\text { B.P. Williams, and M.J. Wutkowski }\end{array}$ & ADA480208 \\
\hline ERDC/CHL TR-08-6 & May 2008 & $\begin{array}{l}\text { Morphologic Examination of the Stability of } \\
\text { Pass Cavallo, Texas, by N.C. Kraus and B.K. } \\
\text { Batten }\end{array}$ & ADA481217 \\
\hline ERDC/CHL TR-08-7 & Jun 2008 & $\begin{array}{l}\text { Modeling Vessel-Generated Currents and } \\
\text { Bed Shear Stresses, by E.A Hammack, D.S. } \\
\text { Smith, and R.L. Stockstill }\end{array}$ & ADA482922 \\
\hline ERDC/CHL TR-08-8 & Jul 2008 & $\begin{array}{l}\text { Houston-Galveston Navigation Channels, } \\
\text { Texas Project: Navigation Channel } \\
\text { Sedimentation Study, Phase 2, by J.N. Tate, } \\
\text { R.C. Berger, and C.G. Ross }\end{array}$ & ADA484391 \\
\hline ERDC/CHL TR-08-9 & Jul 2008 & $\begin{array}{l}\text { Southeast Oahu Coastal Hydrodynamic } \\
\text { Modeling with ADCIRC and STWAVE, by M.A. } \\
\text { Cialone, M.E. Brown, J.M. Smith, and K.K. } \\
\text { Hathaway }\end{array}$ & ADA484274 \\
\hline ERDC/CHL TR-08-10 & Aug 2008 & $\begin{array}{l}\text { Combined Wave and Surge Overtopping of } \\
\text { Levees: Flow Hydrodynamics and } \\
\text { Articulated Concrete Mat Stability, by S.A } \\
\text { Hughes }\end{array}$ & ADA486615 \\
\hline
\end{tabular}




\begin{tabular}{|c|c|c|c|}
\hline ERDC/CHL TR-08-11 & Aug 2008 & $\begin{array}{l}\text { A Hydrodynamic Study of Davis Pond, Near } \\
\text { New Orleans, LA, by T.O. McAlpin, J.V. Letter, } \\
\text { Jr., and S.K. Martin }\end{array}$ & ADA485740 \\
\hline ERDC/CHL TR-08-12 & Aug 2008 & $\begin{array}{l}\text { Dredging in Sediments Containing } \\
\text { Munitions and Explosives of Concern (MEC): } \\
\text { ESTCP Project No. 200321, by T. Welp, G. } \\
\text { Follett, M. Crull, and C. Pollock }\end{array}$ & ADA486382 \\
\hline ERDC/CHL TR-08-13 & Aug 2008 & $\begin{array}{l}\text { CMS-Wave: A Nearshore Spectral Wave } \\
\text { Processes Model for Coastal Inlets and } \\
\text { Navigation Projects, by L. Lin, Z. Demirbilek, } \\
\text { H. Mase, J. Zheng, and F. Yamada }\end{array}$ & ADA486622 \\
\hline ERDC/CHL TR-08-14 & Aug 2008 & $\begin{array}{l}\text { Detection and Evaluation of Scour } \\
\text { Protection for Navigation Dams, by J.E. Hite, } \\
\text { Jr. }\end{array}$ & ADA488666 \\
\hline ERDC/CHL TR-08-15 & Sep 2008 & $\begin{array}{l}\text { Wave Climate and Littoral Sediment } \\
\text { Transport Study for Virginia Beach, VA - } \\
\text { Rudee Inlet to Cape Henry: Hydraulic Model } \\
\text { Study, by M.J. Briggs and E.F. Thompson }\end{array}$ & ADA488664 \\
\hline ERDC/CHL TR-08-16 & Nov 2008 & $\begin{array}{l}\text { Barbers Point Harbor, Hawaii, Jetty } \\
\text { Modification Study: Hydraulic Model Study, } \\
\text { by M.J. Briggs and I. Melito }\end{array}$ & ADA491530 \\
\hline ERDC/CHL TR-09-1 & Jan 2009 & $\begin{array}{l}\text { Wave Transformation Over Reefs: } \\
\text { Evaluation of One-Dimensional Numerical } \\
\text { Models, by Z. Demirbilek, O.G. Nwogu, D.L. } \\
\text { Ward, and A. Sánchez }\end{array}$ & ADA494533 \\
\hline ERDC/CHL TR-09-2 & Jan 2009 & $\begin{array}{l}\text { TWAVE: A Modeling System for Flooding and } \\
\text { Inundation of Islands by Tropical Storms, by } \\
\text { A. Sánchez, Z. Demirbilek, and J.M. Smith }\end{array}$ & ADA494315 \\
\hline ERDC/CHL TR-09-3 & May 2009 & $\begin{array}{l}\text { South Florida Reservoir Embankment Study, } \\
\text { by J.A. Melby, E.C. Burg, D. McVan, and W. } \\
\text { Henderson }\end{array}$ & ADA537472 \\
\hline ERDC/CHL TR-09-4 & May 2009 & $\begin{array}{l}\text { Houston Ship Channel, by D.W. Webb, L.L. } \\
\text { Daggett, and J.C. Hewlett }\end{array}$ & \\
\hline ERDC/CHL TR-09-5 & Aug 2009 & $\begin{array}{l}\text { Martin County, FL, Case Study: Physical and } \\
\text { Economic Performance of Martin County } \\
\text { Federal Shore Protection Project During } \\
2004 \text { Tropical Season, by M.B. Gravens, } \\
\text { L.K. Lent, and B.K. Harper }\end{array}$ & ADA508399 \\
\hline ERDC/CHL TR-09-6 & Aug 2009 & $\begin{array}{l}\text { Houston-Galveston Navigation Channels, } \\
\text { Texas Project: Navigation Channel } \\
\text { Sedimentation Study, Phase } 2 \text { Plan } \\
\text { Simulations, by J.N. Tate and C.G. Ross }\end{array}$ & ADA508369 \\
\hline
\end{tabular}

ERDC/CHL TR-09-7 Sep 2009 Shark River Inlet, New Jersey, Entrance

ADA508583 Shoaling. Report 1, Desk Study, by N.C. Kraus and M.C. Allison 


\begin{tabular}{|c|c|c|c|}
\hline ERDC/CHL TR-09-8 & Sep 2009 & $\begin{array}{l}\text { Barrier Island Migration Over a } \\
\text { Consolidating Substrate, by J.D. Rosati }\end{array}$ & ADA508741 \\
\hline ERDC/CHL TR-09-9 & Jul 2009 & $\begin{array}{l}\text { Bush Canal Floodgate Study, by T.O. } \\
\text { McAlpin, R.C. Berger, and A.M. Henville }\end{array}$ & ADA538125 \\
\hline ERDC/CHL TR-09-10 & Jul 2009 & $\begin{array}{l}\text { A Review of Methods for Moving Boundary } \\
\text { Problems, by C.E. Kees, M.W. Farthing, R.C. } \\
\text { Berger and T.C. Lackey }\end{array}$ & ADA508613 \\
\hline ERDC/CHL TR-09-11 & Jul 2009 & $\begin{array}{l}\text { Evaluating Finite Element Methods for the } \\
\text { Level Set Equation, by M.W. Farthing and } \\
\text { C.E. Kees }\end{array}$ & \\
\hline ERDC/CHL TR-09-12 & Aug 2009 & $\begin{array}{l}\text { Locally Conservative, Stabilized Finite } \\
\text { Element Methods for a Class of Variable } \\
\text { Coefficient Navier-Stokes Equations, by C.E. } \\
\text { Kees, M.W. Farthing, and M.T. Fong }\end{array}$ & ADA508370 \\
\hline ERDC/CHL TR-09-13 & Sep 2009 & $\begin{array}{l}\text { Port Isabel (GIWW) Channel Improvements } \\
\text { at the Queen Isabella Causeway: Laguna } \\
\text { Madre, Texas, Navigation Improvement } \\
\text { Project, by T.W. Shelton and D. Webb }\end{array}$ & ADA508606 \\
\hline 1ERDC/CHL TR-09-14 & Sep 2009 & $\begin{array}{l}\text { Salinas de San Pedro (Cabrillo) Wetland } \\
\text { Restoration Project. Volume I, Main Text, by } \\
\text { J.N. Tate, J.P. McKinney, T.C. Pratt, F.C. } \\
\text { Carson, M.W. Tubman, G.L. Brown, K.M. } \\
\text { Barry, R. McAdory, and M.J. Briggs }\end{array}$ & \\
\hline ERDC/CHL TR-09-15 & Sep 2009 & $\begin{array}{l}\text { Salinas de San Pedro (Cabrillo) Wetland } \\
\text { Restoration Project:.Volume II, Appendices A } \\
\text { Through H, by J.N. Tate, J.P. McKinney, T.C. } \\
\text { Pratt, F.C. Carson, M.W. Tubman, G.L. } \\
\text { Brown, K.M. Barry, R. McAdory, and M.J. } \\
\text { Briggs }\end{array}$ & \\
\hline ERDC/CHL TR-09-16 & Sep 2009 & $\begin{array}{l}\text { Dover Dam Physical Model Study, } \\
\text { Tuscarawas River, Dover OH, by E.C. Burg }\end{array}$ & ADA508610 \\
\hline ERDC/CHL TR-09-17 & Sep 2009 & $\begin{array}{l}\text { Numerical Model Study of the Tuscarawas } \\
\text { River below Dover Dam, Ohio, by R.L. } \\
\text { Stockstill and J.M. Vaughan }\end{array}$ & ADA508614 \\
\hline ERDC/CHL TR-09-18 & Sep 2009 & $\begin{array}{l}\text { J. T. Myers Landside Lock Outlet Diffuser } \\
\text { Study, Ohio River, by J.E. Hite, Jr. }\end{array}$ & ADA508664 \\
\hline ERDC/CHL TR-09-19 & Dec 2009 & $\begin{array}{l}\text { Evaluation of Proposed Channel on } \\
\text { Circulation and Morphology Change at } \\
\text { Kawaihae Harbor and Pelekane Bay, Island } \\
\text { of Hawaii, HI, by H. Li, M.E. Brown, T.D. } \\
\text { Smith, and J.H. Podoski }\end{array}$ & \\
\hline
\end{tabular}




\begin{tabular}{|c|c|c|c|}
\hline ERDC/CHL TR-09-20 & Dec 2009 & $\begin{array}{l}\text { Stability of Blocked River Mouth on West } \\
\text { Coast of Africa: Inlet of Senegal River } \\
\text { Estuary, by K.M. Barry and N.C. Kraus }\end{array}$ & \\
\hline ERDC/CHL TR-10-1 & Feb 2010 & $\begin{array}{l}\text { Numerical Model of the Hoosic River Flood- } \\
\text { Control Channel, Adams, MA, by R.L } \\
\text { Stockstill, J.M. Vaughan, and K. Martin }\end{array}$ & ADA529310 \\
\hline ERDC/CHL TR-10-2 & Apr 2010 & $\begin{array}{l}\text { Sabine-Neches Waterway, Sabine Pass Jetty } \\
\text { System: Past and Future Performance, by } \\
\text { W.C. Seabergh, E.R. Smith, and J.D. Rosati }\end{array}$ & ADA536660 \\
\hline ERDC/CHL TR-10-3 & May 2010 & $\begin{array}{l}\text { Physical Model of Knik Arm and the Port of } \\
\text { Anchorage, Alaska, by S.A. Hughes, J.A. } \\
\text { Cohen, and H.F. Acuff }\end{array}$ & ADA536624 \\
\hline ERDC/CHL TR-10-4 & Jul 2010 & $\begin{array}{l}\text { Shark River Inlet, New Jersey, Entrance } \\
\text { Shoaling. Report 2, Analysis With Coastal } \\
\text { Modeling System, by T.M. Beck and N.C. } \\
\text { Kraus }\end{array}$ & ADA536598 \\
\hline ERDC/CHL TR-10-5 & Jul 2010 & $\begin{array}{l}\text { Herbert Hoover Dike (HHD) Phase 1A } \\
\text { Groundwater Model, by H. Cheng, B.P. } \\
\text { Donnell, E.V. Edris, and S.M. England }\end{array}$ & ADA530199 \\
\hline ERDC/CHL TR-10-6 & Aug 2010 & $\begin{array}{l}\text { Wailupe Stream, Channel Improvement at } \\
\text { Kalanianaole Highway, Honolulu, HI, by B.D. } \\
\text { Fuller }\end{array}$ & ADA526500 \\
\hline ERDC/CHL TR-10-7 & Aug 2010 & $\begin{array}{l}\text { Flood-Side Wave Erosion of Earthen Levees: } \\
\text { Present State of Knowledge and } \\
\text { Assessment of Armoring Necessity, by S.A. } \\
\text { Hughes }\end{array}$ & ADA527497 \\
\hline ERDC/CHL TR-10-8 & Sep 2010 & $\begin{array}{l}\text { Channel Dredging and Geomorphic } \\
\text { Response at and Adjacent to Mobile Pass, } \\
\text { Alabama, by M.R. Byrnes, S.F. Griffee, and } \\
\text { M.S. Osler }\end{array}$ & ADA536622 \\
\hline ERDC/CHL TR-10-9 & Sep 2010 & $\begin{array}{l}\text { Hydrodynamic and Salinity Analysis of } \\
\text { Conceptual Surge Barrier Designs in the } \\
\text { Lake Pontchartrain Region, by S.K. Martin, } \\
\text { T.O. McAlpin, and D.C. McVan }\end{array}$ & ADA529745 \\
\hline ERDC/CHL TR-10-10 & Sep 2010 & $\begin{array}{l}\text { Lake Borgne Surge Barrier Study, by S.K. } \\
\text { Martin, G. Savant, and D.C. McVan }\end{array}$ & ADA530124 \\
\hline ERDC/CHL TR-10-11 & Dec 2010 & $\begin{array}{l}\text { Seabrook and Borgne Alignment } \\
\text { Construction Sequence Hydrodynamic } \\
\text { Study, by J.N. Tate and C.G. Ross }\end{array}$ & ADA533717 \\
\hline ERDC/CHL TR-10-12 & Dec 2010 & $\begin{array}{l}\text { Seabrook Fish Larval Transport Study, by } \\
\text { J.N. Tate, T.C. Lackey, and T.O. McAlpin }\end{array}$ & \\
\hline
\end{tabular}




\begin{tabular}{|c|c|c|c|}
\hline ERDC/CHL TR-10-13 & Dec 2010 & $\begin{array}{l}\text { Waves, Hydrodynamics and Sediment } \\
\text { Transport Modeling at Grays Harbor, WA, by } \\
\text { Z. Demirbilek, L. Lin, J. Smith, E. Hayter, E. } \\
\text { Smith, J. Gailani, G. Norwood, and D. } \\
\text { Michalsen }\end{array}$ & ADA534865 \\
\hline 1ERDC/CHL TR-10-14 & Dec 2010 & $\begin{array}{l}\text { Model Study of Bonneville Spillway Gate, } \\
\text { Columbia River, Washngton: Hydraulic } \\
\text { Model Investigation, by W.G. Davis }\end{array}$ & \\
\hline $\begin{array}{l}\text { ERDC/CHL TR-11-1 } \\
\text { Rep. } 1\end{array}$ & Mar 2011 & $\begin{array}{l}\text { Coastal Storm Surge Analysis System Digital } \\
\text { Elevation Model. Report 1, Intermediate } \\
\text { Submission No. 1.1, by M.F. Forte, J.L. } \\
\text { Hanson, L. Stillwell, M. Blanchard- } \\
\text { Montgomery, B. Blanton, R. Luettich, H. } \\
\text { Roberts, J. Atkinson, and J. Miller }\end{array}$ & ADA539477 \\
\hline
\end{tabular}

ERDC/CHL TR-11-1 Mar 2011

Coastal Storm Surge Analysis:

ADA539306

Rep. 2

Computational System. Report 2, Intermediate Submission No. 1.2, by B.

Blanton, L. Stillwell, H. Roberts, J. Atkinson, S. Zou, M. Forte, J. Hanson and R. Luettich

ERDC/CHL TR-11-1 Jul 2013

Coastal Storm Surge Analysis: Storm

ADA581410

Rep. 3

Forcing. Report 3, Intermediate Submission No. 1.3, by P. Vickery, D. Wadhera, A. Cox, V. Cardone, J. Hanson, and B. Blanton

ERDC/CHL TR-11-1 Jul 2013

Coastal Storm Surge Analysis: Modeling

Rep. 4

System Validation. Report 4, Intermediate

Submission No. 2.0, by J. Hanson, $\mathrm{H}$.

Wadman, B. Blanton, and H. Roberts

ERDC/CHL TR-11-1 Nov 2013

Coastal Storm Surge Analysis: Storm Surge

Results: Report 5: Intermediate Submission

ADA588991

Rep. 5

No. 3, by J.L. Hanson, M.F. Forte, B.

Blanton, M. Gravens, and P. Vickery

ERDC/CHL TR-11-2

Apr 2011

Analysis of Dredged Material Placement

Alternatives for Bottleneck Removal,

Matagorda Ship Channel, Texas, by J. Rosati

III, A.E. Frey, M.E. Brown, and L. Lin

ERDC/CHL TR-11-3

May 2011

Adaptation of the Levee Erosional

Equivalence Method for the Hurricane

Storm Damage Risk Reduction System

(HSDRRS), by S.A. Hughes

ADA583150

Lock Culvert Valves: Hydraulic Design

Considerations, by R.L. Stockstill, E.A.

Hammack, and J.E. Hite, Jr.

ADA571430

ADA543973

Jun 2011

\footnotetext{
1 Limited distribution; see Preface.
} 
ERDC/CHL TR-11-5

ERDC/CHL TR-11-6

ERDC/CHL TR-11-7

ERDC/CHL TR-11-8

ERDC/CHL TR-11-9

ERDC/CHL TR-11-10

Rep. 1

ERDC/CHL TR-11-10

Rep. 2

ERDC/CHL TR-11-10

Rep. 3

ERDC/CHL TR-11-10

Rep. 4

ERDC/CHL TR-12-1
Sep 2011 Vertical Ship Motion Study for Savannah, GA ADA550494 Entrance Channel, by M.J. Briggs and W.G. Henderson

Oct 2011 Morganza to the Gulf of Mexico Floodgate Study, by T.O. McAlpin, I.E. Floyd, C.J. Callegan, T.C. Pratt, and D.M. Washington

Oct 2011 Lock Wall Expedient Repair Demonstration Monitoring, John T. Myers Locks and Dam, Ohio River, by J.R. Lewis, S.C. Woodson, D.W. Scott, J.E. McDonald, H.V.S. GangaRao, and P.V. Vijay

Oct 2011 Periodic Inspections of Hilo, Kahului, Laupahoehoe, and Nawiliwili Breakwaters, Hawaii: Armor Unit Monitoring for Period 2001-2005, by G.B. Myrick, J.A. Melby, E.C.

Burg, and K.L. Acuff

Oct 2011 Storm Damage Reduction Project Design for ADA552352 Wallops Island, Virginia: Version 1.01, by

D.B. King Jr., D.L. Ward, M.H. Hudgins, and

G.G. Williams

Dec 2011 Verification and Validation of the Coastal Modeling System. Report 1, Summary Report, by Z. Demirbilek and J. Rosati

Dec 2011 Verification and Validation of the Coastal Modeling System. Report 2, CMS-Wave, by L. Lin, Z. Demirbilek, R. Thomas, and J. Rosati, III

Dec 2011

Verification and Validation of the Coastal Modeling System. Report 3, CMS-Flow: Hydrodynamics, by A. Sánchez, W. Wu, T.M. Beck, H. Li, J. Rosati III, R. Thomas, J.D. Rosati, Z. Demirbilek, M. Brown, and C. Reed

Dec 2011 Verification and Validation of the Coastal Modeling System. Report 4, CMS-Flow: Sediment Transport and Morphology Change, by A. Sánchez, W. Wu, T.M. Beck, H. Li, J.D. Rosati, Z. Demirbilek, and M. Brown

Jan 2012 New Lock for Soo Locks and Dam, Model Investigations During 2006-2010, Sault Ste. Marie, Michigan, St. Mary's River: Hydraulic Model Investigation, by J.E. Hite, Jr. and C. Bislip-Morales ADA554944

ADA550495

ADA553441

ADA551438

ADA553629

ADA553628

ADA553627

ADA553630

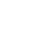




\begin{tabular}{|c|c|c|c|}
\hline ERDC/CHL TR-12-2 & Feb 2012 & $\begin{array}{l}\text { A Practical Guide to Calibration of a GSSHA } \\
\text { Hydrologic Model Using ERDC Automated } \\
\text { Model Calibration Software - Effective and } \\
\text { Efficient Stochastic Global Optimization, by } \\
\text { B.E. Skahill, C.W. Downer, and J.S. Bagget }\end{array}$ & ADA556367 \\
\hline ERDC/CHL TR-12-3 & Feb 2012 & $\begin{array}{l}\text { A Practical Guide to Calibration of a GSSHA } \\
\text { Hydrologic Model Using ERDC Automated } \\
\text { Model Calibration Software - Efficient Local } \\
\text { Search, by B.E. Skahill, C.W. Downer, and } \\
\text { J.S. Bagget }\end{array}$ & ADA556366 \\
\hline ERDC/CHL TR-12-4 & Feb 2012 & $\begin{array}{l}\text { More Efficient Bayesian-based Optimization } \\
\text { and Uncertainty Assessment of Hydrologic } \\
\text { Model Parameters, by B.E. Skahill and J.S. } \\
\text { Baggett }\end{array}$ & ADA556365 \\
\hline ERDC/CHL TR-12-5 & Mar 2012 & $\begin{array}{l}\text { Camp Marmal Flood Study, by J.A. Sharp, } \\
\text { S.H. Scott, M.R. Jourdan, and G. Savant }\end{array}$ & \\
\hline ERDC/CHL TR-12-6 & Jan 2012 & $\begin{array}{l}\text { Brownsville Ship Channel Hydrodynamic } \\
\text { Modeling, by J.N. Tate and C.G. Ross }\end{array}$ & ADA614587 \\
\hline ERDC/CHL TR-12-7 & May 2012 & $\begin{array}{l}\text { Kaumalapau Harbor, Hawaii, Breakwater } \\
\text { Repair, by J.H. Podoski and T.D. Smith }\end{array}$ & ADA561694 \\
\hline ERDC/CHL TR-12-8 & Jun 2012 & $\begin{array}{l}\text { Emergency Closure of Uncontrolled Flow at } \\
\text { Locks and Dams, by S.T. Maynord and R.L. } \\
\text { Stockstill }\end{array}$ & \\
\hline ERDC/CHL TR-12-9 & Jul 2012 & $\begin{array}{l}\text { Littoral Sediment Budget for the Mississippi } \\
\text { Sound Barrier Islands, by M.R. Byrnes, J.D. } \\
\text { Rosati, S.F. Griffee, and J.L. Berlinghoff }\end{array}$ & ADA572117 \\
\hline ERDC/CHL TR-12-10 & Jul 2012 & $\begin{array}{l}\text { Sedimentation Solutions for Military Ocean } \\
\text { Terminal Sunny Point (MOTSU), North } \\
\text { Carolina, by J.A. Sharp, J.N. Tate, and W.H. } \\
\text { McAnally }\end{array}$ & ADA569835 \\
\hline ERDC/CHL TR-12-11 & Jul 2012 & $\begin{array}{l}\text { Erosion Control and Environment } \\
\text { Restoration Plan Development, Matagorda } \\
\text { County, Texas. Phase 1, Preliminary } \\
\text { Investigation, by R. Thomas and L. Dunkin }\end{array}$ & ADA571167 \\
\hline ERDC/CHL TR-12-11 & Aug 2013 & $\begin{array}{l}\text { Erosion Control and Environment } \\
\text { Restoration Plan Development, Matagorda } \\
\text { County, Texas. Phase 2, Preliminary Design, } \\
\text { by J. Rosati III, A.E. Frey, and R.C. Thomas }\end{array}$ & ADA584034 \\
\hline ERDC/CHL TR-12-12 & Aug 2012 & $\begin{array}{l}\text { Validation of the Morganza to the Gulf of } \\
\text { Mexico TABS-MDS Numerical Model, by T.O. } \\
\text { McAlpin, J.V. Letter, Jr. and F.C. Carson }\end{array}$ & \\
\hline ERDC/CHL TR-12-13 & Aug 2012 & $\begin{array}{l}\text { Bayport Flare Hydrodynamic Study for Ship } \\
\text { Simulation, by J.N. Tate and C.G. Ross }\end{array}$ & \\
\hline
\end{tabular}


ERDC/CHL TR-12-14

Rep. 1

ERDC/CHL TR-12-14

Rep. 2

ERDC/CHL TR-12-14

Rep. 3

ERDC/CHL TR-12-15

ERDC/CHL TR-12-16

ERDC/CHL TR-12-17

ERDC/CHL TR-12-18

ERDC/CHL TR-12-19

ERDC/CHL TR-12-20

ERDC/CHL TR-12-21

ERDC/CHL TR-12-22
Aug 2012

St. Johns County, St. Augustine Inlet, FL.

ADA570209

Report 1, Historical Analysis and Sediment

Budget, by K. Legault, J.D. Rosati, J. Engle, and T.M. Beck

Aug 2012

St. Augustine Inlet, Florida: Application of the Coastal Modeling System, Report 2, by T.M. Beck and K. Legault

Aug 2012

Optimization of Ebb Shoal Mining and Beach Nourishment at St. Johns County, St. Augustine Inlet, Florida, Report 3, by T.M.

Beck and K. Legault

Aug 2012

Three-Dimensional Flow Modeling of McNary Dam Forebay, Columbia River, by E.A. Hammack and D.S. Smith

Aug 2012

Lake Michigan: Prediction of Sand Beach and Dune Erosion for Flood Hazard Assessment, by B.D. Johnson

Aug 2012

Sediment Budget for the Indiana Shore from Michigan City Harbor to Burns Waterway Harbor, by A. Morang, A.E. Frey, D.F. Bucaro, S. Brodzinsky, and J.A. Fuller

Sep 2012

Dredged Material Placement Site Capacity Analysis for Navigation Improvement Project at Grays Harbor, WA, by E. Hayter, J. Smith, D. Michalsen, Z. Demirbilek, and L. Lin

Sep 2012

Statistical Analysis and Storm Sampling Approach for Lakes Michigan and St. Clair: Great Lakes Coastal Flood Study, 2012 Federal Inter-Agency Initiative, by N.C. Nadal-Caraballo, J.A. Melby, and B.A. Ebersole

Sep 2012

Two Dimensional Hydrodynamic Analysis of the Moose Creek Floodway, by S.H. Scott, J.A. Sharp, G. Savant, C. Johnson, and D. Ginter

Sep 2012

Two-and Three-Dimensional Laboratory Studies of Wave Breaking, Dissipation, Setup, and Runup on Reefs, by E.R. Smith, T.J. Hesser, and J.M. Smith

Sep 2012 Cross-Shore Numerical Model CSHORE for Waves, Currents, Sediment Transport and Beach Profile Evolution, by B.D. Johnson, N. Kobayashi, and M.B. Gravens
ADA571681

ADA571753

ADA571219

ADA571220

ADA565699

ADA568101

ADA569629

ADA569534

ADA586346

ADA568508 
ERDC/CHL TR-12-23 Oct 2012 Wave Height and Water Level Variability on

ADA569575 Lakes Michigan and St Clair, by J.A. Melby, N.C. Nadal-Caraballo, Y. Pagán-Albelo, and B. Ebersole

ERDC/CHL TR-12-24 Oct 2012

Wave Runup Prediction for Flood Hazard Assessment, by J.A. Melby

ERDC/CHL TR-12-25 Dec 2012

GenCade Version 1 Model Theory and User's Guide, by A.E. Frey, K.J. Connell, H.

ADA576160 Hanson, M. Larson, R.C. Thomas, S. Munger, and A. Zundel

ERDC/CHL TR-12-26 Nov 2012

Lake Michigan Storm: Wave and Water Level Modeling, by R.E. Jensen, M.A.

ADA571674 Cialone, R.S. Chapman, B.A. Ebersole, M. Anderson, and L. Thomas

ERDC/CHL TR-13-1 Feb 2013 West Closure Complex Pump Intake Model, New Orleans, Louisiana, by S.T. Maynord

ERDC/CHL TR-13-2 Feb 2013 Pilot Study Evaluating Nearshore Sediment Placement Sites, Noyo Harbor, CA, by L. Lin, H. Li, M.E. Brown, F. Wu, and L. Andes

ERDC/CHL TR-13-3

May 2013

Physical Model Study of Flowerpot Discharge Outlet, Western Closure Complex, New Orleans, Louisiana, by S.T. Maynord

ERDC/CHL TR-13-4

Jun 2013

Snow Water Equivalent Modeling Capabilities of the GSSHA Watershed Model: Project Report, by M.L. Follum and C.W. Downer

ERDC/CHL TR-13-5

Jun 2013

Lake St. Clair: Storm Wave and Water Level Modeling, by T.J. Hesser, M.A. Cialone, and M.E. Anderson

ERDC/CHL TR-13-6

Jul 2013

2D Hydrodynamic Investigation of Olmsted Cofferdams, by J.A. Sharp, T.O. McAlpin, R.E. Heath, G.C. Lynch, and H.E. Park

ERDC/CHL TR-13-7

Aug 2013

Hydrodynamic and Salinity Transport Modeling of the Morganza to the Gulf of Mexico Study Area, by T.O. McAlpin, J.V. Letter, Jr., G. Savant, and F.C. Carson

ERDC/CHL TR-13-8

Sep 2013

Kankakee River Basin: Evaluation of Sediment Management Strategies, by C.D. Little, Jr., and M.M. Jonas

ERDC/CHL TR-13-9
Aug 2013
Validation of Modeling Flow Approaching Navigation Locks, by C.B. Bislip-Morales and R.L. Stockstill
ADA576421

ADA583046

ADA576181

ADA583028

ADA583025

ADA583023

ADA584088

ADA586079

ADA584400 


\begin{tabular}{|c|c|c|c|}
\hline ERDC/CHL TR-13-10 & Aug 2013 & $\begin{array}{l}\text { Regional Sediment Management Studies of } \\
\text { Matagorda Ship Channel and Matagorda } \\
\text { Bay System, Texas, by S.S. Lambert, S.S. } \\
\text { Willey, T. Campbell, R.C. Thomas, H. Li, L. } \\
\text { Lin, and T.L. Welp }\end{array}$ & ADA585465 \\
\hline ERDC/CHL TR-13-11 & Aug 2013 & $\begin{array}{l}\text { Performance Monitoring of a Nearshore } \\
\text { Berm at Ft. Myers Beach, Florida: Final } \\
\text { Report, by P. Wang, K.E. Brutsche, J.W. } \\
\text { LaGrone, T.M. Beck, J.D. Rosati, and L.S. } \\
\text { Lillycrop }\end{array}$ & ADA585466 \\
\hline ERDC/CHL TR-13-12 & Aug 2013 & $\begin{array}{l}\text { Watts Bar Lock Valve Model Study, by C.B. } \\
\text { Bislip-Morales and J.E. Hite, Jr. }\end{array}$ & ADA585810 \\
\hline ERDC/CHL TR-13-13 & Sep 2013 & $\begin{array}{l}\text { Preliminary Analysis of Morphology Change, } \\
\text { Waves, and Currents for Navigation at } \\
\text { Tillamook Inlet, Oregon, by Z. Demirbilek, H. } \\
\text { Li, L. Lin, T.M. Beck, and H.R. Moritz }\end{array}$ & ADA586339 \\
\hline
\end{tabular}

ERDC/CHL TR-13-14 Nov 2013

Particle Size Distributions and Attenuation on a Stratified Inner Continental Shelf, by R.

ADA592337 Styles

ERDC/CHL TR-13-15 Nov 2013

West Bay Sediment Diversion Effects, by J. Sharp, C. Little, G. Brown, T. Pratt, R. Heath, L. Hubbard, F. Pinkard, K. Martin, N. Clifton, D. Perkey, and N. Ganesh

ERDC/CHL TR-13-16 Nov 2013

Adaptive Hydraulics/Hydrology (AdH) Pilot Point Specification: Guidelines for Solving 3D Groundwater Problems Utilizing Pilot Points, by K.D. Winters

ERDC/CHL TR-14-1

ERDC/CHL TR-14-2

ERDC/CHL TR-14-3

ERDC/CHL TR-14-4

ERDC/CHL TR-14-5
Mar 2014

Scour Protection Downstream of Morganza Control Structure, Morganza, Louisiana, by S.T. Maynord

Mar 2014

Coastal Modeling System: Mathematical Formulations and Numerical Methods, by A. Sánchez, W. Wu, H. Li, M. Brown, C. Reed, J. Rosati, and Z. Demirbilek

May 2014 Vertical Ship Motion Study for Ambrose Entrance Channel, New York, by M.J. Briggs, Z. Demirbilek, and L. Lin

Jul $2014 \quad$ Hawaii Regional Sediment Management Needs Assessment, by T.D. Smith and L.S. Lillycrop

Jul 2014
Mississippi River Hydrodynamic and Delta Management Study (MRHDM) - Geomorphic Assessment, by C.D. Little, Jr. and D.S. Biedenharn
ADA589965

ADA598297

ADA601297

ADA604993

ADA606456 
ERDC/CHL TR-14-6

ERDC/CHL TR-14-7

ERDC/CHL TR-14-8

ERDC/CHL TR-14-9

ERDC/CHL TR-14-10

ERDC/CHL TR-14-11

ERDC/CHL TR-14-12

ERDC/CHL TR-14-13

ERDC/CHL TR-14-14

ERDC/CHL TR-15-1

ERDC/CHL TR-15-2

ERDC/CHL TR-15-3
Aug 2014

Recommendations and Requirements for GenCade Simluations, by A.E. Frey, D.B.

King, and S. Munger

Sep $2014 \quad$ North Atlantic Coast Comprehensive Study Phase I: Statistical Analysis of Historical Extreme Water Levels with Sea Level Change, by N.C. Nadal-Caraballo and J.A. Melby

Mar 2015 Modeling Study for Tangier Island Jetties, Tangier Island, Virginia, by Z. Demirbilek, L. Lin, D.L. Ward, and D.B. King

Mar 2015 Kikiaola Light Draft Harbor Monitoring Plan. Part 2: Numerical Wave Modeling for Evaluation of Structural Alternatives, by Z. Demirbilek, L. Lin, O.G. Nwogu, W.C. Butler, K.K. Hathaway, and T.D. Smith

Sep 2014

Southeast Florida Sediment Assessment and Needs Determination (SAND) Study, by J.D. Ousley, E. Kromhout, M.H. Schrader, and L. Lillycrop

Sep 2014

Modeling Subsurface Storm and Tile Drain Systems in GSSHA with SUPERLINK, by C.W. Downer, N.R. Pradhan, and A.R. Byrd

Oct 2014

Inner Harbor Navigation Canal Basin Velocity Analysis, by J.N. Tate and F.C. Carson

Dec 2014

Comprehensive Condition Survey and Storm Waves, Circulation, and Sediment Study, Dana Point Harbor, California, by C. Lu, A.T. Shak, H. Li, and L. Lin

Dec 2014

Houston-Galveston Navigation Channel Shoaling Study, by J. Tate, B. Gunkel, J. Rosati, E. Wood, A. Sanchez, R. Thomas, N. Ganesh, and T. Pratt

Feb 2015

Numerical Modeling of Trinity River Shoaling below Wallisville, Texas, by J.V. Letter, Jr., G.L. Brown, R. McAdory, and T.C. Pratt

Apr 2015 Hydraulic Evaluation of Marmet Lock Filling and Emptying System, Kanawha River, West Virginia, by R.L. Stockstill

Apr 2015 Three-Dimensional Shallow Water Adaptive Hydraulics (ADH-SW3) Validation: Galveston Bay Hydrodynamics and Salinity Transport, by G. Savant and R.C. Berger
ADA608076

ADA611642

ADA614137

ADA609593

ADA610769

ADA610766

ADA613234

ADA613397

ADA613774

ADA614453

ADA615122 


\begin{tabular}{|c|c|c|c|}
\hline ERDC/CHL TR-15-4 & May 2015 & $\begin{array}{l}\text { Jackson Bar Training Structure Study, by J.A. } \\
\text { Sharp and S.H. Scott }\end{array}$ & ADA618122 \\
\hline ERDC/CHL TR-15-5 & Nov 2015 & $\begin{array}{l}\text { Coastal Storm Hazards from Virginia to } \\
\text { Maine, By N.C. Nadal-Caraballo, J.A. Melby, } \\
\text { V.M. Gonzalez, and A.T. Cox }\end{array}$ & ADA627157 \\
\hline ERDC/CHL TR-15-6 & May 2015 & $\begin{array}{l}\text { Periodic Inspections of Cleveland Harbor } \\
\text { East Breakwater, Ohio, and Burns Harbor } \\
\text { North Breakwater, Indiana, by G.B. Myrick, } \\
\text { J.A. Melby, and E.C. Burg }\end{array}$ & \\
\hline ERDC/CHL TR-15-7 & Jun 2015 & $\begin{array}{l}\text { Hydraulic Evaluation of Culvert Valves at } \\
\text { Eisenhower and Snell Locks, St. Lawrence } \\
\text { Seaway, by R.L. Stockstill, E.A. Hammack, } \\
\text { D.S. Smith, C.B. Bislip-Morales, K. Green, } \\
\text { and J.M. Vaughan }\end{array}$ & ADA620179 \\
\hline ERDC/CHL TR-15-8 & Jun 2015 & $\begin{array}{l}\text { Old River Control Complex Sedimentation } \\
\text { Investigation, by R.E. Heath, G.L. Brown, } \\
\text { C.D. Little, T.C. Pratt, J.J. Ratcliff, D.D. } \\
\text { Abraham, D. Perkey, N.B. Ganesh, K. } \\
\text { Martin, and D.P. May }\end{array}$ & ADA619011 \\
\hline ERDC/CHL TR-15-9 & Jul 2015 & $\begin{array}{l}\text { Modeling of Nearshore-Placed Dredged } \\
\text { Material, by E.R. Smith, R. Permenter, M.C. } \\
\text { Mohr, and S.A. Chader }\end{array}$ & ADA621494 \\
\hline ERDC/CHL TR-15-10 & Jul 2015 & $\begin{array}{l}\text { Marmet Locks and Dam, Kanawha River, } \\
\text { West Virginia, by D.C. Wilson, L.R. Tolliver, } \\
\text { and K.L. Pigg }\end{array}$ & ADA621367 \\
\hline ERDC/CHL TR-15-11 & Aug 2015 & $\begin{array}{l}\text { Development of a Extratropical Storm Wind, } \\
\text { Wave, and Water Level Climatology for the } \\
\text { Offshore Mid-Atlantic, by M.F. Forte and J.L. } \\
\text { Hanson }\end{array}$ & ADA621324 \\
\hline ERDC/CHL TR-15-12 & Aug 2015 & $\begin{array}{l}\text { Numerical Sedimentation Study of Shoaling } \\
\text { on the Ohio River near Mound City, Illinois, } \\
\text { by D. Abraham, N. Clifton, and B. Vessels }\end{array}$ & ADA621156 \\
\hline ERDC/CHL TR-15-13 & Aug 2015 & $\begin{array}{l}\text { Point Judith, Rhode Island, Breakwater Risk } \\
\text { Assessment, by J.A. Melby, N.C. Nadal- } \\
\text { Caraballo, and J. Winkelman }\end{array}$ & ADA620918 \\
\hline ERDC/CHL TR-15-14 & Aug 2015 & $\begin{array}{l}\text { North Atlantic Coast Comprehensive Study } \\
\text { (NACCS) Coastal Storm Model Simulations: } \\
\text { Waves and Water Levels, by M.A. Cialone, } \\
\text { T.C. Massey, M.E. Anderson, A.S. } \\
\text { Grzegorzewski, R.E. Jensen, A. Cialone, D.J. } \\
\text { Mark, K.C. Pevey, B.L. Gunkel, T.O. McAlpin, } \\
\text { N.C. Nadal-Caraballo, J.A. Melby, and J.J. } \\
\text { Ratcliff }\end{array}$ & ADA621343 \\
\hline
\end{tabular}


ERDC/CHL TR-15-15 Nov 2015 Faleasao Harbor, American Samoa:

Investigation of Modifications for Improving Navigation, by Z. Demirbilek, L. Lin, O.G.

Nwogu, J.A. Goo, and T.D. Smith

ERDC/CHL TR-15-16 Dec 2015 Investigation of Impacts Associated with Modifying East Sand Island to Prevent Nesting of Double-Crested Cormorants, by K.C. Pevey, T.O. McAlpin, and H.R. Moritz

ERDC/CHL TR-15-17 Dec 2015 Coastal Foredunes: Identifying Coastal, Aeolian, and Management Interactions Driving Morphologic State Change, by $\mathrm{C}$. Swann, K. Brodie, and N. Spore 


\section{Cold Regions Research Engineering Laboratory (CRREL)}

\section{Contract reports}

\begin{tabular}{|c|c|c|c|}
\hline Report Number & $\underline{\text { Date }}$ & $\underline{\text { Title }}$ & $\underline{A D}$ Number \\
\hline ERDC/CRREL CR-02-1 & Oct 2002 & $\begin{array}{l}\text { A Deployable Wastewater Treatment System, } \\
\text { by J.L. Hill, J.T. Novak, N.G. Love, C.A. Bass, Jr., } \\
\text { M.A. Brennan, C.S. Riddle, and K. Asiedu }\end{array}$ & \\
\hline ERDC/CRREL CR-03-1 & Feb 2003 & $\begin{array}{l}\text { A Preliminary Assessment of a Low Cost } \\
\text { Solution to Water Droplet Spectroscopy and } \\
\text { Liquid Water Content Measurement, by Red } \\
\text { Tail Hawk Corporation }\end{array}$ & \\
\hline ERDC/CRREL CR-04-1 & Jun 2001 & $\begin{array}{l}\text { A Data Report on Washboard Formation, by } \\
\text { S.K. Monaghan, R. Liston, and B. Young }\end{array}$ & \\
\hline ERDC/CRREL CR-06-1 & Nov 2006 & $\begin{array}{l}\text { Sensor Testing in a Controlled Brownout Dust } \\
\text { Environment, by Midwest Research Institute }\end{array}$ & \\
\hline ERDC/CRREL CR-10-1 & Jun 2010 & $\begin{array}{l}\text { Numerical Simulation of Ice Dynamics in } \\
\text { Channels with Vanes and Cross Vanes: Interim } \\
\text { Progress Report, by I. Knack and H.T. Shen }\end{array}$ & \\
\hline ERDC/CRREL CR-10-2 & Jul 2010 & $\begin{array}{l}\text { Vegetation Sampling for Wetland Delineation: } \\
\text { A Review and Synthesis of Methods and } \\
\text { Sampling Issues, by E. Gage and D.J. Cooper }\end{array}$ & ADA524401 \\
\hline ERDC/CRREL CR-10-3 & Aug 2010 & $\begin{array}{l}\text { Growing Season Definition and Use in Wetland } \\
\text { Delineation: A Literature Review, by K. Malone } \\
\text { and H. Williams }\end{array}$ & ADA527538 \\
\hline ERDC/CRREL CR-12-1 & Jan 2012 & $\begin{array}{l}\text { Defining Hydrophytes for Wetland Identification } \\
\text { and Delineation, by R.W. Tiner }\end{array}$ & ADA555761 \\
\hline \multicolumn{4}{|l|}{ Letter reports } \\
\hline Report Number & Date & $\underline{\text { Title }}$ & AD Number \\
\hline ERDC/CRREL LR-00-01 & Feb 2000 & $\begin{array}{l}\text { Impact study of Vessel Effects on the Marine } \\
\text { and Nearshore Zone, Glacier Bay, Alaska, by } \\
\text { J.L. Wuebben, L.E. Hunter, D.E. Lawson, and } \\
\text { S.R. Bigl }\end{array}$ & \\
\hline ERDC/CRREL LR-00-02 & Mar 2000 & $\begin{array}{l}\text { A DC-Resistivity and Ground-Penetrating } \\
\text { Radar Investigation Near Tank 100, Haines } \\
\text { Fuel Terminal, Alaska, by A.J. Delaney, P.R. } \\
\text { Peapples, A. Staples, D.E. Lawson, S.A. } \\
\text { Arcone, and J. Wilkinson }\end{array}$ & \\
\hline
\end{tabular}




\begin{tabular}{|c|c|c|}
\hline ERDC/CRREL LR-00-03 & Apr 2000 & $\begin{array}{l}\text { Impact Loads from Flood Borne Debris: } \\
\text { Review of Literature and Current Guidance, by } \\
\text { R.B. Haehnel and S.F. Daly }\end{array}$ \\
\hline ERDC/CRREL LR-00-04 & Jun 2000 & $\begin{array}{l}\text { Offshore Seismic Reflection Profiling Near the } \\
\text { Haines Fuel Terminal, Alaska, by L.E. Hunter, } \\
\text { A.J. Delaney, P. Peapples, and D.E. Lawson }\end{array}$ \\
\hline ERDC/CRREL LR-00-05 & 2000 & $\begin{array}{l}\text { Rhizosphere-Enhanced Remediation Project } \\
\text { at Osan Air Base, South Korea, by C.M. } \\
\text { Reynolds and B.A. Koenen }\end{array}$ \\
\hline ERDC/CRREL LR-00-06 & 2000 & $\begin{array}{l}\text { Rhizosphere-Enhanced Remediation Project } \\
\text { at Kunsan Air Base, South Korea, by C.M. } \\
\text { Reynolds and B.A. Koenen }\end{array}$ \\
\hline
\end{tabular}

ERDC/CRREL LR-00-07 May 2000 Annual Report: Ice Force Measurements, St. Regis River 2000, by R.B. Haehnel and C.H. Clark

ERDC/CRREL LR-00-08 Nov 1999 Review of Pre-Engineering Designs Ohio River Mainstem Study for Enhanced Ice Management, by A.M. Tuthill, S.F. Daly, and R.B. Haehnel

ERDC/CRREL LR-00-09 Jun 2000 X-Ray Diffraction Analysis of Marine Mud Aquitard, Haines Fuel terminal, Haines, Alaska, by P.R. Peapples, S.A. Arcone, and D.E. Lawson

ERDC/CRREL LR-00-10 Feb 2000 Ten Years of Ice Force Measurements on the St. Regis River, Hogansburg, NY: 1989-1999, by R.B. Haehnel, C.H. Clark, and K.D. White

ERDC/CRREL LR-00-11 Jun 2000

Bedrock and Structure Characterization: Birch Hill Tank Farm and Truck Fill Stand, Fort Wainright, Alaska, by P.R. Peapples, B.N. Astley, D.E. Lawson, A.J. Delaney, and S.A. Arcone

ERDC/CRREL LR-00-12 Jul 2000

Bedrock Resistivity Investigations at the Haines Fuel Terminal, Alaska, by P.R. Peapples, A.J. Delaney, S.A. Arcone, and D.E. Lawson

ERDC/CRREL LR-00-13 Jul 2000

Seismic Profile Evidence for Offshore Flow Pathways Near Tank 100, Haines Fuel Terminal, Haines, Alaska, by P.R. Peapples, L.E. Hunter, A.J. Delaney, S.A. Arcone, and D.E. Lawson

ERDC/CRREL LR-00-14 Sep 2000

Conceptual Study of a Lake Erie Intake to Resist Blockage by Frazil Ice, by S.F. Daly and P. Richmond 
ERDC/CRREL LR-00-15 Sep 2000 Ground Water Data from Fort Richardson, Alaska, for the Period April 1997 to March 2000, by B.N. Astley, C.F. Snyder, D.E. Lawson, C.R. Williams, T. Hall, A. Staples, and J. Denner

ERDC/CRREL LR-00-16

ERDC/CRREL LR-00-17

ERDC/CRREL LR-01-18

Oct 2000

ERDC/CRREL LR-01-19

ERDC/CRREL LR-01-20

ERDC/CRREL LR-01-21

ERDC/CRREL LR-01-23

Dec 2000

Sep 2000

Dec 2000

Offsite Migration Routes Interpreted from a DC Resistivity Model, Haines Fuel Terminal, Alaska, by P.R. Peapples, S.A. Arcone, D.E. Lawson, and A.J. Delaney

Sep 2000

Geophysical Investigations Around Buildings 35-750 and 35-752, Fort Richardson, Alaska, by B.N. Astley, A.J. Delaney, D.E. Lawson, and A. Staples

Measuring Scour Under Ice Winter 1998-99 on the Missouri River, Culbertson, Montana, by L.J. Zabilansky and N.E. Yankielun

Oct 2000 Preliminary Geophysical Investigations at the Armored Vahicle Maintenance Area, OUE, by B.N. Astley, A. Delaney, S.R. Bigl, S. Epps, and D.E. Lawson

Sampling and Analysis Plan: Detailed Site Characterization for Rhizosphere-Enhanced Intrinsic Remediation, Campion Air Station, Alaska, by C.M. Reynolds and B.A. Koenen

Field Summary: Round-One Sampling for Site Characterization at Campion Air Station, Alaska for Rhizosphere-Enhanced Intrinsic Remediation, by C.M. Reynolds, B.A. Koenen, S.E. Hardy, K. Foley and L. Perry

Experimental Results of Shipboard Thick Composite Structures from

Thermomechanical Stresses of Fire, by P. Dutta, G. Durell, and M. Argueso

ERDC/CRREL LR-01-24 Feb 2001 Field Performance Evaluation of Multiple Fiber Reinforced Polymer Bridge Deck Systems Over Existing Girders - Phase I, by R. Lopez-Anido, I. Harik, P. Dutta, and B. Shahrooz

ERDC/CRREL LR-01-25

ERDC/CRREL LR-01-26
Feb 2001

Solutions for Icing on Gates at Turner Falls Dam, Montague, MA, by R.B. Haehnel

Dec 2000 A Sample Set of Ground Water Flow Data from Within Operable Unit 3 at Fort Wainwright, Fairbanks, Alaska from August 1995 to December 1999, by U.S. Army Cold Regions Research and Engineering Laboratory 
ERDC/CRREL LR-01-27 Jan 2000 A Study of Extreme Ice Loads on Power Lines in the St. Lawrence Valley Region, by K.F. Jones

ERDC/CRREL LR-01-28 Mar 2000 Meteorological Study for New York Power Authority Transmission Lines, by K.F. Jones

ERDC/CRREL LR-01-29 Mar 2001 Ambient Noise Data and Environmental Characterization Measurements, North Pomfret, Vermont, by S.N. Decato, F.E. Perron, Jr., and D.G. Albert

1ERDC/CRREL LR-01-30 Oct 2000

Oil/Water Separator Assessment, by C.M. Reynolds, B.A. Koenen, and S.E. Hardy

ERDC/CRREL LR-01-31 Mar 2001

Ground Water Flow Measurements Within Operable Unit 3, Fort Wainright, Alaska, From august 1995 to December 2000, by C.F. Snyder, S.R. Bigl, B. Astley, D.E. Lawson, C.R. Williams, and T.J. Hall

ERDC/CRREL LR-01-32 Sep 2000

Weather and Terrain Effects on Electronic Security Systems: Impact of Force Protection Command Decisions, by L. Peck

ERDC/CRREL LR-01-33 May 2000

Dynamics of Thermal Radiance from Selected Groundcovers in Winter, with Application to Passive Infrared Intrusion Detection, by L. Peck and G. Koenig

ERDC/CRREL LR-01-34 Mar 2001 Historical Aerial Photographic Analysis of the Armored Vehicle Maintenance Area, OUE, Fort Richardson, Alaska, by B.N. Astely and D.E. Lawson

ERDC/CRREL LR-01-35 May 2001

Technology Demonstration Interim Report: Field Demonstration of RhizosphereEnhanced Treatment of OrganicsContaminated Soils on Native American Lands with Application to Northern FUD Sites by C.M. Reynolds

1ERDC/CRREL LR-01-36 Jul 2001

Snow Characteristics at Fort Greely, Alaska for Testing the Silo Closure Mechanism, by J. Buska, P. Smallidge, J. Johnson, M. Sturm, and A. Greatorex

ERDC/CRREL LR-01-37 Nov 1999

Sympathetic Detonator (SYDET) Baseline Signature Measurements in a Tropical Environment, FYOO Technical Test Plan, by D. Albert and J.A. Nagle

ERDC/CRREL LR-01-38 Jun 2001

A Review of Sound Propagation in Complex Urban Terrain, by J.A. Nagle and D.G. Albert

1 Limited distribution; see Preface. 


\begin{tabular}{|c|c|c|}
\hline ERDC/CRREL LR-01-39 & Mar 2001 & $\begin{array}{l}\text { Acoustic Pulse Propagation Over Laterally } \\
\text { Inhomogenous Ground, by D.L. Carbee, D.G. } \\
\text { Albert, F. Perron, Jr., S.N. Decato and J.A. } \\
\text { Nagle }\end{array}$ \\
\hline ERDC/CRREL LR-01-40 & May 2001 & $\begin{array}{l}\text { Ice-Push Damage on Lake Bomoseen, } \\
\text { Vermont, by L.W. Gatto, M.G. Ferrick, and D. J. } \\
\text { Calkins }\end{array}$ \\
\hline ERDC/CRREL LR-01-41 & Aug 2001 & $\begin{array}{l}\text { Remediating and Monitoring White } \\
\text { Phosphorus Contamination at Eagle River } \\
\text { Flats (Operable Unit C), Fort Richardson, } \\
\text { Alaska, by M.E. Walsh, C.H. Racine, C.M. } \\
\text { Collins, M.R. Walsh, R.N. Bailey, C.R. Williams, } \\
\text { G.M. Trachier, and W.D. Eldridge }\end{array}$ \\
\hline ERDC/CRREL LR-01-42 & Nov 1999 & $\begin{array}{l}\text { SYDET Tropical Environment Test Site } \\
\text { Suitability Assessment, by D. Albert and T. } \\
\text { Gilligan }\end{array}$ \\
\hline ERDC/CRREL LR-01-43 & Jul 2001 & $\begin{array}{l}\text { SYDET Acoustic Signature Analysis, } 25-27 \\
\text { Jan. } 2000 \text { SYDET/RAMS IPR, Las Vegas, NV, } \\
\text { by D.G. Albert }\end{array}$ \\
\hline ERDC/CRREL LR-01-44 & Mar 2000 & $\begin{array}{l}\text { Sympathetic Detonator (SYDET) Baseline } \\
\text { Trigger Signature Measurements and Barrier } \\
\text { Wall Effects, FYOO Technical Test Plan, by D.G. } \\
\text { Albert and J.A. Nagle }\end{array}$ \\
\hline ERDC/CRREL LR-01-45 & Jul 2000 & $\begin{array}{l}\text { Barrier Wall Signal Data, SYDeT Wall } \\
\text { Experiment, Blossom Point, MD, 8-9 May } \\
\text { 2000, by D.L. Carbee, D.G. Albert, S.N. } \\
\text { Decato, and J.A. Nagle }\end{array}$ \\
\hline ERDC/CRREL LR-01-46 & Jul 2000 & $\begin{array}{l}\text { Temperate Signal Data, SYDeT Baseline } \\
\text { Experiment \#3, Blossom Point, MD, 1-9 May } \\
\text { 2000, by D.L. Carbee, D.G. Albert, S.N. } \\
\text { Decato, and J.A. Nagle }\end{array}$ \\
\hline ERDC/CRREL LR-02-47 & Oct 2001 & $\begin{array}{l}\text { Response of FRP Joints in Hygrothermal } \\
\text { Environments, by P.K. Dutta }\end{array}$ \\
\hline 1ERDC/CRREL LR-02-48 & Oct 2001 & $\begin{array}{l}\text { IDT Dual-Skin Radome Icing Test, by J. Buska, } \\
\text { P. Smallidge, and A. Greatorex }\end{array}$ \\
\hline ERDC/CRREL LR-02-49 & Sep 2001 & $\begin{array}{l}\text { Barrier Wall Signal Data II, SYDET Wall } \\
\text { Experiment II, Aberdeen, MD, 18-21 June } \\
\text { 2001, by D.L. Carbee, D.G. Albert, S.N. } \\
\text { Decato, and J.A. Nagle }\end{array}$ \\
\hline
\end{tabular}

1 Limited distribution; see Preface. 
ERDC/CRREL LR-02-50 Jun 2001 Potential Contaminant Sources and

Hydrogeology, Armored Vehicle Maintenance

Area, OUE, Fort Richardson, Alaska, by B.N.

Astley, A. Delaney, S. Epps, S.R. Bigl, and D.E. Lawson

1ERDC/CRREL LR-02-51 Jul 2000

Remediating and Monitoring White

Phosphorus Contamination at Eagle River

Flats (Operable Unit C), Fort Richardson,

Alaska, FY99 Report, by M.E. Walsh, C.H.

Racine, C.M. Collins, M.R. Walsh, and R.N.

Bailey

ERDC/CRREL LR-02-52 Sep 2001 Analysis of the Blossom Point 2000 Barrier

Wall Engineering Test, by J.A. Nagle and D.G.

Albert

ERDC/CRREL LR-02-53 May 2001

Infrared Assessment of the Heat Distribution System at the Chicago Housing Authority Lathrop Homes Phase I - Final Letter Report, by G. Phetteplace

ERDC/CRREL LR-02-54 Sep 2001

Development of a Specification for Low Temperature Hot Water Distribution Systems, by V. Meyer and G. Phetteplace

ERDC/CRREL LR-02-55 Oct 2001 Ship Creek Sediment Management Study, Fort Richardson, Alaska, by M.G. Ferrick, C.M. Collins, and L.E. Hunter

ERDC/CRREL LR-02-56 Dec 2001 Annual Report: Ice Force Measurements, St. Regis River 2001, by R.B. Haehnel

ERDC/CRREL LR-02-57 Dec 2001 Fjord Oceanographic Processes Muir Inlet, Glacier Bay, Alaska, 1994-2000, by S.R. Bigl, D.E. Lawson, J.V. Holmes, S.E. Kopczynski, and P.B. Weyrick

ERDC/CRREL LR-02-58 Feb 2002 Conceptual Study of Wintertime Flooding caused by Frazil Ice in Jackson, Wyoming, by S.F. Daly

ERDC/CRREL LR-02-59 Dec 2001 Dugway Proving Ground Installation Restoration Program (GIS): Software Documentation and Training Materials, by P.T. Cedfeldt and D.C. Finnegan

ERDC/CRREL LR-02-60 Nov 2001 Preliminary Hydrogeological Interpretations of the Poleline Road Disposal Area Fort Richardson, Alaska, by S.E. Kopczynski and D.E. Lawson

1 Limited distribution; see Preface. 

ERDC/CRREL LR-02-61 May 2002 Ice Impacts on the Upper Lisle Bridge Resulting from the Proposed Change in Operation of the Whitney Point Lake Project, by S.F. Daly and J.E. Zufelt
ERDC/CRREL LR-02-62 May 2002
Review of Proposed Change to the Fermi 2 General Service Water System De-Ice System for Susceptibility to Frazil Ice, by S.F. Daly
1ERDC/CRREL LR-02-63 Jul 2002
Fort Greeley Test Bed Missile Silo Site Survey Using Ground-Penetrating Radar, by P. Smallidge
ERDC/CRREL LR-02-65 Aug 2002
Spring Runoff Characterization Ely Mine, Vershire, Vermont, Spring 2002, by J.V. Holmes, S.R. Bigl, D.E. Lawson, R.R. Seal II, and N.M. Piatak
ERDC/CRREL LR-02-66 Sep 2002
Vertical Ground-Coupled Heat Exchanger Test Requirements, by G. Phetteplace
1ERDC/CRREL LR-02-67 Jan 2002
Use of Groundwater for HVAC at the UAC Site, by G. Phetteplace
${ }^{1}$ ERDC/CRREL LR-02-68 Oct 2002
Ft. Carson Heat Distribution System IR Survey, 31 July - 4 August 2002, by G. Phetteplace
ERDC/CRREL LR-02-69 Aug 2002
SNTHERM-RT Predictions of Pavement Temperature, by L. Peck, R. Jordan, and G. Koenig

1ERDC/CRREL LR-02-70 Jun 2002

Recommended Tests and Testing Facilities for Unmanned Ground Combat Vehicle (UGCV), by G. Phetteplace, J. Lever, S. Shoop, and C. Ryerson

ERDC/CRREL LR-02-71 Feb 2002

Permafrost Degradation: Problem Statement, Knowledge Gaps and Related Research Activities, by D.M. Cole

ERDC/CRREL LR-02-73 Jul 2002

2001 Remedial Progress Report Operable Unit C - Eagle River Flats, by U.S. Army Engineer Research and Development Center, Cold Regions Research and Engineering Laboratory

1ERDC/CRREL LR-02-74 Jul 2002

Remediating and Monitoring White Phosphorus Contamination at Eagle River Flats (Operable Unit C), Fort Richardson, Alaska: FY 01 Report, by C.M. Collins, M.R. Walsh, M.E. Walsh, C.H. Racine, R.N. Bailey, and C.R. Williams

\footnotetext{
1 Limited distribution; see Preface.
} 
1ERDC/CRREL LR-02-78 Oct 2002 MicroPhase Coatings Laboratory Test Results, by N. Mulherin

1ERDC/CRREL LR-02-79 Aug 2002

Foster-Miller Laboratory Test Results, by N. Mulherin

ERDC/CRREL LR-02-80 Jun 2002 Trends in Chemical Data, Birch Hill Aquifer, Fort Wainright, Alaska, by T.A. Myse, D.E. Lawson, and S.R. Bigl

ERDC/CRREL LR-02-81 Oct 2002 An Experimental Study of the Behavior of Polymer Composites in the Cryogenic Temperature Range, by P. Dutta and S.C. Kwon

ERDC/CRREL LR-02-82 Nov 2002 Review of Material Provided by the Louis Berger Group, Inc., by S.A. Grant

ERDC/CRREL LR-02-83 Sep 2002 Geophysical Investigations at the Former Site of Building 786, Fort Richardson, Alaska, by B.N. Astley and A.J. Delaney

ERDC/CRREL LR-02-84 Dec 2002 Annual Report: Ice Force Measurements, St. Regis River 2002, by R.B. Haehnel and J. Gagnon

ERDC/CRREL LR-02-85 Nov 2002 Preliminary Observations from Geophysical Investigations Conducted at the Poleline Road Disposal Area, OUB, Fort Richardson, Alaska, Summer 2002, by S.R. Bigl and S.E. Kopczynski

ERDC/CRREL LR-02-86 Jan 2002 Preliminary Geophysical Investigations at the Poleline Road Disposal Area, Fort Richardson, Alaska, by P.A. Heiser, S.E. Kopczynski, A. Delaney, S. Epps, and D.E. Lawson

ERDC/CRREL LR-02-87 Jun 2002 Ground Water Data from Operable Unit 5, Fort Wainright, Alaska, for the Period 1995-2002, by S.E. Kopczynski and D.E. Lawson

ERDC/CRREL LR-03-1 Dec 2001 Experimental Results of Shipboard Thick Composite Structures from Thermomechanical Stresses of Fire, by D. Hui, P. Dutta, and G. Durell

ERDC/CRREL LR-03-2 Feb 2003 XM153 Sympathetic Detonator (SYDET) Acoustic Signature Measurements Winter Engineering Test, Camp Ripley, Minnesota, 28 March 2002, by S.N. Decato, D.L. Carbee, D.G. Albert, and J.A. Nagle

1 Limited distribution; see Preface. 
ERDC/CRREL LR-03-3 Jan 2003 Fort Wainright Hydrogeology, 1995-2002, by

S.E. Kopczynski, S.R. Bigl, J.V. Holmes, T.A.

Myse, and C.F. Snyder

1ERDC/CRREL LR-03-4 May 2003

Ground-Based Midcourse Defense Segment (GMD) Silo Mapping at MECK 1, MECK 2, and LF-21, by L. Danyluk, W. Gray, and P. Smallidge

ERDC/CRREL LR-03-5 Dec 2002 Performance of Montana Highway Pavements During Spring Thaw, by V. Janoo and A. Greatorex

ERDC/CRREL LR-03-6 Apr 2003 Geophysical Surveys at Objective Areas B, C, and D, Davis Range Fort Richardson, Alaska, by B. Astley and A. Delaney

ERDC/CRREL LR-03-7 May 2003 Zero-Degree-Cone Test Results, by N.

ERDC/CRREL LR-03-8 Oct 2002 Historical Aerial Photographic Analysis of the Poleline Road Disposal Area, OUB, Fort Richardson, Alaska, by S.A. Epps and S.R. Bigl

ERDC/CRREL LR-03-9 Apr 2003 Historical Photographic Analysis of the Building 786 Site, Fort Richardson, Alaska, by S.A. Epps

ERDC/CRREL LR-03-10 Jul 2002

Extreme Ice Thicknesses and Concurrent Wind Speeds for Freezing rain in the Pacific Northwest, by K.F. Jones

1ERDC/CRREL LR-03-11 Dec 2001 Investigation of the Differences in the Application of the Canadian and U.S. Methodology for Estimates of Ice Loads for a 50-YR Return Period, by K.F. Jones and R. Morris

ERDC/CRREL LR-03-12 Jun 2003

Preliminary Summary of Groundwater Flow Derived from the CRREL Flow Probes, Haines Fuel Terminal, Haines, Alaska, by S. Kopczynski, S. Bigl, and J. Holmes

ERDC/CRREL LR-03-13 Sep 2002 Beta Test of CRRELVIEW and FASSTC, by J. Gagnon

ERDC/CRREL LR-03-14 $2001 \quad$ Review of Potential Impacts of the Proposed GVEA Pwerline on Ecosystems on the Tanana Flats, by M.T. Jorgenson and C.H. Racine

ERDC/CRREL LR-03-15 Jul 2003 Annual Report: Ice Force Measurements, St. regis River 2003, by C.M. Vuyovich, R.B. Haehnel, and J. Gagnon

1 Limited distribution; see Preface. 
ERDC/CRREL LR-03-16 Aug 2003

1ERDC/CRREL LR-03-17 Nov 2003

ERDC/CRREL LR-03-18 Oct 2003

ERDC/CRREL LR-03-19

ERDC/CRREL LR-03-21 Nov 2003

ERDC/CRREL LR-O3-21 NOV 2003

1ERDC/CRREL LR-03-22 Dec 2003

ERDC/CRREL LR-03-23 Jul 2003

1ERDC/CRREL LR-04-01 Jan 2004

ERDC/CRREL LR-04-02 Nov 2002

1ERDC/CRREL LR-04-03 Sep 2003

ERDC/CRREL LR-04-04 May 2003

ERDC/CRREL LR-04-5 Apr 2004

1ERDC/CRREL LR-04-06 Aug 2001

ERDC/CRREL LR-04-07 Nov 2001

1ERDC/CRREL LR-04-08 Mar 2004
Constitutive Modeling for A4 Silt, by N.

Burton, P. Sullivan, M. Evans, and S. Shoop

Laboratory Ice Adhesion Test results, by $\mathrm{N}$. Mulherin

XM153 Sympathetic Detonator (SYDET)

Quick-Look Acoustic Signature Measurements Development Test (DT), Blossom Point, Maryland, 16 September 2003, by D.G. Albert, F.E. Perron, Jr., and S.N. Decato

A Study of the Long-Term Applications of Vinyl ADA431046 Sheet Piles, by P.K. Dutta and U. Vaidya

Fatigue Evaluation of Multiple FiberReinforced Polymer Bridge Deck Systems Over Existing Girders: Phase II Report, by P.K. Dutta, R. Lopez-Anido, S.C. Kwon, and G.D. Durell

Laboratory Ice Adhesion Test Results for Fluoroelastomer Samples, by N. Mulherin

Remediating and Monitoring White Phosphorus Contamination at Eagle River Flats (Operable Unit C), Fort Richardson, Alaska: FY 02 Report, by C.M. Collins and D.W. Cate

Laboratory Ice Adhesion Test Results for Silicone Samples, by N. Mulherin

Laboratory Determination of Unfrozen Water Contents of Soils from the Site of an Artificially Frozen wall, by S.A. Grant and G.E. Boitnott

Technology for Range Security, by L. Peck and J.S. Morse

Knik Inlet Water Sampling, Anchorage, Alaska, by B.N. Astley, A. Staples, and A.J. Delaney

Roofing Problems at the Ambulatory Health Care Center, McGuire AFB, New Jersey, by J.S. Buska and A.R. Greatorex

Contaminant Source Area Treatment Status and Sample Data, by D. McKay

Ground Water Sampling Report, by D. McKay

Contaminant Source Area Treatment Status and Sample Data, by D. McKay

1 Limited distribution; see Preface. 
1ERDC/CRREL LR-04-09 Apr 2002

1ERDC/CRREL LR-04-10 Mar 2000

ERDC/CRREL LR-04-11 Mar 2004

1ERDC/CRREL LR-04-12 Mar 2003

1ERDC/CRREL LR-04-13 Sep 2002

1ERDC/CRREL LR-04-14 Jul 2002

ERDC/CRREL LR-04-15 May 2004

ERDC/CRREL LR-04-16 Jul 2004

1ERDC/CRREL LR-04-17 Jun 2004

ERDC/CRREL LR-04-18 Jun 2004

ERDC/CRREL LR-04-19 Jun 2004

1ERDC/CRREL LR-04-20 Jul 2004

ERDC/CRREL LR-04-21 Aug 2004

1ERDC/CRREL LR-04-22 Jul 2004
Contaminant Source Area Treatment Status and Sample Data, by D. McKay

TCE Source Area Treatment Progress Report, by D. McKay

Investigation of Fuel Contamination Using Laser-Induced Fluorescence Probing Technology, by D. McKay

Contaminant Source Area Treatment Status and Sample Data, by D. McKay

Contaminant Source Area Treatment Status and Sample Data, by D. McKay

Ground Water Sampling Report, by D. McKay

Laboratory Ice Adhesion Test Results for Commercial Icephobic Coatings, by N. Mulherin

Quantifying the Effect of a Freeze-Thaw Cycle on Soil Erosion: Laboratory Experiments, by M.G. Ferrick and L.W. Gatto

Confidential Results of Laboratory Ice Adhesion Tests, by N. Mulherin

Technology Demonstration Final Report: Field Demonstration of Rhizosphere-Enhanced Treatment of Organics-Contaminated Soils on Native American Lands with Application to Northern FUD Sites, by C.M. Reynolds

Cost and Performance Report: Field Demonstration of Rhizosphere-Enhanced Treatment of Organics-Contaminated Soils on Native American Lands with Application to Northern FUD Sites, by C.M. Reynolds

Qualification Environmental Exposures and Durability Testing of SCCI TufLam ${ }^{\mathrm{TM}}$ Structural Composites Systems for Strengthening Concrete and Masonry Structures, by P.K. Dutta

Thermal Testing of Raytheon Composite Aluminum Reflective Shields and Panels, by P.K. Dutta and G.D. Durell

Two Deployments of Remotely Monitored Battlefield Sensor System (REMBASS), by J. Gagnon
ADA431076

ADA431035 
$\begin{array}{ccc}\text { 1ERDC/CRREL LR-04-23 May 2004 } & \begin{array}{l}\text { Analysis of Variation in Passive Infrared } \\ \text { Sensor Signals from Guard Crossings During } \\ \text { the Month of April 04, by J. Gagnon }\end{array} \\ \text { ERDC/CRREL LR-04-24 Aug 2004 } & \begin{array}{l}\text { Laboratory Ice Adhesion Test Results for } \\ \text { Environmentally Stressed, NuSil-Coated } \\ \text { Samples, by N. Mulherin }\end{array} \\ \text { ERDC/CRREL LR-04-25 Jul 2004 } & \begin{array}{l}\text { Using High Spatial Resolution Digital Imagery, } \\ \text { by M.V. Campbell, R.L. Fischer, and T. } \\ \text { Pangburn }\end{array}\end{array}$

ERDC/CRREL LR-04-26 Aug 2004 Soil Gas Sampling Report, by D. McKay

${ }^{1}$ ERDC/CRREL LR-04-27 Jul 2004 Test and Evaluate Winter Concrete Mixtures: A Field Demonstration of an Antifreeze Admixture Made from Off-the-shelf Products, by $\mathrm{C}$. Korhonen and P. Semen

1ERDC/CRREL LR-04-28 Mar 2004 A Guide to the Field Production and Use of Off-the-Shelf Concrete Admixtures as Antifreeze Admixtures, by C.J. Korhonen, P.M. Semen, and L.A. Barna

1ERDC/CRREL LR-04-29 Jun 2004 Placing Antifreeze Concrete at Grand Forks Air Force Base (Draft), by C. Korhonen and P. Semen

1ERDC/CRREL LR-04-30 Sep 2004

Laboratory Ice Adhesion Test Results for Developmental Coatings on Fiberglass Piles, by N. Mulherin

ERDC/CRREL LR-04-31 Sep 2004 Fiber Reinforced Polymers (FRP) as a Solution for Corrosive and Aggressive Environments, by P.K. Dutta and A. Kumar

ERDC/CRREL LR-04-32 Jun 2004 Extreme Ice Thichnesses and Concurrent Wind Speeds for Freezing Rain in the Southeastern United States, by K.F. Jones

1ERDC/CRREL LR-04-33 Sep 2004 Appendix A: CRREL Analyses of Snow Depth and Snowfall Frequency of Occurrence for Fort Greely, Alaska, by J. Buska and P. Smallidge

1ERDC/CRREL LR-04-34 Sep 2004 Appendix B: CRREL Silo Closure Mechanism Static Tests Report, by J. Buska, L. Danyluk, and P. Smallidge

1ERDC/CRREL LR-04-35 Sep 2004

Appendix C: CRREL Cold and 15-Inch Snow Depth Test Report, by P. Smallidge, L. Danyluk, J. Buska, and T. Tantillo

1 Limited distribution; see Preface. 
1ERDC/CRREL LR-04-36 Sep 2004

ERDC/CRREL LR-04-37 Sep 2004

ERDC/CRREL LR-04-38 Sep 2004

ERDC/CRREL LR-04-40 Oct 2003

ERDC/CRREL LR-04-41 Sep 2004

ERDC/CRREL LR-04-42 Oct 2004

ERDC/CRREL LR-04-44 Oct 2004

Oct 2004

ERDC/CRREL LR-05-01 Jan 2005

1ERDC/CRREL LR-05-02 Feb 2005

ERDC/CRREL LR-05-03 Jan 2005

ERDC/CRREL LR-05-04 Mar 2005
Appendix D: CRREL 70 PSF Snow Load Test Report, by L. Danyluk, J. Buska, and P.

Smallidge

Evaluating the Capability of GroundPenetrating Radar to Define Tree Roots and Cracks in Concrete Walls, by A. Palazzo, N. Yankielun, L. Gatto, and T. Cary

Technical Performance Assessment Report: Second lowa Field Demonstration, Winter 2003-2004, by G. Phetteplace, G. Koenig, et al.

Remedial Action Plan for US Army Cold Regions Research and Engineering Laboratory Hanover, NH, by D. McKay

Hydrogeology of the Poleline Road Disposal area, Operable Unit B, Fort Richardson, Alaska, by S.E. Kopczynski, S.R. Bigl, J.V. Holmes, G.S. Baker, D.C. Finnegan, A.J. Delaney, and J.L. Andrews

Extreme Ice Thichnesses from Freezing rain, by K.F. Jones, N. Lott, and R. Thorkildson

Utilidor Survey for the Greater Fairbanks Military Complex Joint Long Range Energy Study, by G. Phetteplace

Maps of Poleline Road Plumes and Groundwater Table, 1997-2003, Operable Unit B, Fort Richardson, Alaska, by S.R. Bigl, S.E. Kopczynski, and J.V. Holmes

Geological Setting of the Birch Hill Tank Farm, Operable Unit 3, Fort Wainright, Alaska, by T.A. Douglas

Analysis of Test Section Data: Phase III of Variable Tire Pressure Study, by M.P. Rollings, C.E. Smith, and S.A Orchino

Spatial Factors for Extreme Ice and Extreme Wind: Task 2 Calculation of Spatial Factors from Ice and Wind Data, by K.F. Jones

Laboratory Ice Adhesion Test Results for Optimized, Developmental NuSil-Coated Samples, by N. Mulherin

\footnotetext{
1 Limited distribution; see Preface.
} 
1ERDC/CRREL LR-05-07 Jun 2005 Pyrex Glass and Honda-Grade Painted Samples, by N. Mulherin

ERDC/CRREL LR-05-08 May 2004

Feasibility of Four-Tractor Fleet for South Pole Traverse Year Three, by J.H. Lever and J. Weale

ERDC/CRREL LR-05-09

ERDC/CRREL LR-05-10

Mar 2005

Shear Zone Snow Bridge Safety Analysis, by J.H. Lever

Operable Unit 3, Permafrost Resistivity Investigation, Fort Wainright, Alaska, by B.N. Astley

ERDC/CRREL LR-05-11 May 2001

Field-Expedient Calculator Programs for Snow Moisture, Snow Density and Soil Moisture, by S.N. Decato

ERDC/CRREL LR-05-13 Aug 2005

Knik Inlet Water Sampling, Anchorage, Alaska, by B.N. Astley and A.J. Delaney

ERDC/CRREL LR-05-14 Mar 2005

Refined 3D Geologic Model of the Poleline Road Disposal Area, Operable Unit B, Fort Richardson, Alaska, by C. Snyder, S.E. Kopczynski, and B.N. Astley

ERDC/CRREL LR-05-15 Nov 2005

Assessment of the Effectiveness of the Israel River Ice Control Structure, Lancaster, NH, by C.M. Vuyovich and K.D. White

ERDC/CRREL LR-05-16 2005

ERDC/CRREL LR-06-01 Feb 2006

Durability Test Report for FIBRWRAP Composites, by P.K. Dutta

Analysis of the Falcon System for Delivering and Mixing DECON Green Components at Sub-Freezing Temperatures, by C.M. Reynolds, L.J. Zabilansky, and S.E. Hardy

1ERDC/CRREL LR-06-02 Mar 2006

Modeling Freeze-Thaw Cycling of the South Pole Station Exterior Sheathing, by G.

Phetteplace and J. Weale

ERDC/CRREL LR-06-03 Jan 2006

An Infrared Survey of the South Pole Station Modernization Project, by G. Phetteplace

ERDC/CRREL LR-06-04 Mar 2006 Fate of Plant Tissue Associated RDX in Surface Soil: SERDP ER-1412 Annual Report for 2005, by C.M. Reynolds, L. Newman, and J. Ferry

ERDC/CRREL LR-06-05 Apr 2006 Laboratory Ice Adhesion Test Results for Titanium Samples, and Urethane-Coated, and Silicone-Coated Samples, by N. Mulherin

1 Limited distribution; see Preface. 


\begin{tabular}{|c|c|c|}
\hline ERDC/CRREL LR-06-06 & Apr 2006 & $\begin{array}{l}\text { Remediating and Monitoring White } \\
\text { Phosphorus Contamination at Eagle River } \\
\text { Flats (Operable Unit C), Fort Richardson, } \\
\text { Alaska: FY05 Data Report, by S.R. Bigl and } \\
\text { C.M. Collins }\end{array}$ \\
\hline ERDC/CRREL LR-06-07 & Jun 2006 & $\begin{array}{l}\text { An Infrared Survey of the New Bassett } \\
\text { Hospital, Fort Wainright, Alaska, by J. Buska } \\
\text { and K. Claffey }\end{array}$ \\
\hline ERDC/CRREL LR-06-08 & Jun 2006 & $\begin{array}{l}\text { Characterization of the Turbulent Flow Under } \\
\text { a Rotorcraft: An Initial Study, by R.B. Haehnel }\end{array}$ \\
\hline ERDC/CRREL LR-06-09 & Jul 2006 & $\begin{array}{l}\text { Air Curtain Tests at Eielson AFB Small Arms } \\
\text { Range, by J. Buska and J. Zufelt }\end{array}$ \\
\hline 1ERDC/CRREL LR-06-10 & Apr 2006 & $\begin{array}{l}\text { Inspection and Infrared Survey of Door Icing } \\
\text { Problem at IDT 1, Fort Greely, Alaska, by J. } \\
\text { Buska and K. Claffey }\end{array}$ \\
\hline ERDC/CRREL LR-06-11 & Aug 2006 & $\begin{array}{l}\text { Permafrost Investigation, Stewart River } \\
\text { Training Area, by B. Astley }\end{array}$ \\
\hline ERDC/CRREL LR-06-12 & Aug 2006 & $\begin{array}{l}\text { Cold Temperature Testing of Geotextiles: New, } \\
\text { and Moistened with Soil Fines Emplaced, by } \\
\text { K.S. Henry and G.R. Durell }\end{array}$ \\
\hline ERDC/CRREL LR-06-13 & Aug 2006 & $\begin{array}{l}\text { Final Report: Ice Force Measurements, St. } \\
\text { Regis River 1989-2004, by R.B. Haehnel, } \\
\text { C.M. Vuyovich, and J. Gagnon }\end{array}$ \\
\hline ERDC/CRREL LR-06-14 & Nov 2006 & $\begin{array}{l}\text { Permafrost Investigation for Munitions } \\
\text { Storage Area Relocation, Eielson Air Force } \\
\text { Base, Alaska, by B. Astley, A. Delaney, A. } \\
\text { Gelvin, S. Saari, and A. Staples }\end{array}$ \\
\hline ERDC/CRREL LR-06-15 & Jul 2006 & $\begin{array}{l}\text { Ground-Penetrating Radar (GPR) } \\
\text { Investigation: Russell Moraine, Yakutat, } \\
\text { Alaska, by S.A Arcone, D.E. Lawson, A.J. } \\
\text { Delaney, and A. Staples }\end{array}$ \\
\hline ERDC/CRREL LR-06-16 & May 2006 & $\begin{array}{l}\text { Visual RADTRAN: User's Guide, by V.J. } \\
\text { Falcone, Jr., J.A. Nagle, and G.C. Koenig }\end{array}$ \\
\hline ERDC/CRREL LR-06-17 & Apr 2006 & $\begin{array}{l}\text { Knik Arm Water Sampling, Anchorage, Alaska, } \\
\text { by B.N. Astley, A. Staples, and J.E. Zufelt }\end{array}$ \\
\hline ERDC/CRREL LR-07-01 & May 2007 & $\begin{array}{l}\text { Remediating and Monitoring White } \\
\text { Phosphorus Contamination at Eagle River } \\
\text { Flats (Operable Unit C), Fort Richardson, } \\
\text { Alaska: FY06 Data Report, by S.R. Bigl and } \\
\text { C.M. Collins }\end{array}$ \\
\hline
\end{tabular}


ERDC/CRREL LR-07-02 2007

ERDC/CRREL LR-07-03 Jun 2007

ERDC/CRREL LR-07-04 Jun 2007

ERDC/CRREL LR-07-05 Jun 2007

ERDC/CRREL LR-07-06 Jun 2007

ERDC/CRREL LR-07-07 Jun 2007

ERDC/CRREL LR-07-08 Jun 2007

ERDC/CRREL LR-07-09 Jun 2007

ERDC/CRREL LR-07-10

Aug 2007

ERDC/CRREL LR-07-10 AuE

ERDC/CRREL LR-07-11 Sep 2007

1ERDC/CRREL LR-07-12 Nov 2007

1ERDC/CRREL LR-07-12 Nov 2007
Estimating Water Content in Snow: A Practical Guide for Measuring, Recording, and Reporting on Snow, by S. Daly and J. Hardy

Infrared Thermography of SPSM Circuit Breaker Panels, by G. Phetteplace and J. Richards

Infrared Thermography of the Building Envelope of the Ice Cube Laboratory, South Pole, Antarctica, by G. Phetteplace, J. Richards, and L. Conchelos

Infrared Thermography of the Building Envelope of the Martin A. Pomerantz Observatory, South Pole, Antarctica, by G. Phetteplace, J. Richards, and L. Conchelos

Infrared Thermography of the Building Envelope of the Dark Sector Laboratory, South Pole, Antarctica, by G. Phetteplace, J. Richards, and L. Conchelos

Infrared Thermography of the Building Envelope of the Atmospheric Research Observatory, South Pole, Antarctica, by G. Phetteplace, J. Richards, and L. Conchelos

Infrared Thermography of the Building Envelope of the New Cryogen Facility, South Pole, Antarctica, by G. Phetteplace, J. Richards, and L. Conchelos

Infrared Survey of the Elevated Station, 20062007 Season, South Pole, Antarctica, by G. Phetteplace

F22 Fighter Town Geophysical Investigation, Elmendorf Air Force Base Alaska, by B. Astley, A. Delaney, K. Bjella, A. Staples, S. Saari, and C. Chalup

Knik Arm Water Sampling, Anchorage, Alaska, May 2007, by B. Astley, J. Zufelt, and A. Staples

Laboratory Shear-Testing Results for Ice Adhered to NASA SILC Samples, by N. Mulherin and R. Haehnel

1 Limited distribution; see Preface. 
ERDC/CRREL LR-07-13 2007

ERDC/CRREL LR-08-01

ERDC/CRREL LR-08-02

1ERDC/CRREL LR-08-03

Apr 2008

ERDC/CRREL LR-08-04 May 2008

ERDC/CRREL LR-08-08 2008

ERDC/CRREL LR-08-09

ERDC/CRREL LR-08-10

Mar 2008

Mar 2008

1ERDC/CRREL LR-08-05 Apr 2008

Oct 2008

Nov 2008
Refined Geologic Interpretations from June 2007 Drilling (AP-5245, AP-5246): Poleline Road Disposal Area, Operable Unit B, Fort Richardson, Alaska, by S. Kopczynski, C. Snyder, and B. Astley

Evaluation of Impacts of Icing and Snow on Use of Photovoltaic Solar Farms in Northern Locations, by R. Haehnel, J. Buska, K. Jones, and A. Greatorex

\section{Remediating and Monitoring White Phosphorus Contamination at Eagle River Flats (Operable Unit C), Fort Richardson, Alaska: FY07 Data Report, by S.R. Bigl and C.M. Collins} Ice Adhesion Test Results, by R.B. Haehnel Air Vehicle Technology Integration Program (AVTIP), Delivery Order 0054: Opportune Landing Site (OLS) Critical Experiment Technology Maturation Plan, by Capt. J. Rufa, K. Eizenga, C. Ventresca, R. McCarty, R. Almassy, and C. Ryerson

Characterization of Freshwater EM Subbottom Sediment Properties and Target Responses for Detection of UXO with Ground-Penetrating Radar (GPR), by S.A. Arcone

EMAS Cold Weather Performance Investigations, by B.A. Coutermarsh

Thule Air Force Base Airfield White Painting and Permafrost Investigation, by K. Bjella

\footnotetext{
1 Limited distribution; see Preface.
} 


\begin{tabular}{|c|c|c|}
\hline ERDC/CRREL LR-08-11 & Sep 2008 & $\begin{array}{l}\text { Scientific Characterization of Cold Region } \\
\text { Environments for Army Testing of Materiel and } \\
\text { Systems and a Technical Analysis of Interior } \\
\text { Alaska, by R.S. Harmon, Col. E.J. Palka, C. } \\
\text { Collins, W. Doe, E. McDonald, K. Redmond, C. } \\
\text { Ryerson, S. Shoop, L. Spears, amd M. Sturm }\end{array}$ \\
\hline ERDC/CRREL LR-08-12 & Sep 2008 & $\begin{array}{l}\text { Initial Set of Use Cases for High-Fidelity } \\
\text { Synthetic Environment / Virtual Autonomous } \\
\text { Navigation Environment Development Tied to } \\
\text { Unmanned Ground Vehicle Capability Gaps, } \\
\text { by J.A. Nagle, N.C. Goerger, and LTC. S.M. } \\
\text { DeLong }\end{array}$ \\
\hline ERDC/CRREL LR-08-13 & Oct 2008 & $\begin{array}{l}\text { Integrated Marine Studies of the Hubbard } \\
\text { Glacier System, Alaska in Support of } \\
\text { Catastrophic Flood Risk Assessment, by D.E. } \\
\text { Lawson }\end{array}$ \\
\hline ERDC/CRREL LR-09-01 & Mar 2009 & $\begin{array}{l}\text { Catastrophic Flooding and the Hubbard } \\
\text { Glacier System: Report on Phase } 1 \text { Airborne } \\
\text { Geophysical Investigation, by D.E. Lawson }\end{array}$ \\
\hline ERDC/CRREL LR-09-02 & Apr 2009 & $\begin{array}{l}\text { Remediating and Monitoring White } \\
\text { Phosphorus Contamination at Eagle River } \\
\text { Flats (Operable Unit C), Fort Richardson, } \\
\text { Alaska, by S.R. Bigl and C.M. Collins }\end{array}$ \\
\hline ERDC/CRREL LR-09-03 & 2009 & $\begin{array}{l}\text { Climate Monitoring in Glacier Bay National } \\
\text { Park and Preserve: Capturing Climate Change } \\
\text { Indicators, } 2007 \text { Annual Report, by D.E. } \\
\text { Lawson, and D.C. Finnegan }\end{array}$ \\
\hline ERDC/CRREL LR-09-04 & 2009 & $\begin{array}{l}\text { A Dendroclimatic Record of Paleoclimate of } \\
\text { the Last 10,000 Years, Glacier Bay National } \\
\text { Park and Preserve: Progress Understanding } \\
\text { Climate Change in Southeast Alaska, Annual } \\
\text { Report 2007, by D. Lawson, G. Wiles, and D. } \\
\text { Finnegan }\end{array}$ \\
\hline ERDC/CRREL LR-09-5 & 2009 & $\begin{array}{l}\text { Climate Monitoring in Glacier Bay National } \\
\text { Park and Preserve: Capturing Climate Change } \\
\text { Indicators, } 2008 \text { Annual Report, by D.E. } \\
\text { Lawson, and D.C. Finnegan }\end{array}$ \\
\hline ERDC/CRREL LR-09-6 & 2009 & $\begin{array}{l}\text { Paleoclimate of the Last } 10,000 \text { Years, } \\
\text { Glacier Bay National Park and Preserve: } \\
\text { Progress Understanding Climate Change in } \\
\text { Southeast Alaska, Annual Report 2008, by D. } \\
\text { Lawson and G. Wiles }\end{array}$ \\
\hline
\end{tabular}


ERDC/CRREL LR-10-01 Oct 2009

ERDC/CRREL LR-10-02 2010

ERDC/CRREL LR-10-4 Jan 2010

ERDC/CRREL LR-10-05

ERDC/CRREL LR-10-06

ERDC/CRREL LR-10-07 Jan 2010

ERDC/CRREL LR-10-08 May 1990

ERDC/CRREL LR-10-09

ERDC/CRREL LR-10-10

ERDC/CRREL LR-10-11 May 2010

Aug 2001

Feb 1990

Facilities at Fort Drum, New York, by J. Buska, A. Greatorex, and W. Tobiasson

Vehicle Trafficability of Freezing and Thawing Ground Conditions, by S. Shoop, G. Koenig, and P. Richmond

Remediating and Monitoring White Phosphorus Contamination at Eagle River Flats (Operable Unit C), Fort Richardson, Alaska: FY09 Data Report, by S.R. Bigl and C.M. Collins

ERDC/CRREL LR-11-01

ERDC/CRREL LR-11-02

Estimating Modulus Values for Layers in a Geocomposite Capillary Barrier Drain, by L.A. Barna, K.S. Henry, D.M. Solano Velez, and J.C. Stormont

Decontamination of VX Nerve and HD $32^{\circ} \mathrm{C}$ Using Cold Weather Variants of the Decontamination Agent Decon Green, by D.B. Ringelberg, K.L. Foley, G.W. Wagner, and C.M. Reynolds

Permafrost Degradation Investigation with Addendum, by K. Bjella

Thule Air Base Airfield White Painting and Permafrost Investigation Phase II, by K. Bjella Investigation, by B. Astley, A. Delaney, A. Gelvin, and A. Staples

Phase III: Guidance for Optimizing Admixture Dosage Rates; Data Review and Project Framework Development, by L.A. Barna

Review of CRS Sirrine 30 April 1990 Report, Recommendations and Calculations on Roofing and Attic Ventilation Problems at Fort Drum, J. Buska, W. Tobiasson, and A. Greatorex

Suitability of a Light Weight Deflectometer (LWD) and Ultrasonic Pulse Velocity (UPV) Meter as EMAS Condition Assessment Tools, by K. MacDonald and B. Coutermarsh

Feb 2011 Settlement Agreement Monitoring Studies Eagle River Flats, Alaska, August 2009, by B. Astley, R. Nenahlo, A. Staples, and A Stewart 
ERDC/CRREL LR-11-03 Mar 2011 Settlement Agreement Monitoring Studies Eagle River Flats, Alaska, August 2010, by B. Astley, R. Nenahlo, A. Staples, and A Stewart

ERDC/CRREL LR-11-04 Jul 2011

Remediating and Monitoring White

Phosphorus Contamination at Eagle River Flats (Operable Unit C), Fort Richardson, Alaska: FY10 Data Report, by M.E. Walsh and C.M. Collins

ERDC/CRREL LR-11-05

ERDC/CRREL LR-11-06

Apr 2011 Climate Site Assessment, by D.E. Lawson

2011 Climate Monitoring in Glacier Bay National

Park and Preserve: Capturing Climate Change Indicators, by D.E. Lawson, M. Klaar,D.C. Finnegan, and S. Campbell

ERDC/CRREL LR-11-07 2011

1ERDC/CRREL LR-11-08 Jul 2011

Paleoclimate of the Last 10,000 Years, Glacier Bay National Park and Preserve: Progress Understanding Climate Change in Southeast Alaska: Annual Report 2010, by D. Lawson, G. Wiles, and N. Wiesenberg

High Performance Plastic Sled Design for Polar Traversing: King HMW-PE Tensile Results, by J.C. Weale, J. Trovillion, and J.H. Lever

1ERDC/CRREL LR-11-09 Jun 2011 High Performance Plastic Sled Design for Polar Traversing: Roechling HMW-PE Tensile Results, by J.C. Weale, J. Trovillion, and J.H. Lever

ERDC/CRREL LR-11-10 Dec 2011 Poleline Road Dispersal Area Hydrologic Analysis and Modeling Summary Report, by C. Snyder and B. Astley

ERDC/CRREL LR-11-11 Jun 2011 WAIS Divide Arch Facility Inspection for Extended Field Seasons, by J.H. Rand, L. Barna, and N. Zeigler

ERDC/CRREL LR-11-12 Dec 2011 Thule Air Base Airfield White Painting and Permafrost Investigation Phase I-IV, by K. Bjella

ERDC/CRREL LR-12-1 Aug 2011 Thule Air Base FY12 Dormitory Permafrost and Geotechnical Investigation, by K. Bjella

ERDC/CRREL LR-12-2 Jan 2012 Thule Air Base FY13 Dormitory Permafrost and Geotechnical Investigation, by K. Bjella

ERDC/CRREL LR-12-3 Oct 2013 Thule Air Base Consolidated Facilities Permafrost and Geotechnical Investigation and Test Pit Addendum, by K. Bjella

1 Limited distribution; see Preface. 


$\begin{array}{lrl}\text { ERDC/CRREL LR-12-4 } & \text { Mar 2012 } & \begin{array}{l}\text { Numerical Modeling of NG Diffusion in } \\ \text { Propellant Grains, by J.S. Pitt }\end{array} \\ \text { ERDC/CRREL LR-12-6 } & \text { Feb 2012 } & \begin{array}{l}\text { Hydrologic Assessment and Water Level } \\ \text { Records for Poleline Road Disposal Area } \\ \text { 1995-2011, Fort Richardson, Alaska, by B. } \\ \text { Astley, A. Staples, and C. Snyder }\end{array} \\ \text { ERDC/CRREL LR-12-7 N Nov 2012 } & \begin{array}{l}\text { Instrumented Below Ground Biomass } \\ \text { Sampler, by J.A. Silvestre-Soto, K. MacDonald, } \\ \text { N. Buck, and S. Shoop }\end{array} \\ \text { ERDC/CRREL LR-12-8 Nov 2012 } & \begin{array}{l}\text { Projections of Future Air Temperatures and } \\ \text { Melt Season Duration for McMurdo Station } \\ \text { and Pegasus Runway, by J.W. Weatherly and J. } \\ \text { Helble }\end{array}\end{array}$

ERDC/CRREL LR-13-1 Feb 2013 West Antarctic Ice Sheet Divide Ice Core Processing Room and Ice Core Storage Facility Design Alternatives, by J.C. Weale

ERDC/CRREL LR-13-2 $2013 \quad$ Paleoclimate of the Last 10,000 Years, Glacier Bay National Park and Preserve: Progress Understanding Climate Change in Southeast Alaska: Annual Report 2012, by D. Lawson, G. Wiles, and N. Wiesenberg

ERDC/CRREL LR-13-3 Jul 2013 Preliminary Site Preparation Assessment and Proposed Earthwork for Phases 1-5, by R. Affleck

1ERDC/CRREL LR-13-4

Sep 2013 Snow Drift Control Recommendations: Forward Operating Site Kurecik, by R.B. Haehnel, B. Tracy, E. Deeb, and J. Weatherly

1ERDC/CRREL LR-14-1 Dec 2013 Laboratory and VASST Testing for Mechanical Properties of Lightly Vegetated Sands, by S.A. Shoop, K.A. MacDonald, and G.D. Durell

ERDC/CRREL LR-14-2 Jan 2014 Expedient Permafrost Resistivity Investigation, by K. Bjella

ERDC/CRREL LR-14-3 Jan 2014 Dalton Highway 9 to 11 Mile Expedient Resistivity Permafrost Investigation, by K. Bjella

1ERDC/CRREL LR-14-4 May 2014 ERDC-CRREL Nominal Mode I Ice adhesion Testing, by D.M. Cole

ERDC/CRREL LR-14-5 Sep 2014 Elastic Analysis of Ice Pier at McMurdo Station, by D.S. Sodhi

ERDC/CRREL LR-14-6 Sep 2014 Maintenance Costs of Equipment Owned by the National Science Foundation: Preliminary Review, by T. Melendy

1 Limited distribution; see Preface. 
1ERDC/CRREL LR-14-7 Dec 2014 A Review of the Feasibility of Continued Use of the Wilkins Aerodrome to Provide Air Support for Australian Antarctcc Operations, by R. Haehnel and J. Weale

\section{Monographs}

\begin{tabular}{|c|c|c|c|}
\hline Report Number & Date & $\underline{\text { Title }}$ & $\underline{\text { AD Number }}$ \\
\hline ERDC/CRREL M-00-1 & Jan 2000 & $\begin{array}{l}\text { Remote Sensing of In-Flight Icing Conditions } \\
\text { Operational, Meteorological, and } \\
\text { Technological Considerations, by C.C. Ryerson }\end{array}$ & ADA373085 \\
\hline ERDC/CRREL M-05-1 & Oct 2005 & $\begin{array}{l}\text { Handbook of Physical Constants and } \\
\text { Functions for Use in Atmospheric Boundary } \\
\text { Layer Studies, by E.L. Andreas }\end{array}$ & ADA440352 \\
\hline 1ERDC/CRREL M-12-1 & Sep 2012 & $\begin{array}{l}\text { EUCOM Natural Backgrounds and U.S. } \\
\text { Analogs, by C.C. Ryerson, C.L. Scott, A.L. } \\
\text { Coplin, S.P. Gaughan, E. Smallidge, T.M. } \\
\text { Sobecki, and J.P. Hardy }\end{array}$ & ADB391118 \\
\hline 1ERDC/CRREL M-13-1 & Aug 2013 & $\begin{array}{l}\text { PACOM Natural Backgrounds and U.S. } \\
\text { Analogs, by C.C. Ryerson, A.L. Coplin, C.L. } \\
\text { Scott, E. Smallidge, T.M. Sobecki, S.P. } \\
\text { Gaughan, and J.P. Hardy }\end{array}$ & ADB392826 \\
\hline 1ERDC/CRREL M-13-2 & Sep 2013 & $\begin{array}{l}\text { NORTHCOM Natural Backgrounds and U.S. } \\
\text { Analogs, by C.C. Ryerson, C.L. Scott, A.L. } \\
\text { Coplin, S.P. Gaughan, E. Smallidge, T.M. } \\
\text { Sobecki, R.A. Melloh, and J.P. Hardy }\end{array}$ & ADB395603 \\
\hline 1ERDC/CRREL M-13-3 & Sep 2013 & $\begin{array}{l}\text { CENTCOM Natural Backgrounds and U.S. } \\
\text { Analogs, by C.C. Ryerson, A.L. Coplin, C.L. } \\
\text { Scott, E. Smallidge, T.M. Sobecki, S.P. } \\
\text { Gaughan, J.P. Hardy and R. Melloh }\end{array}$ & ADB395604 \\
\hline 1ERDC/CRREL M-13-4 & Sep 2013 & $\begin{array}{l}\text { AFRICOM Natural Backgrounds and U.S. } \\
\text { Analogs, by C.C. Ryerson, A.L. Coplin, C.L. } \\
\text { Scott, E.R. Smallidge, T.M. Sobecki, J.P. Hardy, } \\
\text { S.P. Gaughan and R.A. Melloh }\end{array}$ & ADB395605 \\
\hline 1ERDC/CRREL M-13-5 & Oct 2013 & $\begin{array}{l}\text { SOUTHCOM Natural Backgrounds and U.S. } \\
\text { Analogs, by C.C. Ryerson, C.L. Scott, A.L. } \\
\text { Coplin, S.P. Gaughan, T.M. Sobecki, R.A. } \\
\text { Melloh, and J.P. Hardy }\end{array}$ & ADB395606 \\
\hline
\end{tabular}

1 Limited distribution; see Preface. 


\section{Special reports}

\begin{tabular}{|c|c|c|c|}
\hline Report Number & $\underline{\text { Date }}$ & $\underline{\text { Title }}$ & $\underline{\text { AD Number }}$ \\
\hline ERDC/CRREL SR-02-1 & May 2002 & $\begin{array}{l}\text { Snow and Ice Control (SNIC) Equipment and } \\
\text { Its Use by Military Units Worldwide, by N.H. } \\
\text { Collins }\end{array}$ & ADA404737 \\
\hline ERDC/CRREL SR-02-2 & Oct 2002 & $\begin{array}{l}\text { Report on the Workshop on New Grass } \\
\text { Germplasms and Invasive Weed Control: } 30 \\
\text { April-1 May 2002, Fort Carson and the United } \\
\text { States Air Force Academy Colorado Springs, } \\
\text { Colorado, by S.E. Hardy and A.J. Palazzo }\end{array}$ & ADA408310 \\
\hline ERDC/CRREL SR-03-1 & Jul 2003 & $\begin{array}{l}\text { Dugway Proving Ground Installation } \\
\text { Restoration Program GIS: Software } \\
\text { Documentation and Training Materials, by P.T. } \\
\text { Cedfeldt, J.D. Schlagel, and D.C. Finnegan }\end{array}$ & ADA418345 \\
\hline ERDC/CRREL SR-03-2 & Dec 2003 & $\begin{array}{l}\text { An Experiment in Preventing Zebra Mussel } \\
\text { Settlement Using Electro-Expulsive } \\
\text { Separation Technology, by N.D. Mulherin and } \\
\text { A.C. Miller }\end{array}$ & ADA422495 \\
\hline ERDC/CRREL SR-04-1 & Sep 2004 & $\begin{array}{l}\text { Fast All-Season Soil STrength (FASST), by S. } \\
\text { Frankenstein and G.G. Koenig }\end{array}$ & ADA431603 \\
\hline ERDC/CRREL SR-09-1 & Jun 2009 & $\begin{array}{l}\text { User's Manual for the CRREL Multi-Increment } \\
\text { Sampling Tool, by M.R. Walsh }\end{array}$ & \\
\hline ERDC/CRREL SR-09-2 & Aug 2009 & $\begin{array}{l}\text { Snow Harvesting: A Potential Water Source for } \\
\text { Afghanistan, by K.J. Thompson, K.S. Henry, } \\
\text { J.P. Hardy, and A.M. Chalmers }\end{array}$ & ADA507670 \\
\hline ERDC/CRREL SR-10-1 & Jul 2010 & $\begin{array}{l}\text { LiDAR Point Cloud Database Infrastructure: } \\
\text { Hardware and Software Installation } \\
\text { Procedures for Establishing a Sun } \\
\text { Microsystems and Oracle 11g Spatial } \\
\text { Database Installation - Phase 1, by D.C. } \\
\text { Finnegan, M. Montreuil, and M. Smith }\end{array}$ & \\
\hline ERDC/CRREL SR-10-2 & Nov 2010 & $\begin{array}{l}\text { Challenges for Engineering Design, } \\
\text { Construction, and Maintenance of } \\
\text { Infrastructure in Afghanistan, by R.T. Affleck } \\
\text { and R. Freeman }\end{array}$ & ADA532415 \\
\hline ERDC/CRREL SR-11-1 & Nov 2011 & $\begin{array}{l}\text { Flora and Field Guide References Supporting } \\
\text { All U.S. Army Corps of Engineers Wetland } \\
\text { Regional Supplements, by R. Lichvar and L. } \\
\text { Dixon }\end{array}$ & ADA553492 \\
\hline ERDC/CRREL SR-12-1 & Dec 2012 & $\begin{array}{l}\text { Recommendations for Vehicle Dust Control at } \\
\text { McMurdo Station, Antarctica, by P.M. Seman } \\
\text { and R.T. Affleck }\end{array}$ & \\
\hline
\end{tabular}



1ERDC/CRREL SR-13-1 Oct $2013 \quad \begin{aligned} & \text { Enhancing Geospatial Processes for the } \\ & \text { Production of Winter Speed Maps, by R.T. }\end{aligned}$

ADB393494

Affleck, S.P. Gaughan, and P.W. Richmond

ERDC/CRREL SR-14-1 Feb 2014 Stability Operations: Assessment of Science and Technology Gaps and Requirements, by J.M. Roningen and R.T. Affleck

ERDC/CRREL SR-14-2 Sep 2014 Elevated Building Lift Systems on Permanent Snowfields: A Report on the Elevated Building

ADA609374 Lift Systems in Polar Environments Workshop, by J. Weale, L. Barna, W. Tobiasson, and J. Mercer

ERDC/CRREL SR-14-3 Dec 2014 Preliminary Guidelines and Standard Operating Procedure for Drainage and Erosion Control at McMurdo Station, by R. Affleck and M. Carr

ERDC/CRREL SR-15

May 2015

Indicators of Physical and Biological Trends around the McMurdo Station, Antarctica: A Literature Review, by J.P. Hardy

ADA612366

ADA618136

\section{Technical notes}

Report Number

Date

$\underline{\text { Title }}$

ERDC/CRREL TN-01-1

Oct 2001

Expected Cost Effect of Increasing the Size of a Frozen-Ground Waste Containment Project at Ft. Detrick, Maryland, by S.A. Grant

ERDC/CRREL TN-03-1 Jan 2003

Ice Engineering: Ice Jams, Winter 2001-2002

ERDC/CRREL TN-03-2 Apr 2003

Ice Engineering: Early Warning Flood Stage Monitoring Equipment

ERDC/CRREL TN-03-3 Apr 2003

Overland Erosion Due to Freeze-Thaw Cycling: Laboratory Experiments, by L.W. Gatto and M.G. Ferrick

ERDC/CRREL TN-03-4 Oct 2003 Ice Engineering: Progress in Evaluating Surface Coatings for Icing Control at Corps Hydraulic Structures, by N.D. Mulherin and R.B. Haehnel

ERDC/CRREL TN-04-1 Apr 2004 Field Sampling Tools for Explosives Residues Developed at CRREL, by M.R. Walsh

ERDC/CRREL TN-04-2 Apr 2004 Cold Regions Engineering: Inclusion of FreezeThaw-Induced Soil and Bank Erosion in CoE Planning, Engineering, O\&M, and Model Development, by L.W. Gatto, M.G. Ferrick, and K.D. White

\footnotetext{
1 Limited distribution; see Preface.
} 
ERDC/CRREL TN-04-3 Jun 2004 Ice Engineering: Method to Estimate River Ice Thickness Based on Meteorological Data, by K. White

ERDC/CRREL TN-04-4 Jun 2004 Publication of a Map Series on the Aquatic Resources for San Jacinto and Portions of the Santa Margarita Watersheds, by R. Lichvar and M. Ericsson

ERDC/CRREL TN-04-5 Jul 2004 Ice Engineering: Ice Jams, Winter 2002-2003, by T.M. Morgan L. Furman, and K. White

ERDC/CRREL TN-04-6 Sep 2004 Cold Regions Engineering: Combined Effects of Temperature and Soils on Infiltration, by S.A. Grant and K. White

ERDC/CRREL TN-05-1 Jan 2005 Ice Engineering: Method to Evaluate Potential for Ice Impacts on Sediment Stability, by A.M. Tuthill and K.D. White

ERDC/CRREL TN-05-2 Feb 2005 Pre-Screening for Explosives Residues in Soil Prior to HPLC Analysis Utilizing Expray, by K.L. Bjella

ERDC/CRREL TN-05-3 Apr 2005 Ice Engineering: Ice Cover Effects on Scour in Narrow Rivers, by L.J. Zabilansky and K.D. White

ERDC/CRREL TN-05-4 Jun 2005 Common Wetland Delineation Sedges of the Northeast, by B. Lichvar

ERDC/CRREL TN-05-6 Sep 2005 Cold Regions Data Acquisition and Analysis for Section 227 National Shoreline Erosion Control Development and Demonstration Program Miami Park South, Allegan County, Michigan, by M.G. Ferrick, L.W. Gatto, and C.R. Williams

ERDC/CRREL TN-05-7 Dec 2005 Soil Freeze-Thaw Effects on Bank Erosion and Stability: Connecticut River Field Site, Norwich, Vermont, by M.G. Ferrick, L.W. Gatto, and S.A. Grant

ERDC/CRREL TN-06-1 Apr 2006 Seismic-Acoustic Active Range Monitoring for Characterizing Low-Order Ordnance Detonation, by T.S. Anderson and J.C. Weale

ERDC/CRREL TN-06-2 Jul 2006 Ice Engineering: Improving Oil Spill Response in Ice-Covered Waters, by L.J. Zabilansky, D.F. Dickins, I. Buist, K.D. White, and G. Cattabriga

ERDC/CRREL TN-06-3 Jul 2006 Delineating and Evaluating Vegetation Conditions of Vernal Pools Using Spaceborne and Airborne Remote Sensing Techniques, Beale Air Force Base, CA, by R.W. Lichvar, D.C. Finnegan, S. Newman, and W. Ochs 
ERDC/CRREL TN-08-1 Feb 2008 Ice Jam at the Rio Blanco Diversion Weir on the White River in Colorado: A Case Study of In-Stream Structures and Ice, by A.M. Tuthill

ERDC/CRREL TN-08-2 Jun 2008 A Guide to Alaskan Black Spruce Wetland Bryophytes: Species Specific to Delineation for Interior and South Central Regions, by R.D. Seppelt, G.A. Laursen, and R.W. Lichvar

ERDC/CRREL TN-08-3 Sep 2008 Concepts and Procedures for Updating the National Wetland Plant List, by R.W. Lichvar and P. Minkin

ERDC/CRREL TN-09-1 May 2009 Nomenclature and the National Wetland Plant List, by R. Lichvar and J. Kartesz

ERDC/CRREL TN-09-2 Aug 2009 Cold Testing of a Borehole Camera and LED Light for Use at the South Pole, by J. Gagnon

ERDC/CRREL TN-10-1 Jul 2010 Updated Datasheet for the Identification of the Ordinary High Water Mark (OHWM) in the Arid West Region of the Western United States, by K.E. Curtis and R.W. Lichvar

ERDC/CRREL TN-10-2 Jul 2010 Sphagnum as an Indicator of Wetland Hydrology in the Atlantic and Gulf Coastal Plain Region, by J.J. Gillrich and R.W. Lichvar

ERDC/CRREL TN-11-1 Sep 2011 Final Protocol for Assigning Wetland Indicator Status Ratings during National Wetland Plant List Update, by R.W. Lichvar and J.J. Gillrich

ERDC/CRREL TN-12-1 Jul 2012 National Wetland Plant List Indicator Rating Definitions, by R.W. Lichvar, N.C. Melvin, M.L. Butterwick, and W.N. Kirchner

ERDC/CRREL TN-13-1 Sep 2013 Thermal Conductivity and Durability Testing of Inflatable Building Materials, by J.C. Weale and M.A. Knuth

ERDC/CRREL TN-13-2 Oct 2013 Land Information System (LIS) Development Plan: FY13-FY18, by J.B. Eylander

ERDC/CRREL TN-14-1 Mar 2014 Field Testing New Plot Designs and Methods for Determining Hydrophytic Vegetation during Wetland Delineations in the United States, by R.W. Lichvar and J.J. Gillrich

ERDC/CRREL TN-14-2 May 2014 Shelter Deployment at Former Army Camp Tuto, Greenland, by C.D. Aall, J. Lever, J. Mercer, and J. Weale

ERDC/CRREL TN-15-1 Jan 2015 Pegasus Airfield Repair and Protection: Laboratory Trials of White Ice Paint to Improve the Energy Reflectance Properties of the Glacial-Ice Runway Surface, by J.C. Weale 
ERDC/CRREL TN-15-2 Nov 2015 Site Assessment and Feasibility of a New Operations Base on the Greenland Ice Sheet: Addendum to Preliminary Report, by M. Bigl and E. Deeb

\section{Technical reports}

\begin{tabular}{|c|c|c|c|}
\hline Report Number & Date & $\underline{\text { Title }}$ & $\underline{A D}$ Number \\
\hline ERDC/CRREL TR-00-1 & Mar 2000 & $\begin{array}{l}\text { Integrating CAD Data with Geographic } \\
\text { Information Systems Using AutoCAD and } \\
\text { ARD/INFO Software, by P.T. Cedfeldt and M.A. } \\
\text { Scott }\end{array}$ & ADA377146 \\
\hline ERDC/CRREL TR-00-2 & Mar 2000 & $\begin{array}{l}\text { External Contamination of Landmines by } \\
\text { Organic Nitro-Compounds, by D.C. Leggett, } \\
\text { T.F. Jenkins, A.W. Hogan, T. Ranney, and P.H. } \\
\text { Miyares }\end{array}$ & ADA376896 \\
\hline ERDC/CRREL TR-00-3 & Apr 2000 & $\begin{array}{l}\text { Glacial Geology and Stratigraphy of Fort } \\
\text { Richardson, Alaska: A Review of Available } \\
\text { Data on the Hydrogeology, by L.E. Hunter, D.E. } \\
\text { Lawson, S.R. Bigl, P.B. Robinson, and J.D. } \\
\text { Schlage }\end{array}$ & ADA378398 \\
\hline ERDC/CRREL TR-00-4 & Apr 2000 & $\begin{array}{l}\text { Evaluation of Photovoltaic Panels at the South } \\
\text { Pole Station, by C.R. Williams and J. Rand }\end{array}$ & ADA378459 \\
\hline ERDC/CRREL TR-00-5 & Apr 2000 & $\begin{array}{l}\text { UXO Detection at Jefferson Proving Ground } \\
\text { Using Ground-Penetrating Radar, by S.A. } \\
\text { Arcone, K. O'Neill, A.J. Delaney, and P.V. } \\
\text { Sellmann }\end{array}$ & ADA378501 \\
\hline ERDC/CRREL TR-00-6 & Jun 2000 & $\begin{array}{l}\text { Thaw Weakening and Load Restriction } \\
\text { Practices on Low Volume Roads, by M.A. } \\
\text { Kestler, T. Knight, and A.S. Krat }\end{array}$ & ADA380175 \\
\hline ERDC/CRREL TR-00-7 & Jun 2000 & $\begin{array}{l}\text { Evaluating the Hanby Test Kits for Screening } \\
\text { Soil and Groundwater for Total Petroleum } \\
\text { Hydrocarbons: Field Demonstration, by A.D. } \\
\text { Hewitt }\end{array}$ & ADA381764 \\
\hline ERDC/CRREL TR-00-8 & Jul 2000 & $\begin{array}{l}\text { Expedient MESL Construction in Cold } \\
\text { Weather, by J.A. Stark, R.T. Affleck, and S.A. } \\
\text { Orchino }\end{array}$ & ADA382758 \\
\hline ERDC/CRREL TR-00-9 & Jul 2000 & $\begin{array}{l}\text { Bacterial Survival in Snow Made from } \\
\text { Wastewater, by L.V. Parker, M.L. Yushak, C.J. } \\
\text { Martel, and C.M. Reynolds }\end{array}$ & ADA380621 \\
\hline ERDC/CRREL TR-00-10 & Aug 2000 & $\begin{array}{l}\text { Numerical Simulation of River Ice Control with } \\
\text { Booms, by L. Liu and H.T. Shen }\end{array}$ & ADA383060 \\
\hline
\end{tabular}




\begin{tabular}{|c|c|c|}
\hline ERDC/CRREL TR-00-11 & Aug 2000 & $\begin{array}{l}\text { Ship Superstructure Icing: Crystalline and } \\
\text { Physical Properties, by C.C. Ryerson and A.J. } \\
\text { Gow }\end{array}$ \\
\hline ERDC/CRREL TR-00-12 & Aug 2000 & $\begin{array}{l}\text { Use of Surface Snow Sampling to Estimate } \\
\text { the Quantity of Explosives Residues Resulting } \\
\text { from Land Mine Detonations, by T.F. Jenkins, } \\
\text { T.A. Ranney, P.H. Miyares, N.H. Collins, and } \\
\text { A.D. Hewitt }\end{array}$ \\
\hline ERDC/CRREL TR-00-13 & Aug 2000 & $\begin{array}{l}\text { Assessment of Millennium Pipeline Project } \\
\text { Lake Erie Crossing: Ice Scour, Sediment } \\
\text { Sampling, and Turbidity Modeling, by J.H. } \\
\text { Lever, editor }\end{array}$ \\
\hline
\end{tabular}

ADA381910

ERDC/CRREL TR-00-14 Aug 2000

Cazenovia Creek Ice-Control Structure, by J.H. ADA382170 Lever, G. Gooch, and S. Daly

ERDC/CRREL TR-00-15 Aug 2000

Evaluating the Use of Snow-Covered Ranges to Estimate the Explosives Residues that Result From Detonation of Army Munitions, by T.F. Jenkins, T.A. Ranney, M.E. Walsh, P.H. Miyares, A.D. Hewitt, and N.H. Collins

ERDC/CRREL TR-00-16

Sep 2000

A Review of the Thermodynamics of Frost Heave, by K.S. Henry

ADA381594

ADA382997

ERDC/CRREL TR-00-17 Sep 2000

Estimating the Half-Lives of Key Components of the Chemical Vapor Signature of Land Mines, by P.H. Miyares and T.F. Jenkins

ERDC/CRREL TR-00-18 Sep 2000

Geological Investigations and Hydrogeological

ADA383061 Model of Fort Richardson, Alaska, by L.E. Hunter, D.E. Lawson, S.R. Bigl, B.N. Astley, C.F. Snyder, and F.E. Perron, Jr.

ERDC/CRREL TR-00-19

Sep 2000

Frozen Soil Barriers for Explosives Containment, by G.M. Marion and D.K. Pelton

ADA382526

ADA381842

ADA382998

Evaluation of H.E.L.P. Mate 2000 for the

ADA385136

ERDC/CRREL TR-00-20 Sep 2000 Identification and Quantification of Petroleum Hydrocarbon Products, by A.D. Hewitt

ERDC/CRREL TR-00-21 Dec 2000

Physical and Chemical Factors Affecting ADA408780 Contaminant Hydrology in Cold Environments, by S.A. Grant

ERDC/CRREL TR-01-1 Jan 2001 Spatial Analysis of Thaw Depth, by R.T. Affleck and S.A. Shoop

ERDC/CRREL TR-01-2 Jan 2001 Off-the-Shelf Antifreeze Admixture for

ADA388242 Concrete Initial Laboratory Investigation, by C.J. Korhonen and S.A. Orchino

ADA382716

Design of Freezing Bed for Sludge Dewatering

ADA387591 at McMurdo, Antarctica, by C.J. Martel 
ERDC/CRREL TR-01-4 Feb 2001 An Ecological Land Survey for Fort Greely,

ADA391120

Alaska, by M.T. Jorgenson, J.E. Roth, M.D.

Smith, S. Schlentner, W. Lentz, E.R. Pullman, and C.H. Racine

$\begin{array}{rrl}\text { ERDC/CRREL TR-01-5 Feb } 2001 & \begin{array}{l}\text { An Inventory of the Vascular Flora of Fort } \\ \text { Greeley, Interior Alaska, by C. Racine, R. }\end{array}\end{array}$

ADA389271

Lichvar, and M. Duffy

ERDC/CRREL TR-01-6 Feb 2001 Release of Explosive-Related Vapors from

ADA391291 Land Mines, by D.C. Leggett, J.H. Cragin, T.F. Jenkins, and T. Ranney

ERDC/CRREL TR-01-7

Mar 2001

Characterizing Range Scrap and Developing Quality Assurance Coupons for Hot Gas Decontamination Trials, by A.D. Hewitt

ERDC/CRREL TR-01-8

Mar 2001

Influence of Wheel Load Shape on Vertical Stress Reaching Subgrade through an Aggregate Layer, by K.S. Henry

ERDC/CRREL TR-01-9

May 2001

Field Gas Chromatography/Thermionic Detector System for On-Site Determination of Explosives in Soils, by A.D. Hewitt, T.F. Jenkins, and T.A. Ranney

ERDC/CRREL TR-01-10 May 2001 Marine Ice Atlas for Cook Inlet, Alaska, by N.D.
Mulherin, W.B. Tucker III, O.P. Smith, and W.J. Lee

1ERDC/CRREL TR-01-11 Jul 2001

Estimating Rolling Friction of Loose Soil for Aircraft Takeoff on Unpaved Runways, by S.A. Shoop, P.W. Richmond, and R.A. Eaton

ERDC/CRREL TR-01-12 Aug 2001

A Method for Producing Fine-Grained Ice from Snow by Compaction, by D. Diemand and V. Klokov

ERDC/CRREL TR-01-13 Sep 2001

Capillary Tension in Rotting Ice Layers, by R.E. Jordan and J.A. Stark

ERDC/CRREL TR-01-14 Sep 2001

The Effect of Aggregate Angularity on Base Course Performance, by V.C. Janoo and J.J. Bayer II

ERDC/CRREL TR-01-15 Nov 2001

Sampling for Explosives Residues at Fort Greely, Alaska: Reconnaissance Visit July 2000, by M.E. Walsh, C.M. Collins, C.H. Racine, T.F. Jenkins, A.B. Gelvin, and T.A. Ranney

ERDC/CRREL TR-01-16 Nov 2001 Finite Element Modeling of Tire-Terrain Interaction, by S.A. Shoop
ADB272140

ADA399588

ADA399589 ADA400534

ADA398175

ADA398076

\footnotetext{
1 Limited distribution; see Preface.
} 


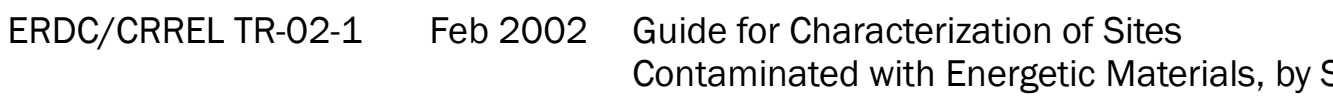

ADA411800

Thiboutot, G. Ampleman, and A.D. Hewitt

ERDC/CRREL TR-02-2 Feb 2002 Maximum Impact Force of Woody Debris on

ADA398916 Floodplain Structures, by R.B. Haehnel and S.F. Daly

ERDC/CRREL TR-02-3 Feb 2002 Analysis of Nitroglycerine in Soils and on Mortar Fins Using GC-TID, by A.D. Hewitt

ADA399520

ERDC/CRREL TR-02-4

ERDC/CRREL TR-02-5

Feb 2002

Ice-Affected Components of Locks and Dams, by A.M. Tuthill

Feb 2002

Effect of High Doses of Chemical Admixtures on the Freeze-Thaw Durability of Portland Cement Concrete, by C. Korhonen

ERDC/CRREL TR-02-6 Feb 2002

Ground Snow Loads for New Hampshire, by W. Tobiasson, J. Buska, A. Greatorex, J. Tirey, J. Fisher, and S. Johnson

ERDC/CRREL TR-02-7

Apr 2002

Off-the-Shelf Antifreeze Admixtures, by C.J. Korhonen

ERDC/CRREL TR-02-8 May 2002

Videomonitoring Performance of the St. Marys River Ice Islands and Ice Boom, by A.M. Tuthill and J.J. Gagnon

1ERDC/CRREL TR-02-9 June 2002

FLIR Mission Planning Performance Enhancement (FMPPE): CEP Test Report, by S. Milton, R. Davis, and G. Koenig

ERDC/CRREL TR-02-10 Aug 2002

Surface Climate and Snow-Weather Relationships of the Kuparuk Basin on Alaska's Arctic Slope, by P.Q. Olsson, L.D. Hinzman, M. Sturm, G.E. Liston, and D.L. Kane

ERDC/CRREL TR-02-11 Aug 2002

Evaluation of New Sensors for Emergency Management, by R. Bolus and A. Bruzewicz

ERDC/CRREL TR-02-12 Aug 2002

Study of Five Discrete Interval-Type Groundwater Sampling Devices, by L.V. Parker and C.H. Clark

ERDC/CRREL TR-02-13 Sep 2002

Army Aircraft Icing, by L. Peck, C.C. Ryerson, and C.J. Martel

ERDC/CRREL TR-02-14 Sep 2002

Survey of River Ice Influences on Channel Bathymetry Along the Fort Peck Reach of the Missouri River, Winter 1998-1999, by L.J. Zabilansky, R. Ettema, J. Wuebben, and N. Yankielun
ADA399952

ADA401277

ADA399953

ADA401312

ADA404845

ADB281968

ADA406170

ADA406310

ADA406027

ADA406321

ADA406302

\footnotetext{
1 Limited distribution; see Preface.
} 
ERDC/CRREL TR-02-15 Oct 2002

Wide-Area Ice Detection Using Time Domain Reflectometry, by N.E. Yankielun, C.C.

Ryerson, and S.L. Jones

ERDC/CRREL TR-02-16 Oct 2002

Long-Term Survival of Enteric Microorganisms in Frozen Wastewater, by L.V. Parker and C.J. Martel

ERDC/CRREL TR-03-1 Jan 2003

Ice Storms in the St. Lawrence Valley Region, by K.F. Jones

ERDC/CRREL TR-03-2 Jan 2003

Ice and Debris Passage for Innovative Lock Designs, by A.M. Tuthill

ERDC/CRREL TR-03-3 Feb 2003

A Statistical Micromechanical Theory of Cone Penetration in Granular Materials, by J.B. Johnson

ERDC/CRREL TR-03-4 Mar 2003

Planning Level Delineation and Geospatial Characterization of Aquatic Resources for San Jacinto and Portions of Santa Margarita Watersheds, Riverside County, California, by R. Lichvar, G. Gustina and M. Ericsson

ERDC/CRREL TR-03-5

Mar 2003

Pavement Subgrade Performance Study: Project Overview, by V. Janoo, L. Irwin, and R. Haehnel

ERDC/CRREL TR-03-6 Apr 2003

Analysis of the Waste Management Practices at Bosnia and Kosovo Base Camps, by C.J. Martel

ERDC/CRREL TR-03-7 Apr 2003

Stability of CL-20, TNAZ, HMX, RDX, NG, and PETN in Moist, Unsaturated Soil, by T.F. Jenkins, C. Bartolini, and T.A. Ranney

ERDC/CRREL TR-03-8 Apr 2003 Remote Determination of Bridging/Fording Sites, by B. Coutermarsh and Sgt. B. Dwinal

ERDC/CRREL TR-03-9 May 2003

A State-Space Model for River Ice Forecasting, ADA415817 by S.F. Daly

ERDC/CRREL TR-03-10 May 2003 Map Series of Aquatic Resources for San Jacinto and Portions of the Santa Margarita Watersheds, by R. Lichvar

ERDC/CRREL TR-03-11 Jul 2003 Remote Assessment of Army Tactical River Crossing Sites Using LIDAR Imagery, by B.A. Coutermarsh

ERDC/CRREL TR-03-12 Jul 2003

Diffusion and Flux of Explosive-Related Compounds in Plastic Mine Surrogates, by J.H. Cragin and D.C. Leggett

ERDC/CRREL TR-03-13 Aug 2003

Solar Flux Initialization Schemes for Distributed Surface Energy Budget Modeling, by G.G. Koenig and D.H. Tofsted
ADA406828

ADA408371

ADA412652

ADA409726

ADA415896

ADA415894

ADA415860

ADA416836

ADA414926

ADA417062

ADA416655

ADA417126

ADA421294

ADA417310 
ERDC/CRREL TR-03-14 Aug 2003

On-Site Processing and Subsampling of Surface Soil Samples for the Analysis of Explosives, by A.D. Hewitt and M.E. Walsh

ERDC/CRREL TR-03-15 Aug 2003

Eagle River Flats Remediation Project Comprehensive Bibliography - 1998 to 2003, by M.R. Walsh

ERDC/CRREL TR-03-16

Sep 2003

Estimates for Explosives Residue from the Detonation of Army Munitions, by A.D. Hewitt, T.F. Jenkins, T.A. Ranney, J.A. Stark, M.E. Walsh, S. Taylor, M.R. Walsh, D.J. Lambert, N.M. Perron, N.H. Collins, and R. Karn

ERDC/CRREL TR-03-17

Sep 2003

Design and Operational Issues While Tunneling in Firn at the South Pole Station, by M. Walsh

ERDC/CRREL TR-03-18

Sep 2003

Assessing Hydraulic Modifications on Vallisneria americana in Peoria Lake, Illinois: A Pilot Study Using Data Sharing Protocols to Integrate Legacy Models, by P.B. Black, E.P.H. Best, E.A. Newcomb, T.J. Birkenstock, W.L. Boyt, R. Heath, and W.F. James

ERDC/CRREL TR-03-19

Sep 2003

An Ecological Land Survey for Fort Richardson, Alaska, by M.T. Jorgenson, J.E. Roth, S.F. Schlentner, E.R. Pullman, M. Macander, and C.H. Racine

ERDC/CRREL TR-03-20

Oct 2003 Improved Native Grasses and Establishment Methods for Use on Military Training Lands, by A.J. Palazzo, S.E. Hardy, and K.B. Jensen

ERDC/CRREL TR-03-21 Oct 2003

Use of Military Demolition Explosives in a Remediation Project, by M.R. Walsh, C.M. Collins, M.T. Meeks, A.O. Lee, and E.G. Wahlgreen

ERDC/CRREL TR-03-22 Nov 2003

A Preliminary Investigation of Diffusion of Volatile Atmospheric Acids in Snow, by J.H. Cragin and D.C. Leggett

ERDC/CRREL TR-03-23 Nov 2003

Fate of Nonindigenous, Endospore-Forming Bacteria in Soils: Strategies for Laboratory and Field Investigations, by C.M. Reynolds, K.L. Foley, D.B. Ringelberg, and L.B. Perry

ERDC/CRREL TR-03-24 Dec 2003 Probability Distributions for the Refractive Index Structure Parameter and the Inner Scale of Turbulence and Their Implications for Flux Averaging, by E.L. Andreas, C.W. Fairall, P.O.G. Persson, and P.S. Guest
ADA416817

ADA416875

ADA417513

ADA417722

ADA417505

ADA417494

ADA418394

ADA418192

ADA421422

ADA430422

ADA421359 
ERDC/CRREL TR-04-1 Jan 2004 Lake Thompson, Mojave Desert, California: A

Desiccating Late Quaternary Lake System, by A.R. Orme

ERDC/CRREL TR-04-2 Feb 2004

Extending the Season for Concrete

Construction and Repair: Phase 1 -

Establishing the Technology, by C.J. Korhonen, P.M. Semen, and L.A. Barna

ERDC/CRREL TR-04-3 Feb 2004

Range Characterization Studies at Donnelly Training Area, Alaska: 2001 and 2002, by M.E. Walsh, C.M. Collins, A.D. Hewitt, M.R. Walsh, T.F. Jenkins, J. Stark, A. Gelvin, T.S. Douglas, N. Perron, D. Lambert, R. Bailey, and K. Myers

ERDC/CRREL TR-04-4 Feb 2004

Continuous Treatment of Low Levels of TNT and RDX in Range Soils Using Surface Liming, by P.G. Thorne, T.F. Jenkins, and M.K. Brown

\begin{tabular}{|c|c|c|}
\hline ERDC/CRREL TR-04-5 & Mar 2004 & $\begin{array}{l}\text { Field-Portable X-Ray Fluorescence (FP-XRF) } \\
\text { Determinations of Metals in Post-Blast } \\
\text { Ordnance Residues, by M.E. Walsh }\end{array}$ \\
\hline ERDC/CRREL TR-04-6 & Apr 2004 & $\begin{array}{l}\text { Cold Regions Issues for Off-Road Autonomous } \\
\text { Vehicles, by D. Diemand and J.H. Lever }\end{array}$ \\
\hline ERDC/CRREL TR-04-7 & Apr 2004 & $\begin{array}{l}\text { Representative Sampling for Energetic } \\
\text { Compounds at an Antitank Firing Range, by } \\
\text { T.F. Jenkins, T.A. Ranney, A.D. Hewitt, M.E. } \\
\text { Walsh, and K.L. Bjella }\end{array}$ \\
\hline ERDC/CRREL TR-04-8 & Apr 2004 & $\begin{array}{l}\text { Field Screening Method for Perchlorate in } \\
\text { Water and Soil, by P.G. Thorne }\end{array}$ \\
\hline ERDC/CRREL TR-04-9 & Apr 2004 & $\begin{array}{l}\text { Laboratory Test of Scour Under Ice: Data and } \\
\text { Preliminary Results, by D. Hains and L. } \\
\text { Zabilansky }\end{array}$ \\
\hline 1ERDC/CRREL TR-04-10 & Apr 2004 & $\begin{array}{l}\text { Point-Source Energetics Detection: Initial } \\
\text { Sensor Evaluation, by N.E. Van Wyck and P.G. } \\
\text { Thorne }\end{array}$ \\
\hline ERDC/CRREL TR-04-11 & Apr 2004 & $\begin{array}{l}\text { Calculations of Inhomogeneous Ground } \\
\text { Effects in Outdoor Sound Propagation Using } \\
\text { the Boundary Element Method (BEM), by D.G. } \\
\text { Albert }\end{array}$ \\
\hline ERDC/CRREL TR-04-12 & May 2004 & $\begin{array}{l}\text { Finite-Difference, Time-Domain Simulation of } \\
\text { Sound Propagation in a Dynamic Atmosphere, } \\
\text { by D.K. Wilson and L. Liu }\end{array}$ \\
\hline
\end{tabular}
Sound Propagation in a Dynamic Atmosphere,
ADA424332

ADA423761

ADA423745

ADA423744

ADA422727

ADA422728

ADA423212

ADA423276

ADA422726

ADA423453

ADA430712

ADA423222 
ERDC/CRREL TR-04-13 Jun 2004

ERDC/CRREL TR-04-14 Nov 2004

ERDC/CRREL TR-04-16 Sep 2004

ERDC/CRREL TR-04-17 Sep 2004

ERDC/CRREL TR-04-18 Oct 2004

ERDC/CRREL TR-04-19 Oct 2004

ERDC/CRREL TR-04-20 Nov 2004

ERDC/CRREL TR-04-21 Nov 2004

ERDC/CRREL TR-04-22 Nov 2004

ERDC/CRREL TR-04-23 Dec 2004

ERDC/CRREL TR-04-23 Dec 2004

ERDC/CRREL TR-04-24 Dec 2004
Underground UXO: Are They a Significant

Source of Explosives in Soil Compared to Lowand High-Order Detonations?, by S. Taylor, J. Lever, M. Walsh, M.E. Walsh, B. Bostick, and B. Packer

Semi-Autonomous Robotic Sampler for

ADA423935 Explosives Residues in Surface Soils, by J.H. Lever, T. Nichols, D. Denton, R. Meador, A. Morlock, J. Kenyon, K. Palmer, and P.G.

Thorne

Sampling Strategies Near a Low-Order Detonation and a Target at an Artillery Impact Area, by T.F. Jenkins, A.D. Hewitt, T.A. Ranney, C.A. Ramsey, D.J. Lambert, K.L. Bjella, and N.M. Perron

Microstructure of West Antarctic Firn and its Effect on Air Permeability, by U. Rick and M. Albert

Blast-Sound-Absorbing Surfaces: A Joint Project of the ERDC and the Netherlands Ministry of Defense, by K. Attenborough, A. Cummings, P. Dutta, P. Schomer, E.

Salomons, E. Standley, O. Umnova, F. Van Den Berg, F. Van Der Eerden, P. Van Der Weele, and E. Védy

ADA426837

ADA427530

ADA428488

Past Research on Sound Propagation Through ADA427598 Forests, by D.G. Albert

Severe Winter Weather in the Continental U.S. ADA427317 and Global Climate Cycles, by S.F. Daly, J.E. Friddell, K.F. Jones, and C.M. Vuyovich

Sediment Transport Under Ice, by R. Ettema and S.F. Daly

Ecosystem Classification and Relationships for Pleistocene Lake Thompson Bed, Mojave Desert, California, by R. Lichvar, S. Sprecher, D. Charlton, G. Gustina, M. Ericsson, and J. Campbell

ADA427634

ADA428273

Mobility of Cargo Trains during Year Two of the Lever, J.C. Weale, R.G. Alger, and G.L. Blaisdell

Use of Small-Diameter Bladder Pumps in Direct-Push Ground Water Monitoring Wells at the CRREL Site, by L.V. Parker, J.W. Govoni, and M.H. Stutz 
ERDC/CRREL TR-04-25 Dec 2004

FASST Vegetation Models, by S. Frankenstein and G. Koenig

ERDC/CRREL TR-05-1 Feb 2005

Improved Performance of Unpaved Roads During Spring Thaw, by K.S. Henry, J.P. Olson, S.P. Farrington, and J. Lens

ERDC/CRREL TR-05-2

Feb 2005

Stability of Nitroguanidine in Moist, Unsaturated Soils, by N.D. Mulherin, T.F. Jenkins, and M.E. Walsh

ERDC/CRREL TR-05-3

Feb 2005

Constitutive Model for a Thawing, FrostSusceptible Sand, by S. Shoop, R. Affleck, V. Janoo, R. Haehnel, and B. Barrett

ERDC/CRREL TR-05-4 Mar 2005

Microbial Community Shifts Associated with RDX Loss in a Saturated and Well-Drained Surface Soil, by D.B. Ringelberg, C.M. Reynolds, K.L. Foley, and L.B. Perry

ERDC/CRREL TR-05-5 Mar 2005

Effect of Acetonitrile on RDX Biodegradation in an Unsaturated Surface Soil, by D.B. Ringelberg, C.M. Reynolds, L.B. Perry, and K.L. Foley

ERDC/CRREL TR-05-6

Mar 2005

Collection Methods and Laboratory Processing of Samples From Donnelly Training Area Firing Points, Alaska, 2003, by M.E. Walsh, C.A. Ramsey, C.M. Collins, A.D. Hewitt, M.R. Walsh, K.L. Bjella, D.J. Lambert, and N.M. Perron

ERDC/CRREL TR-05-7

Mar 2005

Estimating Energetic Residue Loading on Military Artillery Ranges: Large Decision Units, by A.D. Hewitt, T.F. Jenkins, C.A. Ramsey, K.L. Bjella, T.A. Ranney, and N.M. Perron

ERDC/CRREL TR-05-8 Apr 2005

An Examination of Protocols for The Collection of Munitions-Derived Explosives Residues on Snow-Covered Ice, by M.R. Walsh, M.E. Walsh, C.A. Ramsey, and T.F. Jenkins

ERDC/CRREL TR-05-9

Apr 2005

Placing Antifreeze Concrete at Grand Forks Air Force Base, by C. Korhonen and P. Semen

ERDC/CRREL TR-05-10 May 2005 Short-Range Seismic and Acoustic Signature Measurements Through Forest, by S.N. Decato, D.G. Albert, F.E. Perron Jr., and D.L. Carbee

ERDC/CRREL TR-05-11 Jun 2005 Technology for Range Security, by L. Peck ERDC/CRREL TR-05-12 Jul 2005 Disturbance Measurements From Off-Road Vehicles on Seasonal Terrain, by R.T. Affleck
ADA428989

ADA430662

ADA430432

ADA436331

ADA430688

ADA430690

ADA434947

ADA434241

ADA434936

ADA435078

ADA434934

ADA436329

ADA464712 


\begin{tabular}{|c|c|c|}
\hline ERDC/CRREL TR-05-13 & Jul 2005 & $\begin{array}{l}\text { Elution of Energetic Compounds from } \\
\text { Propellant and Composition B Residues, by } \\
\text { A.D. Hewitt and S.R. Bigl }\end{array}$ \\
\hline ERDC/CRREL TR-05-14 & Jul 2005 & $\begin{array}{l}\text { Residues from Live Fire Detonations of 155- } \\
\text { mm Howitzer Rounds, by M.R. Walsh, S. } \\
\text { Taylor, M.E. Walsh, S. Bigl, K. Bjella, T. } \\
\text { Douglas, A. Gelvin, D. Lambert, N. Perron, and } \\
\text { S. Saari }\end{array}$ \\
\hline ERDC/CRREL TR-05-15 & Dec 2005 & $\begin{array}{l}\text { Energetic Residues From Live-Fire } \\
\text { Detonations of 120-mm Mortar Rounds, by } \\
\text { M.R. Walsh, M.E. Walsh, C.M. Collins, S.P. } \\
\text { Saari, J.E. Zufelt, A.B. Gelvin, and J.W. Hug }\end{array}$ \\
\hline ERDC/CRREL TR-06-1 & Jan 2006 & $\begin{array}{l}\text { Assessment of the Effectiveness of the Israel } \\
\text { River Ice Control Structure, Lancaster, NH, by } \\
\text { C.M. Vuyovich and K.D. White }\end{array}$ \\
\hline
\end{tabular}

ERDC/CRREL TR-06-2 Feb 2006

Sampling Studies at an Air Force Live-Fire Bombing Range Impact Area, by T.F. Jenkins, A.D. Hewitt, C.A. Ramsey, K.L. Bjella, S.R. Bigl, and D.J. Lambert

ERDC/CRREL TR-06-3 Feb 2006

Settlement of a Foundation on a Permanent, Deep Snowpack, by G.L. Blaisdell and J.C. Weale

ADA452664

ADA436330

ADA441147

ADA442900

ADA444642

ADA443397

1ERDC/CRREL TR-06-4 Feb 2006 Seismic Detection of Personnel: Field Trials with REMBASS-II and QualTron Sensors, by L. Peck, J.J. Gagnon, and J. Lacombe

ERDC/CRREL TR-06-5

Feb 2006

Distribution of Ordinary High Water Mark (OHWM) Indicators and Their Reliability in ADA444089 Identifying the Limits of "Waters of the United States" in Arid Southwestern Channels, by R.W. Lichvar, D.C. Finnegan, M.P. Ericsson, and W. Ochs

ERDC/CRREL TR-06-6

Mar 2006

Extraction Kinetics of Energetic Compounds from Training Range and Army Ammunition Plant Soils: Platform Shaker vs. Sonic Bath Methods, by M.E. Walsh and D.J. Lambert

$\begin{array}{lrl}\text { ERDC/CRREL TR-06-7 } & \text { Mar 2006 } & \begin{array}{l}\text { Design of Breakup Ice Control Structures, by } \\ \text { A.M. Tuthill and J.H. Lever }\end{array} \\ \text { ERDC/CRREL TR-06-8 } & \text { Apr 2006 } & \begin{array}{l}\text { Extending the Season for Concrete } \\ \text { Construction and Repair: Phase II - Defining } \\ \text { Engineering Parameters, by C.J. Korhonen }\end{array} \\ \text { ERDC/CRREL TR-06-9 } & \text { Apr 2006 } & \begin{array}{l}\text { Variations in FASST Predictions of Soil } \\ \text { Surface Temperatures, by L. Peck }\end{array}\end{array}$

ADA445225

ADA449170 ADA446853 ADA446854

\footnotetext{
1 Limited distribution; see Preface.
} 
ERDC/CRREL TR-06-10 May 2006 Energetic Residues Deposition From 60-mm and 81-mm Mortars, by M.R. Walsh, M.E.

Walsh, C.A. Ramsey, R.J. Rachow, J.E. Zufelt, C.M. Collins, A.B. Gelvin, N.M. Perron, and S.P. Saari

ERDC/CRREL TR-06-11 May 2006

Double Lap Shear Testing of Coating Modified Ice Adhesion to Liquid Oxygen Feed Line Bracket, Space Shuttle External Tank, by M.G. Ferrick, N.D. Mulherin, R.B. Haehnel, B.A. Coutermarsh, G.D. Durell, T.J. Tantillo, T.L. St. Clair, E.S. Weiser, R.J. Cano, T.M. Smith, and E.C. Martinez

1ERDC/CRREL TR-06-12 Jun 2006

Sensor Performance Evaluator for Battlefield Environments (SPEBE). Tutorial, by D.K. Wilson

ERDC/CRREL TR-06-13 Jun 2006

Comparison of Explosives Residues from the Blow-in-Place Detonation of 155-mm HighExplosive Projectiles, by M.R. Walsh, M.E. Walsh, G. Ampleman, S. Thiboutot, and D.D. Walker

ERDC/CRREL TR-06-14 Jun 2006

Efficacy of DECON Green against VX Nerve and HD Mustard Simulants at Subfreezing Temperatures, by C.M. Reynolds, D.B. Ringelberg, and L.B. Perry

ERDC/CRREL TR-06-15 Jul 2006

ERDC/CRREL TR-06-16 Sep 2006

A Generalized Approach to Soil Strength Prediction With Machine Learning Methods, by P.M. Seman

Propagation of Uncertainties in Sea Ice Thickness Calculations From Basin-Scale Operational Observations: A Report Prepared for the International Ice Charting Working Group and the National/Naval Ice Center, by C.A. Geiger

ERDC/CRREL TR-06-18 Nov 2006

Conceptual Model for the Transport of Energetic Residues from Surface Soil to Groundwater by Range Activities, by J.L. Clausen, N. Korte, M. Dodson, J. Robb, and S. Rieven

ERDC/CRREL TR-06-19 Nov 2006
Assessing Fog Oil Deposition to Simulated Plant Surfaces During Military Training, by T.A. Douglas, J.B. Johnson, C.M. Collins, C.M. Reynolds, K.L. Foley, L.B. Perry, A.B. Gelvin, and S.E. Hardy
ADA449108

ADA447148

ADB317892

ADA450471

ADA450742

ADA464726

ADA455355

ADA472270

ADA458324 
ERDC/CRREL TR-06-20

ERDC/CRREL TR-06-21

ERDC/CRREL TR-07-1 Jan 2007

ERDC/CRREL TR-07-2

ERDC/CRREL TR-07-3

ERDC/CRREL TR-07-4

ERDC/CRREL TR-07-5

ERDC/CRREL TR-07-6

Jun 2007

May 2007

Mar 2007

Benefits of Using Remotely Operated Vehicles to Inspect USACE Navigation Structures, by J.H. Lever, G.E. Phetteplace, and J.C. Weale

Acoustic and Seismic Spectra, by D.K. Wilson and J.I. Torrey

Double Lap Shear Testing of Coating-Modified Ice Adhesion to Space Shuttle Component Surfaces, by M.G. Ferrick, N.D. Mulherin, B.A. Coutermarsh, G.D. Durell, L.A. Curtis, T.L. St. Clair, E.S. Weiser, R.J. Cano, T.M. Smith, C.G. Stevenson, and E.C. Martinez

Instrumenting an All-Terrain Vehicle for OffRoad Mobility Analysis, by K.D. Wesson, M.W. Parker, B.A. Coutermarsh, S.A. Shoop, and J.M. Stanley

Explosives Residues Resulting from the Detonation of Common Military Munitions: 2002-2006, by M.R. Walsh

Mar 2007

Blast Absorber Feasibility Test - Short Range Measurements: Aberdeen Test Center, MD, 13-17 June 2005, by F.E. Perron Jr., S.N.

Decato,

D.G. Albert, and D.L. Carbee

Analysis of the Lake Superior Watershed Seasonal Snow Cover, by S.F. Daly, T.B. Baldwin, and P. Weyrick

A Review of the Growth Habits and Restoration Issues for Clitoria fragrans and Polygonella basiramia, by A.J. Palazzo, S.E. Hardy, T.J. Cary, and T. Bashore

ERDC/CRREL TR-07-7 Jun 2007 Development of Environmental Data for Navy, Air Force, and Marine Munitions, by J.L. Clausen, C. Scott, and R.J. Cramer

ERDC/CRREL TR-07-8 Jun 2007

Wetland Plants of Specialized Habitats in the Arid West, by R. Lichvar and L. Dixon

ERDC/CRREL TR-07-9 Aug 2007
Energetic Residues on Alaskan Training Ranges: Studies for US Army Garrison Alaska 2005 and 2006, by M.E. Walsh, C.M. Collins, C.A. Ramsey, T.A. Douglas, R.N. Bailey, M.R. Walsh, A.D. Hewitt, and J.L. Clausen
ADA460716

ADA460557

ADA461425

ADA465866

ADA464882

ADA464975

ADA467988

ADA469090

ADA470912

ADA469459

ADA471042 
ERDC/CRREL TR-07-10 Jul 2007

ERDC/CRREL TR-07-11 Aug 2007

\author{
ERDC/CRREL TR-07-12 \\ ERDC/CRREL TR-07-13
}

ERDC/CRREL TR-07-11

ERDC/CRREL TR-07-14

Aug 2007

Aug 2007

Aug 2007

Measurement of Lateral Tire Performance on Winter Surfaces, by G. Phetteplace, S. Shoop, and T. Slagle Samples at Military Training and Testing Ranges for the Characterization of Energetic Munitions Constituents, by A.D. Hewitt, T.F. Jenkins, M.E. Walsh, M.R. Walsh, S.R. Bigl, and C.A. Ramsey

Environmental Assessment of Lead at Camp Edwards, Massachusetts, Small Arms Ranges, by J.L. Clausen, N. Korte, B. Bostick, B. Rice, M. Walsh, and A. Nelson

Environmental Screening Assessment of Perchlorate Replacements, by J.L. Clausen, S. Clough, M. Gray, and P. Gwinn

Evaluation of the Snap Sampler for Sampling Ground Water Monitoring Wells for VOCs and Explosives, by L.V. Parker and N.D. Mulherin

ERDC/CRREL TR-07-15

Sep 2007

Processing of Training Range Soils for the Analysis of Energetic Compounds, by A. Hewitt, S. Bigl, M. Walsh, S. Brochu, K. Bjella, and D. Lambert

ERDC/CRREL TR-07-16

Sep 2007

Review and Synopsis of Natural and Human Controls on Fluvial Channel Processes in the Arid West, by J.J. Field and R.W. Lichvar

ERDC/CRREL TR-07-17

Sep 2007

Propellant Residues Deposition from Small Arms Munitions, by M.R. Walsh, M.E. Walsh, S.R. Bigl, N.M. Perron, D.J. Lambert, and A.D. Hewitt

ERDC/CRREL TR-07-18

Sep 2007

Evaluation of Dam Decommissioning in an Ice-Affected River: Case Study, by C.M.

Vuyovich and K.D. White

ERDC/CRREL TR-07-19 Oct 2007

Measuring Energetics Residues on Snow, by M.R. Walsh, M.E. Walsh, and C.A. Ramsey

ERDC/CRREL TR-07-20 Oct 2007

Fifty Years of Soviet and Russian Drilling Activity in Polar and Non-Polar Ice: A Chronological History, by H.T. Ueda and P.G. Talalay

ERDC/CRREL TR-07-21 Oct 2007 In Situ California Bearing Ration Database, by P.M. Seman and S.A. Shoop

ERDC/CRREL TR-08-1 Jan 2008 The History of Early Polar Ice Cores, by C.C. Langway, Jr.
ADA471045

ADA471626

ADA472594

ADA471718

ADA471723

ADA472096

ADA473952

ADA472269

ADA475557

ADA472953

ADA472548

ADA473240

ADA475295 


\begin{tabular}{|c|c|c|c|}
\hline ERDC/CRREL TR-08-2 & Feb 2008 & $\begin{array}{l}\text { Ice Considerations in the Design of River } \\
\text { Restoration Structures, by A.M. Tuthill }\end{array}$ & ADA484149 \\
\hline ERDC/CRREL TR-08-3 & Feb 2008 & $\begin{array}{l}\text { A Reconnaissance Snow Survey Across } \\
\text { Northwest Territories and Nunavut, Canada, } \\
\text { April 2007, by M. Sturm, C. Derksen, G. } \\
\text { Liston, A. Silis, D. Solie, J. Holmgren, and H. } \\
\text { Huntington }\end{array}$ & ADA476959 \\
\hline ERDC/CRREL TR-08-4 & Apr 2008 & $\begin{array}{l}\text { GIS-Based OLS Suitability Assessment, by C.C. } \\
\text { Ryerson, F.R. Scott, and B.T. Tracy }\end{array}$ & ADA499672 \\
\hline
\end{tabular}

ERDC/CRREL TR-08-5

ERDC/CRREL TR-08-6

Apr 2008

Overview of Seismic Noise and it's Relevance to Personnel Detection, by L. Peck

Apr 2008

Construction and Instrumentation of FullScale Geogrid Reinforced Pavement Test Sections, by K.S. Henry, E.R. Cortez, L.S. Danyluk, G. Brentrup, N. Lamie, and T.W. Arnold

ERDC/CRREL TR-08-7 Apr 2008

FASST Soil Moisture, Soil Temperature: Original Versus New, by S. Frankenstein

ADA489457

ADA480571

ADA484145

ERDC/CRREL TR-08-8 Apr 2008

Temperatures and Water Levels at Tanana Flats Monitoring Stations, by M.G. Ferrick, C.H. Racine, S. Reidsma, S.P. Saari, A.B. Gelvin, C.M. Collins, and G. Larsen

ERDC/CRREL TR-08-9 May 2008

Opportune Landing Site CBR and Low-Density Laboratory Database, by L.S. Danyluk, S.A. Shoop, R.T. Affleck, and W.L. Wieder

ERDC/CRREL TR-08-10 Jul 2008

Energetic Residues and Crater Geometries from the Firing of 120-mm High-Explosive Mortar Projectiles into Eagle River Flats, June 2007, by M.E. Walsh, C.M. Collins, M.R. Walsh, C.A. Ramsey, S. Taylor, S.R. Bigl, R.N. Bailey, A.D. Hewitt, and M. Prieksat

ERDC/CRREL TR-08-11 Aug 2008

Evaluation of the CRREL Permafrost Tunnel, by K. Bjella, T. Tantillo, J. Weale, and J. Lever

ERDC/CRREL TR-08-12 Aug 2008

A Field Guide to the Identification of the Ordinary High Water Mark (OHWM) in the Arid West Region of the Western United States: A Delineation Manual, by R.W. Lichvar and S.M. McColley

1ERDC/CRREL TR-08-13 Aug 2008

Opportune Landing Site Program: Final Report, by C.C. Ryerson, S.A. Shoop, and G.C. Koenig

ADA480744

ADB340031

ADA484240

ADA485745

ADA486603

ADB349239 
ERDC/CRREL TR-08-14 Sep 2008 Assessment of Superstructure Ice Protection as Applied to Offshore Oil Operations Safety: Problems, Hazards, Needs, and Potential Transfer Technologies, by C.C. Ryerson

ERDC/CRREL TR-08-15 Sep 2008

Demonstration of Remotely Operated Vehicles to Aid Underwater Inspection of Corps of Engineers Navigation Structures: Winfield Locks and Dam 13-17 August 2007, by J.H. Lever and G.E. Phetteplace

ERDC/CRREL TR-08-16 Sep 2008

Suitability Measurement and Analysis for Fort Bliss Naval Air Facility OLS, by R.T. Affleck, C.C. Ryerson, L.A. Barna, and K.J. Claffey

ERDC/CRREL TR-08-17 Oct 2008

Predicting California Bearing Ratio from Trafficability Cone Index Values, by S.A. Shoop, D. Diemand, W.L. Wieder, G. Mason, and P.M. Seman

ERDC/CRREL TR-08-18 Oct 2008

Suitability Measurement and Analysis for EI Centro Naval Air Facility OLS, by R.T. Affleck, C.C. Ryerson, L.A. Barna, and K.J. Claffey

ERDC/CRREL TR-08-19 Oct 2008

Energetic Residues from Blow-in-Place Detonation of $60-\mathrm{mm}$ and 120-mm Fuzed High-Explosive Mortar Cartridges, by M.R. Walsh, C.M. Collins, and A.D. Hewitt

ERDC/CRREL TR-08-20

Nov 2008

Simulation of Fog Oil Deposition During Military Training Operations, by R.B. Haehnel

ERDC/CRREL TR-08-21 Nov 2008 Addressing Uncertainty in Signal Propagation and Sensor Performance Predictions, by D.K. Wilson, C.L. Pettit, S. Mackay, M.S. Lewis, and P.M. Seman

ERDC/CRREL TR-08-22 Nov 2008

Opportune Landing Site Southeastern Indiana Field Data Collection and Assessment, by L.A. Barna, C.C. Ryerson, and R.T. Affleck

ERDC/CRREL TR-08-23 Dec 2008 Opportune Landing Site Program: Field Data Archive, by F.R. Scott, L.A. Barna, R.T. Affleck, K.J. Claffey, E.S. Ochs, and C.C. Ryerson

ERDC/CRREL TR-08-24 Dec 2008

Optimal Sensor Placement with Terrain-Based Constraints and Signal Propagation Effects, by S.N. Vecherin, D.K. Wilson, and C.L. Pettit

ERDC/CRREL TR-08-25 Dec 2008

Evaluation of the Snap Sampler for Sampling Ground Water Monitoring Wells for Inorganic Analytes, by L.V. Parker, N.D. Mulherin, and G.E. Gooch

ERDC/CRREL TR-09-1 Jan 2009 Laboratory Testing of Architectural Exterior Wall Fins, by L. Zabilansky, W. Burch, and T. Hall
ADA495836

ADA490244

ADA494548

ADA494549

ADA491353

ADA491391

ADA491357

ADA494397

ADA503494

ADA494571

ADA494702

ADA536509 
ERDC/CRREL TR-09-2 Feb 2009 Estimating Vertical Stress on Soil Subjected to Vehicular Loading, by T. Olmstead and E. Fischer

ERDC/CRREL TR-09-3 Feb 2009

Sea Spray Icing of Drilling and Production Platforms, by K.F. Jones and E.L Andreas

ERDC/CRREL TR-09-4 Apr 2009 Assessment of Superstructure Ice Protection as Applied to Offshore Oil Operations Safety: Ice Protection Technologies, Safety Enhancements, and Development Needs, by C.C. Ryerson

ERDC/CRREL TR-09-5

May 2009

Vegetation and Channel Morphology Responses to Ordinary High Water Discharge Events in Arid West Stream Channels, by R. Lichvar, D. Cate, C. Photos, L. Dixon, B. Allen, and J. Byersdorfer

ERDC/CRREL TR-09-6 Jun 2009

Validation of Sampling Protocol and the Promulgation of Method Modifications for the Characterization of Energetic Residues on Military Testing and Training Ranges, by A.D. Hewitt, T.F. Jenkins, M.E. Walsh, S.R. Bigl, and S. Brochu

ERDC/CRREL TR-09-7 May 2009 Physical Model Study of Cross Vanes and Ice, by C.M. Vuyovich, A.M. Tuthill, and J.J. Gagnon

ERDC/CRREL TR-09-8 Jul 2009

Energetic Residues from the Expedient Disposal of Artillery Propellants, by M.R. Walsh, M.E. Walsh, and A.D. Hewitt

ERDC/CRREL TR-09-9 Jun 2009 Intermountain West Military Training Lands Planting Guide: Selecting Seed Mixtures for Actively Used Military Lands, by A.J. Palazzo, S.E. Hardy, T.J. Cary, K.H. Asay, K.B. Jensen, and D.G. Ogle

ERDC/CRREL TR-09-11 Oct 2009

Structural Improvements of Flexible Pavements Using Geosynthetics for Base Course Reinforcement, by K.S. Henry, J. Clapp, W. Davids, D. Humphrey, and L. Barna

ERDC/CRREL TR-09-12 Jul 2009

Demonstration/Validation of the Snap Sampler Passive Ground Water Sampling Device for Sampling Inorganic Analytes at the Former Pease Air Force Base, by L. Parker, N. Mulherin, G. Gooch, W. Major, R. Willey, T. Imbrigiotta, J. Gibs, and D. Gronstal

ERDC/CRREL TR-09-13 Dec 2009
Propellant Residues Deposition from Firing of AT4 Rockets, by M.R. Walsh, M.E. Walsh, S. Thiboutot, G. Ampleman, and J. Bryant

ADA496790

ADA496676

ADA508422

ADA517341

ADA508539

ADA536510

ADA507671

ADA518517

ADA536172

ADA535953 
ERDC/CRREL TR-09-14 Jul 2009

ERDC/CRREL TR-09-15 Dec 2009

1ERDC/CRREL TR-09-16 Dec 2009

ERDC/CRREL TR-09-17 Dec 2009

ERDC/CRREL TR-10-1 Feb 2010

ERDC/CRREL TR-10-2 Feb 2010

ERDC/CRREL TR-10-3

ERDC/CRREL TR-10-4

ERDC/CRREL TR-10-5

ERDC/CRREL TR-10-6

1ERDC/CRREL TR-10-7

Feb 2010

Mar 2010

May 2010

Aug 2010

Sep 2010
Monitoring of Streambank Stabilization and River Restoration Structures on Ice-Affected Rivers in Northern Vermont, by A.M. Tuthill

Implementation and Commercialization of New Plant Germplasms for Use on Military Ranges, by A.J. Palazzo, S.E. Hardy, T.J. Cary, K. Jensen, B. Waldron, and S. Larson

Cold Regions Test Center (CRTC) CrossCountry Trail Characterization, by S.A. Shoop, R.T. Affleck, S.D. Fleming, S.N. Bacon, L.M. Spears, and T.G. Caldwell

Object-Oriented Software Model for Battlefield Signal Transmission and Sensing, by D.K. Wilson, R. Bates, and K.K. Yamamoto

Adsorption/Desorption Measurements of Nitroglycerin and Dinitrotoluene in Camp Edwards, Massachusetts Soil, by J.L. Clausen, C. Scott, N. Mulherin, S. Bigl, G. Gooch, T. Douglas, I. Osgerby, and B. Palm

Dissolution Rate, Weathering Mechanics, and Friability of TNT, Comp B, Tritonal, and Octol, by S. Taylor, J. Lever, M. Walsh, J. Fadden, N. Perron, S. Bigl, R. Spanggord, M. Curnow, and B. Packer

Phase II Tungsten Fate-and-Transport Study for Camp Edwards, by J.L. Clausen, A. Bednar, D. Lambert, R. Bailey, M. Kuhlbrush, S. Taylor, and S. Bigl

Characterization of Seismic Noise at Selected Non-Urban Sites, by L. Peck, P. Styles, and S. Toon

Snow Roads at McMurdo Station, Antarctica, by S.A. Shoop, G. Phetteplace, and W.L. Wieder

Cold Weather Admixture Systems Demonstration at Fort Wainwright, Alaska, by L.A. Barna, P.M. Seman, and C.J. Korhonen

FROSTY Experimental Program: The Impact of Ground Frost on Mine Detonation Trailer Use, by S.A. Shoop, B.A. Coutermarsh, R.T. Affleck, L.A. Barna, K. Drouillard, J. Kubik, C.L. Smith, C.R. Williams, S. Merritts, T. Reynolds, and M.D. Parker
ADA508402

ADA611535

ADB367793

ADA522523

ADA520200

ADA518701

ADA520193

ADA535990

ADA535988

ADA535963

ADB401627 
ERDC/CRREL TR-10-8

ERDC/CRREL TR-10-9

ERDC/CRREL TR-10-10

ERDC/CRREL TR-10-11

ERDC/CRREL TR-10-12

ERDC/CRREL TR-10-13

Dec 2010

Dec 2010

Probability and Statistics in Sensor

Performance Modeling, by K.K. Yamamoto,

D.K. Wilson, and C.L. Pettit

and Hardstands on Army Installations in Cold

Regions, by E. Cortez, L. Barna, C. Smith and

T. Peltz

Sep 2010 The Use of Bryophytes as Indicators of Hydric Soils and Wetland Hydrology during Wetland Delineations in the United States, by J.J.

Gillrich and K.C. Bowman

Propellant Residues Deposition from Firing of 40-mm Grenades, by M.R. Walsh, M.E. Walsh, J.W. Hug, S.R. Bigl, K.L. Foley, A.B. Gelvin, and N.M. Perron

Loose-Surface Tire-Terrain Interaction During High-Speed Maneuvers, by N.L. Buck, B.A. Coutermarsh, and S.A. Shoop

Characterization and Fate of Gun and Rocket Propellant Residues on Testing and Training Ranges: Interim Report 2, by M.R. Walsh, G. Ampleman, S. Thiboutot, M.E. Walsh, I. Poulin, A. Bellavance-Godin, R. Martel, G. Bordeleau, S. Brochu, A.D. Hewitt, A. Marois, A. Gagnon, C.M. Collins, D. Gilbert, P. Woods, J.N. Bryant, S.R. Bigl, and K. Gagnon

ERDC/CRREL TR-11-01

Jan 2011

Designing Roads and Retaining Structures for Nangarhar Province, Afghanistan, by R.T. Affleck, S. Sargand, A. Russ, F. Momand, and M.C. Perez Canals

ERDC/CRREL TR-11-02 Jan 2011

Documenting Lessons Learned in Afghanistan Concerning Design and Construction Challenges, by R. Affleck, P. Seman, M. Deegan, R. Freeman and S. Sargand

ERDC/CRREL TR-11-3 Feb 2011 Demonstration/Validation of the Snap Sampler Passive Groundwater Sampling Device at the Former McClellan Air Force Base, by L. Parker, N. Mulherin, T. Hall, C. Scott, K. Gagnon, J. Clausen, W. Major, R. Willey, J. Gibs, T. Imbrigiotta, and D. Gronstal

ERDC/CRREL TR-11-4 Mar 2011 Potable Water Supply Feasibility Study for Summit Station, Greenland, by R.B. Haehnel and M.A. Knuth

ERDC/CRREL TR-11-5
Mar 2011
ADA537467

ADA536220

ADA535950

ADA533233

ADA533718

ADA579913

ADA534998

ADA535388

ADA538084

ADA538302

Russell Fiord by Hubbard Glacier, by S.F. Daly, C. Vuyovich, and D. Finnegan 
ERDC/CRREL TR-11-6

ERDC/CRREL TR-11-7

\author{
ERDC/CRREL TR-11-7
}

ERDC/CRREL TR-11-8

ERDC/CRREL TR-11-9

ERDC/CRREL TR-11-10

Apr 2011

Mar 2011

Mar 2011

Mar 2011

\section{Asstin} Scarce Regions for Use in Water Resource
Applications: A Case Study in the Upper Helmand Watershed, Afghanistan, by C.M. Vuyovich Determinations in Co-located Conventional and Direct-Push Monitoring Wells, by L. Parker, W. McCall, N. Mulherin, D. Williams, and S. Bigl
Feasibility of Overland Traverse to Re-Supply Summit Camp: Fleet Configuration and Economic Analysis, by J.H. Lever, and J.C. Weale

Mobility and Economic Feasibility of the Greenland Inland Traverse (GrIT), by J.H. Lever and J.C. Weale

\section{Engineering Assessment of Big House at} Summit Station, Greenland: Final Report, by L.A. Barna, K.J. Claffey, J.S. Buska, and J.L. Mercer

ERDC/CRREL TR-11-11 Jun 2011

Demonstration/Validation of the Snap Sampler: Cost and Performance: FinalReport, by L. Parker, N. Mulherin, G. Gooch, T. Hall, C. Scott, J. Clausen, W. Major, R. Willey, T. Imbrigiotta, J. Gibs, and D. Gronstal

ERDC/CRREL TR-11-12 Jul 2011

Ordinary High Flows and the Stage-Discharge Relationship in the Arid West Region, by K.E. Curtis, R.W. Lichvar, and L.E. Dixon

ERDC/CRREL TR-11-13 Aug 2011 Characterization and Fate of Gun and Rocket Propellant Residues on Testing and Training Ranges: Final Report, by M.R. Walsh, S. Thiboutot, M.E. Walsh, G. Ampleman, R. Martel, I. Poulin, and S. Taylor

ERDC/CRREL TR-11-14 Oct 2011 Aufeis Formation in Jarvis Creek and Flood Mitigation, by S.F. Daly, J.E. Zufelt, P. Fitzgerald, A. Gelvin, and S. Newman

ERDC/CRREL TR-11-15 Oct 2011 Guidance for Soil Sampling for Energetics and
Metals, by S. Taylor, T.F. Jenkins, S. Bigl, A.D.
Hewitt, M.E. Walsh and M.R. Walsh

ERDC/CRREL TR-11-16 Oct 2011 Greenland Inland Traverse (GrIT): 2010 Mobility Performance and Implications, by J.H. Lever
ADA538601

ADA539292

ADA538994

ADA539745

ADA542773

ADA548770

ADA550816

ADA548745

ADA583020

ADA551375 
$\begin{array}{rrr}\text { ERDC/CRREL TR-12-1 } & \text { Apr 2012 } & \begin{array}{l}\text { The Chena River Watershed Hydrology Model, } \\ \text { by C.M. Vuyovich and S.F. Daly }\end{array} \\ \text { ERDC/CRREL TR-12-2 Apr } 2012 & \begin{array}{l}\text { Community Composition of Bacterial Biofilms } \\ \text { Formed on Simple Soil Based } \\ \text { Bioelectrochemical Cell Anodes and } \\ \text { Cathodes, by D.B. Ringelberg, K.L. Foley, and } \\ \text { C.M. Reynolds }\end{array} \\ \text { ERDC/CRREL TR-12-3 May 2012 } & \begin{array}{l}\text { Drainage Assessment and Flow Monitoring at } \\ \text { McMurdo Station during Austral Summer, by } \\ \text { R. Affleck, C. Vuyovich, M.A. Knuth, and S. } \\ \text { Daly }\end{array}\end{array}$

ERDC/CRREL TR-12-4 Jun 2012 Testing Wetland Delineation Indicators in New England Boulder Fields, by R.W. Lichvar, K.E. Curtis, J.J. Gillrich, and L.E. Dixon

ERDC/CRREL TR-12-5 Jul 2012

Preliminary Permafrost and Hangar Investigation: Naval Arctic Research Lab., Barrow, Alaska, by K. Bjella

ERDC/CRREL TR-12-6 Aug 2012 Initial Effects of Heavy Vehicle Trafficking on Vegetated Soils, by N.L. Buck, S.A. Shoop, and T.J. Cary

ERDC/CRREL TR-12-7 Sep 2012 Effects of Support Structure Porosity on the Drift Accumulation Surrounding an Elevated Building, by A. Song and R. Haehnel

ERDC/CRREL TR-12-8 Sep 2012 Airfield Passenger Transportation System at McMurdo Station, Antarctica, by P.M. Seman

ERDC/CRREL TR-12-9 Sep 2012 Dissolution Rate of Propellant Energetics from Nitrocellulose Matrices, by S. Taylor, K. Dontsova, S. Bigl, C. Richardson, J. Lever, J. Pitt, J.P. Bradley, M. Walsh, and J. Šimůnek

ERDC/CRREL TR-12-10 Sep 2012 Suggested Planting Guidelines - Best Management Practices for Revegetation of Actively Used Training Lands in the Northeastern United States, by A.J. Palazzo, T.J. Cary, P.R. Salon, and M. van der Grinten

ERDC/CRREL TR-12-11 Oct 2012 The National Wetland Plant List, by R.W. Lichvar

ERDC/CRREL TR-12-12 Nov 2012 Demonstration of an Artificial Frozen Barrier, by A.M. Wagner and E. Yarmak, Jr.

ERDC/CRREL TR-12-13 Dec 2012 Rock Material Management at McMurdo Station, Antarctica, by M.A. Knuth and T. Melendy

ERDC/CRREL TR-12-14 Dec 2012 Informal Economy, Pakistan: Component and Macro-Estimations for the Gray and Black Markets, by J.I. Oren
ADA572119

ADA559329

ADA571669

ADA571581

ADA576143

ADA568645

ADA568637

ADA566086

ADA567231

ADA570149

ADA571582 
$\begin{array}{ll}\text { ERDC/CRREL TR-13-1 Jan 2013 } & \text { Laboratory Evaluation of Expedient Low- } \\ & \text { Temperature Concrete Admixtures for } \\ & \text { Repairing Blast Holes in Cold Weather, by J.I. } \\ & \text { Oren, E.R. Cortez, and C.E. Smith, Jr. }\end{array}$

ERDC/CRREL TR-13-2 Jan 2013 Survey of OHWM Indicator Distribution Patterns across Arid West Landscapes, by L. Lefebvre, R. Lichvar, and K. Curtis

ERDC/CRREL TR-13-3 Jan 2013

Channel Classification across Arid West Landscapes in Support of OHW Delineation, by L. Lefebvre, R. Lichvar, K. Curtis, and J. Gillrich

ERDC/CRREL TR-13-4 Jan 2013

RDX in Plant Tissue: Leading to Humification in Surface Soils, by C.M. Reynolds, D.B.

Ringelberg, K.L. Foley, L.A. Newman, C.B.B. Hadden, T.W. Rahn and J.L. Ferry

ERDC/CRREL TR-13-5 Jan 2013

McMurdo Consolidated Airfields Study: Phase I, Basis of Design, by R.B. Haehnel, K. Bjella, M.A. Knuth, and L. Barna

ERDC/CRREL TR-13-6

Mar 2013 Summit Station Skiway Review, by M.A. Knuth, T.D. Melendy, and A.M. Burzynski

ERDC/CRREL TR-13-7 Apr 2013

Icing Management for Coast Guard Assets, by C.C. Ryerson

ERDC/CRREL TR-13-8

Jun 2013

Thule Air Base Airfield White Painting and Permafrost Investigation: Phases I-IV, by K. Bjella

ERDC/CRREL TR-13-9 Jun 2013

Ice Column Design Concept for Summit Station: Laboratory Testing Results, by A.M. Burzynski, J.C. Weale, and L. Barna

ERDC/CRREL TR-13-10 Jun 2013

ERDC/CRREL TR-13-11 Aug 2013

Ririe Dam Release Test Assessment, by S.F. Daly, M. Carr, S. Hall, and J. Giovando

Site Assessment and Feasibility of a New Operations Base on the Greenland Ice Sheet, by A.M. Burzynski, S. Wong, J.L. Mercer, E.J. Deeb, and S.D. Newman

1ERDC/CRREL TR-13-12 Sep 2013

Characterization and Selection of Natural Backgrounds for Camouflage Development, Testing, and Evaluation, by C.L. Scott, C.C. Ryerson, and A.L. Coplin

ERDC/CRREL TR-13-13 Nov 2013
ADA576170

ADA571771

ADA572408

ADA575212

ADA576164

ADA583017

ADA581692

ADA583015

ADA582972

ADA585809

ADB393412

ADA593907
Permafrost Ecosystem Warming Prototype: Installation, Operation, and Initial Site Characterization, by A.M. Wagner, M.C. Beede, and J.E. Zufelt

\footnotetext{
1 Limited distribution; see Preface.
} 
ERDC/CRREL TR-14-1 Feb 2014 Review of Thermosyphon Applications, by A.M. Wagner

ERDC/CRREL TR-14-2 Mar 2014 Examining Discrepancies Among Three Methods Used to Make Hydrophytic Vegetation Determinations for Wetland Delineation Purposes, by R.W. Lichvar and J.J. Gillrich

ERDC/CRREL TR-14-3 Mar 2014 Use of LiDAR to Assist in Delineating Waters of the United States, Including Wetlands, by J. Gillrich and R. Lichvar

ERDC/CRREL TR-14-4

Mar 2014

Demonstration of the AGI Universal Samplers (F.K.A. the GORE ${ }^{\circledR}$ Modules) for Passive Sampling of Groundwater, by L. Parker, R. Willey, T. McHale, W. Major, T. Hall, R. Bailey, K. Gagnon, and G. Gooch

ERDC/CRREL TR-14-5

Apr 2014

Socio-economic Effects of Drought in the Horn of Africa: Population Movements, Livelihoods, Market Prices, and Infrastructure, by J.M. Roningen and J.B. Eylander

ERDC/CRREL TR-14-6

May 2014

Runoff Characterization and Variations at McMurdo Station, Antarctica, by R.T. Affleck, M. Carr, M. Knuth, L. Elliot, C. Chan, and M. Diamond

ERDC/CRREL TR-14-7 May 2014

ERDC/CRREL TR-14-8 Jun 2014

Economic Analysis of the South Pole Traverse by J.H. Lever and P. Thur

Extending the Season for Concrete Construction and Repair: Phase III-Guidance for Optimizing Admixture Dosage Rates, by L.A. Barna and C.J. Korhonen

ERDC/CRREL TR-14-9 Jun 2014

Vehicle Impact Testing of Snow Roads at McMurdo Station, Antarctica, by S.A. Shoop, M.A. Knuth, W.L. Wieder, and M. Preston

ERDC/CRREL TR-14-10 Jul 2014

Extreme Cold Testing of High Performance Fabric Materials: Gelbo Flex, Tensile Strength, and UV Exposure Test Results, by J.C. Weale and J.H. Lever

ERDC/CRREL TR-14-11 Aug 2014
Occurrence and Distribution of Ordinary High Water Mark (OHWM) Indicators in NonPerennial Streams in the Western Mountains, Valleys, and Coast Region of the United States, by M.K. Mersel, R.W. Lichvar, J.J. Gillrich, and L.E. Lefebvre
ADA595037

ADA601490

ADA601990

ADA599028

ADA601348

ADA602401

ADA602402

ADA605496

ADA607492

ADA608562 
ERDC/CRREL TR-14-12 Aug 2014 A Review of Land and Stream Classifications in Support of Developing a National Ordinary High Water Mark (OHWM) Classification, by M.K. Mersel, L.E. Lefebvre, and R.W. Lichvar

ERDC/CRREL TR-14-13 Aug 2014

A Guide to Ordinary High Water Mark (OHWM) Delineation for Non-Perennial Streams in the Western Mountains, Valleys, and Coast Region of the United States, by M.K. Mersel and R.W. Lichvar

ERDC/CRREL TR-14-14

Aug 2014

Component Testing for Modular Pier Replacement at McMurdo Station, Antarctica: Inflatable Pontoons: Gelbo Flex and Full-Scale Cold Storage/Fold Tests, by J.C. Weale and M.A. Knuth

ERDC/CRREL TR-14-15

Aug 2014

Pollutant Concentration in Runoff at McMurdo Station, Antarctica, by R.T. Affleck, M. Carr, L. Elliot, C. Chan, and M. Knuth

ERDC/CRREL TR-14-16

Sep 2014

Evaluation of a New SnowPaver at McMurdo Station, Antarctica, by S.A. Shoop, R. Alger, J. Kunnari, and W.L. Wieder

ERDC/CRREL TR-14-17

Sep 2014

Waste Water Handling Proof of Concepts at McMurdo Station, Antarctica, by T.D. Melendy, R. Haehnel, and K. Colby

ERDC/CRREL TR-14-18

Sep 2014

Development of Conceptual Designs for the Prevention of Ice Formation in the Proposed Maple River Aqueduct, by S.F. Daly, M. Carr, K. Bjella, and R. Haehnel

ERDC/CRREL TR-14-19 Sep 2014

Using Firn Air for Facility Cooling at the WAIS Divide Site, by J. Weale, M. Albert, and G. Phetteplace

ERDC/CRREL TR-14-20

Sep 2014

Coordinated Optimization of Aircraft Routes and Locations of Ground Sensors, by S.N. Vecherin, D.K. Wilson, and C.L. Pettit

ERDC/CRREL TR-14-21 Sep 2014 Antarctic Camps Snow Drift Management Handbook, by R. Haehnel and J. Weatherly

ERDC/CRREL TR-14-22 Sep 2014 Design and Implementation of a Consolidated Airfield at McMurdo, Antarctica, by R.

Haehnel, M.A. Knuth, T. Melendy, C. Hiemstra, and R. Davis

ERDC/CRREL TR-14-23
Dissolution of NTO, DNAN, and Insensitive Munitions Formulations and Their Fates in Soils, by K. Dontsova, S. Taylor, R. PesceRodriguez, M. Brusseau, J. Arthur, N. Mark, M. Walsh, J. Lever, and J. Šimůnek
ADA608563

ADA608564

ADA608701

ADA608702

ADA609348

ADA609370

ADA610392

ADA609372

ADA609373

ADA609592

ADA609591

ADA609594 
ERDC/CRREL TR-14-24 Oct 2014

ERDC/CRREL TR-14-25 Oct 2014

ERDC/CRREL TR-14-26

ERDC/CRREL TR-14-27

ERDC/CRREL TR-15-1 Jan 2015

ERDC/CRREL TR-15-2 Jan 2015

1ERDC/CRREL TR-15-3

ERDC/CRREL TR-15-4

ERDC/CRREL TR-15-5

ERDC/CRREL TR-15-6

ERDC/CRREL TR-15-7

ERDC/CRREL TR-15-8
Mar 2015

Jan 2015

Energetics Residues from the Detonations of IMX-101 and IMX-104 Munitions, by M.R.

Walsh, M.E. Walsh, C.A. Ramsey, S. Thiboutot, G. Ampleman, and J. Dowden

USCS and the USDA Soil Classification System: Development of a Mapping Scheme, by R.A. García-Gaines and S. Frankenstein

Polar Sleds, by J.H. Lever, J.C. Weale, and G.

Durell

Maintenance and Drainage Guidance for the Scott Base Transition, Antarctica, by S. Shoop, J. Hills, and J. Uberuaga

Flow Control and Design Assessment for Drainage System at McMurdo Station, Antarctica, by R. Affleck, M. Carr, and B. West

ADA615402

ADA610788

Environmental Awareness for Sensor and Emitter Employment (EASEE): Software Design Version 2, by D.K. Wilson and K.K. Yamamoto Short-Term Loads: Over-Sea-Ice Traverse from McMurdo Station to Marble Point, by J.C. Weale and D.S. Sodhi

Vertical Temperature Simulation of Pegasus Runway, McMurdo Station, Antarctica, by S.F. Daly, R. Haehnel, and C. Hiemstra

ADA614252

ADB406248

ADA614144

ADA614217

Mar 2015 A Technique to Propagate Clitoria fragrans from Xylopodia, by T.J. Cary, T.L. Bashore, L.M. Leavitt, and A.J. Palazzo

Apr 2015 Soil Temperature and Moisture Effects on Soil

ADA615121 Respiration and Microbial Community Abundance, by R.A. Barbato, K.L. Foley, and C.M. Reynolds

Apr 2015 Estimating COCOM Natural Background Dormancy, by A.L. Coplin and C.C. Ryerson

ADA615120

May 2015

Implementing a Probabilistic Line of Sight in EASEE (Environmental Awareness for Sensor and Emitter Employment), by M.T. Ekegren and K.K. Yamamoto 
ERDC/CRREL TR-15-9 Jul 2015 Remediation of Old South Pole Station: Phase

I: Ground-Penetrating-Radar Surveys, by L.

Barna, Z. Courville, J. Rand, and A. Delaney

ERDC/CRREL TR-15-10 Jul 2015

Remediation of Old South Pole Station Using

Autonomous Data Collection and Remote

Assessment of Ground-Penetrating Radar, by

L. Barna, J. Lever, and A. Delaney

ERDC/CRREL TR-15-11 Jul 2015

Development of Integrated Software

Capabilities for Battlefield Signal Modeling

and Force Protection: Leaders Mission

Planning Tool (LMPT), by K.K. Yamamoto, J.J.

Gagnon, D.G. Albert, and D.K. Wilson

ERDC/CRREL TR-15-12 Jul 2015 Integration of Radio-Frequency Transmission and Radar in Multimodal Signal-Modeling

Software: Environmental Awareness for

Sensor and Emitter Employment (EASEE), by

K.K. Yamamoto, N.J. Reznicek, and D.K.

Wilson

ERDC/CRREL TR-15-13 Oct 2015

Geotechnical Study and Foundation Structural ADA622109 Design, Next Generation lonosonde (NEXION) Installation, Thule Air Base, Greenland, by K. Bjella

ERDC/CRREL TR-15-14 Oct 2015 Imaging of Ground Ice with Surface-Based Geophysics, by K. Bjella, S. Arcone, and T. Douglas

ERDC/CRREL TR-15-15 Oct 2015 Naval Arctic Research Laboratory (NARL)

ADA623818 Subsurface Containment Berm Investigation, by K. Bjella

ERDC/CRREL TR-15-16 Nov 2015 Review of the Probable Maximum Flood (PMF)

ADA624268 Snowmelt Analysis for Success Dam, by S.F. Daly

ERDC/CRREL TR-15-17 Nov 2015 Structural Condition Assessment of Reinforced Base-Course Pavement, by R.T. Affleck, C. Smith, A. Bernier, J. Arbogast, A. Smart, and A. Scholz

ERDC/CRREL TR-15-18 Dec 2015 NHARNG Wind Resource Assessment: Center Strafford Training Center, by B.A. West, C.C. Ryerson, and K.J. Claffey 


\section{Construction Engineering Research Laboratory (CERL)}

\section{Brochures}

Report Number

ERDC/CERL B-11-1

ERDC/CERL B-11-2
Date

Aug 2011

Dec 2011

$\underline{\text { Title }}$

1947 Barracks Fire: Pine Camp (Fort Drum), NY, by S. Enscore, A. Smith, E. Hartman, and C. Cochran

The Architecture of the Department of Defense: A Military Style Guide, by M. Michael, A. Smith, and J. Sin

\section{Contract reports}

\begin{tabular}{|c|c|c|}
\hline Report Number & Date & $\underline{\text { Title }}$ \\
\hline ERDC/CERL CR-01-1 & Oct 2001 & $\begin{array}{l}\text { Historic Limestone Conservation Study } \\
\text { for Fort Riley, Kansas, by M.S. Jensen }\end{array}$ \\
\hline ERDC/CERL CR-03-1 & Jan 2003 & $\begin{array}{l}\text { Technology Demonstration of Nontoxic } \\
\text { Chemical Stripper for Steel: Cost and } \\
\text { Performance Report, by B. Appleman } \\
\text { and P. Nau }\end{array}$ \\
\hline ERDC/CERL CR-03-2 & Jul 2003 & $\begin{array}{l}\text { A Survey of Plethodon sp. } \\
\text { (Plethodontidae) Salamander } \\
\text { Populations in Caves and Sinkholes at } \\
\text { Fort Hood, Texas, by S.J. Taylor and C.A. } \\
\text { Phillips }\end{array}$ \\
\hline 1ERDC/CERL CR-03-3 & Sep 2003 & $\begin{array}{l}\text { Application of Thermochemical } \\
\text { Conversion to Treat Demolition Debris } \\
\text { from Fort Ord, by D.M. Timmons }\end{array}$ \\
\hline ERDC/CERL CR-05-1 & Aug 2005 & $\begin{array}{l}\text { Sound Wave Mitigation Through the } \\
\text { Design of Surface Impedance, by W.C. } \\
\text { Chew and G.L. Wang }\end{array}$ \\
\hline ERDC/CERL CR-05-2 & Nov 2005 & $\begin{array}{l}\text { ECOTONE Manual, by T. Hochstrasser } \\
\text { and D. Peters }\end{array}$ \\
\hline ERDC/CERL CR-06-1 & Feb 2006 & $\begin{array}{l}\text { Absorption of Low-Frequency Sound } \\
\text { Energy by Vegetation: A Laboratory } \\
\text { Investigation, by R.J. Lee }\end{array}$ \\
\hline
\end{tabular}

$\underline{\text { AD Number }}$

ADA412670

ADA416424

ADB295667

ADA437068

ADA452048

ADA445391 Investigation, by R.J. Lee 


\begin{tabular}{|c|c|c|c|}
\hline ERDC/CERL CR-06-2 & Aug 2006 & $\begin{array}{l}\text { Fort Ord Groundwater Remediation } \\
\text { Studies, } 2002 \text { - 2005, by A.R. Flegal, P. } \\
\text { Mantey, C. Oldenburg, and P. Daley }\end{array}$ & ADA470908 \\
\hline ERDC/CERL CR-06-3 & Nov 2006 & $\begin{array}{l}\text { Development of Range Design } \\
\text { Elements and Quality Control/Quality } \\
\text { Assurance Guidance to Reduce } \\
\text { Maintenance Requirements on Training } \\
\text { Ranges, by J. Hernandez, R. Smith, V. } \\
\text { Petty, and J. Lock }\end{array}$ & ADA460751 \\
\hline ERDC/CERL CR-07-1 & Oct 2007 & $\begin{array}{l}\text { Condition Assessment of the Lipari } \\
\text { Landfill Piping System. Interim Report: } \\
\text { Baseline Condition Assessment, by R.A. } \\
\text { Weber }\end{array}$ & \\
\hline ERDC/CERL CR-09-1 & May 2009 & $\begin{array}{l}\text { Approaches Towards the Identification } \\
\text { of Patterns in Violent Events, Baghdad, } \\
\text { Iraq, by L. Anselin and G. Piras }\end{array}$ & ADA500195 \\
\hline ERDC/CERL CR-10-1 & Aug 2010 & $\begin{array}{l}\text { Evaluating Alternative Methodologies } \\
\text { for Capturing As-Built Building } \\
\text { Information Models (BIM) For Existing } \\
\text { Facilities, by E. Rojas, C. Dossick, and J. } \\
\text { Schaufelberger }\end{array}$ & ADA554414 \\
\hline ERDC/CERL CR-10-2 & Aug 2010 & $\begin{array}{l}\text { Developing Best Practices for Capturing } \\
\text { As-Built Building Information Models } \\
\text { (BIM) for Existing Facilities, by E. Rojas, } \\
\text { C. Dossick, and J. Schaufelberger }\end{array}$ & ADA554392 \\
\hline ERDC/CERL CR-11-1 & Sep 2011 & $\begin{array}{l}\text { Relevance of Emerging Ecosystem } \\
\text { Service Science and Policy to the United } \\
\text { States Department of Defense, by E. } \\
\text { Keysar }\end{array}$ & ADA608637 \\
\hline ERDC/CERL CR-11-2 & Sep 2011 & $\begin{array}{l}\text { Experimental Building Information } \\
\text { Models, by M. Johnson and K.K. Fallon }\end{array}$ & ADA552634 \\
\hline ERDC/CERL CR-12-1 & Mar 2012 & $\begin{array}{l}\text { Feasibility of Energy Crops Grown on } \\
\text { Army Lands, by The Louis Berger Group, } \\
\text { Inc. and Utah State University }\end{array}$ & ADA559200 \\
\hline ERDC/CERL CR-12-2 & Mar 2012 & $\begin{array}{l}\text { Ontology for Life-Cycle Modeling of } \\
\text { Heating, Ventilating, and Air } \\
\text { Conditioning (HVAC) Systems: Model } \\
\text { View Definition, by R.J. Hitchcock, N. } \\
\text { Nisbet, C. Wilkins, M. Tanis, R. } \\
\text { Hanninen, and T. Laine }\end{array}$ & \\
\hline
\end{tabular}




\begin{tabular}{|c|c|c|c|}
\hline ERDC/CERL CR-12-3 & May 2012 & $\begin{array}{l}\text { Life-Cycle Model of Mission-Ready and } \\
\text { Sustainable Facilities-Planning Space } \\
\text { Resource Utilization. COBie } \\
\text { Representation of Resource Demands } \\
\text { for Mission-Ready and Sustainable } \\
\text { Facilities, by A.D. Chasey, A. Weizel and } \\
\text { H. Bryan }\end{array}$ & \\
\hline ERDC/CERL CR-12-4 & Mar 2012 & $\begin{array}{l}\text { Ontology for Life-Cycle Modeling of } \\
\text { Heating, Ventilating, and Air } \\
\text { Conditioning (HVAC) Systems: } \\
\text { Experimental Applications Using Revit, } \\
\text { by R.J. Hitchcock, N. Nisbet, C. Wilkins, } \\
\text { M. Tanis, R. Hanninen, and T. Laine }\end{array}$ & ADA580293 \\
\hline ERDC/CERL CR-12-5 & Aug 2012 & $\begin{array}{l}\text { Common Object Library Description, by } \\
\text { Kristine Fallon Associates, Inc. }\end{array}$ & ADA570085 \\
\hline ERDC/CERL CR-12-6 & Sep 2012 & $\begin{array}{l}\text { Sustainability Product Properties in } \\
\text { Building Information Models, by Kristine } \\
\text { Fallon Associates, Inc. }\end{array}$ & ADA587331 \\
\hline ERDC/CERL CR-13-1 & Mar 2013 & $\begin{array}{l}\text { Specifiers Properties Information } \\
\text { Exchange (SPie): Minimum Building } \\
\text { Information Model (BIM) Object } \\
\text { Definitions, by Kalin Associates, Inc. }\end{array}$ & ADA587606 \\
\hline ERDC/CERL CR-13-2 & Jun 2013 & $\begin{array}{l}\text { Ontology for Life-Cycle Modeling of } \\
\text { Electrical Distribution Systems: Model } \\
\text { View Definition, by K.K. Fallon, R.A. } \\
\text { Feldman, G. Williams, and O. Fadojutimi }\end{array}$ & ADA584094 \\
\hline ERDC/CERL CR-13-3 & Jun 2013 & $\begin{array}{l}\text { Ontology for Life-Cycle Modeling of } \\
\text { Electrical Distribution Systems: } \\
\text { Application of Model View Definition } \\
\text { Attributes, by K.K. Fallon, R.A. Feldman, } \\
\text { G. Williams, O. Fadojutimi, and T. } \\
\text { Chipman }\end{array}$ & ADA582294 \\
\hline ERDC/CERL CR-13-4 & Jun 2013 & $\begin{array}{l}\text { Ontology for Life-Cycle Modeling of } \\
\text { Water Distribution Systems: Model View } \\
\text { Definition, by K.K. Fallon, R.A. Feldman, } \\
\text { G. Williams, O. Fadojutimi, and T. } \\
\text { Chipman }\end{array}$ & ADA589612 \\
\hline ERDC/CERL CR-13-5 & Jun 2013 & $\begin{array}{l}\text { Ontology for Life-Cycle Modeling of } \\
\text { Water Distribution Systems: Application } \\
\text { of Model View Definition Attributes, by } \\
\text { K.K. Fallon, R.A. Feldman, G. Williams, } \\
\text { O. Fadojutimi, and T. Chipman }\end{array}$ & ADA589613 \\
\hline
\end{tabular}


ERDC/CERL CR-13-6

Oct 2013

Date

Jan 2001

ERDC/CERL LR-01-2

1ERDC/CERL LR-01-3

1ERDC/CERL LR-01-4

1ERDC/CERL LR-02-3

1ERDC/CERL LR-03-1

1ERDC/CERL LR-03-2

ERDC/CERL LR-03-5

1ERDC/CERL LR-04-1

1ERDC/CERL LR-04-6
Feb 2004

Aug 2004
Oct 2002

Jan 2003
Assessment of Life Cycle Information Exchanges (LCie). Understanding the Value-Added Benefit of a COBie Process, by K. Fallon, O. Fadojutimi, G. Williams, N. Crawford, and D. Gran

$\underline{\text { Title }}$

Survey of Fort Stewart and Hunter Army Airfield Oil/Water Separators: Findings and Recommendations, by G.L. Gerdes, J. Grubich, M.J. Hanson, S. Cosper, S. Bevelheimer, and A. Deguzman

Jan 2001 Survey of Fort Lewis Oil/Water Separators; Findings and Recommendations, by G. Gerdes, M. Hanson, S. Cosper, J. Grubich, W. Newton, J. Galloway, and M. Boutin

Mar $2001 \quad$ Survey of Fort Hood Solvent Parts Cleaners; Findings and

Recommendations, by M.J. Hanson and G.L. Gerdes

Dec 2001 Fort Lee Oil/Water Separator Management Plan, by G. Gerdes and J. Grubich

Fort Lee Slug Discharge Plan, by G.L. Gerdes

Hardy Barracks Building at Camp Zama, Japan: Seismic Evaluation for LifeSafety Performance Level, by G.K. AlChaar and K.M. Schinkoeth

May 2003

Initial Failure Analysis of a PVC ChilledWater Distribution Pipe at Fort Gordon

Aug 2003 Considerations for an Optimal Alternative Energy Technology for Homes in the Mountains of Asheville, North Carolina, by T. Abdallah

Wall Tests Report, by O.S. Marshall

Analysis of Polyvinyl Chloride Water Distribution Pipe Failures at Fort Bragg, by O.S. Marshall
AD Number

ADB263799 


\begin{tabular}{|c|c|c|c|}
\hline 1ERDC/CERL LR-04-7 & Sep 2004 & $\begin{array}{l}\text { Wood Truss Inspection of Bulding } 8 \text {, } \\
\text { Corpus Christi Army Depot, by G.K. Al- } \\
\text { Chaar, L.L. Fasules, and C.M. Cape }\end{array}$ & \\
\hline 1ERDC/CERL LR-04-9 & Dec 2004 & $\begin{array}{l}\text { Adelphi Laboratory Center Water } \\
\text { System Vulnerability Assessment, by } \\
\text { V.L. Van Blaricum and V.F. Hock }\end{array}$ & \\
\hline 1ERDC/CERL LR-05-4 & Aug 2005 & $\begin{array}{l}\text { Evaluation of Quick Release Detergents, } \\
\text { by G.L. Gerdes and J.L. Lattimore }\end{array}$ & \\
\hline${ }^{1}$ ERDC/CERL LR-06-2 & Oct 2006 & $\begin{array}{l}\text { Identification and Evaluation of } \\
\text { Underground Utility Systems at Joliet } \\
\text { Army Ammunition Plant: Phase 2, by } \\
\text { S.D. Cosper, G.L. Gerdes, and C.L. Baker }\end{array}$ & ADB330169 \\
\hline 1ERDC/CERL LR-11-1 & Oct 2011 & $\begin{array}{l}\text { An Overview of Cultural and Natural } \\
\text { Resources Management at US Army } \\
\text { Installations, by S. Enscore, E. Hartman, } \\
\text { R. Woodbury, S. Adams, A. Smith, and } \\
\text { R. Lacey }\end{array}$ & \\
\hline 1ERDC/CERL LR-12-1 & Sep 2012 & $\begin{array}{l}\text { Modeling of Archaeological Site } \\
\text { Location and Significance at White } \\
\text { Sands Missile Range, New Mexico, by } \\
\text { A.M. Hamblin and M.L. Hargrave }\end{array}$ & \\
\hline 1ERDC/CERL LR-12-2 & Sep 2012 & $\begin{array}{l}\text { Considerations in Identifying Army } \\
\text { Lands Suitable for Forest Products and } \\
\text { Agricultural Outleasing, by N.R. Myers, } \\
\text { T.S. Smith, P.J. Guertin, and H. Pitstick. }\end{array}$ & \\
\hline${ }^{1}$ ERDC/CERL LR-12-8 & Dec 2012 & $\begin{array}{l}\text { Communication Plan for a Program } \\
\text { Comment to Manage Cultural } \\
\text { Resources in Impact Areas, by A.M. } \\
\text { Hamblin and C.L. Baxter }\end{array}$ & \\
\hline${ }^{1}$ ERDC/CERL LR-13-1 & Jan 2013 & $\begin{array}{l}\text { Management Decision Package TATM } \\
\text { Program Objective Memorandum (POM) } \\
\text { FY14-18 Process Quality } \\
\text { Assurance/Quality Control (QA/QC) } \\
\text { Review: Model Documentation and } \\
\text { Analysis of Strengths and Weaknesses, } \\
\text { by N.G. Svendsen, D.J. Koch, and H.R. } \\
\text { Howard }\end{array}$ & ADB402574 \\
\hline 1ERDC/CERL LR-13-3 & May 2013 & $\begin{array}{l}\text { Management Decision Package TATM } \\
\text { Program Objective Memorandum (POM) } \\
\text { FY14-18 Process: Determining Off-Road } \\
\text { Training Distribution from Vehicle } \\
\text { Tracking Data, by D.J. Koch, N.G. } \\
\text { Svendsen, and H.R. Howard }\end{array}$ & \\
\hline
\end{tabular}

1 Limited distribution; see Preface. 


$\begin{array}{lll}\text { 1ERDC/CERL LR-13-4 Jul 2013 } & \text { Management Decision Package TATM } \\ & & \text { Program Objective Memorandum (POM) } \\ & \text { FY14-18 Process Quality } \\ & \text { Assurance/Quality Control (QA/QC) } \\ & \text { Review by D.J. Koch and N.G. Svendsen } \\ & & \text { Digital Optical Method (DOM): A New Air ADB408141 } \\ \text { Emissions Opacity Monitoring Tool, by } \\ \text { E.J. Kim and M. Kemme }\end{array}$

\section{Monographs}

\begin{tabular}{|c|c|c|}
\hline Report Number & Date & $\underline{\text { Title }}$ \\
\hline ERDC/CERL M-00-01 & Sep 2000 & $\begin{array}{l}\text { Guarding the Gates: The Story of Fort } \\
\text { Clayton - Its Setting, Its Architecture, and } \\
\text { Its Role in the History of the Panama } \\
\text { Canal, by S. Enscore, S.P. Johnson, J.L. } \\
\text { Webster, and G.L. Cohen }\end{array}$ \\
\hline ERDC/CERL M-06-1 & Apr 2006 & $\begin{array}{l}\text { Interview with Lewis D. Walker, Deputy } \\
\text { Assistant Secretary of the Army for } \\
\text { Environment, Safety and Occupational } \\
\text { Health (retired) : Transcript of an Oral } \\
\text { History Recorded December } 2004 \text { - } \\
\text { January 2005, by D.M. Moorhus }\end{array}$ \\
\hline ERDC/CERL M-06-2 & Aug 2006 & $\begin{array}{l}\text { The Built Environment of Cold War Era } \\
\text { Servicewomen, by D.A. Morrison and S.I. } \\
\text { Enscore }\end{array}$ \\
\hline ERDC/CERL M-07-1 & Mar 2007 & $\begin{array}{l}\text { Interview with Susan Morrisey } \\
\text { Livingstone, Assistant Secretary of the } \\
\text { Army for Installations, Logistics and } \\
\text { Environment : Transcript of an Oral } \\
\text { History Recorded } 14 \text { April and } 14 \text { June } \\
\text { 2005, by D.M. Moorhus }\end{array}$ \\
\hline
\end{tabular}

AD Number

ADA388262 
ERDC/CERL MP-03-4

ERDC/CERL MP-03-5

ERDC/CERL MP-03-6

ERDC/CERL MP-04-1

ERDC/CERL MP-04-2

ERDC/CERL MP-04-3

ERDC/CERL MP-08-2

ERDC/CERL MP-09-1

ERDC/CERL MP-12-1

Jul 2012

ERDC/CERL MP-12-2

Jul 2004
Aug 2003

Historic American Buildings Survey, Ordnance/Motor Repair Shop, Fort Bragg, North Carolina, by A. Smith, M. Stupich, C. Lai, and E. Campbell

Sep $2003 \quad$ Use of Pyrolysis GC/MS for Predicting Emission Byproducts from the Incineration of Double-Base Propellant, by D.M. Cropek, P.A. Kemme, J.M. Day, and J. Cochran

Nov 2003 Historic American Buildings Survey: African American World War II Noncommissioned Officer's Service Club Complex, by A. Smith, S.D. Smith, and M.J. Stupich

Mar $2004 \quad$ Fury: Robotic In-Situ Inspection/Condition Assessment System for Underground Storage Tanks, by C.P. Marsh, A. Siddique, B. Temple, V.M. Hock, and F. Robb

Historic American Buildings Survey Level II Documentation of Building 431, Theater and Building 439, Seaside Chapel Patrick Air Force Base, Florida, by S.I. Enscore, J.L. Webster, and M.J. Stupich

Nov 2004

Sound Propagation Through a Forest: A Predictive Model, by M. White and M. Swearingen

Dec 2008

Level II Documentation of Launch Complex 31/32, Cape Canaveral Air Force Station, Florida, by S.I. Enscore J.L. Webster, A.M. Fike, and M.J. Stupich

Sep 2009 Comprehensive Inventory and Determinations of Eligibility for Fort Riley Buildings: 1857-1963, by S.I. Enscore and J.L. Webster

Level II Documentation of Space Launch Complex 5 at Vandenberg Air Force Base, California, by J.L. Webster, S.I. Enscrore, and M.J. Stupich

Aug 2012 Towards a Pre-Intervention Analytical Methodology, by L.A. Whalley, T.K. Perkins, D.A. Krooks, M.L. Hargrave, and C.C. Rewerts
ADA418848

ADA418613

ADA419818

ADA429286

ADA428938

ADA526603

ADA528062

ADA566233 


\title{
Repair, Evaluation, Maintenance, and Rehabilitation Research program
}

\author{
$\begin{array}{lll}\underline{\text { Report Number }} & \underline{\text { Date }} & \underline{\text { Title }} \\ \text { ERDC/CERL TR-REMR-OM- } & \text { Nov 2005 } & \text { Condition and Performance Rating } \\ 26 & & \text { Procedures for Nonrubble Breakwaters } \\ & \text { and Jetties, by D. Pirie, D. Plotkin, J. }\end{array}$ \\ Kubinski, S. Foltz, and D. McKay
}

AD Number

ADA464021

\section{Special reports}

\begin{tabular}{|c|c|c|c|}
\hline Report Number & Date & $\underline{\text { Title }}$ & AD Number \\
\hline $\begin{array}{l}\text { ERDC-CERL SR-95-36 } \\
\text { Vol. } 2\end{array}$ & Sep 2000 & $\begin{array}{l}\text { The Environmental Compliance } \\
\text { Assessment Management Program } \\
\text { (ECAMP) Air National Guard Supplement } \\
\text { for The Environmental Assessment and } \\
\text { Management (TEAM) Guide (CD-ROM), } \\
\text { by D.A. Krooks }\end{array}$ & ADM001205 \\
\hline ERDC/CERL SR-99-106 & Dec 1999 & $\begin{array}{l}\text { Research Plan to Evaluate the } \\
\text { Relationship Between Maneuver Training } \\
\text { Activities and Red-cockaded Woodpecker } \\
\text { Populations and Habitats on Fort } \\
\text { Stewart, GA, by T.J. Hayden }\end{array}$ & \\
\hline 1ERDC/CERL SR-00-1 & Mar 2000 & $\begin{array}{l}\text { A Guide to Source Material on Ballistic } \\
\text { Missile Defense, by J. Lonnquest, D. } \\
\text { Winkler, and B. Hayworth }\end{array}$ & \\
\hline ERDC/CERL SR-00-2 & May 2000 & $\begin{array}{l}\text { Quantitative and Landscape Approaches } \\
\text { to Amphibian Conservation, by A.J. } \\
\text { Krzysik }\end{array}$ & \\
\hline ERDC/CERL SR-00-4 & Sep 2003 & $\begin{array}{l}\text { OCONUS Compliance Assessment } \\
\text { Protocols - OEBGD (CD-ROM), by D.A } \\
\text { Krooks }\end{array}$ & ADM001554 \\
\hline ERDC/CERL SR-00-5 & Sep 2000 & $\begin{array}{l}\text { OCONUS Compliance Assessment } \\
\text { Protocols - Saudia Arabia (CD-ROM), by } \\
\text { D.A Krooks }\end{array}$ & ADM001208 \\
\hline ERDC/CERL SR-00-6 & Sep 2000 & $\begin{array}{l}\text { OCONUS Compliance Assessment } \\
\text { Protocols - Kuwait (CD-ROM), by D.A } \\
\text { Krooks }\end{array}$ & ADM001202 \\
\hline ERDC/CERL SR-00-7 & Sep 2000 & $\begin{array}{l}\text { OCONUS Compliance Assessment } \\
\text { Protocols - Qatar (CD-ROM), by D.A } \\
\text { Krooks }\end{array}$ & ADM001201 \\
\hline
\end{tabular}

1 Limited distribution; see Preface. 


\begin{tabular}{|c|c|c|c|}
\hline ERDC/CERL SR-00-8 & Sep 2002 & $\begin{array}{l}\text { OCONUS Compliance Assessment } \\
\text { Protocols - Air Force Supplement (CD- } \\
\text { ROM), by D.A Krooks }\end{array}$ & ADM001484 \\
\hline $\begin{array}{l}\text { ERDC/CERL SR-00-8 } \\
\text { REV. }\end{array}$ & Sep 2005 & $\begin{array}{l}\text { OCONUS Compliance Assessment } \\
\text { Protocols - Air Force Supplement (CD- } \\
\text { ROM), by D.A Krooks }\end{array}$ & ADM001819 \\
\hline ERDC/CERL SR-00-9 & Sep 2001 & $\begin{array}{l}\text { OCONUS Compliance Assessment } \\
\text { Protocols - Army Supplement (CD-ROM), } \\
\text { by D.A Krooks }\end{array}$ & ADM001279 \\
\hline ERDC/CERL SR-01-1 & Jan 2001 & $\begin{array}{l}\text { User Guide and Specifications for Baked } \\
\text { Phenolic Coating Systems Applied to } \\
\text { Domestic Hot Water Heat Exchangers, by } \\
\text { V.F. Hock }\end{array}$ & ADA386809 \\
\hline $\begin{array}{l}\text { ERDC/CERL SR-01-2 } \\
\text { REV. }\end{array}$ & Jan 2010 & $\begin{array}{l}\text { The Environmental Assessment and } \\
\text { Management (TEAM) Guide, Virgin } \\
\text { Islands Supplement (CD-ROM) }\end{array}$ & ADM001619 \\
\hline ERDC/CERL SR-01-3 & Mar 2001 & $\begin{array}{l}\text { Red-Cockaded Woodpecker Research at } \\
\text { ERDC/CERL, by H. Balbach and P.M. } \\
\text { Kirby }\end{array}$ & ADA388089 \\
\hline ERDC/CERL SR-01-4 & Mar 2001 & $\begin{array}{l}\text { Development of a Pilot Interactive } \\
\text { Training Program for ATTACC Users, by } \\
\text { G.L. Howard, M.L. Denight, A.B. } \\
\text { Anderson, and J. Cookas }\end{array}$ & ADA388628 \\
\hline ERDC/CERL SR-01-5 & Jun 2001 & $\begin{array}{l}\text { Cost Analysis for Building Removal at } \\
\text { Fort Chaffee, Arkansas, by T.R. Napier, } \\
\text { S.D. Cosper, and J.C. Dearborn }\end{array}$ & ADA391763 \\
\hline ERDC/CERL SR-01-6 & Jun 2001 & $\begin{array}{l}\text { Corporate Lessons Learned (CLL) } \\
\text { System: System Decision Paper, by E.W. } \\
\text { East and J.G. Kirby }\end{array}$ & ADA392319 \\
\hline ERDC/CERL SR-01-8 & Jul 2001 & $\begin{array}{l}\text { Land Use Planning and Sustaining the } \\
\text { Military Land Base, by R.M. Lacey }\end{array}$ & ADA395084 \\
\hline ERDC/CERL SR-01-9 & Jul 2001 & $\begin{array}{l}\text { Integrated Cultural Resources } \\
\text { Management Plan: Marine Corps Recruit } \\
\text { Depot, Parris Island, by S.F. Loechl, M. } \\
\text { Chawla, B.C. Grashof, M. Griffin, A. } \\
\text { Smith, L. Whalley, and J. Zeidler }\end{array}$ & ADA406219 \\
\hline ERDC/CERL SR-01-10 & Jul 2001 & $\begin{array}{l}\text { Army Training and Testing Area Carrying } \\
\text { Capacity (ATTACC) Land Condition } \\
\text { Module (LCM) User Manual, Version } \\
\text { 1.00, by A. Anderson, P. Sydelko, and G. } \\
\text { Teachman }\end{array}$ & ADA406536 \\
\hline ERDC/CERL SR-01-11 & Jul 2001 & $\begin{array}{l}\text { ERDC CERL Executive Summary FYOO } \\
\text { R\&D Program Highlights, by Construction } \\
\text { Engineering Research Laboratory (U.S.) }\end{array}$ & \\
\hline
\end{tabular}




\begin{tabular}{|c|c|c|c|}
\hline ERDC/CERL SR-01-12 & Aug 2001 & $\begin{array}{l}\text { Understanding Condition Indexes: } \\
\text { Current Status and Future Opportunities, } \\
\text { by S.D. Foltz, P.A. Howdyshell, and D.T. } \\
\text { McKay }\end{array}$ & ADA395057 \\
\hline ERDC/CERL SR-01-13 & Sep 2001 & $\begin{array}{l}\text { Air National Guard Weapons Safety } \\
\text { Assessment Protocols (CD-ROM) }\end{array}$ & ADM001563 \\
\hline ERDC/CERL SR-01-13 & Sep 2001 & $\begin{array}{l}\text { Air National Guard Weapons Safety } \\
\text { Assessment Protocols (CD-ROM) }\end{array}$ & ADM001823 \\
\hline $\begin{array}{l}\text { ERDC/CERL SR-01-15 } \\
\text { REV. }\end{array}$ & Sep 2001 & $\begin{array}{l}\text { OCONUS Compliance Assessment } \\
\text { Protocols - United Kingdom (CD-ROM) }\end{array}$ & ADM00182 \\
\hline ERDC/CERL SR-01-16 & Sep 2001 & $\begin{array}{l}\text { Air National Guard Flight Safety } \\
\text { Assessment Protocol (CD-ROM) }\end{array}$ & ADM00182 \\
\hline $\begin{array}{l}\text { ERDC/CERL SR-01-16 } \\
\text { REV-2003 }\end{array}$ & Sep 2001 & $\begin{array}{l}\text { Air National Guard Flight Safety } \\
\text { Assessment Protocol (CD-ROM) }\end{array}$ & ADM00153 \\
\hline ERDC/CERL SR-01-17 & Aug 2001 & $\begin{array}{l}\text { Impacts of Military Vehicle Training } \\
\text { Activities on Vegetation: Bibliography } \\
\text { With Abstracts, by J.S. Fehmi, T. Farmer, } \\
\text { and J.A. Zimmerman }\end{array}$ & ADA395034 \\
\hline ERDC/CERL SR-01-19 & Aug 2001 & $\begin{array}{l}\text { Seismic Response of Low-Rise Masonry } \\
\text { Buildings With Flexible Roof Diaphragms, } \\
\text { by G.L. Cohen, R.E. Klingner, J.R. Hayes, } \\
\text { Jr., and S.C. Sweeney }\end{array}$ & ADA402609 \\
\hline ERDC/CERL SR-01-20 & Sep 2001 & $\begin{array}{l}\text { Design Review and Checking System } \\
\text { (DrChecks), by E.W. East, J.G. Kirby, and } \\
\text { J. Kelly }\end{array}$ & ADA395194 \\
\hline ERDC/CERL SR-01-21 & Dec 2001 & $\begin{array}{l}\text { Proceedings of the Workshop on } \\
\text { Environmental Protection for Forces } \\
\text { Deployment, by R. Lozar and C.R. } \\
\text { Ehlschlaeger, editors }\end{array}$ & ADA413099 \\
\hline ERDC/CERL SR-01-22 & Sep 2001 & $\begin{array}{l}\text { Missiles at the Cape: Missile Systems on } \\
\text { Display at the Air Force Space and } \\
\text { Missile Museum, Cape Canaveral Air } \\
\text { Force Station, Florida, by R. McCullough }\end{array}$ & ADA399207 \\
\hline ERDC/CERL SR-01-23 & Sep 2001 & $\begin{array}{l}\text { Chrome Plating Projects at Watervliet } \\
\text { Arsenal, Fiscal Year 2000, by J.I. } \\
\text { Northrup, J.C. Baird, D. Franklin, and P. } \\
\text { Darcy }\end{array}$ & ADA396131 \\
\hline ERDC/CERL SR-02-1 & Feb 2002 & $\begin{array}{l}\text { Historic Landscape Management Plan } \\
\text { for the U.S. Military Academy at West } \\
\text { Point, New York, by S.K. Loechl, M. } \\
\text { Weaver, S.I. Enscore, and G.B. Kesler }\end{array}$ & \\
\hline
\end{tabular}




\begin{tabular}{|c|c|c|c|}
\hline ERDC/CERL SR-02-2 & Mar 2002 & $\begin{array}{l}\text { Proceedings of the "Partners Along the } \\
\text { Fall Line: Sandhills Ecology and } \\
\text { Ecosystem Management Workshop", by } \\
\text { R.C. Lozar, H.E. Balbach, W.D. Goran, } \\
\text { and B. Collins }\end{array}$ & ADA400802 \\
\hline ERDC/CERL SR-02-3 & Apr 2002 & $\begin{array}{l}\text { Development of a Joint Tightness } \\
\text { Parameter for Sheet Pile Structures; A } \\
\text { Geometry-Based Method for } \\
\text { Comparative Estimation of Leakage } \\
\text { Through Different Sheet Pile Interlock } \\
\text { Configurations, by C.P. Marsh }\end{array}$ & ADA401544 \\
\hline ERDC/CERL SR-02-4 & May 2002 & $\begin{array}{l}\text { Hazardous Asbestos and Lead Optimal } \\
\text { Management System (HALO); } \\
\text { Implementation Guide and User's } \\
\text { Manual, Second Edition, by A.J. } \\
\text { Averbuch, J.J. Long, and A. Kumar }\end{array}$ & ADA402805 \\
\hline ERDC/CERL SR-02-5 & Sep 2015 & $\begin{array}{l}\text { OCONUS Compliance Assessment } \\
\text { Protocols (OCAP) - Japan (CD-ROM) }\end{array}$ & ADM001489 \\
\hline ERDC/CERL SR-02-6 & Sep 2015 & $\begin{array}{l}\text { OCONUS Compliance Assessment } \\
\text { Protocols (OCAP) - Italy (CD-ROM) }\end{array}$ & ADM001484 \\
\hline ERDC/CERL SR-02-7 & Aug 2002 & $\begin{array}{l}\text { Army Training and Testing Area Carrying } \\
\text { Capacity (ATTACC) LS Factor Calculator } \\
\text { User Manual, Version 1.0, by A.B. } \\
\text { Anderson, H. Mitasova, M. Hohmann, } \\
\text { and S. Warren }\end{array}$ & ADA414292 \\
\hline ERDC/CERL SR-02-8 & Jul 2002 & $\begin{array}{l}\text { A Bibliography of Important Plant } \\
\text { Species in the Chihuahuan Desert of } \\
\text { North America (1904 - 2002), by T. } \\
\text { Hochstrasser, D. Peters, J. Fehmi, and K. } \\
\text { VonFinger }\end{array}$ & ADA412831 \\
\hline ERDC/CERL SR-02-10 & Sep 2015 & $\begin{array}{l}\text { Occupational Safety and Health Guide } \\
\text { (OSH Guide) (CD-ROM) }\end{array}$ & ADM001502 \\
\hline $\begin{array}{l}\text { ERDC/CERL SR-02-11 } \\
\text { REV. }\end{array}$ & Apr 2015 & $\begin{array}{l}\text { OCONUS Compliance Assessment } \\
\text { Protocols (OCAP) - Republic of Turkey (Air } \\
\text { Force Version) (CD-ROM) }\end{array}$ & ADM001829 \\
\hline 1ERDC/CERL SR-02-12 & Sep 2002 & $\begin{array}{l}\text { Sustainable Installation Risk } \\
\text { Assessment and Stationing Implications, } \\
\text { by D.F. Fournier, B.M. Deal, E.M. Jenicek, } \\
\text { and A.J. Sagert }\end{array}$ & ADB284576 \\
\hline
\end{tabular}

1 Limited distribution; see Preface. 


\begin{tabular}{|c|c|c|c|}
\hline ERDC/CERL SR-03-1 & Mar 2003 & $\begin{array}{l}\text { Hazardous Asbestos and Lead Optimal } \\
\text { (HALO) Management System; } \\
\text { Demonstration of Lead Hazard } \\
\text { Management Plan Generation, by R.A. } \\
\text { Weber }\end{array}$ & ADA412885 \\
\hline ERDC/CERL SR-03-2 & Apr 2003 & $\begin{array}{l}\text { National Training Center - Fort Irwin, } \\
\text { California; Tribal Consultations Held on } \\
\text { 3-5 September 2002, by T. Britt and S.E. } \\
\text { Perlman }\end{array}$ & ADA415689 \\
\hline $\begin{array}{l}\text { ERDC/CERL SR-03-3 } \\
\text { REV. }\end{array}$ & Sep 2015 & $\begin{array}{l}\text { OCONUS Compliance Assessment } \\
\text { Protocols - The Federal Republic of } \\
\text { Germany (Air Force Version) (CD-ROM) }\end{array}$ & ADM001817 \\
\hline ERDC/CERL SR-03-4 & Sep 2015 & $\begin{array}{l}\text { OCONUS Compliance Assessment } \\
\text { Protocols: Spain (CD-ROM) }\end{array}$ & ADM001830 \\
\hline ERDC/CERL SR-03-5 & Jul 2003 & $\begin{array}{l}\text { Made in the Timber: A Settlement History } \\
\text { of the Fort Leonard Wood Region, by S.D. } \\
\text { Smith }\end{array}$ & \\
\hline ERDC/CERL SR-03-6-REV. & Mar 2015 & $\begin{array}{l}\text { OCONUS Compliance Assessment } \\
\text { Protocols - USAFE Supplement (CD-ROM) }\end{array}$ & ADM001816 \\
\hline ERDC/CERL SR-03-7 & Sep 2015 & $\begin{array}{l}\text { Occupational Safety and Health Guide } \\
\text { (OSH Guide) (CD-ROM) }\end{array}$ & ADM001545 \\
\hline ERDC/CERL SR-03-8 & Aug 2003 & $\begin{array}{l}\text { Micro ROOFER for Windows User Guide. } \\
\text { Version 2.0, by D.M. Bailey }\end{array}$ & ADA417320 \\
\hline ERDC/CERL SR-03-9 & Sep 2015 & $\begin{array}{l}\text { The Environmental Review Guide for } \\
\text { Operations (ERGO) Supplement for the } \\
\text { Environmental Assessment and } \\
\text { Management (TEAM) Guide (CD-ROM) }\end{array}$ & ADM001552 \\
\hline ERDC/CERL SR-03-10 & Sep 2015 & $\begin{array}{l}\text { The Environmental Compliance } \\
\text { Assessment and Management Program } \\
\text { (ECAMP) Supplement for The } \\
\text { Environmental Assessment and } \\
\text { Management (TEAM) Guide (CD-ROM) }\end{array}$ & ADM001570 \\
\hline $\begin{array}{l}\text { ERDC/CERL SR-03-11 } \\
\text { Vol. } 1\end{array}$ & Sep 2015 & $\begin{array}{l}\text { The Environmental Compliance } \\
\text { Assessment and Management Program } \\
\text { (ECAMP) Air National Guard Supplement } \\
\text { for The Environmental Assessment and } \\
\text { Management (TEAM) Guide (CD-ROM) }\end{array}$ & ADM001553 \\
\hline ERDC/CERL SR-03-12 & Sep 2015 & $\begin{array}{l}\text { The Army Reserve Supplement for The } \\
\text { Environmental Assessment and } \\
\text { Management (TEAM) Guide (CD-ROM) }\end{array}$ & ADM001537 \\
\hline ERDC/CERL SR-03-13 & Sep 2015 & $\begin{array}{l}\text { The Active Army Supplement for The } \\
\text { Environmental Assessment and } \\
\text { Management (TEAM) Guide (CD-ROM) }\end{array}$ & \\
\hline
\end{tabular}




\begin{tabular}{|c|c|c|c|}
\hline ERDC/CERL SR-03-14 & Sep 2015 & $\begin{array}{l}\text { The Army National Guard Supplement for } \\
\text { The Environmental Assessment and } \\
\text { Management (TEAM) Guide (CD-ROM) }\end{array}$ & ADM001527 \\
\hline $\begin{array}{l}\text { ERDC/CERL SR-03-15 } \\
\text { REV. }\end{array}$ & Sep 2015 & $\begin{array}{l}\text { OCONUS Compliance Assessment } \\
\text { Protocols (OCAP) - Belgium (Army } \\
\text { Version) (CD-ROM) }\end{array}$ & ADM001827 \\
\hline ERDC/CERL SR-03-16 & Sep 2015 & $\begin{array}{l}\text { The Environmental Assessment and } \\
\text { Management (TEAM) Guide (CD-ROM) }\end{array}$ & ADM001551 \\
\hline $\begin{array}{l}\text { ERDC/CERL SR-03-17 } \\
\text { REV. }\end{array}$ & Sep 2015 & $\begin{array}{l}\text { OCONUS Compliance Assessment } \\
\text { Protocols (OCAP) - The Netherlands (Air } \\
\text { Force Version) (CD-ROM) }\end{array}$ & ADM001831 \\
\hline ERDC/CERL SR-03-18 & Sep 2003 & $\begin{array}{l}\text { Distributed Electrical Power Generation: } \\
\text { Summary of Alternative Available } \\
\text { Technologies, by S.J. Scott, F.H. Holcomb, } \\
\text { and N.M. Josefik }\end{array}$ & ADA421197 \\
\hline 1ERDC/CERL SR-03-20 & Nov 2003 & $\begin{array}{l}\text { U.S. Military Academy Perimeter Fence } \\
\text { Line Views Analysis, West Point, New } \\
\text { York, by S.K. Loechl and M.W. Tooker }\end{array}$ & ADB297362 \\
\hline ERDC/CERL SR-03-21 & Dec 2003 & $\begin{array}{l}\text { Geophysical Surveys in Archaeology: } \\
\text { Guidance for Surveyors and Sponsors, by } \\
\text { L.E. Somers, M.L. Hargrave, and J.E. } \\
\text { Simms }\end{array}$ & ADA429240 \\
\hline $\begin{array}{l}\text { ERDC/CERL SR-04-1 } \\
\text { REV. }\end{array}$ & Sep 2015 & $\begin{array}{l}\text { OCONUS Compliance Assessment } \\
\text { Protocols (OCAP) - Japan (Air Force } \\
\text { Version) (CD-ROM) }\end{array}$ & ADM001814 \\
\hline ERDC/CERL SR-04-3 & Mar 2004 & $\begin{array}{l}\text { SERDP Ecosystem Management Project } \\
\text { (SEMP) } 2003 \text { Technical Report, by H.E. } \\
\text { Balbach, B.S. Collins, V. Dale, J.S. Fehmi, } \\
\text { C.T. Garten, Jr., W.D. Goran, R.M. Kress, } \\
\text { A.J. Krzysik, K.R. Reddy, D.L. Price, and } \\
\text { H.M. Westbury }\end{array}$ & \\
\hline 1ERDC/CERL SR-04-4 & Mar 2004 & $\begin{array}{l}\text { SERDP Ecosystem Management Project } \\
\text { (SEMP) } 2003 \text { Administrative Report, by } \\
\text { W.D. Goran }\end{array}$ & \\
\hline ERDC/CERL SR-04-5 & Apr 2004 & $\begin{array}{l}\text { User Manual Illinois River Restoration } \\
\text { Needs Assessment GIS: RNA-GIS, by S.A. } \\
\text { Tweddale }\end{array}$ & ADA430939 \\
\hline ERDC/CERL SR-04-6 & Apr 2004 & $\begin{array}{l}\text { User Manual Rock River Geographic } \\
\text { Information System: ROCK-GIS, by S.A. } \\
\text { Tweddale }\end{array}$ & ADA430945 \\
\hline ERDC/CERL SR-04-7 & Apr 2004 & $\begin{array}{l}\text { Fort Jackson Range Architectural } \\
\text { Inventory, by A. Stone and S. Stone }\end{array}$ & \\
\hline
\end{tabular}

\footnotetext{
1 Limited distribution; see Preface.
} 


\begin{tabular}{|c|c|c|c|}
\hline ERDC/CERL SR-04-8 & Jun 2004 & $\begin{array}{l}\text { Field Evaluation of Self-Lubricated } \\
\text { Mechanical Components for Civil Works } \\
\text { Navigation Structures, by T.D. Race, A. } \\
\text { Kumar, and L.D. Stephenson }\end{array}$ & ADA429062 \\
\hline $\begin{array}{l}\text { ERDC/CERL SR-04-9 } \\
\text { REV. }\end{array}$ & Sep 2015 & $\begin{array}{l}\text { OCONUS Compliance Assessment } \\
\text { Protocols (OCAP) - The Federal Republic } \\
\text { of Germany (Army Version) (CD-ROM) }\end{array}$ & ADM001808 \\
\hline $\begin{array}{l}\text { ERDC/CERL SR-04-10 } \\
\text { REV. }\end{array}$ & Jun 2015 & $\begin{array}{l}\text { OCONUS Compliance Assessment } \\
\text { Protocols (OCAP) - Italy (Army Version) } \\
\text { (CD-ROM) }\end{array}$ & ADM001807 \\
\hline $\begin{array}{l}\text { ERDC/CERL SR-04-11 } \\
\text { REV. }\end{array}$ & Mar 2015 & $\begin{array}{l}\text { OCONUS Compliance Assessment } \\
\text { Protocols (OCAP) - Italy (Air Force } \\
\text { Version) (CD-ROM) }\end{array}$ & ADM001820 \\
\hline $\begin{array}{l}\text { ERDC/CERL SR-04-12 } \\
\text { REV. }\end{array}$ & Sep 2015 & $\begin{array}{l}\text { OCONUS Compliance Assessment } \\
\text { Protocols (OCAP) - The Netherlands } \\
\text { (Army Version) (CD-ROM) }\end{array}$ & ADM001826 \\
\hline ERDC/CERL SR-04-13 & Jul 2004 & $\begin{array}{l}\text { Energy Savings Measurement and } \\
\text { Verification Toolkit Guide: Version } 2.96 \text {, } \\
\text { by N.C. Zych, M.G. Pennell, and D.M. } \\
\text { Underwood }\end{array}$ & ADA432043 \\
\hline ERDC/CERL SR-04-15 & Jul 2004 & $\begin{array}{l}\text { Fort Gordon Architectural Survey: } \\
\text { Boardman's Lake, by A. Stone and S. } \\
\text { Stone }\end{array}$ & \\
\hline ERDC/CERL SR-04-16 & Sep 2015 & $\begin{array}{l}\text { OCONUS Compliance Assessment } \\
\text { Protocols (OCAP) - Saudi Arabia (Army } \\
\text { Version) (CD-ROM) }\end{array}$ & ADM001805 \\
\hline${ }^{1}$ ERDC/CERL SR-04-17 & Jul 2004 & $\begin{array}{l}\text { Gross Buildable Acres and Facility } \\
\text { Conversion, by R.L. Schneider }\end{array}$ & ADB377280 \\
\hline $\begin{array}{l}\text { ERDC/CERL SR-04-19 } \\
\text { REV. }\end{array}$ & Sep 2015 & $\begin{array}{l}\text { Occupational Safety and Health Guide } \\
\text { (OSH Guide) (CD-ROM). Revision }\end{array}$ & ADM001825 \\
\hline ERDC/CERL SR-04-20 & Sep 2015 & $\begin{array}{l}\text { OCONUS Compliance Assessment } \\
\text { Protocols - Kuwait (Army Version) (CD- } \\
\text { ROM) }\end{array}$ & ADM001810 \\
\hline ERDC/CERL SR-04-21 & Sep 2015 & $\begin{array}{l}\text { Radiation Protection Guide } \\
\text { (Occupational Safety and Health Guide) } \\
\text { (OSH Guide], Part } 5 \text { (CD-ROM) }\end{array}$ & ADM001812 \\
\hline ERDC/CERL SR-04-22 & Sep 2015 & $\begin{array}{l}\text { OCONUS Compliance Assessment } \\
\text { Protocols - Qatar (Army Version) (CD- } \\
\text { ROM) }\end{array}$ & ADM001809 \\
\hline
\end{tabular}

1 Limited distribution; see Preface. 
ERDC/CERL SR-04-23

ERDC/CERL SR-04-24

Vol. 1

ERDC/CERL SR-04-25

ERDC/CERL SR-04-26

ERDC/CERL SR-04-27

ERDC/CERL SR-04-28

ERDC/CERL SR-04-29

ERDC/CERL SR-04-30

ERDC/CERL SR-04-31

ERDC/CERL SR-04-32

Nov 2004

ERDC/CERL SR-04-33

Aug 2004

Oct 2004

Nov 2004

Nov 2004

Oct 2004
Aug 2004 Canola Oil Fuel Cell Demonstration;

Sep 2004

Sep 2004

Sep 2004

Sep 2004
National Training Center-Fort Irwin, California; Native American Consultation Meeting at Fort Mojave, Nevada, Held on 2-3 October 2003, by T. Britt, P. Peyton, and T. Brecht, compiler Volume 1 - Literature Review of Current Reformer Technologies, by J.W. Adams, C. Cassarino, J. Lindstrom, L. Spangler, M.J. Binder, and F.H. Holcomb

Protection of Department of Defense Facilities from Airborne CBR Threats; An Annotated Bibliography, by D.M. Bailey, D. Chu, D.L. Herron, D.M. Schwenk, C.W. Sohn, and D.M. Underwood

Building Energy Performance Improvement Through Advanced Technologies, Smart Organization, and Financing. Proceedings of the Industry Workshop Held in Chicago, IL on 7-8 October 2003 (CD-ROM), by A. Zhivov

Industrial Process and Energy Optimization: Proceedings of the Industry Workshop Held in Gettysburg, PA, 25-27 February 2004 (CD-ROM), by M.C.J. Lin and A. Zhivov

Sustainable Project Rating Tool (SPiRiT), Version 1.4.1: Documentation Guide, by R. Schneider and D.F. Fournier

Requirements Composer User's Manual, by S.D. Nachtigall and B.A. Brucker

Planning Composer Tutorial Through Beta Vision 0.22, by S.D. Nachtigall and B.A. Brucker

Planning Composer User's Guide Through Beta Version 0.22, by S.D. Nachtigall and B.A. Brucker

Layout Composer User's Guide Through Beta Version 0.22, by S.D. Nachtigall and B.A. Brucker

ADA430938

ADA432205

ADA431878

ADM001864

ADM001865

ADA435916

ADA480222

ADA478571

ADA478528

ADA478554

Proceedings of the Facility Area Network

ADA443877 (FAN) Workshop, by F. Grobler, J.G. Kirby, and E.W. East, editors 


\begin{tabular}{|c|c|c|c|}
\hline ERDC/CERL SR-04-36 & Aug 2004 & $\begin{array}{l}\text { ERDC-CERL Quality System Manual, } \\
\text { 2004: Documentation of Methods for } \\
\text { Test Data Recognition in Accordance } \\
\text { with International Accreditation Service } \\
\text { (IAS) Accreditation Criteria for Testing } \\
\text { Laboratories (AC89), by J. Wilcoski }\end{array}$ & \\
\hline ERDC/CERL SR-05-1 & Jan 2005 & $\begin{array}{l}\text { Fort Gordon Architectural Survey; 1942- } \\
\text { 1956, by A. Smith and S. Stone }\end{array}$ & \\
\hline ERDC/CERL SR-05-2 & Mar 2015 & $\begin{array}{l}\text { OCONUS Compliance Assessment } \\
\text { Protocols (OCAP) - Republic of Korea } \\
\text { (Army Version) (CD-ROM) }\end{array}$ & ADM001806 \\
\hline ERDC/CERL SR-05-3 & Mar 2005 & $\begin{array}{l}\text { Freshwater Corrosion in the Duluth- } \\
\text { Superior Harbor: Summary of Initial } \\
\text { Workshop Findings, } 9 \text { September } 2004 \text {, } \\
\text { by C.P. Marsh, J. Bushman, A.D. } \\
\text { Beitelman, R.G. Buchheit, and B.J. Little }\end{array}$ & ADA444753 \\
\hline ERDC/CERL SR-05-4 & Mar 2015 & $\begin{array}{l}\text { OCONUS Compliance Assessment } \\
\text { Protocols (OCAP) - Republic of Korea (Air } \\
\text { Force Version) (CD-ROM) }\end{array}$ & ADM001818 \\
\hline $\begin{array}{l}\text { ERDC/CERL SR-05 } \\
\text { REV. }\end{array}$ & Sep 2015 & $\begin{array}{l}\text { OCONUS Compliance Assessment } \\
\text { Protocols (OCAP) - Belgium (Air Force } \\
\text { Version) (CD-ROM) }\end{array}$ & ADM001815 \\
\hline $\begin{array}{l}\text { ERDC/CERL SR-05-6 } \\
\text { Sup. }\end{array}$ & Mar 2015 & $\begin{array}{l}\text { OCONUS Compliance Assessment } \\
\text { Protocols - Army Supplement (CD-ROM) }\end{array}$ & ADM001821 \\
\hline $\begin{array}{l}\text { ERDC/CERL SR-05-7 } \\
\text { Vol. } 1\end{array}$ & Apr 2005 & $\begin{array}{l}\text { Fort Gordon Cold War Architectural } \\
\text { Survey. Volume 1: Historic Context and } \\
\text { Survey Results, by A. Smith and S. Stone }\end{array}$ & \\
\hline $\begin{array}{l}\text { ERDC/CERL SR-05-7 } \\
\text { Vol. } 2\end{array}$ & Apr 2005 & $\begin{array}{l}\text { Fort Gordon Cold War Architectural } \\
\text { Survey. Volume 2: Signal School Survey } \\
\text { Forms, by A. Smith and S. Stone }\end{array}$ & \\
\hline $\begin{array}{l}\text { ERDC/CERL SR-05-7 } \\
\text { Vol. } 3\end{array}$ & Apr 2005 & $\begin{array}{l}\text { Fort Gordon Cold War Architectural } \\
\text { Survey. Volume 3: Barracks Areas Survey } \\
\text { Forms, by A. Smith and S. Stone }\end{array}$ & \\
\hline $\begin{array}{l}\text { ERDC/CERL SR-05-7 } \\
\text { Vol. } 4\end{array}$ & Apr 2005 & $\begin{array}{l}\text { Fort Gordon Cold War Architectural } \\
\text { Survey. Volume 4: Family Housing Survey } \\
\text { Forms, by A. Smith and S. Stone }\end{array}$ & \\
\hline $\begin{array}{l}\text { ERDC/CERL SR-05-7 } \\
\text { Vol. } 5\end{array}$ & Apr 2005 & $\begin{array}{l}\text { Fort Gordon Cold War Architectural } \\
\text { Survey. Volume 5: Support Buildings } \\
\text { Survey Forms, by A. Smith and S. Stone }\end{array}$ & \\
\hline
\end{tabular}




\begin{tabular}{|c|c|c|}
\hline 1ERDC/CERL SR-05-12 & Jun 2005 & $\begin{array}{l}\text { Considerations for the Development of } \\
\text { the Strategic Sustainability Assessment } \\
\text { Program, by E.M. Jenicek, D.F. Fournier, } \\
\text { N.R. Downs, and B. Boesdorfer }\end{array}$ \\
\hline $\begin{array}{l}\text { ERDC/CERL SR-05-13 } \\
\text { Vol. } 1\end{array}$ & Jun 2005 & $\begin{array}{l}\text { Inventory and Evaluation of Cold War Era } \\
\text { BASOPS Buildings on the New Mexico } \\
\text { Ranges at Fort Bliss, 1956-1961. } \\
\text { Volume 1: Determinations of NRHP } \\
\text { Eligibility, by S. Enscore, A. Smith, S. } \\
\text { Stone, and P. Nowlan }\end{array}$ \\
\hline $\begin{array}{l}\text { ERDC/CERL SR-05-13 } \\
\text { Vol. } 2\end{array}$ & Jun 2005 & $\begin{array}{l}\text { Inventory and Evaluation of Cold War Era } \\
\text { BASOPS Buildings on the New Mexico } \\
\text { Ranges at Fort Bliss, 1956-1961. } \\
\text { Volume 2: Inventory Forms and } \\
\text { Drawings, by S. Enscore, A. Smith, S. } \\
\text { Stone, and P. Nowlan }\end{array}$ \\
\hline ERDC/CERL SR-05-15 & Aug 2005 & $\begin{array}{l}\text { Fort Knox Hammerhead Barracks } \\
\text { Architectural Survey, by S. Stone and A. } \\
\text { Smith }\end{array}$ \\
\hline $\begin{array}{l}\text { ERDC/CERL SR-05-21 } \\
\text { REV. }\end{array}$ & Jan 2010 & $\begin{array}{l}\text { The Environmental Assessment and } \\
\text { Management (TEAM) Guide: Delaware } \\
\text { Supplement, by C. O'Rourke and P.A. } \\
\text { Kemme }\end{array}$ \\
\hline
\end{tabular}

A Landscape Approach to Determining Significance of 19th and 20th Century Farmsteads and Rural Communities, Fort Leonard Wood, Missouri, by S. Enscore, S.K. Loechl, M.W. Tooker, and S.L. Nutt

ERDC/CERL SR-05-34 Oct 2005

ERDC/CERL SR-05-35 REV.

ERDC/CERL SR-05-36 REV.

ERDC/CERL SR-05-38 REV.

Feb 2010

Feb 2010

Jan 2010
Encroachment/Sustainability Technologies Workshop: December 9-10, 2004, by W.D. Goran and K. Fleming, compilers

The Environmental Assessment and Management (TEAM) Guide: Idaho Supplement, by C. O'Rourke and P.A. Kemme

The Environmental Assessment and Management (TEAM) Guide: South Dakota Supplement, by C. O'Rourke and P. Kemme

The Environmental Assessment and Management (TEAM) Guide: Montana Supplement. Revision, by C. O'Rourke and P.A. Kemme
ADA523311

ADA468041

ADA523348

ADA523352

\footnotetext{
1 Limited distribution; see Preface.
} 


\begin{tabular}{|c|c|c|c|}
\hline ERDC/CERL SR-05-40 & Oct 2005 & $\begin{array}{l}\text { Engineered Management Systems in } \\
\text { War: An In-Theater Application of } \\
\text { BUILDERTM, by S.L. Hunter and R.M. } \\
\text { Harry }\end{array}$ & ADA441880 \\
\hline ERDC/CERL SR-05-41 & Jun 2005 & $\begin{array}{l}\text { Fort Leonard Wood Maintenance and } \\
\text { Repair Manual: Black Officer's Club, by } \\
\text { A. Smith and M. Harris }\end{array}$ & ADA439996 \\
\hline ERDC/CERL SR-05-42 & Jun 2005 & $\begin{array}{l}\text { Fort Leonard Wood Maintenance and } \\
\text { Repair Manual: Old Post Headquarters } \\
\text { and lke Skelton House, by A. Smith and } \\
\text { M. Harris }\end{array}$ & \\
\hline ERDC/CERL SR-05-43 & Jun 2005 & $\begin{array}{l}\text { Fort Leonard Wood Maintenance and } \\
\text { Repair Manual: Rolling Heath School } \\
\text { House, by A. Smith, M. Harris, and } \\
\text { S.Stone }\end{array}$ & \\
\hline ERDC/CERL SR-05-44 & Jun 2005 & $\begin{array}{l}\text { Fort Leonard Wood Maintenance and } \\
\text { Repair Manual: Building 1309, } \\
\text { Regimental Commander's Quarters, by A. } \\
\text { Smith, M. McCurdy, and C. Lai }\end{array}$ & \\
\hline ERDC/CERL SR-05-45 & Jun 2005 & $\begin{array}{l}\text { Fort Leonard Wood Maintenance and } \\
\text { Repair Manual: Building 1310, Chapel, } \\
\text { by A. Smith, M. McCurdy, and C. Lai }\end{array}$ & \\
\hline ERDC/CERL SR-05-46 & Jun 2005 & $\begin{array}{l}\text { Fort Leonard Wood Maintenance and } \\
\text { Repair Manual: Building 1314, Dayroom, } \\
\text { by A. Smith, M. Harris, and S. Stone }\end{array}$ & \\
\hline ERDC/CERL SR-05-47 & Jun 2005 & $\begin{array}{l}\text { Fort Leonard Wood Maintenance and } \\
\text { Repair Manual: Building 1315, Mess } \\
\text { Hall, by A. Smith, M. Harris, and S. Stone }\end{array}$ & \\
\hline ERDC/CERL SR-05-48 & Jun 2005 & $\begin{array}{l}\text { Fort Leonard Wood Maintenance and } \\
\text { Repair Manual: Building 1316, Barracks, } \\
\text { by A. Smith, M. Harris, and S. Stone }\end{array}$ & \\
\hline ERDC/CERL SR-05-49 & Jun 2005 & $\begin{array}{l}\text { Fort Leonard Wood Maintenance and } \\
\text { Repair Manual: Bilding 1317, Barracks, } \\
\text { by A. Smith, M. Harris, and S. Stone }\end{array}$ & \\
\hline ERDC/CERL SR-05-50 & Jun 2005 & $\begin{array}{l}\text { Fort Leonard Wood Maintenance and } \\
\text { Repair Manual: Building 1318, Storage, } \\
\text { by A. Smith and M. Harris }\end{array}$ & \\
\hline ERDC/CERL SR-05-51 & Jun 2005 & $\begin{array}{l}\text { Fort Leonard Wood Maintenance and } \\
\text { Repair Manual: Building 1319, Mess } \\
\text { Hall, by A. Smith, M. Harris, and S. Stone }\end{array}$ & \\
\hline ERDC/CERL SR-05-52 & Jun 2005 & $\begin{array}{l}\text { Fort Leonard Wood Maintenance and } \\
\text { Repair Manual: Building 1320, Storage, } \\
\text { by A. Smith and M. Harris }\end{array}$ & \\
\hline
\end{tabular}




\begin{tabular}{|c|c|c|c|}
\hline ERDC/CERL SR-05-53 & Jun 2005 & $\begin{array}{l}\text { Fort Leonard Wood Maintenance and } \\
\text { Repair Manual: Building } 1321 \text {, Barracks, } \\
\text { by A. Smith, M. Harris, and S. Stone }\end{array}$ & \\
\hline ERDC/CERL SR-05-54 & Jun 2005 & $\begin{array}{l}\text { Fort Leonard Wood Maintenance and } \\
\text { Repair Manual: Building 1322, Barracks, } \\
\text { by A. Smith and M. Harris }\end{array}$ & \\
\hline ERDC/CERL SR-05-55 & Jun 2005 & $\begin{array}{l}\text { Fort Leonard Wood Maintenance and } \\
\text { Repair Manual: Building 1323, Dayroom, } \\
\text { by A. Smith, M. Harris, and S. Stone }\end{array}$ & \\
\hline ERDC/CERL SR-05-56 & Jun 2005 & $\begin{array}{l}\text { Fort Leonard Wood Maintenance and } \\
\text { Repair Manual: Building } 1324 \text {, Dayroom, } \\
\text { by A. Smith, M. Harris, and S. Stone }\end{array}$ & \\
\hline ERDC/CERL SR-05-57 & Jun 2005 & $\begin{array}{l}\text { Fort Leonard Wood Maintenance and } \\
\text { Repair Manual: Garlington House and } \\
\text { Building 448, by A. Smith, M. Harris, and } \\
\text { S. Stone }\end{array}$ & \\
\hline ERDC/CERL SR-05-58 & Dec 2005 & $\begin{array}{l}\text { Weldon Spring Ordnance Works Historic } \\
\text { Context, by A. Smith and S. Stone }\end{array}$ & \\
\hline ERDC/CERL SR-05-59 & Dec 2005 & $\begin{array}{l}\text { Procedure for Estimating Weights of } \\
\text { LEAM: User's Guide, by S. Fang, J. } \\
\text { Westervelt, G.Z. Gertner, and A.B. } \\
\text { Anderson }\end{array}$ & ADA444340 \\
\hline ERDC/CERL SR-06-1 & Feb 2006 & $\begin{array}{l}\text { McCrady Training Center Structural } \\
\text { Survey, by A. Smith and S. Stone }\end{array}$ & \\
\hline ERDC/CERL SR-06-2 & Apr 2006 & $\begin{array}{l}\text { Native American Historic Context for the } \\
\text { United States Military Academy: West } \\
\text { Point, New York, by D.K. Mann }\end{array}$ & ADA467809 \\
\hline $\begin{array}{l}\text { ERDC/CERL SR-06-3 } \\
\text { REV. }\end{array}$ & Mar 2010 & $\begin{array}{l}\text { The Environmental Assessment and } \\
\text { Management (TEAM) Guide: Colorado } \\
\text { Supplement, by C. O'Rourke and P. } \\
\text { Heinricher }\end{array}$ & ADA523349 \\
\hline $\begin{array}{l}\text { ERDC/CERL SR-06-4 } \\
\text { REV. }\end{array}$ & Mar 2010 & $\begin{array}{l}\text { The Environmental Assessment and } \\
\text { Management (TEAM) Guide: New } \\
\text { Hampshire Supplement, by C. O'Rourke } \\
\text { and P.A. Kemme }\end{array}$ & ADA523353 \\
\hline $\begin{array}{l}\text { ERDC/CERL SR-06-6 } \\
\text { REV. }\end{array}$ & Mar 2010 & $\begin{array}{l}\text { The Environmental Assessment and } \\
\text { Management (TEAM) Guide: New Mexico } \\
\text { Supplement, by C. O'Rourke and P.A. } \\
\text { Kemme }\end{array}$ & ADA523306 \\
\hline $\begin{array}{l}\text { ERDC/CERL SR-06-10 } \\
\text { REV. }\end{array}$ & Feb 2010 & $\begin{array}{l}\text { The Environmental Assessment and } \\
\text { Management (TEAM) Guide: lowa } \\
\text { Supplement, by C. O'Rourke and P.A. } \\
\text { Kemme }\end{array}$ & ADA523307 \\
\hline
\end{tabular}




\begin{tabular}{|c|c|c|c|}
\hline $\begin{array}{l}\text { ERDC/CERL SR-06-12 } \\
\text { REV. }\end{array}$ & Mar 2010 & $\begin{array}{l}\text { The Environmental Assessment and } \\
\text { Management (TEAM) Guide: North } \\
\text { Carolina Supplement, by C. O'Rourke } \\
\text { and P.A. Kemme }\end{array}$ & ADA523309 \\
\hline $\begin{array}{l}\text { ERDC/CERL SR-06-14 } \\
\text { REV. }\end{array}$ & Mar 2010 & $\begin{array}{l}\text { The Environmental Assessment and } \\
\text { Management (TEAM) Guide: Mississippi } \\
\text { Supplement, by C. O'Rourke and P.A. } \\
\text { Kemme }\end{array}$ & ADA523355 \\
\hline $\begin{array}{l}\text { ERDC/CERL SR-06-15 } \\
\text { REV. }\end{array}$ & Mar 2010 & $\begin{array}{l}\text { The Environmental Assessment and } \\
\text { Management (TEAM) Guide: New York } \\
\text { Supplement, by C. O'Rourke and P.A. } \\
\text { Kemme }\end{array}$ & ADA523308 \\
\hline ERDC/CERL SR-06-16 & Apr 2006 & $\begin{array}{l}\text { An Assessment of Previous } \\
\text { Archaeological Surveys at Fort Campbell, } \\
\text { Kentucky/Tennessee, by P.P. Krejsa and } \\
\text { M.L. Hargrave }\end{array}$ & ADA454125 \\
\hline ERDC/CERL SR-06-17 & May 2006 & $\begin{array}{l}\text { Fort Knox Architectural Survey: } \\
\text { Miscellaneous Buildings, by S. Stone and } \\
\text { A. Smith }\end{array}$ & \\
\hline ERDC/CERL SR-06-18 & May 2006 & $\begin{array}{l}\text { Resuspension Physics of Fine Particles, } \\
\text { by C.W. Sohn }\end{array}$ & ADA468671 \\
\hline $\begin{array}{l}\text { ERDC/CERL SR-06-26 } \\
\text { REV. }\end{array}$ & Jan 2010 & $\begin{array}{l}\text { The Environmental Assessment and } \\
\text { Management (TEAM) Guide: West } \\
\text { Virginia Supplement, by C. O'Rourke and } \\
\text { P.A. Kemme }\end{array}$ & ADA523356 \\
\hline $\begin{array}{l}\text { ERDC/CERL SR-06-28 } \\
\text { Vol. } 2\end{array}$ & Jun 2006 & $\begin{array}{l}\text { Canola Oil Fuel Cell Demonstration: } \\
\text { Volume } 2 \text { - Market Availability of } \\
\text { Agricultural Crops for Fuel Cell } \\
\text { Applications, by J.W. Adams, C. } \\
\text { Cassarino, L. Spangler, D. Johnson, J. } \\
\text { Lindstrom, M.J. Binder, F.H. Holcomb, } \\
\text { and S.M. Lux }\end{array}$ & ADA457432 \\
\hline ERDC/CERL SR-06-29 & Jun 2006 & $\begin{array}{l}\text { Construction Engineering Research } \\
\text { Laboratory Strategic Direction: } 2006 \text {, by } \\
\text { W.D. Goran, D.L. Johnson, J.T. Bandy, } \\
\text { D.K. Hicks, and K.D. Radnitzer }\end{array}$ & \\
\hline ERDC/CERL SR-06-30 & Jun 2006 & $\begin{array}{l}\text { Fort Leonard Wood German POW } \\
\text { Stonework Context and Survey, by A. } \\
\text { Smith, S. Stone, S. Enscore, M. Harris, C. } \\
\text { Lai, W. Meyer, and J. Wolke }\end{array}$ & \\
\hline ERDC/CERL SR-06-40 & Aug 2006 & $\begin{array}{l}\text { Biggs Army Airfield Architectural Survey: } \\
\text { (Biggs Air Force Base 1948-1966), by S. } \\
\text { Enscore, A. Smith, and S. Stone }\end{array}$ & \\
\hline
\end{tabular}




\begin{tabular}{|c|c|c|c|}
\hline $\begin{array}{l}\text { ERDC/CERL SR-06-41 } \\
\text { Vol. } 3\end{array}$ & Aug 2006 & $\begin{array}{l}\text { Canola Oil Fuel Cell Demonstration: } \\
\text { Volume III - Technical, } \\
\text { Commercialization, and Application } \\
\text { Issues Associated with Harvested } \\
\text { Biomass, by J. Adams, C. Cassarino, J. } \\
\text { Lindstrom, L. Eslin, S.M. Lux, and F.H. } \\
\text { Holcomb }\end{array}$ & ADA457436 \\
\hline ERDC/CERL SR-06-42 & Aug 2006 & $\begin{array}{l}\text { Sensor Signature Simulation for Urban } \\
\text { Training Range Facilities: A Scoping } \\
\text { Study, by P.A. Nielsen }\end{array}$ & \\
\hline ERDC/CERL SR-06-43 & Sep 2006 & $\begin{array}{l}\text { Fort Campbell Childers House: Historic } \\
\text { Maintenance and Repair Manual, by A. } \\
\text { Smith, J. Feucht, M.W. Tooker, and S. } \\
\text { Stone }\end{array}$ & ADA478354 \\
\hline ERDC/CERL SR-06-51 & Nov 2006 & $\begin{array}{l}\text { Acoustics Training Presentation for the } \\
\text { Range Managers ToolKit (RMTK) Noise } \\
\text { Tool, by M. Swearingen }\end{array}$ & \\
\hline 1ERDC/CERL SR-06-52 & Oct 2006 & $\begin{array}{l}\text { Cultural Resources Evaluations of the } \\
\text { Original Lighthouse Site (8BR234), the } \\
\text { Cape Canaveral Lighthouse Site } \\
\text { (8BR212), and the New Lighthouse Site } \\
\text { (8BR1660), Cape Canaveral Air Force } \\
\text { Station, Brevard County, Florida, by C.L. } \\
\text { Baxter and T. Britt }\end{array}$ & \\
\hline ERDC/CERL SR-06-53 & Dec 2006 & $\begin{array}{l}\text { Fort Bliss Main Post Early Cold War } \\
\text { BASOPS Building Inventory and } \\
\text { Evaluation, 1951-63, by S. Enscore, A. } \\
\text { Smith, and S. Stone }\end{array}$ & \\
\hline $\begin{array}{l}\text { ERDC/CERL SR-07-2 } \\
\text { Pt. } 1\end{array}$ & Jan 2007 & $\begin{array}{l}\text { William Beaumont General Hospital } \\
\text { Historic District: Building Inventory } \\
\text { Update, by S. Enscore, S. Stone, and A. } \\
\text { Smith }\end{array}$ & \\
\hline $\begin{array}{l}\text { ERDC/CERL SR-07-2 } \\
\text { Pt. } 2\end{array}$ & Jan 2007 & $\begin{array}{l}\text { William Beaumont General Hospital } \\
\text { Historic District: Building Inventory } \\
\text { Update: Buildings } 7139,7151,7152 \text {, } \\
\text { 7155, 7157, 7158, 7159, 7166, 7167, } \\
7183,7184 \text {, by S. Enscore, S. Stone, and } \\
\text { A. Smith }\end{array}$ & \\
\hline ERDC/CERL SR-07-3 & Mar 2007 & $\begin{array}{l}\text { A Direction Finding System for Transient } \\
\text { Signals, by G.W. Swenson, Jr., L.L. Pater, } \\
\text { and M.J. White }\end{array}$ & ADA473868 \\
\hline
\end{tabular}

1 Limited distribution; see Preface. 


\begin{tabular}{|c|c|c|c|}
\hline ERDC/CERL SR-07-5 & May 2007 & $\begin{array}{l}\text { Existing Geospatial Knowledge of Gopher } \\
\text { Tortoise Population and Abundance, by } \\
\text { W.D. Meyer, H.E. Balbach, and J.T. } \\
\text { Berner }\end{array}$ & ADA473829 \\
\hline ERDC/CERL SR-07-6 & May 2007 & $\begin{array}{l}\text { ERDC-CERL LD-870 Download Program } \\
\text { Developed for Aberdeen Test Center: } \\
\text { User's Manual, by B. Niemoeller and E.T. } \\
\text { Nykaza }\end{array}$ & ADA468466 \\
\hline ERDC/CERL SR-07-7 & May 2007 & $\begin{array}{l}\text { ERDC-CERL LD-870 Download Program: } \\
\text { Programming Manual, by B. Niemoeller } \\
\text { and E.T. Nykaza }\end{array}$ & ADA470114 \\
\hline ERDC/CERL SR-07-8 & Jun 2007 & $\begin{array}{l}\text { FLW Rolling Pin Barracks and Associated } \\
\text { Buildings Context and Inventory, by A. } \\
\text { Smith, S. Stone, S. Enscore, and M. } \\
\text { Stupich }\end{array}$ & \\
\hline ERDC/CERL SR-07-11 & Jul 2007 & $\begin{array}{l}\text { Peopling the 'Picketwire': A History of the } \\
\text { Pinon Canyon Maneuver Site, by R.A. } \\
\text { McLain }\end{array}$ & ADA491467 \\
\hline ERDC/CERL SR-07-12 & Aug 2007 & $\begin{array}{l}\text { Biological Assessment of the Effects of } \\
\text { the Proposed Revision of the } 1996 \\
\text { "Management Guidelines for the Red- } \\
\text { cockaded Woodpecker on Army } \\
\text { Installations", by T.J. Hayden }\end{array}$ & ADA491407 \\
\hline ERDC/CERL SR-07-13 & Aug 2007 & $\begin{array}{l}\text { Environmental Assessment of the Effects } \\
\text { of the } 2007 \text { "Management Guidelines for } \\
\text { the Red-cockaded Woodpecker on Army } \\
\text { Installations", by T.J. Hayden }\end{array}$ & ADA485251 \\
\hline ERDC/CERL SR-07-15 & Oct 2007 & $\begin{array}{l}\text { Predicting Future Training Opportunities } \\
\text { Using the Land-Use Evolution and Impact } \\
\text { Assessment Model, by J.D. Westervelt, } \\
\text { S.B. Nemeth, M.J. White, M.R. Kemme, } \\
\text { D.A. Morrison, and C. Eastgate }\end{array}$ & ADA473833 \\
\hline 1ERDC/CERL SR-07-16 & Dec 2007 & $\begin{array}{l}\text { SWEAT Volume 1: Field Inspection Guide } \\
\text { for Sewer, Water, Electric, and } \\
\text { Telecommunications Systems, by S. } \\
\text { Foltz, B. Rives, S. Lux, T. Abdallah, S. } \\
\text { Hunter, and W. Taylor }\end{array}$ & ADB336975 \\
\hline 1ERDC/CERL SR-07-17 & Dec 2007 & $\begin{array}{l}\text { SWEAT Volume 2: Field Inspection Guide } \\
\text { for Buildings, by S.D. Foltz, B.L. Rives, } \\
\text { M.N. Grussing, S.M. Lux, and T. Abdallah }\end{array}$ & ADB359210 \\
\hline
\end{tabular}

1 Limited distribution; see Preface. 
1ERDC/CERL SR-07-18Ｄec 2007

ERDC/CERL SR-07-21

1ERDC/CERL SR-07-22

1ERDC/CERL SR-07-23

ERDC/CERL SR-07-24

ERDC/CERL SR-07-25

ERDC/CERL SR-07-26

ERDC/CERL SR-08-1

ERDC/CERL SR-08-2

1ERDC/CERL SR-08-3

ERDC/CERL SR-08-4
Sep 2007

Sep 2007

Sep 2007

Oct 2007

Nov 2007

Nov 2007

Jan 2008

Feb 2008

Aug 2008

Mar 2008
SWEAT Volume 3: Field Inspection Guide for Transportation Infrastructure, District Utility Networks, and Municipal Solid Waste Systems, by S.D. Foltz, J.A. Burkhalter, W.T. Brown, M.N. Grussing, and S.D. Cosper

Fort Leonard Wood Cantonment Landscape Context, Inventory, and Management, by M.W. Tooker, S. Stone, and A. Smith

Effects of Military Training Noise on Indiana Bat Maternity Colonies:

Preliminary Data, by D.K. Delaney

Use of Automated Radio Telemetry to Monitor Gopher Tortoise Response to Military Training on Camp Shelby: Preliminary Data, by D.K. Delaney, T. Radzio, J. Hackler, and M. Hinderliter

An Investigation of Community Attitudes Toward Blast Noise: Methodology, by L.L. Pater, E.T. Nykaza, G. Luz, A. Atchley, K. Hodgdon, R. Baumgartner, and P. Rathbun

Fort Knox Historic Quarters Assessment, by S. Stone and A. Smith

Fort Knox Historic Landscape Context, Inventory, and Management, by M.W. Tooker and A. Smith

Condition Assessment Aspects of an Asset Management Program, by S.D. Foltz and D.T. McKay

Fort Drum Miscellaneous Building Survey, by A. Smith and S. Stone

Sustainable, Full Spectrum Contingency Operations Gap Assessment, by D. Curtin, S. Bevelheimer, G. Gerdes, T. Hartranft, R. Ducey, S. Foltz, A. Stumpf, and S. Hunter

Provision of Ecosystem Services Through Market-Based Approaches: Department of Defense Applications, by E. Keysar and W.D. Goran
ADA476675

ADA479052

ADB359209

ADA478904

ADB338643

ADA474855

ADA476957

\footnotetext{
1 Limited distribution; see Preface.
} 


\begin{tabular}{|c|c|c|c|}
\hline ERDC/CERL SR-08-6 & May 2008 & $\begin{array}{l}\text { Fort Bliss Standards for the Treatment of } \\
\text { Historic Buildings: An Illustrated } \\
\text { Maintenance and Repair Manual, by S. } \\
\text { Stone, A. Smith, and R. Murphy }\end{array}$ & ADA494700 \\
\hline ERDC/CERL SR-08-7 & May 2008 & $\begin{array}{l}\text { Center for the Advancement of } \\
\text { Sustainability Innovations (CASI): A } \\
\text { Summary of the Center's First Year's } \\
\text { Activities, by W.D. Goran }\end{array}$ & ADA485336 \\
\hline ERDC/CERL SR-08-8 & May 2008 & $\begin{array}{l}\text { Physiological Response and Habituation } \\
\text { of Endangered Species to Military } \\
\text { Training Activities: SERDP } 2006 \text { Annual } \\
\text { Report, by T.J. Hayden, I. Bisson, M. } \\
\text { Wikelski, L. Butler, and L.M. Romero }\end{array}$ & ADA482620 \\
\hline ERDC/CERL SR-08-9 & Jun 2008 & $\begin{array}{l}\text { Forest Health in the Southeastern United } \\
\text { States: Assessment of the State of the } \\
\text { Science, by C.S. Duke, C. Mauldin, and } \\
\text { H. Balbach }\end{array}$ & ADA485256 \\
\hline ERDC/CERL SR-08-11 & $\begin{array}{l}\text { Sep } 2009 \\
\text { Rev. }\end{array}$ & $\begin{array}{l}\text { OCONUS Compliance Assessment } \\
\text { Protocols - Air Force Supplement, by D.A. } \\
\text { Krooks }\end{array}$ & ADA506545 \\
\hline 1ERDC/CERL SR-08-13 & Aug 2008 & $\begin{array}{l}\text { Sustainable, Full Spectrum Contingency } \\
\text { Operations Gap Assessment, by D. } \\
\text { Curtin, S. Bevelheimer, G. Gerdes, T. } \\
\text { Hartranft, R. Ducey, S. Foltz, A. Stumpf, } \\
\text { and S. Hunter }\end{array}$ & ADB342305 \\
\hline ERDC/CERL SR-08-14 & Aug 2008 & $\begin{array}{l}\text { Pythian Powerhouse and Laundry: } \\
\text { Historic Building Survey, by S. Stone, A. } \\
\text { Smith, and S. Lask }\end{array}$ & ADA494547 \\
\hline 1ERDC/CERL SR-08-17 & Jun 2008 & $\begin{array}{l}\text { 89th Regional Readiness Command } \\
\text { Integrated Cultural Resources } \\
\text { Management Plan: FY } 2008 \text { to } 2012 \text {, by } \\
\text { M. Chawla, A. Smith, and K. Ellison }\end{array}$ & \\
\hline ERDC/CERL SR-08-18 & Sep 2008 & $\begin{array}{l}\text { DoD Historic Building Conference: After- } \\
\text { action Report, by S. Bellew and A. Smith }\end{array}$ & ADA491466 \\
\hline ERDC/CERL SR-08-19 & Oct 2008 & $\begin{array}{l}\text { Fort Gordon Woodworth Library: Historic } \\
\text { Building Survey, by S. Stone, M. Stupich, } \\
\text { and A. Smith }\end{array}$ & ADA494701 \\
\hline ERDC/CERL SR-08-20 & Jul 2008 & $\begin{array}{l}\text { Fort Knox Standards for the Treatment of } \\
\text { Historic Buildings: An Illustrated } \\
\text { Maintenance and Repair Manual, by S. } \\
\text { Stone, A. Smith, and R. Murphy }\end{array}$ & \\
\hline
\end{tabular}

1 Limited distribution; see Preface. 


\begin{tabular}{|c|c|c|}
\hline ERDC/CERL SR-09-1 & Feb 2009 & $\begin{array}{l}\text { Estimating the Acoustic Properties of } \\
\text { Two Kinds of Gravel at Frequencies } \\
\text { between } 25 \text { and } 200 \mathrm{~Hz} \text { Using an } \\
\text { Impedance Tube, by G.W. Swenson, Jr., } \\
\text { T.E. Onder, M.J. White, and M.L. Oelze }\end{array}$ \\
\hline ERDC/CERL SR-09-2 & Jan 2009 & $\begin{array}{l}\text { Overhills: Hunt Stable Area: Historic } \\
\text { Building Survey, by A. Smith, J. Feucht, } \\
\text { M. Stupich, S. Stone, C. Lai, and E. } \\
\text { Campbell }\end{array}$ \\
\hline ERDC/CERL SR-09-3 & Jan 2009 & $\begin{array}{l}\text { Overhills: Lindley Nursery Area: Historic } \\
\text { Building Survey, by A. Smith, J. Feucht, } \\
\text { M. Stupich, and C. Lai }\end{array}$ \\
\hline ERDC/CERL SR-09-4 & Jan 2009 & $\begin{array}{l}\text { Overhills: Lake Area: Historic Building } \\
\text { Survey, by A. Smith, J. Feucht, M. } \\
\text { Stupich, and C. Lai }\end{array}$ \\
\hline ERDC/CERL SR-09-5 & Jan 2009 & $\begin{array}{l}\text { Overhills: Shops Complex: Historic } \\
\text { Building Survey, by A. Smith, J. Feucht, } \\
\text { M. Stupich, and C. Lai }\end{array}$ \\
\hline
\end{tabular}

ERDC/CERL SR-09-6 Jan 2009

ERDC/CERL SR-09-7 Jan 2009

ERDC/CERL SR-09-8 Jun 2009

ERDC/CERL SR-09-9 Jun 2009

ERDC/CERL SR-09-11

ERDC/CERL SR-09-12 Sep 2009
Overhills: The Hills Area: Historic Building Survey, by A. Smith, J. Feucht, M. Stupich, S. Stone, C. Lai, and E. Campbell

Aug 2009 Camp Upshur, Marine Corps Base
Overhills: Entrance Compound: Historic Building Survey, by A. Smith, J. Feucht, M. Stupich, S. Stone, C. Lai, and E. Campbell

Actionable Cultural Understanding for Support to Tactical Operations (ACUSTO): Annotated Bibliography for The Effect of Data Quality on Spatial Analysis Results, by L. Galvis and W.D. Meyer

Proceedings of the ERDC-CERL Net Zero Energy (NZE) Installation and Deployed Bases Workshop: Colorado Springs, CO, 3-4 Feb 2009, by C.A. Feickert, T.J. Hartranft, F.H. Holcomb, J.L. Vavrin, A.M. Zhivov, and H. Kim Quantico, VA Architectural Survey, by S. Stone, A. Smith, C. Pogorelac, and M.W. Tooker

ADA505447

ADA522285

Naval District Washington - Anacostia Annex Building Survey, by A. Smith and ADA523304

ADA508545 S. Stone 


\begin{tabular}{|c|c|c|c|}
\hline 1ERDC/CERL SR-09-13 & Sep 2009 & $\begin{array}{l}\text { Adaptive Reuse at Fort Bragg: Water } \\
\text { Treatment Plant and Ordnance Building, } \\
\text { by S. Lask, A. Smith, and S. Stone }\end{array}$ & \\
\hline ERDC/CERL SR-10-2 & Apr 2010 & $\begin{array}{l}\text { Tradeoffs for Renewable Energy Projects: } \\
\text { Environmental, Planning, and Mission } \\
\text { Considerations, by T.S. Smith, R.A. } \\
\text { Ducey, W.J. Stein, and W.D. Goran }\end{array}$ & ADA557322 \\
\hline 1ERDC/CERL SR-10-4 & May 2010 & $\begin{array}{l}\text { Capabilities Integration for Stakeholder } \\
\text { Asset-based Planning Environment - } \\
\text { Coalition Warfare (SHAPE CW), by G. Al- } \\
\text { Chaar and G.L. Cohen }\end{array}$ & ADB362481 \\
\hline ERDC/CERL SR-10-5 & Jun 2010 & $\begin{array}{l}\text { Fort Monroe Historic Landscape } \\
\text { Inventory, Evaluation, and } \\
\text { Recommendations, by M.W. Tooker, A. } \\
\text { Smith, C. Cochran, and C. Pogorelac }\end{array}$ & \\
\hline ERDC/CERL SR-10-6 & Jun 2015 & $\begin{array}{l}\text { OCONUS Compliance Assessment } \\
\text { Protocols -- OEBGD (Air Force and Marine } \\
\text { Corps Version) }\end{array}$ & ADA526808 \\
\hline ERDC/CERL SR-10-7 & Aug 2010 & $\begin{array}{l}\text { Demonstration of Deployable-Renewable } \\
\text { Energy Power Systems (D-REPS) at the } \\
\text { National Training Center, Fort Irwin, CA, } \\
\text { by R.A. Ducey, T. Abdallah, and B. O'Dell }\end{array}$ & \\
\hline ERDC/CERL SR-10-8 & Aug 2010 & $\begin{array}{l}\text { Fort Monroe Historic Image Report, by A. } \\
\text { Smith, M.W. Tooker, M. Roller and R. } \\
\text { Nicholson }\end{array}$ & ADA584064 \\
\hline ERDC/CERL SR-10-9 & Aug 2010 & $\begin{array}{l}\text { Fort Monroe Historic Viewsheds, by M.W. } \\
\text { Tooker, A. Smith, C. Cochran, and C. } \\
\text { Pogorelac }\end{array}$ & ADA572120 \\
\hline ERDC/CERL SR-11-1 & Jan 2011 & $\begin{array}{l}\text { Fort Bragg Old Post Historic District } \\
\text { Landscape Report, by M.W. Tooker, E. } \\
\text { Hartman, and A. Smith }\end{array}$ & ADA557326 \\
\hline ERDC/CERL SR-11-2 & Mar 2011 & $\begin{array}{l}\text { The Value of "Green" to the Army, by T.R. } \\
\text { Napier, A.L. Stumpf, R.L. Schneider, S.L. } \\
\text { Hunter, E.M. Jenicek, and D. Chu }\end{array}$ & ADA540767 \\
\hline ERDC/CERL SR-11-3 & Apr 2011 & $\begin{array}{l}\text { Fort Leonard Wood Culvert and Flagpole: } \\
\text { Historic American Engineering Record, by } \\
\text { C.J. Cochran and A. Smith }\end{array}$ & ADA544482 \\
\hline ERDC/CERL SR-11-4 & Jun 2011 & $\begin{array}{l}\text { Army LEED-Certified Projects, August } \\
2008 \text { - January } 2011 \text {, by R.L. Schneider } \\
\text { and J.A. Kane (Editors) }\end{array}$ & ADA552269 \\
\hline
\end{tabular}


ERDC/CERL SR-11-7

ERDC/CERL SR-11-8

ERDC/CERL SR-12-4

ERDC/CERL SR-12-6

ERDC/CERL SR-12-7

ERDC/CERL SR-12-8

ERDC/CERL SR-12-10

ERDC/CERL SR-12-12

ERDC/CERL SR-12-13

ERDC/CERL SR-12-15

ERDC/CERL SR-13-19
Jun 2011

Water Reuse and Wastewater Recycling at U.S. Army Installations: Policy

Implications, by R.J. Scholze

Aug 2011 Operational Energy Base Camp Studies: Annotated Bibliography, by W.T. Brown, III, L. Curvey, E. Zeigler, S. Foltz, D. Chu, J. Vavrin, G. Anderson, K. Kinnevan, G. Al-Chaar, S.L. Hunter, and F.H. Holcomb

May 2012 Installation Strategic Planning Guidebook, by K.S. Vann, D.R. DellaRovere, P.M. Loechl, and H.E. Balbach

Jun 2012

Energy Savings and Sustainability Opportunities at US Army Corps of Engineers Facilities: A Guide to Identify, Prioritize, and Estimate Projects at Complexes That Have Not Conducted a Facility-Level Energy and Water Evaluation, by D.M. Underwood and L. Curvey

May 2012

Initial Integrated Strategic Sustainability Plan for Fort Leonard Wood, by K.J.

Palmer, S.B. Nemeth, A.L. Stumpf, and S.J. Bevelheimer

Jul 2012

Emerging Challenges and Opportunities in Building Information Modeling for the US Army Installation Management Command, by B.A. Brucker, E.W. East, L.R. Marrano, M.P. Case, W.D. Goran, A. Carroll, and G. DeJesus

Sep 2012

Prediction and Adaptation of Military Natural Infrastructure in Response to Climate Change: Forest Modeling: Fiscal Year 2011 Progress Update, by P.J. Guertin, S.A. Tweddale, and G.Z. Gertner Sep 2012 2012 DoD Historic Building Workshop: After-Action Report for Legacy Project \# 10-387, by M. Michael and A.D. Smith

Sep 2012 Energy and Water Conservation Assessments: A Field Guide, by D.M. Underwood

Dec 2012 Energy Balance Calculations for an Anaerobic Membrane Bioreactor, by C.A. Feickert, K. Guy, and M. Page

Sep 2013 Analysis of Building 839: Carlisle Barracks, Pennsylvania, by A.D. Smith, S.I. Enscore, and M.W. Tooker

ADA546435

ADA557355

ADA566173

ADA570208

ADA572606

ADA570386

ADA586630

ADA570077

ADA602276 


\begin{tabular}{|c|c|c|c|}
\hline ERDC/CERL SR-14-2 & Sep 2014 & $\begin{array}{l}\text { Elevated Building Lift Systems on } \\
\text { Permanent Snowfields: A Report on he } \\
\text { Elevated Building Lift Systems in Polar } \\
\text { Environments Workshop, by J. Weale, L. } \\
\text { Barna, W. Tobiasson, and J. Mercer }\end{array}$ & \\
\hline ERDC/CERL SR-14-3 & Apr 2014 & $\begin{array}{l}\text { Fort Leonard Wood - Building 2101: } \\
\text { Interior Character-Defining Features, } \\
\text { Inventory and Assessment, by A.D. Smith }\end{array}$ & ADA601349 \\
\hline ERDC/CERL SR-14-6 & Aug 2014 & $\begin{array}{l}\text { Matthew Jones House: Historic } \\
\text { Maintenance and Repair Manual, by A.D. } \\
\text { Smith and S.E. Adams }\end{array}$ & ADA611653 \\
\hline ERDC/CERL SR-14-7 & Aug 2014 & $\begin{array}{l}\text { OPAL Land Condition Model, by D. Koch, } \\
\text { S. Tweddale, J. Westervelt, N. Myers, and } \\
\text { H. Howard }\end{array}$ & ADA607639 \\
\hline ERDC/CERL SR-14-8 & Sep 2014 & $\begin{array}{l}\text { Forest Microclimate Characteristics } \\
\text { Review: An Annotated Bibliography, by R. } \\
\text { Keane, H. Pitstick, P.J. Guertin, and D.L. } \\
\text { Gebhart }\end{array}$ & ADA610112 \\
\hline${ }^{1}$ ERDC/CERL SR-14-9 & Sep 2015 & $\begin{array}{l}\text { Air Maneuver Network (AMN) Software: } \\
\text { AMN User Guide }\end{array}$ & ADB403700 \\
\hline ERDC/CERL SR-14-11 & Dec 2014 & $\begin{array}{l}\text { Fiscal Year } 2013 \text { Net Zero Energy-Water- } \\
\text { Waste Portfolio for Fort Leonard Wood, } \\
\text { by A.L. Stumpf, M.P. Case, M.M. } \\
\text { Swanson, B.P. Barnes, S.J. Bevelheimer, } \\
\text { M. Choi, S.D. Cosper, L. Curvey, J. Flores, } \\
\text { N. Garfinkle, D.L. Gebhart, E.M. Jenicek, } \\
\text { R.J. Liesen, T.R. Napier, and G. Rodriguez }\end{array}$ & ADA614646 \\
\hline
\end{tabular}

\section{Technical notes}

\begin{tabular}{|c|c|}
\hline Report Number & Date \\
\hline ERDC/CERL TN -00-1 & Feb 2000 \\
\hline ERDC/CERL TN-00-2 & Mar 2000 \\
\hline ERDC/CERL TN-00-3 & May 2000 \\
\hline ERDC/CERL TN-00-4 & Nov 2000 \\
\hline
\end{tabular}

Title

Geospatial Data Computer-Based Training, by K. Dilks, J. Miller, A. Patel and J. Cookas

AMC Spatial Data Quality Control Project GPS and Data Management Tutorial, by A.K. Patel, J. Miller, J. Cookas, K. Dilks, and T. Vorac

Development of the Training Use Distribution Model (TUDM) Software, by W.D. Meyer and P.J. Guertin

Multi-tiered Vegetation Mapping - Matching Multiple User Requirements to Map Requirements, by P.M. Loechl and L.J. O'Neil

1 Limited distribution; see Preface. 
ERDC/CERL TN-01-1

ERDC/CERL TN-01-2

ERDC/CERL TN-01-2

REV.

ERDC/CERL TN-02-1

ERDC/CERL TN-02-2

ERDC/CERL TN-02-2

REV.

ERDC/CERL TN-02-3

ERDC/CERL TN-02-4

ERDC/CERL TN-03-1

ERDC/CERL TN-03-4

ERDC/CERL TN-04-1

ERDC/CERL TN-04-2

ERDC/CERL TN-04-3

ERDC/CERL TN-04-3

REV.

ERDC/CERL TN-04-4

Sep 2004

ERDC/CERL TN-05-1

Sep 2005

ERDC/CERL TN-05-2

Feb 2001

Nov 2001

Aug 2006

Oct 2002

Oct 2002

Sep 2003

Oct 2002

Oct 2002

Apr 2003

Jul 2003

Jan 2004

May 2004

Jun 2004

Apr 2005

Oct 2005
Proactive Options with Neighbors for Defenseinstallation Sustainability: PONDS ${ }^{\mathrm{TM}}$ : A Web Capability to Support Installations \& Communities Working Together, by S. Loechl and A. Stumpf

The Field of a Sound Source Reflected from a Hard Ground, by G.W. Swenson, Jr. and M.J. White

Energy Trends and Implications for U.S. Army Installations, by E.T. Westervelt and D.F. Fournier

Geospatial Data Repository - Sharing Data Across the Organization and Beyond, by M.O. Ruiz

mLEAM - the Military Land Use Evolution and Impact Assessment Model, by B. Deal

Land Use Evolution \& Impact Assessment Model: Forecasting Future Urban Development and Resulting Impacts on the Military and the Community, by N.R.D. Myers, J.D. Westervelt, J. Terstriep, and W.D. Goran

Building a Computable Facility Model, by B. Brucker Integrated Installation Planning: Technology for Sustainable Installations, by K. Dilks

Integrated Installation Planning: Technology for Sustainable Installations, by K. Dilks, T. Bosada, and M. Case

Dynamic Modeling and Simulation Tools for Utility Systems, by V. Hock, V. VanBlaricum, and W. Taylor

Modeling and Simulation for Force Protection, by D.M. Bailey

Sustaining Military Training Capabilities: Fort Future: Solutions for Installation Transformation, by J.D. Westervelt and W. Goran

Analysis of Regional Risks to Military Installations (ARR$\mathrm{MI})$, by R. Lozar

SEMP Historical Meteorology Evaluation for the Area Near Fort Benning, GA: 1999-2001, by R.C. Lozar

Capability Gap Analysis: Environmental Quality / Installations, by D.L. Johnson. T.A Bozada, R.M. Lacey, T. Hartranft, K. Topudurti, M.J. Hansen, G.W. Schanche, M. Marlatt, W.D. Severinghaus, D.K. Hicks, M.P. Case, D.E. Ellsworth, and W.D. Goran

PONDS: Proactive Options with Neighbors for Defenseinstallation Sustainability, by S. Loechl and A. Stumpf

Ambient Light Encroachment at Military Installations, by R.C. Lozar and R. Schneider 


\begin{tabular}{|c|c|c|}
\hline ERDC/CERL TN-06-1 & Jan 2006 & $\begin{array}{l}\text { Knowledge-Based Inspection Capabilities, by L.R. } \\
\text { Marrano and M.N. Grussing }\end{array}$ \\
\hline ERDC/CERL TN-06-2 & Jan 2006 & $\begin{array}{l}\text { Building-Level Functionality Assessment, by L.R. } \\
\text { Marrano and M.N. Grussing }\end{array}$ \\
\hline ERDC/CERL TN-06-3 & Apr 2006 & $\begin{array}{l}\text { Waterless Urinals: A Technical Evaluation, by A.L. } \\
\text { Stumpf }\end{array}$ \\
\hline ERDC/CERL TN-07-1 & Dec 2007 & $\begin{array}{l}\text { Strategic Sustainability Assessment, by E. Jenicek, D. } \\
\text { Fournier, N. Myers, and B. Deal }\end{array}$ \\
\hline ERDC/CERL TN-08-1 & May 2008 & $\begin{array}{l}\text { Evaluating the Potential for Vehicle Transport of } \\
\text { Propagules of Invasive Species, by H. Balbach, L. Rew, } \\
\text { and J. Fleming }\end{array}$ \\
\hline ERDC/CERL TN-08-2 & May 2008 & $\begin{array}{l}\text { Center for the Advancement of Sustainability } \\
\text { Innovations, by W.D. Gordan, M. Hanson, and A. Stumpf }\end{array}$ \\
\hline ERDC/CERL TN-09-1 & Jan 2009 & $\begin{array}{l}\text { Actionable Cultural Understanding for Support to } \\
\text { Tactical Operations Project in the Geographic Evidence } \\
\text { Reasoning Work Package, by W.D. Meyer and L.A. } \\
\text { Whalley }\end{array}$ \\
\hline ERDC/CERL TN-11-1 & Jan 2011 & $\begin{array}{l}\text { Center for the Advancement of Sustainability } \\
\text { Innovations: Work Plan Calendar Year 2011, by W.D. } \\
\text { Gordan, M. Hanson, and A. Stumpf }\end{array}$ \\
\hline ERDC/CERL TN-11-2 & Jul 2011 & $\begin{array}{l}\text { Net Zero Water for Army Installations: Consideration for } \\
\text { Policy and Technology, by E.M. Jenicek, L.E. Curvey, A.L. } \\
\text { Stumpf, and K. Fishman }\end{array}$ \\
\hline ERDC/CERL TN-12-2 & Jul 2012 & $\begin{array}{l}\text { Contingency Bases and the Problem of Sociocultural } \\
\text { Context, by D.A. Krooks, L.A. Whalley, and H.G. } \\
\text { Anderson }\end{array}$ \\
\hline ERDC/CERL TN-13-1 & Feb 2013 & $\begin{array}{l}\text { Center for the Advancement of Substainability } \\
\text { Innovations (CASI), by W.D. Gordan, M. Hanson, and A. } \\
\text { Stumpf }\end{array}$ \\
\hline ERDC/CERL TN-13-2 & Sep 2013 & $\begin{array}{l}\text { Onsite Army Biofuel Production: Opportunities, } \\
\text { Thresholds, and Considerations, by N.R. Myers, H.R. } \\
\text { Howard, D.L. Gebhart, N.M. Josefik, and M. Sharif }\end{array}$ \\
\hline ERDC/CERL TN-14-1 & Mar 2014 & $\begin{array}{l}\text { Center for the Advancement of Sustainability } \\
\text { Innovations (CASI) Work Plan: Calendar Year 2014, by } \\
\text { W.D. Gordan, M. Hanson, A. Stumpf, and E. Zeigler }\end{array}$ \\
\hline
\end{tabular}

\section{Technical reports}

ERDC/CERL TN-11

Title $\quad \underline{\text { AD Number }}$

ERDC/CERL TR-99-89 Nov 1999

Electrochemical Reduction of

ADA372795

Dinitrotoluene, by S. Pehkonen, J.L.

Jolas, D. Meenakshisundaram, and S.W. Maloney 
ERDC/CERL TR-99-90 Nov 1999

ERDC/CERL TR-99-91

ERDC/CERL TR-99-92

ERDC/CERL TR-99-93

ERDC/CERL TR-99-94

ERDC/CERL TR-99-95

Dec 1999

ERDC/CERL TR 99-99

Dec 1999

ERDC/CERL TR-99-104

ERDC/CERL TR-99-102

ERDC/CERL TR-99-107

ERDC/CERL TR-99-108

Nov 1999

Nov 1999

Nov 1999

Nov 1999

Dec 1999

Dec 1999
Data Warehouse Architecture for Army Installations, by P.V. Reddy and C.G. Schroeder

Performance Analysis of Natural Gas Cooling Technology at Air Force Bases; Youngstown-Warren ARS and WarnerRobins AFB, Fiscal Year 1999, by W.T. Brown III

CERL Noise Monitoring and Warning System 98, by D. Sachs, J.W. Benson, and P.D. Schomer

Greaseless Bushings for Hydropower Applications: Program, Testing, and Results, by J.A. Jones, R.A. Palylyk, P. Willis, and R.A. Weber

TNT and RDX Degradation by Cell-Free Extracts of Clostridium acetobutylicum, by N. Adrian and E. Campbell

Dec 1999 Training Effects Assessment and Reporting for Installations Implementing the 1996 Management Guidelines for the Red-cockaded Woodpecker (RCW) on Army Installations, by T.J. Hayden

Dec 1999 Effects of Microbiotic Soil Crust Organisms and Mycorrhizal Fungi on Seedling Growth of Blackbrush (Coleogyne ramosissima), by R.L. Pendleton, B.K. Pendleton, and G.L. Howard
ADA372690

ADA371091

ADA372654

ADA371755

ADA371882

ADA371555

ADA373526

ADA371845

ADA371924

ADA374116

ADA374242 


\begin{tabular}{|c|c|c|c|}
\hline ERDC/CERL TR-00-1 & Jan 2000 & $\begin{array}{l}\text { Bus Current Feedback for Motor Control, } \\
\text { by H.T. Maase, J.A. Locker, and P.T. Krein }\end{array}$ & ADA377502 \\
\hline ERDC/CERL TR-00-2 & Jun 2000 & $\begin{array}{l}\text { Improved Technologies for the Process } \\
\text { Energy and Pollution Reduction (PEPR) } \\
\text { Analysis Tool, by M.C. Lin, W.R. King, and } \\
\text { R.T. Loran }\end{array}$ & ADA380077 \\
\hline ERDC/CERL TR-00-3 & Jan 2000 & $\begin{array}{l}\text { Assessment for Desiccant Cooling Air- } \\
\text { Conditioning at Antilles High School, Fort } \\
\text { Buchanan, Puerto Rico: Moisture Load } \\
\text { Analysis of the Gymnasium Building, by } \\
\text { J. Barreto-Acobe and M.J. Savoie }\end{array}$ & ADA384111 \\
\hline ERDC/CERL TR-00-4 & Jun 2000 & $\begin{array}{l}\text { Heating, Ventilating, and Air-Conditioning } \\
\text { Controls and Related Systems at Antilles } \\
\text { High School, Fort Buchanan, Puerto } \\
\text { Rico: Condition Assessment Report, by } \\
\text { M.J. Savoie, L. Lister, D.M. Schwenk, and } \\
\text { J. Barreto }\end{array}$ & ADA384104 \\
\hline ERDC/CERL TR-00-5 & Feb 2000 & $\begin{array}{l}\text { Stochastic Models of Plant Diversity: } \\
\text { Application to White Sands Missile } \\
\text { Range, by X. Cao, G.Z. Gertner, B.A. } \\
\text { MacAllister, and A.B. Anderson }\end{array}$ & ADA374140 \\
\hline ERDC/CERL TR-00-6 & Feb 2000 & $\begin{array}{l}\text { Sol-Gel Stabilization of Heavy Metal } \\
\text { Waste, by D. Cropek, P. Kemme, J. Day, } \\
\text { and J. Barrios }\end{array}$ & ADA375073 \\
\hline 1ERDC/CERL TR-00-7 & Jun 2000 & $\begin{array}{l}\text { An Improved Method for Spatial } \\
\text { Extrapolation of Vegetative Cover } \\
\text { Estimated (USLE/RUSLE C FACTOR) } \\
\text { Using LCTA and Remotely Sensed } \\
\text { Imagery, by S.A. Tweddale, C.R. } \\
\text { Echlschlaeger, and W.F. Seybold }\end{array}$ & ADB258311 \\
\hline 1ERDC/CERL TR-00-8 & Jun 2000 & $\begin{array}{l}\text { Validation of Enhancements to the } \\
\text { Universal Soil Loss Equation Topographic } \\
\text { Factor Using 137Cesium, by S.D Warren, } \\
\text { H. Mitasova, D.L. Gebhart, M.G. } \\
\text { Hohmann, S. Landsberger, and F.Y. } \\
\text { Iskander }\end{array}$ & \\
\hline ERDC/CERL TR-00-9 & Apr 2000 & $\begin{array}{l}\text { Treatment of Volatile Organic } \\
\text { Compounds From Gas Streams Using a } \\
\text { Three-Phase Circulating-Bed Biofilm } \\
\text { Reactor, by B.J. Kim, H. Yu, and B.E. } \\
\text { Rittman }\end{array}$ & ADA377606 \\
\hline${ }^{1}$ ERDC/CERL TR-00-10 & Jun 2000 & $\begin{array}{l}\text { Evaluation of the Maneuver Impact } \\
\text { Distribution Map and Its Use in ATTACC, } \\
\text { by P.J. Guertin }\end{array}$ & ADB326559 \\
\hline
\end{tabular}

1 Limited distribution; see Preface. 


\begin{tabular}{|c|c|c|c|}
\hline 1ERDC/CERL TR-00-11 & Apr 2000 & $\begin{array}{l}\text { Design and Construction Review of a } \\
\text { Fire-Flow System at Doha, Qatar, by C.P. } \\
\text { Marsh, O.S. Marshall, I.R. Adiguzel, D.A. } \\
\text { Kessler }\end{array}$ & ADB257799 \\
\hline ERDC/CERL TR-00-12 & Apr 2000 & $\begin{array}{l}\text { Errors in Environmental Assessments: An } \\
\text { Error-Budget Model for Plant } \\
\text { Populations, by X. Cao, G. Gertner, B. } \\
\text { MacAllister, and A. Anderson }\end{array}$ & ADA377507 \\
\hline ERDC/CERL TR-00-13 & May 2000 & $\begin{array}{l}\text { Assessment of Training Noise Impacts on } \\
\text { the Red-Cockaded Woodpecker: } 1999 \\
\text { Results, by D.K. Delaney, L.L. Pater, T.J. } \\
\text { Hayden, L. Swindell, T. Beaty, L. Carlile, } \\
\text { and E. Spadgenske }\end{array}$ & ADA379281 \\
\hline ERDC/CERL TR-00-14 & May 2000 & $\begin{array}{l}\text { Sonolysis of Nitrocellulose Fines, by D. } \\
\text { Cropek and B. Dankowski }\end{array}$ & ADA377921 \\
\hline ERDC/CERL TR-00-15 & Dec 2000 & $\begin{array}{l}\text { Site Evaluation for Application of Fuel } \\
\text { Cell Technology, by M.J. Binder, F.H. } \\
\text { Holcomb, and W.R. Taylor }\end{array}$ & ADA386257 \\
\hline ERDC/CERL TR-00-16 & Aug 2000 & $\begin{array}{l}\text { Installation-Wide GIS Implementation } \\
\text { Issues, by D.L. Szafoni, J.J. Casanova, } \\
\text { D.M. Johnston, and K.M. Dilks }\end{array}$ & ADA381648 \\
\hline ERDC/CERL TR-00-17 & Aug 2000 & $\begin{array}{l}\text { Removing the Veil: Interest of Military } \\
\text { Land Managers in Using Declassified } \\
\text { and Classified Imagery, by R.C. Lozar, W. } \\
\text { Smith, W. Croisant, G. Rasmussen, and } \\
\text { T. Hale }\end{array}$ & ADA382738 \\
\hline ERDC/CERL TR-00-18 & Jun 2000 & $\begin{array}{l}\text { Performance Testing of Fiber-Reinforced } \\
\text { Polymer Composite Overlays for Seismic } \\
\text { Rehabilitation of Unreinforced Masonry } \\
\text { Walls, by O.S. Marshall, Jr., S.C. Sweeney, } \\
\text { and J.C. Trovillion }\end{array}$ & ADA381207 \\
\hline ERDC/CERL TR-00-19 & Oct 2000 & $\begin{array}{l}\text { Sonochemical Degradation Reactions of } \\
\text { Nitrobenzene: Oxidation, Reduction, and } \\
\text { Dimerization, D.M. Cropek }\end{array}$ & ADA382803 \\
\hline ERDC/CERL TR-00-20 & Aug 2000 & $\begin{array}{l}\text { Quality Assurance/Quality Control } \\
\text { Procedures for ITAM GIS Databases, by } \\
\text { D.M. Johnston, D.M. Timlin, D.L. Szafoni, } \\
\text { J.J. Casanova, and K.M. Dilks }\end{array}$ & ADA382487 \\
\hline ERDC/CERL TR-00-21 & Jul 2000 & $\begin{array}{l}\text { Fort Hood Land Management System } \\
\text { (LMS) Military Field Application Site } \\
\text { FYOO In-Progress Review, by B.A. } \\
\text { McAllister, A.B. Anderson, and W. Goran }\end{array}$ & ADA380338 \\
\hline
\end{tabular}

\footnotetext{
1 Limited distribution; see Preface.
} 


\begin{tabular}{|c|c|c|c|}
\hline ERDC/CERL TR-00-22 & Aug 2000 & $\begin{array}{l}\text { Air National Guard ECAMP: Analysis of } \\
\text { the Compliance Assessment Process, by } \\
\text { D. J. Schell }\end{array}$ & ADA382479 \\
\hline ERDC/CERL TR-00-23 & Aug 2000 & $\begin{array}{l}\text { An Infrared Spectroscopic Study of the } \\
\text { Vapor Adsorption of Nitroglycerin and } \\
\text { Pentaerythritol Tetranitrate on Chrysotile } \\
\text { Asbestos, by M.J. Hanson, R.L. } \\
\text { Schneider, B. Berger, A. DeGuzman, D.M. } \\
\text { Cropek, and P.A. Kemme }\end{array}$ & ADA382665 \\
\hline ERDC/CERL TR-00-24 & Aug 2000 & $\begin{array}{l}\text { Condition Assessment of Building } 6237 \text {, } \\
\text { Old Hospital Complex, Fort Carson, CO, } \\
\text { by T.R. Napier and S.A. McCarthy }\end{array}$ & ADA382030 \\
\hline ERDC/CERL TR-00-25 & Aug 2000 & $\begin{array}{l}\text { Electrical and Natural Gas Rates for } \\
\text { Cooling in Major Army Installations, by } \\
\text { C.A. Feickert and C.W. Sohn }\end{array}$ & ADA382337 \\
\hline 1ERDC/CERL TR-00-26 & Sep 2000 & $\begin{array}{l}\text { Receptacle Load Measurements for } \\
\text { Basement / Mezzanine Segment 1, } \\
\text { Pentagon Renovation Project, by P.H. } \\
\text { Nielsen, S.J. Briggs, and L. Lister }\end{array}$ & ADB260306 \\
\hline ERDC/CERL TR-00-27 & Dec 2000 & $\begin{array}{l}\text { Historic Landscape Inventory for the U.S. } \\
\text { Military Academy at West Point, New } \\
\text { York, by D. Timlin and S.K. Loechl }\end{array}$ & ADA392153 \\
\hline ERDC/CERL TR-00-28 & Oct 2000 & $\begin{array}{l}\text { Environmental Management Information } \\
\text { System (EMIS) at Watervilet Arsenal, NY, } \\
\text { by J.I. Northrup, J.C. Boyd, P. Darcy, and } \\
\text { D.J. Schiller }\end{array}$ & ADA383234 \\
\hline ERDC/CERL TR-00-29 & Sep 2000 & $\begin{array}{l}\text { Critical Evaluation of Lock Automation } \\
\text { and Control Equipment at Corps- } \\
\text { Operated Navigation Locks, by P. Wilson, } \\
\text { L.D. Stephenson, and A. Kumar }\end{array}$ & ADA383865 \\
\hline $\begin{array}{l}\text { ERDC/CERL TR-00-29 } \\
\text { 2nd ed. }\end{array}$ & Jul 2001 & $\begin{array}{l}\text { Critical Evaluation of Lock Automation } \\
\text { and Control Equipment at Corps- } \\
\text { Operated Navigation Locks, by P. Wilson, } \\
\text { L.D. Stephenson, and A. Kumar }\end{array}$ & ADA397446 \\
\hline ERDC/CERL TR-00-30 & Jun 2000 & $\begin{array}{l}\text { Visualization in Collaborative } \\
\text { Engineering Design, by P.M. Jones, B.A. } \\
\text { Brucker, V.J. Woods, and B.F. Adeoye }\end{array}$ & ADA383864 \\
\hline ERDC/CERL TR-00-31 & Nov 2000 & $\begin{array}{l}\text { Analysis of Energetic Material Detection } \\
\text { Technologies for Use at Army Energetic } \\
\text { Material Production Facilities, by M.J. } \\
\text { Hanson, L.R. Gizzi, and R.L. Schneider }\end{array}$ & ADA383646 \\
\hline
\end{tabular}




\begin{tabular}{|c|c|c|}
\hline 1ERDC/CERL TR-00-32 & Dec 2000 & $\begin{array}{l}\text { Integrated Smart Building Conceptual } \\
\text { Design for Rodman Materials Research } \\
\text { Laboratory }\end{array}$ \\
\hline ERDC/CERL TR-00-33 & Dec 2000 & $\begin{array}{l}\text { Phosphoric Acid Fuel Cells, by F.H. } \\
\text { Holcomb, M.J. Binder, W.R. Taylor, J.M. } \\
\text { Torrey, and J.F. Westerman }\end{array}$ \\
\hline ERDC/CERL TR-00-34 & Nov 2000 & $\begin{array}{l}\text { Molten Carbonate Fuel Cells (MCFCs) for } \\
\text { Department of Defense Applications, } \\
\text { Rock Island Arsenal MCFC, by F.H. } \\
\text { Holcomb, M.J. Binder, W.R. Taylor, V. } \\
\text { Petraglia, R. Ishii, J. Klingenberg, B. } \\
\text { Sliwinski, L. Griffith, and D. Punwani }\end{array}$ \\
\hline ERDC/CERL TR-00-35 & Nov 2000 & $\begin{array}{l}\text { Marine Corps Air Ground Combat Center } \\
\text { (MCAGCC) Land Management System } \\
\text { (LMS) Military Field Application Site FYOO } \\
\text { In-Process Review, by H.R. Howard, D. } \\
\text { Gebhart, and W. Goran }\end{array}$ \\
\hline ERDC/CERL TR-00-36 & Nov 2000 & $\begin{array}{l}\text { FY99 Lessons Learned from Central } \\
\text { Energy Plant Modernization Site Visits, } \\
\text { by W.T. Brown, M.K. Brewer, C.P. Marsh, } \\
\text { V.L. Van Blaricum, G.E. Phetteplace, M.J. } \\
\text { Savoie, V.F. Hock, P.J. Connor, and H.C. } \\
\text { Gignilliat }\end{array}$ \\
\hline ERDC/CERL TR-00-37 & Nov 2000 & $\begin{array}{l}\text { Compressed Air System Survey at Sierra } \\
\text { Army Depot, CA, by M.C.J. Lin, A.R. Ganji, } \\
\text { S. Liou, and B. Hackett }\end{array}$ \\
\hline ERDC/CERL TR-00-38 & Nov 2000 & $\begin{array}{l}\text { Electrochemical Reduction of } \\
\text { Energetically Contaminated Wastewater: } \\
\text { Development and Testing of Pilot Scale } \\
\text { Reactor, by R. Doppalapudi, D. } \\
\text { Palaniswamy, S.W. Maloney, and G. } \\
\text { Sorial }\end{array}$ \\
\hline ERDC/CERL TR-00-39 & Dec 2000 & $\begin{array}{l}\text { Scoping Report for a Scenario-Based } \\
\text { Planning Protocol for Application in the } \\
\text { Regions of Army Installations, by W.H. } \\
\text { Rose, R.C. Lozar, and R.L. Schneider }\end{array}$ \\
\hline ERDC/CERL TR 00-40 & Dec 2000 & $\begin{array}{l}\text { Designing Coalescing Oil/Water } \\
\text { Separators for Use at Army Washracks, } \\
\text { by G.L. Gerdes, A. DeGuzman, and J. } \\
\text { Grubich }\end{array}$ \\
\hline ERDC/CERL TR-00-41 & Dec 2000 & $\begin{array}{l}\text { Fort Hamilton, New York: Historic } \\
\text { Landscape Inventory, by A. Smith and } \\
\text { S.K. Loechl }\end{array}$ \\
\hline
\end{tabular}

ADB265031

ADA386669

ADA384824

ADA385036

ADA384601

ADA384166

ADA385011

ADA385411

ADA385994

ADA385918 S.K. Loechl

1 Limited distribution; see Preface. 


\begin{tabular}{|c|c|c|c|}
\hline ERDC/CERL TR-00-42 & Dec 2000 & $\begin{array}{l}\text { Reproductive Ecology of the Sandhills } \\
\text { Pyxie Moss (Pyxidanthera barbulata var. } \\
\text { brevifolia) in North Carolina, by A. } \\
\text { Shapiro, J. Zimpfer, and M. Bates }\end{array}$ & ADA386590 \\
\hline ERDC/CERL TR-00-43 & Dec 2000 & $\begin{array}{l}\text { An Evaluation of DGPS-Based } \\
\text { Continuously Operating Vehicle } \\
\text { Monitoring Systems to Determine Site- } \\
\text { Specific Event Severity Factors, by P. } \\
\text { Ayers, M. Vance, L. Haugen, and A.B. } \\
\text { Anderson }\end{array}$ & ADA385704 \\
\hline ERDC/CERL TR-00-44 & Nov 2000 & $\begin{array}{l}\text { Evaluation of Alkyd Primers, by O.S. } \\
\text { Marshall, Jr., and A.D. Beitelman }\end{array}$ & ADA390107 \\
\hline ERDC/CERL TR-00-45 & Dec 2000 & $\begin{array}{l}\text { Ergonomic Assessment of Navigation } \\
\text { Lock Control Rooms and Consoles, by J. } \\
\text { Pentikis }\end{array}$ & ADA389150 \\
\hline ERDC/CERL TR-00-46 & Dec 2000 & $\begin{array}{l}\text { Investigation of Terfenol-D for } \\
\text { Magnetostrictive Tagging of Fiber- } \\
\text { Reinforced Polymer Composites, by R.F. } \\
\text { Quattrone, J.B. Berman, J.C. Trovillion, } \\
\text { C.A. Feickert, J.M. Kamphaus, S.R. } \\
\text { White, V. Giurgiutiu, and G.L. Cohen }\end{array}$ & ADA389133 \\
\hline ERDC/CERL TR-01-1 & Jan 2001 & $\begin{array}{l}\text { Building Codes, Energy, and the } \\
\text { Environment: How Model Building Codes } \\
\text { Affect Sustanability, by B.M. Deal and } \\
\text { D.F. Fournier }\end{array}$ & ADA386072 \\
\hline ERDC/CERL TR-01-2 & Jan 2001 & $\begin{array}{l}\text { Reducing Motorpool Oil/Water Separator } \\
\text { Management Costs, by G.L. Gerdes, M.J. } \\
\text { Hanson, S.D. Cosper, S.J. Bevelheimer, } \\
\text { and L.W. Overbay }\end{array}$ & ADA387154 \\
\hline ERDC/CERL TR-01-3 & Jan 2001 & $\begin{array}{l}\text { Site Evaluation for Application of Fuel } \\
\text { Cell Technology: Naval Oceanographic } \\
\text { Office, John C. Stennis Space Center, } \\
\text { MS, by M.J. Binder, F.H. Holcomb, and } \\
\text { W.R. Taylor }\end{array}$ & ADA387238 \\
\hline ERDC/CERL TR-01-4 & Jan 2001 & $\begin{array}{l}\text { Field Test Results of an Anti- } \\
\text { Scale/Corrosion Resistant Coating for } \\
\text { Hot Water Heat Exchangers, by V.F. Hock, } \\
\text { H. Cardenas, R.H. Knoll and V. Hall }\end{array}$ & ADA386775 \\
\hline ERDC/CERL TR-01-5 & Feb 2001 & $\begin{array}{l}\text { Treatment of Heavy Metal Contaminated } \\
\text { Waste, by D.M. Cropek, J. Day, D. Curtin, } \\
\text { and P.A. Kemme }\end{array}$ & ADA386551 \\
\hline ERDC/CERL TR-01-6 & Jan 2001 & $\begin{array}{l}\text { Demonstration of Anti-Scale Corrosion } \\
\text { Resistant Coatings for Hot Water Heat } \\
\text { Exchangers, by V.F. Hock, H. Cardenas, } \\
\text { R.H. Knoll and V. Hall }\end{array}$ & ADA386805 \\
\hline
\end{tabular}


ERDC/CERL TR-01-7

ERDC/CERL TR-01-8

ERDC/CERL TR-01-9

ERDC/CERL TR-01-10

ERDC/CERL TR-01-11

ERDC/CERL TR-01-12

ERDC/CERL TR-01-13

ERDC/CERL TR-01-14

ERDC/CERL TR-01-15

ERDC/CERL TR-01-16

ERDC/CERL TR-01-17

ERDC/CERL TR-01-18
Mar 2001

Population Viability of Avian Endangered

ADA388185

Species: the PVAvES Program, by R.H.

Melton, L.A. Jette, T.J. Hayden, and T.A.

Beaty

Jan 2001 Improving Design Communication:

Advanced Visualization, by B.F. Adeoye

Feb 2001 Energy Manager Project Assistant: User Manual, by E.M. Jenicek, D.F. Fournier, and $A$. Uzgiris

Feb 2001 Characterization of Microbial Communities in an Anaerobic Fluidized Bioreactor Treating TNT Using Molecular Technologies, by N.R. Adrian, R.A. Sanford, S.H. Oh, and L. Raskin

Feb 2001

Structural Evaluation of Aircraft Hangar 46, Corpus Christi Army Depot, by G.K. Al-Chaar, D.J. Randolph, G.E. Lamb, and P.J. Desai

Feb 2001

Heating, Ventilating, and Air-Conditioning Controls Operations and Maintenance Field Manual, by D.M. Schwenk and R.L. Strohl

Feb 2001

Site Evaluation for Application of Fuel Cell Technology: Fort Bliss, TX, by M.J. Binder, F.H. Holcomb, and W.R. Taylor

Feb 2001 Site Evaluation for Application of Fuel Cell Technology: Fort Huachuca, AZ, by M.J. Binder, F.H. Holcomb, and W.R. Taylor

Mar 2001

Site Evaluation for Application of Fuel Cell Technology: Naval Air Station Fallon, Fallon, NV, by M.J. Binder, F.H. Holcomb, and W.R. Taylor

Feb $2001 \quad$ Site Evaluation for Application of Fuel Cell Technology: Construction Battalion Center, Port Hueneme, CA, by M.J. Binder, F.H. Holcomb, and W.R. Taylor

Feb 2001 Site Evaluation for Application of Fuel Cell Technology: Fort Eustis, VA, by M.J. Binder, F.H. Holcomb, and W.R. Taylor

Feb 2001 Site Evaluation for Application of Fuel Cell Technology: Watervliet Arsenal, NY, by M.J. Binder, F.H. Holcomb, and W.R. Taylor
ADA387320

ADA387379

ADA388042

ADA386649

ADA396130

ADA388689

ADA388692

ADA388694

ADA388670

ADA388691

ADA388687 
ERDC/CERL TR-01-19

ERDC/CERL TR-01-20

ERDC/CERL TR-01-21

ERDC/CERL TR-01-22

ERDC/CERL TR-01-23

ERDC/CERL TR-01-24

ERDC/CERL TR-01-25

ERDC/CERL TR-01-26

ERDC/CERL TR-01-27

ERDC/CERL TR-01-28

ERDC/CERL TR-01-29
Feb 2001

Site Evaluation for Application of Fuel

ADA388695

Cell Technology, 911th Airlift Wing, Pittsburgh, PA, by M.J. Binder, F.H.

Holcomb, and W.R. Taylor

Feb 2001 Site Evaluation for Application of Fuel Cell Technology: Westover Air Reserve Base, MA, by M.J. Binder, F.H. Holcomb, and W.R. Taylor

Feb 2001 Site Evaluation for Application of Fuel Cell Technology: Naval Education Training Center, Newport, RI, by M.J. Binder, F.H. Holcomb, and W.R. Taylor

Feb 2001 Site Evaluation for Application of Fuel Cell Technology: U.S. Naval Academy, Annapolis, MD, by M.J. Binder, F.H. Holcomb, and W.R. Taylor

Feb 2001

Site Evaluation for Application of Fuel Cell Technology: Davis-Monthan Air Force Base, AZ, by M.J. Binder, F.H. Holcomb, and W.R. Taylor

Feb 2001

Site Evaluation for Application of Fuel Cell Technology: Picatinny Arsenal, NJ, by M.J. Binder, F.H. Holcomb, and W.R. Taylor

Mar 2001

Energy-Efficient Lighting on U.S. Army Installations. Lighting Retrofit Survey, by E.M. Jenicek, C. Zimmer, and A. Uzgiris

Mar 2001 Endangered Species Management Plan for Fort Hood, Texas; FY01-05, by T.J. Hayden, J.D. Cornelius, H.J. Weinberg, L.L. Jette, and R.H. Melton

Mar 2001

Management System for Fluid Storage Tanks at Fort Lewis, WA, by J.I. Northrup, J.C. Baird, D.J. Schiller, and J.F. Lee

Apr $2001 \quad$ Site Evaluation for Application of Fuel Cell Technology: U.S. Military Academy, West Point, NY, by M.J. Binder, F.H. Holcomb, and W.R. Taylor

Mar $2001 \quad$ Site Evaluation for Application of Fuel Cell Technology: Barksdale Air Force Base, LA, by M.J. Binder, F.H. Holcomb, and W.R. Taylor
ADA388699

ADA388693

ADA388690

ADA388843

ADA390021

ADA391771

ADA387495

ADA388102

ADA390930

ADA388784 


\begin{tabular}{|c|c|c|c|}
\hline ERDC/CERL TR-01-30 & Mar 2001 & $\begin{array}{l}\text { Site Evaluation for Application of Fuel } \\
\text { Cell Technology: Naval Hospital - Naval } \\
\text { Air Station Jacksonville, FL, by M.J. } \\
\text { Binder, F.H. Holcomb, and W.R. Taylor }\end{array}$ & ADA389158 \\
\hline ERDC/CERL TR-01-31 & Mar 2001 & $\begin{array}{l}\text { Site Evaluation for Application of Fuel } \\
\text { Cell Technology: Nellis Air Force Base, } \\
\text { NV, by M.J. Binder, F.H. Holcomb, and } \\
\text { W.R. Taylor }\end{array}$ & ADA390019 \\
\hline ERDC/CERL TR-01-32 & Mar 2001 & $\begin{array}{l}\text { Site Evaluation for Application of Fuel } \\
\text { Cell Technology: Naval Hospital - Marine } \\
\text { Corps Air Ground Combat Center } \\
\text { Twentynine Palms, CA, by M.J. Binder, } \\
\text { F.H. Holcomb, and W.R. Taylor }\end{array}$ & ADA389308 \\
\hline ERDC/CERL TR-01-33 & Mar 2001 & $\begin{array}{l}\text { Site Evaluation for Application of Fuel } \\
\text { Cell Technology: National Defense Center } \\
\text { for Environmental Excellence (NDCEE), } \\
\text { Johnstown, PA, by M.J. Binder, F.H. } \\
\text { Holcomb, and W.R. Taylor }\end{array}$ & ADA390025 \\
\hline ERDC/CERL TR-01-34 & Mar 2001 & $\begin{array}{l}\text { Environmental Compliance Assessment } \\
\text { Data: Analysis of Data Generated by the } \\
\text { Army's ECAS Program, by D.J. Schell }\end{array}$ & ADA389093 \\
\hline ERDC/CERL TR-01-35 & Jul 2001 & $\begin{array}{l}\text { Condition Prediction Model and } \\
\text { Component Interaction Fault Tree for } \\
\text { Heat Distribution Systems, by C.P. } \\
\text { Marsh, B.A. Temple, and A. Kim }\end{array}$ & ADA392920 \\
\hline ERDC/CERL TR-01-36 & Apr 2001 & $\begin{array}{l}\text { Historical Analysis of Land } \\
\text { Cover/Condition Trends at Fort Bliss, } \\
\text { Texas, Using Remotely Sensed Imagery, } \\
\text { by S.A. Tweddale }\end{array}$ & ADA392738 \\
\hline ERDC/CERL TR-01-37 & Aug 2001 & $\begin{array}{l}\text { Recycled Steel Abrasive Grit. Evaluation } \\
\text { of Rounding and its Effects on Adhesion, } \\
\text { by A.D. Beitelman }\end{array}$ & ADA401724 \\
\hline ERDC/CERL TR-01-38 & Mar 2001 & $\begin{array}{l}\text { Site Evaluation for Application of Fuel } \\
\text { Cell Technology: 934th Airlift Wing, } \\
\text { Minneapolis, MN, by M.J. Binder, F.H. } \\
\text { Holcomb, and W.R. Taylor }\end{array}$ & ADA390023 \\
\hline ERDC/CERL TR-01-39 & May 2001 & $\begin{array}{l}\text { Spatial and Temporal Prediction and } \\
\text { Uncertainty Analysis of Rainfall Erosivity } \\
\text { for the Revised Universal Soil Loss } \\
\text { Equation, by G. Wang, G. Gertner, V. } \\
\text { Singh, S. Shinkareva, P. Parysow, and } \\
\text { A.B. Anderson }\end{array}$ & ADA391025 \\
\hline ERDC/CERL TR-01-40 & May 2001 & $\begin{array}{l}\text { Demonstration of Onsite Wireless } \\
\text { Control of Lock Operating Machinery, by } \\
\text { L.D. Stephenson, P. Wilson, and A. } \\
\text { Kumar }\end{array}$ & ADA403371 \\
\hline
\end{tabular}




\begin{tabular}{|c|c|c|}
\hline ERDC/CERL TR-01-41 & Apr 2001 & $\begin{array}{l}\text { Site Evaluation for Application of Fuel } \\
\text { Cell Technology: Laughlin Air Force Base, } \\
\text { TX, by M.J. Binder, F.H. Holcomb, and } \\
\text { W.R. Taylor }\end{array}$ \\
\hline ERDC/CERL TR-01-42 & Apr 2001 & $\begin{array}{l}\text { Site Evaluation for Application of Fuel } \\
\text { Cell Technology: Fort Richardson, AK, by } \\
\text { M.J. Binder, F.H. Holcomb, and W.R. } \\
\text { Taylor }\end{array}$ \\
\hline ERDC/CERL TR-01-43 & Apr 2001 & $\begin{array}{l}\text { Site Evaluation for Application of Fuel } \\
\text { Cell Technology: Kirtland Air Force Base, } \\
\text { NM, by M.J. Binder, F.H. Holcomb, and } \\
\text { W.R. Taylor }\end{array}$ \\
\hline ERDC/CERL TR-01-44 & Apr 2001 & $\begin{array}{l}\text { Site Evaluation for Application of Fuel } \\
\text { Cell Technology: Subase New London, } \\
\text { Groton, CT, by M.J. Binder, F.H. Holcomb, } \\
\text { and W.R. Taylor }\end{array}$ \\
\hline ERDC/CERL TR-01-45 & May 2001 & $\begin{array}{l}\text { Integrating Remote Sensing and Field } \\
\text { Data to Monitor Changes in Vegetative } \\
\text { Cover on a Multipurpose Range Complex } \\
\text { and Adjacent Training Lands at Camp } \\
\text { Grayling, Michigan, by S. Tweddale, V. } \\
\text { Emrick, and W. Jackson }\end{array}$ \\
\hline
\end{tabular}

ADA389307

Cell Technology: Laughlin Air Force Base, X, by M.J. Binder, F.H. Holcomb, and

Site Evaluation for Application of Fuel

ADA389128

Cell Technology: Fort Richardson, AK, by

M.J. Binder, F.H. Holcomb, and W.R.

Site Evaluation for Application of Fuel

ADA389233

ERDC/CERL TR-01-46 May 2001

Geospatial Data Enterprise Repository: A ADA390487

Report on the Prototype for Fort Hood,

Texas, by M. Ruiz, D. Morrison, D.

Bouwman, K. McNinch, F. Schreiner, and

$S$. Forbes

ERDC/CERL TR-01-47

May 2001

Site Evaluation for Application of Fuel

Cell Technology: Little Rock Air Force

ADA390094

Base, AR, by M.J. Binder, F.H. Holcomb, and W.R. Taylor

ERDC/CERL TR-01-48 Nov 2001 A Fundamental Study of Biofiltration

ADA398734

Processes for VOC Removal From Waste

Gas Streams, by B.J. Kim, M.T. Suidan, X. Zhu, and C. Alonso

ERDC/CERL TR-01-49

May 2001

Site Evaluation for Application of Fuel

Cell Technology: U.S. Army Soldier

ADA389185

ADA390993

Systems Center, by M.J. Binder, F.H.

Holcomb, and W.R. Taylor

ERDC/CERL TR-01-50 Jun $2001 \quad$ Nonfacility Particulate Matter Issues in

ADA392018 the Army - A Comprehensive Review, by M.R. Kemme, J.C. Baird, D.L. Gebhart, M.G. Hohmann, H.R. Howard, D.A. Krooks, and J.I. Northrup

ADA390937 


\begin{tabular}{|c|c|c|c|}
\hline ERDC/CERL TR-01-51 & Jun 2001 & $\begin{array}{l}\text { Site Evaluation for Application of Fuel } \\
\text { Cell Technology: Naval Hospital - Marine } \\
\text { Corps Base, Camp Pendleton, CA, by M.J. } \\
\text { Binder, F.H. Holcomb, and W.R. Taylor }\end{array}$ & ADA390934 \\
\hline ERDC/CERL TR-01-52 & Jun 2001 & $\begin{array}{l}\text { Assessment of Training Noise Impacts on } \\
\text { the Red-Cockaded Woodpecker: } 2000 \\
\text { Results, by D.K. Delaney, L.L. Pater, L.L. } \\
\text { Swindell, T.A. Beaty, L.D. Cargile, and } \\
\text { E.W. Spadgenske }\end{array}$ & ADA392799 \\
\hline ERDC/CERL TR-01-53 & Jul 2001 & $\begin{array}{l}\text { Evaluation of Surface Preparation and } \\
\text { Application Parameters for Arc-Sprayed } \\
\text { Metal Coatings, by A.D. Beitelman and } \\
\text { W. Corbett }\end{array}$ & ADA401295 \\
\hline ERDC/CERL TR-01-54 & Aug 2001 & $\begin{array}{l}\text { EDYS Experimental and Validation } \\
\text { Results for Grassland Communities, by T. } \\
\text { McLendon, W.M. Childress, C. Coldren, } \\
\text { and D.L. Price }\end{array}$ & ADA396255 \\
\hline ERDC/CERL TR-01-55 & Jul 2001 & $\begin{array}{l}\text { Site Evaluation for Application of Fuel } \\
\text { Cell Technology: U.S. Coast Guard } \\
\text { Academy, New London, CT, by M.J. } \\
\text { Binder, F.H. Holcomb, W.R. Taylor, J.M. } \\
\text { Torrey, and J.F. Westerman }\end{array}$ & ADA395029 \\
\hline ERDC/CERL TR-01-56 & Jul 2001 & $\begin{array}{l}\text { Site Evaluation for Application of Fuel } \\
\text { Cell Technology: U.S. Coast Guard Air } \\
\text { Station Cape Cod, MA, by M.J. Binder, } \\
\text { F.H. Holcomb, W.R. Taylor, J.M. Torrey, } \\
\text { and J.F. Westerman }\end{array}$ & ADA395097 \\
\hline ERDC/CERL TR-01-57 & Aug 2001 & $\begin{array}{l}\text { Underground Storage Tank Location and } \\
\text { Mapping of Former Landfills by } \\
\text { Electromagnetic Surveys for the } \\
\text { Delaware National Guard, by P.H. Nielsen }\end{array}$ & ADA395231 \\
\hline ERDC/CERL TR-01-58 & Aug 2001 & $\begin{array}{l}\text { Performance Analysis of Natural Gas } \\
\text { Cooling Technology at Warner-Robins } \\
\text { AFB, GA: Fiscal Year 2000, by W.T. } \\
\text { Brown, III }\end{array}$ & ADA395030 \\
\hline $\begin{array}{l}\text { ERDC/CERL TR-01-59 } \\
\text { Vol. } 3\end{array}$ & Sep 2001 & $\begin{array}{l}\text { Methods for Field Studies of the Effects } \\
\text { of Military Smokes, Obscurants, and } \\
\text { Riot-Control Agents on Threatened and } \\
\text { Endangered Species. Volume 3: } \\
\text { Statistical Methods, by D.M. Cassels, A.J. } \\
\text { Krzysik, and K.A. Reinbold }\end{array}$ & ADA395028 \\
\hline ERDC/CERL TR-01-60 & Aug 2001 & $\begin{array}{l}\text { Site Evaluation for Application of Fuel } \\
\text { Cell Technology: Edwards Air Force Base, } \\
\text { CA, by M.J. Binder, F.H. Holcomb, and } \\
\text { W.R. Taylor }\end{array}$ & ADA395031 \\
\hline
\end{tabular}


ERDC/CERL TR-01-61

ERDC/CERL TR-01-62

ERDC/CERL TR-01-63

ERDC/CERL TR-01-64

ERDC/CERL TR-01-65

ERDC/CERL TR-01-66

ERDC/CERL TR-01-67

ERDC/CERL TR-01-68

ERDC/CERL TR-01-69

ERDC/CERL TR-01-70

ERDC/CERL TR-01-72
Aug 2001

A Catalog of Military Installation

ADA396729

Applications for Classified and

Declassified Satellite Imagery, by R.

Lozar, W. Smith, H. Adeyemi, O. Taylor, R. Jacokes, M.N. Malinas, M. Danjaji, T.

Flaxman, and A. Shearer

Aug 2001 Energy-Efficient Buildings Through

Design Automation, by K.D. McGraw and L.K. Lawrie

Sep 2001 Demonstration and Evaluation of Magnetic Descalers, by K.W. Smothers, C.D. Curtiss, B.T. Gard, R.H. Strauss, and V.F. Hock

Sep 2001

Incineration By-Products of AA2, NC Fines, and NG Slums, by D.M. Cropek, J.M. Day, and P.A. Kemme

Sep 2001

Applications Guide for Compressed Air Systems, by M.C.J. Lin and Y.E. Taha

Oct 2001 Pyrolytic Decomposition Studies of AA2, A Double-Base Propellent, by D.M. Cropek, P.A. Kemme, and J.M. Day

Nov 2001

An Evaluation of Application and Surface Preparation Parameters for Thermal Spray Coatings, by D.J. Varcalle, Jr. and A.D. Beitelman

Nov 2001

Assessment of SCADA Technology Applications to Automate U.S. Army Water and Wastewater Sanitary Systems, by R.J. Scholze and H.H. Zaghloul

Nov 2001

Pilot-Scale Reactor for Electrochemical Reduction of Nitroaromatics in Water: Simulated Wastewater Testing, by R. Doppalapudi, D. Palaniswamy, G. Sorial, and S.W. Maloney

Dec 2001 Chemical Reductive Transformations of Synthetic Organic Compounds: Probe Compound Studies and Mechanistic Modeling, by G.R. Peyton, M.H. LeFaivre, and S.W. Maloney

Dec $2001 \quad$ Invasive Plant Species Survey and Management Guidelines for Schriever Air Force Base, Colorado, by P.J. Guertin and M.G. Hohmann
ADA396128

ADA399455

ADA395160

ADA397536

ADA399586

ADA401338

ADA398730

ADA398742

ADA397728

ADA402802 


\begin{tabular}{|c|c|c|}
\hline ERDC/CERL TR-01-73 & Nov 2001 & $\begin{array}{l}\text { Low-Maintenance Remotely Monitored } \\
\text { Cathodic Protection Systems: } \\
\text { Requirements, Evaluation, and } \\
\text { Implementation Guidance, by V.L. Van } \\
\text { Blaricum, W.R. Norris, J.B. Bushman, and } \\
\text { M.J. Szeliga }\end{array}$ \\
\hline ERDC/CERL TR-01-74 & Nov 2001 & $\begin{array}{l}\text { Performance Benchmarking of Coating } \\
\text { Systems Evaluated in Cyclic Corrosion } \\
\text { Tests, by R.E.F. Weaver and A.D. } \\
\text { Beitelman }\end{array}$ \\
\hline ERDC/CERL TR-02-1 & Jan 2002 & $\begin{array}{l}\text { Evaluating Strength and Stiffness of } \\
\text { Unreinforced Masonry Infill Structures, } \\
\text { by G. Al-Chaar }\end{array}$ \\
\hline ERDC/CERL TR-02-2 & Jan 2002 & $\begin{array}{l}\text { Conflict Management in Collaborative } \\
\text { Engineering Design: Basic Research in } \\
\text { Fundamental Theory, Modeling } \\
\text { Framework, and Computer Support for } \\
\text { Collaborative Engineering Activities, by } \\
\text { S.C-Y. Lu, F. Udwadia, J. Cai, W. Burkett, } \\
\text { M.P. Case, B. Adeoye, and V.J. Woods }\end{array}$ \\
\hline ERDC/CERL TR-02-3 & Jan 2002 & $\begin{array}{l}\text { Urban Encroachment of Military Lands: } \\
\text { Military Installations at Risk, by B.M. } \\
\text { Deal, D.M. Timlin, and W.D. Goran }\end{array}$ \\
\hline
\end{tabular}

ADA403169

ERDC/CERL TR-02-4 Jan 2002 Guidelines for Developing Historic Urban

Growth Series for Military Installation

Risk Assessment, by D.M. Timlin, D.M.

Johnston, and B.M. Deal

ERDC/CERL TR-02-5

Mar 2002

Materials Selection Guide for Army

Installations Exposed to Severely

ADA401335

ADA407072

ADA408525

Corrosive Environments, by J.R. Myers, A.

Kumar, and L.D. Stephenson

ERDC/CERL TR-02-6

Feb 2002 Acute Inhalation Toxicity of Fog Oil

ADA399210

Smoke in the Red-Winged Blackbird, a

Size-Specific Inhalation Surrogate for the

Red-Cockaded Woodpecker, by C. Driver,

M. Ligotke, H. Galloway-Gorby, G. Dennis,

K. Reinbold, and H. Balbach

ERDC/CERL TR-02-7 Jan 2002

Advanced materials Selection Guide for Lock, Dam, and Hydroelectric Plant Components, by A. Kumar, L.D.

Stephenson, and P. Willis

ERDC/CERL TR-02-8

Feb 2002 Evaluation of Galvanized and

Galvalume ${ }^{\circledR} /$ Paint Duplex Coating

Systems for Steel Building Panels, by T.

Race, L.D. Stephenson, and A. Kumar

ADA401129

ADA401147

ADA408249

\section{ADA401129}

ADA399210

ADA408389 


\begin{tabular}{|c|c|c|c|}
\hline ERDC/CERL TR-02-10 & Mar 2002 & $\begin{array}{l}\text { Inspection Procedures for Military Wood } \\
\text { Structures, by G. Al-Chaar, M.A. Issa, and } \\
\text { J.R. Hayes, Jr. }\end{array}$ & ADA401484 \\
\hline ERDC/CERL TR-02-11 & Mar 2002 & $\begin{array}{l}\text { Reduction of Stack Emissions During } \\
\text { Startup, Shutdown, and Malfunction: } \\
\text { Malmstrom Air Force Base, MT, by J. } \\
\text { Vavrin, N. Potts, D. Nguyen, C. Schmidt, } \\
\text { and J. Salley }\end{array}$ & ADA402947 \\
\hline ERDC/CERL TR-02-12 & Apr 2002 & $\begin{array}{l}\text { Alternative Shear Panel Configurations } \\
\text { for Light Wood Construction: } \\
\text { Development, Seismic Performance, and } \\
\text { Design Guidance, by J. Wilcoski, C. } \\
\text { Fischer, T. Allison, and K.J. Malach }\end{array}$ & ADA407570 \\
\hline ERDC/CERL TR-02-13 & May 2002 & $\begin{array}{l}\text { Sustainable Army Training } \\
\text { Lands/Carrying Capacity: Training Use } \\
\text { Distribution Model (TUDM), by P.J. } \\
\text { Guertin and W.D. Meyer }\end{array}$ & ADA405023 \\
\hline ERDC/CERL TR-02-14 & Jun 2002 & $\begin{array}{l}\text { Preliminary Design of a Ventilation } \\
\text { System Scrubber to Reduce Sulfur } \\
\text { Dioxide Emissions at the Watervliet } \\
\text { Arsenal Industrial Wastewater Treatment } \\
\text { Plant, by J.C. Baird, J, Pusich-Lester, and } \\
\text { D. Brown }\end{array}$ & ADA407654 \\
\hline
\end{tabular}

ERDC/CERL TR-02-15 Jul 2002

Natural Gas-Electric Hybrid Cooling

ADA406300 System for Army Facilities - A Decision Tool, by C.W. Sohn and J.L. Alvarado

ERDC/CERL TR-02-16

Aug 2002

Web Interface for Modeling Fog Oil Dispersion During Training, by R.C. Lozar

ERDC/CERL TR-02-17

Aug 2002

Assessment of Effects of Maneuver Training Activities on Red-Cockaded Woodpecker Populations on Fort Stewart, GA, by T.J. Hayden, R.H. Melton, B. Willis, L.B. Martin III, and T. Beaty

ERDC/CERL TR-02-18

Sep 2002

Marine Corps Air Ground Combat Center

ADA423216 (MCAGCC) Land Management System (LMS) Military Field Application Site FY02 In-Progress Review, by H.R. Howard, D. Gebhart, and W.D. Goran

ERDC/CERL TR-02-19 Aug 2002

Chrome Plating Controls Enhancement

ADA407972 to the 120-mm Plating Facility at Watervliet Arsenal, NY: Fiscal Year 2000, by J.C. Baird, D. Franklin, and P. Darcy

ERDC/CERL TR-02-20 S Sep 2002

Heating Supply Options for Malmstrom AFB, MT, by J. Vavrin, N. Potts, D.

ADA406751

ADA413504 Nguyen, T. Blacker, and W. Brown

ADA408339 
ERDC/CERL TR-02-21

ERDC/CERL TR-02-22

ERDC/CERL TR-02-23

ERDC/CERL TR-02-24

ERDC/CERL TR-02-25

ERDC/CERL TR-02-26

ERDC/CERL TR-02-26

App. A

ERDC/CERL TR-02-27

Oct 2002

ERDC/CERL TR-02-28

ERDC/CERL TR-02-29

Aug 2002

Aug 2002
Electro-Osmotic Pulse (EOP) Technology for Control of Water Seepage in Concrete Structures, by M.K. Mclnerney, S. Morefield, S. Cooper, P. Malone, C. Weiss, M. Brady, J.P. Bushman, J. Taylor, and V.F. Hock

Sep 2002 Predictive Service Life Tests for Roofing Membranes: Phase II Investigation of Accelerated Aging Tests for Tracking Degradation of Roofing Membrane Materials, by D.M. Bailey, C.G. Cash, and A.G. Davies, Jr.

Wood-Fired Boiler System Evaluation at Fort Stewart, GA, by N.L. Potts and C.M. Schmidt

Sep 2002

Sustainable Design and Development Charrette for U.S. Army Military Installations in the Korean Peninsula, by C.W. Sohn, A.L. Stumpf, R.A. Ducey, and C. Kim

Sep 2002

Sustainability Indices for Military Installations: An Annotated Bibliography, by E.M. Jenicek, B.M. Deal, and A. Sagert

Sep 2002

Condition Assessment of William Beaumont General Hospital Historic Buildings at Fort Bliss, Texas, by T.R. Napier and S.A. McCarthy

Sep 2002

Condition Assessment of William Beaumont General Hospital Historic Buildings at Fort Bliss, Texas. Appendix A: Building Condition Matrix, by T.R. Napier and S.A. McCarthy

An Assessment of Encroachment Mitigation Techniques for Army Lands, by B.M. Deal, D.F. Fournier, D.M. Timlin, and E.M. Jenicek

Nov 2002 Building Composer: The Development of an Object Model for Facility Planning and Design Based on Customer Criteria, by J.S. Heckel

Nov 2002
Hazardous Materials Information Network (HAZMIN $®)$ Software Conversion Study, by J.C. Baird, J. Mullaney, D. Schiller, and G. Wager
ADA419184

ADA407075

ADA408411

ADA408375

ADA407531

ADA421608

ADA414939

ADA409139

ADA409160

ADA411874 


\begin{tabular}{|c|c|c|c|}
\hline ERDC/CERL TR-02-30 & Nov 2002 & $\begin{array}{l}\text { Prioritization of Threatened and } \\
\text { Endangered Species Sound Research on } \\
\text { Army Installations, by D.K. Delaney }\end{array}$ & ADA415008 \\
\hline ERDC/CERL TR-02-31 & Nov 2002 & $\begin{array}{l}\text { NASA MODIS Products for Military Land } \\
\text { Monitoring and Management, by R.C. } \\
\text { Lozar and H.E. Balbach }\end{array}$ & ADA414942 \\
\hline ERDC/CERL TR-02-32 & Nov 2002 & $\begin{array}{l}\text { Assessment of Training Noise Impacts on } \\
\text { the Red-Cockaded Woodpecker: 1998- } \\
\text { 2000, by D.K. Delaney, L.L. Pater, R.J. } \\
\text { Dooling, B. Lohr, B.F. Brittan-Powell, L.L. } \\
\text { Swindell, T.A. Beaty, L.D. Carlile, E.W. } \\
\text { Spadgenske, B.A. MacAllister, and R.H. } \\
\text { Melton }\end{array}$ & ADA415729 \\
\hline ERDC/CERL TR-02-33 & Dec 2002 & $\begin{array}{l}\text { Design of Fiber-Reinforced Polymer } \\
\text { Materials for Seismic Rehabilitation of } \\
\text { Infilled Concrete Structures, by G.K. Al- } \\
\text { Chaar and G.E. Lamb }\end{array}$ & ADA411018 \\
\hline ERDC/CERL TR-02-34 & Dec 2002 & $\begin{array}{l}\text { Effects of Fog Oil Smoke on the } \\
\text { Hatchability and Fledgling Survival of the } \\
\text { House Sparrow (Passer domesticus), a } \\
\text { Nestling Surrogate for the Red-Cockaded } \\
\text { Woodpecker, by C. Driver, J. Ollero, Y.F } \\
\text { Su, } \\
\text { R. Fulton, G. Dennis, B. Tiller, H. Balbach, } \\
\text { and K. Reinbold }\end{array}$ & ADA411029 \\
\hline ERDC/CERL TR-03-1 & Jan 2003 & $\begin{array}{l}\text { Compressed Air System Survey at Army } \\
\text { Industrial Facilities, by M.C.J. Lin, R.T. } \\
\text { Lorand, D. Presny, J.F. Westerman, S.W. } \\
\text { Aylor, J.C. Skelton, and H. Van Ormer }\end{array}$ & ADA419140 \\
\hline ERDC/CERL TR-03-2 & Jan 2003 & $\begin{array}{l}\text { Demonstration of Natural Gas Engine } \\
\text { Driven Air Compressor at Army Industrial } \\
\text { Facilities, by M.C.J. Lin, S.W. Aylor, R.T. } \\
\text { Lorand, J.C. Skelton, H.V. Ormer, P.A. } \\
\text { Wenner, G. Powers, D. Carlson, W.R. } \\
\text { King, and J.F. Westerman }\end{array}$ & ADA432480 \\
\hline ERDC/CERL TR-03-3 & Jan 2003 & $\begin{array}{l}\text { Decision Tree for Lead-Based Paint } \\
\text { Hazard Control and Abatement for Steel } \\
\text { Structures, by T.D. Race, L.D. } \\
\text { Stephenson, and A. Kumar }\end{array}$ & ADA412832 \\
\hline ERDC/CERL TR-03-4 & Jan 2003 & $\begin{array}{l}\text { Technology Demonstration of Thermal } \\
\text { Spray Vitrification Process at Fort Drum, } \\
\text { NY: Cost/Performance Report, by A. } \\
\text { Kumar, R. Zatorski, R. Weber, and L.D. } \\
\text { Stephenson }\end{array}$ & ADA412669 \\
\hline
\end{tabular}




\begin{tabular}{|c|c|c|c|}
\hline ERDC/CERL TR-03-5 & Mar 2003 & $\begin{array}{l}\text { Overcoating of Lead-Based Paint on } \\
\text { Steel Structures: Cost and Performance } \\
\text { Report, by T.D. Race, A. Kumar, R. A. } \\
\text { Weber, and L.D. Stephenson }\end{array}$ & ADA412886 \\
\hline ERDC/CERL TR-03-6 & Mar 2003 & $\begin{array}{l}\text { Data Management of Watershed } \\
\text { Information and Data Enterprise } \\
\text { Repository Implementation at Fort Hood, } \\
\text { Texas, by W.D. Meyer and M. Ruiz }\end{array}$ & ADA430827 \\
\hline ERDC/CERL TR-03-7 & Mar 2003 & $\begin{array}{l}\text { Assessing the Relationship Between } \\
\text { Worker Productivity and the Indoor } \\
\text { Environment, by E. S. Weidemann, E.M. } \\
\text { Jenicek, D.B. Lister, and C. Zimmer }\end{array}$ & ADA419126 \\
\hline ERDC/CERL TR-03-8 & Apr 2003 & $\begin{array}{l}\text { Process Energy Optimization Level-I } \\
\text { Review: Tobyhanna Army Depot, PA, by } \\
\text { J.Vavrin, M. Lin, and M.R. Kulkarni }\end{array}$ & ADA419130 \\
\hline ERDC/CERL TR-03-9 & May 2003 & $\begin{array}{l}\text { A Geographic Information Systems (GIS) } \\
\text { and Imagery Approach to Historical } \\
\text { Urban Growth Trends Around Military } \\
\text { Installations, by R.C. Lozar, C.R. } \\
\text { EhIschlaeger, and J. Cox }\end{array}$ & ADA421209 \\
\hline
\end{tabular}

ERDC/CERL TR-03-10 May 2003

Investigation of Fiber-Reinforced Polymer ADA416538

for Seismic Rehabilitation of Concrete

Structural Frames with Unreinforced

Masonry Infill, by G.K. Al-Chaar, J.B.

Berman, and S.C. Sweeney

ERDC/CERL TR-03-11 May 2003 Central Heating and Power Plant

Alternatives Review: Fort Wainwright, Alaska, by M.J. Savoie, J.L. Vavrin, M.R. Kemme, C. Schmidt, J. Westerman, J. Lanzarone, H. Gignilliat, and N. Miller

ERDC/CERL TR-03-12 Jun 2003 Design Schematics for a Sustainable Parking Lot: Building 2-2332, ENRD

ADA419118 Classroom, Fort Bragg, NC, by P.M. Loechl, A.L. Stumpf, E.D. Johnson, R.J. Scholze, B.M. Deal, and M.J. Hanson

ERDC/CERL TR-03-13 Jun 2003

Effects of Prescribed Burning on Game Species in the Southeastern United States: A Literature Review, by D.S. Maas, R.L. Musson, and T.J. Hayden

ADA432496

Historical Urban Growth Trends Around Marine Corps Base Camp Lejeune, North Carolina, by R.C. Lozar

ADA415829

ERDC/CERL TR-03-14 Jun 2003

$\begin{array}{lll}\text { ERDC/CERL TR-03-15 Sep } 2003 & \begin{array}{l}\text { Results of Evaluation of Bolt Failures at } \\ \text { the R.C. Byrd Locks and Dam, by R.A. }\end{array}\end{array}$

ADA418687 Weber, V.F. Hock, and S. Morefield

ADA416301 


\begin{tabular}{|c|c|c|c|}
\hline ERDC/CERL TR-03-16 & Jun 2003 & $\begin{array}{l}\text { Initial Assessment of the Soil and } \\
\text { Vegetation of the Illinois National Guard } \\
\text { Sparta Training Area, by J.S. Fehmi, R.L. } \\
\text { McLeese, and J.L. Casebeer }\end{array}$ & ADA416295 \\
\hline ERDC/CERL TR-03-17 & Aug 2003 & $\begin{array}{l}\text { Systems-Level Energy Audit for Main } \\
\text { Complex, Construction Engineering } \\
\text { Research Laboratory, by M.C.J. Lin, D. } \\
\text { Herron, D.M. Schwenk, C.W. Sohn, E. } \\
\text { Westervelt, T. Hartranft, T.D. Miller, N. } \\
\text { Josefik, J. Bush, and P.A. Kemme }\end{array}$ & ADA419115 \\
\hline ERDC/CERL TR-03-18 & Sep 2003 & $\begin{array}{l}\text { Laboratory Evaluation of Moisture Cure } \\
\text { Urethane Coatings, by A.D. Beitelman }\end{array}$ & ADA418758 \\
\hline ERDC/CERL TR-03-19 & Aug 2003 & $\begin{array}{l}\text { Condition Monitoring Technology for Civil } \\
\text { Works Lock Operating Machinery, by A. } \\
\text { Schimpf, L.D. Stephenson, and A. Kumar }\end{array}$ & ADA417254 \\
\hline ERDC/CERL TR-03-20 & Sep 2003 & $\begin{array}{l}\text { Hygrothermal Modeling in the } \\
\text { Application of Fiber-Reinforced Polymers } \\
\text { for Structural Upgrade of Unreinforced } \\
\text { Masonry Walls, by C.A. Feickert, M.W. } \\
\text { Lin, J.C. Trovillion, A.O. Abatan, and J.B. } \\
\text { Berman }\end{array}$ & ADA432639 \\
\hline 1ERDC/CERL TR-03-21 & Sep 2003 & $\begin{array}{l}\text { A Survey of Early Warning Systems } \\
\text { Within the U.S. Army Corps of Engineers } \\
\text { and US. Bureau of Reclamation, by S. } \\
\text { Foltz, K. Rens, D. Yoshimura, J. } \\
\text { Rodriguez, J. Stecker, and R. Todd }\end{array}$ & ADB304729 \\
\hline 1ERDC/CERL TR-03-22 & Sep 2003 & $\begin{array}{l}\text { Design Properties for Equipment } \\
\text { Supporting Frames for Ground-Based } \\
\text { Midcourse Defense Facilities, by J. } \\
\text { Wilcoski, B.M. Decker, J.B. Gambill, and } \\
\text { T.J. Graf }\end{array}$ & ADB304737 \\
\hline $\begin{array}{l}\text { 1ERDC/CERL TR-03-22 } \\
\text { REV. }\end{array}$ & Apr 2007 & $\begin{array}{l}\text { Design Properties for Equipment } \\
\text { Supporting Frames for Ground-Based } \\
\text { Midcourse Defense Facilities, by J. } \\
\text { Wilcoski, B.M. Decker, J.B. Gambill, and } \\
\text { T.J. Graf }\end{array}$ & ADB327529 \\
\hline ERDC/CERL TR-03-23 & Nov 2003 & $\begin{array}{l}\text { Process Optimization Assessment: Fort } \\
\text { Leonard Wood, MO and Fort Carson, CO, } \\
\text { by M.C.J. Lin, J.L. Vavrin, W. Smith, and } \\
\text { C. Conner }\end{array}$ & ADA432762 \\
\hline ERDC/CERL TR-03-24 & Nov 2003 & $\begin{array}{l}\text { Assessment and Application of the LCTA } \\
\text { Protocol at MAGTFTC, Twentynine Palms, } \\
\text { California, by T. McLendon, W.M. } \\
\text { Childress, J.S. Fehmi, and R.M. Evans }\end{array}$ & ADA430762 \\
\hline
\end{tabular}

1 Limited distribution; see Preface. 


\begin{tabular}{|c|c|c|c|}
\hline 1ERDC/CERL TR-03-25 & Dec 2003 & $\begin{array}{l}\text { Fort Richardson Central Heating and } \\
\text { Power Plant: Long-Range Power Study, by } \\
\text { J. Vavrin, J. Westerman, R. Lorand, C. } \\
\text { Schmidt, R. Heintel, W.T. Brown, and M. } \\
\text { Kemme }\end{array}$ & ADB315236 \\
\hline ERDC/CERL TR-03-26 & Dec 2003 & $\begin{array}{l}\text { Spectral Demixing and Spectral Index } \\
\text { Correlations for Subpixel Quantification } \\
\text { of Land-Cover Components from Coarse } \\
\text { Resolution Imagery at Fort Bliss, Texas, } \\
\text { by S. Tweddale, W. Jackson, and P. Pope }\end{array}$ & ADA430946 \\
\hline ERDC/CERL TR-03-27 & Dec 2003 & $\begin{array}{l}\text { Decision Tree for Lead-Based Paint } \\
\text { Management on Building, by T.D. Race } \\
\text { and A. Kumar }\end{array}$ & ADA430884 \\
\hline ERDC/CERL TR-03-28 & Dec 2003 & $\begin{array}{l}\text { Technology Demonstration of a } \\
\text { Microwave-Assisted Lead-Based Paint } \\
\text { Removal Process, by A. Tellakula, L. D. } \\
\text { Stephenson, and A. Kumar }\end{array}$ & ADA431144 \\
\hline ERDC/CERL TR-03-29 & Dec 2003 & $\begin{array}{l}\text { Technology Demonstration of Self- } \\
\text { Healing Coatings for In-Place } \\
\text { Management of Lead-Based Paint } \\
\text { Hazards, by L. D. Stephenson, and A. } \\
\text { Kumar }\end{array}$ & ADA431145 \\
\hline ERDC/CERL TR-03-30 & Dec 2003 & $\begin{array}{l}\text { Technology Demonstration of Membrane } \\
\text { Chemical Strippers for Removal of Lead- } \\
\text { Based Paint on Plaster, by T. Race and A. } \\
\text { Kumar }\end{array}$ & ADA429609 \\
\hline ERDC/CERL TR-03-31 & Dec 2003 & $\begin{array}{l}\text { Technology Assessment of Liquid } \\
\text { Encapsulants for Lead-Based Paint } \\
\text { Abatement, by T.D. Race and A. Kumar }\end{array}$ & ADA429604 \\
\hline ERDC/CERL TR-03-32 & Dec 2003 & $\begin{array}{l}\text { Technology Demonstration of Wet } \\
\text { Abrasive Blasting for Removal of Lead- } \\
\text { and Asbestos-Containing Paint, by T. } \\
\text { Race, A. Kumar, and L.D. Stephenson }\end{array}$ & ADA429620 \\
\hline ERDC/CERL TR-03-33 & Dec 2003 & $\begin{array}{l}\text { Development of Product Descriptions for } \\
\text { Lead-Immobilizing Overcoating Systems, } \\
\text { by T.D. Race and S.A. Drozdz }\end{array}$ & ADA419963 \\
\hline ERDC/CERL TR-04-1 & Feb 2004 & $\begin{array}{l}\text { Celebrating National American Indian } \\
\text { Heritage Month, by D.K. Mann and J. } \\
\text { Grafton }\end{array}$ & ADA422567 \\
\hline
\end{tabular}

1 Limited distribution; see Preface. 
ERDC/CERL TR-04-2

ERDC/CERL TR-04-3

ERDC/CERL TR-04-4

ERDC/CERL TR-04-5

ERDC/CERL TR-04-6

ERDC/CERL TR-04-7

ERDC/CERL TR-04-8

ERDC/CERL TR-04-9

ERDC/CERL TR-04-10
Feb 2004

Identification and Mapping of Sagebrush/Grass Successional Stages with Landsat Thematic Mapper Data at Yakima Training Center, Washington, by C.R. Leedy, P.T. Tueller, W. Gao, and S.A. Tweddale

Feb 2004 DOD Residential Proton Exchange Membrane (PEM) Fuel Cell Demonstration Program: Volume 1 Summary of the Fiscal Year 2001 Program, by M.K. White, F.H. Holcomb, N.M. Josefik, S.M. Lux, and M.J. Binder

Mar 2004

Approaches for Evaluating the Impact of Urban Encroachment on Installation Training/Testing, by J.D. Westervelt

Apr 2004 Methods for Field Studies of the Effects of Military Smokes, Obscurants, and Riot-control Agents on Threatened and Endangered Species: Volume 1:

Background, Overview, Issues, and Recommendations, by T. Smith

Apr 2004

Tri-Directional Seismic Analysis of an Unreinforced Masonry Building with Flexible Diaphragms, by S.C. Sweeney, M.A. Horney, and S.L. Orton

May 2004

Integrating Sustainable Design Principles into the Adaptive Reuse of Historical Properties, by D.F. Fournier and K. Zimnicki

Jun 2004

Installation of a Wastewater SCADA Monitoring System at Fort Bragg, NC, by J. Mullaney, K. McClafferty, G.L. Gerdes, and M.J. Hanson

Jul 2004

The Sustainable Installation Regional Resource Assessment (SIRRA) Capability: Version 1, by E.M. Jenicek, D.F. Fournier, W.D. Goran, N.R. Downs, and A. Sagert

Aug 2004 A Candidate Army Energy and Water Management Strategy, by D.F. Fournier and E.T. Westervelt
ADA431746

ADA422424

ADA431855

ADA431772

ADA430741

ADA429179

ADA429285

ADA431769

ADA431726 
1ERDC/CERL TR-04-11

1ERDC/CERL TR-04-12

ERDC/CERL TR-04-13

ERDC/CERL TR-04-14

ERDC/CERL TR-04-15

ERDC/CERL TR-04-16

ERDC/CERL TR-04-17

ERDC/CERL TR-04-18

ERDC/CERL TR-04-19

ERDC/CERL TR-04-20

ERDC/CERL TR-04-21
Aug 2004

Sep 2004

Sep 2004

Effects of Fog Oil Smoke on Immune Responses in the House Sparrow (Passer domesticus) and Red-winged Blackbird (Agelaius phoeniceus), by C. Driver, A. Jarrell, J. Ollero, B. Tiller, R. Fulton, G. Dennis, H.E. Balbach, and K. Reinbold

Sep $2004 \quad$ Knowledge Discovery in the I-METL Application, by T.R. Littell

Sep 2004

Wildlife Baseline Survey: Illinois Army National Guard, Sparta, Illinois, by D.

Pitts and J.L. Casebeer

Sep 2004

Agave palmeri Inflorescence Production on Fort Huachuca, Arizona, by J.S.

Fehmi, S. Danzer, and J. Roberts

Sep 2004

Process and Energy Optimization Assessment: Rock Island Arsenal, IL, by M.C.J. Lin, A.M. Zhivov, V.M. Boddu, D. Osborn, W.P. Smith, C. Bjork, M.J. Chimack and R.A. Miller

Sep 2004

Results of Source Emissions Testing: UTC Fuel Cell Model PC25C, by M. White and W.R. Taylor

Sep 2004

SPiRiT Scoring Through Self-Assessment Charrettes, by R. Schneider and D.F.

Fournier

Sep 2004

Application of Thermoelectric Devices to Fuel Cell Power Generation:

Demonstration and Evaluation, by $\mathrm{J}$. Huston, C. Wyatt, C. Nichols, M.J. Binder, and F.H. Holcomb

Oct 2004
Phosphoric Acid Fuel Cells: Test and Evaluation, by R.J. Unger, S. Kenner, M.J. Binder, and F.H. Holcomb
ADB307193

ADA430765

ADA429327

ADA430851

ADA430808

ADA435892

ADA431880

ADA435914

ADA432046

ADA431752 
ERDC/CERL TR-04-22ＮＮ２004

ERDC/CERL TR-04-23 Nov 2004

ERDC/CERL TR-04-24

ERDC/CERL TR-04-25

ERDC/CERL TR-04-26

ERDC/CERL TR-04-27

ERDC/CERL TR-04-28

ERDC/CERL TR-04-29

Nov 2004

Dec 2004

Dec 2004
Facility Composer Design Wizards: A Method for Extensible Codified Design Logic Based on Explicit Facility Criteria, by V.J. Woods, S.D. Nachtigall, B.A.

Brucker, and A. Andrillion

Central Heating and Power Plant Conversion at Fort Wainwright, AK: Heating Only with Backup Generation Option, by J.L. Vavrin, N.L. Potts, J. Westerman, R. Lorand, C. Schmidt, R. Heintel, and M.R. Kemme

Nov 2004 Development of Input Maps for the Military Land Use Evolution and Assessment Model (mLEAM) Land Use Change (LUC) Simulation Model, by J.D. Westervelt, K. Brock, W. Choi, and Y.W. Kim

Analysis of Numerical Models for Dispersion of Chemical/Biological Agents in Complex Building Environments, by C.W. Sohn, A. Solberg, and T. Gonsoulin

Nov 2004 The Role of Sleep Disturbance in Predicting Community Response to the Noise of Heavy Weapons, by G.A. Luz, E.T. Nykaza, C.M. Stewart, and L.L. Pater

Monitoring of Federally Threatened and Endangered Species on U.S. Army Installations, by R.H. Melton, H.E. Balbach, and M. Ward

Performance Problems with Group II Hydro-Cracked Turbine Oils in Corps of Engineers Hydropower Facilities, by J.S. Micetic and A.D. Beitelman

Dec 2004 Military Smokes and Obscurants Fate and Effects: A Literature Review Relative to Threatened and Endangered Species, by K. von Stackleberg, C. Amos, T. Smith, D. Cropek, and B. MacAllister
ADA478425

ADA435911

ADA435910

ADA440998

ADA443472

ADA430768

ADA428907

ADA443989 


\begin{tabular}{|c|c|c|c|}
\hline 1ERDC/CERL TR-04-30 & Dec 2004 & $\begin{array}{l}\text { Technologies for Protection of Building } \\
\text { Heating, Ventilating, and Air Conditioning } \\
\text { Systems From Chemical-Biological } \\
\text { Threats, by C.W. Sohn, J.P. Miller, D.L. } \\
\text { Herron, T. Abdallah, P.A. Kemme, and } \\
\text { P.H. Nielsen }\end{array}$ & ADB313198 \\
\hline ERDC/CERL TR-05-1 & Jan 2005 & $\begin{array}{l}\text { Preliminary Guidelines for Installation } \\
\text { Product Line Land Management Suite } \\
\text { Product Developers, by J. Westervelt, } \\
\text { K.M. Dilks, and W.D. Goran }\end{array}$ & ADA450598 \\
\hline ERDC/CERL TR-05-2 & Jan 2005 & $\begin{array}{l}\text { Civil Works Operations \& Maintenance } \\
\text { Management Tools Research Program: } \\
\text { Program Summary FY } 2000 \text { - FY 2002, } \\
\text { by D.T. McKay and S.D. Foltz }\end{array}$ & ADA430037 \\
\hline ERDC/CERL TR-05-3 & Jan 2005 & $\begin{array}{l}\text { X-Ray Fluorescence-Based Multi-Metal } \\
\text { Continuous Emission Monitor: } \\
\text { Development, by K.J. Hay, B.E. Johnsen, } \\
\text { and J.A. Cooper }\end{array}$ & ADA430237 \\
\hline ERDC/CERL TR-05-4 & Jan 2005 & $\begin{array}{l}\text { Ecological Risk Assessment of the } \\
\text { Effects of Military Fog Oil Obscurant } \\
\text { Smoke on the Red-cockaded } \\
\text { Woodpecker, by T. Smith, M.G. } \\
\text { Hohmann, and R.H. Melto }\end{array}$ & ADA435919 \\
\hline ERDC/CERL TR-05-5 & Jan 2005 & $\begin{array}{l}\text { Inhalation Toxicity of Cogenerated } \\
\text { Graphite Flake and Fog Oil Smoke in the } \\
\text { Brown-Headed Cowbird and the Red- } \\
\text { Winged Blackbird, Size-Specific } \\
\text { Inhalation Surrogates for the Red- } \\
\text { Cockaged Woodpecker, by C. Driver, R. } \\
\text { Fulton, J. Ollero, M. Clark, G. Dennis, B. } \\
\text { Tiller, and H.E. Balbach }\end{array}$ & ADA435890 \\
\hline ERDC/CERL TR-05-6 & Feb 2005 & $\begin{array}{l}\text { Joint Long-Range Energy Study for } \\
\text { Greater Fairbanks Military Complex, by } \\
\text { C.L. Bagnall, A.C. Taladay, J.L. Vavrin, } \\
\text { W.T. Brown, A.M. Zhivov, and M.R. } \\
\text { Kemme }\end{array}$ & ADA579750 \\
\hline ERDC/CERL TR-05-7 & Mar 2005 & $\begin{array}{l}\text { Mobile Zone Spray Booth Recirculation } \\
\text { System, by K.J. Hay, J. Baird, C. Smith, } \\
\text { and D. Schiller }\end{array}$ & ADA433803 \\
\hline ERDC/CERL TR-05-8 & Mar 2005 & $\begin{array}{l}\text { Demonstration of the Anaerobic } \\
\text { Fluidized Bed Reactor for Pinkwater } \\
\text { Treatment at McAlester Army } \\
\text { Ammunition Plant, by S.W. Maloney and } \\
\text { R.L. Heine }\end{array}$ & ADA433804 \\
\hline
\end{tabular}

1 Limited distribution; see Preface. 


\begin{tabular}{|c|c|c|c|}
\hline ERDC/CERL TR-05-9 & Mar 2005 & $\begin{array}{l}\text { X-Ray Fluorescence Based Multi-Metal } \\
\text { Continuous Emission Monitor: } \\
\text { Technology Demonstration, by K. J. Hay, } \\
\text { V.M. Boddu, B.E. Johnsen, and J.A. } \\
\text { Cooper }\end{array}$ & ADA433778 \\
\hline ERDC/CERL TR-05-10 & Mar 2005 & $\begin{array}{l}\text { Military Munitions-Related Compounds } \\
\text { Fate and Effects: A Literature Review } \\
\text { Relative to Threatened and Endangered } \\
\text { Species, by K. von Stackleberg, C. Amos, } \\
\text { and T. Smith }\end{array}$ & ADA435907 \\
\hline ERDC/CERL TR-05-11 & Apr 2005 & $\begin{array}{l}\text { Remote Sensing for Threatened and } \\
\text { Endangered Species Habitat } \\
\text { Assessment on Military Lands: A } \\
\text { Literature Review, by S.A. Tweddale and } \\
\text { R.H. Melton }\end{array}$ & ADA435908 \\
\hline ERDC/CERL TR-05-12 & Jun 2005 & $\begin{array}{l}\text { Training Restrictions on Army Lands Due } \\
\text { to High Priority Endangered Species, by } \\
\text { P.J. Guertin }\end{array}$ & ADA435920 \\
\hline ERDC/CERL TR-05-13 & Aug 2005 & $\begin{array}{l}\text { Summary of Threatened and } \\
\text { Endangered Bat-Related Restrictions on } \\
\text { Military Training, Testing, and Land } \\
\text { Management, by A.M. Shapiro and M.G. } \\
\text { Hohmann }\end{array}$ & ADA443510 \\
\hline ERDC/CERL TR-05-14 & Aug 2005 & $\begin{array}{l}\text { Heating, Ventilating, and Air-Conditioning } \\
\text { (HVAC) Control Systems Operations and } \\
\text { Maintenance at Fort Bragg, NC: Training } \\
\text { and Technical Assistance, by D.M. } \\
\text { Schwenk, J. Bush, and D.M. Underwood }\end{array}$ & ADA593467 \\
\hline ERDC/CERL TR-05-15 & Aug 2005 & $\begin{array}{l}\text { Process and Energy Optimization } \\
\text { Assessment Level II Analysis: Rock } \\
\text { Island Arsenal, IL, by M.C.J. Lin, A.M. } \\
\text { Zhivov, D.M. Underwood, D.I. Osborn, A. } \\
\text { Woody, W.P. Smith, C. Bjork, M.J. } \\
\text { Chimack, and R.A. Miller }\end{array}$ & ADA478487 \\
\hline 1ERDC/CERL TR-05-16 & Aug 2005 & $\begin{array}{l}\text { Analysis of Chemical and Biological Filter } \\
\text { Technologies, by T. Gonsoulin, H.E. } \\
\text { Burroughs, and C.W. Sohn }\end{array}$ & ADB313336 \\
\hline ERDC/CERL TR-05-17 & Aug 2005 & $\begin{array}{l}\text { Process and Energy Optimization } \\
\text { Assessment: Sierra Army Depot, CA, by } \\
\text { M.C.J. Lin, A.M. Zhivov, A. Woody, M.J. } \\
\text { Chimack, and R.A. Miller }\end{array}$ & ADA574848 \\
\hline
\end{tabular}




\begin{tabular}{|c|c|c|c|}
\hline ERDC/CERL TR-05-18 & Aug 2005 & $\begin{array}{l}\text { Quarters } 100 \text { Historic Structure } \\
\text { Investigation and Cultural Landscape } \\
\text { Report, United States Military Academy, } \\
\text { West Point, New York, by M.W. Tooker, } \\
\text { B.C. Grashof, S.I. Enscore, and F.S. } \\
\text { Welsh }\end{array}$ & \\
\hline ERDC/CERL TR-05-19 & Aug 2005 & $\begin{array}{l}\text { Quarters } 102 \text { Historic Structure Report } \\
\text { and Cultural Landscape Report, United } \\
\text { States Military Academy, West Point, } \\
\text { New York, by M.W. Tooker, B.C. Grashof, } \\
\text { S.I. Enscore, and F.S. Welsh }\end{array}$ & \\
\hline 1ERDC/CERL TR-05-20 & Sep 2005 & $\begin{array}{l}\text { AN/ALQ-99 TJS Pod Vibration Survey Test } \\
\text { Results, by J. Wilcoski and J.C. Trovillion }\end{array}$ & ADB347579 \\
\hline ERDC/CERL TR-05-21 & Sep 2005 & $\begin{array}{l}\text { Energy Trends and Their Implications for } \\
\text { U.S. Army Installations, by D.F. Fournier } \\
\text { and E.T. Westervelt }\end{array}$ & ADA440265 \\
\hline ERDC/CERL TR-05-22 & Sep 2005 & $\begin{array}{l}\text { DOD Residential Proton Exchange } \\
\text { Membrane (PEM) Fuel Cell } \\
\text { Demonstration Program: Volume } 2 \text { - } \\
\text { Summary of Fiscal Year 2001-2003 } \\
\text { Projects, by M.K. White, S.M. Lux, J.L. } \\
\text { Knight, Dr. M.J. Binder, F.H. Holcomb, } \\
\text { and N.M. Josefik }\end{array}$ & ADA442553 \\
\hline ERDC/CERL TR-05-23 & Sep 2005 & $\begin{array}{l}\text { Use of the Corridor Tool in Support of } \\
\text { Threatened and Endangered Species } \\
\text { Habitat Fragmentation: Input Procedure } \\
\text { and Initial Results, by R.C. Lozar, W. } \\
\text { Hargrove, and F. Hoffman }\end{array}$ & ADA448893 \\
\hline ERDC/CERL TR-05-24 & Sep 2005 & $\begin{array}{l}\text { Watershed Application of the } \\
\text { Sustainable Installations Regional } \\
\text { Resource Assessment Tool, by E.M. } \\
\text { Jenicek, D.F. Fournier, N.R. Downs, and } \\
\text { B. Boesdorfer }\end{array}$ & ADA444062 \\
\hline ERDC/CERL TR-05-25 & Sep 2005 & $\begin{array}{l}\text { Seismic Response of a Half-Scale } \\
\text { Masonry Building with Flexible } \\
\text { Diaphragms, by S.C. Sweeney, M.A. } \\
\text { Horney, and S.L. Orton }\end{array}$ & ADA468395 \\
\hline ERDC/CERL TR-05-26 & Sep 2005 & $\begin{array}{l}\text { Application of the TerreSIM Model to a } \\
\text { Training Area Landscape at Fort Bliss, } \\
\text { TX, by R.J. Bilodeau, J.S. Fehmi, and B. } \\
\text { MacAllister }\end{array}$ & ADA442171 \\
\hline
\end{tabular}

1 Limited distribution; see Preface. 
ERDC/CERL TR-05-27 Oct 2005

ERDC/CERL TR-05-28

ERDC/CERL TR-05-29

ERDC/CERL TR-05-30

ERDC/CERL TR-05-31

ERDC/CERL TR-05-32

ERDC/CERL TR-05-33

1ERDC/CERL TR-05-34

ERDC/CERL TR-05-36

ERDC/CERL TR-05-37

ERDC/CERL TR-05-38

ERDC/CERL TR-05-39
Oct 2005

Oct 2005

Oct 2005

Oct 2005

Nov 2005

Nov 2005

Nov 2005

Dec 2005

Nov 2005

Nov 2005

Nov 2005
Analysis of Gopher Tortoise Population Estimation Techniques, by R.R. Carthy, M.K. Oli, J.B. Wooding, J.E. Berish, and W.D. Meyer

Delisting Process for Endangered Species and Relevance to Populations on Army Lands, by J.S. Graber, T.J. Hayden, and T.S. Smith

Effects of Forest on Blast Noise, by M.E. ADA444542 Swearingen and M.J. White

Guidelines for Developing Habitat-Based Threatened and Endangered Species Population Goals on Army Installations, by A.M. Shapiro and M. Hohmann

Modeling Fog Oil Obscurant Smoke Penetration Into Simulated Tortoise Barrows and Bat Colony Trees, by M. Guelta and H.E. Balbach

Life History Traits of the Threatened Purple Amole (Chlorogalum Purpureum var. Purpureum): Fort Hunter Liggett, California, by J.A. Guretzky, E.R. Clark, and D. Woodbury

Cattle Grazing and Tracked Vehicle Training on Central and Southwest U.S. Army Lands: Potential Consequences for Grassland Ecosystems, by J.A. Guretzky, J.S. Fehmi, and A.B. Anderson

Base Camp Utility Technology Matrix, by A.L. Jantzer and G.L. Gerdes

Military Requirements for JP-8 Reformers ADA449678 and Solid Oxide Fuel Cell Power Systems, by J.D. Stangl, R.O. Wertz, and F.H. Holcomb

Available Conservation Research for Fort Bliss, by J.S. Fehmi and B.A. MacAllister

Determining Research Gaps in

ADA450582

Disturbance Data for Fort Bliss and a

Conceptual Model, by T. Hochstrasser, D. Peters, and J.S. Fehmi

Simulation of Vegetation Recovery from Military Disturbances on Fort Bliss, by T. Hochstrasser, D. Peters, and J.S. Fehmi
ADA444540

ADA464868

ADA444795

ADA450467

ADA467990

ADA444793

ADA467812

ADA450483

\footnotetext{
1 Limited distribution; see Preface.
} 


\begin{tabular}{|c|c|c|c|}
\hline ERDC/CERL TR-05-40 & Oct 2005 & $\begin{array}{l}\text { Estimating Risk from Spillway Gate } \\
\text { Systems on Dams Using Condition } \\
\text { Assessment Data, by A.C. Estes, S.D. } \\
\text { Foltz, and D.T. McKay }\end{array}$ & ADA466342 \\
\hline ERDC/CERL TR-06-1 & Jan 2006 & $\begin{array}{l}\text { Implementation of the U.S. Green } \\
\text { Building Council's LEEDS } \AA \text { as the Army's } \\
\text { Green Building Rating System, by R.L. } \\
\text { Schneider and A.L. Stumpf }\end{array}$ & ADA449538 \\
\hline ERDC/CERL TR-06-2 & Feb 2006 & $\begin{array}{l}\text { Techniques to Remotely Identify and } \\
\text { Evaluate Electrical Power System } \\
\text { Infrastructure, by T. Abdallah, M.K. } \\
\text { Mclnerney, W.R. Taylor, and C.A. Feickert }\end{array}$ & ADA450442 \\
\hline ERDC/CERL TR-06-3 & Mar 2006 & $\begin{array}{l}\text { Fort Knox Trend Analysis, Encroachment } \\
\text { Study, and Perimeter Expansion } \\
\text { Opportunities in Support of Military } \\
\text { Training, by B. MacAllister, R. Lozar, J. } \\
\text { Westervelt, M. White, and J. Rank }\end{array}$ & ADA450350 \\
\hline ERDC/CERL TR-06-4 & Mar 2006 & $\begin{array}{l}\text { Effect of Age-Dependent Forest } \\
\text { Characteristics on Acoustic Propagation, } \\
\text { by M.E. Swearingen }\end{array}$ & ADA447408 \\
\hline ERDC/CERL TR-06-5 & Mar 2006 & $\begin{array}{l}\text { Sampling and Mapping Soil Erosion } \\
\text { Cover Factor for Fort Richardson, Alaska: } \\
\text { Integrating Stratification and an Up- } \\
\text { Scaling Method, by G. Wang, G. Gertner, } \\
\text { A.B. Anderson, and H. Howard }\end{array}$ & ADA448705 \\
\hline ERDC/CERL TR-06-6 & Mar 2006 & $\begin{array}{l}\text { Diesel-Powered Equipment Properties } \\
\text { and Activity Database for DoD Off-Road } \\
\text { Sources: SERDP Project WP-1338, by } \\
\text { M.R. Kemme, W.T. Brown, E.A. Frame, } \\
\text { and R.A. Alvarez }\end{array}$ & ADA447297 \\
\hline ERDC/CERL TR-06-7 & Apr 2006 & $\begin{array}{l}\text { Waste-to-Energy ECIP (Energy } \\
\text { Conservation Investment Program) } \\
\text { Project. Volume 1: An Analysis of } \\
\text { Hydrogen Infrastructure Fuel Cell } \\
\text { Technology, by G. Perez, R. Neathammer, } \\
\text { F.H. Holcomb, R.A. Ducey, B.J. Kim, and } \\
\text { F. Louis }\end{array}$ & ADA449494 \\
\hline ERDC/CERL TR-06-8 & Apr 2006 & $\begin{array}{l}\text { Energy and Process Optimization } \\
\text { Assessment: Fort Stewart, GA, by J.L. } \\
\text { Vavrin, A.M. Zhivov, W.T. Brown, D.M. } \\
\text { Underwood, A. Woody, H. Akbari, M. } \\
\text { Keefover, S. Richter, J. Newman, R. } \\
\text { Miller, A. Hernandez, D. Kulikowski, A. } \\
\text { Hart, and F. Louis }\end{array}$ & ADA449505 \\
\hline
\end{tabular}




\begin{tabular}{|c|c|c|c|}
\hline ERDC/CERL TR-06-9 & Apr 2006 & $\begin{array}{l}\text { Response of Gopher Tortoises to Habitat } \\
\text { Manipulation by Prescribed Burning: Can } \\
\text { Forested Areas Adjacent to Training } \\
\text { Areas Be Improved?, by L. Yager, M. } \\
\text { Hinderliter, and H. Balbach }\end{array}$ & ADA450015 \\
\hline ERDC/CERL TR-06-10 & Apr 2006 & $\begin{array}{l}\text { Effects of Tracked-Vehicle Training } \\
\text { Activity on Gopher Tortoise (Gopherus } \\
\text { polyphemus) Behavior at Fort Benning, } \\
\text { GA, by C. Guyer, R. Birkhead, and H. } \\
\text { Balbach }\end{array}$ & ADA467989 \\
\hline ERDC/CERL TR-06-11 & Apr 2006 & $\begin{array}{l}\text { Process and Energy Optimization } \\
\text { Assessment: Tobyhanna Army Depot, PA, } \\
\text { by M.C.J. Lin, A.M. Zhivov, A. Woody, C. } \\
\text { Bjork, W.P. Smith, M.J. Chimack, and R.A. } \\
\text { Miller }\end{array}$ & ADA450054 \\
\hline ERDC/CERL TR-06-12 & May 2006 & $\begin{array}{l}\text { Co-occurence of Invasive Species on } \\
\text { Priority TES Installations, by P.J. Guertin } \\
\text { and S. Tess }\end{array}$ & ADA449166 \\
\hline ERDC/CERL TR-06-13 & Sep 2006 & $\begin{array}{l}\text { Solubility and Phase Behavior of CL20 in } \\
\text { Supercritical Fluids, by V. Boddu, R.K. } \\
\text { Toghiani, and R. Damavarapu }\end{array}$ & ADA473836 \\
\hline ERDC/CERL TR-06-14 & Jun 2006 & $\begin{array}{l}\text { Evaluation of Soil Loss and Erosion } \\
\text { Control Measures on Ranges and Range } \\
\text { Structures at Installations in Temperate } \\
\text { Climates, by N.G. Svendsen, P.K. Kalita, } \\
\text { and D.L. Gebhart }\end{array}$ & ADA467835 \\
\hline ERDC/CERL TR-06-15 & Jun 2006 & $\begin{array}{l}\text { The Range Managers Toolkit (RMTK) } \\
\text { Noise Tool, by M.E. Swearingen }\end{array}$ & ADA457441 \\
\hline ERDC/CERL TR-06-17 & Jun 2006 & $\begin{array}{l}\text { Detailed Fuel Cell Demonstration Site } \\
\text { Summary Report: Naval Hospital at } \\
\text { Marine Corps Air Ground Combat Center } \\
\text { - Twentynine Palms, by J.M. Torrey, J.F. } \\
\text { Westerman, W.R. Taylor, F.H. Holcomb, } \\
\text { and J. Bush }\end{array}$ & ADA457440 \\
\hline ERDC/CERL TR-06-18 & Jul 2006 & $\begin{array}{l}\text { Evaluation of Models to Support Habitat } \\
\text { Fragmentation Analysis, by H.R. } \\
\text { Akçakaya, K. Cantara, H. Vaillant, D. } \\
\text { Diamond, D. True, C.C. Rewerts, and R. } \\
\text { Lozar }\end{array}$ & ADA458442 \\
\hline ERDC/CERL TR-06-19 & Aug 2006 & $\begin{array}{l}\text { Detailed Fuel Cell Demonstration Site } \\
\text { Summary Report: Edwards Air Force } \\
\text { Base, CA, by J.M. Torrey, J.F. Westerman, } \\
\text { W.R. Taylor, F.H. Holcomb, and J. Bush }\end{array}$ & ADA478463 \\
\hline
\end{tabular}


ERDC/CERL TR-06-20 Jul 2006

ERDC/CERL TR-06-21

ERDC/CERL TR-06-22

ERDC/CERL TR-06-23

1ERDC/CERL TR-06-24

ERDC/CERL TR-06-25

ERDC/CERL TR-06-26

ERDC/CERL TR-06-27

ERDC/CERL TR-06-28

ERDC/CERL TR-06-29

Aug 2006
Sep 2006

Comparison of Regional Vulnerability Factors for Department of Defense (DOD) Installations, by E.M. Jenicek, N.R.D. Myers, B. Boesdorfer, and D.F. Fournier

Sep 2006

Antiterrorism Measures For Historic Properties, by J.L. Webster, P.E. Reicher, and G.L. Cohen

Sep 2006

Base Camp Solid Waste Characterization Study, by G.L. Gerdes and A.L. Jantzer

Sep 2006

Energy and Process Optimization and Benchmarking of Army Industrial Processes, by A.M. Zhivov, M.C.J. Lin, A. Woody, W.M. Worek, M.J. Chimack, and R.A. Miller

Sep 2006

A Characterization of Land Use Trends Around the Perimeter of Military Ranges, by E.M. Jenicek, D.F. Fournier, N.R.D. Myers, and B. Boesdorfer

Sep 2006

Quick Prediction of Future Training/Testing Opportunities Using mLEAM, by J. Westervelt and B. MacAllister

Sep 2006

LEAMram $^{\mathrm{TM}}$ : Land Use Evolution and Impact Assessment Model Residential Attractiveness Model, by J.D. Westervelt and J. Rank

Sep 2006
Green Chemical Treatments for Heating and Cooling Systems, by S.A. Drozdz and V.F. Hock
ADA461391

ADA476918

ADA478339

ADA594302

ADB323774

ADA457423

ADA458388

ADA478355

ADA485271

ADA478368

\footnotetext{
1 Limited distribution; see Preface.
} 


\begin{tabular}{|c|c|c|c|}
\hline ERDC/CERL TR-06-30 & Sep 2006 & $\begin{array}{l}\text { Investigation of Mechanical Processes } \\
\text { for Removing Lead-Based Paint (LBP) } \\
\text { from Wood Siding, by R.H. Falk, J. } \\
\text { Janowiak, R.G. Lampo, T.R. Napier, S.D. } \\
\text { Cosper, S.A. Drozdz, S. Larson, and E.D. } \\
\text { Smith }\end{array}$ & ADA470943 \\
\hline ERDC/CERL TR-06-31 & Nov 2006 & $\begin{array}{l}\text { Defilade, Stationary Target and Moving } \\
\text { Target Embankment, Low Water } \\
\text { Crossing, and Course Road Designs for } \\
\text { Soil Loss Prevention, by N.G. Svendsen, } \\
\text { P.K. Kalita, D.L. Gebhart, and M.L. } \\
\text { Denight }\end{array}$ & ADA460651 \\
\hline ERDC/CERL TR-06-32 & Nov 2006 & $\begin{array}{l}\text { Strategic Sustainability Assessment Pilot } \\
\text { Study: Fall Line Region of the Southeast, } \\
\text { by E.M. Jenicek, N.R.D. Myers, B. } \\
\text { Boesdorfer, and D.F. Fournier }\end{array}$ & ADA597006 \\
\hline ERDC/CERL TR-06-33 & Nov 2006 & $\begin{array}{l}\text { U.S. Army Training and Testing Area } \\
\text { Carrying Capacity (ATTACC) for Munitions } \\
\text { (AFM): User Manual, by A. Stewart, M. } \\
\text { Brown, and A.B. Anderson }\end{array}$ & ADA460554 \\
\hline ERDC/CERL TR-06-34 & Dec 2006 & $\begin{array}{l}\text { Analysis of Steam Heat System at Fort } \\
\text { Myer, VA: Retrofit Options, by A.M. Zhivov, } \\
\text { J.L. Vavrin, A. Woody, S. Richter, and N. } \\
\text { Paetz }\end{array}$ & ADA479155 \\
\hline ERDC/CERL TR-06-35 & Dec 2006 & $\begin{array}{l}\text { Control Dynamics of Adaptive and } \\
\text { Scalable Power and Energy Systems for } \\
\text { Military Micro Grids, by T. Abdallah, R. } \\
\text { Ducey, R.S. Balog, C.A. Feickert, W. } \\
\text { Weaver, A. Akhil, and D. Menicucci }\end{array}$ & ADA460715 \\
\hline ERDC/CERL TR-06-36 & Dec 2006 & $\begin{array}{l}\text { Habitat Fragmentation Handbook for } \\
\text { Installation Planners: Status and } \\
\text { Options, by C. Ehlschlaeger, J. } \\
\text { Westervelt, H. Balbach, H.R. Akçakaya, T. } \\
\text { Hoctor, C. Goodison, W.W. Hargrove, F.M. } \\
\text { Hoffman, W. Rose, and R.C. Lozar }\end{array}$ & ADA467806 \\
\hline ERDC/CERL TR-06-37 & Nov 2006 & $\begin{array}{l}\text { Incorporating Historic Facility Geospatial } \\
\text { Data and Federal Preservation } \\
\text { Requirements into SDSFIE/FMSFIE, by } \\
\text { J.L. Webster, W.D. Meyer, G.L. Cohen, } \\
\text { and B.A. MacAllister }\end{array}$ & ADA491975 \\
\hline ERDC/CERL TR-07-1 & Mar 2007 & $\begin{array}{l}\text { Habitat Selection by the Gopher Tortoise } \\
\text { (Gopherus polyphemus), by T.D. } \\
\text { Tuberville, K.A. Buhlmann, H.E. Balbach, } \\
\text { S.H. Bennett, J.P. Nestor, J.W. Gibbons, } \\
\text { and R.R. Sharitz }\end{array}$ & ADA467817 \\
\hline
\end{tabular}




\begin{tabular}{|c|c|c|c|}
\hline ERDC/CERL TR-07-2 & Jan 2007 & $\begin{array}{l}\text { LBP Concerns in Producing Recycled } \\
\text { Concrete Aggregate from Former Fort } \\
\text { Ord Family Housing, by S.D. Cosper }\end{array}$ & ADA473800 \\
\hline ERDC/CERL TR-07-3 & Feb 2007 & $\begin{array}{l}\text { Development of an Open Building } \\
\text { Automation System Specification Based } \\
\text { on ANSI/ASHRAE 135-2004 (BACnet }{ }^{\circledR} \\
\text { Communications Protocol): A Technical } \\
\text { Assessment, by D.M. Schwenk, S.J. } \\
\text { Briggs, D.M. Underwood, and J. Bush }\end{array}$ & ADA482939 \\
\hline ERDC/CERL TR-07-4 & Mar 2007 & $\begin{array}{l}\text { In-Place Pipe Lining of Pre-Action Fire } \\
\text { Suppression System at Fort McPherson, } \\
\text { GA, by O.S. Marshall }\end{array}$ & ADA466975 \\
\hline ERDC/CERL TR-07-5 & Mar 2007 & $\begin{array}{l}\text { Fugitive Emission Control for the APE } \\
1236 \text { Deactivation Furnace, by K.J. Hay, } \\
\text { C. Sohn, B. Hunt, M.T. Dunstan, and D. } \\
\text { Schiller }\end{array}$ & ADA593105 \\
\hline ERDC/CERL TR-07-6 & Mar 2007 & $\begin{array}{l}\text { Evaluation of Methylene Chloride } \\
\text { Emission Control Technologies at } \\
\text { Anniston Army Depot, by V. Boddu, M.T. } \\
\text { Dunstan, M. Hanson, D. Franklin, J. } \\
\text { Baird, T. Pollard, and J. Larkins }\end{array}$ & ADA590999 \\
\hline ERDC/CERL TR-07-7 & Mar 2007 & $\begin{array}{l}\text { Fort Hood Building and Landscape } \\
\text { Inventory with WWII and Cold War } \\
\text { Context, by J. Webster, M. Tooker, D. } \\
\text { Morrison, S. Enscore, S. Loechl, and M. } \\
\text { Stupich }\end{array}$ & ADA485337 \\
\hline ERDC/CERL TR-07-9 & Mar 2007 & $\begin{array}{l}\text { Proceedings of the 1st Army Installation } \\
\text { Energy Security and Independence } \\
\text { Conference, by T.J. Hartranft, F. Yeboah, } \\
\text { D. Grady, and R. Ducey }\end{array}$ & ADA467999 \\
\hline ERDC/CERL TR-07-10 & Apr 2007 & $\begin{array}{l}\text { Survey of the Golden-Cheeked Warbler } \\
\text { on Fort Hood in Support of NEPA } \\
\text { Requirements, by B. MacAllister, M. } \\
\text { Baranski, T. Hayden, and R. Peak }\end{array}$ & ADA467810 \\
\hline ERDC/CERL TR-07-11 & May 2007 & $\begin{array}{l}\text { Endangered Species Management Plan } \\
\text { for Fort Hood, Texas: FY06-10, by J.D. } \\
\text { Cornelius, T.J. Hayden, and P.J. Guertin }\end{array}$ & ADA471947 \\
\hline ERDC/CERL TR-07-12 & May 2007 & $\begin{array}{l}\text { Development of a Site Comparison } \\
\text { Index: Southeast Upland Forests, by A.J. } \\
\text { Krzysik and H.E. Balbach }\end{array}$ & ADA469214 \\
\hline ERDC/CERL TR-07-13 & May 2007 & $\begin{array}{l}\text { Energy and Process Assessment Protocol } \\
\text { for Industrial Buildings, by A.M. Zhivov, D. } \\
\text { Chu, M.C.J. Lin, M. Chimack, D. Kasten, } \\
\text { A. Woody, J. Pietilainen, T. Kaupinne, T. } \\
\text { Husu, C. Bjork, E. Reinikainen, E. } \\
\text { Shilkrot, F. Schmidt, and W. Smith }\end{array}$ & ADA478393 \\
\hline
\end{tabular}




\begin{tabular}{|c|c|c|c|}
\hline ERDC/CERL TR-07-14 & May 2007 & $\begin{array}{l}\text { Ramgen Power Systems for Military } \\
\text { Engine Applications, by F.H. Holcomb, } \\
\text { C.W. Sohn, G. Tamm, D. Brown, D. } \\
\text { Mahoney, P. Baldwin, K. Belshaw, A. } \\
\text { Koopman, } \\
\text { and D. Witmer }\end{array}$ & ADA478293 \\
\hline ERDC/CERL TR-07-15 & May 2007 & $\begin{array}{l}\text { DoD Sustainability Application Guide for } \\
\text { Historic Properties, by J.L. Webster, K.S. } \\
\text { McQuiggan, C.W. Durst, and J.G. } \\
\text { MacMillan }\end{array}$ & ADA476929 \\
\hline ERDC/CERL TR-07-16 & Jun 2007 & $\begin{array}{l}\text { IMCON LonWorks }{ }^{\circledR} \text { Building Automation } \\
\text { Systems Implementation Strategy: An } \\
\text { Interim Report, by D.M. Schwenk, J. } \\
\text { Bush, L.M. Hughes, S. Briggs, and W. } \\
\text { White }\end{array}$ & ADA478402 \\
\hline ERDC/CERL TR-07-18 & Jun 2007 & $\begin{array}{l}\text { Measuring the Rate and Impact of } \\
\text { Corrosion on DoD Equipment and } \\
\text { Facilities: Final Report on Project AR-F- } \\
311 \text { for FY05, by S.A. Drozdz, W.H. } \\
\text { Abbott, and J.L. Jackson }\end{array}$ & ADA541796 \\
\hline ERDC/CERL TR-07-19 & Jun 2007 & $\begin{array}{l}\text { Leak Detection for Potable Water Lines } \\
\text { at Fort Hood: Final Report on Project AR- } \\
\text { F-313 for FY05, by S. Morefield }\end{array}$ & ADA593380 \\
\hline ERDC/CERL TR-07-20 & Jun 2007 & $\begin{array}{l}\text { Nonhazardous Chemical Treatments and } \\
\text { Smart Monitoring and Control System for } \\
\text { Heating and Cooling Systems: Final } \\
\text { Report on Project AR-F-314 fot FY05, by } \\
\text { S.A. Drozdz, D.W. Hurt, and S. Maloney }\end{array}$ & ADA500865 \\
\hline ERDC/CERL TR-07-21 & Jun 2007 & $\begin{array}{l}\text { Demonstration of Pipe Corrosion } \\
\text { Sensors at Fort Bragg, NC: Final Report } \\
\text { on Project AR-F-317 for FY05, by V.L. Van } \\
\text { Blaricum, V.F. Hock, J. Bushman, and B. } \\
\text { Phull }\end{array}$ & ADA507494 \\
\hline ERDC/CERL TR-07-22 & Jun 2007 & $\begin{array}{l}\text { Demonstration of Ice-Free Cathodic } \\
\text { Protection Systems for Water Storage } \\
\text { Tanks at Fort Drum: Final Report on } \\
\text { Project AR-F-318 for FY05, by V.L. Van } \\
\text { Blaricum, V.F. Hock, T.K. Perkins, J. } \\
\text { Bushman, and B. Phull }\end{array}$ & ADA534424 \\
\hline ERDC/CERL TR-07-23 & Jun 2007 & $\begin{array}{l}\text { Corrosion-Resistant Materials for Water } \\
\text { and Wastewater Treatment Plants at Fort } \\
\text { Bragg: Final Report on Project AR-F-319 } \\
\text { for FY05, by L.D. Stephenson and A. } \\
\text { Kumar }\end{array}$ & ADA507497 \\
\hline
\end{tabular}




\begin{tabular}{|c|c|c|c|}
\hline ERDC/CERL TR-07-24 & Jun 2007 & $\begin{array}{l}\text { Surface-Tolerant Coatings for Aircraft } \\
\text { Hangars, Flight Control Tower, and } \\
\text { Deluge Tanks at Fort Campbell: Final } \\
\text { Report on Project AR-F-320 for FY05, by } \\
\text { L.D. Stephenson, A. Kumar, T.D. Race, } \\
\text { and S. Williams }\end{array}$ & ADA528484 \\
\hline ERDC/CERL TR-07-25 & Jun 2007 & $\begin{array}{l}\text { Remote Monitoring of Cathodic } \\
\text { Protection and Cathodic Protection } \\
\text { System Upgrades for Tanks and } \\
\text { Pipelines at Fort Carson: Final Report on } \\
\text { Project AR-F-321 for FY05, by L.D. } \\
\text { Stephenson, A. Kumar, and J. Bushman }\end{array}$ & ADA528485 \\
\hline ERDC/CERL TR-07-26 & Jun 2007 & $\begin{array}{l}\text { Cathodic Protection of Hot Water Tanks } \\
\text { at Fort Sill: Final Report on Project AR-F- } \\
322 \text { for FY05, by L.D. Stephenson, A. } \\
\text { Kumar, and J. Bushman }\end{array}$ & ADA503860 \\
\hline ERDC/CERL TR-07-28 & Jun 2007 & $\begin{array}{l}\text { Implementation of Electro-Osmotic Pulse } \\
\text { Technology in Building P10000 At Fort } \\
\text { Drum, by O.S. Marshall }\end{array}$ & ADA593174 \\
\hline ERDC/CERL TR-07-29 & Jun 2007 & $\begin{array}{l}\text { Innovative Corrosion-Resistant Coatings } \\
\text { for Heat Distribution Piping at Fort } \\
\text { Jackson, by C.P. Marsh, A.D. Beitelman, } \\
\text { and R.J. Franks }\end{array}$ & ADA472602 \\
\hline ERDC/CERL TR-07-30 & Aug 2007 & $\begin{array}{l}\text { Construction Operations Building } \\
\text { Information Exchange (COBIE): } \\
\text { Requirements Definition and Pilot } \\
\text { Implementation Standard, by E.W. East }\end{array}$ & ADA491899 \\
\hline ERDC/CERL TR-07-31 & Aug 2007 & $\begin{array}{l}\text { A Programmatic Approach to Determine } \\
\text { Eligibility of Prehistoric Sites in the San } \\
\text { Diego Subregion, Southern Coast } \\
\text { Archeological Region, California, for the } \\
\text { National Register of Historic Places, by } \\
\text { S.N. Reddy and T. Britt }\end{array}$ & ADA480835 \\
\hline ERDC/CERL TR-07-32 & Sep 2007 & $\begin{array}{l}\text { Direct Carbon Fuel Cells: Converting } \\
\text { Waste to Electricity, by R.H. Wolk, S. Lux, } \\
\text { S. Gelber, and F.H. Holcomb }\end{array}$ & ADA482934 \\
\hline ERDC/CERL TR-07-33 & Aug 2007 & $\begin{array}{l}\text { Burrow Collapse as a Potential Stressor } \\
\text { on the Gopher Tortoise (Gopherus } \\
\text { polyphemus), by M. Mendonça, R. } \\
\text { Beauman, and H. Balbach }\end{array}$ & ADA471936 \\
\hline 1ERDC/CERL TR-07-34 & Sep 2007 & $\begin{array}{l}\text { Kollsman Night Targeting System } \\
\text { Upgrade Test Report, by J. Wilcoski, J.C. } \\
\text { Trovillion, and P.S. Nelson }\end{array}$ & ADB333788 \\
\hline
\end{tabular}

1 Limited distribution; see Preface. 
ERDC/CERL TR-07-35

ERDC/CERL TR-07-36

ERDC/CERL TR-07-37

1ERDC/CERL TR-07-38

ERDC/CERL TR-07-39

Vol. 1

1ERDC/CERL TR-07-39

Vol. 2

ERDC/CERL TR-07-41

Sep 2007

Sep 2007

ERDC/CERL TR-07-43 Oct 2007 for Electric Grids, by D.D. Massie, P.S
Performance Testing of Historically Appropriate Blast-Resistant Windows: Volume 2 - Test Data, by J.L. Webster and P.E. Reicher

Low Maintenance Water Treatment for Heating and Cooling Systems: Review of Technologies and Guidelines for Implementation, by K.W. Smothers, S.A. Drozdz, and V.F. Hock

Preventive Maintenance and Reliability

ADA482417 Vavrin, W.T. Brown, M.R. Kemme, J. Westerman, R. Lorand, C. Walden, and C. Swinehart

Electrical Assessment, Capacity, and

ADA482419 Alaska, by J.L. Vavrin, W.T. Brown, M.R. Kemme, M.A. Allen, W.J. Percle, R.T. Lorand, D.B. Stauffer, and K. Hudson

Assessment at U.S. Army Installation in Germany: Keiserslautern Army Depot, Piermasens Army Depot, Katterbach Kaserne, Storck Barracks in Illesheim, and U.S. Army Garrison Wiesbaden Schools, by A.M. Zhivov, D.M. Underwood, J.L. Vavrin, A. Woody, C. Bjork, J. Newman, E. Reinkinen, T. Husu, M. Schmidt, M. Klassek, G. Claus, M. Zinsser, R. Vaisanen, T. Kauppinen, $\mathrm{H}$. Erhorn-Kluttig, H. Erhorn, and A. Staudt Curtiss, M. Miller, L. Juby, M. Roberts, F.H. Holcomb, and W.W. Weaver

Performance Testing of Historically Appropriate Blast-Resistant Windows: Volume 1 - Background and Testing Program, by J.L. Webster and P.E. Reicher

Molten Carbonate Fuel Cell Operation With Dual Fuel Flexibility, by J. Daly, G. Steinfeld, D.K. Moyer, and F.H. Holcomb 


\begin{tabular}{|c|c|c|c|}
\hline ERDC/CERL TR-07-44 & Sep 2007 & $\begin{array}{l}\text { Fort Riley Early Cold War Building } \\
\text { Inventory and Evaluation, 1953-1960, by } \\
\text { S. Enscore and J. Webster }\end{array}$ & \\
\hline ERDC/CERL TR-07-45 & Nov 2007 & $\begin{array}{l}\text { LEED } ® \text { for Homes - Pilot Study: } \\
\text { Evaluation for Use in Army Family } \\
\text { Housing, by L. Bobotas, M. Hinson, P. } \\
\text { Christensen, G. Headley, R. Schneider, } \\
\text { and A. Stumpf }\end{array}$ & ADA475401 \\
\hline ERDC/CERL TR-07-46 & Nov 2007 & $\begin{array}{l}\text { Facility Composer }{ }^{\mathrm{TM}} \text { and PACES }{ }^{\mathrm{TM}} \\
\text { Integration: Development of an XML } \\
\text { Interface Based on Industry Foundation } \\
\text { Classes, by S.D. Nachtigall and B.A. } \\
\text { Brucker }\end{array}$ & ADA475289 \\
\hline ERDC/CERL TR-07-47 & Nov 2007 & $\begin{array}{l}\text { Threatened and Endangered Species } \\
\text { Surveillance in Inaccessible Areas: A } \\
\text { Feasibility Study, by H. Balbach, D. Pitts, } \\
\text { W. Meyer, and S. Tweddale }\end{array}$ & ADA478347 \\
\hline ERDC/CERL TR-07-48 & Nov 2007 & $\begin{array}{l}\text { Profiles for High-Priority Species: Focus } \\
\text { of the Army Threatened and Endangered } \\
\text { Species Research Program, by H.E. } \\
\text { Balbach and E.L. Keane }\end{array}$ & ADA478345 \\
\hline ERDC/CERL TR-07-49 & Dec 2007 & $\begin{array}{l}\text { Joint Distributed Regional Training } \\
\text { Capacity: A Scoping Study, by J. } \\
\text { Westervelt, M.P. Case, M.L. Hargrave, } \\
\text { S.J. Bevelheimer, L.J. McCarthy, K.D. } \\
\text { Radnitzer, K. McGuire, W.D. Meyer, J.S. } \\
\text { Rank, B.A. MacAllister, B.J. Kim, N.G. } \\
\text { Svendsen, and H. Howard }\end{array}$ & ADA482949 \\
\hline ERDC/CERL TR-08-3 & Feb 2008 & $\begin{array}{l}\text { Anaerobic Treatment of Wastewaters } \\
\text { Containing Perchlorate from Munitions } \\
\text { Handling and Production, by S.W. } \\
\text { Maloney, E. Atikovic, and M.T. Suidan }\end{array}$ & ADA479114 \\
\hline ERDC/CERL TR-08-4 & Feb 2008 & $\begin{array}{l}\text { Source Term Model for Fine Particle } \\
\text { Resuspension from Indoor Surfaces, by } \\
\text { Y. Kim, A. Gidwani, M. Sippola, and C.W. } \\
\text { Sohn }\end{array}$ & ADA478675 \\
\hline $\begin{array}{l}\text { ERDC/CERL TR-08-5 } \\
\text { Vol. } 1\end{array}$ & Feb 2008 & $\begin{array}{l}\text { Technology Demonstration of the Zero } \\
\text { Emissions Chromium Electroplating } \\
\text { System, by K.J. Hay, S.W. Maloney, J.J. } \\
\text { Cannon, M.R. Phelps, and J. Modrell }\end{array}$ & ADA480675 \\
\hline $\begin{array}{l}\text { ERDC/CERL TR-08-5 } \\
\text { Vol. } 2\end{array}$ & Feb 2008 & $\begin{array}{l}\text { Technology Demonstration of the Zero } \\
\text { Emissions Chromium Electroplating } \\
\text { System; Appendix I: CHPPM Report on } \\
\text { Air Sampling, by K.J. Hay, S.W. Maloney, } \\
\text { J.J. Cannon, M.R. Phelps, and J. Modrell }\end{array}$ & ADA485338 \\
\hline
\end{tabular}




\begin{tabular}{|c|c|c|c|}
\hline ERDC/CERL TR-08-6 & Apr 2008 & $\begin{array}{l}\text { Pseudo Dynamic Testing and Seismic } \\
\text { Rehabilitation of Iraqi Brick, Bearing and } \\
\text { Shear Walls, by G.K. Al-Chaar, S.C. } \\
\text { Sweeney, J.C. Trovillion, O.S. Marshall, } \\
\text { and B. Danielson }\end{array}$ & ADA522226 \\
\hline ERDC/CERL TR-08-7 & Apr 2008 & $\begin{array}{l}\text { Field Test of Gopher Tortoise (Gopherus } \\
\text { Polyphemus) Population Estimation } \\
\text { Techniques, by W.D. Meyer, S.Z. Nomani, } \\
\text { R.R. Carthy, and M.K. Oli }\end{array}$ & ADA486629 \\
\hline 1ERDC/CERL TR-08-8 & May 2008 & $\begin{array}{l}\text { Demonstration of Solid Oxide Fuel Cell, } \\
\text { by T. Conrad, S. Van Scoyoc, S. Kenner, } \\
\text { A.B. Armstrong, T. Konvalina, T.D. } \\
\text { Prevish, S. Logan, Jr., K.A. Spitznagel, } \\
\text { and F.H. Holcomb }\end{array}$ & ADB344274 \\
\hline ERDC/CERL TR-08-9 & Jun 2008 & $\begin{array}{l}\text { Cultural Affiliation Study in Support of } \\
\text { Native American Consultation Efforts for } \\
\text { Fort Gordon, GA: Richmond, Jefferson, } \\
\text { McDuffie, and Columbia Counties, by } \\
\text { C.L. Baxter and T. Britt }\end{array}$ & ADA485265 \\
\hline ERDC/CERL TR-08-10 & Jun 2008 & $\begin{array}{l}\text { Condition Assessment Methodology for } \\
\text { Spillways, by L.E. Chouinard, S. Foltz, J.- } \\
\text { G. Robichaud, and R. Wittebolle }\end{array}$ & ADA485775 \\
\hline ERDC/CERL TR-08-11 & Aug 2008 & $\begin{array}{l}\text { Proceedings of the 1st Army Installation } \\
\text { Waste to Energy Workshop, by F.H. } \\
\text { Holcomb, R.S. Parker, T.J. Hartranft, K. } \\
\text { Preston, H.R. Sanborn, and P.J. Darcy }\end{array}$ & ADA491416 \\
\hline ERDC/CERL TR-08-12 & Sep 2008 & $\begin{array}{l}\text { IMCOM LonWorks }{ }^{\circledR} \text { Building Automation } \\
\text { Systems Implementation Strategy: Final } \\
\text { Report, by D.M. Schwenk, J. Bush, L.M. } \\
\text { Hughes, S. Briggs, and W. White }\end{array}$ & ADA492015 \\
\hline ERDC/CERL TR-08-13 & Sep 2008 & $\begin{array}{l}\text { Hydrothermal Processing of Base Camp } \\
\text { Solid Wastes To Allow Onsite Recycling, } \\
\text { by G.L. Gerdes, D. Curtin, and C. } \\
\text { Gutkowski }\end{array}$ & ADA491636 \\
\hline ERDC/CERL TR-08-14 & Sep 2008 & $\begin{array}{l}\text { Energy Optimization Assessment at U.S. } \\
\text { Army Installations: West Point Military } \\
\text { Academy, NY, by D.M. Underwood, A. } \\
\text { Zhivov, J.P. Miller, J. Vavrin, A. Woody, C. } \\
\text { Bjork, E. Reinkinen, R. Ziegler, W.D. } \\
\text { Chvala, and E.M. Rauch }\end{array}$ & ADA520834 \\
\hline
\end{tabular}

1 Limited distribution; see Preface. 


\begin{tabular}{|c|c|c|c|}
\hline ERDC/CERL TR-08-15 & Sep 2008 & $\begin{array}{l}\text { Energy Optimization Assessment at U.S. } \\
\text { Army Installations: Fort Bliss, TX, by D.M. } \\
\text { Underwood, A.M. Zhivov, J.P. Miller, A. } \\
\text { Woody, R. Colbert, L. Shapiro, C. Bjork, } \\
\text { W.D. Chvala, Jr., and D. Dixon. }\end{array}$ & ADA494713 \\
\hline ERDC/CERL TR-08-16 & Sep 2008 & $\begin{array}{l}\text { Energy Optimization Audit at Humphreys } \\
\text { Engineer Center, by A. Zhivov, A. Woody, } \\
\text { W. Anis, and M. Keefover }\end{array}$ & ADA544746 \\
\hline ERDC/CERL TR-08-17 & Sep 2008 & $\begin{array}{l}\text { Field Assessment of Gopher Tortoise } \\
\text { Habitat at Camp Shelby: Phase I - } \\
\text { Preliminary Understory and Midstory } \\
\text { Habitat Assessment, by D.L. Evans, S.D. } \\
\text { Roberts, J.C. Jones, K.E. Edwards, H.A. } \\
\text { Londo, D. Nicholson, S. Tweddale, and D. } \\
\text { Delaney }\end{array}$ & \\
\hline ERDC/CERL TR-08-19 & Mar 2008 & $\begin{array}{l}\text { Constitutive Models for Nonlinear Finite } \\
\text { Element Analysis of Masonry Prisms and } \\
\text { Infill Walls, by G.K. Al-Chaar and A. } \\
\text { Mehrabi }\end{array}$ & ADA496667 \\
\hline ERDC/CERL TR-08-20 & Oct 2008 & $\begin{array}{l}\text { Tactical Unit Data and Decision } \\
\text { Requirements for Urban Operations, by } \\
\text { J.A. Burkhalter, P.M. Loechl, and E.P. } \\
\text { Zeigler }\end{array}$ & ADA507672 \\
\hline ERDC/CERL TR-08-21 & Dec 2008 & $\begin{array}{l}\text { Lipari Landfill Piping Network Corrosion } \\
\text { Condition Assessment and Service Life } \\
\text { Prediction Analysis, by C.P. Marsh, T.A. } \\
\text { Carlson, R.A. Weber, C.A. Feickert, and } \\
\text { P.B. Stynoski }\end{array}$ & ADA500700 \\
\hline ERDC/CERL TR-09-1 & Jan 2009 & $\begin{array}{l}\text { Handbook on Gopher Tortoise (Gopherus } \\
\text { polyphemus): Health Evaluation } \\
\text { Procedures for Use by Land Managers } \\
\text { and Researchers, by L. Wendland, H. } \\
\text { Balbach, M. Brown, J.D. Berish, R. Littell, } \\
\text { and M. Clark }\end{array}$ & ADA501295 \\
\hline ERDC/CERL TR-09-2 & Jan 2009 & $\begin{array}{l}\text { Estimating Viability of Gopher Tortoise } \\
\text { Populations, by T.D. Tuberville, J.W. } \\
\text { Gibbons, and H.E. Balbach }\end{array}$ & ADA520821 \\
\hline ERDC/CERL TR-09-3 & Jan 2009 & $\begin{array}{l}\text { Energy Optimization Assessments at U.S. } \\
\text { Army Installations: Caserma Ederle } \\
\text { Vicenza, Italy, by D.M. Underwood, A. } \\
\text { Zhivov, A. Woody, C. Bjork, D. Neth, and } \\
\text { R. Ziegler }\end{array}$ & ADA520818 \\
\hline
\end{tabular}




\begin{tabular}{|c|c|c|c|}
\hline ERDC/CERL TR-09-4 & Jan 2009 & $\begin{array}{l}\text { Role of Inspection and Condition } \\
\text { Assessment in U.S. Army Corps of } \\
\text { Engineers Civil Works Infrastructure } \\
\text { Management: Current Practices and } \\
\text { Opportunities for the Future, by D.R. } \\
\text { Uzarski, D.T. McKay, and S.D. Foltz }\end{array}$ & ADA522653 \\
\hline ERDC/CERL TR-09-5 & Feb 2009 & $\begin{array}{l}\text { Heating and Cooling Master Plan for Fort } \\
\text { Bragg, NC, Fiscal Years } 2005 \text { to } 2030 \text {, } \\
\text { by W.T. Brown, III, A.M. Zhivov, D.M. } \\
\text { Schwenk, J. Bush, D.M. Underwood, D. } \\
\text { Chu, S. Richter, R. Ziegler, H. Neuner, } \\
\text { and A.W. Woody }\end{array}$ & ADA501356 \\
\hline ERDC/CERL TR-09-6 & Feb 2009 & $\begin{array}{l}\text { Guidelines for Identifying and Evaluating } \\
\text { Historic Military Landscapes, by S.K. } \\
\text { Loechl, S.I. Enscore, } \\
\text { M.W. Tooker, and S.A. Batzli }\end{array}$ & \\
\hline ERDC/CERL TR-09-7 & Mar 2009 & $\begin{array}{l}\text { Gopher Tortoise Survey Handbook, by } \\
\text { L.S. Smith, J. Stober, H.E. Balbach, and } \\
\text { W.D. Meyer }\end{array}$ & ADA522655 \\
\hline ERDC/CERL TR-09-08 & Mar 2009 & $\begin{array}{l}\text { A Framework and Strategies for } \\
\text { Determining Reference Conditions for } \\
\text { Streams with Legacy Sediments on } \\
\text { Military Installations, by K. Thornton, P. } \\
\text { Downey, H.E. Balbach, and E.L. Keane }\end{array}$ & ADA522251 \\
\hline ERDC/CERL TR-09-9 & Apr 2009 & $\begin{array}{l}\text { Environmentally Friendly Cleaners for } \\
\text { Removing Tar from Metal Surfaces, by } \\
\text { J.C. Baird, V.M. Boddu, P. Khabra, and W. } \\
\text { Ziegler }\end{array}$ & ADA500703 \\
\hline ERDC/CERL TR-09-10 & Jun 2009 & $\begin{array}{l}\text { Natural Gas Engine-Driven Heat Pump } \\
\text { Demonstration at DoD Installations: } \\
\text { Performance and Reliability Summary, by } \\
\text { C.W. Sohn, F.H. Holcomb, I. Mahderekal, } \\
\text { T. Young, and D. Sondeno }\end{array}$ & ADA540435 \\
\hline ERDC/CERL TR-09-11 & Apr 2009 & $\begin{array}{l}\text { Public Reporting and a More Sustainable } \\
\text { Army, by S.D. Foltz, G.L. Gerdes, M.J. } \\
\text { Hanson, D.A. Krooks, and C.C. Rewerts }\end{array}$ & ADA500705 \\
\hline ERDC/CERL TR-09-12 & Apr 2009 & $\begin{array}{l}\text { Proceedings of the Military Applications } \\
\text { for Emerging Water Use Technologies } \\
\text { Workshop, by R.J. Scholze, G.L. Gerdes, } \\
\text { W.D. Goran, J. Hall, K. Preston, M. } \\
\text { McLeod, D. Sheets, and R. Sustich }\end{array}$ & ADA507812 \\
\hline
\end{tabular}




\begin{tabular}{|c|c|c|c|}
\hline ERDC/CERL TR-09-13 & May 2009 & $\begin{array}{l}\text { Actionable Cultural Understanding for } \\
\text { Support to Tactical Operations (ACUSTO): } \\
\text { Toward a New Methodological Template } \\
\text { for Spatial Decision Support System, by } \\
\text { L. Anselin, W.D. Meyer, L.A. Whalley, and } \\
\text { M.J. Savoie }\end{array}$ & ADA522096 \\
\hline ERDC/CERL TR-09-14 & May 2009 & $\begin{array}{l}\text { The Role of Habituation and } \\
\text { Sensitization in Understanding the } \\
\text { Annoyance of Community Exposures to } \\
\text { Impulsive Noise, by G.A. Luz and E.T. } \\
\text { Nykaza }\end{array}$ & ADA540416 \\
\hline ERDC/CERL TR-09-15 & Jun 2009 & $\begin{array}{l}\text { Actionable Cultural Understanding for } \\
\text { Support to Tactical Operations (ACUSTO): } \\
\text { The Effect of Data Quality on Spatial } \\
\text { Analysis Results, by L. Galvis, P.J. } \\
\text { Guertin, and W.D. Meyer }\end{array}$ & ADA522284 \\
\hline ERDC/CERL TR-09-16 & Jun 2009 & $\begin{array}{l}\text { Energy Assessment at Army Installations } \\
\text { in Germany: Campbell Barracks - } \\
\text { Heidelberg, Coleman Barracks - } \\
\text { Manheim, Katterbach Barracks - } \\
\text { Ansbach, Storch Barracks - Illesheim, } \\
\text { and U.S. Depot - Germersheim, by D.M. } \\
\text { Underwood, A. Zhivov, J. Pilarski, A. } \\
\text { Woody, C. Bjork, K. Bohn, and D. Neth }\end{array}$ & ADA523164 \\
\hline ERDC/CERL TR-09-17 & Jun 2009 & $\begin{array}{l}\text { Energy Assessment at Army Installations: } \\
\text { Chievres Airbase Belgium, Schinnen } \\
\text { Emma Mine Netherlands, and Brussels } \\
\text { American School, by D.M. Underwood, } \\
\text { A.M. Zhivov, D. Neth, and A. Woody }\end{array}$ & ADA522204 \\
\hline ERDC/CERL TR-09-18 & Jun 2009 & $\begin{array}{l}\text { Analysis of Service Records } \\
\text { Management Systems for Rescue and } \\
\text { Retention of Cultural Resource } \\
\text { Documents, by S.I.Enscore, J.L. Webster, } \\
\text { P.M. Loechl, and J.L. Barr }\end{array}$ & ADA540432 \\
\hline ERDC/CERL TR-09-19 & Jul 2009 & $\begin{array}{l}\text { A Spatially Explicit Model of Red } \\
\text { Imported Fire Ant Behavior for Managing } \\
\text { Species at Risk on Military Lands, by T. } \\
\text { Peterson, B. Rossmann, J. Drake, and J. } \\
\text { Westervelt }\end{array}$ & ADA505312 \\
\hline ERDC/CERL TR-09-20 & Jul 2009 & $\begin{array}{l}\text { Demonstration of Electronic Capacitor- } \\
\text { Based Water Treatment System for } \\
\text { Application at Military Installations, by } \\
\text { A.D. Beitelman, M.M. Pitts, Jr., R.F.V. } \\
\text { Romo, and C.B. Pitts }\end{array}$ & ADA540444 \\
\hline
\end{tabular}


ERDC/CERL TR-09-22

ERDC/CERL TR-09-23

ERDC/CERL TR-09-24

ERDC/CERL TR-09-25

ERDC/CERL TR-09-26

ERDC/CERL TR-09-27

Aug 2009

ERDC/CERL TR-09-28

Aug 2009

ERDC/CERL TR-09-29

Aug 2009

Aug 2009
Development of a Predictive Corrosion Model Using Locality-Specific Corrosion Indices: Final Report on Project FAR-15 for FY06, by S. Morefield, S.A. Drozdz, V.F. Hock, W.H. Abbott, D. Paul, and J.L. Jackson

Aug 2009 Demonstration of Electro-Osmotic Pulse Technology in Earth-Covered Magazines at Fort A.P. Hill, VA: Final Report on Project FAR-01 for FY06, by O.S. Marshall, Jr.

Aug 2009 Innovative Coating System for Corrosion Prevention and Temperature Reduction in Heat Distribution Manholes: Final Report on Project FAR-11 for FY06, by A.D. Beitelman, T.A. Carlson, B.G. Jones, C.P. Marsh, D. Kessler, J.J. Ong, and L. Zou

Aug 2009 Sustainable Materials Replacement for Prevention of Corrosion at Fort Lewis, WA: Final Report on Project FAR-21 for FY06, by R.G. Lampo, T.R. Napier, and R.L. Schneider

Demonstration of Cathodic Protection Systems for Utilities in Severely Corrosive Environments at Fort Jackson: Final Report on Project FAR-20 for FY06, by L.D. Stephenson, A. Kumar, J.B. Bushman, and B. Phull

Corrosion Prevention of Rebar in Concrete in Critical Facilities Located in Coastal Environments at Okinawa: Final Report on Project FAR-16 for FY06, by L.D. Stephenson, A. Kumar, R. Walde, and M. Merzlikin

Demonstration of a Mixed Oxide Process for Control of Corrosion and Microbiological Growth in Cooling Towers: Final Report on Project FAR-03 for FY06, by S.A. Drozdz

Application of Corrosion- and FireResistant Coating Systems on Buildings 227 and 299 at Rock Island Arsenal: Final Report on Project FAR-13 for FY06, by S.A. Drozdz, P.P. Greigger, R. Fruge, and S.D. Benton
ADA528275

ADA543976

ADA515627

ADA516863

ADA522641

ADA515491

ADA520804

ADA532281 


\begin{tabular}{|c|c|c|c|}
\hline ERDC/CERL TR-09-30 & Aug 2009 & $\begin{array}{l}\text { Implementation of Remote Corrosion- } \\
\text { Monitoring Sensor for Mission-Essential } \\
\text { Structures at Okinawa: Final Report on } \\
\text { Project FAR-04 for FY06, by L.D. } \\
\text { Stephenson, A. Kumar, J. O'Day, B. } \\
\text { Caldwell, K. Kwan, and B.C. Laskowski }\end{array}$ & ADA520458 \\
\hline ERDC/CERL TR-09-31 & Aug 2009 & $\begin{array}{l}\text { Demonstration of Smart Fluorescent and } \\
\text { Self-Healing Coatings for Severely } \\
\text { Corrosive Environments at Vehicle Wash } \\
\text { Facilities: Final Report on Project FAR-02 } \\
\text { for FY06, by A. Kumar, Dr. L.D. } \\
\text { Stephenson, T.D. Race, and T. Bochniak }\end{array}$ & ADA526315 \\
\hline ERDC/CERL TR-09-32 & Sep 2009 & $\begin{array}{l}\text { Location Forecast of Future Urban } \\
\text { Residential Development Near Nellis Air } \\
\text { Force Base, Nevada, by J.D. Westervelt }\end{array}$ & ADA568565 \\
\hline ERDC/CERL TR-09-33 & Sep 2009 & $\begin{array}{l}\text { Historical and Architectural } \\
\text { Documentation of the Interurban Trolley } \\
\text { Bridge at Three Mile Creek, Fort Riley, } \\
\text { Kansas, by S.I. Enscore, J.L. Webster, } \\
\text { and E. Hooker III }\end{array}$ & ADA568244 \\
\hline ERDC/CERL TR-09-34 & Sep 2009 & $\begin{array}{l}\text { Polymerase Chain Reaction (PCR) } \\
\text { Analysis of Microbial Consortia on } \\
\text { Wastewater Treatment Processes for } \\
\text { High Explosives, by C.M. Arnett, G. } \\
\text { Rodriguez, and S.W. Maloney }\end{array}$ & ADA544671 \\
\hline 1ERDC/CERL TR-09-35 & Sep 2009 & $\begin{array}{l}\text { FY2008 Lessons Learned from Army } \\
\text { Utilities Modernization Site Visits, by W.T. } \\
\text { Brown III, T. Abdallah, R. Ducey, S. Foltz, } \\
\text { S. Hunter, M. Kemme, C. Marsh, N. Potts, } \\
\text { R. Scholze, C. Sohn, J. Vavrin, D. Bonk, D. } \\
\text { Brown, A. Price, C. Bermel, D. Burt, R. } \\
\text { Jepson, C. Johnson, D. Mathias, D. } \\
\text { Rollins, and L. Vance }\end{array}$ & ADB370671 \\
\hline 1ERDC/CERL TR-09-36 & Sep 2009 & $\begin{array}{l}\text { Tooele Army Depot Utilities } \\
\text { Modernization Program, by S. Hunter, } \\
\text { W.T. Brown III, D. Rollins, L. Vance, and C. } \\
\text { Johnson }\end{array}$ & ADB370624 \\
\hline 1ERDC/CERL TR-09-37 & Sep 2009 & $\begin{array}{l}\text { Comprehensive Historical and } \\
\text { Architectural Documentation Report for } \\
\text { Fort Riley, Kansas, by S.I. Enscore and } \\
\text { J.L. Webster }\end{array}$ & \\
\hline
\end{tabular}

1 Limited distribution; see Preface. 


\begin{tabular}{|c|c|c|c|}
\hline ERDC/CERL TR-09-38 & Sep 2009 & $\begin{array}{l}\text { Army Installations Water Sustainability } \\
\text { Assessment: An Evaluation of } \\
\text { Vulnerability to Water Supply, by E.M. } \\
\text { Jenicek, N.R.D. Myers, D.F. Fournier, K. } \\
\text { Miller, M. Hessel, R. Carroll, and R. } \\
\text { Holmes }\end{array}$ & ADA525795 \\
\hline ERDC/CERL TR-09-39 & Apr 2009 & $\begin{array}{l}\text { Demonstration of CBR Modeling and } \\
\text { Simulation Tool (CBRSim) Capabilities, } \\
\text { by K.L. Simunich, T.K. Perkins, D.M. } \\
\text { Bailey, D. Brown, and P. Sydelko }\end{array}$ & ADA527691 \\
\hline ERDC/CERL TR-10-1 & Jan 2010 & $\begin{array}{l}\text { System Chemistry to Control Potential } \\
\text { Environmental and Safety Hazards of } \\
\text { Recycled Concrete Aggregate With Lead- } \\
\text { Based Paint, by S.D. Cosper }\end{array}$ & ADA553419 \\
\hline ERDC/CERL TR-10-3 & Jan 2010 & $\begin{array}{l}\text { The History of American Settlement at } \\
\text { Camp Atterbury, by S.D. Smith and C.J. } \\
\text { Cochran }\end{array}$ & ADA513125 \\
\hline ERDC/CERL TR-10-4 & Feb 2010 & $\begin{array}{l}\text { St. Regis Paper Mill: Architectural and } \\
\text { Environmental Survey, by A. Smith, S. } \\
\text { Adams, M.W. Tooker, S. Cosper, and G. } \\
\text { Gerdes }\end{array}$ & ADA523305 \\
\hline ERDC/CERL TR-10-5 & Mar 2010 & $\begin{array}{l}\text { Membrane and Flashing Condition } \\
\text { Indexes for Modified Bitumen Roofs: } \\
\text { Inspection and Distress Manual, by D.M. } \\
\text { Bailey }\end{array}$ & ADA518899 \\
\hline 1ERDC/CERL TR-10-6 & Mar 2010 & $\begin{array}{l}\text { Effect of Basements on Building } \\
\text { Dynamic Response, by B.F. Spencer, H.K. } \\
\text { Jo, J. Wilcoski, and L.A. Bergman }\end{array}$ & ADB359171 \\
\hline 1ERDC/CERL TR-10-7 & Mar 2010 & $\begin{array}{l}\text { Cultural Factors in Architecture, } \\
\text { Construction, and Use of Buildings: A } \\
\text { Report for Baghdad, Tehran, Kabul, and } \\
\text { Islamabad, by P.M. Loechl, S.I. Enscore, } \\
\text { J.L. Webster, and S.K. Loechl }\end{array}$ & \\
\hline ERDC/CERL TR-10-8 & Mar 2010 & $\begin{array}{l}\text { Military Training Lands Historic Context: } \\
\text { Large Arms Ranges, by D. Archibald, A. } \\
\text { Smith, S. Adams, and M. Chawla }\end{array}$ & ADA537095 \\
\hline ERDC/CERL TR-10-9 & Mar 2010 & $\begin{array}{l}\text { Military Training Lands Historic Context: } \\
\text { Miscellaneous Training Sites, by A. } \\
\text { Smith, M.K. Chawla, S. Adams, and D.D. } \\
\text { Archibald }\end{array}$ & ADA537096 \\
\hline
\end{tabular}

1 Limited distribution; see Preface. 


\begin{tabular}{|c|c|c|c|}
\hline ERDC/CERL TR-10-10 & Mar 2010 & $\begin{array}{l}\text { Military Training Lands Historic Context: } \\
\text { Training Village, Mock Sites, And Large } \\
\text { Scale Operations Areas, by D. Archibald, } \\
\text { A. Smith, S. Adams, and M. Chawla }\end{array}$ & ADA537098 \\
\hline ERDC/CERL TR-10-11 & Mar 2010 & $\begin{array}{l}\text { Military Training Lands Historic Context: } \\
\text { Small Arms Ranges, by D. Archibald, A. } \\
\text { Smith, S. Adams, and M. Chawla }\end{array}$ & ADA537097 \\
\hline ERDC/CERL TR-10-13 & Aug 2010 & $\begin{array}{l}\text { Bridging the Gap: The Role of DOD in } \\
\text { Clean Energy Commercialization: DOD } \\
\text { Installations as "Living Laboratories", by } \\
\text { H. Sanborn, R. Parker, and E. Kallio }\end{array}$ & ADA538510 \\
\hline ERDC/CERL TR-10-14 & Aug 2010 & $\begin{array}{l}\text { Sustainable Use of Local Resources for } \\
\text { Improved Energy Security: Phase 2: } \\
\text { Procurement and Installation of Waste- } \\
\text { to-Energy System at Eielson AFB, } \\
\text { Fairbanks, AK, by R. Comly, A. Rehmat, } \\
\text { M. Goold, and T. Abdallah }\end{array}$ & \\
\hline ERDC/CERL TR-10-15 & Aug 2010 & $\begin{array}{l}\text { Energy Security: Emerging Challenges } \\
\text { and Opportunities, by T. Abdallah, S. } \\
\text { Cary, M. Case, W. Goran, J. Harris, K. } \\
\text { Hern, F. Holcomb, J. Hudak, S. Kenney, J. } \\
\text { Miller, and N. Myers }\end{array}$ & ADA609792 \\
\hline ERDC/CERL TR-10-16 & Aug 2010 & $\begin{array}{l}\text { Investigation of Translocation as a Useful } \\
\text { Tool to Sustain Species at Risk, by H.E. } \\
\text { Balbach and E.L. Keane }\end{array}$ & \\
\hline ERDC/CERL TR-10-17 & Sep 2010 & $\begin{array}{l}\text { Development of Army Facility } \\
\text { Functionality Assessment Criteria and } \\
\text { Procedures, by M.N. Grussing, L.R. } \\
\text { Marrano, and M.C. Walters }\end{array}$ & ADA552801 \\
\hline ERDC/CERL TR-10-18 & Sep 2010 & $\begin{array}{l}\text { Development of the Army Facility Mission } \\
\text { Dependency Index for Infrastructure } \\
\text { Asset Management, by M.N. Grussing, S. } \\
\text { Gunderson, M. Canfield, E. Falconer, A. } \\
\text { Antelman, and S.L. Hunter }\end{array}$ & ADA552791 \\
\hline ERDC/CERL TR-10-20 & Sep 2010 & $\begin{array}{l}\text { Energy Assessment at Army Installations } \\
\text { in Japan: Akizuki, Sagami General Depot, } \\
\text { Sagamihara Family Housing, and Camp } \\
\text { Zama, by D.M. Underwood, A.M Zhivov, } \\
\text { C. Bjork, J. Rees, A. Woody, S. Walerczyk, } \\
\text { P. Johnson, J. Locker, and H. Hamers }\end{array}$ & \\
\hline
\end{tabular}

ERDC/CERL TR-10-21 Sep 2010 The Army Priority List of At-Risk Species: ADA558770 2009-2010 Status Update, by $\mathrm{H}$. Balbach, M. Perez-Martinez, and E. Keane 


\begin{tabular}{|c|c|c|c|}
\hline 1ERDC/CERL TR-10-22 & Sep 2010 & $\begin{array}{l}\text { A Socio-Cultural Grammar for Battle } \\
\text { Management Language, by D.A. Krooks } \\
\text { and C.M. Armstrong }\end{array}$ & ADB377389 \\
\hline 1ERDC/CERL TR-10-23 & Sep 2010 & $\begin{array}{l}\text { Energy Assessment at Army Installations } \\
\text { in Korea: Camp Carroll, Camp Henry, } \\
\text { Camp Humphreys, and Camp Walker, by } \\
\text { D.M. Underwood, A.M. Zhivov, D. Neth, S. } \\
\text { Richter, R. Montgomery, A. Woody, H. } \\
\text { Nauner, S. Ochse, and S. Wood }\end{array}$ & ADB370540 \\
\hline ERDC/CERL TR-10-24 & Sep 2010 & $\begin{array}{l}\text { Working Towards Net Zero Energy at Fort } \\
\text { Irwin, CA, by D.M. Underwood, A. Zhivov, } \\
\text { S. Duncan, A. Woody, C. Björk, S. Richter, } \\
\text { D. Neth, D. Pinault, and R. Jank }\end{array}$ & ADA552500 \\
\hline ERDC/CERL TR-10-25 & Oct 2010 & $\begin{array}{l}\text { Field Assessment of Gopher Tortoise } \\
\text { Habitat at Camp Shelby, MS: Phase II: } \\
\text { Overstory and Combined Assessments, } \\
\text { by D.L. Evans, S.D. Roberts, J.C. Jones, } \\
\text { K.E. Edwards, H.A. Londo, D. Nicholson, } \\
\text { S. Tweddale, and D. Delaney }\end{array}$ & ADA544481 \\
\hline ERDC/CERL TR-10-26 & Nov 2010 & $\begin{array}{l}\text { Prediction of Environmental Impact of } \\
\text { High-Energy Materials with Atomistic } \\
\text { Computer Simulations, by N. } \\
\text { Sokkalingam, J.J. Potoff, V.M. Boddu, } \\
\text { S.W. Maloney, and J.C. Baird }\end{array}$ & ADA593906 \\
\hline ERDC/CERL TR-10-27 & Nov 2010 & $\begin{array}{l}\text { Prediction of Physicochemical Properties } \\
\text { of Energetic Materials for Identification } \\
\text { of Treatment Technologies for Waste } \\
\text { Streams, by V.M. Boddu, S.W. Maloney, } \\
\text { R.K. Toghiani, and H. Toghiani }\end{array}$ & ADA567030 \\
\hline ERDC/CERL TR-10-28 & Nov 2010 & $\begin{array}{l}\text { Architectural Survey of a Water Tower in } \\
\text { Youngstown Air Reserve Station, by C.J. } \\
\text { Cochran and A. Smith }\end{array}$ & ADA537176 \\
\hline 1ERDC/CERL TR-10-29 & Dec 2010 & $\begin{array}{l}\text { Infrastructure and Essential Services } \\
\text { (IES) Ontology for Irregular Warfare, by } \\
\text { T.K. Perkins, N.R. Myers, D. Gibbons, D.A. } \\
\text { Morrison, K.L. Nance, W. Tolone, L.A. } \\
\text { Whalley, and T.A. Bozada }\end{array}$ & ADB367933 \\
\hline
\end{tabular}

1 Limited distribution; see Preface. 
ERDC/CERL TR-11-2

ERDC/CERL TR-11-3

1ERDC/CERL TR-11-4

ERDC/CERL TR-11-5

ERDC/CERL TR-11-7

ERDC/CERL TR-11-8

ERDC/CERL TR-11-9

ERDC/CERL TR-11-11
Feb 2011

Progress in the Production of JP-8 Based

ADA552520 Hydrogen and Advanced Tactical Fuels for Military Applications, by C.J.

Zygarlicke, T.R. Aulich, C.A. Wocken, D.F. Pflughoeft-Hassett, T.D. Buckley, J.P. Hurley, J. Jiang, B.G. Oster, N.M. Patel, A.C. Snyder, C.W. Sohn, and W.T. Brown III

Mar 2011 Review of USACE Institutional Information Related to Evaluation of Incremental Changes in Water Resources Planning, by L. Canter, M. Chawla, and C.T. Swor

Mar 2011 Energy Assessment at Fort Lee, VA, by D.M. Underwood, A.M. Zhivov, C. Bjork, D. Neth, J. Rees, E. Reinkinen, S.

Walerczyk, and A. Woody

Mar 2011 Water Sustainability Assessment for Ten Army Installations, by E.M. Jenicek, R.A. Carroll, L.E. Curvey, M.S. Hessel, R.M. Holmes, and E. Pearson

Mar 2011 The Military Landscape: Why US Military Installations Are Located Where They Are, by H.E. Balbach, W.D. Goran, and A.R. Latino

Mar 2011

\section{Landscape Scale Assessment of} Predominant Pine Canopy Height for Red-cockaded Woodpecker Habitat Assessment Using Light Detection and Ranging (LIDAR) Data, by S.A. Tweddale and D. Newcomb

Mar 2011 Anaerobic Treatment of Wastewaters Containing 2,4-dinitroanisole and Nmethyl paranitro aniline from Munitions Handling and Production, by S.W. Maloney, W.E. Platten, III, D. Bailey, and M.T. Suidan

Mar 2011

Sustainability Indicators for the Army Installation Management Command, by C.C. Rewerts, M.J. Hanson, D.A. Krooks, G.G. Gerdes, M.R. Kemme, and W.T. Brown
ADB377347

ADA540884

ADA559000

ADA544184

ADA558049

,


ERDC/CERL TR-11-12

ERDC/CERL TR-11-13

ERDC/CERL TR-11-14

ERDC/CERL TR-11-14

Sup.

ERDC/CERL TR-11-15

ERDC/CERL TR-11-16

Jun 2011

Jun 2011

Jun 2011

Apr 2011

Jun 2011

Jun 2011

Assessment of Two Nonstandard Underground Heat Distribution System Piping Designs: Supplement-Appendices for Final Report on Project F07-AR01, by A.D. Beitelman, C.P. Marsh, D. Neale, V. Meyer, J. Taylor, D. Butler, F. Mandan, L. Clark, and T.A. Carlson

Army Overseas Water Sustainability Study, by E.M. Jenicek, N.R.D. Myers, L. Curvey, and S.B. Nemeth

Operational Site Selection for Unmanned Aircraft, by S. Tweddale, T. Fichtl, S. Tenenbaum, D. Stouch, C. Ehlschlaeger, and K. McGraw

ERDC/CERL TR-11-17 Jun 2011
ADA544301

ADA544176

ADA566453

ADA569541

ADA545736

ADA593905
Emissions, by V.M. Boddu, J.A. Gilmer, and K.J. Hay 


\begin{tabular}{|c|c|c|c|}
\hline ERDC/CERL TR-11-18 & Jun 2011 & $\begin{array}{l}\text { "Market-Smart" Deconstruction and } \\
\text { Material Recovery at Brownfield Sites: } \\
\text { How to Identify and Reuse Existing } \\
\text { Materials Found at Brownfield Sites, by } \\
\text { A.L. Stumpf, S.L. Hunter, S.J. } \\
\text { Bevelheimer, S.D. Cosper, T.R. Napier, G. } \\
\text { Rodriguez, and G.L. Gerdes }\end{array}$ & ADA565716 \\
\hline 1ERDC/CERL TR-11-19 & Jun 2011 & $\begin{array}{l}\text { Electrical Construction Practices in Four } \\
\text { Middle Eastern Cities: Baghdad, Tehran, } \\
\text { Kabul and Islamabad, by T. Abdallah, R. } \\
\text { Ducey, M. Johnson, and J. Delhotal }\end{array}$ & ADB377393 \\
\hline ERDC/CERL TR-11-20 & Jun 2011 & $\begin{array}{l}\text { A Quantitative Study of the Viability of } \\
\text { Greywater Heat Recovery (GWHR): GWHR } \\
\text { Implemented in Barracks and Dining } \\
\text { Facilities, by J.L. Vavrin }\end{array}$ & ADA559324 \\
\hline ERDC/CERL TR-11-21 & Jun 2011 & $\begin{array}{l}\text { Cavitation-Resistant Coatings for } \\
\text { Hydropower Turbines, by R. Sollars and } \\
\text { A.D. Beitelman }\end{array}$ & ADA545717 \\
\hline ERDC/CERL TR-11-22 & Jul 2011 & $\begin{array}{l}\text { Prevention of Toxic Molds in Army } \\
\text { Facilities Using Surface-Applied Biocides, } \\
\text { by L.D. Stephenson, J.L. Lattimore, and } \\
\text { K.M. Torrey }\end{array}$ & \\
\hline ERDC/CERL TR-11-23 & Aug 2011 & $\begin{array}{l}2011 \text { In-Water Testing of Aquatic } \\
\text { Nuisance Species Dispersal Barriers IIA } \\
\text { And IIB with Increased Voltage and } \\
\text { Frequency Operating Parameters, by } \\
\text { M.K. Mclnerney, B.S. Aubin, J.C. } \\
\text { Trovillion, C.L. Baxter, E.T. Trovillion, V.F. } \\
\text { Hock, Jr., and D.M. Weir }\end{array}$ & ADA557402 \\
\hline 1ERDC/CERL TR-11-24 & Aug 2011 & $\begin{array}{l}\text { Energy Assessment of Historical } \\
\text { Buildings at Fort Bliss, TX, by D.M. } \\
\text { Underwood, A.M. Zhivov, R.J. Liesen, W.J. } \\
\text { Stein, A. Woody, S. Adams, C. Grosshart, } \\
\text { H. Fitzpatrick, G. Zielke, and M. DiPaolo }\end{array}$ & ADB378492 \\
\hline ERDC/CERL TR-11-25 & Sep 2011 & $\begin{array}{l}\text { Architectural Survey of Pence } \\
\text { Elementary School, Fort Leonard Wood, } \\
\text { Missouri, by S. Adams, C.J. Cochran, and } \\
\text { A. Smith }\end{array}$ & ADA552793 \\
\hline ERDC/CERL TR-11-27 & Sep 2011 & $\begin{array}{l}\text { Integration of Sustainable Practices into } \\
\text { Standard Army MILCON Designs, by A.L. } \\
\text { Stumpf, J.L. Webster, R.L. Schneider, } \\
\text { E.M. Jenicek, J.A. Kane, and K.L. } \\
\text { Fishman }\end{array}$ & ADA550493 \\
\hline
\end{tabular}

1 Limited distribution; see Preface. 
ERDC/CERL TR-11-28

ERDC/CERL TR-11-29

ERDC/CERL TR-11-32

ERDC/CERL TR-11-33

ERDC/CERL TR-11-34

ERDC/CERL TR-11-36

ERDC/CERL TR-11-37

ERDC/CERL TR-11-38

ERDC/CERL TR-11-39

ERDC/CERL TR-11-40

ERDC/CERL TR-11-41
Sep 2011

Effectiveness of Selected Native Plants as Competitors with Non-indigenous and Invasive Knapweed and Thistle Species, by T. Smith and A.L. Hild

Sep $2011 \quad$ Use of a Climate Change Vulnerability Index for Assessing Species at Risk on Military Lands, by J.H. Sperry and T.J. Hayden

Sep 2011 Random Transect with Adaptive Clustering Sampling Design - ArcPad Applet Manual, by V.M. Backus, L.J. Rew, B.D. Maxwell, and M.G. Hohmann

Sep 2011

Adaptive Web Sampling - ArcPad Applet Manual, by V.M. Backus, L.J. Rew, B.D. Maxwell, and M.G. Hohmann

Sep 2011

A Sustainable Approach for Optimal Stee Sheet Pile Structure Assessment, Maintenance, and Rehabilitation, by K.L. Rens, R. Liu, and S. Foltz

Oct 2011

Forecasting Climate-Induced Ecosystem Changes on Army Installations, by J.D. Westervelt and W.W. Hargrove

Sep 2011

Army Facility Standard Design and ISR-I Mission Criteria Alignment, by M.N. Grussing, K.M. Dilks, and M.C. Walters

Sep 2011

Integration of Sustainment Management Systems (SMS) with the Army Installation Status Report for Infrastructure (ISR-I), by M.N. Grussing, K.M. Dilks, and M.C. Walters

Oct 2011 Optimal Selection of Conservation Lands at Fort Stewart Using Integer

Programming, by S.T.M. Dissanayake, $\mathrm{H}$. Önal, J.D. Westervelt, and H.E. Balbach

Oct 2011 Optimum Selection of Clustered Conservation Areas Within Military Installations, by S.T.M. Dissanayake, H. Önal, J.D. Westervelt, and H.E. Balbach

Nov 2011 Early Design Energy Analysis Using Building Information Modeling Technology, by A.L. Stumpf, H. Kim, and E.M. Jenicek
ADA553671

ADA559189

ADA589680

ADA590180

ADA572118

ADA559196

ADA552803

ADA552799

ADA553512

ADA553526

ADA552789 
ERDC/CERL TR-11-42

ERDC/CERL TR-11-43

1ERDC/CERL TR-11-44

ERDC/CERL TR-11-45

ERDC/CERL TR-11-46

ERDC/CERL TR-11-47

ERDC/CERL TR-12-1

1ERDC/CERL TR-12-2

ERDC/CERL TR-12-3
Nov 2011

Demonstration Of A NanomaterialModified Primer For Use In CorrosionInhibiting Coating Systems, by S.A. Drozdz, T. Hawkins, L. Clark, M. Surratt, J. Kingsley, K. Palutke, and J. Dean

Nov 2011

Remote Performance Monitoring of a Thermoplastic Composite Bridge at Camp Mackall, NC: Final Report on Project F08-AR13, Task A-Thermoplastic Composite Bridges, by R.G. Lampo, B.K. Myers, K. Palutke, and D.M. Butler

Dec 2011

Renewable Energy Systems Demonstration at the "22 Bunkers Complex", Kabul, Afghanistan, by J. Vavrin, E. Chien, A. Lin, B. Everett, R. Ludin, M. Stalcup, H.U. Qaderdan, and S.M. Fazel

Dec 2011

Evaluation of Moisture-Cure Urethane Coatings for Compliance with Industry Specifications, by A.D. Beitelman and J.P. Ryan

Dec 2011

The Use of Natural Pozzolan in Concrete as an Additive or Substitute for Cement, by G.K. Al-Chaar, M. Alkadi, D.A. Yaksic, and L.A. Kallemeyn

Dec 2011

Metal Ion Sensor with Catalytic DNA in a Nanofluidic Intelligent Processor, by D.M. Cropek, T.S. Dalavoy, P.W. Bohn, Y. Lu, J.V. Sweedler, and M.A. Shannon

Jan 2012

Electro Decomposition of Ammonia into Hydrogen for Fuel Cell Use, by G.G. Botte and C.A. Feickert

Feb 2012 Operational Energy Base Camp Studies: Literature Review of Findings and Recommendations, by W.T. Brown, J.L. Vavrin, L.E. Curvey, S.D. Foltz, D. Chu, G. Anderson, S.L. Hunter, and E.P. Zeigler

Mar 2012 Demonstration of Improved Technologies for Rehabilitating Metal Roofing in Severely Corrosive Environments: Final Report on Project F07-AR08, by D.M. Bailey, L.D. Stephenson, A. Kumar, K. Sweeton, L. Clark, M.W. Surratt, K. Palutke, and A. Meier
ADA558997

ADA576173

ADB380637

ADA554426

ADA558534

ADA575220

ADA559187

ADA559315 


\begin{tabular}{|c|c|c|c|}
\hline ERDC/CERL TR-12-4 & Feb 2012 & $\begin{array}{l}\text { Lab-on-a-Chip Sensor for Monitoring } \\
\text { Perchlorate in Ground and Surface } \\
\text { Water, by J.C. Gertsch, I.G. Arcibal, C.S. } \\
\text { Henry, and D.M. Cropek }\end{array}$ & ADA559180 \\
\hline ERDC/CERL TR-12-5 & Mar 2012 & $\begin{array}{l}\text { Identifying Military Impacts on } \\
\text { Archaeological Deposits Based on } \\
\text { Differences in Soil Organic Carbon and } \\
\text { Chemical Elements at Soil Horizon } \\
\text { Interfaces: Final Report on SERDP } \\
\text { Project RC 1698, by D.L. Gebhart, H.A. } \\
\text { Torbert, M.L. Hargrave, R.R. Busby, and } \\
\text { A.J. Palazzo }\end{array}$ & ADA559158 \\
\hline ERDC/CERL TR-12-6 & Apr 2012 & $\begin{array}{l}\text { Prioritizing Historical Archaeological Sites } \\
\text { at Fort Leonard Wood, Pulaski County, } \\
\text { Missouri, by C.G. Carlson-Drexler, E.R. } \\
\text { Hartman, C.L. Baxter, and S.I. Enscore }\end{array}$ & ADA559884 \\
\hline ERDC/CERL TR-12-7 & Apr 2012 & $\begin{array}{l}\text { Historic Context and Management Plan } \\
\text { for the Quarry Pond Archeological } \\
\text { Complex on Fort Drum, by S.I. Enscore } \\
\text { and C.L. Baxter }\end{array}$ & ADA563522 \\
\hline ERDC/CERL TR-12-8 & Apr 2012 & $\begin{array}{l}\text { An Investigation of Community Attitudes } \\
\text { Toward Blast Noise: Complaint Survey } \\
\text { Protocol, by E.T. Nykaza, K. Hodgdon, G. } \\
\text { Wienke, T. Gaugler, P. Krecker, and G. } \\
\text { Luz }\end{array}$ & ADA561216 \\
\hline ERDC/CERL TR-12-9 & Apr 2012 & $\begin{array}{l}\text { An Investigation of Community Attitudes } \\
\text { Toward Blast Noise: General Community } \\
\text { Survey, Study Site 1, by E.T. Nykaza, D. } \\
\text { Valente, S.H. Swift, B. Danielson, P. } \\
\text { Krecker, K. Hodgdon, and T. Gaugler }\end{array}$ & ADA561222 \\
\hline ERDC/CERL TR-12-10 & May 2012 & $\begin{array}{l}\text { Energy Conversion Efficiency Potential } \\
\text { for Forward-Deployed Generation Using } \\
\text { Direct Carbon Fuel Cells, by K. Berner, A. } \\
\text { Perwich, C. Brett, J. Ruflin, P. Pharkya, A. } \\
\text { Guha, S.M. Lux, and F.H. Holcomb }\end{array}$ & ADA565711 \\
\hline ERDC/CERL TR-12-11 & Jun 2012 & $\begin{array}{l}\text { Vehicle Dynamics Monitoring and } \\
\text { Tracking System (VDMTS): Monitoring } \\
\text { Mission Impacts in Support of } \\
\text { Installation Land Management, by D.J. } \\
\text { Koch, P.D. Ayers, H.R. Howard, and G. } \\
\text { Siebert }\end{array}$ & ADA565712 \\
\hline
\end{tabular}




\begin{tabular}{|c|c|c|c|}
\hline 1ERDC/CERL TR-12-12 & Aug 2012 & $\begin{array}{l}\text { Energy Supply Alternatives for the Fort } \\
\text { Carson, CO Combat Aviation Brigade, by } \\
\text { A.M. Zhivov, D.L. Herron, R. Liesen, K. } \\
\text { Budde, S. Richter, R. Ziegler, S. Ochse, } \\
\text { C.A. Lederer, L.W. Fielder, and P. Steitz }\end{array}$ & ADB383028 \\
\hline ERDC/CERL TR-12-13 & Sep 2012 & $\begin{array}{l}\text { Facility Degradation and Prediction } \\
\text { Models for Sustainment, Restoration, } \\
\text { and Modernization (SRM) Planning, by } \\
\text { M.N. Grussing }\end{array}$ & ADA570002 \\
\hline ERDC/CERL TR-12-14 & Sep 2012 & $\begin{array}{l}\text { Analysis of the Mountain View Officers' } \\
\text { Club: Fort Huachuca, Arizona, by A.D. } \\
\text { Smith, S.I. Enscore, and S.L. Hunter }\end{array}$ & \\
\hline ERDC/CERL TR-12-15 & Oct 2012 & $\begin{array}{l}\text { Integrated Water Planning for Army } \\
\text { Training Areas, by E.M. Jenicek, L. } \\
\text { Curvey, I. Mabel, R. Phillips, A.L. Vickers, } \\
\text { and G. Perez }\end{array}$ & \\
\hline ERDC/CERL TR-12-17 & Sep 2012 & $\begin{array}{l}\text { Resource Efficiency in the US Army } \\
\text { Corps of Engineers: Examination of } \\
\text { Strategies to Reduce Energy Use and } \\
\text { Greenhouse Gas Emissions, by P.M. } \\
\text { Loechl, M.R. Kemme, P.S. Shah, and } \\
\text { W.D. Goran }\end{array}$ & ADA569529 \\
\hline ERDC/CERL TR-12-19 & Oct 2012 & $\begin{array}{l}\text { Energy and Greenhouse Gas Emission } \\
\text { Reduction Opportunities for Civil Works } \\
\text { Projects Unique to the US Army Corps of } \\
\text { Engineers, by M.R. Kemme and D.M. } \\
\text { Underwood }\end{array}$ & ADA571664 \\
\hline ERDC/CERL TR-12-20 & Sep 2012 & $\begin{array}{l}\text { ERDC-CERL Participation in the Resilient } \\
\text { Home Program: 2009-2012, by T.R. } \\
\text { Napier }\end{array}$ & \\
\hline ERDC/CERL TR-12-21 & Aug 2012 & $\begin{array}{l}\text { Digital Discover of Ephemeral Ponds, by } \\
\text { J.D. Westervelt }\end{array}$ & ADA585112 \\
\hline 1ERDC/CERL TR-12-24 & Jul 2012 & $\begin{array}{l}\text { A Qualitative Study of Energy Reduction } \\
\text { Opportunities and Indoor Air Quality } \\
\text { Improvements in Facilities in an } \\
\text { Expeditionary Theater: Afghanistan and } \\
\text { Kuwait, by J.L. Vavrin }\end{array}$ & ADB388568 \\
\hline ERDC/CERL TR-12-25 & Sep 2012 & $\begin{array}{l}\text { Demonstration of Energy-Saving Outdoor } \\
\text { Lighting Technologies: Presidio of } \\
\text { Monterey, CA, and Fort Eustis, VA, by P.L. } \\
\text { Edwards, T.R. Napier, and S.B. Nemeth }\end{array}$ & \\
\hline
\end{tabular}

1 Limited distribution; see Preface. 
ERDC/CERL TR-13-2

ERDC/CERL TR-13-3

ERDC/CERL TR-13-4

ERDC/CERL TR-13-5

ERDC/CERL TR-13-6

ERDC/CERL TR-13-7

1ERDC/CERL TR-13-8

ERDC/CERL TR-13-9

ERDC/CERL TR-13-10

ERDC/CERL TR-13-11
Jan 2013

Optimal Management of DoD Lands for Military Training, Ecosystem Services, and Renewable Energy Generation:

Framework and Data Requirements, by S.T.M. Dissanayake, H. Önal, and J.D. Westervelt

Mar 2013 Advanced Bridge Capacity and Structural Integrity Assessment Methodology, by M.B. Gries, R.K. Giles, D.A. Kuchma, B.F. Spencer, L.A. Bergman, and J. Wilcoski

Apr 2013 Improved Reliability Models for Mechanical and Electrical Components at Navigation Lock and Dam and Flood Risk Management Facilities, by R.C. Patev, D.L. Buccini, J.W. Bartek, and S. Foltz

May 2013 Reptiles and Amphibians of Fairchild Air Force Base, WA, by J.H. Sperry

Jun 2013 Polymer Composite Wrapping and Cathodic Protection System for Reinforced Concrete Piles in Marine Applications: Final Report on Project F08-AR07, by D.M. Bailey, V.F. Hock, P.A. Noyce, and M. Restly

Jun 2013

Demonstration of Three CorrosionResistant Sustainable Roofing Systems: Final Report on Project F08-AR02, by D.M. Bailey, L.D. Stephenson, K. Palutke, L. Clark, and M. Merrick

Aug 2013

USACE Support to Contingency Base Energy Management: Lessons Learned, by J.L. Vavrin, W.T. Brown, and W.J. Stein

Aug 2013

Providing Boiler Inspections at US Army Installations: How to Perform Internal/Operational, Efficiency, and Emissions Testing, by N.L. Potts

Aug 2013

Costs and Benefits of Resilient Construction, by T.R. Napier

Aug 2013 Architectural Survey of Pershing Elementary School, Fort Leonard Wood, Missouri, by S.E. Adams and A.D. Smith
ADA575648

ADA582970

ADA582967

ADA582968

ADA582965

ADA583907

ADB402515

ADA599424

ADA608818

\footnotetext{
1 Limited distribution; see Preface.
} 
ERDC/CERL TR-13-12

ERDC/CERL TR-13-13

ERDC/CERL TR-13-14

ERDC/CERL TR-13-15

ERDC/CERL TR-13-16

ERDC/CERL TR-13-17

ERDC/CERL TR-13-18

1ERDC/CERL TR-13-19

ERDC/CERL TR-13-20

ERDC/CERL TR-13-21

ERDC/CERL TR-13-22
Aug 2013

Historic Landscape Survey, Maxwell AFB, ADA612553 Alabama, by M.W. Tooker, E.R. Hartman, and A.D. Smith

Sep 2013 Two for the Price of One: Integration of NEPA and NHPA Procedures, by M.K. Chawla, H.E. Balbach, and E.R. Hartman

Sep 2013 Historic Landscape Survey, Randolph AFB, Texas, by M.W. Tooker, E.R. Hartman, and A.D. Smith

Sep 2013

Modeling Climate-Change Effects on Snake Range Extents for Military Land Management, by A. Rundus, J.D. Westervelt, and J.H. Sperry

Sep 2013

Baseline Water Demand at Forward Operating Bases, by H.G. Anderson, S.W. Maloney, K. Kinnevan, E.D. Smith, K.J. Hay, and G.L. Gerdes

Sep 2013

Contingency Base Camp Solid Waste Generation, by S.D. Cosper, H.G. Anderson, K. Kinnevan, and B.J. Kim

Sep 2013

Contingency Base Camp Operations and Management: Staffing and Organization, by H.G. Anderson and K. Kinnevan

Sep 2013

"Other Subjective Criteria": The US Army's

ADB397060 Understanding of Culture: The Development and Application of a Civil Affairs Coding Schema, by D.A. Krooks, C.M. Armstrong, L.A. Whalley, M.A. Kvitrud, E.C. Raab, and M.L. Remmel

Oct 2013

Demonstration of Corrosion-Resistant Fire Hydrant Retrofits for Military Installations: Final Report on Project F09-AR12, by E.D. Smith, M.D. Ginsberg, and $\mathrm{C}$. Wilson

Oct 2013

Simulation of Wild Pig Control via Hunting and Contraceptives, by J.L. Burton, J.D. Westervelt, and S. Ditchkoff

Oct 2013
ADA608631

ADA597120

ADA613424

ADA613823

ADA614250

ADA587794

ADA589143
Climate Change Impacts on Fort Bragg, NC, by R.C. Lozar, M. Hiett, and J.D. Westervelt 
ERDC/CERL TR-13-23

ERDC/CERL TR-13-25

ERDC/CERL TR-13-26

ERDC/CERL TR-14-1

ERDC/CERL TR-14-2

ERDC/CERL TR-14-3

ERDC/CERL TR-14-4

1ERDC/CERL TR-14-5

ERDC/CERL TR-14-7
Oct 2013

Dec 2013

Dec 2013

Feb 2014

Feb 2014

Feb 2014

Mar 2014

May 2014

Jun 2014
Anticipating Installation Natural

ADA592520

Resource Climate Change Concerns: The

Data, by R.C. Lozar, M. Hiett, and J.D.

Westervelt

Water Sustainability Assessments for Four Net Zero Water Installations, by E.M. Jenicek, L. Curvey, Y. Cruz, and R. Phillips

Naval Weapons Station Earle

Reassessment, by A.D. Smith and M.W. Tooker

Corrosion-Resistant Roof with Integrated Photovoltaic Power System: Final Report on Project F09-AR04, by D.M. Bailey, T. Abdallah, K. Palutke, L. Clark, R. Miles, and M. Merrick

Lipophilic Super-Absorbent Swelling Gels as Cleaners for Use on Weapons Systems and Platforms, by V.M. Boddu, S.M. Uchimiya, M. Ohta, K. Sada, C. Myers, W. Ziegler, and T. Torres

Demonstration of Photovoltaic-Powered Cathodic Protection System with Remote Monitoring Capability: Final Report on Project F08-AR14, by D.M. Bailey, C.P. Marsh, L.D. Stephenson, J. Taylor, L. Clark, D. Butler, and L. Millard

Framing an Understanding of Sociocultural Dynamics for Civil-Military Operations, by L.A. Whalley, N.R. Myers, J.L. Burton, D.A. Morrison, A.M. Rhodes, I. Scarborough, J. Vendrzyk, W. Zhang, N. Vander-Most, K. Taylor, D. Renn, D.A. Krooks, M.K. Chawla, C.C. Rewerts, and T.K. Perkins

Exhaust Hood and Makeup Air Optimization, by D.M. Underwood, A. Woody, M. Murphy, and V.A. Smith

Vietnam and the Home Front: How DoD Installations Adapted, 1962-1975, by E.R. Hartman, S.I. Enscore, and A.D. Smith
ADA595035

ADA597424

ADB400989

ADA593903

ADB400989

ADA614648

\footnotetext{
1 Limited distribution; see Preface.
} 
ERDC/CERL TR-14-8

ERDC/CERL TR-14-9

ERDC/CERL TR-14-10

ERDC/CERL TR-14-11

ERDC/CERL TR-14-12

ERDC/CERL TR-14-13

Aug 2014

ERDC/CERL TR-14-14

Sep 2014

ERDC/CERL TR-14-15

Jun 2014

Jul 2014

Jul 2014

Aug 2014

Aug 2014
OPAL Netlogo Land Condition Model: Application and Validation at Fort Riley, KS, by D. Koch, J. Westervelt, A. Fulton, N. Myers, S. Tweddale, D. Gebhart, R. Busby, A. Dain-Owens, and H. Howard

Using Simple Environmental Variables to Estimate Biomass Disturbance, by $\mathrm{N}$. Myers, D. Koch, A. Fulton, A. Dain-Owens, D. Gebhart, R. Busby, J. Westervelt, and H. Howard

Infrastructure and the Operational Art: A Handbook for Understanding, Visualizing, and Describing Infrastructure Systems, by S.D. Hart, J.L. Klosky, S. Katalenich, B. Spittka, and E. Wright

Demonstration of Noncorrosive, Capacitance-Based Water-Treatment Technology for Chilled-Water Cooling Systems: Final Report on Project F09AR08, by A.D. Beitelman and M.K. Mclnerney
ADA607165

ADA607672

ADA610893

ADA607647

ADA607667

ADA609375

ADA609006 


\begin{tabular}{|c|c|c|c|}
\hline ERDC/CERL TR-14-17 & Sep 2014 & $\begin{array}{l}\text { Application of Maxent Multivariate } \\
\text { Analysis to Define Climate-Change } \\
\text { Effects on Species Distributions and } \\
\text { Changes, by R.C. Lozar and J.D. } \\
\text { Westervelt }\end{array}$ & ADA619835 \\
\hline ERDC/CERL TR-14-18 & Sep 2014 & $\begin{array}{l}\text { Remote Sensing Protocols for } \\
\text { Parameterizing an Individual, Tree- } \\
\text { Based, Forest Growth and Yield Model, } \\
\text { by S.A. Tweddale, P.J. Guertin, and G.Z. } \\
\text { Gertner }\end{array}$ & ADA609386 \\
\hline ERDC/CERL TR-14-20 & Sep 2014 & $\begin{array}{l}\text { Sustainability Criteria for Contingency } \\
\text { Bases, by H.G. Anderson, A.L. Stumpf, G. } \\
\text { Rodriguez, S.L. Hunter, and K. Kinnevan }\end{array}$ & ADA610888 \\
\hline 1ERDC/CERL TR-14-21 & Sep 2014 & $\begin{array}{l}\text { Operational Energy for Contingency } \\
\text { Basecamps: Historical Perspective of } \\
\text { Achievements, Areas Needing } \\
\text { Improvement, Recommendations, and a } \\
\text { "Playbook" for Future Campaigns, by J.L. } \\
\text { Vavrin }\end{array}$ & ADB402651 \\
\hline ERDC/CERL TR-14-22 & Sep 2014 & $\begin{array}{l}\text { Design Enhancements to Facilitate a } \\
\text { Sustainable and Energy Efficient Dining } \\
\text { Facility (DFAC) in a Contingency } \\
\text { Environment, by J.L. Vavrin and I. } \\
\text { McNamara }\end{array}$ & ADA609596 \\
\hline 1ERDC/CERL TR-14-23 & Sep 2014 & $\begin{array}{l}\text { Abbreviated Level I Energy Study of the } \\
\text { New Kabul Compound (NKC), Kabul, } \\
\text { Afghanistan, by J.L. Vavrin }\end{array}$ & ADB402516 \\
\hline ERDC/CERL TR-14-24 & Sep 2014 & $\begin{array}{l}\text { Base-Wide Biodigester for Basecamps in } \\
\text { an Operational Environment, by J.L. } \\
\text { Vavrin and I. McNamara }\end{array}$ & \\
\hline ERDC/CERL TR-14-25 & Sep 2014 & $\begin{array}{l}\text { Streamlined Archaeo-Geophysical Data } \\
\text { Processing and Integration for } \\
\text { Department of Defense Field Use, by E. } \\
\text { Ernenwein, M.L. Hargrave, J. Cothren, } \\
\text { and G. Avery }\end{array}$ & ADA610895 \\
\hline 1ERDC/CERL TR-14-26 & Sep 2014 & $\begin{array}{l}\text { Energy Security at U.S. Army Garrison } \\
\text { Fort Detrick, MD: An Evaluation and } \\
\text { Recommendations To Meet Current and } \\
\text { Future Needs, by W.T. Brown, III, S.L. } \\
\text { Hunter, T. Patel, R.A. Ducey, W.J. Stein, } \\
\text { N.L. Potts, T. Abdallah, J.L. Vavrin, G. } \\
\text { Perez, and N. Peterson }\end{array}$ & ADB402964 \\
\hline
\end{tabular}

Perez, and N. Peterson

1 Limited distribution; see Preface. 


\begin{tabular}{|c|c|c|c|}
\hline ERDC/CERL TR-14-27 & Oct 2014 & $\begin{array}{l}\text { Avian and Herpetological Survey Results } \\
\text { for Fairchild Air Force Base and Ancillary } \\
\text { Properties, by J.H. Sperry }\end{array}$ & ADA610811 \\
\hline ERDC/CERL TR-14-28 & Oct 2014 & $\begin{array}{l}\text { The United States Merchant Marine } \\
\text { Academy Historic District: Nomination to } \\
\text { the National Register of Historic Places, } \\
\text { by A.D. Smith, S.I. Enscore, and M.W. } \\
\text { Tooker }\end{array}$ & ADA611643 \\
\hline ERDC/CERL TR-14-29 & Oct 2014 & $\begin{array}{l}\text { William Barstow Mansion of the United } \\
\text { States Merchant Marine Academy: } \\
\text { Nomination to the National Register of } \\
\text { Historic Places, by A.D. Smith, S.I. } \\
\text { Enscore, and M.W. Tooker }\end{array}$ & ADA611654 \\
\hline ERDC/CERL TR-14-32 & Dec 2014 & $\begin{array}{l}\text { Biofuel Production: Considerations for } \\
\text { USACE Civil Works Business Lines, by } \\
\text { N.R. Myers, D.L. Gebhart, and M.D. Hiett }\end{array}$ & ADA613233 \\
\hline 1ERDC/CERL TR-14-33 & Dec 2014 & $\begin{array}{l}\text { Recyclable Materials Online Marketing } \\
\text { System for Qualified Recycling Programs } \\
\text { (QRPs): Demonstration Results, by G. } \\
\text { Rodriguez, D.S. Gilbert, and S.D. Cosper }\end{array}$ & ADB404064 \\
\hline 1ERDC/CERL TR-15-1 & Feb 2015 & $\begin{array}{l}\text { SMART Energy Efficient Deployable } \\
\text { Shelters (SEEDS): Base Year Report, by } \\
\text { A.H. Shaaban, E.M. Languri, A. Yacout, } \\
\text { and W.T. Brown }\end{array}$ & ADB406836 \\
\hline ERDC/CERL TR-15-2 & Feb 2015 & $\begin{array}{l}\text { Multivariate Bioclimatic Ecosystem } \\
\text { Change Approaches, by R.C. Lozar and } \\
\text { J.D. Westervelt }\end{array}$ & ADA614143 \\
\hline ERDC/CERL TR-15-5 & May 2015 & $\begin{array}{l}\text { Demonstration and Validation of } \\
\text { Corrosion-Mitigation Technologies for } \\
\text { Mechanical Room Utility Piping and } \\
\text { Cooling-Tower Pumps: Final Report on } \\
\text { Project FO7-ARCTC01, by R.B. Mason, } \\
\text { K.L. Klug, R.G. Lampo, A.D. Beitelman, } \\
\text { S.A. Drozdz, and V.F. Hock }\end{array}$ & ADA618148 \\
\hline ERDC/CERL TR-15-6 & May 2015 & $\begin{array}{l}\text { Multifunctional Nanocomposites for } \\
\text { Improved Sustainability and Protection of } \\
\text { Facilities, by D. Mao, I. Pavlovsky, R.L. } \\
\text { Fink, J.C. Trovillion, V.M. Boddu, L.D. } \\
\text { Stephenson, D.J. Lawrence, and A. } \\
\text { Kumar }\end{array}$ & ADA618126 \\
\hline ERDC/CERL TR-15-7 & May 2015 & $\begin{array}{l}\text { Level I Energy and Water Survey, ERDC- } \\
\text { CERL, Champaign, IL, by J.P. Miller, D.M. } \\
\text { Underwood, L.E. Curvey, P. Loechl, and } \\
\text { W.T. Brown, III }\end{array}$ & ADA619834 \\
\hline
\end{tabular}

1 Limited distribution; see Preface. 
ERDC/CERL TR-15-8

ERDC/CERL TR-15-9

ERDC/CERL TR-15-10

ERDC/CERL TR-15-11

ERDC/CERL TR-15-12

ERDC/CERL TR-15-13

ERDC/CERL TR-15-14

ERDC/CERL TR-15-16

ERDC/CERL TR-15-17

ERDC/CERL TR-15-18
May 2015

Prediction of Long Term Degradation of

ADA618149 Insulating Materials, by L.D. Stephenson, A. Heffron, B.B. Mehnert, J.B. Alvey, V. Boddu, E.J. Gao, D.J. Lawrence, and A. Kumar

May 2015 Demonstration and Validation of a HighPerformance Floor-Sealant System to Reduce Concrete Degradation: Final Report on Project F10-AR02, by C.A. Wilson and S.A. Drozdz

Jun 2015

Development of Thermal Bridging Factors for Use in Energy Models, by A. Pagan-Vazquez, D. Chu, J. Straube, R. Ryan, and M. Lawton

Jun 2015

Analytical Frameworks for Addressing Physical, Social, and Institutional Changes in Water Resources Planning and Management, by M.K. Chawla, L.W. Canter, and C.T. Swor

Jun 2015

Demonstration of Corrosion-Resistant Coatings for Air-Conditioning Coils and Fins: Final Report on Project F10-AR01, by A.D. Beitelman and S.A Drozdz

Jul 2015

Energy Performance Measurement and Simulation Modeling of Tactical Soft-Wall Shelters, by M. Deru, E. Bonnema, G. Barker, E. Hancock, and A. Kumar

Jun 2015

A Design for Computationally Enabled

ADA622838 Analyses Supporting the Pre-Intervention Analytical Framework (PIAF), by W.J. Tolone, J. Whitmeyer, J. Walsh, M. Hadzikadic, T. Carmichael, M. Armstrong, T.K. Perkins, and C.C. Rewerts

Development of Cold-Formed Steel Seismic Design Recommendations, by J. Wilcoski and D.A. Foutch

Aug 2015

Kinetic Super-Resolution Long-Wave Infrared (KSR LWIR) Thermography Diagnostic for Building Envelopes: Scott AFB, IL, by J.P. Miller and N. Singh

Aug 2015
ADA620027

ADA620011

ADA620010

ADA619778

ADA621105

ADA621106

ADA621108

ADA621109
Kinetic Super-Resolution Long-Wave Infrared (KSR LWIR) Thermography Diagnostic for Building Envelopes: Camp Lejeune, NC, by J.P. Miller and N. Singh 
ERDC/CERL TR-15-19

ERDC/CERL TR-15-21

ERDC/CERL TR-15-22

ERDC/CERL TR-15-23

ERDC/CERL TR-15-24

ERDC/CERL TR-15-25

Dec 2015

Sep 2015

Sep 2015

Climate Change Impacts on Water and Energy for Army Installations, by J. Miller, J. Wilhoit, K. Tranel, and L. Curvey

Camp Sherman, Ohio: History of a World War I Training Camp, by S.I. Enscore, A.D. Smith, and M.W. Tooker

ERDC/CERL TR-15-26 Sep 2015

1ERDC/CERL TR-15-27

Oct 2015

Comparison and Analysis of Energy Performance of Baseline and Enhanced Temporary Army Shelters, by A. PaganVazquez, D. Chu, M. Kreiger, S. Shrestha, A. Latino, C.T. Decker, D.J. Lawrence, and A. Kumar

Mold Remediation and Recommendations to Resolve Other Major Issues in Concrete B-Huts at Bagram Airfield, Afghanistan, by J.L. Vavrin and W.J. Stein

ERDC/CERL TR-15-28 Oct 2015
Demonstration of the Energy Component of the Installation Master Plan Using the "Net Zero Energy Planner" Tool, by A.M. Zhivov, M.P. Case, R. Liesen, and M. Swanson
ADA621900

ADA621877

ADA622251

ADA624486

ADA621864

ADB411470 
ERDC/CERL TR-15-29

ERDC/CERL TR-15-30

ERDC/CERL TR-15-31

ERDC/CERL TR-15-32

ERDC/CERL TR-15-33

ERDC/CERL TR-15-34

ERDC/CERL TR-15-36

ERDC/CERL TR-15-37

Vol. 1

ERDC/CERL TR-15-37

Vol. 2

ERDC/CERL TR-15-38
Oct 2015

Demonstration and Validation of Materials for Corrosion-Resistant Fencing and Guard Railings in Aggressive Climates. Final Report on Project F09AR02, by C. Olaes, R.G. Lampo, and L. Clark

Sep 2015 Developing Baselines for Prescribed Burning Smoke Management Plans and Best Management Practices, by M.R. Kemme

Sep 2015 Applicability of the FHWA Program Comment for Common Post-1945 Concrete and Steel Bridges, by A.D. Smith and M.W. Tooker

Nov 2015

Evaluation of Sealing Materials and Techniques for Installing Quoin and Miter Block Backing Grout, By S. Foltz, J. Trovillion, and J. Ryan

Dec 2015

Demonstration and Validation of Controlled Low-Strength Materials for Corrosion Mitigation of Buried Steel Pipes: Final Report on Project F09-A17, by S.M. Lux, C.P. Marsh, J.B. Bushman, B.S. Phull, C. Olaes, and L. Clark.

Dec 2015

Inventory and Evaluation of Buildings in the Industrial Area, Cape Canaveral Air Force Station, by S.I. Enscore and J.L. Webster

Dec 2015 Guidance on the Use of Historic Human Remains Detection Dogs for Locating Unmarked Cemetaries, by C.L. Baxter and M.L. Hargrave

Dec 2015 Architectural Survey at Joint Base Langley-Eustis of Fort Eustis Buildings and Structures Built 1946-1975: Volume I, by S.E. Adams and A.D. Smith

Dec 2015

Architectural Survey at Joint Base Langley-Eustis of Fort Eustis Buildings and Structures Built 1946-1975: Volume II (Inventory Forms), by S.E. Adams and A.D. Smith

Dec 2015 Architectural Survey of Ohio Army National Guard Properties: Volume I, by S.E. Adams and A.D. Smith
ADA625511

ADA625592 


\section{Environmental Laboratory (EL)}

\section{Contract reports}

Report Number
ERDC/EL CR-12-1
ERDC/EL CR-12-2

ERDC/EL CR-12-3

ERDC/EL CR-12-4

ERDC/EL CR-13-1

ERDC/EL CR-13-2

ERDC/EL CR-13-3

ERDC/EL CR-14-1

ERDC/EL CR-14-2

Jul 2014

ERDC/EL CR-14-3

Date

Jul 2012
Apr 2012

Dec 2012

Dec 2012

Apr 2013

Jun 2013

Nov 2013

May 2014

\section{ring Environmental Value in Nonmonetary Terms: A Review of Common Practices and Elements, by R.A. Cole}

Approaches to Golden Algae Control: In-Lake Mesocosm Experiments, by D.L. Roelke, B.W. Brooks, J.P. Grover, D.M. Kalisek, and B.L. Harris

Habitat Preference, Dispersal, and Population Trends of Three Species of Invasive Asian Carps in Tributaries of the La Grange Reach of the Illinois River, by M.R. Wilson

TernCOLONY 1.0 Model Description, by C.A. Lott, S.F. Railsback, and C.J.R. Sheppard

Effects of Dam Operations on Least Tern Nesting Habitat and Reproductive Success Below Keystone Dam on the Arkansas River, by C.A. Lott and R.L. Wiley

Golden Algae Control: Efficacy of Hydraulic Manipulations in Coves of Lake Granbury, by D.L. Roelke, B.W. Brooks, J.P. Grover, and V.M. Lundgren

Developing and Testing TernCOLONY 1.0: An Individual-based Model of Least Tern Reproduction, by C.A. Lott, S.F. Railsback, C.J.R. Sheppard, and M.C. Koohafkan

Modeling the Performance of Sand Filters for Removing Runoff Suspended Sediment, by M.S. Dortch

Identification, Development, and Release of Insect Biocontrol Agents for the Management of Phragmites australis, by B. Blossey

Aug 2014
AD Number

ADA558774

ADA572121

ADA582953

ADA587603

ADA599508

ADA601306

ADA604573

ADA607668
Evaluation of Time-Varying Hydrology within the Training Range Environmental Evaluation and Characterization System (TREECS ${ }^{\mathrm{TM}}$ ), by M.S. Dortch 


\section{Instruction reports}

$\begin{array}{llll}\text { Report Number } & \text { Date } & \text { Title } & \text { AD Number } \\ \text { IR EL-99-2 } & \text { Dec 1999 } & \text { Tri- Service Site Characterization and Analysis } & \text { ADA379231 } \\ & \text { Penetrometer System (SCAPS) Validation of } \\ & \text { the Thermal Desorption Sampler for Volatile } \\ & \text { Organic Compounds, by K.F. Myers, R.A. Karn, } \\ & \text { D.Y. Eng, K.F. Konecny, and W.M. Davis }\end{array}$

\section{Letter reports}

\begin{tabular}{|c|c|c|}
\hline Report Number & Date & $\underline{\text { Title }}$ \\
\hline 1ERDC/EL LR-13-1 & Jun 2013 & $\begin{array}{l}\text { The Impact of Invasive Species on Department of Defense } \\
\text { Installations in the Chesapeake Bay Watershed, by J.F. } \\
\text { Shearer, N.E. Harms, and M. Graves }\end{array}$ \\
\hline 1ERDC/EL LR-13-2 & Jul 2013 & $\begin{array}{l}\text { Corrective Actions for Marina Erosion and General Pollutant } \\
\text { Runoff, by S.J. Miller, J.C. Fischenich, M.G. Channell, R.W. } \\
\text { McComas, and K. Kerr }\end{array}$ \\
\hline 1ERDC/EL LR-13-3 & Jul 2013 & $\begin{array}{l}\text { Wetland Regulatory Considerations at Army Installations, by } \\
\text { T.C. Wilder, E.O. Murray, and N.R. Beane }\end{array}$ \\
\hline 1ERDC/EL LR-13-4 & Jul 2013 & $\begin{array}{l}\text { Recommendations for Army Lands Management } \\
\text { Contribution to Oyster Restoration in Chesapeake Bay, by } \\
\text { T.M. Swannack, M.K. Reif, S. Bourne, A.F. Casper, and D.M. } \\
\text { Schulte }\end{array}$ \\
\hline 1ERDC/EL LR-13-5 & Aug 2013 & $\begin{array}{l}\text { Submersed Aquatic Vegetation (SAV) Restoration for Army } \\
\text { Installations on Chesapeake Bay: Identification of Suitable } \\
\text { Sites and Restoration Methodology, by C.S. Owens, R.M. } \\
\text { Smart, T. Beser, G.O. Dick, and L. Dodd }\end{array}$ \\
\hline
\end{tabular}

\section{Miscellaneous papers}

$\begin{array}{llll}\text { Report Number } & \text { Date } & \text { Title } & \text { AD Number } \\ \text { ERDC/EL MP-00-1 } & \text { Sep 2000 } & \begin{array}{l}\text { Advantages and Disadvantages of Aquatic } \\ \text { Plant Management Techniques, by J.D. } \\ \text { Madsen }\end{array} & \text { ADA387448 } \\ \text { ERDC/EL MP-01-1 } & \text { Aug 2001 } & \begin{array}{l}\text { Assessing the Effect of Estimation Error on } \\ \text { Population Viability Analysis: An Example } \\ \text { Using the Black-Capped Vireo, by P. Parysow } \\ \text { and D.J. Tazik }\end{array} & \text { ADA394828 } \\ & & & \end{array}$

1 Limited distribution; see Preface. 
ERDC/EL MP-01-2
Innovative Techniques for Improved Hydroacoustic Bottom Tracking in Dense Aquatic Vegetation, by B.M. Sabol and S.A. Johnston

\section{Special reports}

\begin{tabular}{|c|c|c|c|}
\hline Report Number & $\underline{\text { Date }}$ & $\underline{\text { Title }}$ & $\underline{\text { AD Number }}$ \\
\hline ERDC/EL SR-D-00-1 & Feb 2000 & $\begin{array}{l}\text { RECOVERY: A Contaminated Sediment-Water } \\
\text { Interaction Model, by C.E. Ruiz, P.R. } \\
\text { Schroeder, and N.M. Aziz }\end{array}$ & \\
\hline ERDC/EL SR-W-00-1 & Mar 2000 & $\begin{array}{l}\text { Stream Management, by J.C. Fischenich and } \\
\text { H. Allen }\end{array}$ & \\
\hline ERDC/EL SR-00-1 & Feb 2000 & $\begin{array}{l}\text { Potential Use of Insect Biocontrol Agents for } \\
\text { Reducing the Competitive Ability of Hydrilla } \\
\text { verticillata, by M.J. Grodowitz, R. Doyle, and } \\
\text { R.M. Smart }\end{array}$ & ADA377340 \\
\hline ERDC/EL SR-00-2 & Feb 2000 & $\begin{array}{l}\text { Potential Impacts of the North Fork Hughes } \\
\text { River Project, Ritchie County, West Virginia, } \\
\text { 1999, on Freshwater Mussels (Unionidae), } \\
\text { by A.C. Miller and B.S. Payne }\end{array}$ & ADA373815 \\
\hline ERDC/EL SR-00-3 & Feb 2000 & $\begin{array}{l}\text { Long-Term Management Strategy for } \\
\text { Dredged Material Disposal for Naval } \\
\text { Facilities at Pearl Harbor, Hawaii. Phase 1, } \\
\text { Formulation of Preferred Disposal and } \\
\text { Management Alternatives, by P.R. Schroeder } \\
\text { and M.R. Palermo }\end{array}$ & ADA375283 \\
\hline ERDC/EL SR-00-4 & Mar 2000 & $\begin{array}{l}\text { Long-Term Management Strategy for } \\
\text { Dredged Material Disposal for Naval } \\
\text { Facilities at Pearl Harbor, Hawaii. Phase II, } \\
\text { Evaluation of Alternatives, by P.R. Schroeder, } \\
\text { R.A. Price, D.E. Averett, R. Wade, S.A. } \\
\text { Pranger, D.C. Neumann, and J. Figueroa- } \\
\text { Gonzalez }\end{array}$ & ADA375870 \\
\hline ERDC/EL SR-00-5 & Mar 2000 & $\begin{array}{l}\text { Long-Term Management Strategy for } \\
\text { Dredged Material Disposal for Naval } \\
\text { Facilities at Pearl Harbor, Hawaii. Phase III, } \\
\text { Analysis of Alternatives and Development of } \\
\text { an LTMS, by M.R. Palermo and P.R. } \\
\text { Schroeder }\end{array}$ & ADA376156 \\
\hline ERDC/EL SR-00-6 & Apr 2000 & $\begin{array}{l}\text { Water Quality Studies at Cougar Lake, Blue } \\
\text { River Lake, and the McKenzie River, Oregon, } \\
\text { by J.J. Hains }\end{array}$ & ADA375606 \\
\hline
\end{tabular}




\begin{tabular}{|c|c|c|c|}
\hline ERDC/EL SR-00-7 & Apr 2000 & $\begin{array}{l}\text { Supplemental Water Quality Analysis - St. } \\
\text { Johns Bayou and New Madrid Floodway, by } \\
\text { S.L. Ashby, C.E. Ruiz, and P. Deliman }\end{array}$ & ADA379149 \\
\hline ERDC/EL SR-00-8 & Jun 2000 & $\begin{array}{l}\text { Sediment Resuspension Dynamics in } \\
\text { Canopy- and Meadow-Forming Submersed } \\
\text { Macrophyte Communities, by W.F. James and } \\
\text { J.W. Barko }\end{array}$ & ADA380814 \\
\hline ERDC/EL SR-00-9 & Aug 2000 & $\begin{array}{l}\text { Water Quality Modeling of J. Percy Priest } \\
\text { Reservoir Using CE-QUAL-W2, by J.L. Martin } \\
\text { and T.M. Cole }\end{array}$ & ADA382205 \\
\hline ERDC/EL SR-00-10 & Sep 2000 & $\begin{array}{l}\text { Workshop on Standardizing Hydroacoustic } \\
\text { Methods of Estimating Fish Passage for } \\
\text { Lower Columbia River Dams, by G.R. Ploskey, } \\
\text { D.S. Patterson, C.R. Schilt, and M.E. Hanks }\end{array}$ & ADA383952 \\
\hline ERDC/EL SR-00-11 & Sep 2000 & $\begin{array}{l}\text { Status of Waterhyacinth/Hydrilla Infestations } \\
\text { and Associated Biological Control Agents in } \\
\text { Lower Rio Grande Valley Cooperating } \\
\text { Irrigation Districts, by M.J. Grodowitz, J.E. } \\
\text { Freedman, H. Jones, L. Jeffers, C.F. Lopez, } \\
\text { and F. Nibling }\end{array}$ & ADA383998 \\
\hline ERDC/EL SR-00-12 & Sep 2000 & $\begin{array}{l}\text { Gasoline Alley, Fort Drum Bioremediation } \\
\text { Evaluation, Area 1795, Phase I and Phase II, } \\
\text { by L. Hansen, S. Waisner, D. Ringelberg, H. } \\
\text { Fredrickson, R. Wade, R. Bajpai, and J. Talley }\end{array}$ & ADA385445 \\
\hline ERDC/EL SR-00-13 & Sep 2000 & $\begin{array}{l}\text { Gasoline Alley, Fort Drum Bioremediation } \\
\text { Evaluation, Area 1595, Phase I and Phase II, } \\
\text { by L. Hansen, S. Waisner, D. Ringelberg, H. } \\
\text { Fredrickson, R. Wade, R. Bajpai, and J. Talley }\end{array}$ & ADA385778 \\
\hline ERDC/EL SR-00-14 & Nov 2000 & $\begin{array}{l}\text { Evaluation of Wetland Creation with John F. } \\
\text { Baldwin Ship Channel Sediment, by C.R. Lee, } \\
\text { D.L. Brandon, J.W. Simmers, H.E. Tatem, and } \\
\text { R.A. Price }\end{array}$ & \\
\hline ERDC/EL SR-00-15 & Nov 2000 & $\begin{array}{l}\text { Field Survey of Contaminant Concentrations } \\
\text { in Existing Wetlands in the San Francisco } \\
\text { Bay Area, by C.R. Lee, D.L. Brandon, J.W. } \\
\text { Simmers, H.E. Tatem, R.A. Price, and S.P. } \\
\text { Miner }\end{array}$ & ADA385446 \\
\hline ERDC/EL SR-00-16 & Dec 2000 & $\begin{array}{l}\text { Wetlands Management Handbook, by C.B. } \\
\text { Schneider, and S.W. Sprecher }\end{array}$ & ADA388199 \\
\hline ERDC/EL SR-01-1 & Mar 2001 & $\begin{array}{l}\text { VALLA (Version 1.0): A Simulation Model for } \\
\text { Growth of American Wildcelery, by E.P.H. } \\
\text { Best and W.A. Boyd }\end{array}$ & ADA389343 \\
\hline
\end{tabular}




\begin{tabular}{|c|c|c|c|}
\hline ERDC/EL SR-01-2 & Feb 2001 & $\begin{array}{l}\text { Biological Assessment of Streams } \\
\text { Associated with the Northern Training } \\
\text { Complex at Fort Knox, Kentucky, August } \\
\text { 2000, by B.S. Payne and W.B. Green }\end{array}$ & ADA389370 \\
\hline ERDC/EL SR-01-3 & Jul 2001 & $\begin{array}{l}\text { Water Quality Modeling of Allatoona and } \\
\text { West Point Reservoirs Using CE-QUAL-W2, by } \\
\text { T.M. Cole and D.H. Tillman }\end{array}$ & ADA394432 \\
\hline ERDC/EL SR-02-1 & Jul 2002 & $\begin{array}{l}\text { Watershed Modeling System Hydrological } \\
\text { Simulation Program: Watershed Model User } \\
\text { Documentation and Tutorial, by P.N. } \\
\text { Deliman, C.E. Ruiz, C.T. Manwaring, and E.J. } \\
\text { Nelson }\end{array}$ & ADA405653 \\
\hline ERDC/EL SR-03-1 & Jul 2003 & $\begin{array}{l}\text { POTAM (Version 1.0): A Simulation Model for } \\
\text { Growth of Sago Pondweed, by E.P.H. Best } \\
\text { and W.A. Boyd }\end{array}$ & ADA417049 \\
\hline ERDC/EL SR-04-1 & Feb 2004 & $\begin{array}{l}\text { SELECT Version } 1.0 \text { Beta: A One-Dimensional } \\
\text { Reservoir Selective Withdrawal Model } \\
\text { Spreadsheet, by M.L. Schneider, S.C. } \\
\text { Wilhelms, and L.I. Yates }\end{array}$ & ADA422160 \\
\hline ERDC/EL SR-04-2 & Jun 2004 & $\begin{array}{l}\text { Salvinia molesta D. S. Mitchell (Giant } \\
\text { Salvinia) in the United States: A Review of } \\
\text { Species Ecology and Approaches to } \\
\text { Management, by D.G. McFarland, L.S. } \\
\text { Nelson, M.J. Grodowitz, R.M. Smart, and C.S. } \\
\text { Owens }\end{array}$ & ADA425068 \\
\hline ERDC/EL SR-04-3 & Jul 2004 & $\begin{array}{l}\text { Flood Event Assessment Tool (FEAT) User's } \\
\text { Manual and Technical Documentation, by } \\
\text { J.R. Ballard, Jr., and M.R. Kress }\end{array}$ & ADA426038 \\
\hline 1ERDC/EL SR-04-4 & Jul 2004 & $\begin{array}{l}\text { White Phosphorus Wetland Storage Final } \\
\text { Assessment Report, by J.W. Simmers, R.A. } \\
\text { Price, R.P. Jones, Jr., K.F. Myers, R.A. Karn, } \\
\text { C.D. Hahn, H.E. Tatem, and J.M. Roper }\end{array}$ & ADB301917 \\
\hline ERDC/EL SR-05-1 & Sep 2005 & $\begin{array}{l}\text { A Survey of the Invasive Aquatic and Riparian } \\
\text { Plants of the Lower Rio Grande, 2004, by } \\
\text { C.S. Owens, M.J. Grodowitz, and F. Nibling }\end{array}$ & ADA440204 \\
\hline ERDC/EL SR-09-1 & Aug 2009 & $\begin{array}{l}\text { User's Guide to Linking the CE-QUAL-ICM and } \\
\text { Ecopath Models, by C.F. Cerco, D.H. Tillman, } \\
\text { and T.K. Gerald }\end{array}$ & ADA508368 \\
\hline ERDC/EL SR-09-2 & Sep 2009 & $\begin{array}{l}\text { A Reference Guide for Available Data in } \\
\text { Eastern Louisiana and Mississippi Coastal } \\
\text { Waters: A Data Report for Future Water } \\
\text { Quality Modeling Projects, by T.L. Threadgill }\end{array}$ & \\
\hline
\end{tabular}

\footnotetext{
1 Limited distribution; see Preface.
} 


\begin{tabular}{|c|c|c|c|}
\hline ERDC/EL SR-11-1 & Aug 2011 & $\begin{array}{l}\text { Ecological DYnamics Simulation Model - } \\
\text { Light (EDYS-L): User's Guide Version } 4.6 .4 \text {, by } \\
\text { C.L. Coldren, T. McLendon, W.M. Childress, } \\
\text { D.L. Price, and M.R. Graves }\end{array}$ & ADA548693 \\
\hline ERDC/EL SR-12-1 & Dec 2012 & $\begin{array}{l}\text { HEAT - Habitat Evaluation and Assessment } \\
\text { Tools for Effective Environmental } \\
\text { Evaluations: User's Guide, by K.A. Burks- } \\
\text { Copes, A.C. Webb, M.F. Passmore, and S.D. } \\
\text { McGee-Rosser }\end{array}$ & ADA583087 \\
\hline ERDC/EL SR-15-1 & Feb 2015 & $\begin{array}{l}\text { Determination of Nanomechanical } \\
\text { Properties by Atomic Force Microscopy: } \\
\text { Scientific Operating Procedure SOP-C-2, by } \\
\text { M.F. Cuddy, A.R. Poda, and M.S. Hull }\end{array}$ & ADA616441 \\
\hline ERDC/EL SR-15-2 & Feb 2015 & $\begin{array}{l}\text { Environmental Consequences of } \\
\text { Nanotechnologies: Nanoparticle Dispersion } \\
\text { in Aqueous Media: SOP-T-1, by J.G. Coleman, } \\
\text { A.J. Kennedy, and A.R. Harmon }\end{array}$ & ADA613776 \\
\hline ERDC/EL SR-15-3 & Apr 2015 & $\begin{array}{l}\text { Characterization of Nanomaterials Using Field } \\
\text { Flow Fractionation and Single Particle } \\
\text { Inductively Coupled Plasma Mass } \\
\text { Spectrometery (FFF-ICP-MS and SP-ICP-MS): } \\
\text { Scientific Operating Procedure SOP-C-1, by A.J. } \\
\text { Bednar, A.R. Poda, A.J. Kennedy, K.C. } \\
\text { Armstrong, E.P. Gray, C. Higgins, and J.F. } \\
\text { Ranville }\end{array}$ & ADA614455 \\
\hline ERDC/EL SR-15-4 & Jul 2015 & $\begin{array}{l}\text { Purification and Concentration of } \\
\text { Nanoparticles Using Diafiltration. Scientific } \\
\text { Operating Procedure Series: SOP-P-1, by L.F. } \\
\text { Miller and M.A. Chappell }\end{array}$ & ADA620552 \\
\hline ERDC/EL SR-15-5 & Aug 2015 & $\begin{array}{l}\text { Development of a Chronic Toxicity Testing } \\
\text { Method for Daphnia pulex, by J.G. Laird, A.J. } \\
\text { Kennedy, N.L. Melby, C.D. Lounds, and P. } \\
\text { Gong }\end{array}$ & ADA623139 \\
\hline
\end{tabular}

\section{Technical notes}

\begin{tabular}{|c|c|c|}
\hline$\underline{\text { Report Number }}$ & Date & $\underline{\text { Title }}$ \\
\hline ERDC/EL TN-04-01 & Mar 2004 & $\begin{array}{l}\text { Monitoring Wetland Functional Recovery of Bottomland } \\
\text { Hardwood Sites in the Yazoo Basin, MS, by M.N. } \\
\text { Humphrey, J.P. Lin, B.A. Kleiss, and D.E. Evans }\end{array}$ \\
\hline ERDC/EL TN-04-02 & Jul 2004 & $\begin{array}{l}\text { Restoration Potential of Ruppia maritima and } \\
\text { Potamogeton perfoliatus by Seed in the Mid-Chesapeake } \\
\text { Bay, by S. Ailstock and D. Shafer }\end{array}$ \\
\hline ERDC/EL TN-06-1 & Jul 2006 & $\begin{array}{l}\text { Salinity Measurements and General Condition of Violet } \\
\text { Marsh, Post Hurricane Katrina, by J.P. Lin and B.A. Kleiss }\end{array}$ \\
\hline
\end{tabular}




\begin{tabular}{|c|c|c|}
\hline ERDC/EL TN-06-2 & Jul 2006 & $\begin{array}{l}\text { A Pilot Study of Post-Hurricane Katrina Floodwater } \\
\text { Pumping on Marsh Infauna, by G.L. Ray }\end{array}$ \\
\hline ERDC/EL TN-06-3 & Oct 2006 & $\begin{array}{l}\text { A Pilot Study of the Effects of Post- Hurricane Katrina } \\
\text { Floodwater Pumping on the Chemistry and Toxicity of } \\
\text { Violet Marsh Sediments, by B.C. Suedel, J.A. Steevens, } \\
\text { and D.E. Splichal }\end{array}$ \\
\hline ERDC/EL TN-06-4 & Oct 2006 & $\begin{array}{l}\text { Characterization of Post-Hurricane Katrina Floodwater } \\
\text { Pumping on Marsh Infauna, by G.L. Ray }\end{array}$ \\
\hline ERDC/EL TN-06-5 & Dec 2006 & $\begin{array}{l}\text { Water and Sediment Data for Chemical Indicators of } \\
\text { Contamination, by T. Bowley, S. Larson, and A. Bednar }\end{array}$ \\
\hline ERDC/EL TN-07-1 & Dec 2007 & $\begin{array}{l}\text { Thin Layer Placement of Dredged Material on Coastal } \\
\text { Wetlands: A Review of the Technical and Scientific } \\
\text { Literature, by G.L. Ray }\end{array}$ \\
\hline ERDC/EL TN-09-1 & Aug 2009 & $\begin{array}{l}\text { Evaluation of Remotely Sensed Data for the Application of } \\
\text { Geospatial Techniques to Assess Hurricane Impacts on } \\
\text { Coastal Bird Habitat, by S.S. Jackson, R.A. Fischer, M.P. } \\
\text { Guilfoyle, and J.S. Wakeley }\end{array}$ \\
\hline ERDC/EL TN-10-1 & May 2010 & $\begin{array}{l}\text { Effects of a Nonnative, Invasive Lovegrass on Agave } \\
\text { palmeri Distribution, Abundance, and Insect Pollinator } \\
\text { Communities, by D.L. Lindsay, P. Bailey, R.F. Lance, M.J. } \\
\text { Clifford, R. Delph, and N.S. Cobb }\end{array}$ \\
\hline ERDC/EL TN-10-2 & May 2010 & $\begin{array}{l}\text { Evaluation of a Method for Measuring Lateral } \\
\text { Obscuration of Coastal Marsh Vegetation in Louisiana, by } \\
\text { J.P. Lin, S. Bourne, B. Couvillon, J.M. Smith, G. Snedden, } \\
\text { G.D. Steyer, and S.L. Yost }\end{array}$ \\
\hline ERDC/EL TN-10-3 & Jul 2010 & $\begin{array}{l}\text { HEC-HMS Development in Support of Russian River } \\
\text { Watershed Assessment, by Z. Zhang and B.E. Johnson }\end{array}$ \\
\hline ERDC/EL TN-10-4 & Jul 2010 & $\begin{array}{l}\text { Release of the Biological Control Agent Puccinia jaceae } \\
\text { var. solstitialis for Management of Yellow Starthistle at } \\
\text { Fort Hunter Liggett, CA, by J.F. Shearer and A.M. Hamblin }\end{array}$ \\
\hline ERDC/EL TN-10-5 & Aug 2010 & $\begin{array}{l}\text { Vertical Accretion Rates in Coastal Louisiana: A Review of } \\
\text { the Scientific Literature, by J.C. Jarvis }\end{array}$ \\
\hline ERDC/EL TN-11-1 & Mar 2011 & $\begin{array}{l}\text { Flood Risk Management: Insights from an Expert } \\
\text { Modeling Process, by M.D. Wood, I. Linkov, T. Bridges, D. } \\
\text { Kovacs, S. Thorne, and G. Butte }\end{array}$ \\
\hline ERDC/EL TN-11-2 & Jul 2011 & $\begin{array}{l}\text { Relationships Between Landscape-Level Changes and } \\
\text { Seasonal Bird Communities at Fort Benning, Georgia, by } \\
\text { M.P. Guilfoyle, S.C. Anderson, and S.G. Bourne }\end{array}$ \\
\hline ERDC/EL TN-11-3 & Aug 2011 & $\begin{array}{l}\text { Evaluation of Commercially Available Herbicide Mixes for } \\
\text { Control of Rosette Stage Yellow Starthistle (Centaurea } \\
\text { solstitialis L.), by C.R. Mudge, R.M. Wersal, and L.S. } \\
\text { Nelson }\end{array}$ \\
\hline
\end{tabular}


ERDC/EL TN-11-4

ERDC/EL TN-12-1

ERDC/EL TN-12-2

ERDC/EL TN-13-1

ERDC/EL TN-13-2

ERDC/EL TN-13-3

ERDC/EL TN-14-1

ERDC/EL TN-14-2

ERDC/EL TN-14-3

ERDC/EL TN-14-4

ERDC/EL TN-14-5

ERDC/EL TN-15-1

ERDC/EL TN-15-2
Jul 2014

Aug 2014

Aug 2011

Apr 2012

May 2012

Apr 2013

Jul 2013

Jul 2013

May 2014

Jun 2014

Jul 2014

Mar 2015

Jul 2015
Guidance for USACE Dredging Projects Affected by Oil Spills, by W.P. Lorentz, T.J. Estes, A.J. Bednar, G.R. Lotufo, S.E. Bailey, and J.M. Corbino

Survey for Pathogens of Phragmites in New York, by J.F. Shearer and N.E. Harms

Field Analysis of Munitions Constituents Using a Fieldportable GC-MS, by A.J. Bednar, A.L. Russell, C.A. Hayes, W.T. Jones, P. Tackett, M. Wells, D. Justes, R.A. Kirgan, D. Splichal, L. Parker, and T. Georgian

Chemical Control of Invasive Phragmites in a Great Lakes Marsh: A Field Demonstration, by K.D. Getsinger, A.G. Poovey, E. Kafcas, and J. Schafer

Minnehaha Creek Watershed SWMM5 Model Data Analysis and Future Recommendations, by Z. Zhang and C. Mueller

Identifying, Developing and Releasing Insect Biocontrol Agents for the Management of Phragmites australis, by $B$. Blossey, R.A. Casagrande, L. Tewksburg, H. Hinz, P. Haflinger, L. Martin, and J. Cohen

A Robust, Scalable Framework for Conducting Climate Change Susceptibility Analyses, by E.R. Britzke, N.R. Beane, A.V. Davis, M.D. Whitby, and S.M. Brasfield

PCB Content of Sediments Collected at Manistique Harbor, Michigan, by K. Gustavson

A Rapid Spectrophotometric Screening Method for 2,4dinitroanisole in Laboratory Water, by C.D. Lounds, A.J. Kennedy, A.R. Poda, and A.L. Russell

A Guide for Incorporating AdH Modeling Data into ArcGIS ${ }^{\circledR}$ Using a netCDF: A Case Study for the Sacramento River, by C.L. Saltus, A.V. Davis, T.L. Threadgrill, A. Hammack, and D.L. Smith

A Review of the Recent Scientific Literature on Irrigation Induced and Enhanced Wetlands, by J.F. Berkowitz and D.E. Evans

Developing Conceptual Models for Assessing Climate Change Impacts to Contaminant Availability in Terrestrial Ecosystems, by B.C. Suedel, N.R. Beane, E.R. Britzke, C.R. Montgomery, and S.M. Brasfield

Evaluation of Uncertainty in Constituent Input Parameters for Modeling the Fate of RDX, by M.S. Dortch 


\section{Technical reports}

\begin{tabular}{|c|c|c|}
\hline$\underline{\text { Report Number }}$ & $\underline{\text { Date }}$ & $\underline{\text { Title }}$ \\
\hline TR EL-99-11 & Oct 1999 & $\begin{array}{l}\text { Moist-Soil Impoundments for Wetland } \\
\text { Wildlife, by J.J. Lane and K.C. Jensen }\end{array}$ \\
\hline TR EL-99-12 & Nov 1999 & $\begin{array}{l}\text { An Overview of Jefferson Proving Ground } \\
\text { UXO Technology Demonstration (Phase III) } \\
\text { Contractor Performance Self-assessments, } \\
\text { by J.O. Curtis }\end{array}$ \\
\hline TR EL-99-13 & Nov 1999 & $\begin{array}{l}\text { Water Quality in Richard B. Russell and J. } \\
\text { Strom Thurmond Lakes: Interim Report for } \\
\text { the Period 1997-1998, by J.J. Hains, W.E. } \\
\text { Jabour, R.H. Kennedy, W. Boyd, J.M. } \\
\text { Satterfield, and P.K. Howle }\end{array}$ \\
\hline TR EL-99-14 & Oct 1999 & $\begin{array}{l}\text { An Evaluation of Freshwater Mussels in the } \\
\text { Lower Ohio River in Relation to the Olmsted } \\
\text { Locks and Dam Project: } 1998 \text { Studies, by } \\
\text { B.S. Payne and A.C. Miller }\end{array}$ \\
\hline
\end{tabular}

$\underline{\text { AD Number }}$

ADA371794

ADA371273

ADA371614

TR EL-99-15

Dec 1999

Detailed Reservoir Water Quality Modeling (CE-QUAL-W2), Alabama-CoosaTallapoosa/Apalachicola-ChattahoocheeFlint (ACT/ACF) Comprehensive Water Resource Study, by D.H. Tillman, T.M. Cole, and B.W. Bunch

\begin{tabular}{|c|c|c|}
\hline ERDC/EL TR-00-1 & Jan 2000 & $\begin{array}{l}\text { Zebra Mussel Chemical Control Guide, by } \\
\text { S.L. Sprecher and K.D. Getsinger }\end{array}$ \\
\hline ERDC/EL TR-00-2 & Feb 2000 & $\begin{array}{l}\text { Water Movement in Relation to Fecal } \\
\text { Coliform Contamination in the Metro Beach } \\
\text { Area of the Lake St. Clair, Michigan, by C.S. } \\
\text { Smith, W.F. James, H.L. Eakin, and J.W. } \\
\text { Barko }\end{array}$ \\
\hline ERDC/EL TR-00-3 & Mar 2000 & $\begin{array}{l}\text { Terrestrial Invertebrates, Edwards Air Force } \\
\text { Base, 1997, by G. Pratt }\end{array}$ \\
\hline ERDC/EL TR-00-4 & Apr 2000 & $\begin{array}{l}\text { Simulating Population Dynamics in an } \\
\text { Ecosystem Context Using Coupled Eulerian- } \\
\text { Lagrangian Hybrid Models (CEL HYBRID } \\
\text { Models), by J.M. Nestler and R.A. Goodwin }\end{array}$ \\
\hline ERDC/EL TR-00-5 & Jun 2000 & $\begin{array}{l}\text { Reducing the Effects of Maintenance } \\
\text { Dredging on Freshwater Mussels in the } \\
\text { Alabama River, Alabama, by A.C. Miller }\end{array}$ \\
\hline
\end{tabular}

ADA375208 ADA376315

ADA377014 ADA380298 ADA379934 


\begin{tabular}{|c|c|c|c|}
\hline ERDC/EL TR-00-6 & Jul 2000 & $\begin{array}{l}\text { Summary Report, Risk Assessment } \\
\text { Modeling Workshop, 14-15 May 1998, New } \\
\text { Orleans, Louisiana, by P.N. Deliman, C.E. } \\
\text { Ruiz, and J.A. Gerald }\end{array}$ & ADA380703 \\
\hline ERDC/EL TR-00-7 & Aug 2000 & $\begin{array}{l}\text { Theoretical Basis for the CE-QUAL-W2 River } \\
\text { Basin Model, by S.A. Wells and T.M. Cole }\end{array}$ & ADA382290 \\
\hline ERDC/EL TR-00-8 & Aug 2000 & $\begin{array}{l}\text { Experimental Hydroacoustic Deployments } \\
\text { to Improve Estimates of Fish Guidance } \\
\text { Efficiency, by M.E. Hanks and G.R. Ploskey }\end{array}$ & ADA384681 \\
\hline ERDC/EL TR-00-9 & Sep 2000 & $\begin{array}{l}\text { An Evaluation of Solidification/Stabilization } \\
\text { for Sediments from the Puget Sound Naval } \\
\text { Shipyard, by M.G. Channell }\end{array}$ & ADA384015 \\
\hline ERDC/EL TR-00-10 & Sep 2000 & $\begin{array}{l}\text { Water Quality Model of Florida Bay, by C.F. } \\
\text { Cerco, B.W. Bunch, A.M. Teeter, and M.S. } \\
\text { Dortch }\end{array}$ & ADA385000 \\
\hline ERDC/EL TR-00-11 & Sep 2000 & $\begin{array}{l}\text { Adsorption and Transformation of } \\
\text { Explosives in Low-Carbon Aquifer Soils, by } \\
\text { C.B. Price, J.M. Brannon, S.L. Yost, and C.A. } \\
\text { Hayes }\end{array}$ & ADA385046 \\
\hline ERDC/EL TR-00-12 & Sep 2000 & $\begin{array}{l}\text { Development of a Numerical Fish Surrogate } \\
\text { for Improved Selection of Fish Passage } \\
\text { Design and Operation Alternatives for Lower } \\
\text { Granite Dam: Phase I, by J.M. Nestler, R.A. } \\
\text { Goodwin, and R.S. Chapman }\end{array}$ & ADA385755 \\
\hline ERDC/EL TR-00-13 & Sep 2000 & $\begin{array}{l}\text { Bioremediation Treatability Study for } \\
\text { Remedial Action at Popile, Inc., Site, El } \\
\text { Dorado, Arkansas. Phase II. Pilot-Scale } \\
\text { Evaluation, by L. Hansen, C. Nestler, M. } \\
\text { Channell, D. Ringelberg, H. Fredrickson, } \\
\text { and S. Waisner }\end{array}$ & ADA383479 \\
\hline ERDC/EL TR-00-14 & Sep 2000 & $\begin{array}{l}\text { Removal of RDX From a Contaminated } \\
\text { Groundwater by In Situ Bioremediation, by } \\
\text { S.A. Waisner, H.L. Fredrickson, L.D. Hansen, } \\
\text { and K. Banerji }\end{array}$ & ADA385165 \\
\hline ERDC/EL TR-00-15 & Oct 2000 & $\begin{array}{l}\text { An Analysis of Freshwater Mussels } \\
\text { (Unionidae) in the Upper Ohio River near } \\
\text { Huntington, West Virginia, } 1998 \text { Studies, by } \\
\text { A.C. Miller and B.S. Payne }\end{array}$ & ADA384564 \\
\hline ERDC/EL TR-00-16 & Sep 2000 & $\begin{array}{l}\text { An Investigation of the Mussel Resource at } \\
\text { Selected Locations Along the Alabama } \\
\text { River, Alabama, 1999, by A.C. Miller }\end{array}$ & ADA385866 \\
\hline
\end{tabular}




\begin{tabular}{|c|c|c|c|}
\hline ERDC/EL TR-00-17 & Sep 2000 & $\begin{array}{l}\text { Expanding Wetland Assessment } \\
\text { Procedures: Linking Indices of Wetland } \\
\text { Function with Services and Values, by D.M. } \\
\text { King, L.A. Wainger, C.C. Bartoldus, and J.S. } \\
\text { Wakeley }\end{array}$ & ADA385356 \\
\hline ERDC/EL TR-00-18 & Nov 2000 & $\begin{array}{l}\text { SEAM3D: A Numerical Model for Three- } \\
\text { Dimensional Solute Transport and } \\
\text { Sequential Electron Acceptor-Based } \\
\text { Bioremediation in Groundwater, by D.W. } \\
\text { Waddill and M.A. Widdowson }\end{array}$ & ADA385443 \\
\hline ERDC/EL TR-00-19 & Sep 2000 & $\begin{array}{l}\text { An Evaluation of Aquatic Habitats at } \\
\text { Edwards Air Force Base, California, by A.C. } \\
\text { Miller and B.S. Payne }\end{array}$ & ADA389118 \\
\hline ERDC/EL TR-00-20 & Nov 2000 & $\begin{array}{l}\text { Terrestrial Arthropods of Edwards Air Force } \\
\text { Base, 1996-1998, by G. Pratt }\end{array}$ & ADA386626 \\
\hline ERDC/EL TR-01-1 & Jan 2001 & $\begin{array}{l}\text { Hydroacoustic Evaluation of the Bonneville } \\
\text { Dam Prototype Surface Collector in 1999, } \\
\text { by G.R. Ploskey, P.N. Johnson, W.T. Nagy, } \\
\text { C.R. Schilt, L.R. Lawrence, D.S. Patterson,, , } \\
\text { and J.R. Skalski }\end{array}$ & ADA388388 \\
\hline ERDC/EL TR-01-2 & Jan 2001 & $\begin{array}{l}\text { Hydroacoustic Evaluation of Juvenile } \\
\text { Salmonid Passage Through Experimental } \\
\text { Routes at Bonneville Dam in 1998, by G.R. } \\
\text { Ploskey, W.T. Nagy, L.R. Lawrence, D.S. } \\
\text { Patterson, C.R. Schilt, P.N. Johnson, and } \\
\text { J.R. Skalski }\end{array}$ & ADA387530 \\
\hline ERDC/EL TR-01-3 & Jan 2001 & $\begin{array}{l}\text { RECOVERY Version 2.0, A Mathematical } \\
\text { Model to Predict the Temporal Response of } \\
\text { Surface Water to Contaminated Sediments, } \\
\text { by C.E. Ruiz and T. Gerald }\end{array}$ & ADA390143 \\
\hline ERDC/EL TR-01-4 & Aug 2001 & $\begin{array}{l}\text { An Investigation of Mussel Resources in } \\
\text { Selected Bayous, Northwestern Mississippi, } \\
1999 \text { and 2000, by A.C. Miller and B.S. } \\
\text { Payne }\end{array}$ & ADA395883 \\
\hline ERDC/EL TR-01-5 & Mar 2001 & $\begin{array}{l}\text { A Simulation Model for Growth of the } \\
\text { Submersed Aquatic Macrophyte American } \\
\text { Wildcelery (Vallisneria americana Michx.), } \\
\text { by E.P.H. Best and W.A. Boyd }\end{array}$ & ADA389341 \\
\hline ERDC/EL TR-01-6 & Feb 2001 & $\begin{array}{l}\text { Cost and Performance Report for Tri-Service } \\
\text { Site Characterization and Analysis System } \\
\text { (SCAPS) Thermal Desorption Sampler for } \\
\text { Volatile Organic Compounds, by K.F. Myers, } \\
\text { J. Costanza, D.Y. Eng, R.A. Kam, K.F. } \\
\text { Konecny, and W.M. Davis }\end{array}$ & ADA388547 \\
\hline
\end{tabular}




\begin{tabular}{|c|c|c|c|}
\hline ERDC/EL TR-01-7 & Feb 2001 & $\begin{array}{l}\text { Whole-Lake Applications of Sonar }{ }^{\mathrm{TM}} \text { for } \\
\text { Selective Control of Eurasian Watermilfoil, } \\
\text { by J.D. Getsinger, J.D. Madsen, T.J. } \\
\text { Koschnick, M.D. Netherland, R.M. Stewart, } \\
\text { D.R. Honnell, A.G. Staddon, and C.S. Owens }\end{array}$ & ADA38839 \\
\hline ERDC/EL TR-01-8 & Apr 2001 & $\begin{array}{l}\text { Assessment of Methodologies for High- } \\
\text { Frequency, Fine-Scaled, Spatially } \\
\text { Referenced In Situ Data Collection and } \\
\text { Analysis, by J.J. Hains and R.H. Kennedy }\end{array}$ & ADA391737 \\
\hline ERDC/EL TR-01-9 & Jun 2001 & $\begin{array}{l}\text { Tri-Service Site Characterization and } \\
\text { Analysis Penetrometer System (SCAPS) } \\
\text { Validation of the Hydrosparge Volatile } \\
\text { Organic Compound Sensor, by W.M. Davis, } \\
\text { K.F. Myers, M.B. Wise, and C.V. Thompson }\end{array}$ & ADA3924C \\
\hline ERDC/EL TR-01-10 & Jun 2001 & $\begin{array}{l}\text { Cost and Performance Report for the Tri- } \\
\text { Service Site Characterization and Analysis } \\
\text { Penetrometer System (SCAPS) Hydrosparge } \\
\text { Volatile Organic Compound Sensor, by J. } \\
\text { Costanza, K.F. Myers, and W.M. Davis }\end{array}$ & ADA39327 \\
\hline ERDC/EL TR-01-11 & Jun 2001 & $\begin{array}{l}\text { Hydroacoustic Evaluation of Juvenile } \\
\text { Salmon Passage at The Dalles Dam: 1999, } \\
\text { by G.R. Ploskey, W.T. Nagy, L.R. Lawrence, } \\
\text { M.E. Hanks, C.R. Schilt, P.N. Johnson, G.E. } \\
\text { Johnson, D.S. Patterson, and J.R. Skalski }\end{array}$ & ADA3930s \\
\hline ERDC/EL TR-01-12 & Jul 2001 & $\begin{array}{l}\text { Status of Freshwater Mussels in the Lower } \\
\text { Ohio River in Relation to the Olmsted Locks } \\
\text { and Dam Project: } 1999 \text { Studies, by B.S. } \\
\text { Payne and A.C. Miller }\end{array}$ & ADA39431 \\
\hline ERDC/EL TR-01-13 & Aug 2001 & $\begin{array}{l}\text { Landscape Metrics to Assess Habitat } \\
\text { Suitability for Conservation Bird Species in } \\
\text { the Southeastern United States, by L.P. } \\
\text { Dove }\end{array}$ & ADA39510 \\
\hline ERDC/EL TR-01-14 & Aug 2001 & $\begin{array}{l}\text { Integrated Electronic Data Repository to } \\
\text { Support the South Fork of the Broad River } \\
\text { Research Program, by L.P. Dove and S. } \\
\text { Bong }\end{array}$ & ADA3960 \\
\hline ERDC/EL TR-01-15 & Aug 2001 & $\begin{array}{l}\text { Long-Term Monitoring Program, Fort } \\
\text { Benning, GA; Ecosystem Characterization } \\
\text { and Monitoring Initiative, Version 2.1, by } \\
\text { M.R. Kress }\end{array}$ & ADA3956C \\
\hline ERDC/EL TR-01-16 & Aug 2001 & $\begin{array}{l}\text { Molecular Weight Distribution of the Final } \\
\text { Products of TNT-Hydroxide Reaction, by D.R. } \\
\text { Felt, S.L. Larson, and L.D. Hansen }\end{array}$ & ADA395 \\
\hline
\end{tabular}




\begin{tabular}{|c|c|c|c|}
\hline ERDC/EL TR-01-17 & Aug 2001 & $\begin{array}{l}\text { Kinetics of Base-Catalyzed 2,4,6- } \\
\text { Trinitrotoluene Transformation, by D.R. Felt, } \\
\text { S.L. Larson, and L.D. Hansen }\end{array}$ & ADA395987 \\
\hline ERDC/EL TR-01-18 & Aug 2001 & $\begin{array}{l}\text { S-Tracker Survey of Sites for Long-Term } \\
\text { Erosion/Deposition Monitoring, by C.D. } \\
\text { Hahn, M.R. Graves, and D.L. Price }\end{array}$ & ADA396315 \\
\hline ERDC/EL TR-01-19 & Aug 2001 & $\begin{array}{l}\text { Adsorption and Transformation of RDX in } \\
\text { Low-Carbon Aquifer Soils, by C.B. Price, J.M. } \\
\text { Brannon, S.L. Yost, and C.A. Hayes }\end{array}$ & ADA396604 \\
\hline ERDC/EL TR-01-20 & Sep 2001 & $\begin{array}{l}\text { Advanced UXO Detection/Discrimination } \\
\text { Technology Demonstration-U.S. Army } \\
\text { Jefferson Proving Ground, Madison, } \\
\text { Indiana, by E.R. Cespedes }\end{array}$ & ADA396147 \\
\hline ERDC/EL TR-01-21 & Aug 2001 & $\begin{array}{l}\text { Analysis of CL-20 in Environmental } \\
\text { Matrices: Water and Soil, by S.L. Larson, } \\
\text { D.R. Felt, L. Escalon, J.D. Davis, and L.D. } \\
\text { Hansen }\end{array}$ & ADA397427 \\
\hline ERDC/EL TR-01-22 & Aug 2001 & $\begin{array}{l}\text { GIS-Assisted Spatial Data Management for } \\
\text { Corps of Engineers Real Estate Activities, by } \\
\text { L.P. Dove, M.R. Graves, and E. Lopez }\end{array}$ & ADA397425 \\
\hline ERDC/EL TR-01-23 & Sep 2001 & $\begin{array}{l}\text { Watershed Boundaries and Relationship } \\
\text { Between Stream Order and Watershed } \\
\text { Morphology at Fort Benning, Georgia, by } \\
\text { M.R. Graves }\end{array}$ & ADA397449 \\
\hline ERDC/EL TR-01-24 & Sep 2001 & $\begin{array}{l}\text { Mass-Rearing Hydrellia pakistanae Deonier, } \\
\text { A Biological Control Agent of Hydrilla } \\
\text { verticillata (L.f.) Royle, for Release and } \\
\text { Establishment, by J.E. Freedman, M.J. } \\
\text { Grodowitz, A.F. Confrancesco, and R. Bare }\end{array}$ & ADA397580 \\
\hline ERDC/EL TR-01-25 & Sep 2001 & $\begin{array}{l}\text { Evaluation of Toledo Harbor Dredged Material } \\
\text { for Manufactured Soil. Phase I: Greenhouse } \\
\text { Bench-Scale Test, by T.C. Sturgis, C.R. Lee, } \\
\text { and H.C. Banks, Jr. }\end{array}$ & ADA398267 \\
\hline ERDC/EL TR-01-26 & Sep 2001 & $\begin{array}{l}\text { An Analysis of Freshwater Mussels } \\
\text { (Unionidae) Along Luxapalila Creek, } \\
\text { Mississippi, } 1999 \text { Studies, by A.C. Miller }\end{array}$ & ADA399436 \\
\hline ERDC/EL TR-01-27 & Sep 2001 & $\begin{array}{l}\text { Image Data Acquisition System User's } \\
\text { Guide and Technical Documentation, by } \\
\text { C.D. Hahn and J.R. Ballard, Jr. }\end{array}$ & ADA399452 \\
\hline
\end{tabular}




\begin{tabular}{|c|c|c|c|}
\hline ERDC/EL TR-01-28 & Sep 2001 & $\begin{array}{l}\text { Design, Construction, and Operation of a } \\
\text { Field Demonstration for In Situ } \\
\text { Biodegradation of Vadose Zone Soils } \\
\text { Contaminated with High Explosives, by K. } \\
\text { Rainwater, J. Brown, C. Heintz, T. Mollhagen, } \\
\text { and L.D. Hansen }\end{array}$ & ADA398266 \\
\hline ERDC/EL TR-01-29 & Sep 2001 & $\begin{array}{l}\text { Hydrogeomorphic Approach to Assessing } \\
\text { Wetland Functions: Guidelines for } \\
\text { Developing Regional Guidebooks. Chapter } \\
\text { 3, Developing A Reference Wetland System, } \\
\text { by R.D. Smith }\end{array}$ & ADA399404 \\
\hline ERDC/EL TR-01-30 & Sep 2001 & $\begin{array}{l}\text { Hydrogeomorphic Approach to Assessing } \\
\text { Wetland Functions: Guidelines for } \\
\text { Developing Regional Guidebooks. Chapter } \\
\text { 4, Developing Assessment Models, by R.D. } \\
\text { Smith and J.S. Wakeley }\end{array}$ & ADA399405 \\
\hline ERDC/EL TR-01-31 & Sep 2001 & $\begin{array}{l}\text { Hydrogeomorphic Approach to Assessing } \\
\text { Wetland Functions: Guidelines for } \\
\text { Developing Regional Guidebooks. Chapter } \\
\text { 7, Verifying, Field Testing, and Validating } \\
\text { Assessment Models, by J.S. Wakeley and } \\
\text { R.D. Smith }\end{array}$ & ADA399406 \\
\hline $\begin{array}{l}\text { ERDC/EL TR-01-32 } \\
\text { Vol. } 1\end{array}$ & Sep 2001 & $\begin{array}{l}\text { Computed-Tomography Imaging } \\
\text { SpectroPolarimeter (CTISP) - A Passive } \\
\text { Optical Sensor. Volume 1, Main Text and } \\
\text { Appendix A, by H.H. Bennett, Jr., R.A. } \\
\text { Goodson, and J.O. Curtis }\end{array}$ & ADA399665 \\
\hline $\begin{array}{l}\text { ERDC/EL TR-01-32 } \\
\text { Vol. } 2\end{array}$ & Sep 2001 & $\begin{array}{l}\text { Computed-Tomography Imaging } \\
\text { SpectroPolarimeter (CTISP) - A Passive } \\
\text { Optical Sensor. Volume 2, Appendix B, by } \\
\text { H.H. Bennett, Jr., R.A. Goodson, and J.O. } \\
\text { Curtis }\end{array}$ & ADA399664 \\
\hline ERDC/EL TR-01-33 & Sep 2001 & $\begin{array}{l}\text { Development of Simulators for In Situ } \\
\text { Remediation Evaluation, Design, and } \\
\text { Operation: Final Report, by M.S. Dortch, C.J. } \\
\text { McGrath, J.J. Nitao, M.A. Widdowson, and S. } \\
\text { Yabusaki }\end{array}$ & ADA399606 \\
\hline ERDC/EL TR-01-34 & Sep 2001 & $\begin{array}{l}\text { Macroinvertebrate Communities and } \\
\text { Habitat in Luxapalila Creek, Mississippi and } \\
\text { Alabama, by B.S. Payne, P. Smiley, and A.C. } \\
\text { Miller }\end{array}$ & ADA399416 \\
\hline ERDC/EL TR-01-35 & Oct 2001 & $\begin{array}{l}\text { Evaluation of Manufactured Soil Using } \\
\text { Dredged Material from New York/New } \\
\text { Jersey Harbor Newton Creek Site. Phase 1: } \\
\text { Greenhouse Bench-Scale Test, by T.C. } \\
\text { Sturgis, C.R. Lee, H.C. Banks, Jr., M.R. } \\
\text { Burchell II, and K. Johnson }\end{array}$ & ADA397459 \\
\hline
\end{tabular}


ERDC/EL TR-02-1 Jan 2002

ERDC/EL TR-02-2 Mar 2002

ERDC/EL TR-02-3 Mar 2002

ERDC/EL TR-02-4 Apr 2002

ERDC/EL TR-02-5

ERDC/EL TR-02-6

ERDC/EL TR-02-7

ERDC/EL TR-02-8
Apr 2002

May 2002

Apr 2002

Regional Guidebook for Applying the Hydrogeomorphic Approach to Assessing Wetland Functions of Northwest Gulf of Mexico Tidal Fringe Wetlands, by D.J. Shafer, B. Herczeg, D.W. Moulton, A. Sipocz, K. Jaynes, L.P. Rozas, C.P. Onuf, and W. Miller

A Regional Guidebook for Applying the Hydrogeomorphic Approach to Assessing Wetland Functions of Low-Gradient Riverine Wetlands in Western Tennessee, by T.C. Wilder and T.H. Roberts

A Regional Guidebook for Applying the Hydrogeomorphic Approach to Assessing Wetland Functions of Intermontane Prairie Pothole Wetlands in the Northern Rocky Mountains, by F.R. Hauer, B.J. Cook, M.C. Gilbert, E.J. Clairain, Jr., and R.D. Smith

May $2002 \quad$ Hydroacoustic Evaluation of Fish Passage Through Bonneville Dam in 2000, by G.R. Ploskey, C.R. Schilt, M.E. Hanks, J.R. Skalski, W.T. Nagy, P.N. Johnson, D.S. Patterson, J. Kim, and L.R. Lawrence
ADA403904

ADA401048

ADA401202

ADA402421

ADA402514

ADA402419

ADA402422 


\begin{tabular}{|c|c|c|c|}
\hline ERDC/EL TR-02-9 & May 2002 & $\begin{array}{l}\text { A Regional Guidebook for Applying the } \\
\text { Hydrogeomorphic Approach to Assessing } \\
\text { Wetland Functions of Wet Pine Flats on } \\
\text { Mineral Soils in the Atlantic and Gulf } \\
\text { Coastal Plains, by R.D. Rheinhardt, M.C. } \\
\text { Rheinhardt, and M.M. Brinson }\end{array}$ & ADA403165 \\
\hline ERDC/EL TR-02-10 & May 2002 & $\begin{array}{l}\text { Environmental Fate and Transport Process } \\
\text { Descriptors for Explosives, by J.M. Brannon } \\
\text { and J.C. Pennington }\end{array}$ & ADA403162 \\
\hline ERDC/EL TR-02-11 & Jun 2002 & $\begin{array}{l}\text { Review of USACE-Generated Efficacy and } \\
\text { Dissipation Data for the Aquatic Herbicide } \\
\text { Formulations Aquathol }{ }^{\circledR} \text { and Hydrothol } \circledast \text {, } \\
\text { by S.L. Sprecher, K.D.Getsinger, and J. } \\
\text { Sharp }\end{array}$ & ADA403770 \\
\hline ERDC/EL TR-02-12 & Jun 2002 & $\begin{array}{l}\text { Evaluation of Manufactured Soil Using } \\
\text { Dredged Material from Confined Placement } \\
\text { Facilities in Mobile, Alabama. Phase 1: } \\
\text { Greenhouse Bench-Scale Test, by T.C. } \\
\text { Sturgis, C.R. Lee, H.C. Banks, Jr., K. } \\
\text { Johnson, J.P. Langan, S.I. Rees, and C. } \\
\text { Dyess }\end{array}$ & ADA403483 \\
\hline ERDC/EL TR-02-13 & Jun 2002 & $\begin{array}{l}\text { Mussels Associated With Floodplain } \\
\text { Channels Connected to the Apalachicola } \\
\text { River, by B.S. Payne and A.C. Miller }\end{array}$ & ADA403666 \\
\hline ERDC/EL TR-02-14 & Jun 2002 & $\begin{array}{l}\text { Managing for Ethnic Diversity: Recreation } \\
\text { Facility and Service Modification for Ethnic } \\
\text { Minority Visitors, by R.A. Dunn }\end{array}$ & ADA403992 \\
\hline ERDC/EL TR-02-15 & Jul 2002 & $\begin{array}{l}\text { Hydroacoustic Evaluation of a Prototype } \\
\text { Surface Collector and In-Turbine Screens at } \\
\text { Bonneville Dam Powerhouse } 1 \text { in } 2000 \text {, by } \\
\text { G.R. Ploskey, C.R. Schilt, M.E. Hanks, J.R. } \\
\text { Skalski, W.T. Nagy, P.N. Johnson, D.S. } \\
\text { Patterson, J. Kim, and L.R. Lawrence }\end{array}$ & ADA403912 \\
\hline ERDC/EL TR-02-16 & Jul 2002 & $\begin{array}{l}\text { Tri-Service Site Characterization and } \\
\text { Analysis Penetrometer System Validation of } \\
\text { the Membrane Interface Probe, by K.F. } \\
\text { Myers, W.M. Davis, and J. Costanza }\end{array}$ & ADA403916 \\
\hline ERDC/EL TR-02-17 & Jul 2002 & $\begin{array}{l}\text { Field Evaluation of Hopper Dredge Overflow } \\
\text { for the Delaware River, by J.L. Miller, M.R. } \\
\text { Palermo, and T.W. Groff }\end{array}$ & ADA405645 \\
\hline
\end{tabular}


ERDC/EL TR-02-18 Jul 2002

ERDC/EL TR-02-19 Jul 2002

ERDC/EL TR-02-20 Aug 2002

ERDC/EL TR-02-21 Aug 2002

ERDC/EL TR-02-22

Aug 2002

ERDC/EL TR-02-23 S Sep 2002

ERDC/EL TR-02-24 Sep 2002

ERDC/EL TR-02-25 Sep 2002

ERDC/EL TR-02-26
Sediment Extraction Using Deposit-Feeder Gut Fluids: A Potential Rapid Tool for Assessing Bioaccumulation Potential of Sediment-Associated Contaminants, by D.P. Weston, R.N. Millward, L.M. Mayer, I. Voparil, and G.R. Lotufo

A Regional Guidebook for Applying the Hydrogeomorphic Approach to Assessing Wetland Functions of Flats Wetlands in the Everglades, by C.V. Noble, R. Evans, M. McGuire, K. Trott, M. Davis, and E.J. Clairain, Jr.

Developing a "Regionalized" Version of the Corps of Engineers Wetlands Delineation Manual: Issues and Recommendations, by J.S. Wakeley

A Regional Guidebook for Applying the Hydrogeomorphic Approach to Assessing the Wetland Functions of Riverine Floodplains in the Northern Rocky Mountains, by F.R. Hauer, B.J. Cook, M.C. Gilbert, E.J. Clairiain, Jr., and R.D. Smith

UV-VIS Spectroscopy of 2,4,6-

Trinitrotoluene-Hydroxide Reaction, by D.R. Felt, S.L. Larson, and E.J. Valente

Dissolution Kinetics of High Explosive Compounds (TNX, RDX, HMX), by J.C. Lynch

Management of Eurasian Watermilfoil in Houghton Lake, Michigan: Workshop Summary, by K.D. Getsinger, A.G. Poovey, W.F. James, R.M. Stewart, M.J. Grodowitz, M.J. Maceina, and R.M. Newman

Analysis of GEM-3 Data from the Advanced UXO Detection/Discrimination Technology Demonstration - U.S. Army Jefferson Proving Ground, Madison, Indiana, by R.A. Goodson, H.H. Bennett, Jr., T.A. DeMoss, D.M. Cargile, J.C. Morgan, and M.P. Fields

Vapor-Phase Transport of Explosives Compounds in Soils, by R. Ravikrishna, S.L. Yost, C.B. Price, C.A. Hayes, K.T. Valsaraj, and J.M. Brannon
ADA412729

ADA407663

ADA408324

ADA404026

ADA405650

ADA407773

ADA407776

ADA407985 


\begin{tabular}{|c|c|c|c|}
\hline ERDC/EL TR-02-27 & Sep 2002 & $\begin{array}{l}\text { Compilation of Physical and Chemical } \\
\text { Properties and Toxicity Benchmarks for } \\
\text { Military Range Compounds (CD-ROM), by M. } \\
\text { Zakikhani, M.S. Dortch, and J.A. Gerald }\end{array}$ & ADM001438 \\
\hline ERDC/EL TR-02-28 & Sep 2002 & $\begin{array}{l}\text { GIS-Assisted Spatial Data Management for } \\
\text { Corps of Engineers Real Estate Activities: } \\
\text { Spatial Data Conversion Options, by L.P. } \\
\text { Dove }\end{array}$ & ADA409099 \\
\hline ERDC/EL TR-02-29 & Sep 2002 & $\begin{array}{l}\text { User's Manual for NAVEFF Navigation } \\
\text { Effects Model, by S. Bourne }\end{array}$ & ADA408165 \\
\hline ERDC/EL TR-02-30 & Sep 2002 & $\begin{array}{l}\text { Advanced Digital Processing of Echo } \\
\text { Sounder Signals for Characterization of Very } \\
\text { Dense Submersed Aquatic Vegetation, by } \\
\text { B.M. Sabol, J. Burczynski, and J. Hoffman }\end{array}$ & ADA408960 \\
\hline ERDC/EL TR-02-31 & Sep 2002 & $\begin{array}{l}\text { Freshwater Mussels in the Lower Ohio River } \\
\text { in Relation to the Olmsted Locks and Dam } \\
\text { Project: Update Through } 2001 \text { Studies, by } \\
\text { B.S. Payne and A.C. Miller }\end{array}$ & ADA408113 \\
\hline ERDC/EL TR-02-32 & Sep 2002 & $\begin{array}{l}\text { Effects of Increased Commercial Navigation } \\
\text { Traffic on Freshwater Mussels in the Upper } \\
\text { Mississippi River: Ten-Year Evaluation, by } \\
\text { A.C. Miller and B.S. Payne }\end{array}$ & ADA408166 \\
\hline ERDC/EL TR-02-33 & Sep 2002 & $\begin{array}{l}\text { Tree Canopy Characterization for EO-1 } \\
\text { Reflective and Thermal Infrared Validation } \\
\text { Studies: Rochester, New York, by J.R. } \\
\text { Ballard, Jr., and J.A. Smith }\end{array}$ & ADA408688 \\
\hline ERDC/EL TR-02-34 & Sep 2002 & $\begin{array}{l}\text { Effects of Channel Modification and Flow } \\
\text { Augmentation on Freshwater Mussels in the } \\
\text { Bayou Meto Area, Arkansas, by A.C. Miller } \\
\text { and B.S. Payne }\end{array}$ & ADA408108 \\
\hline ERDC/EL TR-02-35 & Oct 2002 & $\begin{array}{l}\text { Treatability Study for Biologically Active } \\
\text { Zone Enhancement (BAZE) for In Situ RDX } \\
\text { Degradation in Groundwater, by A. H. Wani, } \\
\text { B.R. O'Neal, J.L. Davis, and L.D. Hansen }\end{array}$ & ADA408128 \\
\hline ERDC/EL TR-02-36 & Oct 2002 & $\begin{array}{l}\text { Evaluation of Dredged Material Disposal } \\
\text { and Management for Appomattox River } \\
\text { Federal Navigation Channel, Petersburg, } \\
\text { Virginia. Phases I and II - Environmental and } \\
\text { Engineering Studies, by R. Wade, R.A. Price, } \\
\text { J.W. Simmers, C. Price, M.R. Palermo, and } \\
\text { A.B. Gibson }\end{array}$ & ADA408172 \\
\hline
\end{tabular}


ERDC/EL TR-02-37 Oct 2002

ERDC/EL TR-02-38 Oct 2002

ERDC/EL TR-02-39 Nov 2002

ERDC/EL TR-02-40

Dec 2002

ERDC/EL TR-03-1 Jan 2003

ERDC/EL TR-03-2 Jan 2003

ERDC/EL TR-03-3 Jan 2003

ERDC/EL TR-03-4

Apr 2003

ERDC/EL TR-03-5 Jun 2003

ERDC/EL TR-03-6
Jul 2003

Federal Integrated Biotreatment Research

ADA408792

Consortium (FIBRC): Flask to Field Initiative, by J.W. Talley, R. Bajpai, R. Conway, D.E.

Averett, J.L. Davis, D.R. Felt, and C.C.

Nestler, editors

Soil Separation Mobile Treatment Plant

ADA408188

Demonstration, Bayport Confined Disposal

Facility, Green Bay, Wisconsin, by T.J. Olin-

Estes, S.E. Bailey, D.W. Bowman, and D.L.

Brandon

Use of Whole-Lake Fluridone Treatments to Selectively Control Eurasian Watermilfoil in Burr Pond and Lake Hortonia, Vermont, by K.D. Getsinger, R.M. Smart, J.D. Madsen, A.S. Way, C.S. Owens, H.A. Crosson, and A.J. Burns

Conceptual Methods for Generation of Urban Terrain Data for Military Operations in Urban Terrain (MOUT), by C.D. Hahn, L.S. Bunch, and J.R. Ballard, Jr.

Evaluation of Dredged Material Proposed for Disposal at Island, Nearshore, or Upland Confined Disposal Facilities - Testing Manual, by U.S. Army Corps of Engineers

Immobilization of 2,4- and 2,6-

ADA410821 Dinitrotoluenes in Soils and Compost, by J.C. Pennington, K.A. Thorn, C.A. Hayes, B.E. Porter, and K.R. Kennedy

A Regional Guidebook for Applying the Hydrogeomorphic Approach to Assessing Wetland Functions of Low-Gradient, Blackwater Riverine Wetlands in Peninsular Florida, by C. Uranowski, Z. Lin, M.

DelCharco, C. Huegel, J. Garcia, I. Bartsch, M.S. Flannery, S.J. Miller, J. Bacheler, and W. Ainslie

Effects of Riprap on Riverine and Riparian Ecosystems, by J.C. Fischenich

Panama Lakes Water Quality Modeling Study, by B.W. Bunch, B.E. Johnson, and M.S. Sarruff

A Simulation Model for Growth of the Submersed Aquatic Macrophyte Sago

ADA422448

ADA410988

ADA408831 . 


\begin{tabular}{|c|c|c|c|}
\hline ERDC/EL TR-03-7 & Jul 2003 & $\begin{array}{l}\text { Beneficial Use of Dredged Bedrock in the } \\
\text { New York/New Jersey Harbor, by J. } \\
\text { Banslaben, J.C. Cox, and R.J. Will }\end{array}$ & ADA416503 \\
\hline 1ERDC/EL TR-03-8 & Aug 2003 & $\begin{array}{l}\text { Verification and Validation of the Advanced } \\
\text { Hornet TopAttack Model (Version 2.0) With } \\
\text { Data From Dynamic Flight Test (AP4), Fort } \\
\text { Devens, Massachusetts, 14-22 November } \\
\text { 2002, by J.R. Ballard, Jr., H.H. Bennett, Jr., } \\
\text { and B.M. Sabol }\end{array}$ & ADB292274 \\
\hline 1ERDC/EL TR-03-9 & Aug 2003 & $\begin{array}{l}\text { Advanced Hornet Sublet Simulation Model } \\
\text { TopAttack (Version 2.0), by J.R. Ballard, Jr., } \\
\text { and B.M. Sabol }\end{array}$ & ADB292272 \\
\hline ERDC/EL TR-03-10 & Aug 2003 & $\begin{array}{l}\text { Invasion of Eurasian Watermilfoil in Lakes } \\
\text { of the Western Upper Peninsula, Michigan, } \\
\text { by J.G. Skogerboe, A.G. Poovey, K.D. } \\
\text { Getsinger, and G. Kudray }\end{array}$ & ADA417368 \\
\hline ERDC/EL TR-03-11 & Aug 2003 & $\begin{array}{l}\text { Biologically Active Zone Enhancement } \\
\text { (BAZE) Supplemental Study: Mass Balance } \\
\text { of RDX Biotransformation and Influence of } \\
\text { Aquifer Temperature on RDX } \\
\text { Biodegradation in Groundwater, by A.H. } \\
\text { Wani, D.R. Felt, and J.L. Davis }\end{array}$ & ADA417367 \\
\hline ERDC/EL TR-03-12 & Aug 2003 & $\begin{array}{l}\text { Economic Impacts of Recreation Activities } \\
\text { at Oregon Coastal and River Ports, by W.H. } \\
\text { Chang and R.S. Jackson }\end{array}$ & ADA417770 \\
\hline ERDC/EL TR-03-13 & Aug 2003 & $\begin{array}{l}\text { Using Terminal Services to Serve Geospatial } \\
\text { Software and Data Resources of Corps } \\
\text { Project Offices, by M.R. Graves }\end{array}$ & ADA417623 \\
\hline ERDC/EL TR-03-14 & Sep 2003 & $\begin{array}{l}\text { Response of Wild Rice to Selected Aquatic } \\
\text { Herbicides, by L.S. Nelson, C.S. Owens, and } \\
\text { K.D. Getsinger }\end{array}$ & ADA417366 \\
\hline ERDC/EL TR-03-15 & Sep 2003 & $\begin{array}{l}\text { Lime Treatment of 2,4,6-Trinitrotoluene } \\
\text { Contaminated Soils: Proof of Concept } \\
\text { Study, by L.D. Hansen, S.L. Larson, J.L. } \\
\text { Davis, J.M. Cullinane, C.C. Nestler, and D.R. } \\
\text { Felt }\end{array}$ & ADA417818 \\
\hline 1ERDC/EL TR-03-16 & Sep 2003 & $\begin{array}{l}\text { Description, Verification, and Validation of a } \\
\text { Laser Profilometer Simulation Model for the } \\
\text { Advanced Hornet Sublet Sensor, by B.M. } \\
\text { Sabol, J.R. Ballard, Jr., and T.A. DeMoss }\end{array}$ & ADB293068 \\
\hline
\end{tabular}

1 Limited distribution; see Preface. 


$\begin{array}{lll}\text { ERDC/EL TR-03-17 } & \text { Sep 2003 } & \begin{array}{l}\text { Influence of Ubiquitous Electron Acceptors } \\ \text { on In Situ Anaerobic Biotransformation of } \\ \text { RDX in Groundwater, by A.H. Wani and J.L. } \\ \text { Davis }\end{array} \\ & & \begin{array}{l}\text { Possible Impact of Lake Seminole Hydrilla } \\ \text { by the Introduced Leaf-Mining Fly Hydrellia } \\ \text { pakistanae, by M.J. Grodowitz, A.F. } \\ \text { Cofrancesco, R.M. Stewart, J. Madsen, and } \\ \text { D. Morgan }\end{array}\end{array}$

ERDC/EL TR-03-19 Sep $2003 \quad$ Topical Lime Treatment for Containment of Source Zone Energetics Contamination, by

ADA417846 M.C. Brooks, J.L. Davis, S.L. Larson, D.R. Felt, and C.C. Nestler

ERDC/EL TR-03-20 Sep $2003 \quad$ Chemical Stabilization of Lead in Small Arms Firing Range Soils, by B.A. Tardy, R.M. Bricka, and S.L. Larson

ERDC/EL TR-03-21 Dec 2003

Recreation Visitor Spending Profiles and Economic Benefit to Corps of Engineers Projects, by W.H. Chang, D.B. Propst, D.J. Stynes, and R.S. Jackson

ERDC/EL TR-03-22 ～Dec 2003

Potential for Predation by Fishes to Impact Zebra Mussels Dreissena polymorpha: Insight from Bioenergetics Models, by M.A. Eggleton, S. Miranda, and J.P. Kirk

ERDC/EL TR-04-1 Mar 2004

Advanced UXO Detection/Discrimination

ADA422173 Technology Demonstration - Kaho'olawe Hawaii, by D.M. Cargile, H.H. Bennett, R.A. Goodson, T.A. DeMoss, and E.R. Cespedes

ERDC/EL TR-04-2 May 2004

Risk Characterization for Future Training Scenarios at the Massachusetts Military Reservation (MMR), by M. Zakikhani, M.S. Dortch, S. Coakley, and M. Hawkins

ERDC/EL TR-04-3 May 2004

A Regional Guidebook for Applying The Hydrogeomorphic Approach to Assessing Wetland Functions of Depressional Wetlands in Peninsular, Florida, by C.V. Noble, R. Evans, M. McGuire, K. Trott, M. Davis, and E.J. Clairain, Jr.

ERDC/EL TR-04-4 May 2004

A Regional Guidebook for Applying the Hydrogeomorphic Approach to Assessing Wetland Functions of Rainwater Basin Depressional Wetlands in Nebraska, by R.G. Stutheit, M.C. Gilbert, P.M. Whited, and K.L. Lawrence

ADA417946

ADA418373

ADA420574

ADA422134

ADA424684

ADA425115

ADA425490 


\begin{tabular}{|c|c|c|c|}
\hline ERDC/EL TR-04-5 & May 2004 & $\begin{array}{l}\text { Aquatic Vegetation Restoration in Cooper } \\
\text { Lake, Texas: A Case Study, by G.O. Dick, } \\
\text { R.M. Smart, and J.K. Smith }\end{array}$ & ADA424771 \\
\hline ERDC/EL TR-04-6 & May 2004 & $\begin{array}{l}\text { Aquatic Vegetation Restoration in El Dorado } \\
\text { Lake, Kansas: A Case Study, by G.O. Dick } \\
\text { and R.M. Smart }\end{array}$ & ADA424736 \\
\hline ERDC/EL TR-04-7 & May 2004 & $\begin{array}{l}\text { Aquatic Vegetation Restoration in Arcadia } \\
\text { Lake, Oklahoma: A Case Study, by G.O. } \\
\text { Dick, R.M. Smart, and E.R. Gilliland }\end{array}$ & ADA424448 \\
\hline ERDC/EL TR-04-8 & Jun 2004 & $\begin{array}{l}\text { Water-Quality Changes During Cycle Tests at } \\
\text { Aquifer Storage Recovery (ASR) Systems of } \\
\text { South Florida, by J.E. Mirecki }\end{array}$ & ADA425211 \\
\hline ERDC/EL TR-04-9 & Jun 2004 & $\begin{array}{l}\text { Efficacy of AVAST!@Fluridone Formulation } \\
\text { Against Eurasian Watermilfoil and } \\
\text { Nontarget Submersed Plants, by A.G. } \\
\text { Poovey, J.G. Skogerboe, and K.D. Getsinger }\end{array}$ & ADA425349 \\
\hline ERDC/EL TR-04-10 & Jun 2004 & $\begin{array}{l}\text { Guidance and Lessons Learned from } \\
\text { Monitoring Completed Navigation Projects, } \\
\text { Compiled by L.Z. Hales and D.L. Richey }\end{array}$ & ADA425317 \\
\hline ERDC/EL TR-04-11 & Jul 2004 & $\begin{array}{l}\text { Evaluation of Thorium-232 Distribution at } \\
\text { Kirtland Air Force Base, Defense Nuclear } \\
\text { Weapons School, Training Site 4, by S.L. } \\
\text { Larson, J.H. Ballard, A.J. Bednar, M.G. } \\
\text { Shettlemore, J.C. Morgan, M.P. Fields, C. } \\
\text { Christodoulatos, and R. Manis }\end{array}$ & ADA425881 \\
\hline ERDC/EL TR-04-12 & Aug 2004 & $\begin{array}{l}\text { Three-Dimensional Eutrophication Model of } \\
\text { Lake Washington, Washington State, by C.F. } \\
\text { Cerco, M.R. Noel, and S. Kim }\end{array}$ & ADA427041 \\
\hline ERDC/EL TR-04-13 & Aug 2004 & $\begin{array}{l}\text { Three-Dimensional Eutrophication Model of } \\
\text { the Lower St. John River, Florida, by D.H. } \\
\text { Tillman, C.F. Cerco, M.R. Noel, J.L. Martin, } \\
\text { and J. Hamrick }\end{array}$ & ADA427528 \\
\hline ERDC/EL TR-04-14 & Sep 2004 & $\begin{array}{l}\text { A Simulation Model on the Competition for } \\
\text { Light of Meadow-forming and Canopy- } \\
\text { forming Aquatic Macrophytes at High and } \\
\text { Low Nutrient Availability, by E.P.H. Best, G.A. } \\
\text { Kiker, and W.A. Boyd }\end{array}$ & ADA428026 \\
\hline ERDC/EL TR-04-15 & Sep 2004 & $\begin{array}{l}\text { Topical Application of Phosphate } \\
\text { Amendments to Lead-Contaminated Small } \\
\text { Arms Firing Range Soils, by S. Larson, B. } \\
\text { Tardy, M. Beverly, A. Hearn, M. Thompson, } \\
\text { and G. Williams }\end{array}$ & ADA428037 \\
\hline
\end{tabular}




\begin{tabular}{|c|c|c|c|}
\hline ERDC/EL TR-04-16 & Sep 2004 & $\begin{array}{l}\text { A Regional Guidebook for Applying the } \\
\text { Hydrogeomorphic Approach to Assessing } \\
\text { Wetland Functions of Forested Wetlands in } \\
\text { the Delta Region of Arkansas, Lower } \\
\text { Mississippi River Alluvial Valley, by C.V. } \\
\text { Klimas, E.O. Murray, J. Pagan, H. Langston, } \\
\text { and T. Foti }\end{array}$ & ADA428098 \\
\hline ERDC/EL TR-04-17 & Sep 2004 & $\begin{array}{l}\text { Xenon Spectral Gamma Penetrometer } \\
\text { Probe Characterization and Calibration, by } \\
\text { J.H. Ballard, C.A. Sparrow, and J.C. Morgan }\end{array}$ & ADA428245 \\
\hline ERDC/EL TR-04-18 & Oct 2004 & $\begin{array}{l}\text { Toxicity and Metabolites of } 2,4,6- \\
\text { Trinitrotoluene (TNT) in Plants and Worms } \\
\text { from Exposure to Aged Soil, by E.P.H. Best, } \\
\text { H.E. Tatem, K.N. Geter, M.L. Wells, and B.K. } \\
\text { Lane }\end{array}$ & ADA428035 \\
\hline ERDC/EL TR-04-19 & Sep 2004 & $\begin{array}{l}\text { Exploration of the Potential for } \\
\text { Phytoremediation of Lead-Based-Paint- } \\
\text { Contaminated Soil at Fort Lewis, WA, by } \\
\text { E.P.H. Best, K.N. Geter, and S.L. Larson }\end{array}$ & ADA428023 \\
\hline ERDC/EL TR-05-1 & Jan 2005 & $\begin{array}{l}\text { Aquatic Plant Assessments for Spring Creek } \\
\text { Low-Dose Fluridone Injection Treatment: } \\
\text { Year-of-Treatment and 2-Year Post- } \\
\text { Treatment Findings, by R.M. Stewart, A.S. } \\
\text { Way, C.S. Owens, and D.M. Morgan }\end{array}$ & ADA430443 \\
\hline ERDC/EL TR-05-2 & Jan 2005 & $\begin{array}{l}\text { Invasive Animal Species in Marine and } \\
\text { Estuarine Environments: Biology and } \\
\text { Ecology, by G.L. Ray }\end{array}$ & ADA430308 \\
\hline ERDC/EL TR-05-3 & Feb 2005 & $\begin{array}{l}\text { A Computational Tool for Simulating Plane } \\
\text { Wave Reflectance from Layered Lossy } \\
\text { Media, by J.O. Curtis }\end{array}$ & ADA431408 \\
\hline ERDC/EL TR-05-4 & Mar 2005 & $\begin{array}{l}\text { Update to the Propagation and } \\
\text { Establishment of Aquatic Plants Handbook, } \\
\text { by R.M. Smart, G.O. Dick, and J.R. Snow }\end{array}$ & ADA433366 \\
\hline ERDC/EL TR-05-5 & Aug 2005 & $\begin{array}{l}\text { Electromagnetic Power Attenuation in Soils, } \\
\text { by J.O. Curtis }\end{array}$ & ADA437109 \\
\hline ERDC/EL TR-05-6 & Apr 2005 & $\begin{array}{l}\text { A Survey of the Invasive Aquatic and } \\
\text { Riparian Plants of the Low Rio Grande, by } \\
\text { C.S. Owens, M.J. Grodowitz, and F. Nibling }\end{array}$ & ADA433828 \\
\hline ERDC/EL TR-05-7 & Jun 2005 & $\begin{array}{l}\text { Evaluation of Wanapum Dam Bypass } \\
\text { Configurations for Outmigrating Juvenile } \\
\text { Salmon Using Virtual Fish: Numerical Fish } \\
\text { Surrogate (NFS) Analysis, by R.A. Goodwin, } \\
\text { J.M. Nestler, J.J. Anderson, J. Kim, and T. } \\
\text { Toney }\end{array}$ & ADA434239 \\
\hline
\end{tabular}


ERDC/EL TR-05-8 Jul 2005

ERDC/EL TR-05-9 Aug 2005

ERDC/EL TR-05-10 Aug 2005

ERDC/EL TR-05-11 Aug 2005

ERDC/EL TR-05-12

Aug 2005

ERDC/EL TR-05-13 Sep 2005

ERDC/EL TR-05-14 Sep 2005

ERDC/EL TR-05-15

Sep 2005

ERDC/EL TR-05-16

Dec 2005
Dredging Effects on Eelgrass (Zostera marina) Distribution in a New England Small Boat Harbor, by B. Sabol, D. Shafer, and E. Lord

Use of a High-Resolution 3D Laser Scanner for Minefield Surface Modeling and Terrain Characterization: Temperate Region, by S.S. Jackson and M.J. Bishop

Electrolytic Transformation of Hexahydro1,3,5-Trinitro-1,3,5-Triazine (RDX) and 2,4,6-Trinitrotoluene (TNT) in Aqueous Solutions, by A.H. Wani, B.R. O'Neal, D.M. Gilbert, D.B. Gent, and J.L. Davis

Risk Characterization for Future Training Scenarios at the Massachusetts Military Reservation (MMR), Final Results, by M. Zakikhani, M.S. Dortch, J.A. Gerald, and M.S. Hawkins

A Regional Guidebook for Applying the Hydrogeomorphic Approach to Assessing Wetland Functions of Forested Wetlands in the West Gulf Coastal Plain Region of Arkansas, by C.V. Klimas, E.O. Murray, J. Pagan, H. Langston, and T. Foti

Emerging Concepts for Integrating Human and Environmental Water Needs in River Basin Management, by G. Petts, and R. Kennedy

A Review of Field Technologies for LongTerm Monitoring of Ordnance-Related Compounds in Groundwater, by D.K. MacMillan, and D.E. Splichal

Pre-Construction Biogeochemical Analysis of Mercury in Wetlands Bordering the Hamilton Army Airfield Wetlands Restoration Site: Part 3, by E.P.H. Best, H.L. Fredrickson, H. Hintelmann, O. Clarisse, B. Dimock, G.R. Lotufo, W.A. Boyd, and G.A. Kiker
ADA438020

ADA438210

ADA437953

ADA439867

ADA438474

ADA438156

ADA439456

ADA439941

Data Gap Analysis and Database Expansion ADA443236 of Parameters for Munitions Constitutents, by M. Dortch, M. Zakikhani, J. Furey, R. Meyer, S. Fant, J. Gerald, M. Qasim, H. Fredrickson, P. Honea, H. Bausem, K. Walker, and M. Johnson 


\begin{tabular}{|c|c|c|c|}
\hline ERDC/EL TR-06-1 & Jan 2006 & $\begin{array}{l}\text { Demonstration Applications of ARAMS for } \\
\text { Aquatic and Terrestrial Ecological Risk } \\
\text { Assessment, by M. Zakikhani, D.L. Brandon, } \\
\text { M.S. Dortch, and J.A. Gerald }\end{array}$ & ADA442778 \\
\hline ERDC/EL TR-06-2 & Feb 2006 & $\begin{array}{l}\text { 1-D Thermal Modeling of Layered Materials } \\
\text { in Outdoor Environments, by J.O. Curtis }\end{array}$ & ADA444090 \\
\hline ERDC/EL TR-06-3 & Feb 2006 & $\begin{array}{l}\text { Interim Regional Supplement to the Corps } \\
\text { of Engineers Wetland Delineation Manual: } \\
\text { Alaska Region, by U.S. Army Corps of } \\
\text { Engineers }\end{array}$ & ADA444797 \\
\hline ERDC/EL TR-06-4 & May 2006 & $\begin{array}{l}\text { A Regional Guidebook for Applying the } \\
\text { Hydrogeomorphic Approach to Assessing } \\
\text { Wetland Functions of Depressional } \\
\text { Wetlands in the Upper Des Plaines River } \\
\text { Basin, by J.P. Lin }\end{array}$ & ADA447845 \\
\hline ERDC/EL TR-06-5 & May 2006 & $\begin{array}{l}\text { A Regional Guidebook for Applying the } \\
\text { Hydrogeomorphic Approach to Assessing } \\
\text { Wetland Functions of Prairie Potholes, by } \\
\text { M.C. Gilbert, P.M. Whited, E.J. Clairain, Jr., } \\
\text { and R.D. Smith }\end{array}$ & ADA449172 \\
\hline ERDC/EL TR-06-6 & May 2006 & $\begin{array}{l}\text { Evaluation of Multi-Sensor Unexploded } \\
\text { Ordnance (UXO) Detection System } \\
\text { Developed by Geophysical Solutions, by } \\
\text { H.H. Bennett, Jr., and M.P. Fields }\end{array}$ & ADA454563 \\
\hline ERDC/EL TR-06-7 & Jun 2006 & $\begin{array}{l}\text { Environmental Transport and Fate Process } \\
\text { Descriptors for Propellant Compounds, by } \\
\text { J.E. Mirecki, B. Porter, and C.A. Weiss, Jr. }\end{array}$ & ADA450743 \\
\hline ERDC/EL TR-06-8 & Sep 2006 & $\begin{array}{l}\text { Geochemical Models of Water-Quality } \\
\text { Changes During Aquifer Storage Recovery } \\
\text { (ASR) Cycle Tests, Phase 1: Geochemical } \\
\text { Models Using Existing Data, by J.E. Mirecki }\end{array}$ & ADA455772 \\
\hline ERDC/EL TR-06-9 & Oct 2006 & $\begin{array}{l}\text { Contaminant Fate/Transport Modeling for } \\
\text { Environmental Consequences of IPET Task } \\
\text { 9, by M.S. Dortch, M. Zakikhani, and S.C. } \\
\text { Kim }\end{array}$ & ADA456261 \\
\hline ERDC/EL TR-06-10 & Sep 2006 & $\begin{array}{l}\text { Summary of First Regional Workshop on } \\
\text { Dredging, Beach Nourishment, and Birds on } \\
\text { the South Atlantic Coast, by M.P. Guilfoyle, } \\
\text { R.A. Fischer, D.N. Pashley, and C.A. Lott, } \\
\text { Editors }\end{array}$ & ADA456266 \\
\hline ERDC/EL TR-06-11 & Oct 2006 & $\begin{array}{l}\text { Aberdeen Proving Ground GEM-3 Data } \\
\text { Collection, by H.H. Bennett, Jr., T.A. DeMoss, } \\
\text { M.P. Fields, R.A. Goodson, and J.C. Morgan }\end{array}$ & \\
\hline
\end{tabular}


ERDC/EL TR-06-12 Nov 2006

ERDC/EL TR-06-13 Nov 2006

ERDC/EL TR-06-14 Dec 2006

ERDC/EL TR-06-15

Dec 2006

ERDC/EL TR-06-16

Dec 2006

ERDC/EL TR-06-17

Dec 2006

ERDC/EL TR-07-1 Jan 2007

ERDC/EL TR-07-2 Apr 2007

ERDC/EL TR-07-3 Jun 2007
Development of a Distributed Nutrient Sub- ADA457715 Model (NSM Version 1.0) for Watersheds Kinetic Process Descriptions, by B. Johnson and T. Gerald

Distribution and Abundance of the Interior Population of the Least Tern (Sternula Antillarum), 2005: A Review of the First Complete Range-Wide Survey in the Context of Historic and Ongoing Monitoring Efforts, by C.A. Lott

A Regional Guidebook for Conducting Functional Assessments of Wetland and Riparian Forests in the Ouachita Mountains and Crowley's Ridge Regions of Arkansas, by C.V. Klimas, E.O. Murray, H. Langston, T. Witsell, T. Foti, and R. Holbrook

Summary of a Regional Workshop on

ADA459288 Monitoring Programs for the Interior Least Tern (Sternula Antillarum) - Tulsa, Oklahoma, 15-16 November 2005, by C.A. Lott and D.N. Pashley

Interim Regional Supplement to the Corps of Engineers Wetland Delineation Manual: Arid West Region, by U.S. Army Corps of Engineers

Linkage of a Physically Based Distributed Watershed Model and a Dynamic Plant Growth Model, by B.E. Johnson and C.L. Coldren

Documentation of a One-Dimensional,

ADA460827 Time-Varying Contaminant Transport and Fate Model for Streams, by S. Fant and M.S. Dortch

A Regional Guidebook for Applying the ADA470971 Hydrogeomorphic Approach to Assessing the Functions of Tidal Fringe Wetlands Along the Mississippi and Alabama Gulf Coast, by D.J. Shafer, T.H. Roberts, M.S. Peterson, and K. Schmid

Engineering Considerations for Hydroxide Treatment of Training Ranges, by J.L. Davis,

ADA470974 S.L. Larson, D.R. Felt, C.C. Nestler, W.A. Martin, L. Riggs, E.J. Valente, and G.R. Bishop

ADA460380

ADA461457 


\begin{tabular}{|c|c|c|c|}
\hline ERDC/EL TR-07-4 & Jun 2007 & $\begin{array}{l}\text { Effect of Treatment pH on the End Products } \\
\text { of the Alkaline Hydrolysis of TNT and RDX, } \\
\text { by J.L. Davis, C.C. Nestler, D.R. Felt, and S.L. } \\
\text { Larson }\end{array}$ & ADA469989 \\
\hline ERDC/EL TR-07-5 & Jun 2007 & $\begin{array}{l}\text { Grenade Range Management Using Lime } \\
\text { for Metals Immobilization and Explosives } \\
\text { Transformation: Treatability Study, by S.L. } \\
\text { Larson, J.L. Davis, W.A. Martin, D.R. Felt, } \\
\text { C.C. Nestler, D.L. Brandon, G. Fabian, and } \\
\text { G. O'Connor }\end{array}$ & ADA469458 \\
\hline ERDC/EL TR-07-6 & Jun 2007 & $\begin{array}{l}\text { Treatment and Management of Closed or } \\
\text { Inactive Small Arms Firing Ranges, by S.L. } \\
\text { Larson, C.L. Teeter, V.F. Medina, and W.A. } \\
\text { Martin }\end{array}$ & ADA471052 \\
\hline ERDC/EL TR-07-7 & Jun 2007 & $\begin{array}{l}\text { Environmental Consequences of the Failure } \\
\text { of the New Orleans Levee System During } \\
\text { Hurricane Katrina: Microbiological Analysis, } \\
\text { by H. Fredrickson, J. Furey, C. Foote, and M. } \\
\text { Richmond }\end{array}$ & ADA469456 \\
\hline ERDC/EL TR-07-8 & Jul 2007 & $\begin{array}{l}\text { Transfer of Invasive Species Associated with } \\
\text { the Movement of Military Equipment and } \\
\text { Personnel, by A.F. Cofrancesco, Jr., D.R. } \\
\text { Reaves, and D.E. Averett }\end{array}$ & ADA470914 \\
\hline ERDC/EL TR-07-9 & Aug 2007 & $\begin{array}{l}\text { Regional Guidebook for Applying the } \\
\text { Hydrogeomorphic Approach to Assessing } \\
\text { the Functions of Headwater Slope Wetlands } \\
\text { on the Mississippi and Alabama Coastal } \\
\text { Plans, by C.V. Noble, J.S. Wakeley, T.H. } \\
\text { Roberts, and C. Henderson }\end{array}$ & ADA471734 \\
\hline ERDC/EL TR-07-10 & Aug 2007 & $\begin{array}{l}\text { Development of a Distributed Source } \\
\text { Containment Transport, Transformation, } \\
\text { and Fate (CTT\&F) Sub-Model for Military } \\
\text { Installations, by B. Johnson and Z. Zhang }\end{array}$ & ADA471753 \\
\hline ERDC/EL TR-07-11 & Aug 2007 & $\begin{array}{l}\text { Potential Use of Native and Naturalized } \\
\text { Insect Herbivores and Fungal Pathogens of } \\
\text { Aquatic and Wetland Plants, by J.E. } \\
\text { Freedman, M.J. Grodowitz, R. Swindle, and } \\
\text { J.G. Nachtrieb }\end{array}$ & ADA471715 \\
\hline ERDC/EL TR-07-12 & Aug 2007 & $\begin{array}{l}\text { A Wetland Restoration Spatial Decision } \\
\text { Support System for the Mississippi Gulf } \\
\text { Coast, by J.P. Lin and B.A. Kleiss }\end{array}$ & ADA471738 \\
\hline ERDC/EL TR-07-13 & Aug 2007 & $\begin{array}{l}\text { Environmental Evaluation of Dust Stabilizer } \\
\text { Products, by J. Steevens, B. Suedel, A. } \\
\text { Gibson, A. Kennedy, W. Blackburn, D. } \\
\text { Splichal, and J.T. Pierce }\end{array}$ & ADA471771 \\
\hline
\end{tabular}




\begin{tabular}{|c|c|c|c|}
\hline ERDC/EL TR-07-14 & Sep 2007 & $\begin{array}{l}\text { Carbon-Flow-Based Modeling of } \\
\text { Ecophysiological Processes and Biomass } \\
\text { Dynamics of Submersed Aquatic Plants, by } \\
\text { E.P.H. Best and W.A. Boyd }\end{array}$ & ADA471732 \\
\hline ERDC/EL TR-07-15 & Sep 2007 & $\begin{array}{l}\text { 3D Laser Scanner Data Collection, by L. } \\
\text { Peyman Dove, S.S. Jackson, J.R. Ballard, } \\
\text { T.E. Berry, and M.E. Lord }\end{array}$ & ADA471752 \\
\hline ERDC/EL TR-07-16 & Sep 2007 & $\begin{array}{l}\text { Photochemical Degradation of Composition } \\
\text { B and Its Components, by J.C. Pennington, } \\
\text { K.A. Thorn, L.G. Cox, } \\
\text { D.K. MacMillan, S. Yost, and R.D. Laubscher }\end{array}$ & ADA472238 \\
\hline ERDC/EL TR-07-17 & Sep 2007 & $\begin{array}{l}\text { Root Zone Microbial Communities and } \\
\text { Restoration of Plant Communities in Owens } \\
\text { Valley, California - Phase 1, by H. } \\
\text { Fredrickson, J. Furey, D. Price, C. Foote, and } \\
\text { M. Richmond }\end{array}$ & ADA472131 \\
\hline ERDC/EL TR-07-18 & Sep 2007 & $\begin{array}{l}\text { Chemical Remediation of an Ordnance- } \\
\text { Related Compound: The Alkaline Hydrolysis } \\
\text { of CL-20, by L. Santiago, D.R. Felt, and J.L. } \\
\text { Davis }\end{array}$ & ADA472130 \\
\hline ERDC/EL TR-07-19 & Sep 2007 & $\begin{array}{l}\text { Evaluation of Lime and Persulfate } \\
\text { Treatment for Mixed Contaminant Soil from } \\
\text { Plum Brook Ordnance Works (Sandusky, } \\
\text { OH), by V.F. Medina, S.A. Waisner, A.B. } \\
\text { Morrow, C.C. Nestler, and M. Jones }\end{array}$ & ADA472129 \\
\hline ERDC/EL TR-07-20 & Sep 2007 & $\begin{array}{l}\text { Application of a Water Quality Model to } \\
\text { Mississippi Sound to Evaluate Impacts of } \\
\text { Freshwater Diversions, by M.S. Dortch, M. } \\
\text { Zakikhani, M.R. Noel, and S.C. Kim }\end{array}$ & ADA472574 \\
\hline ERDC/EL TR-07-21 & Sep 2007 & $\begin{array}{l}\text { Pre-Construction Biogeochemical Analysis } \\
\text { of Mercury in Wetlands Bordering the } \\
\text { Hamilton Army Airfield (HAAF) Wetlands } \\
\text { Restoration Site: Part 2, by E.P.H. Best, H.L. } \\
\text { Fredrickson, H. Hintelmann, O. Clarisse, B. } \\
\text { Dimock, C.H. Lutz, G.R. Lotufo, R.N. } \\
\text { Millward, A.J. Bednar, and J.S. Furey }\end{array}$ & ADA472540 \\
\hline ERDC/EL TR-07-22 & Oct 2007 & $\begin{array}{l}\text { Assessment of the Population Status of the } \\
\text { Gray Bat (Myotis grisescens): Status Review, } \\
\text { DoD Initiatives, and Results of a Multi- } \\
\text { Agency Effort to Survey Wintering } \\
\text { Populations at Major Hibernacula, 2005- } \\
\text { 2007, by C.O. Martin }\end{array}$ & ADA473199 \\
\hline
\end{tabular}


1ERDC/EL TR-07-23 Sep 2007

ERDC/EL TR-07-24 Sep 2007

ERDC/EL TR-07-25 Nov 2007

ERDC-EL TR-07-26 Nov 2007

ERDC/EL TR-07-27 Nov 2007

ERDC/EL TR-07-28 Nov 2007

ERDC/EL TR-08-1 Jan 2008

ERDC/EL TR-08-2 Jan 2008

ERDC/EL TR-03-3 Jan 2008

ERDC/EL TR-08-4
Feb 2008
An Explosive Source Term Characterization and Fate Model for Firing Ranges, by J.A. Gerald, M.S. Dortch, T.K. Gerald, and J.M. Brannon

Regional Supplement to the Corps of Engineers Wetland Delineation Manual: Alaska Region (Version 2.0), by U.S. Army Corps of Engineers

Potential for Biodegradation of the Alkaline Hydrolysis End Products of TNT and RDX, by D.R. Felt, C.C. Nestler, J.L. Davis, and S.L. Larson

Summary of Second Regional Workshop on Dredging, Beach Nourishment, and Birds on the North Atlantic Coast, by M.P. Guilfoyle, R.A. Fischer, D.N. Pashley, and C.A. Lott, Editors

Summary of Available Guidance and Best Practices for Determining Suitability of Dredged Material for Beneficial Uses, by D.L. Brandon and R.A. Price

Yuma Proving Ground GEM-3-E Data Collection, by H.H. Bennett, Jr., T.A. DeMoss, M.P. Fields, R.A. Goodson, C.D. Hahn, and J.C. Morgan

Economic Impacts from Spending by Community Dock Owners at Table Rock Lake, by B.L. Amsden, D.B. Propst, W.H. Chang, R. Kasul, L. Lee, and K. Perales

Economic Impacts from Spending by Community Dock Owners at Pomme de Terre Lake, by D.B. Propst, B.L. Amsden, W.H. Chang, R. Kasul, L. Lee, and K. Perales

Economic Impacts from Spending by Community Dock Owners at Rough River Lake, by K. Perales, D.B. Propst, B.L. Amsden, W.H. Chang, R. Kasul, and L. Lee

The Four Rs of Environmental Dredging: Resuspension, Release, Residual, and Risk, by T.S. Bridges, S. Ells, D. Hayes, D. Mount, S.C. Nadeau, M.R. Palermo, C. Patmont, and P. Schroeder ADA475751

ADB333396

ADA473823

ADA474432

ADA474358

ADA474463

ADA474759

ADA475832

ADA477867

\footnotetext{
1 Limited distribution; see Preface.
} 


\begin{tabular}{|c|c|c|c|}
\hline ERDC/EL TR-08-5 & Feb 2008 & $\begin{array}{l}\text { Economic Impacts from Spending by } \\
\text { Marina Slip Reenter at Raystown Lake, by } \\
\text { B.L. Amsden, W.H. Chang, R. Kasul, L. Lee, } \\
\text { K. Perales, and D.B. Propst }\end{array}$ & ADA477873 \\
\hline ERDC/EL TR-08-6 & Feb 2008 & $\begin{array}{l}\text { Economic Impacts from Spending by } \\
\text { Marina Slip Renters and Private Dock } \\
\text { Owners at Lake Sidney Lanier, by D.B. } \\
\text { Propst, W.H. Chang, R. Kasul, L. Lee, K. } \\
\text { Perales, and B.L. Amsden }\end{array}$ & ADA477869 \\
\hline ERDC/EL TR-08-7 & Feb 2008 & $\begin{array}{l}\text { Economic Impacts from Spending by } \\
\text { Marina Slip Renters at Harry S. Truman } \\
\text { Dam and Reservoir, by D.B. Propst, B.L. } \\
\text { Amsden, W.H. Chang, R. Kasul, L. Lee, and } \\
\text { K. Perales }\end{array}$ & ADA477875 \\
\hline ERDC/EL TR-08-8 & Feb 2008 & $\begin{array}{l}\text { Economic Impacts from Spending by Private } \\
\text { Dock Owners at Lake Barkley, by R. Kasul, } \\
\text { L. Lee, K. Perales, D.B. Propst, B.L. Amsden, } \\
\text { and W.H. Chang }\end{array}$ & ADA477884 \\
\hline ERDC/EL TR-08-9 & Feb 2008 & $\begin{array}{l}\text { Multi-Sensor Systems Development for UXO } \\
\text { Detection and Discrimination: Man-Portable } \\
\text { Dual Magnetic/Electromagnetic Induction } \\
\text { Sensor, by D. Wright, H.H. Bennett, Jr., L. } \\
\text { Peyman Dove, J.H. Ballard, M.P. Fields, T.A. } \\
\text { Demoss, and D.K. Butler }\end{array}$ & ADA477585 \\
\hline ERDC/EL TR-08-10 & Mar 2008 & $\begin{array}{l}\text { Use of Coupled Eutrophication and Network } \\
\text { Models for Examination of Fisheries and } \\
\text { Eutrophication Processes, by C.F. Cerco and } \\
\text { D.H. Tillman }\end{array}$ & ADA480933 \\
\hline ERDC/EL TR-08-11 & Mar 2008 & $\begin{array}{l}\text { Economic Impacts From Spending by } \\
\text { Private Dock Owners at Hartwell Lake, by L. } \\
\text { Lee, K. Perales, D. Propst, B.L. Amsden, } \\
\text { W.H. Chang, and R. Kasul }\end{array}$ & ADA480308 \\
\hline ERDC/EL TR-08-12 & Mar 2008 & $\begin{array}{l}\text { Interim Regional Supplement to the Corps } \\
\text { of Engineers Wetland Delineation Manual: } \\
\text { Great Plans Region, by U.S. Army Corps of } \\
\text { Engineers }\end{array}$ & ADA479138 \\
\hline ERDC/EL TR-08-13 & Apr 2008 & $\begin{array}{l}\text { Interim Regional Supplement to the Corps } \\
\text { of Engineers Wetland Delineation Manual: } \\
\text { Western Mountains, Valleys, and Coast } \\
\text { Region, by U.S. Army Corps of Engineers }\end{array}$ & ADA480936 \\
\hline ERDC/EL TR-08-14 & Apr 2008 & $\begin{array}{l}\text { Using a Multi-Scale Assessment of } \\
\text { Watershed Integrity (MAWI) Approach for } \\
\text { Establishing Baseline Conditions in } \\
\text { Watersheds, by J.P. Lin, R.D. Smith, and B.A. } \\
\text { Kleiss }\end{array}$ & ADA479141 \\
\hline
\end{tabular}




\begin{tabular}{|c|c|c|c|}
\hline ERDC/EL TR-08-15 & Apr 2008 & $\begin{array}{l}\text { Multi-Sensor Systems Development for UXO } \\
\text { Detection and Discrimination: Hand-Held } \\
\text { Dual Magnetic/Electromagnetic Induction } \\
\text { Sensor, by D. Wright, H.H. Bennett, Jr., L. } \\
\text { Peyman Dove, and D.K. Butler }\end{array}$ & ADA480572 \\
\hline $\begin{array}{l}\text { ERDC/EL TR-08-16 } \\
\text { REV. }\end{array}$ & Jul 2008 & $\begin{array}{l}\text { Dredged Material Analysis Tools: } \\
\text { Performance of Acute and Chronic } \\
\text { Sediment Toxicity Methods, by J. Steevens, } \\
\text { A. Kennedy, D. Farrar, C. McNemar, M.R. } \\
\text { Reiss, R.K. Kropp, J. Doi, and T. Bridges }\end{array}$ & ADA485346 \\
\hline ERDC/EL TR-08-17 & Apr 2008 & $\begin{array}{l}\text { Investigations of the Controlling Factors for } \\
\text { Air Emissions Associated With the Dredging } \\
\text { of Indiana Harbor and Canal (IHC) and CDF } \\
\text { Operations, by L.J. Thibodeaux, K.T. } \\
\text { Valsaraj, } \\
\text { R. Ravikrishna, K. Fountain, and C.L. Price }\end{array}$ & ADA482382 \\
\hline ERDC/EL TR-08-18 & Jun 2008 & $\begin{array}{l}\text { Gulf Sturgeon Movements In and Near the } \\
\text { Mississippi River Gulf Outlet, by J.P. Kirk }\end{array}$ & ADA482945 \\
\hline ERDC/EL TR-08-19 & Jun 2008 & $\begin{array}{l}\text { Evaluation of Potential Impacts of the Lake } \\
\text { Maurepas Diversion Project to Gulf and } \\
\text { Pallid Sturgeon, by J.P. Kirk, K.J. Killgore, } \\
\text { and J.J. Hoover }\end{array}$ & ADA482913 \\
\hline ERDC/EL TR-08-20 & Jun 2008 & $\begin{array}{l}\text { Large-Scale Submerged Aquatic Vegetation } \\
\text { Restoration in Chesapeake Bay: Status } \\
\text { Report, 2003-2006, by D.J. Shafer and P. } \\
\text { Bergstrom }\end{array}$ & ADA484194 \\
\hline ERDC/EL TR-08-21 & Jun 2008 & $\begin{array}{l}\text { Potential for Introduction of Invasive } \\
\text { Species into Louisiana from Illinois River } \\
\text { Dredged Material, by J.F. Shearer }\end{array}$ & ADA484148 \\
\hline ERDC/EL TR-08-22 & Aug 2008 & $\begin{array}{l}\text { Development of a Biological Control } \\
\text { Program for Eurasian Watermilfoil } \\
\text { (Myriophyllum spicatum), by M.J.W. Cock, } \\
\text { H.L. Hinz, G. Grosskopf, and P. Häfliger }\end{array}$ & ADA485741 \\
\hline ERDC/EL TR-08-23 & Aug 2008 & $\begin{array}{l}\text { A Regional Guidebook for Conducting } \\
\text { Functional Assessments of Forested } \\
\text { Wetlands in the Arkansas Valley Region of } \\
\text { Arkansas, by C.V. Klimas, E.O. Murray, H. } \\
\text { Langston, J. Pagan, T. Witsell, and T. Foti }\end{array}$ & ADA486605 \\
\hline
\end{tabular}




\begin{tabular}{|c|c|c|c|}
\hline ERDC/EL TR-08-24 & Sep 2008 & $\begin{array}{l}\text { Grenade Range Management Using Lime } \\
\text { for Dual Role of Metals Immobilization and } \\
\text { Explosives Transformation: Field } \\
\text { Demonstration at Fort Jackson, SC, by S.L. } \\
\text { Larson, J.L. Davis, W.A. Martin, D.R. Felt, } \\
\text { C.C. Nestler, G. Fabian, G. O'Connor, G. } \\
\text { Zynda, and B. Johnson }\end{array}$ & ADA489029 \\
\hline ERDC/EL TR-08-25 & Sep 2008 & $\begin{array}{l}\text { System-Wide Water Resources Program } \\
\text { Nutrient Sub-Model (SWWRP-NSM) Version } \\
\text { 1.1, by B.E. Johnson, T.K. Gerald, and Z. } \\
\text { Zhang }\end{array}$ & ADA486627 \\
\hline ERDC/EL TR-08-26 & Sep 2008 & $\begin{array}{l}\text { Effects of Hurricane Katrina-Related Levee } \\
\text { Failures on Wetland Sediments, by B. } \\
\text { Suedel, J. Steevens, A. Kennedy, and S. } \\
\text { Brasfield }\end{array}$ & ADA486575 \\
\hline ERDC/EL TR-08-27 & Sep 2008 & $\begin{array}{l}\text { Interim Regional Supplement to the Corps } \\
\text { of Engineers Wetland Delineation Manual: } \\
\text { Midwest Region, by U.S. Army Corps of } \\
\text { Engineers }\end{array}$ & ADA489744 \\
\hline ERDC/EL TR-08-28 & Sep 2008 & $\begin{array}{l}\text { Regional Supplement to the Corps of } \\
\text { Engineers Wetland Delineation Manual: } \\
\text { Arid West Region (Version 2.0), by U.S. Army } \\
\text { Corps of Engineers }\end{array}$ & ADA489704 \\
\hline ERDC/EL TR-08-29 & Sep 2008 & $\begin{array}{l}\text { Technical Guidelines for Environmental } \\
\text { Dredging of Contaminated Sediments, by } \\
\text { M.R. Palermo, P.R. Schroeder, T.J. Estes, } \\
\text { and N.R. Francingues }\end{array}$ & ADA488763 \\
\hline ERDC/EL TR-08-30 & Oct 2008 & $\begin{array}{l}\text { Interim Regional Supplement to the Corps } \\
\text { of Engineers Wetland Delineation Manual: } \\
\text { Atlantic and Gulf Coastal Plain Region, by } \\
\text { U.S. Army Corps of Engineers }\end{array}$ & \\
\hline ERDC/EL TR-08-31 & Sep 2008 & $\begin{array}{l}\text { A Regional Guidebook for Conducting } \\
\text { Functional Assessments of Forested } \\
\text { Wetlands and Riparian Areas in the Ozark } \\
\text { Mountains Region of Arkansas, by C.V. } \\
\text { Klimas, E.O. Murray, H. Langston, J. Pagan, } \\
\text { T. Witsell, and T. Foti }\end{array}$ & ADA489754 \\
\hline ERDC/EL TR-08-32 & Sep 2008 & $\begin{array}{l}\text { UXO Characterization: Comparing Cued } \\
\text { Surveying to Standard Detection and } \\
\text { Discrimination Approaches. Report } 1 \text { of } 9 \text {, } \\
\text { Summary Report, by S.D. Billings }\end{array}$ & \\
\hline
\end{tabular}




\begin{tabular}{|c|c|c|}
\hline ERDC/EL TR-08-33 & Sep 2008 & $\begin{array}{l}\text { UXO Characterization: Comparing Cued } \\
\text { Surveying to Standard Detection and } \\
\text { Discrimination Approaches. Report } 2 \text { of } 9 \text {, } \\
\text { Ground Penetrating Radar for Unexploded } \\
\text { Ordnance Characterization; Fundamentals, } \\
\text { by S.D. Billings and K. Kingdon }\end{array}$ \\
\hline ERDC/EL TR-08-34 & Sep 2008 & $\begin{array}{l}\text { UXO Characterization: Comparing Cued } \\
\text { Surveying to Standard Detection and } \\
\text { Discrimination Approaches. Report } 3 \text { of 9, } \\
\text { Test Stand Magnetic and Electromagnetic } \\
\text { Measurements of Unexploded Ordnance, by } \\
\text { S.D. Billings, L.R. Pasion, S. Walker, and C. } \\
\text { Pasion }\end{array}$ \\
\hline ERDC/EL TR-08-35 & Sep 2008 & $\begin{array}{l}\text { UXO Characterization: Comparing Cued } \\
\text { Surveying to Standard Detection and } \\
\text { Discrimination Approaches. Report } 4 \text { of 9, } \\
\text { UXO Characterization Using Magnetic, } \\
\text { Electromagnetic, and Ground Penetrating } \\
\text { Radar Measurements at the Sky Research } \\
\text { Test Plot, by S.D. Billings, L.R. Pasion, K. } \\
\text { Kingdon, and J. Jacobson }\end{array}$ \\
\hline ERDC/EL TR-08-36 & Sep 2008 & $\begin{array}{l}\text { UXO Characterization: Comparing Cued } \\
\text { Surveying to Standard Detection and } \\
\text { Discrimination Approaches. Report } 5 \text { of 9, } \\
\text { Optimized Data Collection Platforms and } \\
\text { Deployment Modes for Unexploded } \\
\text { Ordnance Characterization, by S.D. Billings, } \\
\text { L.R. Pasion, K. Kingdon, S. Walker, and J. } \\
\text { Jacobson }\end{array}$ \\
\hline ERDC/EL TR-08-37 & Sep 2008 & $\begin{array}{l}\text { UXO Characterization: Comparing Cued } \\
\text { Surveying to Standard Detection and } \\
\text { Discrimination Approaches. Report } 6 \text { of 9, } \\
\text { Advanced Electromagnetic and Magnetic } \\
\text { Methods for Discrimination of Unexploded } \\
\text { Ordnance, by S.D. Billings, L.R. Pasion, N. } \\
\text { Lhomme and L.P. Song }\end{array}$ \\
\hline ERDC/EL TR-08-38 & Dec 2008 & $\begin{array}{l}\text { UXO Characterization: Comparing Cued } \\
\text { Surveying to Standard Detection and } \\
\text { Discrimination Approaches. Report } 7 \text { of 9, } \\
\text { Marine Corps Base Camp Lejeune: UXO } \\
\text { Characterization Using Ground Penetrating } \\
\text { Radar, by K. Kingdon and S.D. Billings }\end{array}$ \\
\hline
\end{tabular}


ERDC/EL TR-08-39 Sep 2008

ERDC/EL TR-08-40 Sep 2008

ERDC/EL TR-08-41 Oct 2008

ERDC/EL TR-08-42

Dec 2008

ERDC/EL TR-09-1 Mar 2009

ERDC/EL TR-09-2 Jun 2009

ERDC/EL TR-09-3 Jun 2009

ERDC/EL TR-09-4 Jun 2009

ERDC/EL TR-09-5 Jun 2009
UXO Characterization: Comparing Cued Surveying to Standard Detection and Discrimination Approaches. Report 8 of 9, Marine Corps Base Camp Lejeune: UXO Characterization Using Magnetic and Electromagnetic Data, by S.D. Billings, L.R. Pasion, L. Beran, K. Kingdon, and J. Jacobson

UXO Characterization: Comparing Cued Surveying to Standard Detection and Discrimination Approaches. Report 9 of 9, Former Lowry Bombing and Gunnery Range; Comparison of UXO Characterization Performance Using Area and Cuedinterrogation Survey Modes, by S.D. Billings, L.R. Pasion, K. Kingdon, S. Walker, and J. Jacobson

Evaluation of Regulatory Guidelines to Minimize Impacts to Seagrasses from Single-family Residential Dock Structures in Florida and Puerto Rico, by D.J. Shafer, J. Karazsia, L. Carrubba, and C. Martin

Recreation Visitor Survey Analysis - South Atlantic Division, by J.B. Marcy, L. Lee, and C. Wibowo

ADA494529

Separation of Depleted Uranium From Soil, by S. Larson, J. Ballard, V. Medina, M.

Thompson, G. O'Connor, C. Griggs, and C. Nestler

Hand Grenade Residuals, by S.L. Larson, J.L. Davis, W.A. Martin, D.R. Felt, C.C. Nestler, G.L. Fabian, and G. O'Connor

ADA496696

Corbicula fluminea as a Bioaccumulation Indicator Species: A Case Study at the Columbia and Willamette Rivers, by T.J. Sherman, M.D. Siipola, R.A. Abney, D.B. Ebner, J. Clarke, G. Ray, and J.A. Steevens

ADA500888

ADA507673

Development of a River and Stream Water ADA500782 Quality Module, by B.E. Johnson and Z. Zhang

Flotation Analysis for Boat Docks on U.S. Army Corps of Engineers Projects, by J.B. Marcy and J. Johnson 


\begin{tabular}{|c|c|c|c|}
\hline ERDC/EL TR-09-6 & Jul 2009 & $\begin{array}{l}\text { Hydrogeomorphic Approach to Assessing } \\
\text { Wetland Functions: Guidelines for } \\
\text { Developing Regional Guidelines. Chapter 8, } \\
\text { Developing the Assessment Protocol, by C.V. } \\
\text { Noble and L. Carpenter }\end{array}$ & ADA508436 \\
\hline ERDC/EL TR-09-7 & Jun 2009 & $\begin{array}{l}\text { The Corps of Engineers and Prairie } \\
\text { Restoration: Synopsis of the First Corps } \\
\text { Prairie Workshop, Follow-up Actions, and } \\
\text { Thoughts on the Future of Prairie } \\
\text { Restoration and Management on } \\
\text { Operational Projects, by C.O. Martin, E.P. } \\
\text { Peloquin, P. Bailey, M.A. Watkins, and M.E. } \\
\text { Like }\end{array}$ & ADA507749 \\
\hline ERDC/EL TR-09-8 & Aug 2009 & $\begin{array}{l}\text { Interim Regional Supplement to the Corps } \\
\text { of Engineers Wetland Delineation Manual: } \\
\text { Caribbean Islands Region, by U.S. Army } \\
\text { Corps of Engineers }\end{array}$ & ADA508340 \\
\hline ERDC/EL TR-09-9 & Aug 2009 & $\begin{array}{l}\text { Recreating the } 1950 \text { 's Chesapeake Bay: } \\
\text { Use of a Network Model to Guide the } \\
\text { Application of a Eutrophication Model, by } \\
\text { D.H. Tillman and C.F. Cerco }\end{array}$ & ADA508342 \\
\hline ERDC/EL TR-09-10 & Aug 2009 & $\begin{array}{l}\text { Ecological Effects of Exotic and Native } \\
\text { Aquatic Vegetation, by R.M. Smart, G.O. } \\
\text { Dick, J.R. Snow, D.R. Honnell, D.H. Smith, } \\
\text { and J.K. Smith }\end{array}$ & ADA508423 \\
\hline ERDC/EL TR-09-11 & Aug 2009 & $\begin{array}{l}\text { Methods for Tier } 1 \text { Modeling within the } \\
\text { Training Range Environmental Evaluation } \\
\text { and Characterization System, by M.S. } \\
\text { Dortch, J.A. Gerald, and B.E. Johnson }\end{array}$ & ADA508357 \\
\hline ERDC/EL TR-09-12 & May 2009 & $\begin{array}{l}\text { Enhanced Tools and Techniques to Support } \\
\text { Debris Management in Disaster Response } \\
\text { Missions, by M. Channell, M.R. Graves, V.F. } \\
\text { Medina, A.B. Morrow, D. Brandon, and C.C. } \\
\text { Nestler }\end{array}$ & ADA508559 \\
\hline ERDC/EL TR-09-13 & Sep 2009 & $\begin{array}{l}\text { Distribution and Abundance of Piping } \\
\text { Plovers (Charadrius melodus) and Snowy } \\
\text { Plovers (Charadrius alexandrinus) on the } \\
\text { West Coast of Florida Before and After the } \\
\text { 2004/2005 Hurricane Seasons, by C.A. } \\
\text { Lott }\end{array}$ & ADA508641 \\
\hline ERDC/EL TR-09-14 & Sep 2009 & $\begin{array}{l}\text { Habitat Associations of Shoreline- } \\
\text { Dependent Birds in Barrier Island } \\
\text { Ecosystems During Fall Migration in Lee } \\
\text { County, Florida, by C.A. Lott, C.S. Ewell, Jr., } \\
\text { and K.L. Volansky }\end{array}$ & ADA542717 \\
\hline
\end{tabular}




\begin{tabular}{|c|c|c|c|}
\hline ERDC/EL TR-09-15 & Dec 2009 & $\begin{array}{l}\text { Florida Coastal Engineering and Bird } \\
\text { Conservation Geographic Information } \\
\text { System (GIS) Manual, by C.A. Lott, P.A. } \\
\text { Durkee, W.A. Gierhart, and P.P. Kelly }\end{array}$ & ADA537470 \\
\hline ERDC/EL TR-09-16 & Sep 2009 & $\begin{array}{l}\text { Unexploded Ordnance (UXO) Data Analysis } \\
\text { System (DAS), by R.A. Goodson, J.C. } \\
\text { Morgan, D.K. Butler, M.P. Fields, H.H. } \\
\text { Bennett, Jr., and T.A. DeMoss }\end{array}$ & ADA508382 \\
\hline ERDC/EL TR-09-17 & Nov 2009 & $\begin{array}{l}\text { Evaluation of Dredged Material Disposal } \\
\text { and Management for Upper James River } \\
\text { Federal Navigation Channel, Richmond, } \\
\text { Virginia: Modeling and Testing of } \\
\text { Contaminant Release for Expansion of } \\
\text { Richmond Deepwater Terminal, by R. Wade } \\
\text { and P. Schroeder }\end{array}$ & \\
\hline ERDC/EL TR-09-19 & Oct 2009 & $\begin{array}{l}\text { Interim Regional Supplement to the Corps } \\
\text { of Engineers Wetland Delineation Manual: } \\
\text { Northcentral and Northeast Region, by U.S. } \\
\text { Army Corps of Engineers }\end{array}$ & \\
\hline ERDC/EL TR-09-20 & Dec 2009 & $\begin{array}{l}\text { Legacy Chlordane in Soils from Housing } \\
\text { Areas Treated with Organochlorine } \\
\text { Pesticides, by V.F. Medina, S.A. Waisner, } \\
\text { A.B. Morrow, A.D. Butler, D.R. Johnson, A. } \\
\text { Harrison, and C.C. Nestler }\end{array}$ & ADA529312 \\
\hline ERDC/EL TR-09-21 & Dec 2009 & $\begin{array}{l}\text { Preconstruction Biogeochemical Analysis of } \\
\text { Mercury in Wetlands Bordering the } \\
\text { Hamilton Army Airfield (HAAF) Wetlands } \\
\text { Restoration Site: Part 3, by E.P.H. Best, H.L. } \\
\text { Fredrickson, H. Hintelmann, O. Clarisse, B. } \\
\text { Dimock, G.R. Lotufo, W.A. Boyd, and G.A. } \\
\text { Kiker }\end{array}$ & ADA529222 \\
\hline ERDC/EL TR-09-22 & Dec 2009 & $\begin{array}{l}\text { Comparison of DGT Sentinels and } \\
\text { Bioassays for Long-term Mercury TMDL } \\
\text { Monitoring under San Francisco Bay Field } \\
\text { Conditions, by E.P.H. Best, H. Hintelmann, } \\
\text { O. Clarisse, J.S. Furey, B. Greenfield, and B. } \\
\text { Dimock }\end{array}$ & \\
\hline ERDC/EL TR-10-1 & Mar 2010 & $\begin{array}{l}\text { Regional Supplement to the Corps of } \\
\text { Engineers Wetland Delineation Manual: } \\
\text { Great Plains Region (Version 2.0), by U.S. } \\
\text { Army Corps of Engineers }\end{array}$ & ADA529176 \\
\hline ERDC/EL TR-10-2 & May 2010 & $\begin{array}{l}\text { Determining Steady-state Tissue Residues } \\
\text { for Invertebrates in Contaminated } \\
\text { Sediment, by A.J. Kennedy, G.R. Lotufo, J.A. } \\
\text { Steevens, and T.S. Bridges }\end{array}$ & ADA529313 \\
\hline
\end{tabular}




\begin{tabular}{|c|c|c|c|}
\hline ERDC/EL TR-10-3 & May 2010 & $\begin{array}{l}\text { Regional Supplement to the Corps of } \\
\text { Engineers Wetland Delineation Manual: } \\
\text { Western Mountains, Valleys, and Coast } \\
\text { Region (Version 2.0), by U.S. Army Corps of } \\
\text { Engineers }\end{array}$ & ADA529168 \\
\hline ERDC/EL TR-10-4 & May 2010 & $\begin{array}{l}\text { Laboratory Studies and Preliminary } \\
\text { Evaluation of Destructive Technologies for } \\
\text { the Removal of RDX from the Water Waste } \\
\text { Stream of Holston Army Ammunition Plant, } \\
\text { by D.B. Gent, J.L. Johnson, D.R. Felt, G. } \\
\text { O'Connor and S.L. Larson }\end{array}$ & ADA522315 \\
\hline ERDC/EL TR-10-5 & May 2010 & $\begin{array}{l}\text { Implementing Herpetofaunal Inventory and } \\
\text { Monitoring Efforts on Corps of Engineers } \\
\text { Project Lands, by M.P. Guilfoyle }\end{array}$ & ADA529163 \\
\hline ERDC/EL TR-10-6 & May 2010 & $\begin{array}{l}\text { Interim Regional Supplement to the Corps } \\
\text { of Engineers Wetland Delineation Manual: } \\
\text { Hawal'I and Pacific Islands Region, by U.S. } \\
\text { Army Corps of Engineers }\end{array}$ & ADA529165 \\
\hline 1ERDC/EL TR-10-7 & May 2010 & $\begin{array}{l}\text { Characterization of RDX Load in the Holston } \\
\text { Army Ammunition Plant Dewatering System, } \\
\text { by D.B. Gent, J.L. Johnson, D.R. Felt, L. } \\
\text { Reynolds, G. O'Connor, and S.L. Larson }\end{array}$ & \\
\hline ERDC/EL TR-10-8 & Jun 2010 & $\begin{array}{l}\text { Laboratory Demonstration of Abiotic } \\
\text { Technologies for Removal of RDX from a } \\
\text { Process Waste Stream, by D.B. Gent, J.L. } \\
\text { Johnson, D.R. Felt, G. O'Connor, E. Holland, } \\
\text { S. May, and S.L. Larson }\end{array}$ & ADA529314 \\
\hline ERDC/EL TR-10-9 & Jul 2010 & $\begin{array}{l}\text { Interim Regional Supplement to the Corps } \\
\text { of Engineers Wetland Delineation Manual: } \\
\text { Eastern Mountains and Piedmont Region, } \\
\text { by U.S. Army Corps of Engineers }\end{array}$ & ADA529316 \\
\hline ERDC/EL TR-10-10 & Jun 2010 & $\begin{array}{l}\text { Topical Lime Application for the } \\
\text { Management of Munitions Constituents } \\
\text { Following Blow-in-Place Operations, by J.L. } \\
\text { Johnson, J.L. Davis, and C.C. Nestler }\end{array}$ & ADA536677 \\
\hline ERDC/EL TR-10-11 & Jul 2010 & $\begin{array}{l}\text { Operational Draft Regional Guidebook for } \\
\text { the Functional Assessment of High-gradient } \\
\text { Ephemeral and Intermittent Headwater } \\
\text { Streams in Western West Virginia and } \\
\text { Eastern Kentucky, by U.S. Army Corps of } \\
\text { Engineers }\end{array}$ & ADA525599 \\
\hline
\end{tabular}

1 Limited distribution; see Preface. 


\begin{tabular}{|c|c|c|c|}
\hline ERDC/EL TR-10-12 & Jul 2010 & $\begin{array}{l}\text { A New Nonmonetary Metric for Indicating } \\
\text { Environmental Benefits from Ecosystem } \\
\text { Restoration Projects of the U.S. Army Corps } \\
\text { of Engineers: Report 2, by R.A. Cole }\end{array}$ & ADA525570 \\
\hline ERDC/EL TR-10-13 & Jul 2010 & $\begin{array}{l}\text { Incidence and Management Costs of } \\
\text { Freshwater Aquatic Nuisance Species at } \\
\text { Projects Operated by the U.S. Army Corps of } \\
\text { Engineers, by R.A. Cole, P.F. Scodari, and } \\
\text { M.A. Franklin }\end{array}$ & ADA525578 \\
\hline ERDC/EL TR-10-14 & Jul 2010 & $\begin{array}{l}\text { Biodegradation of Perchlorate in Laboratory } \\
\text { Reactors Under Different Environmental } \\
\text { Conditions, by A.B. Morrow, V.F. Medina, } \\
\text { and B.A. Extine }\end{array}$ & ADA528090 \\
\hline ERDC/EL TR-10-15 & Aug 2010 & $\begin{array}{l}\text { Implementing Rapid Bioassessment } \\
\text { Protocols (RBP's) for Watershed Monitoring, } \\
\text { by M.D. Farr, M.D. Antwine, and B.S. Payne }\end{array}$ & ADA527531 \\
\hline ERDC/EL TR-10-16 & Aug 2010 & $\begin{array}{l}\text { Regional Supplement to the Corps of } \\
\text { Engineers Wetland Delineation Manual: } \\
\text { Midwest Region (Version 2.0), by U.S. Army } \\
\text { Corps of Engineers }\end{array}$ & ADA528100 \\
\hline ERDC/EL TR-10-17 & Oct 2010 & $\begin{array}{l}\text { A Regional Guidebook for Applying the } \\
\text { Hydrogeomorphic Approach to the } \\
\text { Functional Assessment of Forested } \\
\text { Wetlands in Alluvial Valleys of East Texas, by } \\
\text { H.M. Williams, A.J. Miller, R.S. McNamee, } \\
\text { and C.V. Klimas }\end{array}$ & ADA531871 \\
\hline ERDC/EL TR-10-18 & Nov 2010 & $\begin{array}{l}\text { Characterization of Park Visitors, Visitation } \\
\text { Levels, and Associated Economic Impacts } \\
\text { of Recreation at Bull Shoals, Norfork, and } \\
\text { Table Rock Lakes, by R. Kasul, D. Stynes, L. } \\
\text { Lee, W.H. Chang, R.S. Jackson, C. Wibowo, } \\
\text { S. Franco, and K. Perales }\end{array}$ & ADA532857 \\
\hline 1ERDC/EL TR-10-19 & Oct 2009 & $\begin{array}{l}\text { Proof-of-Concept Application of Tier } 1 \\
\text { Modeling Approach Within the Training } \\
\text { Range Environmental Evaluation and } \\
\text { Characterization System, by M.S. Dortch, } \\
\text { B.E. Johnson, and J.A Gerald }\end{array}$ & \\
\hline ERDC/EL TR-10-20 & Nov 2010 & $\begin{array}{l}\text { Regional Supplement to the Corps of } \\
\text { Engineers Wetland Delineation Manual: } \\
\text { Atlantic and Gulf Coastal Plain Region } \\
\text { (Version 2.0), by U.S. Army Corps of } \\
\text { Engineers }\end{array}$ & ADA533785 \\
\hline
\end{tabular}

1 Limited distribution; see Preface. 


\begin{tabular}{|c|c|c|c|}
\hline ERDC/EL TR-10-21 & Dec 2010 & $\begin{array}{l}\text { Environmental Habitat Conditions } \\
\text { Associated with Freshwater Dreissenids, by } \\
\text { M.D. Farr and B.S. Payne }\end{array}$ & ADA535120 \\
\hline ERDC/EL TR-10-22 & Dec 2010 & $\begin{array}{l}\text { Early Season Applications of Fluridone for } \\
\text { Control of Curlyleaf Pondweed, by A.G. } \\
\text { Poovey, L.M. Glomski, M.D. Netherland, and } \\
\text { J.G. Skogerboe }\end{array}$ & ADA537033 \\
\hline ERDC/EL TR-11-1 & Mar 2011 & $\begin{array}{l}\text { Mass Balance, Beneficial Use Products, and } \\
\text { Cost Comparisons of Four Sediment } \\
\text { Treatment Technologies Near } \\
\text { Commercialization, by T.J. Estes, V.S. Magar, } \\
\text { D.E. Averett, N.D. Soler, T.E. Myers, E.J. } \\
\text { Glisch and D.A. Acevedo }\end{array}$ & ADA539024 \\
\hline ERDC/EL TR-11-2 & Mar 2011 & $\begin{array}{l}\text { Methods for Tier } 2 \text { Modeling Within the } \\
\text { Training Range Environmental Evaluation } \\
\text { and Characterization System, by M.S. } \\
\text { Dortch, B.E. Johnson, Z. Zhang, and J.A. } \\
\text { Gerald }\end{array}$ & ADA538499 \\
\hline ERDC/EL TR-11-3 & Apr 2011 & $\begin{array}{l}\text { Chemical Degradation of PCBs in Alaskan } \\
\text { Soils, by S.A. Waisner, A.B. Morrow, C.C. } \\
\text { Nestler, C. Coyle, and V.F. Medina }\end{array}$ & ADA541875 \\
\hline ERDC/EL TR-11-4 & May 2011 & $\begin{array}{l}\text { Regional Supplement to the Corps of } \\
\text { Engineers Wetland Delineation Manual: } \\
\text { Caribbean Islands Region (Version 2.0), by } \\
\text { U.S. Army Corps of Engineers }\end{array}$ & ADA543979 \\
\hline ERDC/EL TR-11-5 & Jun 2011 & $\begin{array}{l}\text { Utilization of Herbicide } \\
\text { Concentration/Exposure Time Relationships } \\
\text { for Controlling Submersed Invasive Plants } \\
\text { on Lake Gaston, Virginia/North Carolina, by } \\
\text { K.D. Getsinger, A.G. Poovey, L. Glomski, J.G. } \\
\text { Slade, and R.J. Richardson }\end{array}$ & ADA544173 \\
\hline ERDC/EL TR-11-6 & Jul 2011 & $\begin{array}{l}\text { A Bibliography of Selected Literature on } \\
\text { Indirect Impacts Associated with Clean } \\
\text { Water Act Section } 404 \text { Permits, by T.C. } \\
\text { Wilder, W.M. Ford, and M.M. Perkins }\end{array}$ & ADA545318 \\
\hline ERDC/EL TR-11-7 & Jul 2011 & $\begin{array}{l}\text { Environmental Enhancements and } \\
\text { Navigation Infrastructure: A Study of } \\
\text { Existing Practices, Innovative Ideas, } \\
\text { Impediments, and Research Needs, by T.J. } \\
\text { Fredette, C.M. Foran, S.M. Brasfield, and } \\
\text { B.C. Suedel }\end{array}$ & ADA554943 \\
\hline
\end{tabular}




\begin{tabular}{|c|c|c|c|}
\hline ERDC/EL TR-11-8 & Aug 2011 & $\begin{array}{l}\text { Water Quality And Sediment Evaluation for } \\
\text { Inner Harbor Navigation Canal Lock } \\
\text { Replacement Project, New Orleans, } \\
\text { Louisiana, by G.R. Lotufo, T.J. Estes, P.R. } \\
\text { Schroeder, J.M. Corbino, E.J. Glisch, and } \\
\text { R.F. Mach }\end{array}$ & ADA547436 \\
\hline ERDC/EL TR-11-9 & Aug 2011 & $\begin{array}{l}\text { Evaluation of Metals Release from } \\
\text { Oxidation of Fly Ash during Dredging of the } \\
\text { Emory River, TN, by J.A. Steevens, A.J. } \\
\text { Bednar, M.A. Chappell, A.J. Kennedy, J.M. } \\
\text { Seiter, J.K. Stanley, and D.E. Averett }\end{array}$ & ADA549336 \\
\hline ERDC/EL TR-11-10 & Aug 2011 & $\begin{array}{l}\text { Proof-of-Concept Application of Tier } 2 \\
\text { Modeling Approach within the Training } \\
\text { Range Environmental Evaluation And } \\
\text { Characterization System, by M.S. Dortch, } \\
\text { B.E. Johnson, J.A. Gerald, Z. Zhang, and A.P. } \\
\text { Simmons }\end{array}$ & ADA548007 \\
\hline ERDC/EL TR-11-11 & Sep 2011 & $\begin{array}{l}\text { Regional Guidebook for Applying the } \\
\text { Hydrogeomorphic Approach to Assessing } \\
\text { the Functions of Headwater Slope Wetlands } \\
\text { on the South Carolina Coastal Plain, by C.V. } \\
\text { Noble, E.O. Murray, C.V. Klimas, and W. } \\
\text { Ainslie }\end{array}$ & ADA548927 \\
\hline ERDC/EL TR-11-12 & Sep 2011 & $\begin{array}{l}\text { A Regional Guidebook for Applying the } \\
\text { Hydrogeomorphic Approach to Assessing } \\
\text { Functions of Forested Wetlands in the Delta } \\
\text { Region of Arkansas, Lower Mississippi River } \\
\text { Alluvial Valley, Version 2.0, by C.V. Klimas, } \\
\text { E.O. Murray, J. Pagan, H. Langston, and T. } \\
\text { Foti }\end{array}$ & ADA550812 \\
\hline ERDC/EL TR-11-13 & Oct 2011 & $\begin{array}{l}\text { Remote Sensing for Inland Water Quality } \\
\text { Monitoring: A U.S. Army Corps of Engineers } \\
\text { Perspective, by M. Reif }\end{array}$ & ADA551404 \\
\hline ERDC/EL TR-11-14 & Oct 2011 & $\begin{array}{l}\text { Bayesian Networks for Modeling Dredging } \\
\text { Decisions, by M.T. Schultz, T.D. Borrowman, } \\
\text { and M.J. Small }\end{array}$ & ADA552536 \\
\hline ERDC/EL TR-11-15 & Oct 2011 & $\begin{array}{l}\text { Evaluation of Volatilization Potential for } \\
\text { Legacy Chlordane in Military Housing Area } \\
\text { Soils, by S.A. Waisner, V.F. Medina, M.A. } \\
\text { Jones, and C.C. Nestler }\end{array}$ & ADA552496 \\
\hline ERDC/EL TR-11-16 & Oct 2011 & $\begin{array}{l}\text { Management of Munitions Constituents in } \\
\text { Soil Using Alkaline Hydrolysis: A Guide for } \\
\text { Practitioners, by J.L. Johnson, D.R. Felt, W.A. } \\
\text { Martin, R. Britto, C.C. Nestler, and S.L. } \\
\text { Larson }\end{array}$ & ADA552790 \\
\hline
\end{tabular}




\begin{tabular}{|c|c|c|c|}
\hline ERDC/EL TR-11-17 & Dec 2011 & $\begin{array}{l}\text { Development of Methodology to Classify } \\
\text { Historical Panchromatic Aerial Photography: } \\
\text { Analysis of Landscape Features on Point Au } \\
\text { Fer Island, Louisiana - from } 1956 \text { to 2009: } \\
\text { A Case Study, by G.M. Suir, C.L. Saltus, J.B. } \\
\text { Johnston, and J.A. Barras }\end{array}$ & ADA554145 \\
\hline ERDC/EL TR-12-1 & Jan 2012 & $\begin{array}{l}\text { Regional Supplement to the Corps of } \\
\text { Engineers Wetland Delineation Manual: } \\
\text { Northcentral and Northeast Region (Version } \\
\text { 2.0), by U.S. Army Corps of Engineers }\end{array}$ & \\
\hline ERDC/EL TR-12-2 & Jan 2012 & $\begin{array}{l}\text { The Results of a Laboratory Feasibility } \\
\text { Study for the Biological Treatment of } \\
\text { Umatilla Groundwater, by V.F. Medina, H. } \\
\text { Knotek-Smith, D. Gent, and A. Morrow }\end{array}$ & ADA556012 \\
\hline 1ERDC/EL TR-12-3 & Jan 2012 & $\begin{array}{l}\text { Validation Applications of the Training } \\
\text { Range Environmental Evaluation and } \\
\text { Characterization System (TREECS } \\
\text { M.S. }) \text {, by } \\
\text { M.Sortch }\end{array}$ & \\
\hline ERDC/EL TR-12-4 & Jan 2012 & $\begin{array}{l}\text { Open Burn/Open Detonation (OBOD) Area } \\
\text { Management Using Lime For Explosives } \\
\text { Transformation and Metals Immobilization: } \\
\text { ESTCP Project Number ER-0742, by W.A. } \\
\text { Martin, D.R. Felt, S.L. Larson, G.L. Fabian, } \\
\text { and C.C. Nestler }\end{array}$ & ADA556181 \\
\hline ERDC/EL TR-12-5 & Feb 2012 & $\begin{array}{l}\text { Regional Supplement to the Corps of } \\
\text { Engineers Wetland Delineation Manual: } \\
\text { Hawai'l and Pacific Islands Region (Version } \\
\text { 2.0), by U.S. Army Corps of Engineers }\end{array}$ & \\
\hline ERDC/EL TR-12-6 & Mar 2012 & $\begin{array}{l}\text { Incorporation of Chemical Contaminants } \\
\text { into the Combined ICM/SEDZLJ Models, by } \\
\text { C.F. Cerco }\end{array}$ & ADA557329 \\
\hline ERDC/EL TR-12-7 & Mar 2012 & $\begin{array}{l}\text { Land And Forest Area Changes In The } \\
\text { Vicinity Of The Mississippi River Gulf Outlet, } \\
\text { Central Wetlands Region, 1935-2010, by } \\
\text { C.L. Saltus, G.M. Suir, and J.A. Barras }\end{array}$ & ADA558171 \\
\hline 1ERDC/EL TR-12-8 & Mar 2012 & $\begin{array}{l}\text { Alternative Treatment Options for Open } \\
\text { Burning of Explosive Waste at Holston Army } \\
\text { Ammunition Plant, by J.L. Johnson, D.B. } \\
\text { Gent, D.R. Felt, A.L. Thompson, S.L. Larson, } \\
\text { B. Smolinski, and G. O'Connor }\end{array}$ & \\
\hline
\end{tabular}


ERDC/EL TR-12-9 Apr 2012

ERDC/EL TR-12-10

Apr 2012

ERDC/EL TR-12-11

Apr 2012

ERDC/EL TR-12-12

ERDC/EL TR-12-13

ERDC/EL TR-12-14

ERDC/EL TR-12-15

Jul 2012

ERDC/EL TR-12-16

Aug 2012

ERDC/EL TR-12-17

May 2012

Jun 2012

Sep 2012
The Effect of Acid Neutralization on Analytical Results Produced from SW846 Method 8330 after the Alkaline Hydrolysis of Explosives in Soil, by S.L. Larson, D.R. Felt, S. Waisner, C.C. Nestler, C.G. Coyle, and V.F. Medina

Selective Control of Eurasian Watermilfoil in Houghton Lake, Michigan: 2002-2006, by C.S. Smith, K.D. Getsinger, A.G. Poovey, W.F. James, M.D. Netherland, R.M. Stewart, M.A. Heilman, S. McNaught, A. Groves, P. Tyning, and P. Hausler

User Guide for Applying the Training Range Environmental Evaluation and Characterization System (TREECS ${ }^{\mathrm{TM}}$ ), by J.A. Gerald, B.E. Johnson, and M.S. Dortch

Combining the ICM Eutrophication Model with the SEDZLJ Sediment Transport Model, by C.F. Cerco
ADA571678

ADA559623

ADA570210

ADA571751

ADA570374

ADA572122 
ERDC/EL TR-12-18 Aug 2012

ERDC/EL TR-12-19

ERDC/EL TR-12-20

ERDC/EL TR-12-21

ERDC/EL TR-12-22

ERDC/EL TR-12-23

REV.

ERDC/EL TR-12-24

ERDC/EL TR-12-25 for the Middle Rio Grande, Albuquerque, New Mexico: Model Documentation, by K.A. Burks-Copes and A.C. Webb
Aug 2012

Sep 2012

Jul 2013

Sep 2012

Potential Natural Vegetation of the Mississip
Alluvial Valley: Bayou Meto Basin, Arkansas,

Field Atlas, by C. Klimas, T. Foti, J. Pagan, and M. Williamson

Large-Scale Physical Separation of Depleted Uranium from Soil, by S.L. Larson, V.F. Medina, J. Ballard, C. Griggs, M. Wynter, D. Mackie, B. King, and C. Nestler

A Bosque Riparian Community Index Model

ADA572123

ADA571679

ADA570211

ADA566399

ADA571368

ADA568646

ADA565718

ADA565719

ADA565721

Ecological Modeling Guide for Ecosystem

EnviroFish, Version 1.0: User's Manual, by J.J. Hoover, D. Johnson, D. Johnson, G. Casper

Maintenance Lead Containment at Active Demonstration, by M. Wynter, S.L. Larson, W.A. Martin, C.S. Griggs, G. O'Connor, D.

Middle Rio Grande Bosque Ecosystem Restoration Feasibility Study Habitat Assessment Using Habitat Evaluation Documentation, by K.A. Burks-Copes and The Identification of Military Installations as Important Migratory Bird Stopover Sites and the Development of Bird Migration Forecast R.A. Fischer, M.P. Guilfoyle, J. Valente, S.A. Gauthreaux, Jr., C.G. Belser, D.V. Blaricom, J.W. Livingston, E. Cohen, and F.R. Moore

Mississippi Alluvial Valley: St. Francis Basin, Arkansas, Field Atlas, by C. Klimas, T. Foti, J. Pagan, and M. Williamson
ERDC/EL TR-12-26 


\begin{tabular}{|c|c|c|}
\hline ERDC/EL TR-12-27 & Sep 2012 & $\begin{array}{l}\text { Potential Natural Vegetation of the } \\
\text { Mississippi Alluvial Valley: Western } \\
\text { Lowlands, Arkansas, Field Atlas, by C. } \\
\text { Klimas, T. Foti, J. Pagan, E. Murray, and M. } \\
\text { Williamson }\end{array}$ \\
\hline ERDC/EL TR-12-28 & Sep 2012 & $\begin{array}{l}\text { Potential Natural Vegetation of the } \\
\text { Mississippi Alluvial Valley: Boeuf-Tensas } \\
\text { Basin, Arkansas, Field Atlas, by C. Klimas, T. } \\
\text { Foti, J. Pagan, M. Williamson, and R.D. } \\
\text { Smith }\end{array}$ \\
\hline ERDC/EL TR-12-29 & Sep 2012 & $\begin{array}{l}\text { Use of Activated Carbon to Control } \\
\text { Volatilization of Organic Contaminants from } \\
\text { the Indiana Harbor Confined Disposal } \\
\text { Facility, by T.E. Myers, C.B. Price, D.E. } \\
\text { Averett, and P.R. Schroeder }\end{array}$ \\
\hline ERDC/EL TR-12-30 & Dec 2012 & $\begin{array}{l}\text { Laboratory Study for Evaluating } \\
\text { Performance of Unit Processes to Treat the } \\
\text { Electrodialysis Reversal (EDR) Reject } \\
\text { Stream for the Proposed Fort Irwin Water } \\
\text { Treatment Plant, by V.F. Medina, S.A. } \\
\text { Waisner, J.L. Johnson, R. Wade, J. Mattei- } \\
\text { Sosa, and R. Brown }\end{array}$ \\
\hline
\end{tabular}

ERDC/EL TR-12-31 Dec 2012

ERDC/EL TR-12-32 Dec 2012

ERDC/EL TR-12-33 Dec 2012

ERDC/EL TR-13-1
Apr 2013
A Community-based Ecosystem Response Model for the Resacas (Oxbow Lakes) of the Lower Rio Grande: Model Documentation, by K.A. Burks-Copes and A.C. Webb

Preparing Inputs for New Applications of the TernCOLONY Simulation Model, by C.A. Lott, J.J. Valente, R.A. Fischer, and C.J.R. Sheppard

Identification of Microbial Gene Biomarkers for in situ RDX Biodegradation: Project ER1609, by F.H. Crocker, K.J. Indest, C.M. Jung, D.E. Hancock, M.E. Merritt, C. Florizone, H.P. Chen, G.R. Stewart, S. Zhu, N. Sukdeo, M.C. Fortin, S.J. Hallam, W.W. Mohn, L.D. Eltis, N.N. Perreault, J.S. Zhao, L. Paquet, A. Halasz, and J. Hawari

ADA569532

ADA568102

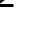

A Regional Guidebook for Applying the Hydrogeomorphic Approach to Assessing Wetland Functions of Forested Wetlands in Alluvial Valleys of the Coastal Plain of the Southeastern United States, by T.C. Wilder, R.D. Rheinhardt, and C.V. Noble
ADA575880

ADA583590 


\begin{tabular}{|c|c|c|c|}
\hline ERDC/EL TR-13-2 & Mar 2013 & $\begin{array}{l}\text { Development of Environmental Health } \\
\text { Criteria for Insensitive Munitions: Aquatic } \\
\text { Ecotoxicological Exposures Using 2,4- } \\
\text { Dinitroanisole, by A.J. Kennedy, C.D. } \\
\text { Lounds, N.L. Melby, J.G. Laird, B. Winstead, } \\
\text { S.M. Brasfield, and M.S. Johnson }\end{array}$ & ADA583153 \\
\hline ERDC/EL TR-13-3 & Mar 2013 & $\begin{array}{l}\text { Bayou Segnette Waterway Dredged Material } \\
\text { Placement Study Preliminary Assessment: } \\
\text { Summary of Findings and } \\
\text { Recommendations, by G.M. Suir, C.D. } \\
\text { Piercy, and J.B. Johnston }\end{array}$ & ADA583151 \\
\hline ERDC/EL TR-13-4 & Mar 2013 & $\begin{array}{l}\text { Science-based Framework for } \\
\text { Environmental Benefits Assessment, by J.C. } \\
\text { Fischenich, S.K. McKay, S.J. Miller, D. Price, } \\
\text { B. Pruitt, L. Skaggs, B. Suedel, and D. Tazik }\end{array}$ & ADA583092 \\
\hline ERDC/EL TR-13-5 & Apr 2013 & $\begin{array}{l}\text { Selective Control of Eurasian Watermilfoil } \\
\text { and Curlyleaf Pondweed in Noxon Rapids } \\
\text { Reservoir, Montana: Aquatic Herbicide } \\
\text { Evaluations, 2009-2010, by K.D. Getsinger, } \\
\text { J.G. Skogerboe, J.D. Madsen, R.M. Wersal, } \\
\text { J.J. Nawrocki, R.J. Richardson, and M.R. } \\
\text { Sterberg }\end{array}$ & ADA583088 \\
\hline ERDC/EL TR-13-6 & Jun 2013 & $\begin{array}{l}\text { Modeling Firing Range Best Management } \\
\text { Practices with TREECS }{ }^{T M} \text {, by M.S. Dortch, } \\
\text { B.E. Johnson, and J.A. Gerald }\end{array}$ & ADA582153 \\
\hline ERDC/EL TR-13-7 & Jun 2013 & $\begin{array}{l}\text { Two-Dimensional (2-D) Acoustic Fish } \\
\text { Tracking at River Mile 85, Sacramento } \\
\text { River, California, by P.T. Sandstrom, D.L. } \\
\text { Smith, and B. Mulvey }\end{array}$ & ADA583086 \\
\hline ERDC/EL TR-13-8 & Jun 2013 & $\begin{array}{l}\text { Summary Review of the Aquatic Toxicology } \\
\text { of Munitions Constituents, by G.R. Lotufo, } \\
\text { G. Rosen, W. Wild, and G. Carton }\end{array}$ & ADA583083 \\
\hline ERDC/EL TR-13-9 & Jun 2013 & $\begin{array}{l}\text { Propagation and Establishment of Native } \\
\text { Plants for Vegetative Restoration of Aquatic } \\
\text { Ecosystems, by G.O. Dick, R.M. Smart, and } \\
\text { L.L. Dodd }\end{array}$ & ADA582960 \\
\hline ERDC/EL TR-13-10 & Jun 2013 & $\begin{array}{l}\text { Characterization of Firing Range Soil from } \\
\text { Camp Edwards, MA, and the Efficacy of Acid } \\
\text { and Alkaline Hydrolysis for the Remediation } \\
\text { of M1 } 105 \mathrm{~mm} \text { M } 67 \text { Propellant, by D.B. } \\
\text { Gent, J.L. Johnson, and I.T. Osgerby }\end{array}$ & ADA583085 \\
\hline
\end{tabular}


ERDC/EL TR-13-11 Jun 2013

ERDC/EL TR-13-12 Jun 2013

ERDC/EL TR-13-13 Jul 2013

ERDC/EL TR-13-14 Jul 2013

ERDC/EL TR-13-15 Jul 2013

1ERDC/EL TR-13-16

Jul 2013

ERDC/EL TR-13-17 Aug 2013

ERDC/EL TR-13-18 Sep 2013

ERDC/EL TR-13-20 Nov 2013
Hydrogeomorphic (HGM) Approach to Assessing Wetland Functions: Guidelines for Developing Guidebooks (Version 2), by R.D. Smith, C.V. Noble, and J.F. Berkowitz

Regional Guidebook for Applying the Hydrogeomorphic Approach to Assessing the Functions of Flat and Seasonally Inundated Depression Wetlands on the Highland Rim, by C.V. Noble, T.H. Roberts, K.L. Morgan, A.J. Hill, V.S. Neary, and R.W. Cripps

Phytoplankton as Particles - A New Approach to Modeling Algal Blooms, by C.F. Cerco and M.R. Noel

A Regional Guidebook for Applying the Hydrogeomorphic Approach to Assessing Functions of Forested Wetlands in the Mississippi Alluvial Valley, by E.O. Murray and C.V. Klimas

Clear Creek Watershed Flood Risk Management Habitat Assessments Using Habitat Evaluation Procedures (HEP): Analyses, Results and Documentation, by K.A. Burks-Copes and A.C. Webb

The Evaluation and Treatment Technologies for Process Wastewater Resulting from IMX101 Production, by D.B. Gent, A. Thompson, S. Waisner, J.L. Johnson, B. Smolinski and G. O'Connor

Incorporating Ecosystem Goods and Services in Environmental Planning: A Literature Review of Definitions, Classification and Operational Approaches, by D.J. Tazik, J. Cushing, E. Murray, and L. Wainger

A Multi-Scale Approach to Assess and Restore Ecosystems in a Watershed Context, by R.D. Smith and C.V. Klimas

Evaluation of Treatment Technologies for Wastewater from Insensitive Munitions Production. Phase 1: Technology DownSelection, by D. Felt, J.L. Johnson, S. Larson, B. Hubbard, K. Henry, C. Nestler, and J.H. Ballard
ADA583904

ADA583076

ADA583082

ADA583077

ADA581179

ADA584398

ADA586174

ADA592972

\footnotetext{
1 Limited distribution; see Preface.
} 


\begin{tabular}{|c|c|c|c|}
\hline ERDC/EL TR-14-1 & Jan 2014 & $\begin{array}{l}\text { Taxonomic Evaluation of Cleveland Harbor } \\
\text { Lake Areas, by A.J. Kennedy, N.E. Harms, } \\
\text { and J.M. Miller }\end{array}$ & ADA592183 \\
\hline ERDC/EL TR-14-2 & Feb 2014 & $\begin{array}{l}\text { Hydrology Model Formulation within the } \\
\text { Training Range Environmental Evaluation } \\
\text { and Characterization System (TREECS }{ }^{\mathrm{TM}} \text { ), by } \\
\text { B.E. Johnson and M.S. Dortch }\end{array}$ & ADA597404 \\
\hline ERDC/EL TR-14-3 & Mar 2014 & $\begin{array}{l}\text { Characterization of Underwater Sounds } \\
\text { Produced by Trailing Suction Hopper } \\
\text { Dredges During Sand Mining and Pump-out } \\
\text { Operations, by K.J. Reine, D. Clarke, C. } \\
\text { Dickerson, and G. Wikel }\end{array}$ & ADA597877 \\
\hline ERDC/EL TR-14-4 & Mar 2014 & $\begin{array}{l}\text { Selective Control of Eurasian Watermilfoil } \\
\text { and Curlyleaf Pondweed in Noxon Rapids } \\
\text { Reservoir, Montana: Herbicide Small-Plot } \\
\text { Evaluations, 2010-2011, by K.D. Getsinger, } \\
\text { J.G. Skogerboe, R.M. Wersal, J.D. Madsen, } \\
\text { J.J. Nawrocki, R.J. Richardson, and M.R. } \\
\text { Sternberg }\end{array}$ & ADA601434 \\
\hline ERDC/EL TR-14-5 & Apr 2014 & $\begin{array}{l}\text { Cost Analysis of Remediation Systems for } \\
\text { Depleted Uranium, by J. Walters, J. Mackey, } \\
\text { K. Maki, R. Northcutt, J.V. Farr, W.A. Martin, } \\
\text { S.L. Larson, J.H. Ballard, and C. Nestler }\end{array}$ & ADA599275 \\
\hline ERDC/EL TR-14-6 & Apr 2014 & $\begin{array}{l}\text { Development of Landscape Metrics to } \\
\text { Support Process-Driven Ecological } \\
\text { Modeling, by M.K. Reif and T.M. Swannack }\end{array}$ & ADA599506 \\
\hline ERDC/EL TR-14-7 & Apr 2014 & $\begin{array}{l}\text { Validating the Operational Draft Regional } \\
\text { Guidebook for the Functional Assessment } \\
\text { of High-Gradient Ephemeral and } \\
\text { Intermittent Headwater Streams in Western } \\
\text { West Virginia and Eastern Kentucky, by C.V. } \\
\text { Noble, E.A. Summers, and J.F. Berkowitz }\end{array}$ & ADA602324 \\
\hline ERDC/EL TR-14-8 & Apr 2014 & $\begin{array}{l}\text { SAVEWS Jr. User's Manual, Version 1.0, by } \\
\text { B. Sabol, E. Melton, D. Shafer, J. Jarvis, S. } \\
\text { Evert, and R. Loyd }\end{array}$ & ADA599307 \\
\hline 1ERDC/EL TR-14-9 & Jul 2014 & $\begin{array}{l}\text { Treatment of lowa Army Ammunition Plant } \\
\text { Wastewater from Insensitive Munitions } \\
\text { Production Phase 2. Evaluation of } \\
\text { Candidate Technologies, by D. Felt, J.L. } \\
\text { Johnson, S. Waisner, S. Larson, B. Hubbard, } \\
\text { K. Henry, C. Nestler, and J.H. Ballard }\end{array}$ & \\
\hline
\end{tabular}

K. Henry, C. Nestler, and J.H. Ballard

1 Limited distribution; see Preface. 


\begin{tabular}{|c|c|c|c|}
\hline ERDC/EL TR-14-10 & Jul 2014 & $\begin{array}{l}\text { Fisheries Resource Utilization of an } \\
\text { Estuarine Borrow Pit in Mobile Bay, } \\
\text { Alabama, by K.J. Reine, D.G. Clarke, and } \\
\text { G.L. Ray }\end{array}$ & ADA606028 \\
\hline ERDC/EL TR-14-11 & Aug 2014 & $\begin{array}{l}\text { Economical Treatment of Dredged Material } \\
\text { to Facilitate Beneficial Use, by T.J. Estes } \\
\text { and C.J. McGrath }\end{array}$ & ADA608601 \\
\hline ERDC/EL TR-14-12 & Nov 2014 & $\begin{array}{l}\text { Assessing Impacts of Navigation Dredging } \\
\text { on Atlantic Sturgeon (Acipenser oxyrinchus), } \\
\text { by K. Reine, D. Clarke, M. Balzaik, S. } \\
\text { O'Haire, C. Dickerson, C. Frederickson, G. } \\
\text { Garman, C. Hager, A. Spells, and C. Turner }\end{array}$ & ADA611655 \\
\hline ERDC/EL TR-14-13 & Nov 2014 & $\begin{array}{l}\text { Calculation of Oyster Benefits with a } \\
\text { Bioenergetics Model of the Virginia Oyster, } \\
\text { by C.F. Cerco }\end{array}$ & ADA611656 \\
\hline 1ERDC/EL TR-14-14 & Dec 2014 & $\begin{array}{l}\text { Life Cycle Cost Models for IMX Wastewater } \\
\text { Treatment, by P.M. Fugate, E.T. Gill, G.A. } \\
\text { Hamilton, R.M. Jolly, J.V. Farr, S.L. Iarson, } \\
\text { J.L. Johnson, D.R. Felt, C.C. Nestler, and J.H. } \\
\text { Ballard }\end{array}$ & \\
\hline ERDC/EL TR-15-1 & Apr 2015 & $\begin{array}{l}\text { Sediment Resuspension by Ship Traffic in } \\
\text { Newark Bay, New Jersey, by D. Clarke, K.J. } \\
\text { Reine, C. Dickerson, C. Alcoba, J. Gallo, B. } \\
\text { Wisemiller, and S. Zappala }\end{array}$ & ADA615348 \\
\hline 1ERDC/EL TR-15-2 & Apr 2015 & $\begin{array}{l}\text { Engineering Analysis for Nitrate Removal from } \\
\text { Explosive Production and Facility Operations } \\
\text { Wastewater at lowa Army Ammunition Plant } \\
\text { (IAAAP), by D. Felt, J. Johnson, S. Larson, R. } \\
\text { Wade, R. Hudson, D. Flynn, K. Henry, C. } \\
\text { Nestler and J. Ballard }\end{array}$ & \\
\hline 1ERDC/EL TR-15-3 & Apr 2015 & $\begin{array}{l}\text { Evaluation and Treatment Technologies for } \\
\text { Wastewater from Pruduction of Insensitive } \\
\text { Munitions: Pilot Plant Development and } \\
\text { Demonstration, by J.L. Johnson, D. Felt, S. } \\
\text { Larson, B. Hubbard, K. Henry, J. Ballard, } \\
\text { and C. Nestler }\end{array}$ & \\
\hline ERDC/EL TR-15-4 & May 2015 & $\begin{array}{l}\text { Development of a Scalable Process Control } \\
\text { System for Chemical Soil Washing to } \\
\text { Remove Uranyl Oxide, by J.P. McCown, R.J. } \\
\text { Unz, C.A. Waggoner, J.H. Ballard, S.L. } \\
\text { Larson, and P. Arienti }\end{array}$ & ADA618135 \\
\hline
\end{tabular}

1 Limited distribution; see Preface. 


\begin{tabular}{|c|c|c|c|}
\hline ERDC/EL TR-15-5 & Jun 2015 & $\begin{array}{l}\text { Characterization of Suspended Sediment } \\
\text { Plumes Resulting from Barge Decanting in } \\
\text { San Francisco Bay, by K.J. Reine and P.R. } \\
\text { Schroeder }\end{array}$ & ADA620009 \\
\hline ERDC/EL TR-15-6 & Jul 2015 & $\begin{array}{l}\text { Evaluation of Eurasian Watermilfoil Control } \\
\text { Techniques Using Aquatic Herbicides in Fort } \\
\text { Peck Lake, Montana, by T.G. Pennington, } \\
\text { K.D. Getsinger, J.G. Skogerboe, and P.L. } \\
\text { Gilbert }\end{array}$ & ADA619009 \\
\hline ERDC/EL TR-15-7 & Jul 2015 & $\begin{array}{l}\text { Modules for Modeling Firing Range Best } \\
\text { Management Practices within TREECS } \\
\text { M.S. by } \\
\text { M. Dortch and J.A. Gerald }\end{array}$ & ADA621373 \\
\hline ERDC/EL TR-15-8 & Jul 2015 & $\begin{array}{l}\text { Kinetics Formulations for ICM-Lite: A Tool to } \\
\text { Predict and Quantify Ecosystem Benefits in } \\
\text { Aquatic Systems, by C.F. Cerco }\end{array}$ & ADA621372 \\
\hline ERDC/EL TR-15-9 & Jul 2015 & $\begin{array}{l}\text { Zebra Mussel Chemical Control Guide: } \\
\text { Version 2.0, by L.M. Glomski }\end{array}$ & ADA621371 \\
\hline ERDC/EL TR-15-10 & Jul 2015 & $\begin{array}{l}\text { Review of Dredging Elutriate Application } \\
\text { Factors: Relevance to Acute-to-Chronic } \\
\text { Protection, Contaminant, and Endpoint } \\
\text { Specificity, by A.J. Kennedy, G.R. Lotufo, and } \\
\text { J.A. Steevens }\end{array}$ & ADA621370 \\
\hline 1ERDC/EL TR-15-11 & Nov 2015 & $\begin{array}{l}\text { Treatment of Wastewater from Production } \\
\text { of Insensitive Munitions: Solids Removal in } \\
\text { IMX Load and Pack Process Water: } \\
\text { Technology and Cost-Optimization, by J.L. } \\
\text { Johnson, D. Felt, S. Larson, L. Gurtowski, B. } \\
\text { Hubbard, D. Flynn, J. Ballard, and C. Nestler }\end{array}$ & \\
\hline ERDC/EL TR-15-12 & Dec 2015 & $\begin{array}{l}\text { Regional Guidebook for the Functional } \\
\text { Assessment of Organic Flats, Slopes, and } \\
\text { Depressional Wetlands in the Northcentral } \\
\text { and Northeast Region, by U.S. Army Corps } \\
\text { of Engineers }\end{array}$ & \\
\hline
\end{tabular}

1 Limited distribution; see Preface. 


\section{Geospatial Research Laboratory (GRL)1}

\section{Technical reports}

$\begin{array}{llll}\text { Report Number } & \text { Date } & \text { Title } & \text { AD Number } \\ \text { ERDC/GRL TR-14-1 } & \text { Aug 2014 } & \text { Creating Orthographically Rectified } & \text { ADA610394 } \\ & & \text { Satellite Multi-Spectral Imagery with High } & \\ & & \text { Resolution Digital Elevation Model from } & \\ & & \text { LiDAR: A Tutorial, by R.O. Brown } & \end{array}$

\footnotetext{
${ }^{1}$ See also Topographic Engineering Laboratory.
} 


\section{Geotechnical and Structures Laboratory (GSL) 1}

\section{Contract reports}

\begin{tabular}{|c|c|c|c|}
\hline Report Number & Date & $\underline{\text { Title }}$ & $\underline{\text { AD Number }}$ \\
\hline 2ERDC/GSL CR-07-1 & Jul 2007 & $\begin{array}{l}\text { Effect of Equation of State on Hydroplus } \\
\text { Yield Estimates for Contained Explosions in } \\
\text { Frozen Rocks: Report 4, Simulation of } \\
\text { Flyer-Plate-Impact Experiments In Dry, } \\
\text { Saturated, and Frozen-Saturated Salem } \\
\text { Limestone, by H.D. Zimmerman, J.A. } \\
\text { Carney, S.H. Schuster, and Y.M. Ito }\end{array}$ & ADB330022 \\
\hline ERDC/GSL CR-07-2 & Aug 2007 & $\begin{array}{l}\text { Effects of Porosity and RMQ on Explosive- } \\
\text { Induced Ground Shock in Dry and } \\
\text { Saturated Shale, Sandstone, and Granite } \\
\text { (CD-ROM), by H.D. Zimmerman and R.T. } \\
\text { Shimano }\end{array}$ & ADB322539 \\
\hline
\end{tabular}

\section{Handbooks}

Report Number

Date $\quad \underline{\text { Title }}$

2ERDC/GSL FH-11-1

Apr 2011

Route Remediation Handbook: Repairing Improvised Explosive Device Craters, by V. Pratt, L. Priddy, and J.S. Tingle

ERDC/GSL FH-11-2

Oct 2011 Inspector's Handbook: Hot Mix Asphalt Construction, by R. Brown, V. Pratt, and J.S. Tingle

\section{Letter reports}

$\begin{array}{lll}\text { Report Number } & \text { Date } & \text { Title } \\ \text { 2ERDC/GSL LR-07-1 } & \text { Jul 2007 } & \text { Performance Validation of CENTCOM } \\ & \text { Contingency Standard Roof Designs } \\ & \text { Exposed to Indirect Fire Weapons' Effects, } \\ & \text { by M.J. Roth, R.D. Stinson, W.F. Heard, E.J. } \\ & \text { Conrath, and J.M. Rea }\end{array}$

1 See also Geotechnical Laboratory. See also Structures Laboratory.

2 Limited distribution; see Preface. 


\section{Special reports}

$\underline{\text { Report Number } \quad \underline{\text { Date }} \quad \underline{\text { Title }} \quad \text { AD Number }}$

1ERDC/GSL SR-00-1 Nov 2000 Airfield Pavement Evaluation, Hood Army

ADB262389 Airfield, Fort Hood, Texas, by P.S. McCaffrey, Jr., and R.W. Grau

1ERDC/GSL SR-00-2 Dec 2000 Airfield Pavement Evaluation, Robert Gray Army

ADB263209 Airfield, Fort Hood, Texas, by R.W. Grau

1ERDC/GSL SR-01-1 May 2001 Airfield Pavement Evaluation, Davison Army

ADB268395 Airfield, Fort Belvoir, Virginia, by R.W. Grau and P.S. McCaffrey

1ERDC/GSL SR-01-2 Jul 2001

Airfield Pavement Evaluation, Waynesville

ADB270798 Regional Airport at Forney Field, Fort Leonard Wood, Missouri, by R.W. Grau and P.S. McCaffrey, Jr.

1ERDC/GSL SR-01-3 Dec 2001 Airfield Pavement Evaluation, Sherman Army Airfield, Fort Leavenworth, Kansas, by R.W. Grau and P.S. McCaffrey, Jr.

1ERDC/GSL SR-02-1 Feb 2002 Airfield Pavement Evaluation, Lawson Army Airfield, Fort Benning, Georgia, by R.W. Grau and P.S. McCaffrey, Jr.

1ERDC/GSL SR-02-2 Mar 2002 Airfield Pavement Condition Survey, Sabre Army Heliport, Fort Campbell, Kentucky, by P.S. McCaffrey, Jr.

1ERDC/GSL SR-02-3 Jul 2002

Airfield Pavement Evaluation, Laguna Army Airfield, Yuma Proving Ground, Arizona, by R.W. Grau and P.S. McCaffrey, Jr.

1ERDC/GSL SR-02-4 Aug 2002 Airfield Pavement Evaluation, Gray Army Airfield, Fort Lewis, Washington, by R.W. Grau, P.S. McCaffrey, Jr., and D.D. Mathews

1ERDC/GSL SR-02-5 Nov 2002 Airfield Pavement Evaluation, Libby Army Airfield, Fort Huachuca, Arizona, by R.W. Grau, P.S. McCaffrey, Jr., and D.D. Mathews

1ERDC/GSL SR-02-6

Dec 2002

Airfield Pavement Evaluation, Marshall Army

ADB285665 Airfield, Fort Riley, Kansas, by P.S. McCaffrey, Jr.

1ERDC/GSL SR-03-1 Feb 2003 Airfield Pavement Evaluation, Biggs Army

ADB287182 Airfield, Fort Bliss, Texas, by R.W. Grau and P.S. McCaffrey, Jr.

ERDC/GSL SR-03-2 Mar 2003 Evaluation of Runway Preservation System, by J.E. Shoenberger and J.K. Newman

ADA412952

1 Limited distribution; see Preface. 
1ERDC/GSL SR-03-3 Apr 2003 Airfield Pavement Evaluation, Butts Army

ADB288487

Airfield, Fort Carson, Colorado, by R.W. Grau, P.S. McCaffrey, Jr., and D.D. Mathews

1ERDC/GSL SR-03-4 Apr 2003

Airfield Pavement Evaluation, Dyess Army

ADB288637 Airfield, Roi-Namur, Kwajalein Atoll, Marshall Islands, by L.D. Phillips, P.S. McCaffrey, Jr., and D.D. Mathews

1ERDC/GSL SR-03-5 May 2003 Airfield Pavement Evaluation, Bucholz Army Airfield, Kwajalein Atoll, Marshall Islands, by R.W. Grau and P.S. McCaffrey, Jr.

1ERDC/GSL SR-03-6 Jul 2003 Airfield Pavement Evaluation, Volk Field, Air National Guard, Camp Douglas, Wisconsin, by L.D. Phillips and R.W. Grau

1ERDC/GSL SR-03-7 Aug 2003 Airfield Pavement Condition Survey, Simmons Army Airfield, Fort Bragg, North Carolina, by L.D. Phillips and R.W. Grau

1ERDC/GSL SR-03-8 Aug 2003 Airfield Pavement Evaluation, Polk Army Airfield, ADB292810 Fort Polk, Louisiana, by P.S. McCaffrey, Jr.

1ERDC/GSL SR-03-9 Dec 2003 Airfield Pavement Evaluation, Amedee Army Airfield, Sierra Army Depot, California, by P.S. ADB296355 McCaffrey, Jr.

1ERDC/GSL SR-03-10 Dec 2003 Airfield Pavement Evaluation, Felker Army Airfield, Fort Eustis, Virginia, by R.W. Grau

ADB288714

ADB291363

ADB292698

Airfield Pavement Evaluation, Allen Army Airfield, Fort Greely, Alaska, by T.S. Nguyen and P.S. McCaffrey, Jr.

1ERDC/GSL SR-04-2 Feb 2004 Airfield Pavement Condition Survey, Mackall Army Airfield, Fort Bragg, North Carolina, by R.W. Grau

1ERDC/GSL SR-04-3 May 2004 Airfield Pavement Evaluation, Los Alamitos Army Airfield, Los Alamitos, California, by A.A.

ADB296819

1ERDC/GSL SR-04-1 Feb 2004 Stewart and L.D. Phillips

1ERDC/GSL SR-04-4 Sep 2004 Airfield Pavement Evaluation, Hunter Army Airfield, Fort Stewart, Georgia, by P.S. McCaffrey, Jr.

1ERDC/GSL SR-04-5 Sep 2004 Airfield Pavement Evaluation, Camp Guernsey Army Airfield, Guernsey, Wyoming, by T.S. Nguyen and D.D. Mathews

1ERDC/GSL SR-05-1 Jan 2005 Airfield Pavement Evaluation, Campbell Army Airfield, Fort Campbell, Kentucky, by R.W. Grau ADB298005

ADB298009

ADB300829

ADB303935

ADB303934

ADB306926

1 Limited distribution; see Preface. 


\begin{tabular}{|c|c|c|c|}
\hline 1ERDC/GSL SR-05-2 & Jul 2005 & $\begin{array}{l}\text { Airfield Pavement Evaluation, Wainwright Army } \\
\text { Airfield, Fort Wainwright, Alaska, by H.M. } \\
\text { Parsons and D.D. Mathews }\end{array}$ & ADB312342 \\
\hline 1ERDC/GSL SR-05-3 & Jul 2005 & $\begin{array}{l}\text { Airfield Pavement Evaluation, Blackstone Army } \\
\text { Airfield, Fort Pickett, Virginia, by C.A. Gartrell } \\
\text { and P.S. McCaffrey, Jr. }\end{array}$ & ADB312049 \\
\hline 1ERDC/GSL SR-05-4 & Aug 2005 & $\begin{array}{l}\text { Airfield Pavement Evaluation, Wheeler-Sack } \\
\text { Army Airfield, Fort Drum, New York, by S.R. } \\
\text { Jersey }\end{array}$ & ADB312343 \\
\hline 1ERDC/GSL SR-05-5 & Sep 2005 & $\begin{array}{l}\text { Airfield Pavement Condition Survey, Davison } \\
\text { Army Airfield, Fort Belvoir, Virginia, by H.M. } \\
\text { Parsons }\end{array}$ & \\
\hline 1ERDC/GSL SR-05-6 & Sep 2005 & $\begin{array}{l}\text { Airfield Pavement Evaluation, Gray Army } \\
\text { Airfield, Fort Lewis, Washington, by R.W. Grau }\end{array}$ & \\
\hline${ }^{1}$ ERDC/GSL SR-05-7 & Sep 2005 & $\begin{array}{l}\text { Airfield Pavement Evaluation, Redstone Army } \\
\text { Airfield, Redstone Arsenal, Huntsville, Alabama, } \\
\text { by H.M. Parsons and D.D. Mathews }\end{array}$ & \\
\hline 1ERDC/GSL SR-05-8 & Sep 2005 & $\begin{array}{l}\text { Airfield Pavement Condition Survey, Sherman } \\
\text { Army Airfield, Fort Leavenworth, Kansas, by } \\
\text { H.M. Parsons and L. Edwards }\end{array}$ & \\
\hline 1ERDC/GSL SR-05-9 & Nov 2005 & $\begin{array}{l}\text { Airfield Pavement Evaluation, Selah Creek } \\
\text { Airstrip and Vagabond Army Airfield, Yakima } \\
\text { Firing Center, Washington, by E.M. Velez-Vega } \\
\text { and D.D. Mathews }\end{array}$ & ADB314797 \\
\hline ERDC/GSL SR-05-10 & Dec 2005 & $\begin{array}{l}\text { Airfield Pavement Evaluation, Phillips Army } \\
\text { Airfield, Aberdeen Proving Ground, Maryland, by } \\
\text { L.D. Phillips }\end{array}$ & \\
\hline 1ERDC/GSL SR-06-1 & Feb 2006 & $\begin{array}{l}\text { Airfield Pavement Evaluation, Henry Post Army } \\
\text { Airfield, Fort Sill, Oklahoma, by L.D. Phillips }\end{array}$ & \\
\hline 1ERDC/GSL SR-06-2 & Jul 2006 & $\begin{array}{l}\text { Airfield Pavement Evaluation, A-511, Camp } \\
\text { Humphreys, Pyongtaek, Korea, by L.D. Phillips } \\
\text { and M. Crawford }\end{array}$ & \\
\hline 1ERDC/GSL SR-06-3 & Jul 2006 & $\begin{array}{l}\text { Airfield Pavement Condition Survey, Hood Army } \\
\text { Airfield, Fort Hood, Texas, by V.M. Moore }\end{array}$ & \\
\hline 1ERDC/GSL SR-06-4 & Jul 2006 & $\begin{array}{l}\text { Airfield Pavement Evaluation, Lawson Army } \\
\text { Airfield, Fort Benning, Georgia, by T.W. Rushing }\end{array}$ & \\
\hline 1ERDC/GSL SR-06-5 & Aug 2006 & $\begin{array}{l}\text { Airfield Pavement Evaluation Survey, Robert } \\
\text { Gray Army Airfield, Fort Hood, Texas, by J.A. } \\
\text { Harrison }\end{array}$ & \\
\hline${ }^{1}$ ERDC/GSL SR-06-6 & Sep 2006 & $\begin{array}{l}\text { Airfield Pavement Condition Survey, Butts Army } \\
\text { Airfield, Fort Carson, Colorado, by H.M. Parsons }\end{array}$ & \\
\hline
\end{tabular}

1 Limited distribution; see Preface. 


\begin{tabular}{|c|c|c|c|}
\hline ERDC/GSL SR-06-7 & Oct 2006 & $\begin{array}{l}\text { Dust Control Field Handbook: Standard } \\
\text { Practices for Mitigating Dust on Helipads, Lines } \\
\text { of Communication, Airfields, and Base Camps, } \\
\text { by J.F. Rushing and J.S. Tingle }\end{array}$ & \\
\hline 1ERDC/GSL SR-06-8 & Dec 2006 & $\begin{array}{l}\text { Airfield Pavement Evaluation, Lowe Army } \\
\text { Heliport, Fort Rucker, Alabama, by H.M. Parsons } \\
\text { and C.T. Bradley }\end{array}$ & \\
\hline ERDC/GSL SR-06-9 & Dec 2006 & $\begin{array}{l}\text { Operating the Portable Seismic Pavement } \\
\text { Analyzer, by H.P. Bell }\end{array}$ & ADA461413 \\
\hline 1ERDC/GSL SR-07-1 & Jan 2007 & $\begin{array}{l}\text { Airfield Pavement Evaluation, Godman Army } \\
\text { Airfield, Fort Knox, Kentucky, by T.W. Rushing }\end{array}$ & \\
\hline 1ERDC/GSL SR-07-2 & Jan 2007 & $\begin{array}{l}\text { Airfield Pavement Evaluation, Bryant Army } \\
\text { Airfield, Fort Richardson, Anchorage, Alaska, by } \\
\text { R.S. Walker }\end{array}$ & \\
\hline 1ERDC/GSL SR-07-3 & Jan 2007 & $\begin{array}{l}\text { Airfield Pavement Evaluation, Cairns Army } \\
\text { Airfield, Fort Rucker, Alabama, by T.V. Jobe and } \\
\text { T.J. McCaffrey }\end{array}$ & \\
\hline ERDC/GSL SR-07-4 & Sep 2007 & $\begin{array}{l}\text { Evaluation of Stone-Monument Repair Materials } \\
\text { for Potential Use in Interim Repair of Frost- } \\
\text { Damaged Concrete Navigation Structures, by } \\
\text { T.S. Poole and E.F. O'Neil }\end{array}$ & \\
\hline ERDC/GSL SR-09-1 & Feb 2009 & $\begin{array}{l}\text { The Spring } 2008 \text { Midwest Flood: Observations } \\
\text { of Missouri and lowa Levee Breaches, } 21-23 \\
\text { July } 2008 \text {, by J.R. Kelley, N. Vroman, C. Groves, } \\
\text { L. Harder, and G. Sills }\end{array}$ & \\
\hline ERDC/GSL SR-09-2 & Feb 2009 & $\begin{array}{l}\text { Classification Systems for Earthen Levees: A } \\
\text { Worldwide Review, by L.D. Wakeley and J.B. } \\
\text { Dunbar }\end{array}$ & \\
\hline ERDC/GSL SR-09-3 & Apr 2009 & $\begin{array}{l}\text { Constitutive Analysis of Polyurethane Foam } \\
\text { Composite Mixtures: A Literature Review, by L.P. } \\
\text { Priddy and W.D. Hodo }\end{array}$ & \\
\hline ERDC/GSL SR-09-4 & Sep 2009 & $\begin{array}{l}\text { Cavity Expansion Experiments with Spherical } \\
\text { Explosive Charges in Concrete, by J.K. Gran, J.Q. } \\
\text { Ehrgott, Jr., and J.D. Cargile }\end{array}$ & ADA508554 \\
\hline 1ERDC/GSL SR-09-5 & Sep 2009 & $\begin{array}{l}\text { Typical Construction Practices and Material } \\
\text { Properties in Southwest Asia, by S.T. } \\
\text { Montgomery and C.B. Blount }\end{array}$ & \\
\hline 1ERDC/GSL SR-09-6 & Sep 2009 & $\begin{array}{l}\text { Force Protection/Vulnerability Assessment } \\
\text { (FPVA) Tools Survey, by S.T. Montgomery and } \\
\text { B.M. Garton }\end{array}$ & \\
\hline
\end{tabular}

B.M. Garton

1 Limited distribution; see Preface. 


\begin{tabular}{|c|c|c|c|}
\hline ERDC/GSL SR-09-7 & Sep 2009 & $\begin{array}{l}\text { Evaluation of Lattice Block Structure (LBS) Mat } \\
\text { Strength and Deformation Behavior, by A.J. Falls } \\
\text { and T.W. Rushing }\end{array}$ & \\
\hline ERDC/GSL SR-10-1 & Feb 2010 & $\begin{array}{l}\text { Long-Term Performance Evaluation of Asphalt } \\
\text { Surface Treatments: Product Placement, by J.F. } \\
\text { Rushing and A.J. Falls }\end{array}$ & ADA529159 \\
\hline ERDC/GSL SR-10-2 & Jul 2010 & $\begin{array}{l}\text { A Literature Review of Processes for Gravel } \\
\text { Deposit Identification in the Lower Mississippi } \\
\text { River, by D.S. Biedenharn and M.K. Corcoran }\end{array}$ & ADA526307 \\
\hline $\begin{array}{l}\text { 1ERDC/GSL SR-10-3 } \\
\text { Rep. } 1\end{array}$ & Dec 2010 & $\begin{array}{l}\text { Border Tunneling Activity Detection System- } \\
\text { Point (BTADS-P): Report 1: Operations and } \\
\text { Maintenance Manual, by S.L. McComas, J.R. } \\
\text { McKenna, M. Mattice, A.P. Lester, S.W. } \\
\text { Broadfoot, M.H. McKenna, L.J. Perren, K.B. } \\
\text { Parkman, S.D. Sloan, and R. McNeil }\end{array}$ & \\
\hline $\begin{array}{l}\text { 1ERDC/GSL SR-10-3 } \\
\text { Rep. } 2\end{array}$ & Sep 2011 & $\begin{array}{l}\text { Border Tunneling Activity Detection System- } \\
\text { Point (BTADS-P): Report 2: Training Manual for } \\
\text { Analysis Operations Center (AOC) Watches, by } \\
\text { S. McComas, J. McKenna, M. Mattice, and R. } \\
\text { McNeil }\end{array}$ & \\
\hline 1ERDC/GSL SR-10-4 & Sep 2010 & $\begin{array}{l}\text { ATPlanner-Dams User's Guide, by W.M. Hossley, } \\
\text { L.K. Davis, Y. Seda-Sanabria, and E.E. Matheu }\end{array}$ & \\
\hline ERDC/GSL SR-11-1 & Aug 2011 & $\begin{array}{l}\text { Ultra High Performance Concrete Information } \\
\text { and Literature Search - 2011: (UHPC I\&LS- } \\
\text { 2011), by B.P. DiPaolo }\end{array}$ & \\
\hline 1ERDC/GSL SR-13-1 & Aug 2013 & $\begin{array}{l}\text { High-Strength and Ultra-High Performance } \\
\text { Concrete Test Panel Development, Coalition } \\
\text { Warfare Study, by B.H. Green, W.S. Hart, R.A. } \\
\text { Andreatta, K.E. Walker, B.H. Sherwin, J.A. } \\
\text { Morson, M.E. Mann, and D.A. Scott }\end{array}$ & ADB391681 \\
\hline ERDC/GSL SR-13-2 & Aug 2013 & $\begin{array}{l}\text { Procedures for One-Pass Vehicle Cone Index } \\
\text { (VCI1) Determination for Acquisition Support, by } \\
\text { M.T. Stevens, B.W. Towne, G.L. Mason, J.D. } \\
\text { Priddy, J.E. Osorio, and C.A. Barela }\end{array}$ & ADA585813 \\
\hline ERDC/GSL SR-14-1 & Apr 2014 & $\begin{array}{l}\text { Levels of Autonomy and Autonomous System } \\
\text { Performance Assessment for Intelligent } \\
\text { Unmanned Systems, by P.J. Durst and W. Gray }\end{array}$ & ADA601656 \\
\hline 1ERDC/GSL SR-14-2 & Jul 2014 & $\begin{array}{l}\text { NATO Reference Mobility Model Terrain Dataset } \\
\text { Geostatistics, by E.A. Baylot, G.M. Brandon, M.T. } \\
\text { Stevens, J.G. Green, and J.A. Patterson }\end{array}$ & \\
\hline
\end{tabular}

1 Limited distribution; see Preface. 
ERDC/GSL SR-15-1 Jul 2015 Sample Preparation of Nano-sized Inorganic Materials for Scanning Electron Microscopy or Transmission Electron Microscopy: Scientific Operating Procedure SOP-P-2, by C.A. Weiss, Jr., and R.D. Moser

ERDC/GSL SR-15-2 Jul 2015
State-of-Practice on the Dynamic Response of Structures Strengthened with Fiber Reinforced Polymers (FRPs), by E. Pabon, Y. Otero, F.J.

Acosta, R.D. Moser, C.K. Crane, and B.H. Green

ADA621448

ADA621492

\section{Technical notes}

\begin{tabular}{|c|c|c|}
\hline Report Number & $\underline{\text { Date }}$ & $\underline{\text { Title }}$ \\
\hline 1ERDC/GSL TN-08-1 & Sep 2008 & $\begin{array}{l}\text { Lagrangian Computational Approaches for } \\
\text { Interactions Among Explosives, Soils, Air, and } \\
\text { Structures, by C.A. Gerlach and G.R. Johnson }\end{array}$ \\
\hline 1ERDC/GSL TN-09-1 & Feb 2009 & $\begin{array}{l}\text { Development of Advanced Computational } \\
\text { Approaches for Explosive-Soil-Air-Structure } \\
\text { Interactions, Fragmentation, and Shaped } \\
\text { Charges, by C.A. Gerlach and G.R. Johnson }\end{array}$ \\
\hline 1ERDC/GSL TN-10-1 & Aug 2010 & $\begin{array}{l}\text { An Investigation of UHPC/RPC Materials for } \\
\text { Enhanced Penetration Resistance, by B.P. } \\
\text { DiPaolo, B.H. Green, R.N. Boone, and R.E. } \\
\text { Magee }\end{array}$ \\
\hline ERDC/GSL TN-14-1 & Aug 2014 & $\begin{array}{l}\text { Electromagnetic Induction Survey of the } \\
\text { Mississippi River in Cleveland, Mississippi, by } \\
\text { J.B. Dunbar and M.K. Corcoran }\end{array}$ \\
\hline ERDC/GSL TN-14-2 & Aug 2014 & $\begin{array}{l}\text { Review of Instrumentation and Monitoring for } \\
\text { USACE Levees, by J.B. Dunbar, G. Galan-Comas, } \\
\text { L.A. Walshire, R.E. Wahl, D. Yule, M.K. Corcoran, } \\
\text { J. Llopis, and A.L. Bufkin }\end{array}$ \\
\hline ERDC/GSL TN-14-3 & Nov 2014 & $\begin{array}{l}\text { Discussions on Laboratory Testing of } \\
\text { Backwards Erosion Piping of Soil: An Interview } \\
\text { with John H. Schmertmann and Frank C. } \\
\text { Townsend, by B.A. Robbins }\end{array}$ \\
\hline
\end{tabular}

\section{Technical reports}

$\begin{array}{llll}\text { Report Number } & \underline{\text { Date }} & \underline{\text { Title }} & \underline{\text { AD Number }} \\ \text { ERDC/GSL TR-00-1 } & \text { Nov 2000 } & \begin{array}{l}\text { Overview of Current Prestressing Technology in } \\ \text { Offshore Structures, by S.X. Yao, B.C. Gerwick, } \\ \text { and D.E. Berner }\end{array} & \end{array}$

\footnotetext{
1 Limited distribution; see Preface.
} 


$\begin{array}{lll}\text { ERDC/GSL TR-00-2 Nov } 2000 & \text { Assessment of Heavy-Lift Equipment for In-the- ADA389095 } \\ & \text { Wet Construction of Navigation Structures, by } \\ & \text { B.C. Gerwick, S.X. Yao, D.E. Berner, and R.R. } \\ & \text { Bittner }\end{array}$

1ERDC/GSL TR-00-3 Dec 2000 Tunnel Closure by Explosive Demolition, by L.K. ADB264018 Davis

$\begin{array}{lrl}\text { ERDC/GSL TR-00-4 Dec 2000 } & \begin{array}{l}\text { Determination of Rock Mass Rating and } \\ \text { Deformation Moduli - 14 Cross Sections of } \\ \text { Portugues Dam Foundation - December 1999, } \\ \text { by M.E. Glynn, J.L. Wibowo, J.B. Warriner, and } \\ \text { G.A. Nicholson }\end{array} \\ \text { ERDC/GSL TR-00-5 Dec 2000 } & \begin{array}{l}\text { Assessment of Microgravimetry for UXO } \\ \text { Detection and Discrimination, by D.K. Butler }\end{array}\end{array}$

ADA387616

1ERDC/GSL TR-01-1 Mar 2001 Results for Multiple-Detonation, Small-Scale Experiments (Collateral Expulsion Experiments), Chemical Simulant (TEP) Series, Tests MB1-MB10, and Biological Simulant (BT) Series, Tests MB11-MB15 in Support of the Collateral Effects Environment Program. By P.W. Graham, V.P. Chiarito, D. Moore, and G.E. Albritton

1ERDC/GSL TR-01-2 Mar 2001 BlastX Code, Version 4.2, User's Manual, by J.R. Britt, D.E. Ranta, and C.E. Joachim

ADA387603

ADB266252

ADB265626

ERDC/GSL TR-01-3 Mar 2001 Development of a Granular Media Model for Finite Element Analysis, by D.M. Smith, J.F. Peters, and R.S. Rollings

1ERDC/GSL TR-01-4 Mar 2001 Experimental Results for Multiple-Detonation, Small-Scale Experiments, Tests MB16A-MB21 (Concrete Responding Wall and Adjacent Room Container Spillage Series) in Support of the Collateral Effects Environment Program, by P.W. Graham, V.P. Chiarito, and G.E. Albritton

ADA389345

ADB268158

1ERDC/GSL TR-01-5 Mar 2001 Mobility Comparison Evaluation of a U.S.
Equipment Transporter System (HETS,
M1070/M1000) and a Modified HETS Equipped with a Sand Mobility Enhancement Kit (SMEK), by D.W. Moore
ERDC/GSL TR-01-6 May 2001 Dynamic Response of Brittle Materials from Penetration and Split Hopkinson Pressure Bar Experiments, by D.J. Frew

ADA393003

ADB268207

Expedient Road Construction Over Soft Soils,

ADA393001 by R.L. Santoni, C.J. Smith, J.S. Tingle, and S.L. Webster

1 Limited distribution; see Preface. 


\begin{tabular}{|c|c|c|c|}
\hline ERDC/GSL TR-01-8 & Aug 2001 & $\begin{array}{l}\text { Convex Watershed-Reservoir Model for Risk } \\
\text { Assessment of Spillways and Nonoverflow } \\
\text { Dam Monoliths Subjected to Flood Hazard, by } \\
\text { L.A. de Bejar }\end{array}$ & ADA394434 \\
\hline 1ERDC/GSL TR-01-9 & Sep 2001 & $\begin{array}{l}\text { Small-Scale Structure-Medium-Interaction } \\
\text { Experiments: Experiment } 4 \text { Test Results, by } \\
\text { B.R. Phillips, J.E. Windham, and D.R. Rickman }\end{array}$ & ADB271022 \\
\hline ERDC/GSL TR-01-10 & Aug 2001 & $\begin{array}{l}\text { Locating And Characterizing Unexploded } \\
\text { Ordnance Using Time Domain Electromagnetic } \\
\text { Induction, by L.R. Paison and D.W. Oldenburg }\end{array}$ & ADA394435 \\
\hline ERDC/GSL TR-01-11 & Aug 2001 & $\begin{array}{l}\text { Falling-Weight Deflectometer Study: Optimizing } \\
\text { the Number of Replicates and the Spacing of } \\
\text { Test Stations, by R.B. Freeman and D.R. } \\
\text { Alexander }\end{array}$ & ADA395725 \\
\hline
\end{tabular}

ERDC/GSL TR-01-12 Aug 2001 Use of Ground Penetrating Radar for Locating

ADA395692 Contraband Aboard Ocean Going Vessels: Feasibility Study, by J.L. Llopis and J. Simms

ERDC/GSL TR-01-13 Aug 2001 Hydrogeology of Proposed Harbor Site at Head

ADA395644 of Akutan Bay, Akutan Island, Alaska, by J.B. Dunbar, M.K. Corcoran, and W.L. Murphy

1ERDC/GSL TR-01-14 Aug 2001 Geophysical Surveys at Camp Eagle and Camp ADB271929 Page, Republic of Korea, by J.L. Llopis and C.R. Malone

ERDC/GSL TR-01-15 Aug 2001

Material Properties and Characteristics for ADA398867 Development of an Expert System for Coal-Tar Sealers, by J.E. Shoenberger

ERDC/GSL TR-01-16 Aug 2001

Application of Wavelet Analysis to Logistics Test Vehicle Ride Experiment Results, by A.W. Harrell, C. Grey, and W. Willoughby

1ERDC/GSL TR-01-17 Sep 2001 Experimental Results for 1/6-Scale High Temperature Incendiary ( $\mathrm{HTI}$ ) and High Explosive (HE) Dry Biological Simulant (BT) Tests in Light-Steel Buildings in Support of the Collateral Effects Environment Program, by V.P. Chiarito, P.W. Ggraham, and G.E. Albritton

ERDC/GSL TR-01-18 Sep 2001 Quantity Distances for Ammunition in ISO

ADA398611 Containers, by L.K. Davis and M.B. Ford

ADA396792

ADB272942

Basin F Subregional Groundwater Model, by E. ADA399450 Mazion, Jr., J.H. May, B. Abraham, and M.K.

Corcoran

1 Limited distribution; see Preface. 
1ERDC/GSL TR-01-20 Oct 2001

ERDC/GSL TR-01-21 Oct 2001

ERDC/GSL TR-01-21

ERDC/GSL TR-01-22 Oct 2001 Trafficability, by G. Mason, R. Ahlvin, and J.
Green

1ERDC/GSL TR-01-23 Dec 2001 Mobility Evaluation of British King GTS100 Heavy Equipment Transporter (HET) SemiTrailer and Foreign HET Project Summary, by D.W. Moore and R.N. Tennant

$\begin{array}{lc}\text { ERDC/GSL TR-01-24 } & \text { Dec } 2001 \\ \text { 1ERDC/GSL TR-02-1 } & \text { Jan } 2002\end{array}$

ERDC/GSL TR-02-4 Mar 2002 Rapid Strengthening of Reinforced Concrete Beams with Mechanically Fastened, FiberReinforced Polymeric Composite Materials, by L.C. Bank, A.J. Lamanna, J.C. Ray, and G.I. Velazquez

1ERDC/GSL TR-02-5 Mar 2002 Site Documentation: Fuhrungsbunker bei Schwepnitz, Konigsbruch, Germany, by L.K. Davis

1ERDC/GSL TR-02-6 Apr 2002

Experimental Results of Scaled DE169 Tests Using Wet Biological Simulant (BT) in LightSteel Buildings in Support of the Collateral Effects Environment Program, by P.W. Graham, V.P. Chiarito, E.N. Adcock, and G.E. Albritton
1ERDC/GSL TR-02-7 May 2002 Multiple-Fragment Impact Experiments on Reinforced Concrete Slabs, by F.D. Dallriva and J.L. Davis
ERDC/GSL TR-02-8 May 2002 Installation of Fiber-Optic Cables Under Flood- Protection Structures Using Horizontal Directional Drilling Techniques, by P.J. Conroy, C.A. Latorre, and L.D. Wakeley

ADB274501

ADA397514

ADA401205

ADB277653

ADA402418

ADB277682

ADA400415

ADB278518

ADB279667

ADB281022

ADA404033 


$\begin{array}{lll}\text { ERDC/GSL TR-02-9 Jun 2002 } & \begin{array}{l}\text { Guidelines for Installation of Utilities Beneath } \\ \text { Corps of Engineers Levees Using Horizontal } \\ \text { Directional Drilling, by C.A. Latorre, L.D. } \\ \text { Wakeley, and P.J. Conroy }\end{array} \\ \text { 1ERDC/GSL TR-02-10 Jun 2002 } & \begin{array}{l}\text { Development of Algorithms for Dual Delivery } \\ \text { Problems, by M.D. Adley, B. Rohani, J.D. } \\ \text { Cargile, and R.P. Berger }\end{array} \\ \text { ERDC/GSL TR-02-11 Jul 2002 } & \begin{array}{l}\text { Lateral Load Distribution Factors for Military } \\ \text { Vehicles on Multi-Girder Bridges, by J.C. Pinero } \\ \text { M.P. Singh, and J.C. Ray }\end{array} \\ & \text { Jul 2002 } & \begin{array}{l}\text { Rapid Strengthening of Full-Sized Concrete } \\ \text { Beams with Powder-Actuated Fastening } \\ \text { Systems and Fiber-Reinforced Polymer (FRP) } \\ \text { Composite Materials, by L.C. Bank, D.T. } \\ \text { Borowicz, A.J. Lamanna, J.C. Ray, and G.I. } \\ \text { Velazquez }\end{array}\end{array}$

ERDC/GSL TR-02-13 Aug 2002

1ERDC/GSL TR-02-14 Jul 2002

ERDC/GSL TR-02-15 Aug 2002

ERDC/GSL TR-02-16 Sep 2002 Geophysical Inversion of Total-Field Magnetic Data, by S.D. Billings, L.R. Pasion, and D.W. Oldenburg

ERDC/GSL TR-02-17 Sep 2002 Methodology for Mobility Tactical Decision Aids Incorporated in the Joint Mapping Tool Kit, by G.B. McKinley, B.T. Webb, and D.A. Horner

1ERDC/GSL TR-02-18 Sep 2002

Fabric Retrofits of Concrete Masonry Exterior Walls - Blast Response Evaluation. (U.S./Israeli 1998 Series, "Divine Camel", Test 3), by R.J. Dinan, D.R. Coltharp, P.T. Townsend, and J.M. Watt, Jr.

ERDC/GSL TR-02-19 Sep 2002 Performance of Levee Underseepage Controls: A Critical Review, by T.F. Wolff

1ERDC/GSL TR-02-20 Oct 2002 Exterior Building Wall Retrofits - Weapon Fragment Penetration Evaluation; U.S./Israeli 2000 Test-Series, by R.J. Dinan, D.R. Coltharp, P.T. Townsend, and J.M. Watt, Jr.
ADA403684

ADB282392

ADA404604

ADA405701

ADA406634

ADB282549

ADA408337

ADA407658

ADB284702

ADA408143

ADB285614

\footnotetext{
1 Limited distribution; see Preface.
} 


$\begin{array}{lllll}\text { ERDC/GSL TR-02-21 } & \text { Nov 2002 } & \begin{array}{l}\text { Procedure for Categorizing Ground Vehicles, by } \\ \text { E.A. Baylot and B.Q. Gates }\end{array} & \text { ADA408852 } \\ \text { ERDC/GSL TR-02-22 } & \text { Dec 2002 } & \begin{array}{l}\text { Positioning Systems for Float-In and Lift-In } \\ \text { Construction in Inland Waterways, by S.X. Yao } \\ \text { and B.C. Gerwick }\end{array} & \text { ADA409535 } \\ \text { ERDC/GSL TR-03-1 } & \text { Feb 2003 } & \begin{array}{l}\text { Rejuvenators, Rejuvenator/Sealers, and Seal } \\ \text { Coats for Airfield Pavements, by J.E. } \\ \text { Shoenberger }\end{array} & \text { ADA412361 } \\ \text { 1ERDC/GSL TR-03-2 } & \text { Feb 2003 } & \begin{array}{l}\text { Methodology and User's Guide for PENCURV +: } \\ \text { Version 1.0, by M.D. Adley, R.P. Berger, J.D. }\end{array} & \text { ADB287716 } \\ \text { Cargile, and D.D. Boswell } & & \end{array}$

1ERDC/GSL TR-03-3 Feb 2003 Experimental Results for Small-Scale Tests 96 Through 104B: Chemical Simulant Evaluations and Calibration Tests Cal-1 Through Cal-12, by P.W. Graham and G.E. Albritton

1ERDC/GSL TR-03-4 May 2003 Experimental Results for Laboratory Expulsion Tests 52 through 59 and Repeat Tests 32B, 32C, 34B, and 41B (Chemical Test Series) in Support of the Collateral Effects Environment Program, by V.P. Chiarito, P.W. Graham, and G.E. Albritton

ADB287800

ADB290838

Flood Simulation Study of the Rio Grande Levees Near Las Cruces, New Mexico, Using Seismic and Electrical Geophysical Methods, by J.B. Dunbar, J.R. McKenna, E.W. Smith, R.D. Miller and J. Ivanov

\begin{tabular}{|c|c|c|}
\hline 1ERDC/GSL TR-03-5 & Jul 2003 & $\begin{array}{l}\text { Constructibility Study of Water-and Gelled- } \\
\text { Water-Filled Tube Barricades, by T.K. Cummins } \\
\text { J.H. Weathersby, P.G. Kinnebrew, K.P. Walters, } \\
\text { and J.H. White }\end{array}$ \\
\hline 1ERDC/GSL TR-03-6 & Jul 2003 & $\begin{array}{l}\text { Overhead Cover for Infantry Fighting Positions } \\
\text { by P.G. Kinnebrew, S. Laird, J.H. Weathersby, } \\
\text { and J.H. White }\end{array}$ \\
\hline ERDC/GSL TR-03-7 & Jul 2003 & $\begin{array}{l}\text { Enhanced Coastal Trafficability: Road } \\
\text { Construction Over Sandy Soils, by R.L. Santon }\end{array}$ \\
\hline 1ERDC/GSL TR-03-8 & Jul 2003 & $\begin{array}{l}\text { Experimental Results for } 1 / 3-\text { Scale Dipole } \\
\text { Tiger } 1 \text { and } 1 / 11.6 \text { Scale Tests } 63,64 \text {, and } 6 \\
\text { in Support of the Collateral Effects } \\
\text { Environment Program, by P.W. Graham, V.P. } \\
\text { Chiarito, and G.E. Albritton }\end{array}$ \\
\hline ERDC/GSL TR-03-9 & Aug 2003 & $\begin{array}{l}\text { Investigation of Bond Slip Between Concrete } \\
\text { and Steel Reinforcement Under Dynamic } \\
\text { Loading Conditions, by J.H. Weathersby }\end{array}$ \\
\hline
\end{tabular}

ERDC/GSL TR-03-4 Jul 2007

Rep. 8

Loading Conditions, by J.H. Weathersby

1 Limited distribution; see Preface. 
ERDC/GSL TR-03-10 Jul 2003

ERDC/GSL TR-03-11 Aug 2003

ERDC/GSL TR-03-12 Aug 2003

ERDC/GSL TR-03-13 Aug 2003

ERDC/GSL TR-03-14 Aug 2003

ERDC/GSL TR-03-15 Aug 2003

1ERDC/GSL TR-03-16 Aug 2003

ERDC/GSL TR-03-17 Sep 2003

Rep. 1

1ERDC/GSL TR-03-21 Sep 2003

ERDC/GSL TR-03-22 Sep 2003
Geologic Investigation of the Middle

Mississippi River (CD-ROM), by E.G. Woerner,

J.B. Dunbar, E. Villanueva, and L.M. Smith

Field Study of Live Load Distribution Factors and Dynamic Load Allowance on Reinforced Concrete T-Beam Bridges, by M.D. Trimble, T.E. Cousins, and Y. Seda-Sanabria

A Study of Effective Moment of Inertia Models for Full-Scale Reinforced Concrete T-Beams Subjected to a Tandem-Axle Load Configuration, by J.E. Wickline, T.E. Cousins, and Y. Seda-Sanabria

Third US-Japan Workshop on Advanced Research on Earthquake Engineering for Dams, San Diego, California, 22-23 June 2002, by R.L. Hall, Y. Yamaguchi, E.E. Matheu, and Z.H. Duron, editors

\section{Proposed Design Criteria on Thin-Wall Precast} Panels for Hydraulic Concrete Structures, by S.X. Yao, D.E. Berner, W. Miles, B.D. Fehl, M. Walker, and S.C. Woodson

\section{Applications of Synthetic Aperture Radar (SAR) to Unexploded Ordnance (UXO) Delineation, by} J.E. Simms

Experimental Results of 1/3-Scale Dipole Orbit Tests Conducted in FY 1995 and FY 2000 (Container Spillage Investigation Using Dry Biological Simulants) in Support of the Collateral Effects Environment Program, by P.W. Graham, V.P. Chiarito, and G.E. Albritton

Pavement Model Generation Interface, Report 1 - Formulation and Operation of the System, by B.W. McPheeters and D.M. Smith

Criteria for Multispectral Decoy Construction and Employment, by C.B. Blount, B.P. Durst, K. Van Peursem, and L.J. Watkins

Data Collection and Analysis of Moisture and Soil Strength Information for Validation of $\mathrm{New}$ State-of-the-Ground Models, by G.L. Mason, D.W. Moore, G.M. Brandon, and D.L. Leese
ADM001497

ADA417357

ADA417481

ADA417586

ADA417479

ADA417715

ADB292910

ADA417965

ADB293203

ADA421658

\footnotetext{
1 Limited distribution; see Preface.
} 


\begin{tabular}{|c|c|c|c|}
\hline ERDC/GSL TR-03-24 & Nov 2003 & $\begin{array}{l}\text { E-Krete }{ }^{\mathrm{TM}} \text { Polymer Composite Micro-Overlay for } \\
\text { Airfields: Laboratory Results and Field } \\
\text { Demonstrations, by J.K. Newman and } \\
\text { J.E.Shoenberger }\end{array}$ & ADA419412 \\
\hline 1ERDC/GSL TR-04-1 & Feb 2004 & $\begin{array}{l}\text { Experimental Results of 1/3-Scale Wall Tests } 1 \\
\text { Through 5: Shielding Biological and Chemical } \\
\text { Simulant Containers (Container Spillage Tests) } \\
\text { in Support of the Consequence Assessment } \\
\text { Program, by P.W. Graham and G.E. Albritton }\end{array}$ & ADB298435 \\
\hline 1ERDC/GSL TR-04-2 & Mar 2004 & $\begin{array}{l}\text { Miniature-Scale Experiments of Airblast } \\
\text { Diffraction Over Barrier Walls: Results and } \\
\text { Analysis, by D.D. Rickman and D.W. Murrell }\end{array}$ & ADB298150 \\
\hline ERDC/GSL TR-04-3 & Feb 2004 & $\begin{array}{l}\text { Mission Level Mobility Analysis of the U.S. } \\
\text { Marine Corps HIMARS Vehicles, by R.A. Jones, } \\
\text { S.J. Price, and R.B. Ahlvin }\end{array}$ & ADA422287 \\
\hline ERDC/GSL TR-04-4 & Jun 2004 & $\begin{array}{l}\text { A Partially Saturated Constitutive Theory for } \\
\text { Compacted Fills, by E.S. Berney IV }\end{array}$ & ADA425462 \\
\hline ERDC/GSL TR-04-5 & Jul 2004 & $\begin{array}{l}\text { Strengthening of Concrete Beams With } \\
\text { Fasteners and Composite Material Strips- } \\
\text { Scaling and Anchorage Issues, by L.C. Bank, } \\
\text { D.T. Borowicz, D. Aroya, A.J. Lamanna, G.I. } \\
\text { Velazquez, and J.C. Ray }\end{array}$ & ADA426411 \\
\hline 1ERDC/GSL TR-04-7 & Aug 2004 & $\begin{array}{l}\text { Scale-Model Experiments to Investigate the } \\
\text { Effect of Concrete Pavements on Embankment } \\
\text { Craters, by D.D. Rickman and D.W. Moore }\end{array}$ & ADB303540 \\
\hline ERDC/GSL TR-04-8 & Aug 2004 & $\begin{array}{l}\text { Guidelines for Planning Unexploded Ordnance } \\
\text { (UXO) Detection Surveys, by J.E. Simms, R.J. } \\
\text { Larson, W.L. Murphy, and D.K. Butler }\end{array}$ & ADA427038 \\
\hline ERDC/GSL TR-04-9 & Sep 2004 & $\begin{array}{l}\text { Assessment of Foreign Bridge Standards and } \\
\text { Techniques, by A.J. Lamanna, M. Lok, G.I. } \\
\text { Velzaquez, J.C. Ray, and T.R. Stanton }\end{array}$ & ADA429078 \\
\hline ERDC/GSL TR-04-10 & Sep 2004 & $\begin{array}{l}\text { Evaluation of Expedient Methods for Mitigating } \\
\text { Dust on Helipads, by J.S. Tingle, A. Harrison, } \\
\text { and J.F. Rushing }\end{array}$ & ADA429008 \\
\hline ERDC/GSL TR-04-11 & Sep 2004 & $\begin{array}{l}\text { Vehicle Capacity API for Transportation } \\
\text { Infrastructure Network Builder (TINet), by G.B. } \\
\text { McKinley }\end{array}$ & ADA427994 \\
\hline ERDC/GSL TR-04-12 & $\begin{array}{l}\text { Sep } 2004 \\
\text { Rev. July } \\
2010\end{array}$ & $\begin{array}{l}\text { Prediction of Piping Erosion Along Middle } \\
\text { Mississippi River Levees-An Empirical Model, } \\
\text { by M. E. Glynn and J. Kuszmaul }\end{array}$ & ADA428221 \\
\hline
\end{tabular}




\begin{tabular}{|c|c|c|c|}
\hline ERDC/GSL TR-04-13 & Sep 2004 & $\begin{array}{l}\text { Folsom Dam Outlet Works Modification } \\
\text { Project: Dynamic Stress Analysis of Overflow } \\
\text { and Nonoverflow Sections, by E.E. Matheu, } \\
\text { R.L. Hall, and R.V. Kala }\end{array}$ & ADA427798 \\
\hline 1ERDC/GSL TR-04-14 & Sep 2004 & $\begin{array}{l}\text { An Evaluation of the Penetration Augmented } \\
\text { Munition (PAM) as a Roadway Cratering } \\
\text { Device, by D.D. Rickman, D.W. Moore, and R.N. } \\
\text { Walters }\end{array}$ & ADB304358 \\
\hline 1ERDC/GSL TR-04-15 & Sep 2004 & $\begin{array}{l}\text { Explosive Cratering of Asphalt Roadways: The } \\
\text { Penetration Augmented Munition (PAM) Follow- } \\
\text { on Experiments, by D.D. Rickman and D.W. } \\
\text { Moore }\end{array}$ & ADB304388 \\
\hline ERDC/GSL TR-04-16 & Sep 2004 & $\begin{array}{l}\text { Seismic Analysis of Intake Towers Considering } \\
\text { Multiple-Support Excitation and Soil-Structure } \\
\text { Interaction Effects, by A.L. Vidot, L.E. Suarez, } \\
\text { E.E. Matheu, and M.K. Sharp }\end{array}$ & ADA427787 \\
\hline 1ERDC/GSL TR-04-17 & Sep 2004 & $\begin{array}{l}\text { Sand Island Tunnel Reconnaissance Study, } \\
\text { Construction and Design of Tunnel } \\
\text { Alternatives, Cost Estimate, by M.E. Glynn, A.J. } \\
\text { Pollak, E.J. Cording, J. Mahar, D.C. McCarry, S. } \\
\text { Narasimharajan, I. Maevski, and W.L. Murphy }\end{array}$ & ADB304361 \\
\hline${ }^{1}$ ERDC/GSL TR-04-18 & Sep 2004 & $\begin{array}{l}\text { Determination of Rock Mass Rating and } \\
\text { Deformation Moduli - Six Cross Sections of } \\
\text { Portugues Dam Foundation, Comparison of } \\
2000 \text { and } 2003 \text { Analyses, by M.E. Glynn and } \\
\text { G.A. Nicholson }\end{array}$ & ADB304157 \\
\hline 1ERDC/GSL TR-05-1 & Jan 2005 & $\begin{array}{l}\text { Improved Algorithms for Dual Delivery } \\
\text { Problems, by M.D. Adley, J.D. Cargile, R.P. } \\
\text { Berger, B. Rohani, and B. Patterson }\end{array}$ & ADB305954 \\
\hline $\begin{array}{l}\text { ERDC/GSL TR-05-2 } \\
\text { Rep. } 1\end{array}$ & Jan 2005 & $\begin{array}{l}\text { Rapid Maximum-On-Ground (MOG) } \\
\text { Enhancement Technologies. Report 1. Matting } \\
\text { Systems for Contingency Helipads and C-130 } \\
\text { Test Sections, by G.L. Anderton and C.A. } \\
\text { Gartrell }\end{array}$ & ADA431207 \\
\hline 1ERDC/GSL TR-05-4 & Jan 2005 & $\begin{array}{l}\text { Experimental Results for the } 1 / 6-\text { Scale Divine } \\
\text { Umpire Demonstration Test and Calibration } \\
\text { Test in Support of the Consequence } \\
\text { Assessment Program, by P.W. Graham and G.E. } \\
\text { Albritton }\end{array}$ & ADB307003 \\
\hline ERDC/GSL TR-05-5 & Jan 2005 & $\begin{array}{l}\text { Evaluation of Recharge Trench System, North } \\
\text { Boundary Containment Treatment System, } \\
\text { Rocky Mountain Arsenal, Commerce City, } \\
\text { Colorado, by M.K. Corcoran, D.M. Patrick, N.G. } \\
\text { Gaggiani, and J.H. May }\end{array}$ & ADA431205 \\
\hline
\end{tabular}

1 Limited distribution; see Preface. 


\begin{tabular}{|c|c|c|c|}
\hline ERDC/GSL TR-05-6 & Feb 2005 & $\begin{array}{l}\text { Standard for Ground Vehicle Mobility, by E.A. } \\
\text { Baylot, Jr., B.Q. Gates, J.G. Green, P.W. } \\
\text { Richmond, N.C. Goerger, G.L. Mason, C.L. } \\
\text { Cummins, and L.S. Bunch }\end{array}$ & ADA433075 \\
\hline ERDC/GSL TR-05-7 & Mar 2005 & $\begin{array}{l}\text { Expedient Repair Materials for Roadway } \\
\text { Pavements, by J.E. Shoenberger, W.D. Hodo, } \\
\text { C.A. Weiss, Jr., P.G. Malone, and T.S. Poole }\end{array}$ & ADA432378 \\
\hline 1ERDC/GSL TR-05-8 & Mar 2005 & $\begin{array}{l}\text { Wet Bio Test Series, Experimental Campaigns } \\
1-4, \text { Tests WB-1 through WB- } 45 \text { and } \\
\text { Calibration Tests Cal } 1 \text { through Cal } 8 \text { in } \\
\text { Support of the Consequence Assessment } \\
\text { Program, by P.W. Graham and G.E. Albritton }\end{array}$ & ADB307936 \\
\hline ERDC/GSL TR-05-9 & Mar 2005 & $\begin{array}{l}\text { Evaluation of Application Methods and } \\
\text { Products for Mitigating Dust for Lines-of- } \\
\text { Communication and Base Camp Operations, } \\
\text { by J.F. Rushing, J.A. Harrison, and J.S. Tingle }\end{array}$ & ADA433127 \\
\hline ERDC/GSL TR-05-10 & Apr 2005 & $\begin{array}{l}\text { Characterization of Reinforced Concrete } \\
\text { Bridges Using Dynamic Response } \\
\text { Measurements for Use in Load Capacity } \\
\text { Estimation, by Z.H. Duron, D. Sutoyo, G. Lee, } \\
\text { and Y. Seda-Sanabria }\end{array}$ & ADA433799 \\
\hline 1ERDC/GSL TR-05-11 & Apr 2005 & $\begin{array}{l}\text { Field Evaluation of Rapid Airfield Assessment } \\
\text { Technologies, by L.D. Phillips }\end{array}$ & ADB309620 \\
\hline ERDC/GSL TR-05-12 & May 2005 & $\begin{array}{l}\text { Geomorphic Investigation of Bakers Bayou } \\
\text { Near Lonoke, Arkansas, by J.B. Dunbar }\end{array}$ & ADA434045 \\
\hline ERDC/GSL TR-05-14 & Jun 2005 & $\begin{array}{l}\text { Folsom Dam Outlet Works Modification } \\
\text { Project: Simplified Three-Dimensional Stress } \\
\text { Analysis of Monolith 12, by E.E. Matheu and } \\
\text { S.B. Garner }\end{array}$ & ADA437088 \\
\hline ERDC/GSL TR-05-16 & Jul 2005 & $\begin{array}{l}\text { Laboratory Characterization of Fine Aggregate } \\
\text { Cementitious Material, by E.M. Williams, S.A. } \\
\text { Akers, and P.A. Reed }\end{array}$ & ADA435634 \\
\hline ERDC/GSL TR-05-17 & Jul 2005 & $\begin{array}{l}\text { Using Geophysics to Assess the Condition of } \\
\text { Small Embankment Dams, by T.R. Brosten, J.L. } \\
\text { Llopis, and J.R. Kelley }\end{array}$ & ADA438045 \\
\hline ERDC/GSL TR-05-18 & Aug 2005 & $\begin{array}{l}\text { In Situ Geophysical Surveys for Estimation of } \\
\text { Foundation Rock Properties, Concrete Gravity } \\
\text { Section, Folsom Dam, by J.L. Llopis, M.K. } \\
\text { Sharp, and E.E. Matheu }\end{array}$ & ADA438857 \\
\hline
\end{tabular}


$\begin{array}{ll}\text { ERDC/GSL TR-05-19 Sep } 2005 & \text { Sediment Capping and Natural Recovery: } \\ & \text { Contaminant Transport Fundamentals With } \\ & \text { Applications to Sediment Caps, by D.M. } \\ & \text { Petrovski, M.K. Corcoran, J.H. May, and D.M. } \\ & \text { Patrick }\end{array}$

1ERDC/GSL TR-05-20 Sep 2005

Dam Incidents Involving U.S. Army Corps of Engineers Structures, by J.B. Dunbar, E. Villanueva, W.L. Murphy, and M.K. Corcoran

1ERDC/GSL TR-05-21 Sep 2005

Construction Practices and Material Properties in Turkey, by S.T. Montgomery and R.C. Dove

ERDC/GSL TR-05-22 Sep 2005

Dynamic Testing and Numerical Correlation Studies For Folsom Dam, by Z. Duron, E.E. matheu, V.P. Chiarito, J.F. Hall, and M.K. Sharp

ERDC/GSL TR-05-23 Oct 2005

Dust Abatement Methods for Lines-ofCommunication and Base Camps in Temperate Climates, by J.F. Rushing, V.M. Moore, J.S. Tingle, Q. Mason, and T. McCaffrey

1ERDC/GSL TR-06-1 Jan 2006

Methodology and User's Guide for PENCURV+, Version 1.5, by M.D. Adley, R.P. Berger, J.D. Cargile, and D.D. Boswell

ERDC/GSL TR-06-2 Feb 2006

Evaluation of Chemical Dust Palliatives for Helipads, by J.F. Rushing, V.M. Moore, and J.S. Tingle

1ERDC/GSL TR-06-3 Apr 2006

Experimental Results for Deflagration of Chemical Simulant: Scoping Tests 66-74 and Primary Deflagration Tests 75-86 in Support of the Consequence Assessment Program, by P.W. Graham and G.E. Albritton

1ERDC/GSL TR-06-4 May 2006

Magneto Inductive-Remote Activation Munitions System (MI-RAMS): MI Field Penetration Tests at the Capitol Peak Tunnel Complex and LTS2 Structure, White Sands Missile Range, New Mexico, and the U16B Tunnel Complex, Nevada Test Site, Nevada, by J.E Windham, T.A. Waddell, and C. DeLuca

1ERDC/GSL TR-06-5 May 2006

Experimental Results for Ram Angle Test Series: Scoping Tests RA-1 Through RA-30 in Support of the Consequence Assessment Program, by P.W. Graham, J.A. Atchison, and G.E. Albritton
ADA438041

ADB311793

ADA446669

ADA440551

ADA444812 


\begin{abstract}
1ERDC/GSL TR-06-6 Jun 2006 Scale-Model Experiments to Investigate the Effect of Steel-Reinforced and RollerCompacted Concrete Pavements on Crater Mitigation, by D.D. Rickman, D.W. Moore, and J.W. Hall III

1ERDC/GSL TR-06-7 Aug 2006

Evaluation of the Current Vulnerability of Expeditionary Shelters to Airblast, by S.C. Lofton and J.L. Davis

1ERDC/GSL TR-06-8 Aug 2006

Effects of Particle Size and Computational Approach on Calculated Shock-Wave Propagation through Coarse Boulder Backfills, by H.D. Zimmerman and V.E. Koik

1ERDC/GSL TR-06-9 Aug 2006

Experimental Results for Small-Scale Tunnel Tracer Detection Test Series: Tests TS-32 Through TS-47 in Support of the Consequence Assessment Program, by P.W. Graham, M.H. McKenna, G.E. Albritton, and L.W. Stockham

1ERDC/GSL TR-06-10 Aug 2006

Determination of Unit Section Modulus for Finite Element Modeling of Matting Systems, by E.S. Berney IV, W.D. Hodo, and J.A. Vera
\end{abstract}

ERDC/GSL TR-06-11 Sep 2006

\section{Durability Evaluation of Polymeric Materials for Expeditionary Helipads, by V.M. Moore, J.F.} Rushing, and J.S. Tingle

ERDC/GSL TR-06-12 Sep 2006

Expedient Gap Definition Using 3D LADAR, by L. Edwards and S.R. Jersey

1ERDC/GSL TR-06-13 Sep 2006

Subscale Projectile Penetration Experiments into Intact and Jointed Rock Targets, by M.L. Green, D.J. Frew, B. Rohani, and J.D. Cargile

1ERDC/GSL TR-06-14 Sep 2006

Geologic and Geophysical Properties of Soil Samples from Two Sites in Iraq, by J.R. Kelley, J.R. McKenna, and L.D. Wakeley

ERDC/GSL TR-06-15 Sep 2006

Laboratory Characterization of SAM-35 Concrete, by E.M. Williams, S.A. Akers, and P.A. Reed

ERDC/GSL TR-06-16 Sep 2006 Laboratory Characterization of White Masonry Concrete, by E.M. Williams, S.A. Akers, and P.A. Reed

1ERDC/GSL TR-06-17 Sep 2006 Ride and Shock Performance Specification Test Results for the Expeditionary Fighting Vehicle (EFV), by R.A. Jones, D.W. Moore, and S.J. Price
ADB318272

ADA454916

ADA456251

ADA456250

ADB321130

\footnotetext{
1 Limited distribution; see Preface.
} 


\begin{abstract}
1ERDC/GSL TR-06-18 Sep 2006 Standoff Mortoa Fragment Velocity Before and After Perforation of Conventional Building Walls, by L.A. de Bejar, L. Simmons, and J.L. Davis

1ERDC/GSL TR-06-19 Sep 2006

Small-Scale Structure-Medium-Interaction Experiments: Test Results for Experiments 5 through 8, by B.R. Phillips, J.E. Windham, and D.D. Rickman

1ERDC/GSL TR-06-21 Dec 2006

Tunnel Detection Technology Demonstrations: Otay Mesa and Calexico, California, by J.R. McKenna, R. Horton, G. Elbring, A. Clymer, and C. Hansen
\end{abstract}

1ERDC/GSL TR-06-22 Nov 2006

Estimating Forces on Structural Panels Due to Blast-Induced Fragmentation of Mortars, by L.A. de Bejar, J.L. Davis, and L. Simmons

1ERDC/GSL TR-06-23 Sep 2006

Magneto Inductive-Remote Activation Munitions System (MI-RAMS): MI Field Penetration Tests at the Mont Terri and Grimsel Underground Laboratories in Switzerland and the HADES Underground Laboratory in Belgium, by J.E Windham, T.A. Waddell, C. DeLuca, and A.E. Jackson, Jr.

1ERDC/GSL TR-06-24 Sep 2006

Development of an Improved Analytic Technique for Prediction of Ground Shock Hoop Stresses in Spherical Flow Fields, by J.E. Windham and R.E. Walker

1ERDC/GSL TR-06-25 Dec 2006 Conceptual Studies for Rapidly Deployable Battlespace Gap Structures, by L.C. Bank, J.S. Russell, J.P. Hanus, G.I. Velazquez, W. VarelaOrtiz, and J.C. Ray

ERDC/GSL TR-06-26 Dec 2006 Unbonded Aggregate Surface Roads, by R.B. Freeman, D.A. Goss, P.S. McCaffrey, J.G. Tom, T.S. Poole, L.T. Lee, and P.A. Taylor

ERDC/GSL TR-06-27 Dec 2006

Seismic Measurement of Concrete Strength Properties, by H.P. Bell

1ERDC/GSL TR-06-28 Dec 2006

Baseline of the DeltaEM Gradiometer at Three Federal Facilities, by J.R. McKenna, L.J. Perren, and T.E. McGill

1ERDC/GSL TR-06-29 Dec 2006

Experimental Results for Improvised Dispersal Devices, Tests IDD-1 through IDD-17 and Calibration Tests 1-25 in Support of the Consequence Assessment Program, by P.W. Graham and G.E. Albritton
ADB322190

ADB323769

ADA460698

ADA460086

\footnotetext{
1 Limited distribution; see Preface.
} 


\begin{tabular}{|c|c|c|c|}
\hline 1ERDC/GSL TR-06-30 & Dec 2006 & $\begin{array}{l}\text { Use of International Organization for } \\
\text { Standardization Shipping Containers for } \\
\text { Belowground Personnel Bunkers, by J.H. } \\
\text { Weathersby, M.J. Roth, and J.H. White }\end{array}$ & \\
\hline ERDC/GSL TR-07-1 & Feb 2007 & $\begin{array}{l}\text { Evaluation of Expeditionary Mat Surfacings for } \\
\text { Beach Roads, by T.S. Rushing, J.S. Tingle, and } \\
\text { Q.S. Mason }\end{array}$ & \\
\hline ERDC/GSL TR-07-2 & Mar 2007 & $\begin{array}{l}\text { Geomorphic Identification and Verification of } \\
\text { Recent Sedimentation Patterns in the } \\
\text { Woonasquatucket River, North Providence, } \\
\text { Rhode Island, by M.K. Corcoran }\end{array}$ & ADA464865 \\
\hline 1ERDC/GSL TR-07-3 & Feb 2007 & $\begin{array}{l}\text { Crater and Damage Effects and Ground Shock } \\
\text { Loading From Standoff Detonations on } \\
\text { Concrete Slabs With Varied Edge Fixity, by J.Q. } \\
\text { Ehrgott, Jr., J.D. Cargile, and J.E. Windham }\end{array}$ & ADB325795 \\
\hline 1ERDC/GSL TR-07-4 & Mar 2007 & $\begin{array}{l}\text { Experimental Results for Field Expedient } \\
\text { Demilitarization (FED) Test Series, Tests FED-1 } \\
\text { through FED-15 and Calibration Tests } 1 \text { and } 2 \\
\text { in Support of the Consequence Assessment } \\
\text { Program, by P.W. Graham, G.E. Albritton and } \\
\text { L.W. Stockham }\end{array}$ & \\
\hline 1ERDC/GSL TR-07-5 & Mar 2007 & $\begin{array}{l}\text { AM2 and M19 Airfield Mat Evaluation for the } \\
\text { Rapid Parking Ramp Expansion Program, by } \\
\text { T.W. Rushing and J.S. Tingle }\end{array}$ & \\
\hline 1ERDC/GSL TR-07-8 & Apr 2007 & $\begin{array}{l}\text { Experimental Results for Ram Angle Follow-on } \\
\text { Test Series: Tests RA-31 Through RA- } 42 \text { in } \\
\text { Support of the Consequence Assessment } \\
\text { Program, by P.W. Graham and G.E. Albritton }\end{array}$ & \\
\hline ERDC/GSL TR-07-9 & Apr 2007 & $\begin{array}{l}\text { Grout Impregnation of Pre-Placed Recycled } \\
\text { Concrete Pavement (RCP) for Rapid Repair of } \\
\text { Deteriorated Portland Cement Concrete } \\
\text { Airfield Pavement, by T.A. Mann, R.B. Freeman, } \\
\text { and G.L. Anderton }\end{array}$ & ADA467797 \\
\hline $\begin{array}{l}\text { 1ERDC/GSL TR-07-10 } \\
\text { Rep. } 1\end{array}$ & Apr 2007 & $\begin{array}{l}\text { Field Fortification Scale Modeling to } \\
\text { Characterize Internal Blast Conditions } \\
\text { Resulting from External Detonations: Report 1, } \\
\text { 1/8-Scale Model of Large Observation Post, by } \\
\text { M.J. Roth, R.D. Stinson, and C.B. Blount }\end{array}$ & \\
\hline $\begin{array}{l}\text { 1ERDC/GSL TR-07-10 } \\
\text { Rep. } 2\end{array}$ & Apr 2007 & $\begin{array}{l}\text { Field Fortification Scale Modeling to } \\
\text { Characterize Internal Blast Conditions } \\
\text { Resulting from External Detonations: Report 2, } \\
\text { 1/8-Scale Model of Small Observation Post, by } \\
\text { M.J. Roth, R.D. Stinson, and C.B. Blount }\end{array}$ & \\
\hline
\end{tabular}

1 Limited distribution; see Preface. 
1ERDC/GSL TR-07-10 Apr 2007

Rep. 3

1ERDC/GSL TR-07-10 Apr 2007

Rep. 4

1ERDC/GSL TR-07-11 May 2007

1ERDC/GSL TR-07-12 May 2007

1ERDC/GSL TR-07-13 May 2007

IERC/GSL TR-07-13 May 2007

ERDC/GSL TR-07-14 May 2007

1ERDC/GSL TR-07-15 May 2007

1ERDC/GSL TR-07-16 Jun 2007

ERDC/GSL TR-07-17 Jun 2007

ERDC/GSL TR-07-18 Jun 2007

ERDC/GSL TR-07-19 Jun 2007
Field Fortification Scale Modeling to Characterize Internal Blast Conditions Resulting from External Detonations: Report 3, 1/8-Scale Model of 20-ft Aboveground MILVAN Bunker, by R.D. Stinson, M.J. Roth, and C.B. Blount

Field Fortification Scale Modeling to Characterize Internal Blast Conditions Resulting from External Detonations: Report 4, 1/8-Scale Model of 40-ft Belowground MILVAN Bunker, by R.D. Stinson, M.J. Roth, and C.B. Blount

Experimental Results for Weapon in Tank Scoping Test Series: Tests WT-1 through WT-12 in Support of the Consequence Assessment Program, by P.W. Graham and G.E. Albritton

Evaluation of Corrugated Aluminum Arches to Construct Improved, Revetted Fighting Positions, by M.J. Roth and M.E. Booth

Estimating the Risk of Embankment Dam Incidents Related to Seepage Based on Historical Records of Prior Incidents, by J.S. Kuszmaul, M.K. Corcoran, E. Villanueva, and J.B. Dunbar

Feasibility Investigation into Strengthening of Timber Bridge Stringers, by A.J. Lamanna, A. Akbiyik, J.C. Ray, and G.I. Velázquez

Use of Rapidly Cured Inflatable Composite Beams for Military Small-Gap Bridging, by W. Varela-Ortiz, G.I. Velázquez, and C.Y. Lugo Investigations for Airfield Damage Repair Kit Modifications and Improvements, by C.A. Gartrell

Load Test and Load Rating Report for Bridge 305 Over Foster's Creek Located at Naval Weapons Facility, Charleston, SC, by J.L. Schulz, B.C. Commander, T.R. Stanton, W. Varela-Ortiz, C.Y. Lugo, and M.H. McKenna

Evaluation Criteria for Aged Asphalt Concrete Surfaces, by H.P. Bell and R.B. Freeman

Laboratory Investigation of Chemical Dust Pallative Performance on Sandy Soil, by J.F. Rushing, J.K. Newman, and T.J. McCaffrey
ADA468971

ADA469215

ADA470955

ADA469306

\footnotetext{
1 Limited distribution; see Preface.
} 


\begin{tabular}{|c|c|c|c|}
\hline ERDC/GSL TR-07-20 & Jun 2007 & $\begin{array}{l}\text { A Comparative Field Study of Permastripe }{ }^{\mathrm{TM}} \\
\text { Polymer Concrete and Waterborne Airfield } \\
\text { Pavement Markings, by J.K. Newman, D. } \\
\text { Speidel, R. Boeger, and B. Hudson }\end{array}$ & ADA469457 \\
\hline ERDC/GSL TR-07-21 & Jul 2007 & $\begin{array}{l}\text { Geophysical Surveys for Assessing Levee } \\
\text { Foundation Conditions, Sacramento River } \\
\text { Levees, Sacramento, CA, by J.L. Llopis, E.W. } \\
\text { Smith, and R.E. North }\end{array}$ & ADA470918 \\
\hline $\begin{array}{l}\text { 1ERDC/GSL TR-07-22 } \\
\text { Rep. } 1\end{array}$ & Aug 2007 & $\begin{array}{l}\text { Development of Barricades for Protective and } \\
\text { Safety Measures at a Munitions and } \\
\text { Explosives of Concern Site. Report 1: } \\
\text { Aluminum Open-Front Barricade, by R.D. } \\
\text { Stinson, W.F. Heard, T.K. Cummins, and M. } \\
\text { Crull }\end{array}$ & ADB330821 \\
\hline ERDC/GSL TR-07-23 & Aug 2007 & $\begin{array}{l}\text { Laboratory Characterization of Gray Masonry } \\
\text { Concrete, by E.M. Williams, S.A. Akers, and P.A. } \\
\text { Reed }\end{array}$ & ADA472947 \\
\hline ERDC/GSL TR-07-24 & Aug 2007 & $\begin{array}{l}\text { Laboratory Characterization of Solid Grade SW } \\
\text { Brick, by E.M. Williams, S.A. Akers, and P.A. } \\
\text { Reed }\end{array}$ & ADA472942 \\
\hline ERDC/GSL TR-07-25 & Sep 2007 & $\begin{array}{l}\text { Geophysical Surveys for Assessing Levee } \\
\text { Foundation Conditions, Feather River Levees, } \\
\text { Marysville/Yuba City, California, by J.L. Llopis } \\
\text { and J.E. Simms }\end{array}$ & ADA471724 \\
\hline ERDC/GSL TR-07-26 & Sep 2007 & $\begin{array}{l}\text { Fluvial Instability and Channel Degradation of } \\
\text { Amite River and its Tributaries, Southwest } \\
\text { Mississippi and Southeast Louisiana, by D.R. } \\
\text { Hood, D.M. Patrick, and M.K. Corcoran }\end{array}$ & ADA471731 \\
\hline ERDC/GSL TR-07-27 & Sep 2007 & $\begin{array}{l}\text { Laboratory and Field Investigations of Small } \\
\text { Crater Repair Technologies, by L.P. Priddy, J.S. } \\
\text { Tingle, T.J. McCaffrey, and R.S. Rollings }\end{array}$ & ADA471743 \\
\hline${ }^{1} \mathrm{ERDC} / \mathrm{GSL}$ TR-07-28 & Nov 2007 & $\begin{array}{l}\text { Small-Scale Structure-Medium-Interaction } \\
\text { Experiments } 9 \text { through 11, Test Results, by } \\
\text { B.R. Phillips, J.E. Windham, and D.D. Rickman }\end{array}$ & ADB334267 \\
\hline 1ERDC/GSL TR-07-29 & Dec 2007 & $\begin{array}{l}\text { Prototype Mat System Evaluation, by T.W. } \\
\text { Rushing and N. Torres }\end{array}$ & \\
\hline${ }^{1}$ ERDC/GSL TR-07-30 & Dec 2007 & $\begin{array}{l}\text { Field Testing and Load Rating Report, Bridge S- } \\
\text { 1801, Camp Casey, South Korea, by B. } \\
\text { Commander, J. Grimson, W. Varela-Ortiz, T.R. } \\
\text { Stanton, G. Velazquez, and G.M. Hansler }\end{array}$ & \\
\hline${ }^{1}$ ERDC/GSL TR-07-32 & Dec 2007 & $\begin{array}{l}\text { (U) Investigation of Pre-Detonation Layer Blast } \\
\text { Shielding Effects, by M.J. Roth, R.D. Stinson, } \\
\text { and T.E. McGill }\end{array}$ & \\
\hline
\end{tabular}

1 Limited distribution; see Preface. 


\begin{tabular}{|c|c|c|c|}
\hline ERDC/GSL TR-07-33 & Dec 2007 & $\begin{array}{l}\text { Full-Scale Instrumented Testing and Analysis of } \\
\text { Matting Systems for Airfield Parking Ramps } \\
\text { and Taxiways, by C.A. Gartrell }\end{array}$ & ADA476667 \\
\hline 1ERDC/GSL TR-08-1 & Feb 2008 & $\begin{array}{l}\text { Analysis, Design and Testing of International } \\
\text { Organization for Standardization Container } \\
\text { Reinforcement System, by W. Varela-Ortiz, G.I. } \\
\text { Velázquez, and L.A. Gonzalez }\end{array}$ & \\
\hline ERDC/GSL TR-08-2 & Feb 2008 & $\begin{array}{l}\text { Mechanical and Physical Properties of ASTM } \\
\text { C33 Sand, by E.S. Berney IV and D.M. Smith }\end{array}$ & ADA477592 \\
\hline ERDC/GSL TR-08-3 & Mar 2008 & $\begin{array}{l}\text { A Rapid Soils Analysis Kit, by E.S. Berney IV } \\
\text { and R.E. Wahl }\end{array}$ & ADA484159 \\
\hline 1ERDC/GSL TR-08-4 & Apr 2008 & $\begin{array}{l}\text { Static Experiments of GMLRS Warheads } \\
\text { against Earth-Timber Bunkers Emplaced in a } \\
\text { Sand Backfill, by D.D. Rickman, J.Q. Ehrgott, } \\
\text { Jr., and J.W. Hall III }\end{array}$ & \\
\hline 1ERDC/GSL TR-08-5 & Apr 2008 & $\begin{array}{l}\text { Evaluation of NAVAIR High Power Run-Up } \\
\text { Anchors, by G.J. Norwood and J.S. Tingle }\end{array}$ & \\
\hline ERDC/GSL TR-08-6 & May 2008 & $\begin{array}{l}\text { Evaluation Criteria for Aged Asphalt Concrete } \\
\text { Surfaces; Phase II, by H.P. Bell, R.B. Freeman, } \\
\text { and E.R. Brown }\end{array}$ & ADA481737 \\
\hline ERDC/GSL TR-08-7 & May 2008 & $\begin{array}{l}\text { Quality Assurance for Rapid Airfield } \\
\text { Construction, by R.B. Freeman, T.A. Mann, L.W. } \\
\text { Mason, C.A. Gartrell, and V.M. Moore }\end{array}$ & ADA481168 \\
\hline ERDC/GSL TR-08-8 & May 2008 & $\begin{array}{l}\text { Field Testing and Load Rating Report, Bridge S- } \\
\text { 1090, Camp Casey, South Korea, by B. } \\
\text { Commander, J. Grimson, W. Varela-Ortiz, T.R. } \\
\text { Stanton, C.Y. Lugo, and G.M. Hansler }\end{array}$ & ADA481801 \\
\hline 1ERDC/GSL TR-08-9 & Jun 2008 & $\begin{array}{l}\text { Investigations for Airfield Damage Repair Kit } \\
\text { Modifications and Improvements, Phase 2, by } \\
\text { C.A. Gartrell }\end{array}$ & ADB339855 \\
\hline ERDC/GSL TR-08-10 & Jun 2008 & $\begin{array}{l}\text { Laboratory Characterization of Type S Mortar, } \\
\text { by E.M. Williams, S.A. Akers, and P.A. Reed }\end{array}$ & \\
\hline ERDC/GSL TR-08-11 & Jun 2008 & $\begin{array}{l}\text { Laboratory Characterization of Adobe, by E.M. } \\
\text { Williams, S.A. Akers, and P.A. Reed }\end{array}$ & \\
\hline 1ERDC/GSL TR-08-12 & Jun 2008 & $\begin{array}{l}\text { Laboratory Characterization of Eglin Fuze and } \\
\text { Holloman Fuze Concretes, by E.M. Williams, } \\
\text { S.A. Akers, and P.A. Reed }\end{array}$ & \\
\hline 1ERDC/GSL TR-08-13 & Jun 2008 & $\begin{array}{l}\text { AM2 } 10 \text { CBR Subgrade Sensitivity Test for the } \\
\text { Rapid Parking Ramp Expansion Program, by } \\
\text { T.W. Rushing, N. Torres, and Q.S. Mason }\end{array}$ & \\
\hline
\end{tabular}

T.W. Rushing, N. Torres, and Q.S. Mason

1 Limited distribution; see Preface. 
1ERDC/GSL TR-08-14 Jul 2008

1ERDC/GSL TR-08-15 Aug 2008

ERDC/GSL TR-08-16 Jul 2008

ERDC/GSL TR-08-17 Jul 2008

ERDC/GSL TR-08-18 Jul 2008

1ERDC/GSL TR-08-19 Jul 2008

1ERDC/GSL TR-08-20 Jul 2008

${ }^{1}$ ERDC/GSL TR-08-21 Jul 2008

ERDC/GSL TR-08-22 Sep 2008

1ERDC/GSL TR-08-23 Sep 2008
Small-Scale Structure-Medium-Interaction

ADB342079

Experiments: Test Results for Experiments 12-

14, by J.Q. Ehrgott, Jr., J.E. Windham, D.D.

Rickman, B.R. Phillips, T.A. Waddell, and A.E.

Jackson, Jr.

Mechanics of Thin-Slab Perforation by Kinetic-

Energy Projectiles, by M.D. Adley, A.O. Frank, and B. Rohani

Homogenization via Sequential Projection to Nested Subspaces Spanned by Orthogonal Scaling and Wavelet Orthonormal Families of Functions, by L.A. de Bejar

Joint Rapid Airfield Construction (JRAC) 2007 Technology Demonstration, by G.L. Anderton, E.S. Berney IV, T.A. Mann, J.K. Newman, E.A. Baylot, D.K. Miller, and Q. Mason

ADA485319

ADA485296

Field Testing and Load Rating Report, Bridge S- ADA485300 4360, Camp Hovey, South Korea, by B.

Commander, J. Grimson, W. Varela-Ortiz, T.R.

Stanton, G.I. Velazquez, and G.M. Hansler

Experimental Determination of the Ignition or Explosion Potential of Ground Torch Fuel Tanks When Exposed to Threat Projectiles, by R.D. Stinson, S.T. Montgomery, R.E. Magee, Jr., and M.J. Roth

Experimental Results for Biological Simulant Release Near Detonation Fireballs: SmallScale Tests 105 through 110 and Follow-On Repeat Tests, by P.W. Graham and G.E. Albritton

Results for Component Vulnerability Experiments: Tests 1 and 2 at Fort Polk, LA, Field Test Site, by P.W. Graham, G.E. Albritton, and E.N. Adcock

Risk Assessment of Rock Surface Spillway Erosion Using Parametric Studies, by E. Villanueva and J.L. Wibowo

Blast Vulnerability and Risk Assessment of a Lock and Dam Project, by G.W. McMahon, J.L. O'Daniel, L.K. Davis, B.E. Walker, V.E. LeGarde, and R.A. Weed 


\begin{tabular}{|c|c|c|c|}
\hline ERDC/GSL TR-08-24 & Sep 2008 & $\begin{array}{l}\text { Flexural and Tensile Properties of Thin, Very } \\
\text { High-Strength, Fiber-Reinforced Concrete } \\
\text { Panels, by M.J. Roth }\end{array}$ & ADA492800 \\
\hline 1ERDC/GSL TR-08-25 & Sep 2008 & $\begin{array}{l}\text { AM2 } 15 \text { CBR Subgrade Sensitivity Test for the } \\
\text { Rapid Parking Ramp Expansion Program, by } \\
\text { T.W. Rushing and Q.S. Mason }\end{array}$ & \\
\hline ERDC/GSL TR-08-26 & Oct 2008 & $\begin{array}{l}\text { Evaluation of Minimum Asphalt Concrete } \\
\text { Thickness Criteria, by H.P. Bell and L.W. Mason }\end{array}$ & \\
\hline 1ERDC/GSL TR-08-27 & Oct 2008 & $\begin{array}{l}\text { Advanced Airfield Damage Repair } \\
\text { Technologies, Phase I, by L.P. Priddy, C. Moore, } \\
\text { and E. Padilla-Salinas }\end{array}$ & \\
\hline 1ERDC/GSL TR-08-28 & Sep 2008 & $\begin{array}{l}\text { Optimization of the Explosive Removal of } \\
\text { Concrete from Double Reinforced Walls, by } \\
\text { D.D. Rickman, T.W. Shelton, J.Q. Ehrgott, Jr., } \\
\text { S.A. Akers, D.W. Moore, T.A. Waddell, and J.E. } \\
\text { Windham }\end{array}$ & ADB346034 \\
\hline 1ERDC/GSL TR-08-29 & Dec 2008 & $\begin{array}{l}\text { Validation of the Protective Performance of } \\
\text { Modular Concrete Bunkers Against Rocket and } \\
\text { Mortar Attack, by M.J. Roth, B.P. Durst, and } \\
\text { P.G. Kinnebrew }\end{array}$ & \\
\hline 1ERDC/GSL TR-09-1 & Jan 2009 & $\begin{array}{l}\text { Small-Scale Prototype Mat System Evaluation } \\
\text { for the AMX Program, by T.W. Rushing, J.S. } \\
\text { Tingle, and L.I. Garcia }\end{array}$ & \\
\hline 1ERDC/GSL TR-09-2 & Jan 2009 & $\begin{array}{l}\text { Field Evaluation of the Navy Injectable Foam } \\
\text { Airfield Damage Repair Concept, by L.P. Priddy }\end{array}$ & \\
\hline 1ERDC/GSL TR-09-3 & Feb 2009 & $\begin{array}{l}\text { Improving Air Delivery Capability Against } \\
\text { Protective Structures (IACAPS), Phase 1, by J.Q. } \\
\text { Ehrgott, Jr., J.G. Averett, C.D. Thomas, J.D. } \\
\text { Cargile, J.W. Hall III, and T.A Waddell }\end{array}$ & ADB347940 \\
\hline 1ERDC/GSL TR-09-4 & Feb 2009 & $\begin{array}{l}\text { Evaluation of NAVAIR High Power Run-up } \\
\text { Anchors, Phase II, by C.A. Gartrell and R.B. } \\
\text { Freeman }\end{array}$ & \\
\hline ERDC/GSL TR-09-5 & Mar 2009 & $\begin{array}{l}\text { Laboratory Characterization of Type N Mortar, } \\
\text { by E.M. Williams, S.A. Akers, and P.A. Reed }\end{array}$ & ADA502083 \\
\hline ERDC/GSL TR-09-6 & Mar 2009 & $\begin{array}{l}\text { Investigation of Sliver-Spall Damage at Offutt } \\
\text { Air Force Base, Nebraska, by T.S. Poole and } \\
\text { R.S. Rollings }\end{array}$ & \\
\hline 1ERDC/GSL TR-09-7 & May 2009 & $\begin{array}{l}\text { Full-Scale Evaluation of Blast Effects on Soil- } \\
\text { Based Field Fortifications, ADF Trial 845, by } \\
\text { M.J. Roth and R.D. Stinson }\end{array}$ & \\
\hline
\end{tabular}




\begin{tabular}{|c|c|c|c|}
\hline ERDC/GSL TR-09-8 & May 2009 & $\begin{array}{l}\text { Enhanced Vehicle Dynamics Module, by D.C. } \\
\text { Creighton, G.B. McKinley, R.A. Jones, and R.B. } \\
\text { Ahlvin }\end{array}$ & ADA500759 \\
\hline EDRC/GSL TR-09-9 & May 2009 & $\begin{array}{l}\text { Field Testing and Load Rating Report, Bridge } \\
\text { FSBR-514, Fort Shafter, Hawaii, by B. } \\
\text { Commander, W. Varela-Ortiz, T.R. Stanton, and } \\
\text { H. Diaz-Alvarez }\end{array}$ & ADA501408 \\
\hline 1ERDC/GSL TR-09-10 & May 2009 & $\begin{array}{l}\text { Suitability of Flexible Drainage Pipes for Use in } \\
\text { Contingency Airfield Construction, by R.B. } \\
\text { Freeman, G.J. Norwood, P.S. McCaffrey, and } \\
\text { J.S. Tingle }\end{array}$ & \\
\hline 1ERDC/GSL TR-09-12 & May 2009 & $\begin{array}{l}\text { CRATR Limited Operational Utility Assessment } \\
1 \text { (LOUA1), Tyndall Air Force Base, Florida, by } \\
\text { J.S. Tingle, L.P. Priddy, M.C. Edwards, C.A. } \\
\text { Gartrell, and T.J. McCaffrey }\end{array}$ & \\
\hline ERDC/GSL TR-09-13 & May 2009 & $\begin{array}{l}\text { Evaluation of Laboratory Procedures for } \\
\text { Testing Asphalt Surface Treatments for Airfield } \\
\text { Pavements, by J.F. Rushing and J.G. Tom, Jr. }\end{array}$ & \\
\hline 1ERDC/GSL TR-09-14 & May 2009 & $\begin{array}{l}\text { Experimental Results for Tests 87-95, Light- } \\
\text { Steel Metal Buildings with Stored Chemical } \\
\text { Simulant (TEP), by P.W. Graham and G.E. } \\
\text { Albritton }\end{array}$ & \\
\hline ERDC/GSL TR-09-15 & Jun 2009 & $\begin{array}{l}\text { In Situ Determination of Flexural Strength } \\
\text { Using Seismic Testing, by H.P. Bell }\end{array}$ & \\
\hline $\begin{array}{l}\text { 1ERDC/GSL TR-09-16 } \\
\text { Rep. } 1\end{array}$ & Dec 2009 & $\begin{array}{l}\text { Infrasound Assessment of Infrastructure. } \\
\text { Report 1, Field Testing and Finite Element } \\
\text { Analysis for Railroad Bridge A.B 0.3, Fort } \\
\text { Leonard Wood, Missouri, by H. Diaz-Alveraz, } \\
\text { M.H. McKenna, and P.F. Mlakar }\end{array}$ & ADB356827 \\
\hline $\begin{array}{l}\text { 1ERDC/GSL TR-09-16 } \\
\text { Rep. 2, Vol. } 1\end{array}$ & Feb 2010 & $\begin{array}{l}\text { Infrasound Assessment of Infrastructure. } \\
\text { Report 2, Experimental Infrasound } \\
\text { Measurements of Railroad Bridge A.B 0.3, Fort } \\
\text { Leonard Wood, Missouri. Volume I: Main Text, } \\
\text { by M.H. McKenna, A.F. Lester and S.J. } \\
\text { McComas }\end{array}$ & \\
\hline $\begin{array}{l}\text { 1ERDC/GSL TR-09-16 } \\
\text { Rep. 2, Vol. } 2\end{array}$ & Feb 2010 & $\begin{array}{l}\text { Infrasound Assessment of Infrastructure. } \\
\text { Report 2, Experimental Infrasound } \\
\text { Measurements of Railroad Bridge A.B 0.3, Fort } \\
\text { Leonard Wood, Missouri. Volume II: } \\
\text { Appendixes A-D, by M.H. McKenna, A.F. Lester } \\
\text { and S.J. McComas }\end{array}$ & \\
\hline
\end{tabular}


1ERDC/GSL TR-09-16 Mar 2010 Rep. 3

ERDC/GSL TR-09-17 Jun 2009

ERDC/GSL TR-09-18 Jun 2009

ERDC/GSL TR-09-19 Jul 2009

ERDC/GSL TR-09-20 Jul 2009

1ERDC/GSL TR-09-21 Jul 2009

ERDC/GSL TR-09-22 Jul 2009

1ERDC/GSL TR-09-23 Jul 2009

ERDC/GSL TR-09-24 Aug 2009

ERDC/GSL TR-09-25 Aug 2009

ERDC/GSL TR-09-26 Aug 2009

1ERDC/GSL TR-09-27 Aug 2009
Infrasound Assessment of Infrastructure. Report 3, Numerical Simulation of StructuralAcoustic Coupling and Infrasonic Propagation Modeling for Railroad Bridge A.B 0.3, Fort Leonard Wood, Missouri, by M.H. McKenna, S. Yushanov, K. Koppenhoefer, and J.R. McKenna

Laboratory Characterization of Redstone Technical Test Center Brick, by S.S. Graham, E.M. Williams, and P.A. Reed

Field Evaluation of Asphalt Surface Treatment Usage and Performance, by J.F. Rushing

Evaluation of Airfield Pavement Drainage Layers, by J.F. Rushing and M. Mejias-Santiago

In Situ Evaluation of Unsurfaced Portland Cement-Stabilized Soil Airfields, by J.R. Griffin and J.S. Tingle

Laboratory Characterization of Test-Bed Soils for the Aberdeen Test Center Experiments with the SA-155 Projectile, by E.M. Williams, S.S. Graham, and P.A. Reed

Laboratory Characterization of Cor-Tuf Concrete With and Without Steel Fibers, by E.M. Williams, S.S. Graham, P.A. Reed, and T.S. Rushing

Laboratory Characterization of Near-Surface Soils from the AAA Iraq Site, by E.M. Williams, J.E. Windham, S.S. Graham, and P.A. Reed

Evaluation of Supa-Trac Matting for Expeditionary Roads, by T.W. Rushing, J.S. Tingle, T.J. McCaffrey, and T.S. Rushing

Analysis of Long Wave Infrared (LWIR) Soil Data to Predict Reflectance Response, by J.E. Simms, E.S. Berney IV, D.W. Harrelson, M.K. Corcoran, and R.M. Castellane

Evaluation of Ultra High Molecular Weight (UHMW) Polyethylene Panels for Aircraft Arresting Systems, by E.R. Brown

Laboratory Characterization of Test-bed Soils for the Eglin AFB Experiments with Multiple Detonations of OF-540 Projectiles, by E.M. Williams, J.E. Windham, S.S. Graham and P.A. Reed
ADB354140

ADA508359

ADB354139

ADA509343

ADA508400

ADA508608

ADB354141

\footnotetext{
1 Limited distribution; see Preface.
} 
1ERDC/GSL TR-09-28 Sep 2009 Experimental Results for Explosive Depth of Burst Test Series on Dry Biological Simulant (BT); Tests DOB-1 Through -5, Repeat and Calibration Tests, by P.W. Graham and G.E. Albritton

1ERDC/GSL TR-09-29 Sep 2009

Laboratory Characterization of Near-Surface Soils from the AAB Iraq Site, by E.M. Williams, J.E. Windham, S.S. Graham and P.A. Reed

1ERDC/GSL TR-09-30 Sep 2009

Laboratory Characterization of Test-bed Soils for the Eglin AFB Experiments with a Single Chinese 122-mm Projectile, by E.M. Williams, J.E. Windham, S.S. Graham and P.A. Reed

1ERDC/GSL TR-09-31 Sep 2009

Laboratory Characterization of Test-bed Soils for the Aberdeen Test Center Experiments with an OF-540 Projectile, by E.M. Williams, S.S. Graham and P.A. Reed

1ERDC/GSL TR-09-32 Sep 2009

Laboratory Characterization of Near-Surface Soils from the AAD Iraq Site, by E.M. Williams, J.E. Windham, S.S. Graham and P.A. Reed

1ERDC/GSL TR-09-33 Sep 2009

Improving Air Delivery Capability Against Protective Structures (IACAPS), Phase 2, by R.G. Rhett, Jr., J.Q. Ehrgott, Jr., J.G. Averett, J.D. Cargile, J.W. Hall III, and T.A. Waddell

ERDC/GSL TR-09-35 Oct 2009

Quasi-static High Strength Low-Alloy Vanadium Steel Reinforced Concrete Slab Experiments, by S.D. Robert, C.F. Johnson, and S.C. Woodson

ERDC/GSL TR-09-36 Oct 2009

1ERDC/GSL TR-09-37 Nov 2009 Cyclic Plate Testing of Geogrid-Reinforced Highway Pavements, by S.R. Jersey and J.S. Tingle

Anchor Evaluation for Vehicle Affresting System, by C.A. Gartrell, M. Mejias-Santiago, and R.B. Freeman

1ERDC/GSL TR-09-38 Dec 2009 Mobility Comparison of MRAP, ASV, and UpArmored HMMWV Operating in Select Areas of Iraq, by G.L. Mason, E.A. Baylot, B.L. Wojtysiak, S.A. Zweidler, P. Melick, N.C. Goerger, P.W. Richmond, and J.G. Green

ERDC/GSL TR-09-39 Dec 2009 Development of Ndesign Criteria for Using the Superpave Gyratory Compactor to Design Asphalt Pavement Mixtures for Airfields, by J.F. Rushing
ADB354109

ADB354112

ADB354168

ADB354111

ADB353940

ADB356073

\footnotetext{
1 Limited distribution; see Preface.
} 


\begin{tabular}{|c|c|c|c|}
\hline 1ERDC/GSL TR-10-3 & Jan 2010 & $\begin{array}{l}\text { Project WATER HAZARD: Scale-Model Studies } \\
\text { of the Responses of Water-Backed Earthen } \\
\text { Embankments to Explosive Attack, by D.D. } \\
\text { Rickman }\end{array}$ & ADB357120 \\
\hline 1ERDC/GSL TR-10-4 & Mar 2010 & $\begin{array}{l}\text { Susceptibility of Modified Fiberglass- } \\
\text { Reinforced Polyester Matting System to Aircraft } \\
\text { Jet Blast, by H.P. Bell, C.F. Johnson, J.S. Tingle, } \\
\text { and Q. Mason }\end{array}$ & ADB358142 \\
\hline 1ERDC/GSL TR-10-5 & Mar 2010 & $\begin{array}{l}\text { Evaluation of Foam Backfill Technologies for } \\
\text { Crater Repair, by L.P. Priddy, M. Mejias- } \\
\text { Santiago, and J.F. Rowland }\end{array}$ & \\
\hline 1ERDC/GSL TR-10-6 & Jul 2010 & $\begin{array}{l}\text { Numerical Simulations of Cratering Effects in } \\
\text { Embankment Dams, by B.J. Armstrong, S.A. } \\
\text { Akers, L.K. Davis, R.J. Moral, Y. Seda-Sanabria, } \\
\text { and E.E. Matheu }\end{array}$ & \\
\hline ERDC/GSL TR-10-7 & Mar 2010 & $\begin{array}{l}\text { Tactical Wheeled Vehicle Survivability: Results } \\
\text { of Experiments to Quantify Aboveground } \\
\text { Impulse, by J.Q. Ehrgott, Jr. }\end{array}$ & ADA521275 \\
\hline 1ERDC/GSL TR-10-8 & Mar 2010 & $\begin{array}{l}\text { Laboratory Characterization of Near-Surface } \\
\text { Soils from the AAC Iraq Site, by E.M. Williams, } \\
\text { J.E. Windham, S.S. Graham, and P.A. Reed }\end{array}$ & ADB360544 \\
\hline 1ERDC/GSL TR-10-9 & Apr 2010 & $\begin{array}{l}\text { Large-Scale } 10 \text { CBR Prototype Mat System } \\
\text { Evaluation for the AMX Program, by T.W. } \\
\text { Rushing }\end{array}$ & \\
\hline 1ERDC/GSL TR-10-10 & Apr 2010 & $\begin{array}{l}\text { Development of the Modular Protective } \\
\text { System: Validation of Protection from Direct } \\
\text { Fire, Indirect Fire, and Bare Charge Threats, by } \\
\text { W.F. Heard, R.N. Boone, M.J. Roth, P.G. } \\
\text { Kinnebrew, and B.P. Durst }\end{array}$ & \\
\hline 1ERDC/GSL TR-10-11 & Apr 2010 & $\begin{array}{l}\text { Experimental Results for the Roof Venting } \\
\text { Comparison Series Tests 1-4 and the Roof } \\
\text { Debris Drop Series Tests 1-5, by P.W. Graham, } \\
\text { L.D. Garrett, and G.E. albritton }\end{array}$ & \\
\hline 1ERDC/GSL TR-10-12 & May 2010 & $\begin{array}{l}\text { Development of a Simplified Embankment } \\
\text { Cratering Model, by L.K. Davis }\end{array}$ & \\
\hline 1ERDC/GSL TR-10-13 & May 2010 & $\begin{array}{l}\text { X-FLEXTM Retrofit: Results from Full-Scale } \\
\text { Explosive Experiments, by C.F. Johnson, D.R. } \\
\text { Coltharp, J.L. Davis, and P.G. Kinnebrew }\end{array}$ & \\
\hline ERDC/GSL TR-10-14 & Jun 2010 & $\begin{array}{l}\text { Certification Tests on Cold Patch Asphalt } \\
\text { Repair Materials for Use in Airfield Pavements, } \\
\text { by M. Mejías-Santiago, F. del Valle-Roldán, and } \\
\text { L.P. Priddy }\end{array}$ & ADA523874 \\
\hline
\end{tabular}

1 Limited distribution; see Preface. 
1ERDC/GSL TR-10-15 Jun 2010

1ERDC/GSL TR-10-16 Jun 2010

1ERDC/GSL TR-10-17 Jun 2010

1ERDC/GSL TR-10-18 Jun 2010

ERDC/GSL TR-10-19 Jun 2010

1ERDC/GSL TR-10-20 Jul 2010

1ERDC/GSL TR-10-21 Jul 2010

1ERDC/GSL TR-10-22 Jul 2010

1ERDC/GSL TR-10-23 Jul 2010

1ERDC/GSL TR-10-24 Aug 2010
Tactical Wheeled Vehicle Survivability:

Construction and Characterization of Dry Sand Testbeds in Bare Charge Experiments, by J.Q. Ehrgott Jr., E.M. Williams, J.E. Windham, S.A. Akers, M.D. Adley, S.S. Graham, and P.A. Reed

Tactical Wheeled Vehicle Survivability: Construction and Characterization of Intermediate-Air-Voids, Silty Sand Testbeds in Bare Charge Experiments, by J.Q. Ehrgott Jr., E.M. Williams, J.E. Windham, S.A. Akers, M.D. Adley, S.S. Graham, P.A. Reed and T.A. Waddell

Tactical Wheeled Vehicle Survivability: Construction and Characterization of Wet Clay Testbeds in Bare Charge Experiments, by J.Q. Ehrgott Jr., E.M. Williams, J.E. Windham, S.A. Akers, M.D. Adley, S.S. Graham, and P.A. Reed

Experimental and Computational Study of Damage to Navigation Lock Walls from WaterSide Attack, Fiscal Year 2007 Program, by G.W. McMahon, J.L. O'Daniel, R.E. Walker, and C.T. Sullivan

Field Testing and Load Rating of the World's First Thermoplastic Bridge: Bridge T-8518, Camp Mackall, Fort Bragg, North Carolina, by B. Commander and H. Diaz-Alvarez

Field Evaluation of the Navy Foam Dispenser for Threat Munition Crater Repair, by J.D. Kyzar, L.P. Priddy, and J.F. Rowland

Centrifuge Model Tests of Blast Effects on Gravity Dams, by W. Vanadit-Ellis, L.K. Davis, and R.E. Walker

Experimental and Computational Study of Damage to Navigation Lock Walls from WaterSide Attack, Fiscal Year 2009 Program, by C.T. Sullivan, J.L. O'Daniel, R.E. Walker, T.L. Bevins and T.S. Oesch

Physical Properties of Disturbed Soils, by E.S. Berney, IV and C. Roig-Silva

Underground Reservoir Damage Model for the BVA Tool, by J.A. Rullan-Rodriguez, R.E. Walker, W.M. Hossley, and G.W. McMahon
ADB360756

ADB360830

ADB360757 


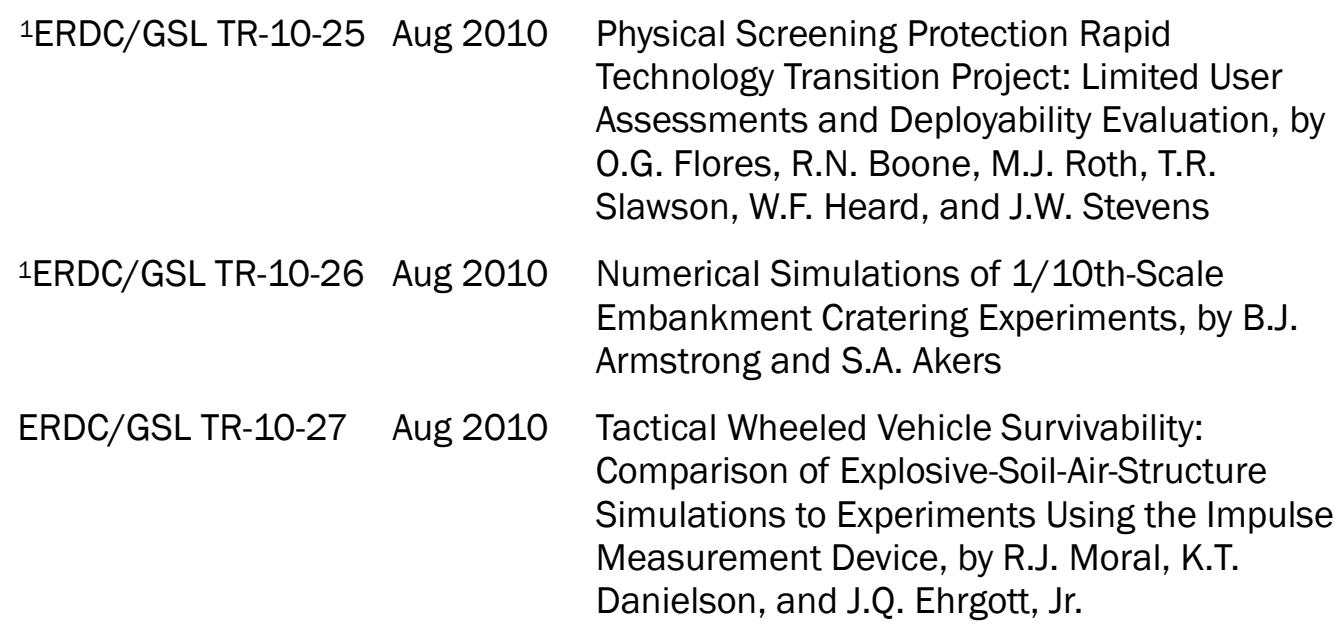

1ERDC/GSL TR-10-28 Aug 2010

1ERDC/GSL TR-10-29 Aug 2010

1ERDC/GSL TR-10-30 Aug 2010

ERDC/GSL TR-10-31 Aug 2010

1ERDC/GSL TR-10-32 Aug 2010

1ERDC/GSL TR-10-33 Sep 2010

ERDC/GSL TR-10-34 Sep 2010
Investigation into the Material Requirements for Mitigation of Indirect Fire Fragmentation from 82-mm and 120-mm Mortars, by M.J. Roth, R.D. Stinson, T.K. Cummins, B.P. Durst, and P.G. Kinnebrew

Investigation into the Effectiveness of Airblast Initiation of Point-Detonating Mortar Fuzes: Scoping Calculations and Proof-of-Concept Experiments, by T.E. McGill, T.K. Cummins, N.R. Boone, M.J. Roth, T.R. Slawson, B.P. Durst, and P.G. Kinnebrew

An Engineering Synthesis of Bridge Load Capacities Within the Country of Turkey, by R.D. Whitlow, W.N. Marianos, Jr., and J.C. Ray

Controlling Sulfate Attack in Mississippi ADA529748 Department of Transportation Structures, by C.A. Weiss, Jr., M.C. Sykes, T.S. Poole, J.G. Tom, B.H. Green, B.D. Neeley, and P.G. Malone

Development of a Simplified Blast Damage Prediction Model for Gravity Dams, by L.K. Davis

Physical Screening Protection Rapid Technology Transition Project: Direct and Indirect Fire Performance Evaluation, by O.G. Flores, R.N. Boone, M.J. Roth, T.R. Slawson, W.F. Heard, and R.E. Magee, Jr.

Advanced Airfield Damage Repair Equipment Testing, by M.C. Edwards
ADA539413 
1ERDC/GSL TR-10-35 Sep 2010 Mobility Performance Test Results for a Segmented Rubber Band Track Concept at 29 Tons Gross Vehicle Weight, by J.D. Priddy and B.W. Towne

1ERDC/GSL TR-10-36 Sep 2010

X-FLEX ${ }^{\text {TM }}$ Retrofit: Results from Subscale Static and Dynamic Experiments, by C.F. Johnson, J.L. Davis, D.R. Coltharp, B.P. Durst and L.L. Smith

ERDC/GSL TR-10-37 Sep 2010

Load Rating of the Lahontan Arch Spillway Bridge at Fallon, NV, by H. Díaz-Álvarez and O. Carrasquillo-Franco

ERDC/GSL TR-10-38 Sep 2010

Laboratory and Field Evaluation of Dust Abatement Products for Expedient Helipads, by L. Edwards, J.S. Tingle, and Q. Mason

1ERDC/GSL TR-10-41 Sep 2010

Numerical Simulations of Embankment Dam Cratering Effects, by B.J. Armstrong, E. Ruiz, S.A. Akers, and R.J. Moral

1ERDC/GSL TR-10-42 Sep 2010

Experimental Results for Bimodal Droplet Test Series: Tests 1-20 and PT1, by P.W. Graham, G.E. Albritton and L.W. Stockham

1ERDC/GSL TR-10-43 Sep 2010

Numerical Simulations of Gravity Dams Subjected to Underwater Explosive Attacks, by R.S. Browning IV, J.L. O'Daniel, and R.E. Walker

ERDC/GSL TR-10-44 Oct 2010

1ERDC/GSL TR-10-45 Oct 2010

Emergency Gap Closures, by J.A. Padula, D.D. Abraham, and K.L. Haskins

Development of Damage Prediction Models for Navigation Locks and Spillways, by J.A. RullanRodriguez, W.M. Hossley, and R.E. Walker

ERDC/GSL TR-10-46 Oct 2010

Laboratory Investigation of the Characterization of Cor-Tuf Flexural and Splitting Tensile Properties, by M.J. Roth, T.S. Rushing, O.G. Flores, D.K. Sham, and J.W. Stevens

ERDC/GSL TR-10-48 Nov 2010

Field Testing and Load Rating of a Short-Span Thermoplastic Bridge System, Bridge T-8519, by B. Commander and H. Diaz-Alvarez

1ERDC/GSL TR-10-49 Nov 2010

Characterization of Near-Surface Soils from the GM1 Afghanistan Site, by H.B. Beatty, S.S. Graham, P.A. Reed, S.A. Akers, M.D. Adley, E.M. Williams, and J.E. Windham
ADA531953

ADA530105

ADA531863

ADA532411

ADB365722

1 Limited distribution; see Preface 
1ERDC/GSL TR-10-50 Nov 2010

ERDC/GSL TR-10-51 Nov 2010

ERDC/GSL TR-10-52 Dec 2010

1ERDC/GSL TR-10-54 Dec 2010

ERDC/GSLTR-10-54 Dec 2010

1ERDC/GSL TR-11-1 Jan 2011

1ERDC/GSL TR-11-2 Jan 2011

Physical Screening Protection Rapid Technology Transition Project: Bare Charge Performance Evaluation, by O.G. Flores, R.N. Boone, M.J. Roth, T.R. Slawson, W.F. Heard, and J.W. Stevens

The Advanced Fundamental Concrete (AFC) Model, by M.D. Adley, A.O. Frank, K.T. Danielson, S.A. Akers, and J.L. O'Daniel

Load Rating of Rock Island Bridge 00275, by S.B. Garner and H. Diaz-Alvarez

Numerical Simulations of Embankment Cratering Mitigation Methods, by S.A. Akers, R.J. Moral, N.T. Williams, and A.O. Frank

Performance Validation of CENTCOM Nonstandard Rood Designs Exposed to Indirect Fire Weapons' Effects, by P.M. Kieffer and B.W. Bullock

Live-Flight Certification Testing of Deployable Crater Repair Technologies, by L.P. Priddy, T.W. Rushing and J.S. Tingle

Development and Testing of Mitigation Measures for Damage to Earthen Embankments from Explosive Attack: Results from Screening Experiments, by R.G. Rhett, Jr., D.D. Rickman, and J.W. Hall, III

1ERDC/GSL TR-11-3 Feb 2011 The Geological Component of Subsurface Construction in Central and Western Asia: Islamabad, Pakistan; Baghdad, Iraq; Tehran, Iran; and Kabul, Afghanistan, by B.D. Haugen and L.D. Wakeley

1ERDC/GSL TR-11-5 Feb 2011 Construction, Quality Control, and

ADB402711 Characterization of ATC Testbed Soil, by J.Q. Ehrgott, Jr., R.G. Rhett, Jr., A.J. Johnston, C.D. Walters, H.B. Beatty, P.A. Reed, M.D. Adley, and J.E. Windham

1ERDC/GSL TR-11-6 Feb 2011 Development and Optimization of Contact Charges to Produce Cleared Openings in Reinforced Concrete Walls, by T.W. Shelton, J.Q. Ehrgott, Jr., D.D. Rickman, and S.A. Akers

\footnotetext{
1 Limited distribution; see Preface.
} 
1ERDC/GSL TR-11-7 Feb 2011 Live-Flight Certification Testing of CRATR Technologies, Avon Park Air Force Range, Florida, by L.P. Priddy, J.R. Griffin, and J.S. Tingle

ERDC/GSL TR-11-8 Mar 2011 Brick Paving Systems in Expeditionary Environments: Laboratory Testing, by $\mathrm{H}$. Bell

1ERDC/GSL TR-11-9 Mar 2011 Evaluation of the Tri-Max 280 Fire Suppression System Against Class A Grass and Brush Fires, by P.G. Bly and J.S. Tingle

1ERDC/GSL TR-11-10 Mar 2011 Relationship Between Composition Properties and High-Pressure Properties Used for Constitutive Modeling of Earthen Dams, by E. Ruiz, J.E. Windham, S.A. Akers, and O. Carrasquillo

1ERDC/GSL TR-11-11 Mar 2011 Rep. 1

Validation of Numerical Modeling and Analysis of Steel Bridge Towers Subjected to Blast Loadings. Report 1: Series 1 tests, by R.E. Walker, J.C. Ray, L.A. Walker, and J.K. Minor

1ERDC/GSL TR-11-11 Mar 2011 Validation of Numerical Modeling and Analysis Rep. 2 of Steel Bridge Towers Subjected to Blast Loadings. Report 2: Series 2 tests, by R.E. Walker, J.C. Ray, L.A. Walker, and J.K. Minor

1ERDC/GSL TR-11-11 Mar 2011 Validation of Numerical Modeling and Analysis Rep. 3 of Steel Bridge Towers Subjected to Blast Loadings. Report 3: Series 3 tests, by R.E. Walker, J.C. Ray, L.A. Walker, and J.K. Minor

1ERDC/GSL TR-11-11 Mar 2011 Rep. 4

Validation of Numerical Modeling and Analysis of Steel Bridge Towers Subjected to Blast Loadings. Report 4: Series 4 tests, by R.E. Walker, J.C. Ray, L.A. Walker, and J.K. Minor

1ERDC/GSL TR-11-12 Mar 2011 Small-Scale Prototype Mat System Evaluation for the AMX Program: Second Developmental Test of Prototype Mat Systems, by T.W. Rushing, H.P. Bell, and J.S. Tingle

ERDC/GSL TR-11-13 Apr 2011

Development of Laboratory Testing Criteria for Evaluating Cementitious, Rapid-Setting Pavement Repair Materials, by L.P. Priddy

1ERDC/GSL TR-11-14 Apr 2011

Physical Screening Protection Rapid Technology Transition Project: Shoulder-Fired Rocket Performance Evaluation, by O.G. Flores. R.N. Boone, M.J. Roth, T.R. Slawson, W.F. Heard, and R.W. Wayne 
1ERDC/GSL TR-11-15 Apr 2011

1ERDC/GSL TR-11-16 Apr 2011

1ERDC/GSL TR-11-17 Apr 2011

1ERDC/GSL TR-11-18 May 2011

1ERDC/GSL TR-11-19 May 2011

1ERDC/GSL TR-11-20 May 2011

1ERDC/GSL TR-11-21 May 2011

1ERDC/GSL TR-11-22 Jun 2011

ERDC/GSL TR-11-24 Aug 2011

ERDC/GSL TR-11-25 Aug 2011
Field Evaluation of Threat Munition Crater Repairs for Enduring Route Remediation, by L.P. Priddy, J.S. Tingle, J.D. Kyzar, and J. Rowland

Characterization of Near-Surface Soils from GA1 Afghanistan Site, by H.B. Beatty, S.S. Graham, P.A. Reed, S.A. Akers, M.D. Adley, and J.E. Windham

Characterization of Near-Surface Soils from the GB1 Afghanistan Site, by H.B. Beatty, S.S. Graham, P.A. Reed, S.A. Akers, M.D. Adley, T.A Waddell, and J.E. Windham

Experimental Results for the Accuracy of Mass Out-Flow Determined by Sampling: Phase 1 Test Series: Tests 1-15, by P.W. Graham, S.C. Foster, G.E. Albritton, L.W. Stockham, and W.R. Seebaugh

Characterization of Near-Surface Soils from the GS1 Afghanistan Site, by H.B. Beatty, S.S. Graham, P.A. Reed, S.A. Akers, M.D. Adley, and J.E. Windham

\section{Long-Term Performance Evaluation of Asphalt} Surface Treatments: Year One Evaluations, by A.J. Falls and J.F. Rushing

Characterization of Near-Surface Soils from the GT1 Afghanistan Site, by H.B. Beatty, S.S. Graham, P.A. Reed, S.A. Akers, M.D. Adley, and J.E. Windham

PARALLAX PLUS: Follow-on Testing of the Response of the PARALLAX Earthen Embankment to Explosive Attacks, by D.D. Rickman, R.G. Rhett, Jr., and J.W. Hall, III

Evaluation of Bridges Subjected to Military Loading and Dynamic Hydraulic Effects: Review of Design Regulations, Selection Criteria, and Inspection Procedures for Bridge Railing Systems, by A.M. Figueroa, E. Negrón, G. Portela, R.N. González-Rivera, H. DíazÁlvarez, and G.I. Velázquez

ADA548121
ADB371347

ADB370538

ADB370561

ADB371339

\author{
AD
}

Remote Detection of Ultra-Light Aircraft (ULAC): Persistent Ground Detection of Ultra Light Aircraft, by M. McKenna, C.P. Simpson, J. Dibiase, J. McKenna, P. Ainsleigh, and S. Sloan 
ERDC/GSL TR-11-26 Aug 2011 The High-Rate-Brittle (HRB) Microplane

Concrete Model, by A.O. Frank, M.D. Adley, K.

Danielson, J. O'Daniel, and C. Ertle

ERDC/GSL TR-11-27 Aug 2011 Minimum Thickness Requirements for Asphalt

Surface Course and Base Layer in Airfield

Pavements, by W.R. Barker, A. Bianchini, E.R.

Brown, and C.R. Gonzalez

ERDC/GSL TR-11-28 Aug 2011 Influence of Soil Properties on the

Aboveground Blast Environment from a Near-

5urface Detonation, by J.Q. Ehrgott, Jr.

ERDC/GSL TR-11-29 Aug 2011 Laboratory Characterization of Talley Brick, by

H.B. Beatty, S.S. Graham, E.M. Williams, and

P.A. Reed

1ERDC/GSL TR-11-30 Aug 2011

Characterization of Near-Surface Soils from the GQ1 Afghanistan Site, by H.B. Beatty, S.S.

Graham, P.A. Reed, S.A. Akers, M.D. Adley, and J.E. Windham

1ERDC/GSL TR-11-31 Aug 2011

Characterization of the Near-Surface Soil

ADB372959

Backfill from the CUL1 Dormant Thunder

Trench, by H.B. Beatty, S.S. Graham, P.A. Reed, S.A. Akers, M.D. Adley, T.A. Waddell, and J.E. Windham

1ERDC/GSL TR-11-32 Aug 2011 Characterization of Near-Surface Soils from the GH1 Afghanistan Site, by H.B. Beatty, S.S. Graham, P.A. Reed, S.A. Akers, M.D. Adley, and J.E. Windham

ADA549201

ADB372960

ADB372966

$\begin{array}{rrr}\text { ERDC/GSL TR-11-33 Sep } 2011 & \begin{array}{l}\text { Analysis and Load Rating of Pre-flex Composite } \\ \text { Beams, by G. Portela, U. Barajas, and J.A. }\end{array}\end{array}$

ADA550595 Albarran-Garcia

1ERDC/GSL TR-11-34 Sep 2011 Intermediate Scale Gravity Dam Test Plan Investigation and Numerical Modeling Support, by J.L. O'Daniel, R.S. Browning, and R.E. Walker

ERDC/GSL TR-11-35 Sep 2011 A Multiscale Meshfree Approach for Modeling Fragment Penetration into Ultra High-Strength Concrete, by J.S. Chen, S.W. Chi, C.H. Lee, S P. Lin, C. Marodon, M.J. Roth, and T.R. Slawson

ADA548938

1ERDC/GSL TR-11-36 Sep 2011 Field-Prepared Rapid-Setting Concretes: Phase I, Laboratory Testing, by B.A. Williams, L.P.

Priddy, and P.G. Bly

1ERDC/GSL TR-11-37 Sep 2011 Large-Scale 6-CBR Prototype Mat System

Evaluation for the AMX Program, by T.W.

Rushing, L. Garcia, and Q.S. Mason

1 Limited distribution; see Preface. 
ERDC/GSL TR-11-38 Sep 2011 An Evaluation of the Effect of Soil Parameters on Explosive Cratering: Results and Analyses of Intermediate-Scale Tests, by D.D. Rickman, R.G. Rhett, Jr., S.A. Akers, J.W. Hall, III, and J.E. Windham

1ERDC/GSL TR-11-39 Oct 2011

Numerical Modeling of Impulse Measurement Device Tests Involving a Clay Backfill (Tests BM-C-01 through -05), by G.C. Bessette and J.R. Britt

1ERDC/GSL TR-11-40 Oct 2011

Assessment of the Vulnerability of Cable Bundles of Cable-Stayed Bridges to Explosive Threats, by V.P. Chiarito, J.C. Ray, P. Papados, C.P. Rabalais, T.G. Coleman, P.J. O'Connor, and E.M. Weinstein

ERDC/GSL TR-11-41 Sep 2011

Evaluation of Nondestructive Methods for Determining Pavement Thickness, by L. Edwards and Q. Mason

ERDC/GSL TR-11-42 Nov 2011

Device Comparison for Determining Field Soil Moisture Content, by E.S. Berney IV, J.D. Kyzar, and L.O. Oyelam

1ERDC/GSL TR-11-43 Nov 2011 Rep. 1

1ERDC/GSL TR-11-43 Apr 2012 Rep. 2

1ERDC/GSL TR-12-1 Jan 2012 Rep. 1

1ERDC/GSL TR-12-2 Jan 2012

ERDC/GSL TR-12-3 Feb 2012 Rev. Dec 2013
Culvert End Treatments for the Denial of Culvert-Emplaced IEDs. Report 1: Investigation of Type I, II, and III Denial Devices, by K.L. Haskins, J.C. Ray, C.J. Eckert, S.P. Rowell, J.R. McKenna, and M.D. O'Neill

Culvert End Treatments for the Denial of Culvert-Emplaced IEDs. Report 2: Investigation of Type 1A Denial Devices, by K.L. Haskins, J.C. Ray, J.R. McKenna, and M.D. O'Neill

Asphalt Surfce Treatments. Report 1: Product Placement and Evaluation, by J.F. Rushing, W.D. Hodo, A.J. Falls, and C.B. Andrews

Mitigation of Hand-Emplaced Threats to Steel Cables and Structural Steel Members, by J.C. Ray, V.P. Chiarito, and S.L. Kinnebrew

Evaluation of Warm-Mix Asphalt Technologies for Use on Airfield Pavements, by M. MejíasSantiago, J.D. Doyle, I.L. Howard, and E.R. Brown
ADA552103

ADA552792

ADB387969

ADA590558

\footnotetext{
1 Limited distribution; see Preface.
} 
1ERDC/GSL TR-12-6 Mar 2012 Development of the Modular Protective System Overhead Cover: Evaluation and Validation of Protection from Indirect-Fire Threats, by O.G. Flores, O. Esquilin-Mangual, R.N. Boone, D.K. Sham, J.A. Sherburn, D.H. Nelson, W.F. Heard, T.R. Slawson, and M.J. Roth

1ERDC/GSL TR-12-7 Mar 2012

Development and Testing of Innovative Repair Materials for Blast Mitigation Application on Navigation Lock Walls: Use of Shock-Absorbing Concrete (SACON®), by C.A. Weiss, Jr., R.W. Haskins, B.E. Walker, B.H. Green, B.H.

Sherwin, J. Morson, and K.E. Walker

1ERDC/GSL TR-12-8 Mar 2012

Vulnerability of Reinforced Concrete CableStayed Bridge Tower Walls to Vehicle-Borne Improvised Explosive Devices. Test Series 1, Baseline Vulnerability Tests, by V.P. Chiarito, J.K. Minor, R.E. Walker, J.C. Ray, D.C. Guynes, and S.A. Kiger

ERDC/GSL TR-12-9 Mar 2012 Defining Soil Materials for 3-D Models of the Near Surface: Preliminary Findings, by C. RoigSilva, B.D. Haugen, and L.D. Wakeley

1ERDC/GSL TR-12-10 Mar 2012

An Elastic-Plastic Material Model for Concrete under High Rate Impulsive Loads: Modeling, Implementation, and Testing of the High Rate Brittle (HRB) Concrete Model, by A.O. Frank

1ERDC/GSL TR-12-11 Mar 2012

Field Prepared Rapid-Setting Concretes: Phase II, Field Testing, by L.P. Priddy, P.G. Bly, J.F. Rowland, and B.A. Williams

1ERDC/GSL TR-12-12 Mar 2012

Long-Term Performance Evaluation of Asphalt Surface Treatments: Year Two Evaluations, by A.J. Falls and J.F. Rushing

ERDC/GSL TR-12-13 Mar 2012

Structure-Property Relationships of Steel Cylindrical Shells, by R.G. Hidalgo-Hernandez, P.G. Allison, B.A. Williams, L.A. de Béjar, W.S. Hart, and J. Morson

1ERDC/GSL TR-12-14 Apr 2012

Evaluation of WebCore Prototype AMX Mat System, by L. Garcia, T.W. Rushing, and Q.S. Mason

Pavement-Transportation Computer Assisted Structural Engineering (PCASE) Implementation of the Modified Berggren (ModBerg) Equation for Computing the Frost Penetration Depth within Pavement Structures, by A. Bianchini and C.R. Gonzalez

ADB379136

ADB392015

ADB385956

ADA559001

ADA559915

ADA558519

ADB387970 
ERDC/GSL TR-12-16 Apr 2012

Rep. 1

ERDC/GSL TR-12-16 Dec 2013

Rep. 2

ERDC/GSL TR-12-17 Apr 2012

ERDC/GSL TR-12-18 Apr 2012

1ERDC/GSL TR-12-19 May 2012

ERDC/GSLTR-12-19 May 2012

Performance Evaluation Experiments, by

O.G. Flores, D.K. Sham, C.D. Price, O. Esquilin-

Mangual, B.A. Jones, B.A. Steed, T.E. McGill, M.

Edwards, R.N. Boone, and B.W. Bullock

ERDC/GSL TR-12-20 May 2012

Determining the Effective Modulus of

Subgrade Reaction for Design of Rigid Airfield

Pavements Having Base Layers, by W.R.

Barker, and D.R. Alexander

1ERDC/GSL TR-12-21 Jun 2012

Tactical Wheeled Vehicle Survivability: Results of Experiments to Quantify Effects of Charge

Depth of Burial and Soil Type on Aboveground Impulse, by G.K. Doles, J.Q. Ehrgott Jr., J.R.

Holmes, and J.E. Windham

1ERDC/GSL TR-12-22 Jun 2012

Parametric Study of Innovative Materials Used for Blast Mitigation, by B.W. Foust and T.S.

Oesch

1ERDC/GSL TR-12-23 Jun 2012

Small Scale Tunnel Vulnerability Experiments, by B.W. Foust, J.T. Baylot, R.A. Weed, and T.S. Oesch

ERDC/GSL TR-12-24 Jul 2012

Brick Paving Systems in Expeditionary Environments: Field Testing, by H.P. Bell and Q. Mason

1ERDC/GSL TR-12-25 Jul 2012
Structured-Materials (Struc'dMats) Design Concept and Its Application for Protective Structures Panels: Blast and Sequenced Ballistic-Blast Testing, by BP. DiPaolo, C.F. Johnson, B.H. Green, W.S. Hart, R.E. Magee, and B.A. Robbins
ADB382394

ADB392165

ADB392122

ADA571165

ADB392240

\footnotetext{
1 Limited distribution; see Preface.
} 


\begin{tabular}{|c|c|c|c|}
\hline ERDC/GSL TR-12-26 & Jul 2012 & $\begin{array}{l}\text { Laboratory Characterization of Adobe } \\
\text { (Scottsdale), by H.B. Beatty, S.S. Graham, R.E. } \\
\text { Moxley, S.A. Akers, and P.A. Reed }\end{array}$ & ADA564210 \\
\hline ERDC/GSL TR-12-28 & Aug 2012 & $\begin{array}{l}\text { Patterned Non-affine Motion in Granular } \\
\text { Media, by J.F. Peters and L.E. Walizer }\end{array}$ & \\
\hline 1ERDC/GSL TR-12-29 & Aug 2012 & $\begin{array}{l}\text { A Route Corridor Flood Vulnerability System, by } \\
\text { G.B. McKinley, M.L. Follum, M.R. Jourdan, G.L. } \\
\text { Mason, C.W. LaHatte, and J.D. Ellis }\end{array}$ & ADB392141 \\
\hline ERDC/GSL TR-12-30 & Aug 2012 & $\begin{array}{l}\text { Modeling Nanomechanical Behavior of } \\
\text { Calcium-Silicate-Hydrate, by M.Q. Chandler, J.F. } \\
\text { Peters, and D. Pelessone }\end{array}$ & ADA572605 \\
\hline 1ERDC/GSL TR-12-31 & Aug 2012 & $\begin{array}{l}\text { Penetration Modeling and Simulation of a } \\
\text { Shoulder-Fired Munition Using the High Rate } \\
\text { Brittle (HRB) Concrete Model, by A.O. Frank } \\
\text { and R.E. Moxley }\end{array}$ & ADB382834 \\
\hline 1ERDC/GSL TR-12-32 & Sep 2012 & $\begin{array}{l}\text { Evaluation of Faun Aluminum Mat Systems, by } \\
\text { T.W. Rushing, L. Garcia, and Q.S. Mason }\end{array}$ & \\
\hline 1ERDC/GSL TR-12-33 & Nov 2012 & $\begin{array}{l}\text { Measurement of Close-In Airblast Pressures } \\
\text { and Impulses Resulting from the Detonation of } \\
\text { Homemade Explosives, by T.S. Oesch, J.R. } \\
\text { Britt, B.E. Walker, G.C. Bessette, and G.W. } \\
\text { McMahon }\end{array}$ & ADB388137 \\
\hline
\end{tabular}

1ERDC/GSL TR-12-34 Dec 2012 Rogue Wave: Scale-Model Studies of Explosive Attacks on Water-Backed Type II Levees, by D.D. Rickman and R.G. Rhett, Jr.

1ERDC/GSL TR-12-35 Dec 2012 Initial Testing of the Loci-Blast Code for Practical Airblast Applications, by G.C. Bessette and J.R. Britt

ERDC/GSL TR-12-36 Dec 2012 User's Manual for Nonlinear Meshfree Analysis

ADB387353 Program (NMAP) Version 1.0, by S.W. Chi, C.H. Lee, J.S. Chen, M.J. Roth, and T.R. Slawson

ERDC/GSL TR-12-37 Dec 2012 Structural, Material, and Geotechnical ADA576155 Solutions to Levee and Floodwall Construction and Retrofitting - Physical Modeling, by W. Vanadit-Ellis, E.W. Smith, L.T. Lee, and J.S. Case

ERDC/GSL TR-13-1 Jan 2013 Methodology for Scour Evaluation of US Army Installation Bridges: A Proposed Evaluation for ADA576130 Scour Risk and Channel Instability, by D. Suazo-Davila, W. Silva-Araya, and J. RiveraSantos 
1ERDC/GSL TR-13-3 Mar 2013 Arc-of-Instability and Combatant Command Terrain Geostatistics and Ground Vehicle Mobility Predictions, by E.A. Baylot, M.T. Stevens, J.A. Patterson, G.M. Brandon, and J.G. Green 1ERDC/GSL TR-13-4 Mar 2013 $\begin{aligned} & \text { Physical Property Influence on Ballistic } \\ & \text { Resistance of Ultra-High Performance Concrete }\end{aligned}$ Panels, by J.F. Burroughs, T.S. Rushing, N. Boone, and R.E. Magee, Jr.

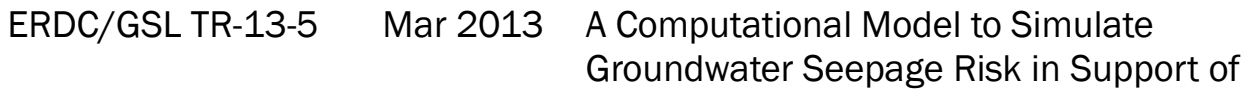
Geotechnical Investigations of Levee and Dam Projects, by B.T. Yuill and C.M. Roig-Silva

ERDC/GSL TR-13-6 Mar 2013

Non-Nuclear Alternatives to Monitoring Moisture-Density Response in Soils, by E.S. Berney IV, M. Mejías-Santiago, and J.D. Kyzar

ERDC/GSL TR-13-7 Apr 2013

Investigation of Lift Bonding for RollerCompacted Concrete with Low Normal Loads at Variable Placement Times, by B.A. Williams, B.H. Green, R.A. Andreatta, J.A. Morson, M.K. Taylor, K.E. Walker, D.E. Wilson, and W.S. Hart

ADB391078

ADA583073

ADA583071

ADA583065

1ERDC/GSL TR-13-8 Apr 2013 Long-Term Performance Evaluation of Asphalt Surface Treatments: 2012 Inspections, by J.F. Rushing, A.J. Falls, and C.B. Andrews

ERDC/GSL TR-13-9 Apr 2013 Virtual Material Laboratory (VML), Version 1.0: Applications to Advanced Fundamental Concrete (AFC) Model, by M.D. Adley, K.T. Danielson, and A.O. Frank

1ERDC/GSL TR-13-10 Apr 2013 AM2 Sand Subgrade Sensitivity Test, by L. Garcia nd T.W. Rushing

ADB392060

1ERDC/GSL TR-13-11 Apr 2013

Development of a Safety Factor (SF) Graph for a Damaged and Undamaged Modular Protective System (MPS) Frame Under MPS Overhead Cover (MPS-OHC) Vertical Loads, by O. Esquilin-Mangual, O.G. Flores, D.K. Sham, J. Roberts, W.J. McCleave, R.N. Boone, and T.R. Slawson

1ERDC/GSL TR-13-12 Apr 2013 Underbelly Blast Effects: Results of ShallowBuried 155mm Artillery Shell Experiments, by G.K. Doles, J.Q. Ehrgott, Jr., and J.E. Windham

ADB392140

1 Limited distribution; see Preface. 
1ERDC/GSL TR-13-13 Apr 2013

Effects of Underwater Bubble Jetting on Dam Structures: Big Black Test Site Larger-Scale Tests, by C.T. Sullivan, J.L. O'Daniel, and R.E. Walker

1ERDC/GSL TR-13-14 Apr 2013

M3A1, 40-Ib Shaped Charge Penetration Evaluations, by S.E. Robert, J.Q. Ehrgott, Jr., and J.H. Ellison

ERDC/GSL TR-13-15 Apr 2013

Electromigration and Deposition of Micro-Scale Calcium Carbonate Structures with Controlled Morphology and Polymorphism, by P.G. Allison, R.D. Moser, M.Q. Chandler, O.L. Rodriguez, P.G. Malone, and C.A. Weiss, Jr.

ERDC/GSL TR-13-16 Apr 2013

Synthesis of Carbonate-Based Micro/Nanoscale Particles With Controlled Morphology and Mineralogy, by K. TorresCancel, R.D. Moser, C.A. Weiss, Jr., P.G. Allison, M.Q. Chandler, O.R. Rodriguez, and P.G. Malone

ERDC/GSL TR-13-17 Apr 2013 Techniques to Investigate Impact Damage in Ultra-High Performance Concretes, by R.D. Moser, P.G. Allison, and M.Q. Chandler

1ERDC/GSL TR-13-18 Apr 2013

M42 Dual Purpose Improved Conventional Munition (DPICM) Characterization Study, by C.D. Price, T.R. Slawson, J.A. Sherburn, and J.L. Davis

1ERDC/GSL TR-13-19 May 2013

M31 MCEAGS Sand and Weak Soil Installation Trade Study, by G.J. Norwood

ERDC/GSL TR-13-20 May 2013 Evaluation of a Non-Nuclear Soil Density
Gauge on Fine-Grained Soils, by M. Mejías-
Santiago, E.S. Berney IV, and C.T. Bradley

1ERDC/GSL TR-13-21 Jun 2013

Pendulum Experiments to Investigate Impulse Due to Detonations of Cased and Uncased Charges, by J.E. Payne, J.Q. Ehrgott, Jr., and J.D. Cargile

ERDC/GSL TR-13-22 Jun 2013

Expansive Soil Characterization and ShrinkSwell Behavior Study: Mississippi's Yazoo Clay, by L.T. Lee Jr.

ERDC/GSL TR-13-23 Jun 2013
Laboratory and Field Evaluation of In-Place Asphalt Recycling Technologies for Small Airfield Repair, by M. Mejías-Santiago, W.D. Carruth, J.C. Petermann, and D.H. Hitzelberger
ADB392126

ADA583062

ADA583060

ADA581191

ADA581212

ADB392284

ADA581214

\footnotetext{
1 Limited distribution; see Preface.
} 
ERDC/GSL TR-13-24 Jun 2013

Evaluation of Precast Panels for Airfield

Pavement Repair. Phase 1: System

Optimization and Test Section Construction, by

P.G. Bly, L.P. Priddy, C.J. Jackson, and Q.S.

Mason

ERDC/GSL TR-13-24 Sep 2013
1ERDC/GSL TR-13-25 Jul 2013

(1)

Evaluation of Precast Panels for Airfield

Pavement Repair. Phase 2: Results of Accelerated Pavement Testing, by L.P. Priddy, P.G. Bly, C.J. Jackson, and T.N. Brogdon

Comparative Performance Evaluation of Protective Earth-Filled Revetment Systems, Class II Wall 24-Month Evaluation, by

D.K.Sham, O.G. Flores, B.W. Bullock, and M.J. Roth

1ERDC/GSL TR-13-26 Jul 2013

Comparative Performance Evaluation of Protective Earth-Filled Revetment Systems, Class II Wall 18-Month Evaluation, by

D.K.Sham, O.G. Flores, B.W. Bullock, and M.J. Roth

ERDC/GSL TR-13-27 Jul 2013

1ERDC/GSL TR-13-28 Jul 2013

1ERDC/GSL TR-13-29 Jul 2013

1ERDC/GSL TR-13-30 Jul 2013

ERDC/GSL TR-13-31 Jul 2013

1ERDC/GSL TR-13-32 Jul 2013

1ERDC/GSL TR-13-33 Jul 2013
Full-Scale Evaluation of DuraDeck $\AA$ and MegaDeck ${ }^{\mathrm{TM}}$ Matting Systems, by T.W. Rushing and L. Garcia

Comparative Performance Evaluation of Protective Earth-Filled Revetment Systems, Class II Wall 12-Month Evaluation, by O.G.

Flores, B.W. Bullock, M.J. Roth, and D.K. Sham

Comparative Performance Evaluation of Protective Earth-Filled Revetment Systems, Class II Wall 6-Month Evaluation, by M.J. Roth, B.W. Bullock, O.G. Flores, and D.K. Sham

Comparative Performance Evaluation of Protective Earth-Filled Revetment Systems, by M.J. Roth, B.W. Bullock, and O.G. Flores

Evaluation of the Air Void Analyzer, by P.G. Bly and L.A. Ventorini

Cold Weather Crater Repair Testing at Malmstrom Air Force Base, Montana, by L. Edwards, H.P. Bell, W.D. Carruth, J.R. Griffin, and J.S. Tingle

CRATR Technology Demonstration: Operational Utility Assessment Avon Park Air Force Range, Florida, by L.P. Priddy, J.S. Tingle, J.R. Griffin, M.C. Edwards, and T.J. McCaffrey

ADA582186

ADA585856

ADB392431

ADB391445

ADA583056

ADB392430

ADB392429

ADA583906

ADB392283

ADB392337 
ERDC/GSL TR-13-34 Jul 2013

ERDC/GSL TR-13-35 Aug 2013

paring Production and Placement of Warm-Mix Asphalt to Traditional Hot-Mix Asphalt for Constructing Airfield Pavements, by J.F. Rushing, M. Mejías-Santiago, and J.D. Doyle

ERDC/GSL TR-13-36 Aug 2013

HSLA-V Rebar Dynamic Blast Load Experiment, by S.D. Robert, C.F. Johnson, and S.W. Woodson

1ERDC/GSL TR-13-37 Aug 2013

Occupant-Centric Survivability: Results of Experiments to Quantify Effects of Homemade Explosive Charge Depth of Burial and Soil Type on Above-Ground Impulse, by G.K. Doles, J.Q. Ehrgott, Jr., and J.E. Windham

1ERDC/GSL TR-13-38 Aug 2013

Development of a Blast Damage Estimation Model for Levee Systems, by L.K. Davis and W.M. Hossley

1ERDC/GSL TR-13-39 Oct 2013

CRATR Technology Demonstration: Limited Operational Utility Assessment 2, Tyndall Air Force Base, Florida, by L.P. Priddy, J.S. Tingle, M.C. Edwards, J.R. Griffin, and T.J. McCaffrey

ERDC/GSL TR-13-40 Dec 2013 Analysis of Barge Impact with Bridge Pier, by A.M. Jordan, R.D. Costley, H. Diaz-Alvarez, M.H. McKenna, and C.P. Simpson

ERDC/GSL TR-13-41 Dec 2013 Laboratory Performance Testing of Warm-Mix Asphalt Technologies for Airfield Pavements, by J.D. Doyle, J.F. Rushing, M. Mejías-Santiago, T.J. McCaffrey, L.C. Warnock, and M.K. Taylor

1ERDC/GSL TR-13-42 Dec 2013 Wet Weather Crater Repair Testing at Silver Flag Exercise Site, Tyndall Air Force Base, Florida, by H.P. Bell, L. Edwards, W.D. Carruth, J.S. Tingle, and J.R. Griffin

1ERDC/GSL TR-14-1 Jan 2014 Nuclear Quadrupole Resonance (NQR) Detector Study, by S.E. Robert, D.P. Mclnnis, J.R. Fairley, P.J. Durst, E.S. Berney IV, C.A. Barela, R.D. Ellison, and J.H. Ellison

ERDC/GSL TR-14-2 Jan 2014 Evaluation of Nontraditional Airfield Pavement Surfaces for Contingency Operations, by L.P. Priddy and C.A. Rutland
ADA584018

ADA584033

ADB392534

ADB393913

ADA590740

ADA593915

1 Limited distribution; see Preface. 


\begin{tabular}{|c|c|c|c|}
\hline ERDC/GSL TR-14-3 & Jan 2014 & $\begin{array}{l}\text { Full-Scale Accelerated Pavement Testing of } \\
\text { Warm-Mix Asphalt (WMA) for Airfield } \\
\text { Pavements, by M. Mejías-Santiago, J.D. Doyle, } \\
\text { and J.F. Rushing }\end{array}$ & ADA596027 \\
\hline ERDC/GSL TR-14-4 & Feb 2014 & $\begin{array}{l}\text { An Investigation of Concrete Deterioration at } \\
\text { South Florida Water Management District } \\
\text { Structure S65E, by R.D. Moser, E.R. Gore, C.A. } \\
\text { Weiss Jr., J.E. Mirecki, B.H. Green, and R.V. } \\
\text { Felice }\end{array}$ & ADA595038 \\
\hline 1ERDC/GSL TR-14-5 & Feb 2014 & $\begin{array}{l}\text { Occupant-Centric Survivability: Results of } \\
\text { Experiments to Quantify Effects of Soil } \\
\text { Parameters on Aboveground Impulse, by G.K. } \\
\text { Doles, J.Q. Ehrgott, Jr., and J.E. Windham }\end{array}$ & \\
\hline ERDC/GSL TR-14-6 & Mar 2014 & $\begin{array}{l}\text { CBR-Beta Design Procedure for Aggregate- } \\
\text { Surfaced Airfield Pavements, by A. Bianchini } \\
\text { and C.R. Gonzalez }\end{array}$ & ADA597679 \\
\hline 1ERDC/GSL TR-14-7 & Apr 2014 & $\begin{array}{l}\text { AM2 } 25 \text { CBR Subgrade Sensitivity Test, by L. } \\
\text { Garcia, T.W. Rushing, and Q.S. Mason }\end{array}$ & ADB399299 \\
\hline ERDC/GSL TR-14-8 & Apr 2014 & $\begin{array}{l}\text { Improved Concrete Cutting and Excavation } \\
\text { Capabilities for Crater Repair. Phase 1, by H.P. } \\
\text { Bell, L. Edwards, J.F. Rowland, B. Andrews, Q.S. } \\
\text { Mason, and C.A. Rutland }\end{array}$ & ADA599024 \\
\hline ERDC/GSL TR-14-8 & May 2015 & $\begin{array}{l}\text { Improved Concrete Cutting and Excavation } \\
\text { Capabilities for Crater Repair. Phase 2, by L. } \\
\text { Edwards, H.P. Bell, J.F. Rowland, and C.A. } \\
\text { Rutland }\end{array}$ & ADA618124 \\
\hline 1ERDC/GSL TR-14-9 & Apr 2014 & $\begin{array}{l}\text { UIUC-DARPA Nonlinear Energy Sink Response } \\
\text { to Dynamic Loading Created by Blast, by M.S. } \\
\text { Holmer, A.M. Allen, T.S. Oesch, and G. } \\
\text { Emmanuelli }\end{array}$ & ADB399613 \\
\hline ERDC/GSL TR-14-10 & Apr 2014 & $\begin{array}{l}\text { Validation Tests of a Non-Nuclear Combined } \\
\text { Asphalt and Soil Density Gauge, by E.S. Berney } \\
\text { IV, M. Mejías-Santiago, and J. Beasley }\end{array}$ & ADA600942 \\
\hline ERDC/GSL TR-14-11 & Apr 2014 & $\begin{array}{l}\text { Field Evaluation of Ultra-High Pressure Water } \\
\text { Systems for Runway Rubber Removal, by A.B. } \\
\text { Pullen, L. Edwards, C.A. Rutland, and J.S. } \\
\text { Tingle }\end{array}$ & ADA601902 \\
\hline 1ERDC/GSL TR-14-12 & Apr 2014 & $\begin{array}{l}\text { Evaluation and Demonstration of Systems for } \\
\text { Defeat of a High-Velocity Penetrator: Focus } \\
\text { Area } 1 \text { Single-Layer Systems and Focus Area } 4 \\
\text { Multi-Layer Systems, by M.I. Hammons, J.A. } \\
\text { Sherburn, J.K. Minor, W. Myers, J.G. Averett, } \\
\text { and O. Flores-Perez }\end{array}$ & ADB400806 \\
\hline
\end{tabular}

1 Limited distribution; see Preface. 
ERDC/GSL TR-14-13 May 2014 Evaluation of Faun MLC-70 Trackway Mat

ADA601345 System Under Simulated F-15 Traffic, by T.W. Rushing, L. Garcia, and Q.S. Mason

ERDC/GSL TR-14-14 May 2014

Geotechnical Centrifuge Experiments to Evaluate Piping in Foundation Soils, by D.A.

ADA602067 Leavell, J.L. Wibowo, D.E. Yule, and R.C. Strange

ERDC/GSL TR-14-15 Jun 2014

Performance of Geogrid-Stabilized Gravel Flexible Base with Bituminous Surface Treatment, by G.J. Norwood and J.S. Tingle

1ERDC/GSL TR-14-16 Jun 2014 Expeditionary Barrier System:

Recommendations on Technical Specifications and First Article Testing, by M.J. Roth, J.F. Burroughs, A.M. Allen, J.L. Williamson, and B.W. Bullock

ERDC/GSL TR-14-17 Jun 2014

Evaluating the Superpave Option in Unified Facilities Guide Specification 32-12-15.13, Hot ADA602781 Mix Asphalt Airfield Paving, by J.F. Rushing, T.J. McCaffrey, and L.C. Warnock

ERDC/GSL TR-14-18 Jun 2014

Analysis of Lightweight Materials for the AM2

ADA602783 System, by P.G. Allison, T.W. Rushing, and L. Garcia

ERDC/GSL TR-14-19 Jun 2014

Emissions Reductions Associated with the Use

ADA602786 of Warm-Mix Asphalt as Compared to Hot-Mix Asphalt, by M. Mejías-Santiago and L.V. Osborn

1ERDC/GSL TR-14-20 Jun 2014

Evaluation of Hardened Aircraft Shelter ADB400787 Baseline Design: Focus Area 0, Weapon Effects Study, by W.S. Myers, Jr., J.G. Averett, R.E. Moxley, A.A. Armstrong, A.J. Burroughs, R.G. Cooper, J.W. Hall, III, J.D. Cargile, B.L. Henry, J.L. Davis, M.I. Hammons, J.A. Sherburn, T.R. Slawson, and T.A. Waddell

1ERDC/GSL TR-14-21 Jun 2014 Mobility Comparison of RG31-A3 MRAP Configurations Operating in Select Areas of Afghanistan, by G.L. Mason, J.G. Green, G.B. McKinley, and J.A. Patterson

1ERDC/GSL TR-14-22 Jun 2014

Millimeter-Wave Command Wire (CW) Phenomenology Study, by J.R. Fairley, S.E. Robert, E.S. Berney IV, R.M. Castellane, L.L. Miller, R.D. Ellison, C.A. Barela, and C.T. Bradley 
ERDC/GSL TR-14-23 Jun 2014

1ERDC/GSL TR-14-24 Jul 2014

1ERDC/GSL TR-14-25 Jul 2014

ERDC/GSL TR-14-26 Jul 2014

ERDC/GSL TR-14-27 Jul 2014

ERDC/GSL TR-14-28 Jul 2014

1ERDC/GSL TR-14-29 Jul 2014

1ERDC/GSL TR-14-30 Jul 2014

1ERDC/GSL TR-14-31 Jul 2014

1ERDC/GSL TR-14-32 Jul 2014

ERDC/GSL TR-14-33 Aug 2014
Geophysical Surveys for Locating Buried

ADA605512

Utilities, Lake Pontchartrain Levees, New Orleans, by J.L. Llopis, J.E. Simms, and G.A. Riddick

Near Field Airblast Characterization of Hydrogen Peroxide/Sucrose Mixtures, by G.

Emmanuelli, B.E. Walker, G.C. Bessette, T.S. Oech, J.R. Britt, S.T. Hardesty, and J.W. Fisher

Mobility Suitability of MRAP Variants in Selected Worldwide Environments, by J.G. Green, M.T. Stevens, A.P. Joshi, and G.L. Mason

Expedient Evaluation of Alkali-Silica Reaction Susceptibility of Aggregates: Characterizing Existing and Exploratory Test Methods, by R.D. Moser, E.R. Gore, O. Rivera, M.A. Ramsey, K. Torres-Cancel, C.A. Weiss Jr., C.A. Rutland, and J.S. Tingle

ADB401511

ADB400772

Development of Envelope Curves for Predicting ADA606867 Void Dimensions from Overturned Trees, by B.A. Robbins, J.L. Wibowo, K.S. Holden, and M.K. Corcoran

Performance of Geogrid-Stabilized Gravel Flexible Pavements, by G.J. Norwood and J.S. Tingle

Soil Analysis and Testing to Support HME-C ADB401313 Program, by J.E. Osorio, B.W. Towne, G.B. McKinley, C.A. Barela, and R.D. Ellison

Enhanced Vehicle Dynamics Module (VehDyn Version 4.3), by G.B. McKinley

ADB401603

Structural Analysis and Design of Seals for Coal Mine Safety, by G.W. McMahon, J.A. Rullán-Rodríguez, M.S. Homer, R.E. Walker, J.L. O'Daniel, J.R. Britt, and R.K. Zipf

Supersonic Pulse-Jet IED Excavator (SPIEDX): Digging Performance Testing and System Development Description, by P.M. Kieffer, R.E. Walker, S.L. Garlington, and R. Butrym

Geophysical Surveys for Detecting Anomalous Conditions, Algiers Canal Levees, New Orleans, Louisiana, by J.L. Llopis and J.B. Dunbar ADA607660

ADB403473

ADf


1ERDC/GSL TR-14-34 Aug 2014 Focus Area 5: Full-Scale Demonstration and

ADB401435

Performance Evaluation, by C.D. Price, J.L.

Williamson, B.A. Jones, M.I. Hammons, T.R.

Slawson, and J.A. Sherburn

1ERDC/GSL TR-14-35 Aug 2014

Effect of Underwater Bubble Jetting on Dam

Structures: Mitigation Tests (Series 1), by S.P.

ADB401344

Rowell, J.L. O'Daniel, K.A. Flournoy, and M.C.

Edwards

1ERDC/GSL TR-14-36 Aug 2014

Laboratory Characterization of Aberdeen Test Center Engineered Roadway Soil, by S.S.

Graham, S.A. Akers, K.J. Ratliff, and T.A.

Waddell

ERDC/GSL TR-14-37 Sep 2014 AM2 100 CBR Subgrade Sensitivity Test, by L. Garcia, T.W. Rushing, B.A. Williams, and C.A. Rutland

ERDC/GSL TR-14-38 Sep 2014 AM2 3-4 Alternate Lay Pattern Evaluation, by

ADA610771

T.W. Rushing, L. Garcia, J.S. Tingle, P.G. Allison, and C.A. Rutland

1ERDC/GSL TR-14-39 Nov 2014 Evaluation of Nanoparticle Polymer Material for High-Strength Culverts. Report 1: Full-Scale Validation Testing, by P.M. Kieffer, R.E. Walker, and A.J. Jackson

1ERDC/GSL TR-14-40 Dec 2014 Route Reconnaissance and Clearance

ADB406523 Advanced Proofing Technology Study, by S.E. Robert, J.E. Osorio, D.P. McInnis, G.B.

McKinley, J.R. Fairley, C.A. Barela, R.D. Ellison, and H.M. Barlow

1ERDC/GSL TR-15-1 Jan 2015 Occupant-Centric Survivability:

ADB403965 Characterization of the OCP-E-SC Testbed Soil, by T.N. Williams, S.A. Akers, S.S. Graham, and K.J. Ratliff

1ERDC/GSL TR-15-2 Jan 2015 The Virtual Material Laboratory (VML), Version

ADB406225 2.0: Applications to the Hybrid Elastic-Plastic (HEP) Material Model, by M.D. Adley, S.A. Akers, N.T. Williams, and K.T. Danielson

1ERDC/GSL TR-15-3 Jan 2015 Numerical Procedures for Capturing Aboveground Impulse from Buried Bare and Cased Explosives Using EPIC, by T.N. Williams, S.A. Akers, and K.T. Danielson

1ERDC/GSL TR-15-4 Feb 2015 Structural Performance of the Modular Protective System (MPS) for Licensing and Acquisition Support, by C.S. Stephens, B.A. Jones, B.A. Williams, and R.N. Boone

ADB403474

ADB401385 


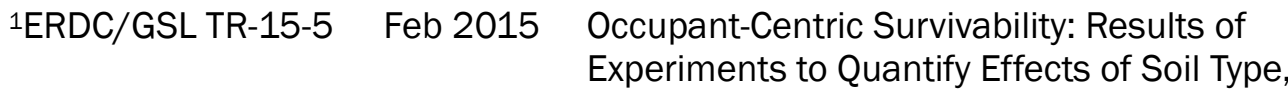
Placement Parameters, and Charge Parameters on Aboveground Impulse, by G.K. Doles, J.Q. Ehrgott, Jr., and J.E. Windham

1ERDC/GSL TR-15-6 Feb 2015

Asphalt Surface Treatments' Impact on ADB405581 Pavement Condition at Army Airfields After Five Years, by J.F. Rushing, A.J. Falls, and C.B. Andrews

ERDC/GSL TR-15-7 Apr 2015

Development of the Deep Truss Overhead Cover Protection System, by K.L. Haskins, M.D. O'Neal, C.P. Vol, T.L. Wetmore, O. EsquilinMangual, and J.C. Ray

1ERDC/GSL TR-15-8 Apr 2015

Development of the Modular Protective System

ADB407035 Overhead Cover: Numerical Model for Dynamic Response Evaluation, by O. Esquilin-Mangual, O.G. Flores, J.A. Sherburn, R.N. Boone, and T.R. Slawson

1ERDC/GSL TR-15-9 Apr 2015

PIRATE MOON: Scale-Model Studies of ADB407481 Explosive Attacks on Water-Backed Type III Levees, by D.D. Rickman and R.G. Rhett, Jr.

ERDC/GSL TR-15-10 May 2015

Evaluation of Precast Portland Cement

ADB408322 Concrete Panels for Airfield Pavement Repairs, by L.P. Priddy

1ERDC/GSL TR-15-11 May 2015

Occupant-Centric Survivability: Characterization of the OCP-A-SC Testbed Soil, by T.N. Williams, S.A. Akers, S.S. Graham, K.J. Ratliff, and J.Q. Ehrgott, Jr

1ERDC/GSL TR-15-12 May 2015 Analysis of Crater Damage to Earthen Levees Using the CTH Computer Code, by B.J. Armstrong and S.A. Akers

ERDC/GSL TR-15-13 Jun 2015

Field Jet Erosion Tests on the Mississippi River Collocated Demonstration Section, Plaquemines Parish, Louisiana, by J.L. Wibowo, P.A. Taylor, B.A. Robbins, and E.W. Smith

ERDC/GSL TR-15-14 Jun 2015

AM2 Opposite Lay Evaluation, by L. Garcia, W. ADA620022 Vanadit-Ellis, T.W. Rushing, J.S. Tingle, and C.A. Rutland

ADA619960 
1ERDC/GSL TR-15-15 Jun 2015

1ERDC/GSL TR-15-16 Jul 2015

1ERDC/GSL TR-15-17 Jul 2015

1ERDC/GSL TR-15-18 Jul 2015

1ERDC/GSL TR-15-19 Jul 2015

1ERDC/GSL TR-15-21 Aug 2015

ERDC/GSL TR-15-22 Aug 2015

ERDC/GSL TR-15-23 Aug 2015

1ERDC/GSL TR-15-24 Jul 2015

1ERDC/GSL TR-15-25 Aug 2015
(U) Examination of Constructability and Performance of the TMPS to VBIED Events. (U)

Report 1, TMPS Construction and Experimental Series 1 (Evaluation as a Protective Space), by J.M. Roberts, C.B. Blount, J.M. Hoemann, and C.R. Ackerman

Hardened Alternative Trailer System. Report 1: Concept Evaluation at Full Scale, by J.M. Roberts, J.M. Hoemann, C.B. Blount, and C.R. Ackerman

MineX3D, An Engineering Model for Predicting Loading on Vehicles from Underbelly Blast, by G.C. Bessette, G. Emmanuelli, and J.T. Baylot

Soft-Soil Vehicle Cone Index Testing with the AAV RAM/RS, by J.E. Osorio, B.W. Towne, J.T. Carrillo, R.D. Ellison, and C.A. Barela

Design and Dynamic Response Evaluation for the Beam Connections of the Modular Protective System - Overhead Cover, by 0.

Esquilin-Mangual, D.K. Sham, O.G. Flores, and C.M. Adorno-Bonilla

Development and Testing of ShrinkageCompensating Grouts for Use at the Nevada National Security Site: U1a Complex, by W.R. Long, M.A. Ramsey, D.A. Scott, R.D. Moser, B.H. Green, and K.E. Walker

Impact of Steel Fiber Size and Shape on the Mechanical Properties of Ultra-High Performance Concrete, by D.A. Scott, W.R. Long, R.D. Moser, B.H. Green, J.L. O'Daniel, and B.A. Williams

Software Implementation of a Polarized Bidirectional Reflectance Distribution Function Model for Ray-Tracing Applications, by J.F. Peters and C. Goodin

Review of Candidate Commercial Explosives for Birds Point-New Madrid Floodway Activation, by C.W. Ertle, L.A. Walker, M.J. Roth, and R.N. Boone

Evaluation of Stabilization Approaches for Compressed Earth Blocks, by T.S. Rushing, J.F. Furroughs, and C.P. Rusche 
ERDC/GSL TR-15-26 Aug 2015

Rep. 1

ERDC/GSL TR-15-27 Aug 2015

ERDC/GSL TR-15-28 Aug 2015

ERDC/GSL TR-15-29 Aug 2015

ERDC/GSL TR-15-30 Aug 2015

ERDC/GSL TR-15-31 Aug 2015

ERDC/GSL TR-15-32 Aug 2015

1ERDC/GSL TR-15-33 Aug 2015

(E)

1ERDC/GSL TR-15-34 Aug 2015

.

1ERDC/GSL TR-15-35 Aug 2015
Unconventional Hydrocarbon Development Hazards Within The Central United States.

Report 1: Overview and Potential Risk to Infrastructure, by O.S. Taylor, A.P. Lester, and T.A. Lee III

Large Crater Repair at Silver Flag Exercise Site, ADA620903 Tyndall Air Force Base, Florida, by W.D.

Carruth, L. Edwards, H.P. Bell, J.S. Tingle, J.R.

Griffin, and C.A. Rutland

AM2 Mat End Connector Modeling and

Performance Validation, by L. Garcia, T.W.

Rushing, Q. Mason, J.S. Tingle, and C.A.

Rutland

Concrete Cutting Refinement for Crater Repair, by H.P. Bell, L.P. Priddy, Q.S. Mason, and C.A. Rutland

\section{AM2 Brickwork Pattern Evaluation with}

Refurbished Matting, by L. Garcia, T.W.

Rushing, and J.S. Tingle

Evaluation of Procedures for Backcalculation of Airfield Pavement Moduli, by L.P. Priddy, A. Bianchini, C.R. Gonzalez, and C.S. Dossett

AM2 Modified 2-1 Lay Pattern Evaluation under F-15E Traffic, by L. Garcia, J. Heiser, T.W. Rushing, C.T. Bradley, J.S. Tingle, and C.A. Rutland

Response of Concrete Specimens to Underwater Explosions: Small-Scale Experiments, by K.A. Flournoy, J.L. O'Daniel, and S.P. Rowell

Soil Testbed Specification, Construction, and Quality Control for Vehicle Underbody Blast Testing, by J.E. Windham, J.Q. Ehrgott, Jr., G.K. Doles, K.T. Danielson, L.N. Lynch, and T.A .Waddell

Modeling the Reactive Burn of Ammonium Nitrate Aluminum (AN/AI 12:1) under ShallowBuried Explosive Detonations: Comparisons with the Impulse Measurement Devise (IMD) Experiments, by A.O. Frank, K.T. Danielson, G.K. Doles, and R.J. Moral
ADA620913

ADA620724

ADA620904

ADA620909

ADA620910

ADA620916

ADB408670

ADB409699

\footnotetext{
1 Limited distribution; see Preface.
} 
1ERDC/GSL TR-15-36 Aug 2015

Testing with Indian Head Oxidizer: 2-Liter
Scale, by M.J. Roth, D.C. Guynes, C.W. Ertle, L.D. Garrett, A.J. Jackson, R.E. Magee, and D.V. Senior

1ERDC/GSL TR-15-37 Oct 2015

Occupant-Centric Survivability: Results of Underbelly Blast Experiments and Simulations on Aboveground Flat-Surface Rigid Structures, by G.K. Doles, N.T. Williams, J.Q. Ehrgott, Jr., S.A. Akers, K.T. Danielson, and J.E. Windham

1ERDC/GSL TR-15-38 Nov 2015

Experimental and Analytical Research on Spillway Gates by J.A. Rullan-Rodriguez, W.H. Hossley, and R.S. Browning

1ERDC/GSL TR-15-39 Nov 2015

Evaluation of Geotextiles for Blast Mitigation of Zoned Embankment Dams: the Fat Boy 6 Experimental Effort for the United States Bureau of Reclamation, by R.J. Moral, A.A. Armstrong, D.D. Rickman, K. Langston, G.H. Sutley, and J. Rohde

1ERDC/GSL TR-15-40 Nov 2015

Mixture Proportioning and Characterization of a 10-15 ksi High-Strength Concrete for Use at the Naval Air Weapons Station, China Lake, California, by W.R. Long, D.A. Scott, S.S. Graham, B.H. Green, K.E. Walker, and C.P. Rusche

1ERDC/GSL TR-15-42 Dec 2015 Effect of Underwater Bubble Jetting on Dam Structures: Mitigation Tests (Series 2), by K.A. Flournoy, J.L. O'Daniel, S.P. Rowell, and M.C. Edwards

1ERDC/GSL TR-15-43 Dec 2015 Occupant-Centric Survivability: Results of Underbody Blast Experiments and Simulations on Aboveground V-Hull Rigid Structures, by G.K. Doles, N.T. Williams, J.Q. Ehrgott, Jr., J.E. Windham, S.A. Akers, J.E. Payne, K.T. Danielson, T.W. Shelton, and A.J. Johnston

ADB410351

ADB410825 


\section{GeoTACS tech notes}

$\begin{array}{lll}\text { Report Number } & \underline{\text { Date }} & \underline{\text { Title }} \\ \text { ERDC/GSL GeoTACS } & \text { Apr 2011 } & \begin{array}{l}\text { Defining 3-D Geologic Architecture and Soil } \\ \text { Variability for Sensor Simulations, by B.D. } \\ \text { TN-11-1 }\end{array} \\ & \text { Haugen, S.W. Broadfoot, L.D. Wakeley, C. Roig- } \\ & \text { Silva, S.G. Bourne, and C.A. Talbot }\end{array}$

ERDC/GSL GeoTACS Apr 2011 Steel-Shot Method for Measuring the Density TN-11-2 of Soils, by C.A. Gartrell, L.D. Wakeley, R.B. Freeman, E.S. Berney, and J.R. Kelley

1ERDC/GSL GeoTACS Jun 2011 TN-11-3

Geologic Setting of a Soil Sampling Site at GM1, Afghanistan, by J.R. Kelley, S.D. Sloan, LTC W.R. Gatewood, and J.R. McKenna

1ERDC/GSL GeoTACS Jun 2011 TN-11-4

Geologic Setting of a Soil Sampling Site at GQ1, Afghanistan, by J.R. Kelley, MAJ B. Borkowiski, LCpl J. Marshall, and J.R. McKenna

1ERDC/GSL GeoTACS Jun 2011 TN-11-5

Geologic Setting of a Soil Sampling Site at GS1, Afghanistan, by J.R. Kelley, S.D. Sloan, LTC W.R. Gatewood, MAJ B. Borkowski, and J.R. Mckenna

1ERDC/GSL GeoTACS Jul 2011 TN-11-6

Preparation of Soils for X-Ray Diffraction, by A.R.M. Berg

ERDC/GSL GeoTACS Jul 2011 TN-11-7

Distinguishing Purposefully Disturbed Soil from Other Anthropogenically and Naturally Modified Soils, by S.W. Broadfoot, J.R. Kelley, E.S. Berney IV, L.D. Wakeley, J.R. McKenna, and C. Roig-Silva

1ERDC/GSL GeoTACS Jul 2011 TN-11-8

Geologic Setting of Fort Carson, Colorado - a Possible Analog for a Site in Afghanistan, by J.R. Kelley, C. Roig-Silva, T.E. Berry Jr., and G.G. Koenig

1ERDC/GSL GeoTACS Jul 2011 TN-11-9

Geologic Setting of a Soil Sampling Site at Baghdad, Iraq, by J.R. Kelley, T.E. Berry Jr., L.D. Wakeley, and J.R. McKenna

1ERDC/GSL GeoTACS Jul 2011 TN-11-10

Geologic Setting of a Soil Sampling Site in the Western Desert, Iraq, by J.R. Kelley, T.E. Berry Jr., L.D. Wakeley, and J.R. McKenna

1ERDC/GSL GeoTACS Aug 2011 TN-11-11

Geologic Setting of a Soil Sampling Site at GA1, Afghanistan, by J.R. Kelley, S.D. Sloan, LTC W.R. Gatewood, MAJ B. Borkowski and J.R. McKenna

1 Limited distribution; see Preface. 
1ERDC/GSL GeoTACS Dec 2011 Geologic Setting of a Soil Sampling Site at

TN-11-12 Umm Qsar, Iraq, by J.R. Kelley, T.E. Berry Jr., L.D. Wakeley, and J.R. McKenna

1ERDC/GSL GeoTACS Dec 2011 Geologic Setting of a Soil Sampling Site at TN-11-13 GH1, Afghanistan, by J.R. Kelley, S.D. Sloan, MAJ B. Borkowski, and J.R. McKenna

ERDC/GSL GeoTACS Sep 2013 Testing Produce for Estimating Fully Softened TN-13-1 Shear Strengths of Soils Using Reconstituted Material, by I. Stephens and A. Branch 


\section{Geotechnical Laboratory (GL)1}

\section{Special reports}

\begin{tabular}{|c|c|c|c|}
\hline Report Number & $\underline{\text { Date }}$ & $\underline{\text { Title }}$ & AD Number \\
\hline 2ERDC/GL SR-00-1 & Feb 2000 & $\begin{array}{l}\text { Airfield Pavement Evaluation, } \\
\text { Wainwright Army Airfield, Fort } \\
\text { Wainwright, Alaska, by P.S. McCaffrey, } \\
\text { Jr., and R.W. Grau }\end{array}$ & ADB252961 \\
\hline ²ERDC/GL SR-00-2 & May 2000 & $\begin{array}{l}\text { Airfield Pavement Evaluation, Campbell } \\
\text { Army Airfield, Fort Campbell, Kentucky, } \\
\text { by R.L. Santoni }\end{array}$ & ADB254567 \\
\hline ²ERDC/GL SR-00-3 & Aug 2000 & $\begin{array}{l}\text { Airfield Pavement Evaluation, Bradshaw } \\
\text { Army Airfield, Pohakuloa Training Area, } \\
\text { Hawaii, by R.W. Grau and P.S. } \\
\text { McCaffrey, Jr. }\end{array}$ & ADB257201 \\
\hline 2ERDC/GL SR-00-4 & Aug 2000 & $\begin{array}{l}\text { Airfield Pavement Evaluation, Wheeler } \\
\text { Army Airfield, Schofield Barracks, Oahu, } \\
\text { Hawaii, by P.S. McCaffrey, Jr. }\end{array}$ & ADB257517 \\
\hline 2ERDC/GL SR-00-5 & Aug 2000 & $\begin{array}{l}\text { Airfield Pavement Evaluation, Bucholz } \\
\text { Army Airfield, Kwajalein Atoll, Marshall } \\
\text { Islands, by R.W. Grau }\end{array}$ & ADB257330 \\
\hline ²ERDC/GL SR-00-6 & Aug 2000 & $\begin{array}{l}\text { Airfield Pavement Evaluation, Dyess } \\
\text { Army Airfield, Roi-Namur, Kwajalein } \\
\text { Atoll, Marshall Islands, by P.S. } \\
\text { McCaffrey, Jr. }\end{array}$ & ADB257409 \\
\hline
\end{tabular}

\section{Technical reports}

$\begin{array}{llll}\text { Report Number } & \underline{\text { Date }} & \underline{\text { Title }} & \text { AD Number } \\ \text { TR GL-99-11 } & \text { Dec 1999 } & \begin{array}{l}\text { A Case History of Embankment failure: } \\ \text { Geological and Geotechnical Aspects of } \\ \text { the Ceoltex Levee Failure, New Orleans, } \\ \text { Louisiana, by J.B. Dunbar, V.H. Torrey III, }\end{array} & \\ & & \text { ADA L.D. Wakeley } & \\ \text { 2ERDC/GL TR-00-1 } & \text { Feb 2000 } & \begin{array}{l}\text { Mobility Evaluation of Czech PA 70 N } \\ \text { HET Trailer With 55-Ton Payload, by }\end{array} & \text { ADB252399 } \\ & & \text { D.W. Moore and R.A. Jones } & \end{array}$

\footnotetext{
1 The Geotechnical Laboratory merged with the Structures Laboratory. See also Geotechnical and Structures Laboratory.

2 Limited distribution; see Preface.
} 


\begin{tabular}{|c|c|c|c|}
\hline ERDC/GL TR-00-2 & Mar 2000 & $\begin{array}{l}\text { Engineering Properties of Resin } \\
\text { Modified Pavement (RMP) for } \\
\text { Mechanistic Design, by G.L. Anderton }\end{array}$ & ADA376263 \\
\hline ERDC/GL TR-00-3 & May 2000 & $\begin{array}{l}\text { Response of Granular Layers in Flexible } \\
\text { Pavements Subjected to Aircraft } \\
\text { Loadings, by D.M. Smith }\end{array}$ & ADA379144 \\
\hline $\begin{array}{l}\text { 1ERDC/GL TR-00- } \\
\text { Rep. } 1\end{array}$ & Jul 2000 & $\begin{array}{l}\text { Mobility Performance Comparison } \\
\text { Between the T130 Steel Link Track and } \\
\text { XT-168 Rubber Band Track on the } \\
\text { M113A2 APC. Report 1, Soft Soil, } \\
\text { Traction, Obstacle Crossing, by J.D. } \\
\text { Priddy and D.W. Moore }\end{array}$ & ADB256695 \\
\hline ERDC/GL TR-00-5 & Aug 2000 & $\begin{array}{l}\text { Biot-Based Geoacoustic Investigation of } \\
\text { Lake Arkabutla, Mississippi, by R.G. } \\
\text { McGee, R.F. Ballard, Jr., and R.L. Leist }\end{array}$ & ADA383169 \\
\hline ERDC/GL TR-00-6 & Aug 2000 & $\begin{array}{l}\text { An Environmental Distress Prediction } \\
\text { Model for Flexible Army Airfield } \\
\text { Pavements, by W.P. Grogan }\end{array}$ & ADA382359 \\
\hline ERDC/GL TR-00-7 & Aug 2000 & $\begin{array}{l}\text { Application of DEM to Micro-Mechanical } \\
\text { Theory for Large Deformations of } \\
\text { Granular Media, by D.A. Horner and J.F. } \\
\text { Peters }\end{array}$ & ADA382942 \\
\hline 1ERDC/GL TR-00-8 & Sep 2000 & $\begin{array}{l}\text { Traction Enhancement Evaluation of the } \\
\text { M88A2 HERCULES, by M.W. Gray }\end{array}$ & ADB258241 \\
\hline ERDC/GL TR-00-9 & Sep 2000 & $\begin{array}{l}\text { Sensor Technology for Weather and } \\
\text { Terrain, by A.W. Harrell }\end{array}$ & ADA383546 \\
\hline ERDC/GL TR-00-10 & Sep 2000 & $\begin{array}{l}\text { Eagle Terrain Preprocessor, by G.B. } \\
\text { McKinley, T.C. Falls, and D.C. Stuart }\end{array}$ & ADA383207 \\
\hline 1ERDC/GL TR-00-11 & Aug 2000 & $\begin{array}{l}\text { Field Test Program: Results from Dual } \\
\text { Crane Load Tests at Drydock I and } \\
\text { Drydock } 2 \text {, Norfolk Naval Shipyard, by } \\
\text { J.A. Harrison and D.R. Alexander }\end{array}$ & ADB259852 \\
\hline
\end{tabular}

1 Limited distribution; see Preface. 


\title{
9 Information Technology Laboratory (ITL)
}

\section{Contract reports}

$\begin{array}{lll}\text { Report Number } & \text { Date } & \text { Title } \\ \text { ERDC/ITL CR-06-1 } & \text { Apr 2006 } & \begin{array}{l}\text { Assessing the Reliability of Highly Redundant Welded Steel } \\ \text { Frame Structures, by T.P. McAllister and B.R. Ellingwood }\end{array}\end{array}$

\section{Letter reports}

$\begin{array}{llll}\text { Report Number } & \text { Date } & \underline{\text { Title }} & \text { AD Number } \\ \text { 1ERDC/ITL LR-12-1 } & \text { Aug 2012 } & \begin{array}{l}\text { One-stop Assessment of Building 4554 Fort } \\ \text { Meade, Maryland, by G.A. Riveros and G.E. De } \\ \text { Jesus }\end{array} & \text { ADB390289 }\end{array}$

\section{Miscellaneous papers}

$\begin{array}{llll}\text { Report Number } & \text { Date } & \text { Title } & \text { AD Number } \\ \text { ERDC/ITL MP-06-1 } & \text { Feb 2006 } & \begin{array}{l}\text { Mesh-Independent Methods for Agent Movement, } \\ \text { by J-R.C. Cheng }\end{array} & \text { ADA47435 }\end{array}$

\section{Special reports}

\begin{tabular}{|c|c|c|}
\hline$\underline{\text { Report Number }}$ & Date & $\underline{\text { Title }}$ \\
\hline ERDC/ITL SR-00-1 & Nov 2000 & $\begin{array}{l}\text { Guide for Preparing Technical Information } \\
\text { Reports of the Engineer Research and } \\
\text { Development Center (Waterways Experiment } \\
\text { Station) }\end{array}$ \\
\hline ERDC/ITL SR-01-1 & Sep 2001 & $\begin{array}{l}\text { Preliminary Investigation of the Visualization of } \\
\text { Buildings in the OneSAF Environment, by M.E. } \\
\text { Pace and W.R. Bennett }\end{array}$ \\
\hline ERDC/ITL SR-03-1 & Aug 2003 & $\begin{array}{l}\text { User's Guide: Computer Program for Simulation } \\
\text { of Construction Sequence for Stiff Wall Systems } \\
\text { With Multiple Levels of Anchors (CMULTIANC), by } \\
\text { W.P. Dawkins, R.W. Strom, and R.M. Ebeling }\end{array}$ \\
\hline ERDC/ITL SR-04-1 & Jan 2006 & $\begin{array}{l}\text { Guide for Preparing Technical Information } \\
\text { Reports of the Engineer Research and } \\
\text { Development Center }\end{array}$ \\
\hline
\end{tabular}

$\underline{\text { AD Number }}$

ADA397450

ADA417175

ADA445281

\author{
Development Center
}

1 Limited distribution; see Preface. 


\section{Technical reports}

\begin{tabular}{|c|c|c|c|}
\hline Report Number & $\underline{\text { Date }}$ & $\underline{\text { Title }}$ & AD Number \\
\hline $\begin{array}{l}\text { ERDC/ITL TR-99-1 } \\
\text { Rep. } 2\end{array}$ & Aug 2000 & $\begin{array}{l}\text { Development of an Improved Numerical Model } \\
\text { for Concrete-to-Soil Interfaces in Soil-Structure } \\
\text { Interaction Analyses. Report 2: Final Study, by } \\
\text { J.E. Gomez, G.M. Filz, and R.M. Ebeling }\end{array}$ & ADA385382 \\
\hline ERDC/ITL TR-99-5 & Dec 1999 & Rivet Replacement Analysis, by E.E. Reichle & ADA374408 \\
\hline RDC/ITL TR-00-1 & Jan 2000 & $\begin{array}{l}\text { Evaluation and Comparison of Stability Analysis } \\
\text { and Uplift Criteria for Concrete Gravity Dams by } \\
\text { Three Federal Agencies, by R.M. Ebeling, L.K. } \\
\text { Nuss, F.T. Tracy, and B. Brand }\end{array}$ & ADA374718 \\
\hline ERDC/ITL TR-00-2 & Jul 2000 & $\begin{array}{l}\text { Reliability and Stability Assessment of Concrete } \\
\text { Gravity Structures (RCSLIDE): User's Guide, by } \\
\text { M.A. Leggett, M.E. Pace, F. Lyles, and K. } \\
\text { Abraham }\end{array}$ & ADA381759 \\
\hline ERDC/ITL TR-00-3 & Nov 2000 & $\begin{array}{l}\text { Investigation of Risk Assessment Methodology } \\
\text { for Dam Gates and Associated Operating } \\
\text { Equipment, by C.S. Putcha and R.C. Patev }\end{array}$ & ADA386670 \\
\hline ERDC/ITL TR-00-4 & Nov 2000 & $\begin{array}{l}\text { Probabilistic Barge Impact Analysis of the Upper } \\
\text { Guide and Guard Walls at Marmet Locks and } \\
\text { Dam, by R.C. Patev }\end{array}$ & ADA386261 \\
\hline ERDC/ITL TR-00-5 & Nov 2000 & $\begin{array}{l}\text { Theoretical Manual for Pile Foundations, by R.L. } \\
\text { Mosher and W.P. Dawkins }\end{array}$ & ADA386246 \\
\hline ERDC/ITL TR-00-6 & Nov 2000 & $\begin{array}{l}\text { Physical Data Collection for Lock Wall } \\
\text { Deterioration, by R.C. Patev, P.F. Mlakar, and L.M. } \\
\text { Bryant }\end{array}$ & ADA386607 \\
\hline ERDC/ITL TR-00-7 & Dec 2000 & $\begin{array}{l}\text { Extended Load/Unload/Reload Hyperbolic Model } \\
\text { for Interfaces: Parameter Values and Model } \\
\text { Performance for the Contact Between Concrete } \\
\text { and Coarse Sand, by J.E. Gomez, G.M. Filz, and } \\
\text { R.M. Ebeling }\end{array}$ & ADA388061 \\
\hline ERDC/ITL TR-01-1 & Dec 2001 & $\begin{array}{l}\text { State of the Practice in the Design of Tall, Stiff, } \\
\text { and Flexible Tieback Retaining Walls, by R.W. } \\
\text { Strom and R.M. Ebeling }\end{array}$ & ADA405009 \\
\hline ERDC/ITL TR-01-2 & Dec 2001 & $\begin{array}{l}\text { SOILSTRUCT-ALPHA for Personal Computers. } \\
\text { Report 1.: Visual Modeler, by B.C. White and } \\
\text { R.M. Ebeling }\end{array}$ & ADA395693 \\
\hline ERDC/ITL TR-01-3 & Aug 2001 & $\begin{array}{l}\text { Finite Element Modeling of Cooling Coil Effects in } \\
\text { Mass Concrete Systems, by R.M. Strigel }\end{array}$ & ADA397458 \\
\hline ERDC/ITL TR-01-4 & Sep 2001 & $\begin{array}{l}\text { Investigation of Wall Friction, Surcharge Loads, } \\
\text { and Moment Reduction Curves for Anchored } \\
\text { Sheet-Pile Walls, by W.P. Dawkins }\end{array}$ & ADA397516 \\
\hline
\end{tabular}




\begin{tabular}{|c|c|c|c|}
\hline ERDC/ITL TR-01-5 & Sep 2001 & $\begin{array}{l}\text { Development of Geodetic Conversion Routines, } \\
\text { by V. Danushkodi }\end{array}$ & ADA394986 \\
\hline ERDC/ITL TR-01-6 & Sep 2001 & $\begin{array}{l}\text { A/E/C CADD Standard; Main Text and } \\
\text { Appendices A, B, and C. }\end{array}$ & ADA397525 \\
\hline ERDC/ITL TR-01-6 & Sep 2001 & A/E/C CADD Standard; Appendix D & ADA397526 \\
\hline ERDC/ITL TR-01-7 & Dec 2001 & $\begin{array}{l}\text { Smeared and Discrete Crack Evaluations of a } \\
\text { Lock Exhibiting Earth Pressure-Induced } \\
\text { Cracking, by R.M. Ebeling, R.C. Patev, and G.A. } \\
\text { Riveros }\end{array}$ & ADA398483 \\
\hline ERDC/ITL TR-01-8 & Dec 2001 & $\begin{array}{l}\text { Multiple-Criteria Decision-Making in the Design } \\
\text { of Innovative Lock Walls for Barge Impact; Phase } \\
\text { 1, by J.H. Lambert, Y.Y. Haimes, J.L. Tsang, P. } \\
\text { Jiang, and R.C. Patev }\end{array}$ & ADA404050 \\
\hline ERDC/ITL TR-02-1 & Dec 2002 & $\begin{array}{l}\text { Risk Analysis of Design-Improvement } \\
\text { Alternatives to the Lindy Claiborne Boggs Lock } \\
\text { and Dam, by B.M. Ayyub, A.N. Blair, and R.C. } \\
\text { Patev }\end{array}$ & ADA411318 \\
\hline ERDC/ITL TR-02-2 & Dec 2002 & $\begin{array}{l}\text { Expert-Opinion Elicitation for the Risk Analysis of } \\
\text { Design-Improvement Alternatives to the Lindy } \\
\text { Claiborne Boggs Lock and Dam, by B.M. Ayyub, } \\
\text { A.N. Blair, and R.C. Patev }\end{array}$ & ADA411314 \\
\hline ERDC/ITL TR-02-3 & Sep 2002 & $\begin{array}{l}\text { Seismic Analysis of Cantilever Retaining Walls, } \\
\text { Phase I, by R.A. Green and R.M. Ebeling }\end{array}$ & ADA408335 \\
\hline ERDC/ITL TR-02-4 & Dec 2002 & $\begin{array}{l}\text { Risk Assessment Procedures for Innovative } \\
\text { Navigation Projects, by N.J. Tuholski, H. Gluver, } \\
\text { C.A. Cornell, B.C. Gerwick, Jr., R.C. Patev, and J.A. } \\
\text { Padula }\end{array}$ & ADA410763 \\
\hline ERDC/ITL TR-02-5 & Dec 2002 & $\begin{array}{l}\text { Multiple-Criteria Decision-Making in the Design } \\
\text { of Innovative Lock Walls for Barge Impact; Phase } \\
2 \text {, Implementation of Methodologies, by J.L. } \\
\text { Tsang, J.H. Lambert, and R.C. Patev }\end{array}$ & ADA410814 \\
\hline ERDC/ITL TR-02-6 & Sep 2002 & $\begin{array}{l}\text { Fragility Analysis of Concrete Gravity Dams, by } \\
\text { P.B. Tekie and B.R. Ellingwood }\end{array}$ & ADA408107 \\
\hline ERDC/ITL TR-02-7 & Nov 2002 & $\begin{array}{l}\text { Numerical Methods to Model Excavation of Soil } \\
\text { Adjacent to Retaining Structures, by M.S. } \\
\text { Gutierrez, R.M. Ebeling, and G.M. Filz }\end{array}$ & ADA408889 \\
\hline ERDC/ITL TR-02-8 & Nov 2002 & $\begin{array}{l}\text { Analysis of the Added Mass of a Barge in } \\
\text { Restricted Waters. Phase } 1 \text { Model, by M.E. } \\
\text { McCormick, D.R.B. Kraemer, P. Hudson, and W. } \\
\text { Noble }\end{array}$ & ADA408896 \\
\hline ERDC/ITL TR-02-9 & Nov 2002 & $\begin{array}{l}\text { Simplified Procedures for the Design of Tall, } \\
\text { Flexible Anchored Tieback Walls, by R.M. } \\
\text { Ebeling, M. Azene, and R.W. Strom }\end{array}$ & \\
\hline
\end{tabular}


ERDC/ITL TR-02-10 Nov 2002

ERDC/ITL TR-02-11 Dec 2002

ERDC/ITL TR-03-1 Jan 2003

ERDC/ITL TR-03-2 Jan 2003

ERDC/ITL TR-03-3 Apr 2003

ERDC/ITL TR-03-4 Aug 2003

ERDC/ITL TR-03-5 Aug 2003

ERDC/ITL TR-03-6 Aug 2003

ERDC/ITL TR-03-7 Dec 2003

ERDC/ITL TR-04-1 Sep 2009

ERDC/ITL TR-04-2 Aug 2004

ERDC/ITL TR-04-3 Aug 2004

ERDC/ITL TR-04-4 Aug 2004
Simplified Procedures for the Design of Tall, Stiff

Tieback Walls, by R.W. Strom and R.M. Ebeling

Methods Used in Tieback Wall Design and

Construction to Prevent Local Anchor Failure,

Progressive Anchorage Failure, and Ground

Mass Stability Failure, by R.W. Strom and R.M.

Ebeling

Investigative Study for Underwater Construction

of Lock Floors and Culverts, by B.D. Fehl, T.W.

Gaddie, and K. Abraham

Prototype Barge Impact Experiments, Allegheny Lock and Dam 2, Pittsburgh, Pennsylvania, by

R.C. Patev, B.C. Barker, and L.V. Koestler III

ADA410844

ADA415165

Velocity, Controlled Barge Impact Experiments, December 1998, by J.R. Arroyo, R.M. Ebeling, and B.C. Barker

Design by Analysis of Innovative Navigation

ADA417431

Structures: Theoretical Manual, by K.T. Slattery and G.A. Riveros

Design by Analysis of Innovative Navigation Structures: User Manual, by K.T. Slattery and G.A. Riveros

ADA417396

ADA417419

Analysis of the Added Mass of a Barge in

Restricted Waters. Phase 2 Model, by D.R.B.

Kraemer and M.E. McCormick

Full-Scale Barge Impact Experiments, Robert C.

Byrd Lock and Dam, Gallipolis Ferry, West

Virginia, by R.C. Patev, B.C. Barker, and L.V.

Koestler III

CAD Details Library, by the CAD/BIM Technology Center

ADA425199

A Numerical Method for Computing Barge Impact ADA427100 Forces Based on Ultimate Strength of the Lashings between Barges, by J.R. Arroyo and R.M. Ebeling

Simple Methods Used to Estimate the LimitState Axial Load Capability of Spillway Invert

ADA427082 Slabs, by R.W. Strom and R.M. Ebeling

Development of the TI-01 Application

Benchmark, by R.W. Alter, D.Q. Duffy, M.R. Fahey, ADA427046 Ward, Jr. 
ERDC/ITL TR-05-1 Mar 2005

Barge Train Maximum Impact Forces Using Limit States for the Lashings Between Barges, by J.R.

Arroyo and R.M. Ebeling

1ERDC/ITL TR-05-2 Apr 2005

A Regional Monitoring Concept for Corps of

Engineers Structures, by J.A. Evans and R.W.

Haskins

ERDC/ITL TR-05-3 May 2005

Seismic Structural Considerations for the Stem and Base of Retaining Walls Subjected to Earthquake Ground Motions, by R.W. Strom and R.M. Ebeling

ERDC/ITL TR-05-4 Aug 2005

The USACE DataNet: Providing Efficient Data Access Through a Net-Centric Framework, by C.D. Martin, C.D. Butler, J.T. Stinson, and D.C. Stuart

ERDC/ITL TR-06-2 Dec 2006

ERDC/ITL TR-07-1 Jun 2007

1ERDC/ITL TR-07-2 Nov 2007

ERDC/ITL TR-08-1 Jan 2008

ERDC/ITL TR-08-2 Nov 2008

ERDC/ITL TR-08-3 Nov 2008

ERDC/ITL TR-09-1 Jun 2009

ERDC/ITL TR-09-2 Jul 2009
Rotational Response of Toe-Restrained Retaining Walls to Earthquake Ground Motions, by R.M. Ebeling and B.C. White

Translational Response of Toe-Restrained Retaining Walls to Earthquake Ground Motions Using CorpsWallSlip (CWSlip), by R.M. Ebeling, A. Chase, and B.C. White

USACE ProjectWise Implementation Guide: ProjectWise Collaboration Model (PCM) 1.0, Version 1.0, by E.L. Huell, P.L. Ferguson, R.R. Rogers II, and M. Keathley

User's Guide: Fracture Mechanics Analysis of Reinforced Concrete Beams (FMARCB), by G.A. Riveros, V.S. Gopalaratnam, and A. Chase

Limiting Impact Force Due to Yielding and Buckling of the Plates and Internal Structural Frame at the Impact Corner of the Barge during Its Glancing Blow Impact with a Lock Approach Wall, by R.M. Ebeling and T.W. Warren

Fragility Analysis of a Concrete Gravity Dam and Its System Response Curve Computed by the Analytical Program GDLAD_Sloping_Base, by R.M. Ebeling, M.T. Fong, A. Chase, Sr., and E. Arredondo

Numerical Investigation of Miter Gates, by G.A. Riveros, J.L. Ayala Burgos, and J. Perez

A/E/C CAD Standard, Release 4.0
ADA433428

ADB307353

ADA434485

ADA438169

ADA468663

ADA469305

ADB334066

ADA492851

ADA501252

ADA508417

\footnotetext{
1 Limited distribution; see Preface.
} 


\begin{abstract}
ERDC/ITL TR-09-3 Aug 2009 Limiting Impact Force Due to Yielding and Buckling of the Plates and Internal Structural Frame at the Bow of a Barge during Its Head-on Impact with a Bullnose or Cellular Structure, by R.M. Ebeling and T.W. Warren
\end{abstract}

ERDC/ITL TR-09-4 Sep 2009

Rept. 1

ERDC/ITL TR-09-5 Nov 2009

ERDC/ITL TR-10-1 Jun 2010

ERDC/ITL TR-11-1 Aug 2011

ERDC/ITL TR-12-1 Jun 2012

ERDC/ITL TR-12-1 Aug 2015

ERDC/ITL TR-12-2 Aug 2012

ERDC/ITL TR-12-3 Sep 2012

ERDC/ITL TR-12-4 Aug 2012

ERDC/ITL TR-12-5 Dec 2012 Approach Wall Systems Founded on Groups of Piles and Subjected to Barge Train Impact, by

A System for Collecting and Compiling Condition Data for Hydraulic Steel Structures for Use in the Assessment of Risk and Reliability and Prioritization of Maintenance and Repairs. Report 1: Miter Gates, by P.W. Sauser and G.A. Riveros

A Non-Linear Fracture Mechanics Numerical Solution for Reinforced Concrete Deep Beams: A Theoretical Manual for the Fracture Mechanics Analysis of Reinforced Concrete Beams (FMARCB) Program, by G.A. Riveros and V.S. Gopalaratnam

Force Time History During the Impact of a Barge Train with a Lock Approach Wall Using Impact_Force, by R.M. Ebeling, B.C. White, A.N. Mohamed, and B.C. Barker

Dynamic Structural Flexible-Beam Response to a Moving Barge Train Impact Force Time-History Using Impact_Beam, by R.M. Ebeling, A.N. Mohamed, J.R. Arroyo, B.C. White, R.W. Strom, and B.C. Barker

CAD Drafting Standard, by S.C. Spangler

A/E/C Graphics Standard. Release 2.0 (formerly CAD Drafting Standard), by S.C. Spangler

Report 1: Facility Life-Cycle Process and Technology Innovation, by S.D. Carstafhnur and D.L. Dixon

Simplified Analysis Procedures for Flexible R.M. Ebeling, R.W. Strom, B.C. White, and K. Abraham

Complete Soil-Structure Interaction (SSI)

Analyses of I-walls Embedded in Level Ground During Flood Loading, by M.E. Pace, K. Abraham, and R.M. Ebeling

Capacity Verification for Modifying Little Sunflower Flood Control Drainage Structure Stop Log, by G.A. Riveros, D. Dixon, and E. Arredondo
ADA548303

ADA621158

ADA571762

ADA570343

ADA508401

ADA529195

\author{
ADA571762
}

\section{ADA570346}


$\begin{array}{lll}\text { ERDC/ITL TR-12-6 } & \text { Dec 2012 } & \text { A/E/C CAD Standard, Release 5.0 } \\ \text { ERDC/ITL TR-12-6 } & \text { Aug 2015 } & \text { A/E/C CAD Standard, Release 6.0 } \\ \text { ERDC/ITL TR-13-1 } & \text { Apr 2013 } & \begin{array}{l}\text { Fatigue Repair of Steel Hydraulic Structures } \\ \text { (SHS) using Carbon Fiber Reinforced Polymers } \\ \text { (CFRP): Feasibility Study, by H.N. Mahmoud and } \\ \text { G.A. Riveros }\end{array}\end{array}$

ERDC/ITL TR-13-2 Sep 2013 Simulation and Advanced Second Moment

ERDC/ITL TR-13-3 Aug 2013

ERDC/ITL TR-13-4 Sep 2013

ERDC/ITL TR-14-1 Jun 2014

ERDC/ITL TR-14-2 Aug 2014 Corrosion Induced Loss of Capacity and

ERDC/ITL TR-14-3 Sep 2014 Fatigue Assessment of Underwater CFRP-

ERDC/ITL TR-15-1 Jul 2015
Reliability Analyses of Pile Groups Using CPGA-R:

Formulation, User's Guide, and Example

Problems, by R.M. Ebeling, B.C. White, and M.T.

Fong

Underwater Inspection of Navigation Structures with an Acoustic Camera, by J.A. Evans, T.W. Warren, and R.W. Haskins

Towards Development of Innovative Bio-Inspired Materials by Analyzing the Hydrodynamic Properties of Polyondon Spathula (Paddlefish) Rostrum, by R.R. Patel and G.A. Riveros

A Procedure for Predicting the Deterioration of Steel Hydraulic Structures to Enhance their Maintenance, Management, and Rehabilitation, by G.A. Riveros, E. Arredondo, K. Walker, D.

Dixon, V. Fermo, J. Davis, C. Boler, and L. Whitlow Development of a Guided Wave Condition Assessment Method for Multistrand Anchor Systems Used in Corps Projects, by R.W. Haskins, J.A. Evans, and R.M. Ebeling Repaired Steel Panels using Finite Element Analysis, by H.N. Mahmoud, A. Como, and G.A. Riveros

ADA576185

ADA585467

ADA584035

ADA586268

ADA602788

ADA608714

ADA609350

Detection of Microcracks in Trunnion Rods Using Ultrasonic Guided Waves, by J.A. Evans and R.W.

ADA619008 Haskins 


\section{Structures Laboratory (SL) ${ }^{1}$}

\section{Technical reports}

\begin{tabular}{|c|c|c|c|}
\hline Report Number & Date & $\underline{\text { Title }}$ & $\underline{\text { AD Number }}$ \\
\hline TR SL-99-12 & Oct 1999 & $\begin{array}{l}\text { Use of Permeable Formwork in Placing and } \\
\text { Curing Concrete, by P.G. Malone }\end{array}$ & ADA371665 \\
\hline ERDC/SL TR-00-1 & Apr 2000 & $\begin{array}{l}1996 \text { Singapore Ground Shock Test, by D.W. } \\
\text { Murrell and C.J. Joachim }\end{array}$ & ADA377852 \\
\hline${ }^{2} \mathrm{ERDC} / \mathrm{SL}$ TR-00-2 & Jul 2000 & $\begin{array}{l}\text { DIPOLE TIGER Subscale Experiment 2, by J.L. } \\
\text { Davis and F.D. Dallriva }\end{array}$ & ADB256796 \\
\hline ERDC/SL TR-00-3 & Aug 2000 & $\begin{array}{l}\text { State-of-the-Art Report on High-Strength, High- } \\
\text { Durability Structural Low-Density Concrete for } \\
\text { Applications in Severe Marine Environments, by } \\
\text { T.A. Holm and T.W. Bremner }\end{array}$ & \\
\hline ERDC/SL TR-00-4 & Aug 2000 & $\begin{array}{l}\text { Analysis of Water Shock Data and Bubble } \\
\text { Screen Effectiveness on the Blast Effect } \\
\text { Mitigation Test Series, Wilmington Harbor, North } \\
\text { Carolina, by D.D. Rickman }\end{array}$ & ADA382742 \\
\hline ERDC/SL TR-00-5 & Aug 2000 & $\begin{array}{l}\text { Effects of an Anchoring Configuration on the } \\
\text { Static Response of Geotextile and Geogrid } \\
\text { Fabrics, by L. Simmons }\end{array}$ & ADA383258 \\
\hline ERDC/SL TR-00-6 & Aug 2000 & $\begin{array}{l}\text { Ultimate Deflection Response of Lightly } \\
\text { Reinforced Concrete Intake Towers, by R.C. } \\
\text { Dove }\end{array}$ & ADA384422 \\
\hline ERDC/SL TR-00-7 & Sep 2000 & $\begin{array}{l}\text { Nonlinear, Incremental Structural Analysis of } \\
\text { Zintel Canyon Dam, by R.E. Hollenbeck and S.B. } \\
\text { Tatro }\end{array}$ & ADA385135 \\
\hline ERDC/SL TR-00-8 & Sep 2000 & $\begin{array}{l}\text { Case Histories of Mass Concrete Thermal } \\
\text { Studies, by S.B. Tatro, A.A. Bombich, and J.R. } \\
\text { Hess }\end{array}$ & ADA385129 \\
\hline 2ERDC/SL TR-00-9 & Sep 2000 & $\begin{array}{l}\text { Empirical Model for Multi-Hit Crater Damage to } \\
\text { Concrete Slabs, by L.K. Davis }\end{array}$ & ADB260392 \\
\hline
\end{tabular}

1 The Structures Laboratory merged with the Geotechnical Laboratory. See also Geotechnical and Structures Laboratory.

2 Limited distribution; see Preface. 


\section{Topographic Engineering Center (TEC) ${ }^{1}$}

\section{Contract reports}

\begin{tabular}{|c|c|c|c|}
\hline Report Number & Date & $\underline{\text { Title }}$ & AD Number \\
\hline ERDC/TEC CR-00-1 & Jun 2000 & $\begin{array}{l}\text { RADIUS: Model-Based Optimization, by SRI } \\
\text { International: P.V. Fua, C.I. Connolly, A.J. } \\
\text { Heller, L.H. Quam, and T.M. Strat }\end{array}$ & ADA380187 \\
\hline ERDC/TEC CR-00-2 & Jun 2000 & $\begin{array}{l}\text { Research in Knowledge-Based Automatic } \\
\text { Feature Extraction, by University of Southern } \\
\text { California: R. Nevatia and A. Huertas }\end{array}$ & ADA380197 \\
\hline ERDC/TEC CR-00-3 & Jun 2000 & $\begin{array}{l}\text { Automated Cartographic Feature Attribution } \\
\text { Using Panchromatic and Hyperspectral } \\
\text { Imagery, by Carnegie Mellon University: D.M. } \\
\text { McKeown, Jr., J.C. McGlone, S.D. Cochran, } \\
\text { J.A. Shufelt, W.A. Harvey, and D.A. Yocum }\end{array}$ & ADA380211 \\
\hline${ }^{2} \mathrm{ERDC} / \mathrm{TEC}$ CR 00-5 & Nov 2000 & $\begin{array}{l}\text { Improved Vehicle Positioning and Navigation } \\
\text { Using Low Cost Sensors, by R. Levi }\end{array}$ & ADB291825 \\
\hline ERDC/TEC CR-01-1 & Mar 2001 & $\begin{array}{l}\text { Ascender 2: Knowledge-Directed Image } \\
\text { Understanding for Site Reconstruction, by A. } \\
\text { Hanson, E. Riseman, and H. Schultz }\end{array}$ & ADA388649 \\
\hline ERDC/TEC CR-02-1 & Jul 2002 & $\begin{array}{l}\text { A Real Three-Dimensional Digital Terrain Map } \\
\text { System, by Physical Optics Corporation: S. } \\
\text { Peng }\end{array}$ & ADB284450 \\
\hline 2ERDC/TEC CR-02-2 & Jul 2002 & $\begin{array}{l}\text { Techniques for Viewing Terrain Data on } \\
\text { Handheld Displays, by J. Tesar, D. Haanpaa, } \\
\text { and D. Melcher }\end{array}$ & ADB282319 \\
\hline ERDC/TEC CR-03-1 & Jan 2003 & $\begin{array}{l}\text { Enhanced Accuracy INS/GPS System Utilizing } \\
\text { Low-Cost Sensors and Geophysical Models, } \\
\text { by D. Johnson and N. Voronka }\end{array}$ & ADB286777 \\
\hline ERDC/TEC CR-03-2 & Aug 2003 & $\begin{array}{l}\text { Improved Vehicle Positioning and Navigation } \\
\text { Using Low Cost Sensors: Phase II, by E. } \\
\text { Erpelding, B. Graham, R. Levi, and A. } \\
\text { Stubberud }\end{array}$ & ADB259540 \\
\hline
\end{tabular}

\footnotetext{
1 See also Geospatial Research Laboratory.

2 Limited distribution; see Preface.
} 


\section{Special reports}

\begin{tabular}{|c|c|c|c|}
\hline Report Number & $\underline{\text { Date }}$ & $\underline{\text { Title }}$ & AD Number \\
\hline ERDC/TEC SR-00-1 & May 2004 & $\begin{array}{l}\text { Handbook for Transformation of Datums, } \\
\text { Projections, Grids, and Common Coordinate } \\
\text { Systems, by J. Ackeret, F. Esch, C. Gard, F. } \\
\text { Gloeckler, D. Oimen, J. Perez, J. Simpson, D. } \\
\text { Specht, D. Stoner, J. Watts, T. Witte, and } \\
\text { Maj. H. Rossanfer }\end{array}$ & ADA478730 \\
\hline ERDC/TEC SR-08-1 & Sep 2008 & $\begin{array}{l}\text { Functional Decomposition of Modeling and } \\
\text { Simulation Terrain Database Generation } \\
\text { Process: Using Integration Definition for } \\
\text { Function Modeling (IDEFØ), by V.R. Yakich } \\
\text { and J.D. Lashlee }\end{array}$ & ADA492047 \\
\hline ERDC/TEC SR-10-1 & Aug 2010 & $\begin{array}{l}\text { Transforming the Geocomputational } \\
\text { Battlespace Framework with HDF5, by M. } \\
\text { Folk, P. Cao, and J.A. Nedza }\end{array}$ & ADA527559 \\
\hline \multicolumn{4}{|l|}{ Letter reports } \\
\hline Report Number & Date & $\underline{\text { Title }}$ & $\underline{\text { AD Number }}$ \\
\hline ERDC/TEC LR-00-1 & Mar 2000 & $\begin{array}{l}\text { Central California Valley Interferometric } \\
\text { Synthetic Aperture Radar (IFSAR) Collection, } \\
\text { by J. Damron and C. Daniel }\end{array}$ & ADA379457 \\
\hline
\end{tabular}

\section{Technical notes}

$\begin{array}{ll}\text { Report Number } & \underline{\text { Date }} \\ \text { ERDC/TEC TN-00-1 } & \text { Jun } 2000\end{array}$

$\underline{\text { Title }}$

Generating a Coastal Boundary and Merging Bathymetry with DTED $®$ Level 1 Using Arclnfo: A Modeling and Simulation Application, by J.J. Damron

\section{Technical reports}

$\begin{array}{llll}\text { Report Number } & \text { Date } & \text { Title } & \text { AD Number } \\ \text { ERDC/TEC TR-01-1 } & \text { Mar 2001 } & \begin{array}{l}\text { Estimating Understory Stem Density from } \\ \text { Overstory Structural Characteristics, by P. } \\ \text { Krause, M. Campbell, and H. Puffenberger }\end{array} & \text { ADA390781 } \\ \text { ERDC/TEC TR-01-2 } & \text { Jul 2000 } & \begin{array}{l}\text { Evaluating IFSAR and LIDAR Technologies } \\ \text { Using Arclnfo: Red River Pilot Study, by J. } \\ \text { Damron and C. Daniel }\end{array} & \text { ADA434465 } \\ & & & \end{array}$


$\begin{array}{lll}\text { ERDC/TEC TR-01-3 Sep } 2000 & \begin{array}{l}\text { Comparing Digital Flood Insurance Rate } \\ \text { Maps (DFIRMs) to Interferometric Synth }\end{array}\end{array}$

ADA486484

Aperture Radar (IFSAR) Products, by J.

Damron

ERDC/TEC TR-02-1 Dec 2002

A Suggested Methodology for the

ADA409009

Computation of Imagery-Based Terrain Data

Reliability and Implementation into Tactical

Decision Models, by K. Slocum

ERDC/TEC TR-03-1 Mar 2003 Understory Density Characteristics in Several

ADA413189

Midlatitude Temperate Forests, by P. Krause, H. Puffenberger, B. Graff, and C. Gard

ERDC/TEC TR-05-1 Nov 2005

The Chameleon Concept: Modeling

ADA443839 Quaternary Geomorphic Surfaces Using Laboratory, Field, and Imaging Spectrometry in the Lower Colorado Sonoran Desert

ERDC/TEC TR-08-1 Aug 2008 Enterprise GIS Implementation at Yuma Test Center, Arizona: A Strategic Plan for Geospatial Data Management and Administration, by J.D. Lashlee, W. Sutton, B. Bowles, and V. Morrill

ERDC/TEC TR-08-2 Sep 2007 A Survey of Terrain Modeling Technologies ADA492698 and Techniques, by N. Gorkavyi, J. Snyder, and J.D. Lashlee 


\section{Aquatic Nuisance Species Research Program (ANSRP)}

\section{Bulletins}

Report Number

Vol-04-1

Vol-06-1

Vol-09-1

Vol-14-1

\section{Technical notes}

Report Number
ERDC/TN ANSRP-03-1
ERDC/TN ANSRP-03-2

ERDC/TN ANSRP-03-3

Sep 2003

Date

Jan 2003

Sep 2003

ERDC/TN ANSRP-04-1
Date

Feb 2004

Jul 2006

Apr 2009

Mar 2014
May 2004

Can Hydraulic Barriers Stop the Spread of the Round Goby?, by J.J. Hoover, S.R. Adams, and K.J. Killgore

Pulse-Power: A Possible Alternative to Chemicals for Zebra Mussel Control; Summary of 2000 Field Studies, by G. Smythe and A. Miller

Performance Testing of a Passive Low-Velocity Filtration Strainer for Use in Excluding Zebra Mussel Post Larvae from Water Intake Systems, by B.S. Payne

A Probability Tree Applied to a Common Zebra Mussel Dispersal Issue, by B.S. Payne and A.C. Miller 
ERDC/TN ANSRP-05-1

ERDC/TN ANSRP-05-2

ERDC/TN ANSRP-05-3

ERDC/TN ANSRP-05-4

ERDC/TN ANSRP-05-5

ERDC/TN ANSRP-05-6

ERDC/TN ANSRP-06-1

ERDC/TN ANSRP-06-2

ERDC/TN ANSRP-06-3

ERDC/TN ANSRP-06-4

ERDC/TN ANSRP-07-1
Aug 2005

Aug 2005

Sep 2005

Sep 2005

Sep 2005

Sep 2005

Jul 2006

Aug 2006

Sep 2006

Oct 2006

May 2007
Invasive Estuarine and Marine Animals of the North Atlantic, by G.L. Ray

Invasive Marine and Estuarine Animals of California, by G.L. Ray

Invasive Marine and Estuarine Animals of Hawai'i and other Pacific Islands, by G.L. Ray

Invasive Marine and Estuarine Animals of the Gulf of Mexico, by G.L. Ray

Invasive Marine and Estuarine Animals of the South Atlantic and Puerto Rico, by G.L. Ray

Invasive Marine and Estuarine Animals of the Pacific Northwest and Alaska, by G.L. Ray

Risk, Uncertainty, and Decision Analysis Applied to the Management of Aquatic Nuisance Species, by J. Kim and T.S. Bridges

Identification and Initial Screening of New Compounds to Control Harmful Algal Blooms, by A.G. Poovey and M.D. Netherland

Freshwater Aquatic Nuisance Species Impacts and Management Costs and Benefits at Federal Water Resources Projects ${ }_{1}$, by R.A. Cole

Application of Risk Assessment and Decision Analysis to Aquatic Nuisance Species, by B.C. Suedel, T.S. Bridges, J. Kim, B.S. Payne, and A.C. Miller

Life History Attributes of Asian Carps in the Upper Mississippi River System, by J.E. Garvey, K.L. DeGrandchamp, and C.J. Williamson 
ERDC/TN ANSRP-07-2

ERDC/TN ANSRP-07-3

ERDC/TN ANSRP-07-4

ERDC/TN ANSRP-09-1

ERDC/TN ANSRP-09-2

ERDC/TN ANSRP-10-1

ERDC/TN ANSRP-10-2

ERDC/TN ANSRP-12-1

ERDC/TN ANSRP-12-2
Aug 2007

Aug 2007

Nov 2007

Jan 2009

Jan 2009

May 2010

May 2010

Mar 2012

Jun 2012
Detection of Apoptosis in Early Life Stages as a Tool to Evaluate Chemical Control of Invasive Species, by J.W. Lynn, K.D. Perry, V.L. Wilson, A.J. Kennedy, R.N. Millward, and J.A. Steevens

Applying Life Stage Sensitivity Data in Chemical Control Strategies for Invasive Animal Species, by R.N. Millward, A.J. Kennedy, J.W. Lynn, K.D. Perry, S. Ruiz, and J.A. Steevens

Floodplain Wetlands as Nurseries for Silver Carp, Hypophthalmichthys molitrix: A Conceptual Model for Use in Managing Local Populations, by K.A. Varble, J.J. Hoover, S.G. George, C.E. Murphy, and K.J.Killgore

The Impact of Harmful Algal Blooms on USACE Operations, by I. Linkov, F.K. Satterstrom, D. Loney, and J.A. Steevens

Screening of Various Herbicide Modes of Action for Selective Control of Algae Responsible for Harmful Blooms, by M.D. Netherland, C.A. Lembi, and A.G. Poovey

Impact of Data Availability on Site Assessment and Predictive Behavior of Aquatic Invasive Species, by J.F. Shearer and M.J. Grodowitz

Predicting the Potential for Invasive Species Establishment by Using Environmental Tolerance Data, by J.F. Shearer and M.J. Grodowitz

Invasive Species Costs to Corps Civil Works Activities, by J.E. Henderson

Detecting eDNA of Invasive Dreissenid Mussels: Report on Capital Investment Project, by R.F. Lance and M.R. Carr 
ERDC/TN ANSRP-12-3

ERDC/TN ANSRP-13-1

ERDC/TN ANSRP-13-2

ERDC/TN ANSRP-14-1

ERDC/TN ANSRP-15-1

ERDC/TN ANSRP-15-2
Aug 2012

Swimming Performance of Bighead Carp and Silver Carp: Methodology, Metrics, and Management Applications, by J.J. Hoover, L.W. Southern, A.W. Katzenmeyer, and N.M. Hahn

Jan 2013 Environmental Factors Influencing Blooms of a Neurotoxic Stigonematalan Cyanobacterium Responsible for Avian Vacuolar Myelinopathy by S.B. Wilde, R.S. Haynie, J.A. Herrin, M.W. Hook, J. Kupfer, and M.D. Netherland

Nov 2013 Demonstrating the Ecosystem Effects of Armored Suckermouth Catfishes (Loricariidae): A Feasibility Study Using Mesocosms, by J.J. Hoover, N.M. Hahn, and J.A. Collins

Mar $2014 \quad$ Burrowing by Sailfin Catfish (Pterygoplichthys sp.): A Potential Cause of Erosion in Disturbed Environments, by 0 . van den Ende

Jul 2015 Development of Operational Protocols for Electric Barrier Systems on the Chicago Sanitary and Ship Canal: Induction of Passage-Preventing Behaviors in Small Sizes of Silver Carp,

by F.M. Holliman, K.J. Killgore, and C. Shea

Aug 2015
Failure to Detect the Neurotoxin $\beta$-n-methylamino-Ialanine in Samples Collected during an Avian Vacuolar Myelinopathy (AVM) Epornitic in J. Strom Thurmond Lake, by R.S. Haynie, S.J. Christensen, S. Banack, R.R. Bidigare, J.A. Herrin, and S.B. Wilde 


\title{
13 Aquatic Plant Control Research Program (APCRP)
}

\section{Bulletins}

$\begin{array}{lll}\text { Report Number } & \underline{\text { Date }} & \underline{\text { Title }} \\ \text { Vol. A-00-1 } & \text { Dec 2000 } & \begin{array}{l}\text { Economic Value of Aquatic Vegetation to Fisheries, by J.P. Kirk } \\ \text { and J.E. Henderson }\end{array} \\ \text { Vol. A-02-1 } & \text { Aug 2002 } & \begin{array}{l}\text { "So how much is it worth?" Economic Impacts of Recreational } \\ \text { Fishing Under Different Aquatic Plant Conditions, by J.E. } \\ \text { Henderson and P. Kirk }\end{array} \\ \text { Vol. A-04-1 } & \text { Nov 2004 } & \begin{array}{l}\text { Aquatic Vegetation Restoration in Drakes Creek, Tennessee } \\ \text { by G.O. Dick, R.M. Smart, and J.R. Snow }\end{array} \\ \text { Vol. A-12-1 } & \text { Jun 2012 } & \begin{array}{l}\text { Development of an Integrated Pest Management Approach } \\ \text { for Controlling Giant Salvinia Using Herbicides and Insects, by } \\ \text { C.R. Mudge and N.E. Harms }\end{array}\end{array}$

\section{Technical notes}

\section{Biological control}

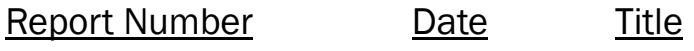 \\ ERDC/TN APCRP-BC-02 Mar 2001 Dose Response Studies of Mycoleptodiscus terrestris \\ Formulations on Hydrilla verticillata, by J.F. Shearer \\ ERDC/TN APCRP-BC-03 Apr 2001 Recovery of Endophytic Fungi from Myriophyllum spicatum, by \\ J.F. Shearer \\ ERDC/TN APCRP-BC-04 Jun 2002 Effect of a New Growth Medium on Mycoleptodiscus terrestris \\ (Gerd.) Ostazeski, by J.F. Shearer \\ ERDC/TN APCRP-BC-05 Jul 2002 Developing Methodologies to Assess the Influence of \\ Nutritional and Physical Characteristics of Hydrilla verticillata \\ on its Biological Control Agents, by M.J. Grodowitz and D.G. \\ McFarland \\ ERDC/TN APCRP-BC-06 Sep 2003 Microsporidia Infection in Neochetina eichhorniae and N. \\ bruchi Populations in Texas, by S. Lewis, M.J. Grodowitz and J. \\ Freedman \\ ERDC/TN APCRP-BC-07 Apr 2004 \\ Impacts of Euhrychiopsis lecontei (Dietz) from Different \\ Populations on the Growth and Nutrition of Eurasian \\ Watermilfoil, by A.F. Cofrancesco, D.G. McFarland, J.D. \\ Madsen, A.G. Poovey, and H.L. Jones
}


ERDC/TN APCRP-BC-08 Feb 2007

ERDC/TN APCRP-BC-9 Aug 2007

ERDC/TN APCRP-BC-10 Mar 2009

ERDC/TN APCRP-BC-11 Mar 2009

ERDC/TN APCRP-BC-12 Jun 2009

ERDC/TN APCRP-BC-13 Sep 2009

ERDC/TN APCRP-BC-14 Sep 2009

ERDC/TN APCRP-BC-15 Oct 2009

ERDC/TN APCRP-BC-16 Oct 2009

ERDC/TN APCRP-BC-17 Feb 2010

ERDC/TN APCRP-BC-18 Dec 2010

ERDC/TN APCRP-BC-19 Dec 2010

ERDC/TN APCRP-BC-20 Dec 2010

ERDC/TN APCRP-BC-21 Dec 2010

ERDC/TN APCRP-BC-22 May 2011
Impact of Herbivory and Plant Competition on the Growth of Hydrilla in Small Ponds, by M.J. Grodowitz, C.S. Owens, R.M. Smart, and J.G. Nachtrieb

Impact of Invertebrate Herbivory on Native Aquatic Macrophytes, by J.G. Nachtrieb, M.J. Grodowitz, and R.M .Smart

Preliminary Testing of Mycoleptodiscus terrestris Formulations, by J.F. Shearer

Mycoleptodiscus terrestris: An Endophyte Turned Latent Pathogen of Eurasian Watermilfoil, by J.F. Shearer

Mass-Rearing Hydrellia pakistanae Deonier and $\mathrm{H}$. balciunasi Bock for the Management of Hydrilla verticillata, by N. Harms, M. Grodowitz, and J. Nachtrieb

Storage Stability of Dried Microsclerotia of the Biological Control Pathogen Mycoleptodiscus Terrestris, by J.F. Shearer

Senescence as a Factor in Latent Pathogen Infection in Eurasian Watermilfoil, by J.F. Shearer

Parasitism and Host Selection Behavior of Trichopria columbiana Ashmead and its Effect on Establishment and Dynamics of Hydrellia spp. Populations, by M.J. Grodowitz, J.G. Nachtrieb, N. Harms, R. Swindle, and C. Snell

Mass-Rearing Cyrtobagous salvinae Calder and Sands for the Management of Salvinia molesta Mitchell, by N. Harms, M. Grodowitz, and J. Nachtrieb

Suitability of Using Introduced Hydrellia spp. For Management of Monoecious Hydrilla verticillata (L.f.) Royle, by M. Grodowitz, J. Nachtrieb, N. Harms, and J. Freedman

The Impact of the Introduced Hydrellia spp. On the FluridoneResistant Biotype of Hydrilla verticillata, by M. Grodowitz, C. Ashton, C. DuBose, J. Freedman, J.G. Nachtrieb, and N. Harms

Effect of Dried Mycoleptodiscus terrestris Inoculums on Fluridone-Susceptible and Fluridone-Resistant Hydrilla Biotypes, by J.F. Shearer and M.J. Grodowitz

Relationship Between Eurasian Watermilfoil Phenology and Endophyte Presence, by J.F. Shearer

Survey of Insect Herbivores Associated with Aquatic and Wetland Plants in the United States, by N.E. Harms and M.J. Grodowitz

Progress Report on Field Surveys to Identify Biocontrol Agents of Hydrilla verticillata in China during 2010, by J. Ding, J. Zhang, and W. Huang 
ERDC/TN APCRP-BC-23 Oct 2011 Application of early Detection and Rapid Response

Management Techniques to Control Hydrilla, by J.P. Kirk and K.L. Manuel

ERDC/TN APCRP-BC-24 Oct 2011

Effect of Dried Mycoleptodiscus terrestris inoculums on dioecious hydrilla, by J.F. Shearer, B.D. Durham, and J.E. Freedman

ERDC/TN APCRP-BC-25 Dec 2011 Overwintering Biology and Sex Ratio of the Parasitoid Trichopria Columbiana Ashmead (Hymenoptera: Diapriidae) in North Texas, by N.E. Harms and M.J. Grodowitz

ERDC/TN APCRP-BC-26 Dec 2011 Do Hydrilla Leaf-mining Flies Contribute to Increased Hydrilla Fragmentation?, by C.S. Owens, M.J. Grodowitz, and R.M. Smart

ERDC/TN APCRP-BC-27 Jun 2012

The Screening of Pathogens as Potential Biological Control Agents for Management of Hydrilla verticillata, by J.F. Shearer

ERDC/TN APCRP-BC-28 Jun 2012 Progress Report on Field Surveys to Identify Biocontrol Agents of Hydrilla verticillata in China during 2011, by J. Zhang, M. Purcell, B. Tian and J. Ding

ERDC/TN APCRP-BC-29 Jun 2012 The Combined Effects of Hydrellia spp. Herbivory and Native Plant Competition on the Biomass and Surface Coverage of Hydrilla, by J.G. Nachtrieb, M.J. Grodowitz, and R.M. Smart

ERDC/TN APCRP-BC-30 Jun 2013 Evaluation of a New Biological Control Pathogen for Management of Eurasian Watermilfoil, by J.F. Shearer

ERDC/TN APCRP-BC-31 Jan 2014 Surveys for Pathogens of Monoecious Hydrilla, by J.F. Shearer

ERDC/TN APCRP-BC-32 Feb 2014 Genetic Relationships among Invasive Hydrilla (Hydrilla verticillata L.f. Royle) Biotypes in the US and Their Implications for Management, by N.E. Harms, D.A. Williams, and M.J. Grodowitz

ERDC/TN APCRP-BC-33 Jul 2014

The Use of Megamelus scutellaris Berg in the Southern United States as a Biocontrol Agent of Waterhyacinth (Eichhornia crassipes (Mart.), by M.J. Grodowitz, S. Johnson, and N.E. Harms

ERDC/TN APCRP-BC-34 Oct 2014

Surveys for Pathogens of Monoecious Hydrilla in 2013, by J.F. Shearer

ERDC/TN APCRP-BC-35 Jun 2015

Apparent Herbivory and Indigenous Pathogens of Invasive Flowering Rush (Butomus umbellatus L.) in the Pacific Northwest, by N.E. Harms and J.F. Shearer

ERDC/TN APCRP-BC-36 Jul 2015
Progress Report on Field Surveys to Identify Biocontrol Agents of Hydrilla verticillata from June - September 2012, by J. Zhang, M. Purcell, B. Tian, and J. Ding 


\section{Chemical control}

\begin{tabular}{|c|c|c|}
\hline Report Number & Date & $\underline{\text { Title }}$ \\
\hline ERDC/TN APCRP-CC-02 & May 2004 & $\begin{array}{l}\text { Using Diquat in Combination with Endothall Under Turbid } \\
\text { Water Conditions to Control Hydrilla, by A.G. Poovey and J.G. } \\
\text { Skogerboe }\end{array}$ \\
\hline RDC/TN APCRP-CC-04 & Aug 2004 & $\begin{array}{l}\text { Combining Endothall with Other Herbicides for Improved } \\
\text { Control of Hydrilla - A Field Demonstration, by J. Skogerboe, T. } \\
\text { Pennington, J. Hyde, and C. Aguillard }\end{array}$ \\
\hline RDC/TN APCRP-CC-05 & Oct 2006 & $\begin{array}{l}\text { Selective Control of Eurasian Watermilfoil and Curlyleaf } \\
\text { Pondweed Using Low Doses of Endothall Combined with 2,4- } \\
\text { D, by J.G. Skogerboe and K.D. Getsinger }\end{array}$ \\
\hline RDC/TN APCRP-CC-06 & Mar 2008 & $\begin{array}{l}\text { Effects of Turbidity on Fluridone Treatments for Curlyleaf } \\
\text { Pondweed Control, by A.G. Poovey, M.D. Netherland, and W. } \\
\text { Crowell }\end{array}$ \\
\hline RDC/TN APCRP-CC-07 & Mar 2008 & $\begin{array}{l}\text { Evaluation of 2,4-D Ester and Triclopyr Amine Against } \\
\text { Waterlily and Spatterdock, by L.M. Glomski and L.S. Nelson }\end{array}$ \\
\hline RDC/TN APCRP-CC-08 & Jun 2008 & $\begin{array}{l}\text { Early-season, Low-dose Applications of Endothall to } \\
\text { Selectively Control Curlyleaf Pondweed in Minnesota Lakes, } \\
\text { by J.G. Skogerboe, A. Poovey, K.D. Getsinger, W. Crowell, and } \\
\text { E. Macbeth }\end{array}$ \\
\hline ERDC/TN APCRP-CC-09 & Feb 2009 & $\begin{array}{l}\text { Integrated Weed Management Strategies for Control of } \\
\text { Hydrilla, by L.S. Nelson and J.F. Shearer }\end{array}$ \\
\hline ERDC/TN APCRP-CC-10 & Apr 2009 & $\begin{array}{l}\text { Potential Impact of Submersed 2,4-D Potential Impact of } \\
\text { Submersed 2,4-D on Native Emergent Plants, by L.M. } \\
\text { Glomski, M.D. Netherland, and L.S. Nelson }\end{array}$ \\
\hline RDC/TN APCRP-CC-11 & Jul 2009 & $\begin{array}{l}\text { Combining ALS-inhibiting Herbicides with the Fungal } \\
\text { Pathogen Mycoleptodiscus terrestris for Control of Hydrilla, by } \\
\text { J.F. Shearer and L.S. Nelson }\end{array}$ \\
\hline ERDC/TN APCRP-CC-12 & Sep 2009 & $\begin{array}{l}\text { Effect of Submersed Applications of Bispyribac-sodium on } \\
\text { Non-target Emergent Vegetation, by L.M. Glomski and C.R. } \\
\text { Mudge }\end{array}$ \\
\hline ERDC/TN APCRP-CC-14 & Apr 2010 & $\begin{array}{l}\text { Combinations of Endothall with 2,4-D and Triclopyr for } \\
\text { Eurasian Watermilfoil Control, by J.D. Madsen, R.M. Wersal, } \\
\text { K.D. Getsinger, and J.G. Skogerboe }\end{array}$ \\
\hline ERDC/TN APCRP-CC-15 & Mar 2011 & $\begin{array}{l}\text { Endothall Concentration Exposure Time Evaluation Against } \\
\text { Eurasian Watermilfoil at a Lower Water Temperature, by C.R. } \\
\text { Mudge and H.J. Theel }\end{array}$ \\
\hline ERDC/TN APCRP-CC-16 & May 2011 & $\begin{array}{l}\text { Utilizing a Small-scale Primary Screening Method to Evaluate } \\
\text { Activity of the Bleaching Herbicide Topramezone on Invasive } \\
\text { and Native Submersed Plants, by L.M. Glomski and M.D. } \\
\text { Netherland }\end{array}$ \\
\hline
\end{tabular}


ERDC/TN APCRP-CC-17 Apr 2012

ERDC/TN APCRP-CC-18 Mar 2013

ERDC/TN APCRP-CC-19 Jun 2013

\section{Ecological assessments}

\begin{tabular}{|c|c|c|}
\hline Report Number & Date & $\underline{\text { Title }}$ \\
\hline ERDC/TN APCRP-EA-01 & July 2000 & $\begin{array}{l}\text { Factors Contributing to the Spread of Hydrilla in Lakes and } \\
\text { Reservoirs, by J.D. Madsen and C.S. Owens }\end{array}$ \\
\hline ERDC/TN APCRP-EA-02 & Mar 2001 & $\begin{array}{l}\text { Direct and Indirect Impacts of Submersed Aquatic Vegetation } \\
\text { on the Nutrient Budget of an Urban Oxbow Lake, by W.F. } \\
\text { James, J.W. Barko, and H.L. Eakin }\end{array}$ \\
\hline ERDC/TN APCRP-EA-03 & Jun 2001 & $\begin{array}{l}\text { Shear Stress and Sediment Resuspension in Canopy- and } \\
\text { Meadow-Forming Submersed Macrophyte Communities, by } \\
\text { W.F. James, J.W. Barko, and M.G. Butler }\end{array}$ \\
\hline ERDC/TN APCRP-EA-04 & Nov 2001 & $\begin{array}{l}\text { Rehabilitation of a Shallow Lake (Big Muskego Lake, } \\
\text { Wisconsin) Via Drawdown: Sediment Response, by W.F. } \\
\text { James, H.L. Eakin, and J.W. Barko }\end{array}$ \\
\hline ERDC/TN APCRP-EA-05 & Jan 2002 & $\begin{array}{l}\text { Experimental Determination of the Impacts of Sediment } \\
\text { Desiccation and Rewetting on Sediment Physical and } \\
\text { Chemical Characteristics in Lawrence Lake, Pool 8, Upper } \\
\text { Mississippi River, by W.F. James, J.W. Barko, and H.L. Eakin }\end{array}$ \\
\hline ERDC/TN APCRP-EA-06 & Sep 2003 & $\begin{array}{l}\text { Manipulation of Sediment Nitrogen via Dewatering and } \\
\text { Rehydration: Implications for Macrophyte Control and } \\
\text { Nitrogen Dissipation, by W.F. James, H.L. Eakin, and J.W. } \\
\text { Barko }\end{array}$ \\
\hline ERDC/TN APCRP-EA-07 & Jul 2004 & $\begin{array}{l}\text { Modeling the Impacts of Suspended Sediment Concentration } \\
\text { and Current Velocity on Submersed Vegetation in an Illinois } \\
\text { River Pool, USA, by E.P.H. Best, A.H. Teeter, and S.K. Nair }\end{array}$ \\
\hline ERDC/TN APCRP-EA-08 & Sep 2004 & $\begin{array}{l}\text { Impacts of Mechanical Macrophyte Removal Devices on } \\
\text { Sediment Scouring in Littoral Habitats: I. Historical Survey of } \\
\text { Operations in Minnesota Lakes, by W.F. James, D.I. Wright, } \\
\text { H.L. Eakin, and J.W. Barko }\end{array}$ \\
\hline ERDC/TN APCRP-EA-09 & Sep 2004 & $\begin{array}{l}\text { Migratory Waterfowl Habitat Selection in Relation to Aquatic } \\
\text { Vegetation, by G.O. Dick, J.K. Smith, and R.M. Smart }\end{array}$ \\
\hline ERDC/TN APCRP-EA-10 & Aug 2005 & $\begin{array}{l}\text { Experimental Effects of Lime Application on Aquatic } \\
\text { Macrophytes: 1. Growth Response Versus Concentration, by } \\
\text { W.F. James, H.L. Eakin, and J.W. Barko }\end{array}$ \\
\hline
\end{tabular}

Impact of Herbicide Combinations on Two Biotypes of the Submersed Plant Vallisneria americana, by C.R. Mudge and L.M. Glomski

Small-scale Primary Screening Method to Predict Impacts of the Herbicide Flumioxazin on Native and Invasive Emergent Plants, by L.M. Glomski and M.D. Netherland

Evaluation of Glyphosate, Flumioxazin and Imazamox against Japanese Knotweed s. I., by L.M. Glomski 
ERDC/TN APCRP-EA-11 Sep 2005

ERDC/TN APCRP-EA-12 Mar 2006

ERDC/TN APCRP-EA-13 Mar 2006

ERDC/TNAPCRP-EA-13 Mar 2006

ERDC/TN APCRP-EA-14 Apr 2007

ERDC/TN APCRP-EA-15 Apr 2007

ERDC/TN APCRP-EA-16 Sep 2007

ERDC/TN APCRP-EA-17 Jan 2008

ERDC/TN APCRP-EA-18 Jun 2008

ERDC/TN APCRP-EA-19 Nov 2008

ERDC/TN APCRP-EA-20 Dec 2008

ERDC/TN APCRP-EA-21 Jul 2009

ERDC/TN APCRP-EA-22 May 2010

ERDC/TN APCRP-EA-23 Jul 2010

ERDC/TN APCRP-EA-24 Jul 2010
Propagation and Production of Native Aquatic Plants, by G.O.

Dick, R.M. Smart, and J.R. Snow

Experimental Effects of Lime Application on Aquatic Macrophytes: 2. Growth Response Versus Treatment Time and Lime Concentration, by W.F. James and J.W. Barko

Impacts of Mechanical Macrophyte Removal Devices on Sediment Scouring in Littoral Habitats: II. Experimental Operation in the Littoral Zone of Eau Galle Reservoir, Wisconsin, by W.F. James, D.I. Wright, J.W. Barko and H.L. Eakin

Experimental Effects of Lime Application on Aquatic Macrophytes: 4. Growth Response of Three Species, by W.F. James

Contribution of Potamogeton crispus Decay to the Phosphorus Budget of McGinnis Lake, Wisconsin, by W.F. James, A. Dechamps, N. Turyk, and P. McGinley

Distribution and Abundance of Eurasian Watermilfoil (Myriophyllum spicatum L.) and Curly-leaf Pondweed (Potamogeton crispus L.) in Shawano Lake, Wisconsin, by C.S. Owens, W.F. James, J.G. Skogerboe, and R.M. Smart

Experimental Effects of Lime Application on Aquatic Macrophytes: 3. Growth Response Versus Exposure Time, by W.F. James

Growth Response of Potamogeton crispus to Lime Application in Experimental Mesocosms, by W.F. James

Point Intercept and Surface Observation GPS (SOG): A Comparison of Survey Methods - Lake Gaston, NC/VA, by L. Dodd-Williams, G.O. Dick, R.M. Smart, and C.S. Owens

Environmental Factors Affecting Aquatic Plant Growth Potential in Marinuka Lake,Wisconsin, by W.F. James

Development of a Multi-Attribute Utility Analysis Model for Selecting Aquatic Plant Restoration Sites in Reservoirs, by M.J. Grodowitz, M. Smart, G.O. Dick, J.A. Stokes, and J. Snow

Management of Half Moon Lake, Wisconsin, for Improved Native Submersed Macrophyte Growth, by W.F. James

Effects of Nutrients, Salinity, and pH on Salvinia molesta (Mitchell) Growth, by C.S. Owens and R.M. Smart

Comparison of Three Biomass Sampling Techniques on Submersed Aquatic Plants in a Northern Tier Lake, by C.S. Owens, R.M. Smart, P.E. Williams, and M.R. Spickard 
ERDC/TN APCRP-EA-25 Oct 2010 Aluminum Sulfate Application to Improve Under-Water Light Condition for Native Submersed Macrophyte Restoration: Alum to Phosphorus Binding Ratio Considerations, by W.F. James

ERDC/TN APCRP-EA-26 Oct 2011 Shade and Depth Effects on the Growth of Giant Salvinia, by C.S. Owens, R.M. Smart, and G.O. Dick

ERDC/TN APCRP-EA-27 Jan 2014 Using High-Resolution, Regional-Scale Data to Characterize Floating Aquatic Nuisance Vegetation in Coastal Louisiana Navigation Channels, by Y.C. Allen and G.M. Suir

\title{
Integrated control
}

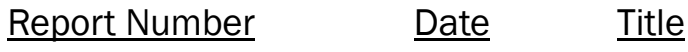

ERDC/TN APCRP-IC-03 Jul 2002 Response of Eurasian Watermilfoil to Integrated FluridoneFungal Pathogen Treatment, by L.S. Nelson and J.F. Shearer

\section{Miscellaneous}

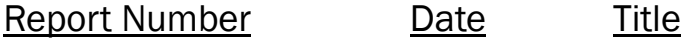 \\ ERDC/TN APCRP-MI-05 Oct 2000 Macrophyte Management via Mechanical Shredding: Effects on \\ Water Quality in Lake Champlain (Vermont-New York), by W.F. \\ James, J.W. Barko, and H.L. Eakin \\ ERDC/TN APCRP-MI-06 Feb 2001 Foraging Behavior of Fishes in Aquatic Plants, by S.L. Harrel, \\ E.D. Dibble, and K.J. Killgore \\ ERDC/TN APCRP-MI-8 Jan 2014 Establishing Research and Management Priorities for \\ Monoecious Hydrilla, by M.D. Netherland and M. Greer
}




\section{Dredging Operations and Environmental Research Program (DOER)}

\section{Technical notes}

\begin{tabular}{|c|c|c|}
\hline Report Number & Date & $\underline{\text { Title }}$ \\
\hline ERDC/TN DOER-C9 & Nov 1999 & $\begin{array}{l}\text { Phytoreclamation of Dredged Material: A Working } \\
\text { Group Summary by R.A. Price, C.R. Lee and J.W. } \\
\text { Simmers }\end{array}$ \\
\hline ERDC/TN DOER-C10 & Mar 2000 & $\begin{array}{l}\text { Protocols for a Rapid Clean-up/Extraction Procedure } \\
\text { and an Improved P450RGS Dioxin Screening Assay } \\
\text { for Sediments, by C.Y. Ang, L.S. Inouye, D.D. McCant } \\
\text { and V.A. McFarland }\end{array}$ \\
\hline ERDC/TN DOER-C11 & Mar 2000 & $\begin{array}{l}\text { Concepts and Technologies for Bioremediation in } \\
\text { Confined Disposal Facilities, by T.E. Myers and C.W. } \\
\text { Williford }\end{array}$ \\
\hline ERDC/TN DOER-C12 & Feb 2000 & $\begin{array}{l}\text { Reclamation and Beneficial Use of Contaminated } \\
\text { Dredged Material: Implementation Guidance for } \\
\text { Select Options, by C.R. Lee }\end{array}$ \\
\hline ERDC/TN DOER-C13 & Jul 2000 & $\begin{array}{l}\text { Determining Recovery Potential of Dredged Material } \\
\text { for Beneficial Use - Soil Separation Concepts, by T.J. } \\
\text { Olin-Estes and M.R. Palermo }\end{array}$ \\
\hline ERDC/TN DOER-C14 & Jul 2000 & $\begin{array}{l}\text { Determining Recovery Potential of Dredged Material for } \\
\text { Beneficial Use - Site Characterization: Prescriptive } \\
\text { Approach, by T.J. Olin-Estes and M.R. Palermo }\end{array}$ \\
\hline ERDC/TN DOER-C15 & Jul 2000 & $\begin{array}{l}\text { Determining Recovery Potential of Dredged Material } \\
\text { for Beneficial Use - Site Characterization: Statistical } \\
\text { Approach, by T.J. Olin-Estes }\end{array}$ \\
\hline ERDC/TN DOER-C16 & Jul 2000 & $\begin{array}{l}\text { Leachate Screening Considerations, by P.R. } \\
\text { Schroeder }\end{array}$ \\
\hline ERDC/TN DOER-C17 & Aug 2000 & $\begin{array}{l}\text { Equipment and Processes for Removing Debris and } \\
\text { Trash from Dredged Material, by T.E. Myers and D.D. } \\
\text { Adrian }\end{array}$ \\
\hline ERDC/TN DOER-C18 & Aug 2000 & $\begin{array}{l}\text { Confined Disposal Facility (CDF) Containment } \\
\text { Features: A Summary of Field Experience, by M.R. } \\
\text { Palermo and D.E. Averett }\end{array}$ \\
\hline ERDC/TN DOER-C19 & Dec 2000 & $\begin{array}{l}\text { Biomarker-Based Analysis for Contaminants in } \\
\text { Sediments/Soil: Review of Cell-Based Assays and } \\
\text { cDNA Arrays, by L.S. Inouye and V.A. McFarland }\end{array}$ \\
\hline ERDC/TN DOER-C2O & Mar 2001 & $\begin{array}{l}\text { Implementation Guidance for the Control of } \\
\text { Undesirable Vegetation on Dredged Material, by C.R. } \\
\text { Lee }\end{array}$ \\
\hline
\end{tabular}


ERDC/TN DOER-C21

ERDC/TN DOER-C22

ERDC/TN DOER-C23

ERDC/TN DOER-C24

ERDC/TN DOER-C25

ERDC/TN DOER-C26

ERDC/TN DOER-C27

ERDC/TN DOER-C28

ERDC/TN DOER-C29

ERDC/TN DOER-C3O

ERDC/TN DOER-C31

ERDC/TN DOER-C32

ERDC/TN DOER-C33

ERDC/TN DOER-C34
Aug 2001

Sep 2001 Replaced Jul 2002

Sep 2001

Dec 2001

Dec 2001

Jul 2002

Jul 2002

Aug 2002

Jan 2003

Feb 2003

Feb 2003

Jan 2003

Jan 2003

Jul 2004
Subaqueous Cap Design: Selection of Bioturbation Profiles, Depths, and Process Rates, by D.G. Clarke, M.R. Palermo, and T.C. Sturgis

Toxicological and Bioaccumulation Testing of Dredged Material in Confined Disposal Facilities Using Plants and Worms, by E.P.H. Best, H.E. Tatem, L. Winfield, and J.W. Simmers

Review of Field Validation Studies of Sediment Bioassays for the Regulatory Evaluation of Dredged Material, by D.W. Moore

Determining Recovery Potential of Dredged Material for Beneficial Use - Debris and Trash Removal, by P.A. Spaine, D.W. Thompson, L.W. Jones, and T.E. Myers

Manufactured Soil Field Demonstrations on Brownfields and Abandoned Minelands, by C.R. Lee

Subaqueous Capping and Natural Recovery: Understanding the Hydrogeologic Setting at Contaminated Sediment Sites, by T.C. Winter

Planning Level Cost-Benefit Analysis for Physical Separation at Confined Disposal Facilities, by T.J. OlinEstes, S.E. Bailey, S.A. Heisey, and K.D. Hofseth

Evaluation of Surface Runoff Water in a Freshwater Confined Disposal Facility - Effects of Vegetation, by R.A. Price

Review of Phytoreclamation and Management Approaches for Dredged Material Contaminated with Lead, by C.R. Lee and R.A. Price

A New Transgenic Cell Line for Detection of Invertebrate Endocrine Disrupters: Laboratory Protocol for its Use, by V.A. McFarland, L.S. Inouye, and C.Y. Ang

Effects of Confined Disposal Facility and Vadose Zone Characteristics on Leachate Quality, by P.R. Schroeder and N.M. Aziz

Validation of Pathway Analysis of Metals from Aged Dredged Material Using Plants and Worms, by E.P.H. Best, K.N. Geter, and H.E. Tatem

Dredged Material Composting at Milwaukee and Green Bay, WI, Confined Disposal Facilities, by T.E. Myers, D.W. Bowman, and K.F. Myers

Dispersion of Leachate in Aquifers, by P.R. Schroeder and N.M. Aziz 
ERDC/TN DOER-C35 $\quad$ Sep 2004
ERDC/TN DOER-C36 Jul 2011
Dredged material management

$\frac{\text { Report Number }}{\text { ERDC/TN DOER-D1 }}$

ERDC/TN DOER-D2

ERDC/TN DOER-D3

ERDC/TN DOER-D4

ERDC/TN DOER-D5

ERDC/TN DOER-D6

ERDC/TN DOER-D7

ERDC/TN DOER-D8

ERDC/TN DOER-D9

ERDC/TN DOER-D10

ERDC/TN DOER-D11
Date $\quad \underline{\text { Title }}$

Aug 2004 Predicting Geotechnical Parameters of Fine-grained Dredged Materials Using the Slump Test Method and Index Property Correlations, by L.T. Lee

Sep 2004 Variability in Geotechnical Properties of Sediments and Dredged Materials, by L.T. Lee

Jun 2005 Nearshore Placed Mound Physical Model Experiment, by E.R. Smith and J.Z. Gailani

Jul 2005 Particle Tracking Model (PTM) in the SMS: I. Graphical Interface, by Z. Demirbilek, J. Smith, A. Zundel, R. Jones, N. MacDonald, and M. Davies

Jul 2005 Particle Tracking Model (PTM) II: Overview of Features and Capabilities, by M.H. Davies, N.J. MacDonald, Z. Demirbilek, S.J. Smith, A.K. Zundel, and R.D. Jones

Jul 2005 Particle Tracking Model (PTM) in the SMS: III. Tutorial with Examples, by Z. Demirbilek, S.J. Smith, A.K. Zundel, R.D. Jones, N.J. McDonald, and M.E. Davies

Sep 2005 Floristic Inventories of Confined Disposal Facilities in the Great Lakes Area of Concern, by R.A. Price, G. Wilhelm, and P. Horner

Jul 2006 Summary of Measurement Protocols Resuspended from Dredging Operations, by T.D. Borrowman

Nov 2007 Manufactured Soil Field Demonstration for Constructing Wetlands to Treat Acid Mine Drainage on Abandoned Minelands, by C.R. Lee, D.L. Brandon, and R.A. Price

Jul 2010 Sustainable Confined Disposal Facilities for Long-term Management of Dredged Material, by S.E. Bailey, T.J. Estes, P.R. Schroeder, T.E. Myers, J.D. Rosati, T.L. Welp, L.T. Lee, W.V. Gwin, and D.E. Averett

May 2011 CDF Characterization for Beneficial Reuse of Dredged Material - Establishing Precedents Based on a Case Study, by T. Estes and J. Clarke 
ERDC/TN DOER-D12

ERDC/TN DOER-D13

ERDC/TN DOER-D14

ERDC/TN DOER-D15

ERDC/TN DOER-D16

ERDC/TN DOER-D17

ERDC/TN DOER-D18
Dec 2011 Sampling Strategies for Confined Disposal Facilities (CDF) Characterization, by J.U. Clarke, C.J. McGrath, and T.J. Estes

Sep 2011 Bench Testing Report - Analytical Variability as a Function of Sediment Sample Extraction Mass, by D.A. Acevedo and T.J. Estes

May 2012 A Review of Risk-Based Approaches to the Development of Screening Criteria for Soils and Application to Beneficial Use of Dredged Material, by S.E. Bailey, D.E. Averett, and P.R. Schroeder

Oct 2012 Particle Tracking Model Data Analysis Tools - Part 1: Capabilities in SMS, by Z. Demirbilek, T. Lackey, and A.K. Zundel

Oct 2012 Particle Tracking Model Data Analysis Tools - Part 2: Capabilities in SMS, by Z. Demirbilek, T. Lackey, and A.K. Zundel

Aug 2014

Field Feasibility Study on the Use of Existing Commercially Available Instrumentation to Detect Fine-Scale $(\leq 1 \mathrm{~mm})$ Bottom Elevation Changes: Currituck Sound, North Carolina, by D.W. Perkey and H.M. Wadman

Jul 2015 Particle Tracking Model Transport Process Verification: Diffusion Algorithm, by D.B. King Jr. and T.C. Lackey

\section{Environmental resource protection}

\begin{tabular}{|c|c|c|}
\hline Report Number & Date & $\underline{\text { Title }}$ \\
\hline ERDC/TN DOER-E7 & Apr 2000 & $\begin{array}{l}\text { Acoustic Monitoring of Dredging-Related Suspended- } \\
\text { Sediment Plumes, by M.W. Tubman and W.D. Corson }\end{array}$ \\
\hline ERDC/TN DOER-E8 & Jun 2000 & $\begin{array}{l}\text { Improved Methods for Correlating Turbidity and } \\
\text { Suspended Solids for Monitoring, by E.L. Thackston } \\
\text { and M.R. Palermo }\end{array}$ \\
\hline ERDC/TN DOER-E9 & May 2000 & $\begin{array}{l}\text { Assessment of Potential Impacts of Dredging } \\
\text { Operations Due to Sediment Resuspension, by D.G. } \\
\text { Clarke and D.H. Wilber }\end{array}$ \\
\hline ERDC/TN DOER-E10 & Apr 2000 & $\begin{array}{l}\text { Description of the SSFATE Numerical Modeling } \\
\text { System, by B.H. Johnson, E. Andersen, T. Isaji, A.M. } \\
\text { Teeter, and D.G. Clarke }\end{array}$ \\
\hline ERDC/TN DOER-E11 & Mar 2000 & $\begin{array}{l}\text { FISHFATE Users Guide: Spatially Temporally Explicit } \\
\text { Population Simulation Model, by J.S. Ault, G.A. } \\
\text { Meester, K.C. Lindeman, and J. Juo }\end{array}$ \\
\hline ERDC/TN DOER-E12 & Jul 2000 & $\begin{array}{l}\text { Demonstration of the SSFATE Numerical Modeling } \\
\text { System, by J.C. Swanson, T. Isaji, M. Ward, B.H. } \\
\text { Johnson, A. Teeter, and D.G. Clarke }\end{array}$ \\
\hline
\end{tabular}


ERDC/TN DOER-E13

ERDC/TN DOER-E14

ERDC/TN DOER-E15

ERDC/TN DOER-E16

ERDC/TN DOER-E17

ERDC/TN DOER-E18

ERDC/TN DOER-E19

ERDC/TN DOER-E2O

ERDC/TN DOER-E21

ERDC/TN DOER-E22

ERDC/TN DOER-E23

ERDC/TN DOER-E24

ERDC/TN DOER-E25

ERDC/TN DOER-E26
Feb 2001 Sturgeon Detection Using Biochemical Methods, by S. Ross, E. Zinkevich, V. Vasileva, A. Kasumyan, and D. Clarke

Aug 2001 Characterization of Underwater Sounds Produced by Bucket Dredging Operations, by C. Dickerson, K.J. Reine, and D.G. Clarke

May 2002 Acoustic Characterization of Suspended Sediment Plumes Resulting from Barge Overflow, by K.J. Reine, D.G. Clarke, and C. Dickerson

Sep 2004 Larval Fish Feeding Responses to Variable Suspended Sediment and Planktonic Prey Concentrations, by D. Colby, and D. Hos

Sep 2004 Summary of Interior Least Tern Research and Monitoring Workshop, by M.P. Guilfoyle, R.A. Fischer, D.N. Pashley, and C. Lott

Feb 2005 Tagging and Tracking Technologies for Freshwater and Marine Fishes, by K. Reine

Mar 2005 Rates and Effects of Sedimentation in the Context of Dredging and Dredged Material Placement, by J.D. Germano, and D. Cary

May 2005 Sedimentation: Potential Biological Effects of Dredging Operations in Estuarine and Marine Environments, by D.H. Wilber, W. Brostoff, D.G. Clarke, and G.L. Ray

Sep 2005 Silt Curtains as a Dredging Project Management Practice, by N.R. Francingues and M.R. Palermo

Nov 2005 Paddlefish and Sturgeon Entrainment by Dredges: Swimming Performance as an Indicator of Risk, by J.J. Hoover, K.J. Killgore, D.G. Clarke, H. Smith, A. Turnage, and J. Beard

Mar 2008 Comparison of Acoustic and Aerial Photographic Methods for Quantifying the Distribution of Submersed Aquatic Vegetation in Sagamore Creek, $\mathrm{NH}$, by B. Sabol, E. Lord, K. Reine, and D. Shafer

Aug 2008 Dredged Material as a Tool for Management of Tern and Skimmer Nesting Habitats, by W. Golder, D. Allen, S. Cameron, and T. Wilder

Oct 2008 Coastal Inlets as Strategic Habitat for Shorebirds in the Southeastern United States, by B.R. Harrington

Sep 2009 Analysis of Organic Contaminants in Dredged Material using a Field-Portable GC-MS, by A.J. Bednar, R.A. Kirgan, J.M. Corgino, and A.L. Russell 
ERDC/TN DOER-E27

ERDC/TN DOER-E28

ERDC/TN DOER-E29

ERDC/TN DOER-E30

ERDC/TN DOER-E31

ERDC/TN DOER-E32

ERDC/TN DOER-E33

ERDC/TN DOER-E34

ERDC/TN DOER-E35

ERDC/TN DOER-E36

ERDC/TN DOER-E37

ERDC/TN DOER-E38
Oct 2010

The Relationship Between Acoustic Target Strength and Body Length for Atlantic Sturgeon (Acipenser oxyrinchus oxyrinchus ), by K. Reine, D. Clarke, C. Dickerson, C. Hager, M. Balazik, G. Garmin, A. Spells, and $\mathrm{C}$. Frederickson

Sep 2011 Conservation and Management of Eastern Gulf Coast Snowy Plovers (Charadrius alexandrinus), by C.A. Lott and R.A. Fischer

Dec 2011 Reducing Human Disturbance to Waterbird Communities Near Corps of Engineers Projects, by J.J. Valente and R.A. Fischer

Jan 2012 Ground Truth Sampling to Support Remote Sensing Research and Development: Submersed aquatic Vegetation Species Discrimination Using an Airborne Hyperspectral/Lidar System, by M. Reif, C. Piercy, J. Jarvis, B. Sabol, C. Macon, R. Loyd, P. Colarusso, H. Dierssen, and J. Aitken

Feb 2012 Fishery Resource Use of an Offshore Dredged Material Mound, by K.J. Reine, D. Clarke, and C. Dickerson

Aug 2012 A Fish Larvae and Egg Exposure System (FLEES) for Evaluating the Effects of Suspended Sediments on Aquatic Life, by C.H. Lutz, D.G. Clarke, and B.C. Suedel

Aug 2012 Fishery Resource Utilization of a Restored Estuarine Borrow Pit: A Beneficial Use of Dredged Material Case Study, by K.J. Reine, D.G. Clarke, G.L. Ray, and C. Dickerson

Sep 2012 Characterization of Underwater Sounds Produced by a Hydraulic Cutterhead Dredge Fracturing Limestone Rock, by K.J. Reine, D.G. Clarke, and C. Dickerson

Dec 2012 Demonstration of Commercial Off-the-Shelf (COTS) Acoustic Technologies for Manatee Detection, by P. Stodola, J. Furey, and B. Sabol

Dec 2012 Characterization of Underwater Sounds Produced by a Backhoe Dredge Excavating Rock and Gravel, by K. Reine, D. Clarke, and C. Dickerson

Jun 2013 A Pre-Restoration Fishery Resource Utilization Assessment of an Estuarine Borrow Pit in Mobile Bay, Alabama, by K.J. Reine, D.G. Clarke, and C. Dickerson

Mar 2014 Characterization of Underwater Sounds Produced by a Hydraulic Cutterhead Dredge during Maintenance Dredging in the Stockton Deepwater Shipping Channel, California, by K.J. Reine and C. Dickerson 


\section{Innovative operations technologies}

\begin{tabular}{|c|c|c|}
\hline Report Number & Date & $\underline{\text { Title }}$ \\
\hline ERDC/TN DOER-I1 & $\begin{array}{l}\text { Jul } 1999 \\
\text { Rev. Apr } \\
2000\end{array}$ & $\begin{array}{l}\text { Case Studies: Monitoring Pipeline Dredges, by J. } \\
\text { Rosati and T. Welp }\end{array}$ \\
\hline ERDC/TN DOER-I2 & Jul 2000 & $\begin{array}{l}\text { Initial Corps Experience with Tons Dry Solids (TDS) } \\
\text { Measurement, by T.L. Welp, and J. Rosati, III }\end{array}$ \\
\hline ERDC/TN DOER-I3 & Jul 2000 & $\begin{array}{l}\text { Application of Dredge Monitoring Systems to Dredge } \\
\text { Contract Administration Quality Assurance, by S.H. } \\
\text { Scott }\end{array}$ \\
\hline ERDC/TN DOER-14 & Aug 2000 & $\begin{array}{l}\text { Silent Inspector for Hydraulic Pipeline Dredges, by J. } \\
\text { Rosati }\end{array}$ \\
\hline ERDC/TN DOER-15 & Aug 2000 & $\begin{array}{l}\text { Uncertainty Analysis Applied to Dredge Production } \\
\text { Calculation, by S. Scott }\end{array}$ \\
\hline ERDC/TN DOER-16 & Mar 2001 & $\begin{array}{l}\text { Silent Inspector Implementation Procedures for } \\
\text { Hopper and Pipeline Dredges, by J. Rosati, III and T.L. } \\
\text { Prickett }\end{array}$ \\
\hline
\end{tabular}

\section{Nearshore processes}

\begin{tabular}{|c|c|c|}
\hline Report Number & Date & $\underline{\text { Title }}$ \\
\hline ERDC/TN DOER-N5 & Jul 2000 & $\begin{array}{l}\text { Geotechnical Design Considerations for Contained } \\
\text { Aquatic Disposal, by M.P. Rollings }\end{array}$ \\
\hline ERDC/TN DOER-N6 & Mar 2000 & $\begin{array}{l}\text { Construction and Monitoring of a Mixed-Sediment } \\
\text { Mound Offshore of Mobile Bay, Alabama, by J.E. Davis, } \\
\text { D.K. Stauble, and M.P. Rollings }\end{array}$ \\
\hline ERDC/TN DOER-N7 & Aug 2000 & $\begin{array}{l}\text { Underflow Spreading from an Open-Water Pipeline } \\
\text { Disposal, by A.M. Teeter }\end{array}$ \\
\hline ERDC/TN DOER-N8 & Apr 2001 & $\begin{array}{l}\text { Graphical User Interface for LTFATE Version 2.0, by J.Z. } \\
\text { Gailani, E. Howlett, T. Isaji, and C. Galagan }\end{array}$ \\
\hline ERDC/TN DOER-N9 & Apr 2001 & $\begin{array}{l}\text { Effects of Bentonite Clay on Sediment Erosion Rates, } \\
\text { by J.Z. Gailani, L. Jin, J. McNeil, and W. Lick }\end{array}$ \\
\hline ERDC/TN DOER-N10 & Apr 2001 & $\begin{array}{l}\text { Erosion rates and Bulk Properties of Dredged } \\
\text { Sediments from Mobile, Alabama, by J.Z. Gailani, A. } \\
\text { Kiehl, J. McNeil, L. Jin, and W. Lick }\end{array}$ \\
\hline ERDC/TN DOER-N11 & Apr 2001 & $\begin{array}{l}\text { Simulating Underflow Spreading from a Shallow-Water } \\
\text { Pipeline Disposal, by A.M. Teeter }\end{array}$ \\
\hline ERDC/TN DOER-N12 & Dec 2001 & $\begin{array}{l}\text { In Situ Expedient Test Methods to Determine } \\
\text { Geotechnical Properties of Dredged Materials, by L.T. } \\
\text { Lee }\end{array}$ \\
\hline
\end{tabular}


ERDC/TN DOER-N13

ERDC/TN DOER-N14

ERDC/TN DOER-N15

ERDC/TN DOER-N16

\section{Risk}

Report Number

ERDC/TN DOER-R2

ERDC/TN DOER-R3

ERDC/TN DOER-R4

ERDC/TN DOER-R5

ERDC/TN DOER-R6

ERDC/TN DOER-R7

ERDC/TN DOER-R8

ERDC/TN DOER-R9

ERDC/TN DOER-R10
Dec 2001 Geotechnical Properties and Sediment

Characterization for Dredged Material Models, by L.T. Lee

Dec 2001 Development of Methodology for Predicting Fate of Dredged Material Placed on Riverbanks, by K.N.

Raphelt, S. Tingle, R.E. Heath, and Y. Chu

Oct 2002 Improved Sand Transport Model for LTFATE (Version 2.0), by J.Z. Gailani

Aug 2002 Sediment Dispersion Near Dredge Pipeline Discharge in Laguna Madre, Texas, by A.M. Teeter
Date

Dec 2001

Sep 2004

Sep 2004

Sep 2004

Dec 2004

Sep 2005

Sep 2005

Sep 2005

Jul 2006 $\underline{\text { Title }}$

Implementation of Dredging Risk Assessment Modeling Applications for Evaluation of the No-Action Scenario and Dredging Impacts, by P.N. Deliman, C.E. Ruiz, and P.R. Schroeder

Validating Pathway Analysis of Organic Contaminants from Aged Dredged Material Using Plants and Worms, by E.P.H. Best, K. Geter, H.E. Tatem, H.L. Fredrickson, M. Richmond, J. Furey, and M. Wells

Development of Gene Expression Fingerprints for Identification of Environmental Contaminants Using cDNA Arrays, by L.S. Inouye, C.Y. Ang, and V.A. McFarland

Analysis of Uncertainty in Estimating Dioxin Bioaccumulation Potential in Sediment-Exposed Benthos, by J.U. Clarke, V.A. McFarland, C.H. Lutz, R.P. Jones, and S.W. Pickard

Liner Design Guidance for Confined Disposal Facility Leachate Control, by E.J. LeBoeuf, E.L. Thackston, P.R. Schroeder, and M.R. Palermo

Design Guidance for Confined Disposal Facility Lateral Seepage Control, by E.J. LeBoeuf, and E.L. Thackston

Cost Estimating for Contaminated Sediment Treatment A Summary of the State of the Practice, by T.E. Myers

Equipment and Placement Techniques for Subaqueous Capping, by S.E. Bailey and M.R. Palermo

Evaluation of Chemical Clarification Polymers and Methods for Removal of Dissolved Metals from CDF Effluent, by S.E. Bailey, S. Hwang, M.C. Brooks, and P.R. Schroeder 
ERDC/TN DOER-R11

ERDC/TN DOER-R12

ERDC/TN DOER-R13

ERDC/TN DOER-R14

ERDC/TN DOER-R15

ERDC/TN DOER-R16

ERDC/TN DOER-R17

ERDC/TN DOER-R18

ERDC/TN DOER-R19

ERDC/TN DOER-R20

ERDC/TN DOER-R21

ERDC/TN DOER-R22

ERDC/TN DOER-R23
Aug 2006

Screening Evaluations for Upland Confined Disposal Facility Effluent Quality, by P. Schroeder, T. Estes, and S. Bailey

Sep 2008 Screening Evaluations for Upland Confined Disposal Facility Surface Runoff Quality, by P.R. Schroeder, S.E. Bailey, T.J. Estes, and R.A. Price

Sep 2009 Comparison of the Direct Scoring Method and MultiCriteria Decision Analysis for Dredged Material Management Decision Making, by B.C. Suedel, J. Kim, and C.J. Banks

Feb 2011 28-Day Chronic Sublethal Test Method for Evaluating Whole Sediments Using an Early Life Stage of the Marine Polychaete Neanthes arenaceodentata, by J.D. Farrar and T.S. Bridges

Apr 2011 Development of a Bioaccumulation Test Method with the Amphipod Leptocheirus plumulosus, by J.D. Farrar, G. Lotufo, and J. Sims

Jun 2011 Environmental Enhancements and Navigation Infrastructure: Existing Practices, Innovative Ideas, and Research Needs, by T.J. Fredette, C.M. Foran, S.M. Brasfield, and B.C. Suedel

Aug 2011 Bioaccumulation Models: State of the Application at Large Superfund Sites, by K. Gustavson, T. von Stackelberg, I. Linkov, and T. Bridges

Oct 2011 An Introduction to Using Bayesian Networks to Model Dredging Decisions, by M.T. Schultz and T.D. Borrowman

Dec 2012 Riparian Vegetation, Natural Succession, and the Challenge of Maintaining Bare Sandbar Nesting Habitat for Least Terns and Piping Plovers, by R.L. Wiley and C.A. Lott

Aug 2013 Operationalizing Engineering With Nature - Regional Sediment Management Principles and Practices into Operations and Maintenance Dredging Beneficial Use Project Management, by C.J. Banks and J.M. Gerhardt Smith

Sep $2013 \quad$ Implementing Engineering With Nature within the Corps: A Workshop, by C.J. Banks, T.J. Fredette, B.C. Suedel, and T.S. Bridges

Jun 2015 Dredged Material Management Categories for Tracking Beneficial Use, by J.L. Childs

Aug 2015 Conceptual Model Development for Sea Turtle Nesting by L.M. Dunkin, M.K. Reif, T.M. Swannack, and J.M. Gerhardt-Smith 


\section{Dredging technologies}

Report Number

ERDC/TN DOER-T1

ERDC/TN DOER-T2

ERDC/TN DOER-T3

ERDC/TN DOER-T4

ERDC/TN DOER-T5

ERDC/TN DOER-T6

ERDC/TN DOER-T7

ERDC/TN DOER-T8

ERDC/TN DOER-T9

ERDC/TN DOER-T10

ERDC/TN DOER-T11
Date

Feb 2000

Dec 2000

Jan 2001

Dec 2001

Aug 2006

Sep 2004

Oct 2004

Mar 2007

Oct 2007

Sep 2011

Jul 2013 $\underline{\text { Title }}$

Innovations in Dredging Technology: Equipment, Operations, and Management, by N.R. Francingues, T.N. McLellan, R.J. Hopman, R.G. Vann, and T.D. Woodward

Innovative Dredged Sediment Decontamination and Treatment Technologies, by N.R. Francingues, and D.W. Thompson

The Corps of Engineers Telescoping Weir for Confined Placement Sites, by N.R. Francingues, E.C. McNair, R.G. Vann, and T.D. Woodward

Special PIANC Session on Environmental Dredging, by N.R. Francingues

Pipeline Optimization Program (PLOP), by D. Wilson

Status of Current Hopper and Bin Measurement Technologies, by T. Welp, J. Rosati, and G. Howell

Mechanical Dewatering of Navigation Sediments: Equipment, Bench-Scale Testing, and Fact Sheets, by T.J. Estes, J. Waugh, R.L. Schwartz, G. Green, V. Buhr, B. Braddock, and H.D. Detzner

Recycled Glass and Dredged Materials, by L.T. Lee, Jr.

A Microscale Approach for the Quantitative Detection of PCBs and PAHs in Small Tissue Masses, by R. Millward, R. Jones, R. Karn, and A. Harrison

Physical Separation Process Demonstrations--A Review of Three Dredging Projects, by D.E. Averett and T.J. Estes

Laboratory Feasibility Study Concerning the Use of the SediMeter ${ }^{\mathrm{TM}}$ to Detect Fine-Scale $(\leq 1 \mathrm{~mm})$ Sedimentation Resulting from Dredging Operations, by D.W. Perkey and H.M. Wadman

\section{Technical reports}

Report Number

Date

$\underline{\text { Title }}$

ERDC TR-DOER-5
Innovations in Dredging Technology: Equipment, Operations, and Management, by T.N. McLellan and R.J. Hopman 


\section{Dredging Operations Technical Support Program (DOTS)}

\section{Bulletins}

\begin{tabular}{lll} 
Report Number & Date & Title \\
Vol. 3 No. 1 & Mar 2000 & Dredging Research \\
Vol. 3 No. 2 & Jun 2000 & Dredging Research \\
Vol. 3 No. 3 & Sep 2000 & Dredging Research \\
Vol. 3 No. 4 & Dec 2000 & Dredging Research \\
Vol. 4 No. 1 & Mar 2001 & Dredging Research \\
Vol. 4 No. 2 & Jun 2001 & Dredging Research \\
Vol. 4 No. 3 & Sep 2001 & Dredging Research \\
Vol. 4 No. 4 & Dec 2001 & Dredging Research \\
Vol. 5 No. 1 & Mar 2002 & Dredging Research \\
Vol. 5 No. 2 & Jun 2002 & Dredging Research \\
Vol. 5 No. 3 & Sep 2002 & Dredging Research \\
Vol. 5 No. 4 & Dec 2002 & Dredging Research \\
Vol. 6 No. 1 & Mar 2003 & Dredging Research \\
Vol. 6 No. 2 & Jun 2003 & Dredging Research \\
Vol. 6 No. 3 & Sep 2003 & Dredging Research \\
Vol. 7 No. 1 & Mar 2004 & Dredging Research \\
Vol. 7 No. 2 & Aug 2004 & Dredging Research \\
Vol. 8 No. 1 & Jul 2005 & Dredging Research \\
& & \\
\hline & &
\end{tabular}

\section{Technical notes}

$\begin{array}{lll}\text { Report Number } & \text { Date } & \text { Title } \\ \text { ERDC/TN DOTS-14-01 } & \text { Aug 2014 } & \begin{array}{l}\text { New Standard Weir Design for Dredged Material } \\ \text { Management Area, Jacksonville District, by C.K. Maglio, } \\ \text { J.W. Bearce, M.A. Presley, and J.L. Grover }\end{array} \\ & & \begin{array}{l}\text { Evaluation of Hydraulic Fracturing (Fracking) Plays for } \\ \text { ERDC/TN DOTS-15-1 }\end{array} \\ & \text { Jan 2015 } & \begin{array}{l}\text { Potential Impact on USACE-Managed Waterways, by V.F. } \\ \text { Medina and B. Suedel }\end{array}\end{array}$




\section{Ecosystem Characterization and Monitoring Initiative Program (ECMI)}

\section{Technical notes}

\begin{tabular}{|c|c|c|}
\hline Report Number & Date & $\underline{\text { Title }}$ \\
\hline ERDC/EL TN-ECMI-01-01 & Sep 2001 & $\begin{array}{l}\text { Classification of Land-Cover Types for the Fort Benning } \\
\text { Ecoregion Using Enhanced Thematic Mapper Data, by } \\
\text { S.G. Bourne and M.R. Graves }\end{array}$ \\
\hline ERDC/EL TN-ECMI-01-02 & Sep 2001 & $\begin{array}{l}\text { Ground Control Survey at Fort Benning, Georgia, by C.D. } \\
\text { Hahn }\end{array}$ \\
\hline ERDC/EL TN-ECMI-02-1 & Oct 2002 & $\begin{array}{l}\text { Evaluation of ECMI Instrumentation Deployed at Fort } \\
\text { Benning, by C.D. Hahn }\end{array}$ \\
\hline ERDC/EL TN-ECMI-02-2 & Oct 2002 & $\begin{array}{l}\text { Landscape Pattern Metrics at Fort Benning, Georgia, by } \\
\text { M.R. Graves and S.G. Bourne }\end{array}$ \\
\hline ERDC/EL TN-ECMI-04-1 & Nov 2004 & $\begin{array}{l}\text { Classification of Land-Cover Types for the Fort Benning } \\
\text { Ecoregion Using Enhanced Thematic Mapper Data: } \\
\text { January } 2003 \text { Imagery, by S.S. Jackson, S.G. Bourne, } \\
\text { and M.R. Graves }\end{array}$ \\
\hline ERDC/EL TN-ECMI-05-1 & Jul 2005 & $\begin{array}{l}\text { An Automated Procedure to Monitor Urban } \\
\text { Encroachment Over Time on Fort Benning Military } \\
\text { Installation, by S.S. Jackson and S.G. Bourne }\end{array}$ \\
\hline ERDC/EL TN-ECMI-05-2 & Aug 2005 & $\begin{array}{l}\text { Resources, Equipment and Logistics in Support of Long- } \\
\text { term Monitoring at Fort Benning, by D. Leese }\end{array}$ \\
\hline ERDC/EL TN-ECMI-05-3 & Sep 2005 & $\begin{array}{l}\text { Development of a Distributed Source Contaminant } \\
\text { Transport Model for ARAMS, by B.E. Johnson and Z. } \\
\text { Zhang }\end{array}$ \\
\hline
\end{tabular}




\section{Ecosystem Management and Restoration Research Program (EMRRP)}

\section{Bulletins}

\begin{tabular}{|c|c|c|}
\hline Report Number & Date & Title \\
\hline $\begin{array}{l}\text { EMRRP Bulletin Vol. 2, } \\
\text { No. } 3\end{array}$ & Oct 1999 & $\begin{array}{l}\text { Overview of Stream Restoration Technology: State of } \\
\text { the Science, by J.C. Fischenich }\end{array}$ \\
\hline EMRRP Bulletin 01-1 & May 2001 & $\begin{array}{l}\text { Technologies for Urban Stream Restoration and } \\
\text { Watershed Management, by J.C. Fischenich }\end{array}$ \\
\hline EMRRP Bulletin 03-1 & Jan 2003 & $\begin{array}{l}\text { Riparian Restoration and Management Needs in the } \\
\text { Arid and Semi-arid Western United States, by R.A. } \\
\text { Fischer }\end{array}$ \\
\hline EMRRP Bulletin 04-1 & May 2004 & $\begin{array}{l}\text { Catalog of Community Habitat Models, by A.C. Webb } \\
\text { and L.J. O'Neil }\end{array}$ \\
\hline EMRRP Bulletin 10-1 & Dec 2010 & $\begin{array}{l}\text { CEMCAT: Conceptual Ecological Model Construction } \\
\text { Assistance Toolbox, by P.S. Daylander and J.C. } \\
\text { Fischenich }\end{array}$ \\
\hline
\end{tabular}

\section{Technical notes}

\section{Environmental Benefits Assessment (EBA)}

\begin{tabular}{|c|c|c|}
\hline Report Number & Date & $\underline{\text { Title }}$ \\
\hline ERDC/TN EMRRP-EBA-01 & Feb 2008 & $\begin{array}{l}\text { The Application of Conceptual Models to Ecosystem } \\
\text { Restoration, by J.C. Fischenich }\end{array}$ \\
\hline ERDC/TN EMRRP-EBA-02 & Sep 2008 & $\begin{array}{l}\text { A Metric and GIS Tool for Measuring Connectivity Among } \\
\text { Habitat Patches Using Least-Cost Distances, by J.P. Lin }\end{array}$ \\
\hline ERDC/TN EMRRP-EBA-03 & Sep 2009 & Reducing Spreadsheet Errors, by S.K. McKay \\
\hline ERDC/TN EMRRP-EBA-4 & Jul 2010 & $\begin{array}{l}\text { Metric Development for Environmental Benefits Analysis, } \\
\text { by by S.K. McKay, B.A. Pruitt, M. Harberg, A.P. Covich, } \\
\text { M.A. Kenney, and J.C. Fischenich }\end{array}$ \\
\hline ERDC/TN EMRRP-EBA-5 & Jul 2010 & $\begin{array}{l}\text { Improving Conceptual Model Development: Avoiding } \\
\text { Underperformance Due to Project Uncertainties, by A.F. } \\
\text { Casper, R.A. Efroymson, S.M. Davis, G. Steyer, and B. } \\
\text { Zettle }\end{array}$ \\
\hline ERDC/TN EMRRP-EBA-6 & Feb 2011 & $\begin{array}{l}\text { Environmental Benefits Analysis of Fish Passage on the } \\
\text { Truckee River, Nevada: A Case Study of Multi-Action- } \\
\text { Dependent Benefits Quantification, by J. Conyngham, S.K. } \\
\text { McKay, C. Fischenich, and D. Artho }\end{array}$ \\
\hline
\end{tabular}


ERDC/TN EMRRP-EBA-7 Mar 2011

ERDC/TN EMRRP-EBA-8 Mar 2011

ERDC/TN EMRRP-EBA-9 May 2011

ERDC/TN EMRRP-EBA-10 Apr 2012

ERDC/TN EMRRP-EBA-11 May 2012

ERDC/TN EMRRP-EBA-12 Jun 2012

ERDC/TN EMRRP-EBA-13 Jul 2012

ERDC/TN EMRRP-EBA-14 Aug 2012

ERDC/TN EMRRP-EBA-15 Aug 2012

ERDC/TN EMRRP-EBA-16 Oct 2012

ERDC/TN EMRRP-EBA-17 Nov 2012

ERDC/TN EMRRP-EBA-18 Dec 2012

ERDC/TN EMRRP-EBA-19 Jun 2013

ERDC/TN EMRRP-EBA-20 Jul 2014
Using Multi-Criteria Decision Analysis to Support

Ecosystem Restoration Planning, by B.C. Suedel, K.

Burks-Copes, J. Kim, and K. McKay

Hydrologic Analyses for Stream Restoration Design, by

J.C. Fischenich and S.K. McKay

Using General Land Office Survey Records in Ecosystem Restoration Planning, by M. Perkins, C. Klimas, J. Dunbar, T. Foti, and J. Pagan

The Application of Adaptive Management to Ecosystem Restoration Projects, by C. Fischenich and C. Vogt

The Use of Reference Ecosystems as a Basis for Assessing Restoration Benefits, by B.A. Pruitt, S.J. Miller, C.H. Theiling, and J.C. Fischenich

Reference Concepts in Ecosystem Restoration and Environmental Benefits Analysis (EBA): Principles and Practices, by S.J. Miller, B.A. Pruitt, C.H. Theiling, J.C. Fischenich, and S.B. Komlos

Stability Thresholds and Performance Standards for Flexible Lining Materials in Channel and Slope Restoration Applications, by S.J. Miller, J.C. Fischenich, and C.I. Thornton

An Approach for Developing Regional Environmental Benefits Models, by S.K. McKay and B.A. Pruitt

Application of Risk Management and Uncertainty Concepts and Methods for Ecosystem Restoration:

Principles and Best Practice, by B.C. Suedel, L.J. Valverde, Jr., J. Vogel, I. Linkov, J.C. Fischenich, T. Bridges, and M. Plumley

Ecosystem Restoration Objectives and Metrics, by S.K. McKay, I. Linkov, J.C. Fischenich, S.J. Miller, and L.J. Valverde, Jr.

Currituck Sound Estuary Restoration: A Case Study in Objective Setting, by S.K. McKay, C.R. Wilson, and D. Piatkowski

Evaluating Protocols to Quantify the Significance of Aquatic Ecosystems at Regional and National Scales: Proceedings of a Workshop,

Cambridge, MA, 20-22 July 2011, by D.J. Tazik

Metric Selection for Ecosytem Restoration, by M. Convertino, K. Baker, C. Lu, J.T. Vogel, K. McKay, and I. Linkov

Case Study: Sensitivity Analysis of the Barataria Basin Barrier Shoreline Wetland Value Assessment Model, by S.K. McKay and J.C. Fischenich 
ERDC/TN EMRRP-EBA-21 Jul 2014

ERDC/TN EMRRP-EBA-22 Aug 2014
Uncertainty and Sensitivity of Ecosystem Restoration Decisions: A Case Study from Coastal Louisiana, by S.K. McKay and J.C. Fischenich

Case Study: Southwest Coastal Louisiana Conceptual Ecosystem Model Development, by J.C. Fischenich and T.K. Barnes

\section{Ecosystem impacts (EI)}

$\begin{array}{ll}\text { Report Number } & \text { Date } \\ \text { ERDC TN-EMRRP-EI-01 } & \text { Jul 2000 } \\ \text { ERDC TN-EMRRP-EI-02 } & \text { Jan 2008 } \\ \text { ERDC TN-EMRRP-EI-03 } & \text { Sep 2008 } \\ \text { ERDC TN-EMRRP-EI-04 } & \text { Apr 2009 }\end{array}$

$\underline{\text { Title }}$

Quantifying Habitat Benefits of Restored Backwaters, by J.J. Hoover, K.J. Killgore, and G.L. Young

Habitat Equivalency Analysis: A Potential Tool for Estimating Environmental Benefits, by G.L. Ray

Short-Term Sediment Burial Effects on the Seagrass Phyllospadix scouleri, by C. Craig, S. Wyllie-Echeverria, E. Carrington, and D. Shafer

Application of Habitat Equivalency Analysis to USACE Projects, by G.L. Ray

\section{Ecosystem management and support systems (EM)}

\begin{tabular}{|c|c|c|}
\hline Report Number & Date & $\underline{\text { Title }}$ \\
\hline ERDC TN-EMRRP-EM-01 & Jul 2000 & $\begin{array}{l}\text { Linking Biological Models and Spatial Descriptions of } \\
\text { Environmental Complexity with Coupled Models, by J.M. } \\
\text { Nestler, R.A. Goodwin, and L.T. Schneider }\end{array}$ \\
\hline ERDC TN-EMRRP-EM-02 & Jan 2002 & $\begin{array}{l}\text { Simulating Movement of Highly Mobile Aquatic Biota: } \\
\text { Foundation for Population Modeling in an Ecosystem } \\
\text { Context, by J.M. Nestler, R.A. Goodwin, and L.T. Toney }\end{array}$ \\
\hline ERDC TN-EMRRP-EM-03 & May 2002 & $\begin{array}{l}\text { Small Floodplain Pools as Habitat for Fishes and } \\
\text { Amphibians: Methods for Evaluation, by J.J. Hoover and } \\
\text { K.J. Killgore }\end{array}$ \\
\hline ERDC TN-EMRRP-EM-04 & Sep 2006 & $\begin{array}{l}\text { Natural Resources Level One Inventories: What are the } \\
\text { Needs and Process for Corps Projects?, By C.O. Martin, J. } \\
\text { Krause, and D.N. Wiese }\end{array}$ \\
\hline ERDC TN-EMRRP-EM-05 & Sep 2006 & $\begin{array}{l}\text { Creating a Wetland Restoration Decision Support System } \\
\text { Using GIS Tools, by J.P. Lin, S.G. Bourne, and B.A. Kleiss }\end{array}$ \\
\hline ERDC TN-EMRRP-EM-06 & Sep 2007 & $\begin{array}{l}\text { Availability of an ArcGIS Wetland Restoration Spatial } \\
\text { Decision Support System (SDSS) Tool, by J.P. Lin and B.A. } \\
\text { Kleiss }\end{array}$ \\
\hline ERDC TN-EMRRP-EM-07 & Sep 2007 & $\begin{array}{l}\text { Availability of Patch Calculator, an ArcGIS v.9 Tool for the } \\
\text { Analysis of Landscape Patches, by J.P. Lin }\end{array}$ \\
\hline
\end{tabular}


ERDC TN-EMRRP-EM-08 Aug 2010

ERDC TN-EMRRP-EM-09 Dec 2010

ERDC TN-EMRRP-EM-10 Oct 2011
Initial Application of a Landscape Evolution Model to a Louisiana Wetland, by C.F. Cerco

Guidelines for Assessing the Condition of Lands and Waters Managed by the U.S. Army Corps of Engineers, by J.F. Krause and W.M. Ford

Ecological Forecasting Tools and Planning of Ecosystem Restoration Projects, by C.M. Foran, I. Linkov, E.A. Moberg, D.L. Smith, and D.M. Soballe

\section{Ecosystem restoration (ER)}

\begin{tabular}{|c|c|}
\hline Report Number & Date \\
\hline ERDC/TN EMRRP-ER-01 & Sep 2003 \\
\hline ERDC/TN EMRRP-ER-02 & Nov 2003 \\
\hline ERDC/TN EMRRP-ER-03 & Feb 2006 \\
\hline ERDC/TN EMRRP-ER-04 & Oct 2006 \\
\hline ERDC/TN EMRRP-ER-05 & Feb 2007 \\
\hline ERDC/TN EMRRP-ER-06 & Aug 2007 \\
\hline ERDC/TN EMRRP-ER-07 & Sep 2007 \\
\hline
\end{tabular}

ERDC/TN EMRRP-ER-08 Feb 2008

ERDC/TN EMRRP-ER-09 May 2008

ERDC/TN EMRRP-ER-10 Aug 2008

ERDC/TN EMRRP-ER-11 Feb 2009

ERDC/TN EMRRP-ER-12 Sep 2009 $\underline{\text { Title }}$

Economic Values Associated with Construction of Oyster Reefs by the Corps of Engineers, by J. Henderson and L.J. O'Neil

Willow Stake Installation: Example Contract Specifications, by D. Shafer and A. Lee

Experimental Gravel Bar Habitat Creation in the Tombigbee River, Mississippi, by A.C. Miller

Guidelines for the Acquisition of Aerial Photography for Digital Photo-Interpretation of Submerged Aquatic Vegetation (SAV), by S.S. Jackson, M.R. Graves, and D.J. Shafer

Overview of Prairie Planting Techniques and Maintenance Requirements, by P. Bailey and C.O. Martin

Long-Term Development of Planted Mangrove Wetlands in Florida, by D. Shafer and T. Roberts

Surfgrass Restoration in the Northeast Pacific, by T.

Wyllie-Echeverria, M. Hannan, S. Wyllie-Echeverria, and D. Shafer

Restoration of Delta Streams: A Case History and Conceptual Model, by K.J. Killgore, J.J. Hoover, C.E. Murphy, K.D. Parrish, D.R. Johnson, and K.F. Myers

Cottonwoods of the Midwest: A Community Profile, by W. Mitchell, J. O'Neil, and A. Webb

Library of Habitat Models to Evaluate Benefits of Aquatic Restoration Projects on Fishes, by K.J. Killgore, J.J.

Hoover, and C.E. Murphy

Prairies and Water Management on Corps Lands, by P. Bailey

Use of Alternative Materials for Oyster Reef Construction, by D. Schulte, G. Ray, and D. Shafer 
ERDC/TN EMRRP-ER-13 Apr 2010

ERDC/TN EMRRP-ER-14 Apr 2012

ERDC/TN EMRRP-ER-15

Aug 2012

ERDC/TN EMRRP-ER-16

Aug 2012

ERDC/TN EMRRP-ER-17

ERDC/TN EMRRP-ER-18 Jul 2013

ERDC/TN EMRRP-ER-19 Jan 2014

ERDC/TN EMRRP-ER-20 Feb 2014

Sep 2012
Addressing Risk and Uncertainty in Planning Ecological Restoration Projects, by C.E. Yoe, K. Burks-Copes, M.T. Schultz, and B.C. Suedel

An Illustrative Case Study of the Application of Uncertainty Concepts and Methods for Ecosystem Restoration, by M. Convertino, B.C. Suedel, K.M. Baker, J.T. Vogel, L.J. Valverde, Jr., J.C. Fischenich, and I. Linkov

Ranking Secondary Channels for Restoration Using an Index Approach, by K.J. Killgore, J.J. Hoover, B.R. Lewis, and R. Nassar

Potential Natural Vegetation Maps for Ecosystem Restoration in the Mississippi Alluvial Valley, by C. Klimas, T. Foti, J. Pagan, M. Williamson, and E. Murray

Ranking Restoration Alternatives for the Lower Mississippi River: Application of Multi-Criteria Decision Analysis, by K.A. Boysen, J.J. Hoover, and K.J. Killgore

Incorporating Ecosystem Goods and Services in Environmental Planning - Definitions, Classification and Operational Approaches, by E. Murray, J. Cushing, L. Wainger, and D.J. Tazik

Retrospective Evaluation of the Protocol for US Army Corps of Engineers Aquatic Ecosystem Restoration Projects Part 2: Database Content and Data Entry Guidelines, by J.S. Gardner, E.E. Maynard, D.L. Price, and J.C. Fischenich

Retrospective Evaluation of Corps Aquatic Ecosystem Restoration Projects Protocol Part 1: Project Overview, by J. Gardner, E. Maynard, D. Price, and C. Fischenich

\section{Rapid quantification and assessment methods (RQ)}

$\begin{array}{ll}\text { Report Number } & \text { Date } \\ \text { ERDC/TN EMRRP-RQ-01 } & \text { Jan 2009 }\end{array}$

ERDC/TN EMRRP-RQ-02 Sep 2014 $\underline{\text { Title }}$

Applying an Avian Index of Biological Integrity to Assess and Monitor Arid and Semi-arid Riparian Ecosystems, by M.P. Guilfoyle, J.S. Wakeley, and R.A. Fischer

Development of Genetic Markers for Environmental DNA (eDNA) Monitoring of Sturgeon, by H.L. Farrington and R.F. Lance

\section{Species information (SI)}

$\begin{array}{lll}\text { Report Number } & \underline{\text { Date }} & \text { Title } \\ \text { ERDC/TN EMRRP-SI-09 } & \text { Jan 2000 } & \text { Width of Riparian Zones for Birds, by R.A. Fischer }\end{array}$


ERDC/TN EMRRP-SI-10 Apr 2000

ERDC/TN EMRRP-SI-11 Apr 2000

ERDC/TN EMRRP-SI-12 Apr 2000

ERDC/TN EMRRP-SI-13 Apr 2000

ERDC/TN EMRRP-SI-14 Apr 2000

ERDC/TN EMRRP-SI-15 Apr 2000

ERDC/TN EMRRP-SI-16 May 2000

ERDC/TN EMRRP-SI-17 Sep 2000

ERDC/TN EMRRP-SI-18 Dec 2000

ERDC/TN EMRRP-SI-19 Apr 2001

ERDC/TN EMRRP-SI-20 Jul 2001

ERDC/TN EMRRP-SI-21 Sep 2001

ERDC/TN EMRRP-SI-22 Aug 2001

ERDC/TN EMRRP-SI-23 Nov 2001

ERDC/TN EMRRP-SI-24

Sep 2002

ERDC/TN EMRRP-SI-25

May 2002
Characterization of Sensitive Species and Habitats Affected by the Operation of USACE Water Resource Development Projects, by R.L. Kasul, C.O. Martin, and H.H. Allen

Riparian Raptors Potentially Impacted by USACE

Reservoir Operations, by W.A. Mitchell, M.P. Guilfoyle, M.S. Wolters, and C.O. Martin

Riparian Raptors on USACE Projects: Bald Eagle (Haliaeetus leucocephalus), by M.P. Guilfoyle, D.E. Evans, R.A. Fischer, and C.O. Martin

Riparian Raptors on USACE Projects: Osprey (Pandion haliaetus), by W.A. Mitchell and M.S. Wolters

Riparian Raptors on USACE Projects: Peregrine Falcon (Falco peregrinus), by W.A. Mitchell, D.E. Evans, and R.A. Fischer

Riparian Raptors on USACE Projects: Red-shouldered Hawk (Buteo lineatus), by M.P. Guilfoyle and M.S. Wolters

Bald Eagle Recovery Efforts at Corps of Engineers Projects, by R.A. Fischer

Riparian Shorebirds Potentially Impacted by USACE Reservoir Operations, by W.A. Mitchell, M.P. Guilfoyle, and M.S. Wolters

Bat Habitat Restoration and Management Opportunities on Corps of Engineers Projects, by C.O. Martin

Sensitive Western Riparian Songbirds Potentially Impacted by USACE Reservoir Operations, by M.P. Guilfoyle

The Importance of Corps of Engineers Lands to Migrating and Breeding Birds, by R.A. Fischer and H.R. Hamilton

Management of Bottomland Hardwood Forests for Nongame Bird Communities on Corps of Engineers Projects, by M.P. Guilfoyle

Riparian Habitat Management for Reptiles and Amphibians on Corps of Engineers Projects, by D.D. Dickerson

Hedgerow and Fencerow Management on Corps of Engineers Projects, by W.A. Mitchell, W.P. Kuvleskey, Jr., D. Burks, and C.O. Martin

Eastern Cave- and Crevice-Dwelling Bats Potentially Impacted by USACE Reservoir Operations, by C.O. Martin, W.A. Mitchell, and M.S. Wolters
Cave- and Crevice-Dwelling Bats on USACE Projects: Gray Bat (Myotis grisescens), by W.A. Mitchell and C.O. Martin 
ERDC/TN EMRRP-SI-27

May 2002

ERDC/TN EMRRP-SI-28 Jul 2002

ERDC/TN EMRRP-SI-29 Jul 2002

ERDC/TN EMRRP-SI-30 Sep 2005

ERDC/TN EMRRP-SI-31 Apr 2007

ERDC/TN EMRRP-SI-32 Jun 2007

ERDC/TN EMRRP-SI-33 Dec 2007

ERDC/TN EMRRP-SI-34 Jul 2009

ERDC/TN EMRRP-SI-35 Dec 2010
Cave- and Crevice-Dwelling Bats on USACE Projects: Townsend's Big-eared Bat (Corynorhinus townsendii), by W.A. Mitchell

Black-capped Vireo and Golden-cheeked Warbler Populations Potentially Impacted by USACE Reservoir Operations, by M.P. Guilfoyle

Riparian Habitat Management for Mammals on Corps of Engineers Projects, by C.O. Martin

Status and Importance of Prairie Ecosystems on Corps of Engineers Projects, by C.O. Martin and E.P. Peloquin

Regional Availability of Plants for Prairie Restoration, by P. Bailey and C.O. Martin

Implementing Avian Inventory and Monitoring Efforts on Corps of Engineers Project Lands, by M.P. Guilfoyle and R.A. Fischer

An Evaluation of the Level I Natural Resources Inventory Process on Corps Operational Projects, by C.O. Martin and J.F. Krause

Mammalian Survey Techniques for Level II Natural Resource Inventories on Corps of Engineers Projects (Part I), by C.O. Martin

Mammalian Survey Techniques for Level II Natural Resource Inventories on Corps of Engineers Projects (Part II - Bats), by C.O. Martin

\section{Stream restoration (SR)}

\begin{tabular}{|c|c|c|}
\hline Report Number & Date & Title \\
\hline ERDC/TN EMRRP-SR-01 & Feb 2000 & Glossary of Stream Restoration Terms, by C. Fischenich \\
\hline ERDC/TN EMRRP-SR-02 & Feb 2000 & $\begin{array}{l}\text { Stream Restoration - Principles and Practices, by C. } \\
\text { Fischenich }\end{array}$ \\
\hline ERDC/TN EMRRP-SR-03 & Feb 2000 & Preliminary Watershed Assessment, by C. Fischenich \\
\hline ERDC/TN EMRRP-SR-04 & Feb 2000 & $\begin{array}{l}\text { Coir Geotextile Roll and Wetland Plants for Streambank } \\
\text { Erosion Control, by H.H. Allen and C. Fischenich }\end{array}$ \\
\hline ERDC/TN EMRRP-SR-05 & Feb 2000 & Computing Scour, by C. Fischenich and M. Landers \\
\hline ERDC/TN EMRRP-SR-06 & May 2000 & $\begin{array}{l}\text { Habitat Requirements for Freshwater Fishes, by J.V. } \\
\text { Morrow, Jr. and C. Fischenich }\end{array}$ \\
\hline ERDC/TN EMRRP-SR-07 & May 2000 & Resistance Due to Vegetation, by C. Fischenich \\
\hline ERDC/TN EMRRP-SR-08 & Feb 2000 & $\begin{array}{l}\text { Determining Drag Coefficients and Area for Vegetation, by } \\
\text { C. Fischenich and S. Dudley }\end{array}$ \\
\hline
\end{tabular}




\begin{tabular}{|c|c|c|}
\hline ERDC/TN EMRRP-SR-09 & May 2000 & $\begin{array}{l}\text { Reconnection of Floodplains with Incised Channels, by C. } \\
\text { Fischenich and J.V. Morrow, Jr. }\end{array}$ \\
\hline ERDC/TN EMRRP-SR-10 & Apr 2000 & $\begin{array}{l}\text { Robert Manning (A Historical Perspective), by C. } \\
\text { Fischenich }\end{array}$ \\
\hline ERDC/TN EMRRP-SR-11 & Feb 2000 & Boulder Clusters, by C. Fischenich and R. Seal \\
\hline ERDC/TN EMRRP-SR-12 & Feb 2000 & $\begin{array}{l}\text { Irrigation Systems for Establishing Riparian Vegetation, by } \\
\text { C. Fischenich }\end{array}$ \\
\hline ERDC/TN EMRRP-SR-13 & May 2000 & $\begin{array}{l}\text { Streambank Habitat Enhancement with Large Woody } \\
\text { Debris, by J.C. Fischenich and J.V. Morrow, Jr. }\end{array}$ \\
\hline ERDC/TN EMRRP-SR-14 & May 2000 & $\begin{array}{l}\text { Acid Mine Drainage Treatment, by J. Fripp, P.F. } \\
\text { Ziemkiewicz, and H. Charkavorki }\end{array}$ \\
\hline ERDC/ TN EMRRP-SR-19 & Aug 2002 & Design of Low-Flow Channels, by C. Fischenich \\
\hline ERDC/TN EMRRP-SR-21 & May 2000 & $\begin{array}{l}\text { Rootwad Composites for Streambank Erosion Control and } \\
\text { Fish Habitat Enhancement, by T. Sylte and C. Fischenich }\end{array}$ \\
\hline ERDC/TN EMRRP-SR-22 & May 2000 & $\begin{array}{l}\text { Gabions for Streambank Erosion Control, by G.E. Freeman } \\
\text { and J.C. Fischenich }\end{array}$ \\
\hline ERDC/TN EMRRP-SR-23 & May 2001 & $\begin{array}{l}\text { Brush Mattresses for Streambank Erosion Control, by H.H. } \\
\text { Allen and C. Fischenich }\end{array}$ \\
\hline ERDC/TN EMRRP-SR-24 & Apr 2000 & $\begin{array}{l}\text { Design Recommendations for Riparian Corridors and } \\
\text { Vegetated Buffer Strips, by R.A. Fischer and J.C. } \\
\text { Fischenich }\end{array}$ \\
\hline ERDC/TN EMRRP-SR-25 & Jan 2001 & $\begin{array}{l}\text { Riparian Terminology: Confusion and Clarification, by R.A. } \\
\text { Fischer, C.O. Martin, J.T. Ratti, and J. Guidice }\end{array}$ \\
\hline ERDC/TN EMRRP-SR-26 & May 2001 & $\begin{array}{l}\text { Determining Optimal Degree of Soil Compaction for } \\
\text { Balancing Mechanical Stability and Plant Growth Capacity, } \\
\text { by W. Goldsmith, M. Silva, and C. Fischenich }\end{array}$ \\
\hline ERDC/TN EMRRP-SR-28 & May 2001 & $\begin{array}{l}\text { Units and Conversions for Stream Restoration Projects, by } \\
\text { G.E. Freeman and C. Fischenich }\end{array}$ \\
\hline ERDC/TN EMRRP-SR-29 & May 2001 & $\begin{array}{l}\text { Stability Thresholds for Stream Restoration Materials, by } \\
\text { C. Fischenich }\end{array}$ \\
\hline ERDC/TN EMRRP-SR-30 & May 2003 & $\begin{array}{l}\text { Vegetated Reinforced Soil Slope Streambank Erosion } \\
\text { Control, by R.B. Sotir and J.C. Fischenich }\end{array}$ \\
\hline ERDC/TN EMRRP-SR-31 & May 2001 & $\begin{array}{l}\text { Live and Inert Fascine Streambank Erosion Control, by } \\
\text { R.B. Sotir and C. Fischenich }\end{array}$ \\
\hline ERDC/TN EMRRP-SR-32 & May 2001 & Impacts of Stabilization Measures, by C. Fischenich \\
\hline ERDC/TN EMRRP-SR-33 & May 2001 & Plant Material Selection and Acquisition, by C. Fischenich \\
\hline ERDC/TN EMRRP-SR-34 & Aug 2002 & $\begin{array}{l}\text { An Assessment of Watershed Planning in Corps of } \\
\text { Engineers Civil Works Projects, by S. Hansen and C. } \\
\text { Fischenich }\end{array}$ \\
\hline
\end{tabular}




\begin{tabular}{|c|c|c|}
\hline ERDC/TN EMRRP-SR-35 & Nov 2007 & $\begin{array}{l}\text { Live Stake and Joint Planting for Streambank Erosion } \\
\text { Control, by R.B. Sotir and J.C. Fischenich }\end{array}$ \\
\hline ERDC/TN EMRRP-SR-36 & Sep 2002 & $\begin{array}{l}\text { Techniques for Measuring Substrate Embeddedness, by T. } \\
\text { Sylte and C. Fischenich }\end{array}$ \\
\hline ERDC/TN EMRRP-SR-39 & Sep 2007 & $\begin{array}{l}\text { Sediment Sampling and Analysis for Stream Restoration } \\
\text { Projects, by C. Fischenich and C. Little }\end{array}$ \\
\hline ERDC/TN EMRRP-SR-40 & Aug 2007 & $\begin{array}{l}\text { Vegetation Impacts Upon Stream Width, by C. Fischenich } \\
\text { and D. McComas }\end{array}$ \\
\hline ERDC/TN EMRRP-SR-41 & Aug 2007 & $\begin{array}{l}\text { Hydraulic Losses in River Meanders, by G.L. Brown, R.R. } \\
\text { Copeland, and C. Fischenich }\end{array}$ \\
\hline ERDC/TN EMRRP-SR-42 & Apr 2004 & $\begin{array}{l}\text { Landscaping Considerations for Urban Stream Restoration } \\
\text { Projects, by P. Bailey and C. Fischenich }\end{array}$ \\
\hline ERDC/TN EMRRP-SR-44 & Feb 2004 & $\begin{array}{l}\text { Using Soil Amendments to Improve Riparian Plant Survival } \\
\text { in Arid and Semi-arid Landscapes, by R.A. Fischer }\end{array}$ \\
\hline ERDC/TN EMRRP-SR-45 & Jul 2005 & $\begin{array}{l}\text { Recreation Enhancements for Urban Streams, by P. Bailey, } \\
\text { C. Fischenich, and J. Marcy }\end{array}$ \\
\hline ERDC/TN EMRRP-SR-46 & Aug 2013 & $\begin{array}{l}\text { Alternative Environmental Flow Management Schemes, by } \\
\text { S.K. McKay }\end{array}$ \\
\hline ERDC/TN EMRRP-SR-47 & Jun 2014 & $\begin{array}{l}\text { Application and Evaluation of the HEC-RAS-Nutrient } \\
\text { Simulation Module (NSM I), by Z. Zhang and B.E. Johnson }\end{array}$ \\
\hline ERDC/TN EMRRP-SR-50 & Aug 2006 & $\begin{array}{l}\text { Guidelines for Establishing Monitoring Programs to Assess } \\
\text { the Success of Riparian Restoration Efforts in Arid and } \\
\text { Semi-arid Landscapes, by M.P. Guilfoyle and R.A. Fischer }\end{array}$ \\
\hline ERDC/TN EMRRP-SR-52 & Sep 2006 & $\begin{array}{l}\text { Functional Objectives for Stream Restoration, by J.C. } \\
\text { Fischenich }\end{array}$ \\
\hline ERDC/TN EMRRP-SR-55 & Dec 2009 & $\begin{array}{l}\text { Influence of Hydrologic Connectivity on Plant Species } \\
\text { Diversity Along Southwestern Rivers: Implications for } \\
\text { Restoration, by J.C. Stromberg, M.S. White, J.M. White, D. } \\
\text { Shorrock, and R.A. Fischer }\end{array}$ \\
\hline ERDC/TN EMRRP-SR-65 & Jun 2009 & $\begin{array}{l}\text { DAM_Explorer: A Modeling Frameowrk for Assessing the } \\
\text { Physical Response of Streams to Dam Removal, by J. } \\
\text { Conyngham and C. Wallen }\end{array}$ \\
\hline ERDC/TN EMRRP-SR-66 & Jun 2009 & $\begin{array}{l}\text { Data Needs and Case Study Assessment for Dam Fate } \\
\text { Determination and Removal Porjects: A Checklist, by J. } \\
\text { Conyngham }\end{array}$ \\
\hline ERDC/TN EMRRP-SR-80 & Sep 2006 & $\begin{array}{l}\text { Engineering and Ecological Aspects of Dam Removal - An } \\
\text { Overview, by J. Conyngham, J.C. Fischenich, and K.D. } \\
\text { White }\end{array}$ \\
\hline
\end{tabular}




\section{Engineering with Nature Program (EWN)}

\section{Technical notes}

\begin{tabular}{|c|c|c|}
\hline Report Number & Date & $\underline{\text { Title }}$ \\
\hline ERDC TN-EWN-14-1 & Jul 2014 & $\begin{array}{l}\text { USACE Regional Sediment Management and Engineering } \\
\text { With Nature } 2012 \text { Workshop Summary, by C.J. Banks and } \\
\text { J.M. Gerhardt Smith }\end{array}$ \\
\hline ERDC TN-EWN-14-2 & Aug 2014 & $\begin{array}{l}\text { Epifaunal Community Development on Great Lakes } \\
\text { Breakwaters: An Engineering With Nature Demonstration } \\
\text { Project, by T.J. Fredette, B. Suedel, C.J. Banks, R.J. Ruby, P. } \\
\text { Bijhouwer, and A.M. Friona }\end{array}$ \\
\hline ERDC TN-EWN-14-3 & Aug 2014 & $\begin{array}{l}\text { USACE Regional Sediment Management and Engineering } \\
\text { With Nature } 2013 \text { Workshop Summary, by J.M. Gerhardt } \\
\text { Smith and C.J. Banks }\end{array}$ \\
\hline ERDC TN-EWN-14-4 & Aug 2014 & $\begin{array}{l}\text { Use of Strategic Placement of Dredged Sediments to } \\
\text { Support Horseshoe Island in the Atchafalaya River, } \\
\text { Louisiana: A Preliminary Ecological Survey, by J.F. } \\
\text { Berkowitz, N.R. Beane, D.E. Evans, B. Suedel, and J.M. } \\
\text { Corbino }\end{array}$ \\
\hline ERDC TN-EWN-15-1 & Jul 2015 & $\begin{array}{l}\text { Engineering With Nature Geographic Project Mapping Tool } \\
\text { (EWN ProMap), by T.J. Fredette, B.C. Suedel, A.V. Davis, } \\
\text { and C.J. Banks }\end{array}$ \\
\hline ERDC TN-EWN-15-2 & Jul 2015 & $\begin{array}{l}\text { Deer Island Aquatic Ecosystem Restoration Project, by J. } \\
\text { Gerhardt Smith, J. McDonald, S. Ivester Rees, and N. } \\
\text { Lovelace }\end{array}$ \\
\hline
\end{tabular}




\section{Environmental Effects of Dredging Program (EEDP)}

\section{Technical notes}

\section{Section 01 - Aquatic disposal}

\begin{tabular}{|c|c|c|}
\hline Report Number & Date & $\underline{\text { Title }}$ \\
\hline ERDC/TN EEDP-01-44 & Apr 2000 & $\begin{array}{l}\text { Application of Population Modeling to Evaluate Chronic } \\
\text { Toxicity in the Estuarine Amphipod Leptocheirus } \\
\text { plumulosus, by T.S. Bridges and S. Carroll }\end{array}$ \\
\hline ERDC/TN EEDP-01-45 & Jun 2000 & $\begin{array}{l}\text { Genotoxicity Testing in Sediments: Progress in } \\
\text { Developing a Transgenic Polychaete Model, by L.S. } \\
\text { Inouye and V.A. McFarland }\end{array}$ \\
\hline ERDC/TN EEDP-01-46 & Aug 2000 & $\begin{array}{l}\text { Total Maximum Daily Loads (TMDLs): A Perspective, by } \\
\text { J.L. Martin and R.H. Kennedy }\end{array}$ \\
\hline ERDC/TN EEDP-01-47 & May 2001 & $\begin{array}{l}\text { Annotated Bibliography and Guide to Products of the } \\
\text { LEDO Bioaccumulation and Adverse Effects Work Unit, } \\
\text { by V.A. McFarland and S.A. Jarvis }\end{array}$ \\
\hline ERDC/TN EEDP-01-48 & May 2002 & $\begin{array}{l}\text { Development of a Biological-Effects-Based Approach to } \\
\text { Assess the Significance of Contaminant } \\
\text { Bioaccumulation, by J.A. Steevens and P.F. Landrum }\end{array}$ \\
\hline ERDC/TN EEDP-01-49 & Apr 2003 & $\begin{array}{l}\text { Interim Guidance on Assessing the Risk Posed by } \\
\text { Pathogens Associated with Dredged Material, by K.J. } \\
\text { Indest }\end{array}$ \\
\hline ERDC/TN EEDP-01-50 & May 2003 & $\begin{array}{l}\text { Development of a New Bioaccumulation Testing } \\
\text { Approach: The Use of DDE as a Challenge Chemical to } \\
\text { Predict Contaminant Bioaccumulation, by L.J. Yoo, J.A. } \\
\text { Steevens, and P.F. Landrum }\end{array}$ \\
\hline
\end{tabular}

\section{Section 02 - Upland disposal}

\begin{tabular}{|c|c|c|}
\hline Report Number & Date & $\underline{\text { Title }}$ \\
\hline ERDC/TN EEDP-02-28 & Dec 1999 & $\begin{array}{l}\text { Prediction of Volatile Losses from Contaminated } \\
\text { Exposed Sediments, by C. Price, J. Brannon, S. Yost, R. } \\
\text { Ravikrishna, and K.T. Valsaraj }\end{array}$ \\
\hline ERDC/TN EEDP-02-29 & Jun 2000 & $\begin{array}{l}\text { Simplified Laboratory Runoff Procedure(SLRP): } \\
\text { Procedure and Application, by R.A. Price and J.G. } \\
\text { Skogerboe }\end{array}$ \\
\hline ERDC/TN EEDP-02-30 & Mar 2001 & $\begin{array}{l}\text { Volatile Losses from Resuspended Dredged Material, by } \\
\text { C. Price, J. Brannon, S. Yost, F. Sanchez, L. Thibodeaux, } \\
\text { K. Valsaraj, and R. Ravikrishna }\end{array}$ \\
\hline
\end{tabular}




\begin{abstract}
ERDC/TN EEDP-02-31 Apr $2003 \quad$ Development of Sediment Extracts for Rapid Assessment of Organic Contaminant Bioavailability, by C. Price, L. Inouye, J.M. Brannon, V. McFarland, and C. Hayes
\end{abstract}

\section{Section 04 -- Regulatory}

\begin{tabular}{|c|c|}
\hline Report Number & $\underline{\text { Date }}$ \\
\hline ERDC/TN EEDP-04-33 & Dec 2002 \\
\hline ERDC/TN EEDP-04-34 & Jul 2003 \\
\hline ERDC/TN EEDP-04-35 & Dec 2002 \\
\hline ERDC/TN EEDP-04-36 & Jan 2005 \\
\hline ERDC/TN EEDP-04-37 & Jun 2007 \\
\hline
\end{tabular}

ERDC/TN EEDP-04-37

Section 06 -- Management

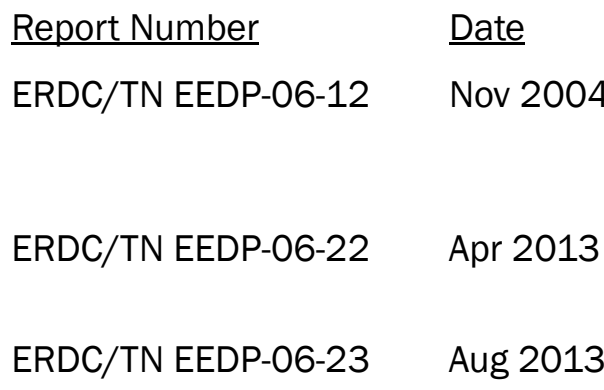

Title

Selecting Tier III Water Column Toxicity Standards for CDF Discharges: Statistical Alternatives, by J.U. Clarke, P.R. Schroeder, and J.A. Steevens

Toxicological Exposure of Sediment-Bound Hydrophobic Organic Contaminants as a Function of the Quality of Sediment Organic Carbon and Microbial Degradation, by H.L. Fredrickson, J.W. Talley, J.S. Furey, and S. Nicholl

Development of a Rapid, Inexpensive Bioassay for Screening Contaminant Bioavailability in Sediment Using mRNA Profiling, by E. Perkins, H. Fredrickson, and G. Lotufo

Analytical Chemistry Detection Limits and the Evaluation of Dredged Sediment, by R.P. Jones and J.U. Clarke

Overdepth Dredging and Characterization Depth Recommendations, by J.F. Tavolaro, J.R. Wilson, T.L. Welp, J.E. Clausner, and A.Y. Premo

\section{$\underline{\text { Title }}$}

The Automated Dredging and Disposal Alternatives Modeling System (ADDAMS), by P.R. Schroeder, M.R. Palermo, T.E. Myers, and C.M. Lloyd

The Association Between Confined Disposal Facilities and Mosquitoes, by J.G. Nachtrieb and M.J. Grodowitz Costs Associated with Endangered Species Act Compliance, by J.E. Henderson 


\section{Environmental Quality Technology Program (EQT)}

\section{Technical notes}

\begin{tabular}{|c|c|c|}
\hline Report Number & Date & $\underline{\text { Title }}$ \\
\hline ERDC TN-EQT-06-1 & Oct 2006 & $\begin{array}{l}\text { CTT\&F: Distributed Sources Chemical Transport, } \\
\text { Transformation and Fate Submodel, by B.E. Johnson and } \\
\text { Z. Zhang }\end{array}$ \\
\hline ERDC TN-EQT-09-1 & Dec 2009 & $\begin{array}{l}\text { Determination of Low Level NOMA in Soils, by A.J. Bednar, } \\
\text { R.A. Karn, C. Mao, D.E. Splichal, D.B. Taggart, and K.H. } \\
\text { Coats }\end{array}$ \\
\hline ERDC TN-EQT-09-2 & Dec 2009 & $\begin{array}{l}\text { Establishment of the TREECS Platform: A Survey of } \\
\text { Existing Tools, Portals, and Frameworks, by J.A. Gerald, } \\
\text { M.S. Dortch, B.E. Johnson, and M.R. Fontan }\end{array}$ \\
\hline ERDC TN-EQT-10-1 & May 2010 & $\begin{array}{l}\text { Polarized Illuminator for Very-Near Infrared Imaging, by J. } \\
\text { Furey and C. Morgan }\end{array}$ \\
\hline ERDC TN-EQT-10-2 & Oct 2010 & $\begin{array}{l}\text { Applying Multicriteria Decision Analysis to Managing } \\
\text { Species at Risk and Other Critical Resources on Military } \\
\text { Installations, by B.C. Suedel, J. Kim, and R.F. Lance }\end{array}$ \\
\hline ERDC TN-EQT-12-1 & Apr 2012 & $\begin{array}{l}\text { Estimating Solubility for Modeling the Fate of Heavy Metals } \\
\text { with the Training Range Environmental Evaluation and } \\
\text { Characterization System (TREECS }\end{array}$ \\
\hline ERDC TN-EQT-12-2 & Aug 2012 & $\begin{array}{l}\text { Applying the TREECS }{ }^{\mathrm{TM}} \text { to Strontium } 90 \text { for Borschi } \\
\text { Watershed near Chernobyl, Ukraine, by M.S. Dortch }\end{array}$ \\
\hline ERDC TN-EQT-13-1 & Sep 2013 & $\begin{array}{l}\text { Modeling RDX Reduction within Iron Bed Reactors, by M.S. } \\
\text { Dortch and H.M. Smith }\end{array}$ \\
\hline ERDC TN-EQT-13-2 & Dec 2013 & $\begin{array}{l}\text { Application of TREECS }{ }^{\mathrm{TM}} \text { to Small Arms Firing Ranges at } \\
\text { Fort Leonard Wood, MO, by M.S. Dortch }\end{array}$ \\
\hline
\end{tabular}




\section{Innovations for Navigation Projects Research Program (INP)}

\section{Technical reports}

Report Number

ERDC TR-INP-00-1
Date

Mar 2000 $\underline{\text { Title }}$

Technologies for Positioning and Placement of Underwater Structures, by R.G. Mann and V.P. Chiarito 


\section{Natural Resources Research Program (NRRP)}

\section{Bulletins}

$\begin{array}{lll}\text { Report Number } & \underline{\text { Date }} & \underline{\text { Title }} \\ \text { Vol. R-99-2 } & \text { Nov 1999 } & \text { Recnotes } \\ \text { Vol. R-01-1 } & \text { May 2001 } & \text { Recnotes }\end{array}$

\section{Technical notes}

\section{Ecological resources (ECO)}

$\begin{array}{lll}\text { Report Number } & \text { Date } & \text { Title } \\ \text { ERDC TN-NRTS-ECO-02 } & \text { Mar 2001 } & \begin{array}{l}\text { Linkages to Biodiversity, Ecosystems, and Society, by } \\ \text { H.R. Hamilton and D.J. Tazik }\end{array}\end{array}$

\section{Recreation (REC)}

$\begin{array}{lll}\text { Report Number } & \text { Date } & \text { Title } \\ \text { ERDC/NRTN REC-13 } & \text { Jul 2002 } & \begin{array}{l}\text { Hispanic Recreation at Corps of Engineers Lakes in the } \\ \text { Greater Tulsa Area: Results of Two Hispanic Focus } \\ \text { Groups, by R.A. Dunn, R.L. Kasul, D. Brown }\end{array} \\ \text { ERDC/NRTN REC-14 } & \text { Sep 2003 } & \begin{array}{l}\text { Results of a Pilot Customer Satisfaction Survey of Corps } \\ \text { of Engineers Recreation Visitors, by R.L. Kasul, W-H. } \\ \text { Chang, and S.F. Franco }\end{array}\end{array}$




\section{Recreation Research Program (RRP)}

\section{Technical reports}

$\begin{array}{llll}\text { Report Number } & \text { Date } & \text { Title } & \text { AD Number } \\ \text { TR R-99-1 } & \text { Dec 1999 } & \begin{array}{l}\text { Methodology for Recreation Data Acquisition } \\ \text { and Evaluation for Ethnic Minority Visitors to }\end{array} & \text { ADA374585 } \\ & & \text { Corps of Engineers Projects, by R.A. Dunn and } \\ & & \text { D.M. Quebedeaux }\end{array}$




\section{Regional Sediment Management Demonstration Program (RSM)}

\section{Bulletins}

$\begin{array}{lll}\text { Report Number } & \underline{\text { Date }} & \underline{\text { Title }} \\ \text { Vol. } 1 & \text { Winter/Spring 2003 } & \text { Regional Sediment Management } \\ \text { Vol. } 2 & \text { Summer/Fall 2003 } & \text { Regional Sediment Management } \\ \text { Vol. } 2 & \text { Winter/Spring 2004 } & \text { Regional Sediment Management } \\ \text { Vol. } 3 & \text { Summer/Fall 2004 } & \text { Regional Sediment Management } \\ \text { Vol. } 4 & \text { Winter/Spring 2006 } & \text { Regional Sediment Management }\end{array}$

\section{Technical notes (also published as ERDC CHETNs and one CRREL tech note)}

\begin{tabular}{|c|c|}
\hline Report Number & Date \\
\hline ERDC/RSM-TN-1 & Jun 2001 \\
\hline ERDC/RSM-TN-4 & Mar 2002 \\
\hline ERDC/RSM-TN-5 & Jun 2002 \\
\hline ERDC/RSM-TN-6 & Jun 2002 \\
\hline ERDC/RSM-TN-7 & Jun 2002 \\
\hline ERDC/RSM-TN-8 & $\begin{array}{l}\text { Jun } 2002, \\
\text { Rev. Jun } 2003\end{array}$ \\
\hline ERDC/RSM-TN-9 & Apr 2003 \\
\hline
\end{tabular}

$\underline{\text { Title }}$

The Corps of Engineers National Regional Sediment Management Demonstration Program, by J.D. Rosati, B.D. Carlson, J.E. Davis, and T.D. Smith

Overview of Regional Coastal Sediment Processes and Controls, by M. Larson, J.D. Rosati, and N.C. Kraus

Lessons Learned from Existing Projects on Shoaling in Harbors and Navigation Channels, by T.M. Parchure and A.M. Teeter Potential Methods for Reducing Shoaling in Harbors and Navigation Channels, by T.M. Parchure and A.M. Teeter

Sediment Budget Analysis System-A: SBAS-A for ArcView@ Application, by R. Dopsovic, L. Hardegree, and J. Rosati

Authorities and Policies Supporting Implementation of Regional Sediment Management, by L.R. Martin

Overland Erosion Due To Freeze-Thaw Cycling: Laboratory Experiments, by L.W. Gatto and M.G. Ferrick 


\section{Project briefs}

\begin{tabular}{|c|c|c|}
\hline Report Number & Date & Title \\
\hline ERDC/RSM-DB1 & Apr 2003 & $\begin{array}{l}\text { Detroit District, Ludington, Michigan, to } \\
\text { Michigan City, Indiana }\end{array}$ \\
\hline ERDC/RSM-DB2 & Jun 2003 & Jacksonville District: Northeast Florida \\
\hline ERDC/RSM-DB3 & Jun 2003 & Jacksonville District: Southwest Florida \\
\hline ERDC/RSM-DB4 & Jun 2003 & Mobile District, Northern Gulf of Mexico \\
\hline ERDC/RSM-DB5 & Jun 2003 & Los Angeles District, State of California \\
\hline ERDC/RSM-DB6 & Jun 2003 & $\begin{array}{l}\text { Philadelphia District: Cape May County, New } \\
\text { Jersey }\end{array}$ \\
\hline ERDC/RSM-DB7 & Jun 2003 & $\begin{array}{l}\text { Portland District, Mouth of Columbia River, } \\
\text { Oregon and Washington }\end{array}$ \\
\hline ERDC/RSM-DB8 & Jun 2003 & $\begin{array}{l}\text { New York District: Endangered Shore Birds } \\
\text { Habitat, Long Island, New York }\end{array}$ \\
\hline ERDC/RSM-DB9 & Jun 2003 & $\begin{array}{l}\text { New York District: Town of Hempstead, Long } \\
\text { Island, New York }\end{array}$ \\
\hline ERDC/RSM-DB10 & Jun 2003 & $\begin{array}{l}\text { New York District: Regional Sediment Budget } \\
\text { for Long Island, New York }\end{array}$ \\
\hline ERDC/RSM-DB11 & Jan 2004 & $\begin{array}{l}\text { South Atlantic Division, Regional Sediment } \\
\text { Management Demonstration Project }\end{array}$ \\
\hline ERDC/RSM-DB12 & Aug 2005 & Honolulu District, Southeast Oahu, Hawaii \\
\hline ERDC/RSM-DB13 & Aug 2005 & $\begin{array}{l}\text { Northwestern Division: Program } \\
\text { Management Plan for Regional Sediment } \\
\text { Management }\end{array}$ \\
\hline
\end{tabular}




\section{Strategic Environmental Research and Development Program (SERDP)}

\section{Contract reports}

Report Number

CR SERDP-99-1

Date

Dec 1999
Date

Dec 1999

TR SERDP-99-4

TR SERDP-99-5

\section{Technical reports}

Report Number
TR SERDP-99-4

Dec 1999

\section{$\underline{\text { Title }}$}

MT3DMS: A Modular Three-Dimensional Multispecies Transport Model for Simulation of Advection, Dispersion, and Chemical Reactions of Contaminants in Groundwater Systems; Documentation and User's Guide, by C. Zheng, P.P. Wang

\section{$\underline{\text { Title }}$}

Explosives Conjugation Products in Remediation Matrices: Final Report, by J.C. Pennington, K.A. Thorn, L.S. Inouye, V.A. McFarland, A.S. Jarvis, C.H. Lutz, C.A. Hayes, and B.E. Porter

Management of Bottomland Hardwoods and Deepwater Swamps for Threatened and Endangered Species, by R.A. Fischer, C.O. Martin, K. Robertson, W.R. Whitworth, and M.G. Harper 


\section{Submerged Aquatic Vegetation Program (SAV)}

\section{Technical notes}

\begin{tabular}{|c|c|c|}
\hline Report Number & Date & $\underline{\text { Title }}$ \\
\hline ERDC/TN SAV-06-1 & Jan 2006 & $\begin{array}{l}\text { Applications and Limitations of } \\
\text { Micropropagation for the Production of } \\
\text { Underwater Grasses, by S. Ailstock and D. } \\
\text { Shafer }\end{array}$ \\
\hline ERDC/TN SAV-06-2 & Apr 2006 & $\begin{array}{l}\text { Buoy-Deployed Seeding: A New Low-Cost } \\
\text { Technique for Restoration of Submerged } \\
\text { Aquatic Vegetation from Seed, by C. } \\
\text { Pickerell, S. Schott, and S. Wyllie-Echeverria }\end{array}$ \\
\hline ERDC/TN SAV-06-3 & Aug 2006 & $\begin{array}{l}\text { Protocol for Large-Scale Collection, } \\
\text { Processing, and Storage of Seeds of Two } \\
\text { Mesohaline Submerged Aquatic Plant } \\
\text { Species, by S. Ailstock and D. Shafer }\end{array}$ \\
\hline ERDC/TN SAV-06-4 & Dec 2006 & $\begin{array}{l}\text { Reproductive Ecology of Vallisneria } \\
\text { americana Michaux, by D.G. McFarland }\end{array}$ \\
\hline ERDC/TN SAV-07-1 & Dec 2007 & $\begin{array}{l}\text { A Summary of Eelgrass (Zostera marina) } \\
\text { Reproductive Biology with an Emphasis on } \\
\text { Seed Biology and Ecology from the } \\
\text { Chesapeake Bay Region, by R.J. Orth, S.R. } \\
\text { Marion, and K.A. Moore }\end{array}$ \\
\hline ERDC/TN SAV-07-2 & Dec 2007 & $\begin{array}{l}\text { Innovative Techniques for Large-scale } \\
\text { Collection, Processing, and Storage of } \\
\text { Eelgrass (Zostera marina) Seeds, by R.J. Orth } \\
\text { and S.R. Marion }\end{array}$ \\
\hline ERDC/TN SAV-07-3 & Dec 2007 & $\begin{array}{l}\text { Using Seeds to Propagate and Restore } \\
\text { Vallisneria americana Michaux (Wild Celery) } \\
\text { in the Chesapeake Bay, by K.A. Moore and } \\
\text { J.C. Jarvis }\end{array}$ \\
\hline ERDC/TN SAV-08-1 & Mar 2008 & $\begin{array}{l}\text { Restoring Eelgrass (Zostera marina) from } \\
\text { Seed: A Comparison of Planting Methods for } \\
\text { Large-Scale Projects, by R. Orth, S. Marion, } \\
\text { S. Granger, and M. Traber }\end{array}$ \\
\hline ERDC/TN SAV-08-2 & Sep 2008 & $\begin{array}{l}\text { GigaUnit Transplant System: A New } \\
\text { Mechanical Tool for Transplanting } \\
\text { Submerged Aquatic Vegetation, by D.J. } \\
\text { Shafer }\end{array}$ \\
\hline
\end{tabular}


ERDC/TN SAV-09-1 Aug 2009

ERDC/TN SAV-11-1

May 2011

Production and Field Planting of Vegetative Propagules for Restoration of Redhead Grass and Sago Pondweed in Chesapeake Bay, by L. Murray, W.M. Kemp, D. Hindle, and D. Shafer

An Improved Method for Processing large Quantities of Seeds of Mesohaline Submerged Aquatic Plants, by S. Ailstock, D. Shafer, B Lenderking, and M. Norman 


\section{System-wide Modeling, Assessment, and Restoration Techniques Program (SMART)}

\section{Technical notes}

\begin{tabular}{|c|c|c|}
\hline Report Number & Date & $\underline{\text { Title }}$ \\
\hline ERDC/TN SMART-04-1 & Sep 2004 & $\begin{array}{l}\text { Use of the Hydrological Simulation Program-FORTRAN } \\
\text { (HSPF) Model for Watershed Studies, by B.E. Skahill }\end{array}$ \\
\hline ERDC/TN SMART-04-2 & Sep 2004 & $\begin{array}{l}\text { Watershed Analysis with the Hydrologic Engineering } \\
\text { Center's River Analysis System (HEC-RAS), by C.R. } \\
\text { Goodell and G.W. Brunner }\end{array}$ \\
\hline ERDC/TN SMART-04-3 & Sep 2004 & $\begin{array}{l}\text { Description of the Hydrologic Engineering Center's } \\
\text { Hydrologic Modeling System (HEC-HMS) and } \\
\text { Application to Watershed Studies, by M. Fleming }\end{array}$ \\
\hline ERDC/TN SMART-04-4 & Sep 2004 & $\begin{array}{l}\text { The Ecosystem Functions Model: A Tool for Restoration } \\
\text { Planning by, J.T. Hickey and C.N. Dunn }\end{array}$ \\
\hline ERDC/TN SMART-04-5 & Sep 2004 & $\begin{array}{l}\text { Soil Phosphorus Compositional Characteristics as a } \\
\text { Function of Land-Use Practice in the Upper Eau Galle } \\
\text { River Watershed, Wisconsin, by W.F. James, H.L. Eakin, } \\
\text { C.E. Ruiz, and J.W. Barko }\end{array}$ \\
\hline ERDC/TN SMART-04-6 & Sep 2004 & $\begin{array}{l}\text { Variations in Field-Scale Nitrogen and Phosphorus } \\
\text { Concentrations in Runoff as a Function of Land-Use } \\
\text { Practice, by W.F. James, H.L. Eakin, C.E. Ruiz, and J.W. } \\
\text { Barko }\end{array}$ \\
\hline ERDC/TN SMART-04-7 & Sep 2004 & $\begin{array}{l}\text { Longitudinal Loading and Nutrient Compositional } \\
\text { Gradients in an Agriculturally Managed Watershed in } \\
\text { West-Central Wisconsin, by W.F. James, C.E. Ruiz, J.W. } \\
\text { Barko, and H.L. Eakin }\end{array}$ \\
\hline ERDC/TN SMART-04-8 & Sep 2004 & $\begin{array}{l}\text { Nutrient Loading Characteristics for Two Sub- } \\
\text { watersheds Exhibiting Differing Agricultural Land-Use } \\
\text { Practices, by W.F. James, C.E. Ruiz, and J.W. Barko }\end{array}$ \\
\hline ERDC/TN SMART-04-9 & Sep 2004 & $\begin{array}{l}\text { Conceptual Models to Support Environmental Planning } \\
\text { and Operations, by J.E. Henderson and L.J. O'Neil }\end{array}$ \\
\hline
\end{tabular}




\section{System-wide Water Resources Program (SWWRP)}

\section{Technical notes}

\begin{tabular}{|c|c|c|}
\hline Report Number & Date & $\underline{\text { Title }}$ \\
\hline ERDC TN-SWWRP-05-1 & Aug 2005 & $\begin{array}{l}\text { Regional Morphology Analysis Package (RMAP). Part 2, } \\
\text { User's Guide and Tutorial, by B.K. Batten and N.C. } \\
\text { Kraus }\end{array}$ \\
\hline ERDC TN-SWWRP-05-2 & Sep 2005 & $\begin{array}{l}\text { Particle Entrainment Simulator at the U.S. Army } \\
\text { Engineer Research and Development Center, by T.M. } \\
\text { Parchure and J.Z. Gailani }\end{array}$ \\
\hline ERDC TN-SWWRP-05-3 & Dec 2005 & $\begin{array}{l}\text { A Watershed Assessment Tool for Evaluating } \\
\text { Ecological Condition, Proposed Impacts, and } \\
\text { Restoration Potential at Multiple Scales, by R.D. Smith, } \\
\text { C.V. Klimas, and B.A. Kleiss }\end{array}$ \\
\hline ERDC TN-SWWRP-06-1 & Feb 2006 & $\begin{array}{l}\text { Effect of Residence Time on Net Nitrate Retention in } \\
\text { Flow-Regulated Backwaters of the Upper Mississippi } \\
\text { River, by W.F. James, W.B. Richardson, D.M. Soballe, } \\
\text { J.W. Barko, and H.L. Eakin }\end{array}$ \\
\hline ERDC TN-SWWRP-06-2 & Mar 2006 & $\begin{array}{l}\text { The U.S. Army Corps of Engineers' Coastal Inlets } \\
\text { Research, with Special } \\
\text { Reference To Shore Bird Habitat, by J.D. Rosati and } \\
\text { N.C. Kraus }\end{array}$ \\
\hline ERDC TN-SWWRP-06-3 & Mar 2006 & $\begin{array}{l}\text { Understanding Sediment Sources, Pathways and Sinks } \\
\text { in Regional Sediment Management: Wash Load and } \\
\text { Bed-Material Load Concept, by D.S. Biedenharn, L.C. } \\
\text { Hubbard, C.R. Thorne, and C.C. Watson }\end{array}$ \\
\hline ERDC TN-SWWRP-06-4 & Apr 2006 & $\begin{array}{l}\text { Understanding Sediment Sources, Pathways and Sinks } \\
\text { in Regional Sediment Management: Application of } \\
\text { Wash Load and Bed-Material Load Concept, by D.S. } \\
\text { Biedenharn, L.C. Hubbard, C.R. Thorne, and C.C. } \\
\text { Watson }\end{array}$ \\
\hline ERDC TN-SWWRP-06-5 & May 2006 & $\begin{array}{l}\text { Cascade Version 1: User's Guide, by K.J. Connell and } \\
\text { N.C. Kraus }\end{array}$ \\
\hline ERDC TN-SWWRP-06-6 & Jun 2006 & $\begin{array}{l}\text { ADH Sediment Module Testing, by J.N. Tate and R.C. } \\
\text { Berger }\end{array}$ \\
\hline ERDC TN-SWWRP-06-7 & Jun 2006 & $\begin{array}{l}\text { Cascade Version 1: Theory and Model Formulation, by } \\
\text { M. Larson, N.C. Kraus, and K.J. Connell }\end{array}$ \\
\hline ERDC TN-SWWRP-06-8 & Aug 2006 & $\begin{array}{l}\text { Nitrogen Processing Efficiency of an Upper Mississippi } \\
\text { River Backwater Lake, by W.F. James, W.B. Richardson, } \\
\text { E.A. Strauss, L.A. Bartsch, and J.C. Cavanaugh }\end{array}$ \\
\hline
\end{tabular}


ERDC TN-SWWRP-06-9 Aug 2006

ERDC TN-SWWRP-06-10 Sep 2006

ERDC TN-SWWRP-06-11 Nov 2006

ERDC TN-SWWRP-07-1 Jan 2007

ERDC TN-SWWRP-07-2 May 2007

ERDC TN-SWWRP-07-3 Jul 2007

ERDC TN-SWWRP-07-4 Aug 2007

ERDC TN-SWWRP-07-5 Aug 20007

ERDC TN-SWWRP-07-6 Aug 2007

ERDC TN-SWWRP-07-7 Sep 2007

ERDC TN-SWWRP-07-8 Oct 2007

ERDC TN-SWWRP-07-9 Oct 2007

ERDC TN-SWWRP-07-10 Nov 2007

ERDC TN-SWWRP-07-11 Nov 2007

ERDC TN-SWWRP-08-1 Jan 2008
Conceptual Processes for Linking Eutrophication and Network Models, by D.H. Tillman, C.F. Cerco and M.R. Noel

Sediment-Tracing Technology: An Overview, by M.K. Corcoran and J.R. Kelley

Parameter Estimation Tools for Hydrologic and Hydraulic Simulations, by J.P. Hallberg

Watershed Scale TMDL Model: Multidimensional Sediment Erosion, Transport, and Fate, by C.W. Downer and A. Byrd

Nitrate Uptake Capacity and Efficiency of Upper Mississippi River Flow-Regulated Backwaters, by W.F. James, W.B. Richardson, and D.M. Soballe

The Ecosystem Concept and Linking Models of Physical-Chemical Processes to Ecological Responses: Introduction and Annotated Bibliography, by J. Hains and D. Soballe

Template for Conceptual Model Construction: Model Review and Corps Applications, by J.E. Henderson and L.J. O’Neil

Full-Plane STWAVE with Bottom Friction: II. Model Overview, by J.M. Smith

Modeling Nearshore Waves for Hurricane Katrina, by J.M. Smith

Template for Conceptual Model Construction: Model Components and Application of the Template, by J.E. Henderson and L.J. O'Neil

Development of a Simple Soil Moisture Model in the Hydrologic Simulator GSSHA, by C.W. Downer

Regional Morphology analysis Package (RMAP):

Empirical Orthogonal Function Analysis, Background and Examples, by K.J. Connell and M. Larson

Expanded Simulation Models (Version 3.0) for Growth of the Submersed Aquatic Plants American Wildcelery, Sago Pondweed, Hydrilla, and Eurasian Watermilfoil, by E.P.H. Best and W.A. Boyd

Algorithm Considerations for Evaluating Phosphorus Transport and Environmental Mangement Strategies Using a Grid-Based Spatial Watershed Model, by W.F. James and B.E. Johnson

Sediment-Water Nitrogen Fluxes in a Backwater System of the Upper Mississippi River, by W.F. James, W.B. Richardson, and D.M. Soballe 


\begin{tabular}{|c|c|c|}
\hline ERDC TN-SWWRP-08-2 & Mar 2008 & $\begin{array}{l}\text { Demonstration of GSSHA Hydrology } \\
\text { and Sediment at Eau Galle Watershed } \\
\text { Near Spring Valley, Wisconsin, by C.W. Downer }\end{array}$ \\
\hline ERDC TN-SWWRP-08-3 & Mar 2008 & $\begin{array}{l}\text { Demonstration of GSSHA Hydrology } \\
\text { at Goodwin Creek Experimental Watershed, by C.W. } \\
\text { Downer }\end{array}$ \\
\hline ERDC TN-SWWRP-08-4 & Mar 2008 & $\begin{array}{l}\text { The Use of Sand Fences in Barrier Island } \\
\text { Restoration: Experience on the Louisiana Coast, by } \\
\text { S.M. Khalil }\end{array}$ \\
\hline ERDC TN-SWWRP-08-5 & Jul 2008 & $\begin{array}{l}\text { Non-orthogonal Channel and Reservoir } \\
\text { Routing in GSSHA, by C.W. Downer, F.L. Ogden, J. } \\
\text { Neidzialek, and A. Byrd }\end{array}$ \\
\hline ERDC TN-SWWRP-08-6 & Sep 2008 & $\begin{array}{l}\text { Concepts for Sensor Data Fusion to Detect Vegetation } \\
\text { Stress and Implications on Ecosystem Health } \\
\text { Following Hurricane Katrina, by S.S. Jackson, G.T. } \\
\text { Raber, J.A. Griffith, and M.R. Graves }\end{array}$ \\
\hline ERDC TN-SWWRP-09-1 & Jan 2009 & $\begin{array}{l}\text { Sediment Equilibrium and Diffusive Fluxes in Relation } \\
\text { to Phosphorus Dynamics in the Turbid Minnesota } \\
\text { River, } \\
\text { by W.F. James }\end{array}$ \\
\hline ERDC TN-SWWRP-09-2 & Jan 2009 & $\begin{array}{l}\text { Simulation of Reactive Constituent Fate and Transport } \\
\text { in Hydrologic Simulator GSSHA, by Charles W. Downer }\end{array}$ \\
\hline ERDC TN-SWWRP-09-3 & May 2009 & $\begin{array}{l}\text { Considerations for Modeling Flow Control Structuresin } \\
\text { ADaptive Hydraulics (ADH), by G. Savant and C. Berger }\end{array}$ \\
\hline ERDC TN-SWWRP-09-4 & May 2009 & $\begin{array}{l}\text { Considerations for Stationary Ice Covered Flows in } \\
\text { Adaptive Hydraulics (ADH), by G.L. Brown, G. Savant, C. } \\
\text { Berger, and D.S. Smith }\end{array}$ \\
\hline ERDC TN-SWWRP-09-5 & Jun 2009 & $\begin{array}{l}\text { A Recalibrated Simulation Model (Version 3.0) on the } \\
\text { Competition for Light by American wildcelery and Sago } \\
\text { pondweed at High and Low Nutrient Availability, by } \\
\text { E.P.H. Best and W.A. Boyd }\end{array}$ \\
\hline ERDC TN-SWWRP-09-6 & Sep 2009 & $\begin{array}{l}\text { Soil Exchangeable Phosphorus Pools, Equilibrium } \\
\text { Characteristics, and Mass Distribution Coefficients for } \\
\text { Eight-Mile Run Watershed, Wisconsin, by W.F. James, } \\
\text { B.E. Johnson, Z. Zhang, C.W. Downer, and A.R. Byrd }\end{array}$ \\
\hline ERDC TN-SWWRP-09-7 & Sep 2009 & $\begin{array}{l}\text { Comparison of Results from the EDYS and EDYS-L } \\
\text { Ecological Simulation Models as Applied to Vegetation } \\
\text { and Hydrological Dynamics on the Honey Creek } \\
\text { Watershed, Texas, by T. McLendon, C.L. Coldren, and } \\
\text { D.L. Price }\end{array}$ \\
\hline ERDC TN-SWWRP-09-8 & Sep 2009 & $\begin{array}{l}\text { Nitrogen Cycling and Fate in a Floodplain Backwater of } \\
\text { the Upper Mississippi River, by W.F. James }\end{array}$ \\
\hline
\end{tabular}




\begin{tabular}{|c|c|c|}
\hline ERDC TN-SWWRP-10-1 & Apr 2010 & $\begin{array}{l}\text { Integration of the Individual-Based Fish Bioenergetics } \\
\text { Model into a Spatially Explicit Water Quality Model (CE- } \\
\text { QUAL-ICM), by P.S. Dalyander and C.F. Cerco }\end{array}$ \\
\hline ERDC TN-SWWRP-10-2 & Apr 2010 & $\begin{array}{l}\text { Demonstration of a Coupled Watershed-Nearshore } \\
\text { Model, by H. Cheng, J.C. Cheng, R.M. Hunter, and H. } \\
\text { Lin }\end{array}$ \\
\hline ERDC TN-SWWRP-10-3 & Aug 2010 & $\begin{array}{l}\text { Improved Soil Erosion and Sediment Transport in } \\
\text { GSSHA, by C.W. Downer, F.L. Ogden, N. Pradhan, S. } \\
\text { Liu, and A.R. Byrd }\end{array}$ \\
\hline ERDC TN-SWWRP-10-4 & Aug 2010 & $\begin{array}{l}\text { Computing Locally-Mass-Conservative } \\
\text { Fluxes from Multi-dimensional Finite } \\
\text { Element Flow Simulations, by J.C. Cheng, H. Cheng, } \\
\text { M.W. Farthing, and C.E. Kees }\end{array}$ \\
\hline ERDC TN-SWWRP-10-5 & Oct 2010 & $\begin{array}{l}\text { Exchangeable Phosphorus Pools and } \\
\text { Equilibrium Characteristics for River } \\
\text { Sediment as a Function of Particle Size, } \\
\text { by W.F. James }\end{array}$ \\
\hline ERDC TN-SWWRP-10-6 & Oct 2010 & $\begin{array}{l}\text { Intelligent Adaptive Time-Step Control for Modeling } \\
\text { Rapidly-Evolving Hydrodynamic Flows in Adaptive } \\
\text { Hydraulics (ADH), by G. Savant, C. Berger, T.O. McAlpin, } \\
\text { and J.N. Tate }\end{array}$ \\
\hline ERDC TN-SWWRP-11-1 & Jan 2011 & $\begin{array}{l}\text { A Generic Modeling Approach to Biomass Dynamics of } \\
\text { Sagittaria latifolia } \\
\text { and Spartina alterniflora, by E.P.H. Best, W.A. Boyd, } \\
\text { and K.P. Kenow }\end{array}$ \\
\hline ERDC TN-SWWRP-11-2 & Feb 2011 & $\begin{array}{l}\text { Meeting Water Quality and Water Control Objectives in } \\
\text { River Basins with Multiple Reservoirs, by D.H. Tillman, } \\
\text { G.C. Modini, and S.A.Wells }\end{array}$ \\
\hline ERDC TN-SWWRP-12-1 & Aug 2012 & $\begin{array}{l}\text { Storm Drain Effects on Urban Flooding, by F.L. Ogden, } \\
\text { J.M. Niedzialek, and A.R. Byrd }\end{array}$ \\
\hline
\end{tabular}




\section{Water Quality Research Program (WQRP)}

\section{Technical notes}

\section{Assessment methodologies (AM)}

\begin{tabular}{|c|c|c|}
\hline$\underline{\text { Report Number }}$ & Date & $\underline{\text { Title }}$ \\
\hline ERDC WQTN-AM-05 & Mar 2000 & $\begin{array}{l}\text { Spatial Interpolation Techniques for Water Quality } \\
\text { Analysis, by P. LaPotin and R. Kennedy }\end{array}$ \\
\hline ERDC WQTN-AM-06 & Mar 2000 & $\begin{array}{l}\text { Investigating Water Quality with a Towed Sensor Array, } \\
\text { by J.J. Hains and R.H. Kennedy }\end{array}$ \\
\hline ERDC WQTN-AM-07 & Jun 2000 & $\begin{array}{l}\text { Development of Unsupervised Classification } \\
\text { Techniques for Water Quality Analysis, by P. La Potin } \\
\text { and R.H. Kennedy }\end{array}$ \\
\hline ERDC WQTN-AM-08 & Jul 2000 & $\begin{array}{l}\text { Nutrient Criteria: Considerations for Corps of } \\
\text { Engineers Reservoirs, by R.H. Kennedy }\end{array}$ \\
\hline ERDC WQTN-AM-09 & Jul 2000 & CE-QUAL-W2, Version 3, by S.A. Wells and T.M. Cole \\
\hline ERDC WQTN-AM-10 & Jul 2000 & $\begin{array}{l}\text { Decision Support for Water Resource Management: } \\
\text { Integration of Water Control and Water Quality Data, by } \\
\text { R. Kennedy, T. Pangburn, E. Ochs, J. Schlagel, and W. } \\
\text { Boyd }\end{array}$ \\
\hline ERDC WQTN-AM-11 & Sep 2001 & $\begin{array}{l}\text { Low-Temperature Microbial Activity in River Systems, } \\
\text { by K.D. White, C.M. Reynolds, D. Ringelberg, J.P. } \\
\text { Laible, K.L. Foley, and L.B. Perry }\end{array}$ \\
\hline ERDC WQTN-AM-12 & Jun 2002 & $\begin{array}{l}\text { Gridded Surface Subsurface Hydrologic Analysis } \\
\text { (GSSHA) Model Simulation of Hydrologic Conditions } \\
\text { and Restoration Scenarios for the Judicial Ditch } 31 \\
\text { Watershed, Minnesota, by C.W. Downer, W.F. James, A. } \\
\text { Byrd, and G.W. Eggers }\end{array}$ \\
\hline ERDC WQTN-AM-13 & Jul 2002 & $\begin{array}{l}\text { Assessing Water Quality Functions of Wetlands, by S.L. } \\
\text { Ashby }\end{array}$ \\
\hline ERDC WQTN-AM-14 & May 2003 & $\begin{array}{l}\text { Assessment of Environmental and Economic Benefits } \\
\text { Associated with Streambank Stabilization and } \\
\text { Phosphorus Retention, by L.C. Hubbard, D.S. } \\
\text { Biedenharn, and S.L. Ashby }\end{array}$ \\
\hline ERDC WQTN-AM-15 & Oct 2007 & $\begin{array}{l}\text { A Primer for the Linkage between Unstructured Water } \\
\text { Quality Model CE-QUAL-ICM and Structured Three- } \\
\text { Dimensional Hydrodynamic Model CH3D-WES, by S.C. } \\
\text { Kim }\end{array}$ \\
\hline ERDC WQTN-AM-16 & Aug 2013 & $\begin{array}{l}\text { Planning Guide for Fish Passage at Pittsburgh District } \\
\text { Dams, by D.L. Smith, J.M. Nestler, and T.J. Maier }\end{array}$ \\
\hline
\end{tabular}




\section{Case studies (CS)}

\begin{tabular}{|c|c|}
\hline Report Number & Date \\
\hline ERDC WQTN-CS-02 & Aug 2001 \\
\hline ERDC WQTN-CS-03 & Sep 2001 \\
\hline ERDC WQTN-CS-04 & Apr 2004 \\
\hline
\end{tabular}

\begin{tabular}{|c|c|}
\hline Report Number & Date \\
\hline ERDC WQTN-MS-04 & Mar 1999 \\
\hline ERDC WQTN-MS-05 & Dec 2000 \\
\hline ERDC WQTN-MS-06 & Sep 2001 \\
\hline ERDC WQTN-MS-07 & Apr 2004 \\
\hline ERDC WQTN-MS-08 & Aug 2014 \\
\hline ERDC WQTN-MS-9 & Aug 2015 \\
\hline
\end{tabular}

\section{$\underline{\text { Title }}$}

Water Quality Indicators for Reservoirs: Proceedings of a Workshop, by K.W. Thornton, K.W and R.H. Kennedy

Characterization of U.S. Army Corps of Engineers Reservoirs: Design and Operational Considerations, by R.H. Kennedy, J. Clarke, W. Boyd, and T. Cole

Characterization of Sandbar Willow Stems for Erosion Control Applications, by J.L. Tingle and C. Hoag

Limnological Responses to Changes in the Withdrawal Zone of Eau Galle Reservoir, Wisconsin, by W.F. James, H.L. Eakin, and J.W. Barko

Analysis of the Challenges and Opportunities of Hydrokinetic Turbine Development Affecting the US Army Corps of Engineers, by D.L. Smith, J.M. Nestler, R. Styles, and B. Tetreault

Evaluation of Environmentally Acceptable Lubricants (EALS) for Dams Managed by the U.S. Army Corps of Engineers, by V.F. Medina

\section{Miscellaneous (MI)}

$\begin{array}{ll}\text { Report Number } & \underline{\text { Date }} \\ \text { ERDC WQTN-MI-07 } & \text { Jul 2000 } \\ \text { ERDC WQTN-MI-08 } & \text { Jul 2001 }\end{array}$

$\underline{\text { Title }}$

Total Maximum Daily Loads (TMDLs): A Perspective, by J.L. Martin and R.H. Kennedy

Application of HSPF-AGCHEM Module within the WMS for the LeSueur Basin, by P.D. Deliman, C.E. Ruiz, A.S. Donigian, T.H. Jobes, E.J. Nelson, and C.T. Manwaring 
Process descriptions (PD)

\begin{tabular}{|c|c|c|}
\hline Report Number & Date & $\underline{\text { Title }}$ \\
\hline ERDC WQTN-PD-07 & Dec 2000 & $\begin{array}{l}\text { Nutrient Recycling Impacts by Zebra Mussels in } \\
\text { Harper's Ferry Slough, Upper Mississippi River, by W.F. } \\
\text { James, J.W. Barko, H.L. Eakin, J.S. Hendrickson, A.C. } \\
\text { Miller, and J. Sauer }\end{array}$ \\
\hline ERDC WQTN-PD-08 & Feb 2001 & $\begin{array}{l}\text { Phosphorus Loading from the Redwood River Basin: } \\
\text { Fractionation of Labile and Refractory Components, by } \\
\text { W.F. James, J.W. Barko, and H.L. Eakin }\end{array}$ \\
\hline ERDC WQTN-PD-09 & May 2001 & $\begin{array}{l}\text { Enhanced Phosphorus Recycling by Zebra Mussels at } \\
\text { High Density Levels in Relation to Food Supply, by W.F. } \\
\text { James, J.W. Barko, and H.L. Eakin }\end{array}$ \\
\hline ERDC WQTN-PD-10 & Jul 2001 & $\begin{array}{l}\text { Loading of Biologically Available Constituents from an } \\
\text { Agricultural Subwatershed in the Redwood River Basin, } \\
\text { Minnesota, by W.F. James, J.W. Barko, H.L. Eakin and } \\
\text { G.W. Eggers }\end{array}$ \\
\hline ERDC WQTN-PD-11 & Sep 2001 & $\begin{array}{l}\text { Water Quality Additions to CASC2D - TAPS, by P.N. } \\
\text { Deliman, T.K. Gerald, and C.E. Ruiz }\end{array}$ \\
\hline ERDC WQTN-PD-12 & Aug 2002 & $\begin{array}{l}\text { Longitudinal Gradients in Phosphorus Characteristics } \\
\text { in the Minnesota-Upper Mississippi River System, by } \\
\text { W.F. James, J.W. Barko, and H.L. Eakin }\end{array}$ \\
\hline ERDC WQTN-PD-13 & Aug 2003 & $\begin{array}{l}\text { Alum Dosage Determination Based on Redox-Sensitive } \\
\text { Sediment Phosphorus Concentrations, by W.F. James } \\
\text { and J.W. Barko }\end{array}$ \\
\hline ERDC WQTN-PD-14 & Mar 2004 & $\begin{array}{l}\text { Phosphorus Loading and Compositional Characteristics } \\
\text { in Eight-Mile Run Watershed, Wisconsin, by W.F. James, } \\
\text { H.L. Eakin and J.W. Barko }\end{array}$ \\
\hline ERDC WQTN-PD-15 & Apr 2004 & $\begin{array}{l}\text { Phosphorus Forms and Export from Four Sub- } \\
\text { watersheds in the Upper Eau Galle River Basin } \\
\text { Exhibiting Differing Land-Use Practices, by W.F. James, } \\
\text { H.L. Eakin, and J.W. Barko }\end{array}$ \\
\hline ERDC WQTN-PD-16 & Sep 2004 & $\begin{array}{l}\text { Winter Community Structure Changes in Frazil Ice and } \\
\text { Open Water in Riverine Systems, by K.D. White, C.M. } \\
\text { Reynolds, D.B. Ringelberg, K.L. Foley, and L.B. Perry }\end{array}$ \\
\hline ERDC WQTN-PD-17 & Aug 2005 & $\begin{array}{l}\text { Phosphorus Saturation Characteristics in Relation to } \\
\text { Land-Use Practice for Soils in the Upper Eau Galle } \\
\text { River Watershed, Wisconsin, by W.F. James, J.W. Barko, } \\
\text { and D.M. Soballe }\end{array}$ \\
\hline ERDC WQTN-PD-18 & Mar 2006 & $\begin{array}{l}\text { Phosphorus Equilibrium Characteristics for Soils in the } \\
\text { Upper Eau Galle River Watershed, Wisconsin, by W.F. } \\
\text { James }\end{array}$ \\
\hline
\end{tabular}




\section{Wetlands Regulatory Assistance Program (WRAP)}

\section{Technical notes}

\begin{tabular}{|c|c|c|}
\hline Report Number & Date & $\underline{\text { Title }}$ \\
\hline ERDC TN-WRAP-00-01 & Jun 2000 & $\begin{array}{l}\text { Guidelines for Conducting and Reporting Hydrologic } \\
\text { Assessments of Potential Wetland Sites, by A.G. Warne } \\
\text { and J.S. Wakeley }\end{array}$ \\
\hline ERDC TN-WRAP-00-02 & Jul 2000 & $\begin{array}{l}\text { Installing Monitoring Wells/Piezometers in Wetlands,, by } \\
\text { S.W. Sprecher }\end{array}$ \\
\hline ERDC TN-WRAP-00-03 & Jul 2000 & $\begin{array}{l}\text { Importing Plant Stock for Wetland Restoration and } \\
\text { Creation: Maintaining Genetic Diversity and Integrity, by } \\
\text { W. Streever and E. Perkins }\end{array}$ \\
\hline ERDC TN-WRAP-01-01 & Apr 2001 & $\begin{array}{l}\text { Control of Beaver Flooding at Restoration Projects, by S. } \\
\text { Brown, D. Shafer, and S. Anderson }\end{array}$ \\
\hline ERDC TN-WRAP-01-02 & May 2001 & $\begin{array}{l}\text { Evaluation of the Use of Grid Platforms to Minimize } \\
\text { Shading Impacts to Seagrasses, by D.J. Shafer and J. } \\
\text { Robinson }\end{array}$ \\
\hline ERDC TN-WRAP-01-03 & May 2001 & $\begin{array}{l}\text { Upper Yellowstone River Hydrogeomorphic Functional } \\
\text { Assessment for Temporal and Synoptic Cumulative } \\
\text { Impact Analyses, by F.R. Hauer, B.J. Cook, M. Miller, C. } \\
\text { Noble, and T. Gonser }\end{array}$ \\
\hline ERDC TN-WRAP-01-04 & May 2001 & $\begin{array}{l}\text { Functional Assessment Using the Hydrogeomorphic } \\
\text { Approach: Applying the Wet Pine Flats Guidebook in the } \\
\text { Southeast, by J.S. Wakeley, J.A. Barlow, and W.R. } \\
\text { Bunkley }\end{array}$ \\
\hline ERDC TN-WRAP-01-05 & Sep 2001 & $\begin{array}{l}\text { Bioengineering as a Tool for Restoring Ecological } \\
\text { Integrity to the Carson River, by K.L. Piper, J.C. Hoag, } \\
\text { H.H. Allen, G. Durham, J.C. Fischenich, and R.O. } \\
\text { Anderson }\end{array}$ \\
\hline ERDC TN-WRAP-01-06 & May 2002 & $\begin{array}{l}\text { Technical and Scientific Considerations for Upland and } \\
\text { Riparian Buffer Strips in the Section } 404 \text { Permit } \\
\text { Process, by R.A. Fischer }\end{array}$ \\
\hline ERDC TN-WRAP-01-07 & Sep 2001 & $\begin{array}{l}\text { Akutan Harbor Project: Delineation of Wetlands on } \\
\text { Akutan Island, Alaska, by J.S. Wakeley, C.V. Noble, and } \\
\text { M.J. Bishop }\end{array}$ \\
\hline ERDC TN-WRAP-01-08 & Sep 2001 & $\begin{array}{l}\text { Akutan Harbor Project: Development of a Digital } \\
\text { Elevation Model and Topographic Map, by T.E. Berry, } \\
\text { M.R. Graves, and M.J. Bishop }\end{array}$ \\
\hline ERDC TN-WRAP-02-01 & May 2002 & $\begin{array}{l}\text { Implementing CD-Based Wetland Delineation Training, } \\
\text { by J.S. Wakeley }\end{array}$ \\
\hline
\end{tabular}


ERDC TN-WRAP-02-02

ERDC TN-WRAP-02-03

ERDC TN-WRAP-02-04

ERDC TN-WRAP-02-05

Nov 2002

May 2002

May 2002

ERDC TN-WRAP-03-01

May 2003

ERDC TN-WRAP-04-1 Apr 2004

ERDC TN-WRAP-04-2 S Sep 2004

ERDC TN-WRAP-04-3 S Sep 2004

ERDC TN-WRAP-05-1 Jan 2005

ERDC TN-WRAP-05-2 Jun 2005

ERDC TN-WRAP-05-3 Dec 2005

ERDC TN-WRAP-06-1 Feb 2006

ERDC TN-WRAP-06-2 Jan 2006

ERDC TN-WRAP-09-1 Sep 2009

ERDC TN-WRAP-12-1 Aug 2012

ERDC TN-WRAP-14-1 Dec 2014
Duration and Frequency of Ponded Water on Arid Southwestern Playas, by B. Lichvar, G. Gustina, and R. Bolus

Approaches for the Mitigation of Water Quality Functions of Impacted Wetlands - A Review, by S. Ashby

Watershed Best Management Practices for Water Quality Protection, Management, and Restoration, by R. Kennedy

Summarizing Responses to Corps District Requests for WRAP Scientific and Technical Assistance, by R. Lazor, J. Shirley, and V. Dickerson

Availability of a CD-Based Tutorial on Wetland Identification, by J.S. Wakeley

Field Indicators and Literature Summary for an Arid Southwestern Aquatic Resource Delineation at Twentynine Palms, CA, by R. Lichvar

Availability of a PowerPoint-Based Tutorial on Applying PLOAD for Wetlands Management, by J.P. Lin and B.A. Kleiss

Review of Published Export Coefficient and Event Mean Concentration (EMC) Data, by J.P. Lin

A National Survey of Potential Wetland Hydrology Regional Indicators, by C.V. Noble, D.J. Martel, and J.S. Wakeley

Technical Standard for Water-Table Monitoring of Potential Wetland Sites, by U. S. Army Corps of Engineers

Ecological Functions of Shallow, Unvegetated Estuarine Habitats and Potential Dredging Impacts (with emphasis on Chesapeake Bay), by G.L. Ray

The Role of Seagrasses and Kelps in Marine Fish Support by D. Blackmon, T. Wyllie-Echeverria, and D.J. Shafer

Water Table Monitoring Project Design, by C.V. Noble

Using IRIS Tubes to Monitor Reduced Conditions in Soils - Project Design, by J.F. Berkowitz

Updating Regional Supplements to the Corps of Engineers Wetland Delineation Manual, by J.F. Berkowitz

Framework for the Data-Driven Geographical Expansion of Rapid Ecological Assessment Methods by J.F.

Berkowitz, C.V. Noble, and Z.M. Wilson 


\section{Technical reports}

$\begin{array}{llll}\text { Report Number } & \text { Date } & \underline{\text { Title }} & \text { AD Number } \\ \text { ERDC/EL TR-WRAP-00-1 } & \text { Apr 2000 } & \begin{array}{l}\text { Accessing and Using Meteorological Data } \\ \text { to Evaluate Wetland Hydrology, by S.W. } \\ \text { Sprecher and A.G. Warne }\end{array} & \text { ADA38910 } \\ \text { ERDC/EL TR-WRP-RE-21 } & \text { Mar 2000 } & \begin{array}{l}\text { Wetlands Engineering Handbook, } \\ \text { Compiled by D.F. Hayes, T.J. Olin, J.C. } \\ \text { Fischenich, and M.R. Palermo }\end{array} & \text { ADA379359 } \\ & & \end{array}$




\section{Wetlands Research Program (WRP)}

\section{Technical bulletins}

$\begin{array}{lll}\text { Report Number } & \underline{\text { Date }} & \underline{\text { Title }} \\ \text { CRWRP-2, No. } 1 & \text { Mar 2000 } & \text { Wetlands Research Bulletin }\end{array}$

\section{Technical notes}

$\begin{array}{ll}\text { Report Number } & \text { Date } \\ \text { ERDC TN-WRP-HS-CP-2.1 } & \text { Feb 2003 }\end{array}$

Section FW - Fish/wildlife

Report Number

WRP TN FW-RS-3.1

Date

Oct 1999 $\underline{\text { Title }}$

Effects of Headcutting on the Bottomland Hardwood Wetlands Adjacent to the Wold River, Tennessee, by K. Weins and T.H. Roberts

$\underline{\text { Title }}$

Foraging Habitat for Bird Species or Bird Diversity in Wetland Design, by B. Harrington and B. Streever

\section{Section HS -- Hydraulics}

Report Number

Date

ERDC TN-WRP-HS-CP-2.1 Feb 2003

ERDC TN-WRP-HS-CP-2.2 Feb 2003

ERDC TN-WRP-HS-CP-2.3 Sep 2004 $\underline{\text { Title }}$

Effects of Headcutting on the Bottomland Hardwood Wetlands Adjacent to the Wolf River, Tennessee, by K. Weins and T. Roberts

Preliminary Evaluation of Critical Wave Energy Thresholds at Natural and Created Coastal Wetlands, by D.J. Shafer, R. Roland, and S.L. Douglass

Effects of Headcutting on Groundwater Levels in Bottomland Hardwood Wetlands of the Wolf River, Tennessee, by M.S. Peterson, T.H. Roberts, and D.J. Shafer

$\underline{\text { Title }}$

Numerical Assessment of Hydrologic Functions in Prairie Potholes, by G. Pohll and J. Tracy 


\section{Section VN - Vegetation}

$\begin{array}{lll}\text { Report Number } & \text { Date } & \text { Title } \\ \text { ERDC TN-WRP-VN-RS-3.2 } & \text { Oct 2000 } & \begin{array}{l}\text { Restoration of Mangrove Habitat, by R.R. Lewis and B. } \\ \text { Streever }\end{array}\end{array}$

\section{Section WG - Wetlands general}

Report Number

ERDC TN-WRP-WG-RS-3.4 Mar 2000

ERDC TN-WRP-WG-RS-3.5 Sep 2002 $\underline{\text { Title }}$

Salt Marsh Planting: Example Contract Specifications, by C.B. Schneider, W. Streever, and R. Medina Bottomland Hardwood Planting: Example Contract Specifications, by M.N. Humphrey and D.J. Shafer 


\section{Zebra Mussel Research Program (ZMR)}

\section{Bulletins}

Report Number Date

V. 1 No. $1 \quad$ Jun 2001

\section{Technical notes}

$\begin{array}{lll}\text { Report Number } & \text { Date } & \text { Title } \\ \text { ERDC TN-ZMR-2-22 } & \text { Dec 2000 } & \begin{array}{l}\text { Plasma Pulse Technology to Control Zebra Mussel } \\ \text { Biofouling, by G.L. Macie, P. Lowery, and C. Cooper }\end{array} \\ \text { ERDC TN-ZMR 2-23 } & \text { Dec 2000 } & \begin{array}{l}\text { Controlling Zebra Mussels, Quagga Mussels, and } \\ \text { Biofilm Growth with the Plasma Sparker, by A.C. Miller } \\ \text { and P. Lowery }\end{array} \\ & & \begin{array}{l}\text { Overview of Electrical Technologies for Controlling } \\ \text { Dreissenids, with Emphasis on Pulse-Power Systems, } \\ \text { ERDC TN-ZMR 3-23 }\end{array} \\ & \text { Dec 1999 A.G. Smythe and E.A. Dardeau, Jr. }\end{array}$




\section{Miscellaneous Publications}

Date

2000

2002

2004

2006

2009

2011

2015
Publication

US Army Environmental Restoration: Technologies for Cleanup of UXO, Explosives, and Energetics, by U.S. Army Engineer Research and Development Center

A Walk Through the Corps of Engineers' Dredge Wheeler. (electronic resource)

The First 75 Years: History of Hydraulics Engineering at the Waterways Experiment Station, by B.H. Fatheree

The History of Geotechnical Engineering at the Waterways Experiment Station: 1932-2000, by B.H. Fatheree

2009 US Army Corps of Engineers Research and Development Conference. Science and Technology: The Cornerstone for Building Strong (electronic resource)

Research and Development in the U.S. Army Corps of Engineers: Improving the Common Stock of Knowledge, by Damon Manders

Cold Regions Research and Engineering Laboratory: The First Fifty Years, by United States Army, Corps of Engineers, Cold Regions Research and Engineering Laboratory 


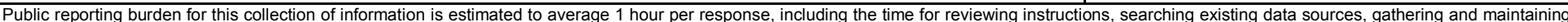

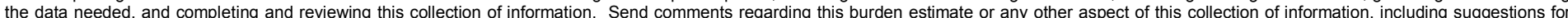

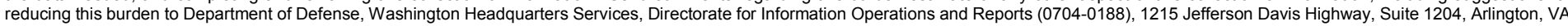

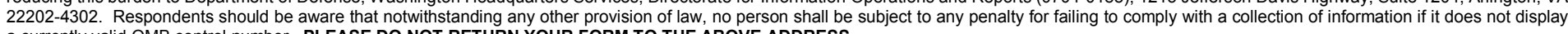
a currently valid OMB control number. PLEASE DO NOT RETURN YOUR FORM TO THE ABOVE ADDRESS.
1. REPORT DATE (DD-MM-YYYY) 2. REPORT TYPE
3. DATES COVERED (From - To)

January 2017 Final

\section{TITLE AND SUBTITLE}

5a. CONTRACT NUMBER

Publications of the U.S. Army Engineer Research and Development Center: October 1999-December 2015

\section{5b. GRANT NUMBER}

5c. PROGRAM ELEMENT NUMBER

\section{AUTHOR(S)}

James A. Dolan

\section{5d. PROJECT NUMBER}

5e. TASK NUMBER

5f. WORK UNIT NUMBER

\section{PERFORMING ORGANIZATION NAME(S) AND ADDRESS(ES)}

8. PERFORMING ORGANIZATION REPORT NUMBER

Information Technology Laboratory

U.S. Army Engineer Research and Development Center

ERDC/ITL SR-17-1

3909 Halls Ferry Road

Vicksburg, MS 39180-6199

\section{SPONSORING / MONITORING AGENCY NAME(S) AND ADDRESS(ES)}

U.S. Army Corps Engineer Research and Development Center

3909 Halls Ferry Road

Vicksburg, MS 39180-6199

11. SPONSOR/MONITOR'S REPORT NUMBER(S)

\section{DISTRIBUTION / AVAILABILITY STATEMENT}

Approved for public release; distribution is unlimited.

\section{SUPPLEMENTARY NOTES}

\section{ABSTRACT}

Publications issued October 1999 through December 2015 by the U.S. Army Engineer Research and Development Center (ERDC) are listed. The publications are grouped according to the technical laboratories or technical program for which they were prepared.

Procedures for obtaining ERDC reports are included in the Preface.

\section{SUBJECT TERMS}

Civil engineering-bibliography

Civil engineering -- Cold weather conditions-bibliography

Civil engineering - Design and construction-bibliography

Coastal engineering-bibliography

Engineer Research and Development Center (U.S.) - Bibliography
Environmental engineering-bibliography

Geotechnical engineering-bibliography

Government publications - United States

Hydraulic engineering-bibliography

Information technology-bibliography

Military engineering-bibliography

\begin{tabular}{|c|c|c|c|c|c|}
\hline \multicolumn{3}{|c|}{ 16. SECURITY CLASSIFICATION OF: } & \multirow{2}{*}{$\begin{array}{l}\text { 17. LIMITATION } \\
\text { OF ABSTRACT }\end{array}$} & \multirow{2}{*}{$\begin{array}{l}\text { 18. NUMBER } \\
\text { OF PAGES }\end{array}$} & \multirow{2}{*}{$\begin{array}{l}\text { 19a. NAME OF RESPONSIBLE } \\
\text { PERSON } \\
\begin{array}{l}\text { 19b. TELEPHONE NUMBER (include } \\
\text { area code) }\end{array}\end{array}$} \\
\hline a. REPORT & b. ABSTRACT & c. THIS PAGE & & & \\
\hline
\end{tabular}

